2. To: (Receiving Organization)

FDH Hanford Company

5. Proj./Prog./Dept./Div.:

Plutonium Finishing Plant

8. Originator Remarks:

This document is being approved for release.

3. From: (Originating Organization)

EDNW Criticality and shielding

6. Design Authority/Design Agent/Cog. Engr.

B. S. Mo

11. Receiver Remarks:

11A. Design Baseline Document? $\mathrm{O}$ Yes $O$ No

\section{Related EDT No.: \\ $\mathrm{N} / \mathrm{A}$ \\ 7. Purchase Order No.: \\ $\mathrm{N} / \mathrm{A}$ \\ 9. Equip./Component No.: \\ $\mathrm{N} / \mathrm{A}$}

10. System/BIdg./Facility:

234-5Z

12. Major Assm. Dwg. No.:

N/A

13. Permit/Permit Application No.:

$\mathrm{N} / \mathrm{A}$

14. Required Response Date:

$\mathrm{N} / \mathrm{A}$

\begin{tabular}{|c|c|l|l|l|}
\hline \multicolumn{2}{|c|}{15.} & DATA TRANSMITTED \\
\hline $\begin{array}{c}\text { (A) } \\
\text { No. }\end{array}$ & (B) DocumentDrawing No. & $\begin{array}{c}\text { (C) Sheet } \\
\text { No. }\end{array}$ & $\begin{array}{l}\text { (D) Rev. } \\
\text { No. }\end{array}$ & (E) Title or Description of Data Transmitted \\
\hline 1 & HNF-5988 & - & 0 & CSER 00-001: \\
\hline & & & & Criticality Sa fety \\
\hline & & & & Evaluation Report For \\
\hline & & & & Cementation Operations \\
\hline & & & & for the PFP \\
\hline & & & & \\
\hline
\end{tabular}

\begin{tabular}{|c|c|c|c|}
\hline (F) & (G) & (H) & $(I)$ \\
\hline $\begin{array}{c}\text { Approval } \\
\text { Desig- } \\
\text { nator }\end{array}$ & $\begin{array}{c}\text { Reason Trans- } \\
\text { mittal }\end{array}$ & $\begin{array}{c}\text { Origi- } \\
\text { nator } \\
\text { Dispo- } \\
\text { stion }\end{array}$ & $\begin{array}{c}\text { Receiv- } \\
\text { or } \\
\text { Dispo- } \\
\text { sition }\end{array}$ \\
\hline & & & \\
\hline
\end{tabular}

16.

KEY

\begin{tabular}{c|l}
\hline Approval Designator (F) & \\
\hline E, S, Q, D OR N/A & 1. Approval \\
(See WHC-CM-3-5, & 2. Release \\
Sec. 12.7) & 3. Information
\end{tabular}

17.

Reason for Transmittal (G)

Disposition (H) \& (I)

4. Review
5. Post-Revlew
6. Dist. (Rocelpt Acknow. Required)

SIGNATURE/DISTRIBUTION

(See Approval Designator for required signatures)

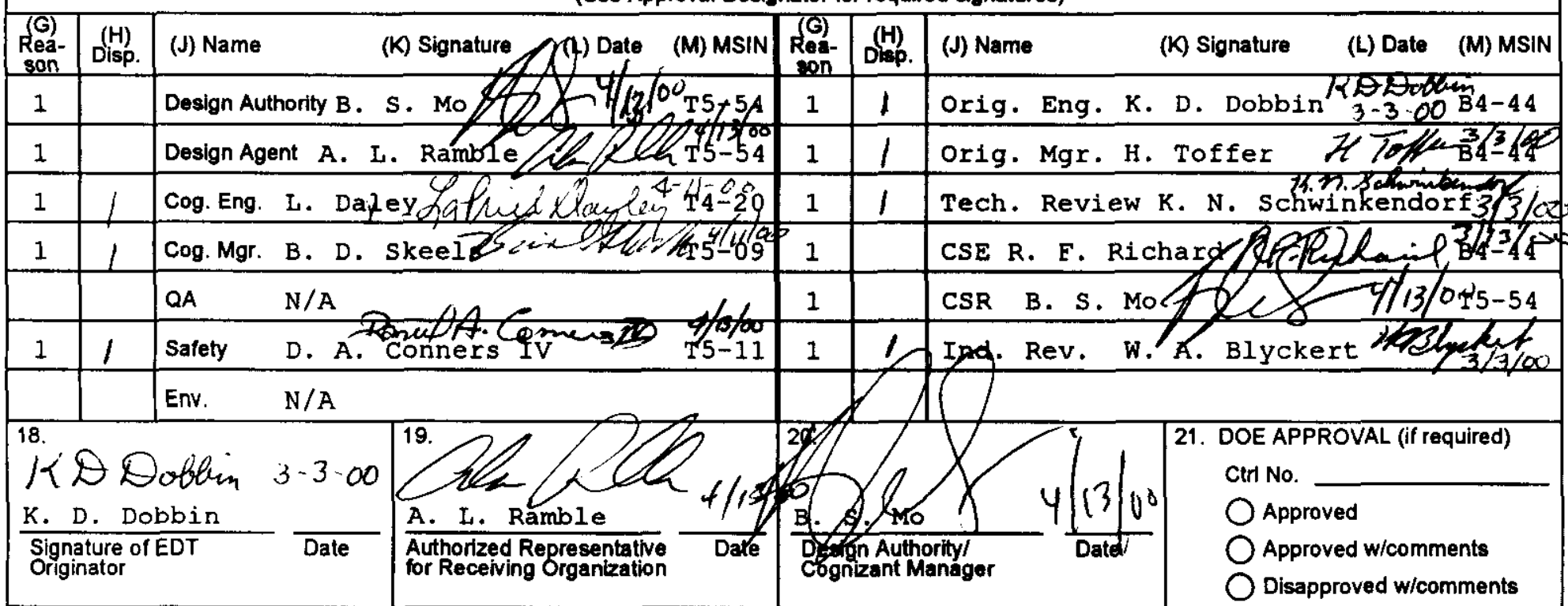




\section{DISTRIBUTION SHEET}

To

Distribution

Project Title/Work Order

CSER 00-001: Criticality Safety Evaluation Report For Cementation Operations at the PFP

\begin{tabular}{|c|}
\hline Name \\
\hline Fluor Daniel Hanford \\
\hline D. A. Conners \\
\hline L. Daley \\
\hline G. R. Franz \\
\hline J. D. Carlson \\
\hline B. D. Skeels \\
\hline A. L. Ramble \\
\hline R. W. Szempruch \\
\hline S. M. Sax \\
\hline J. P. King \\
\hline B. S. Mo \\
\hline DOE-RL \\
\hline S. J. Altschuler \\
\hline L. T. Nirider \\
\hline DOE/RL Reading Room \\
\hline Docket Files (2 copies) \\
\hline Central Files (Orig. +2 Copies) \\
\hline Fluor Federal Services \\
\hline K. D. Dobbin \\
\hline D. G. Erickson \\
\hline J. P. Estrellado Jr. \\
\hline H. Toffer \\
\hline D. W. Wootan \\
\hline E. M. Miller \\
\hline A. B. Rau (3) \\
\hline R. F. Richard \\
\hline G. L. Rippy \\
\hline K. N. Schwinkendorf \\
\hline S. R. Templin \\
\hline A. D. Wilkinson \\
\hline
\end{tabular}

\section{From}

Criticality and Shielding FFS

\author{
ECN No. N/A
}

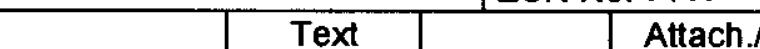

\begin{tabular}{l|c|c|c|c|} 
MSIN & $\begin{array}{c}\text { Text } \\
\text { With All } \\
\text { Attach. }\end{array}$ & Text Only & $\begin{array}{c}\text { Attach./ } \\
\text { Appendix } \\
\text { Only }\end{array}$ & $\begin{array}{c}\text { EDT/ECN } \\
\text { Only }\end{array}$ \\
\hline
\end{tabular}

Page 1 of 1

Date $3 / 3 / 00$

EDT No. 619995
T5-11

T $4-20$

A. $0-26$

T5-57

T5-09

T5-54

T5- 48

T5-15

T5-51

T5-54

\begin{tabular}{|l|l|l|} 
& & \\
$\mathrm{x}$ & & \\
$\mathrm{x}$ & & \\
\hline
\end{tabular}

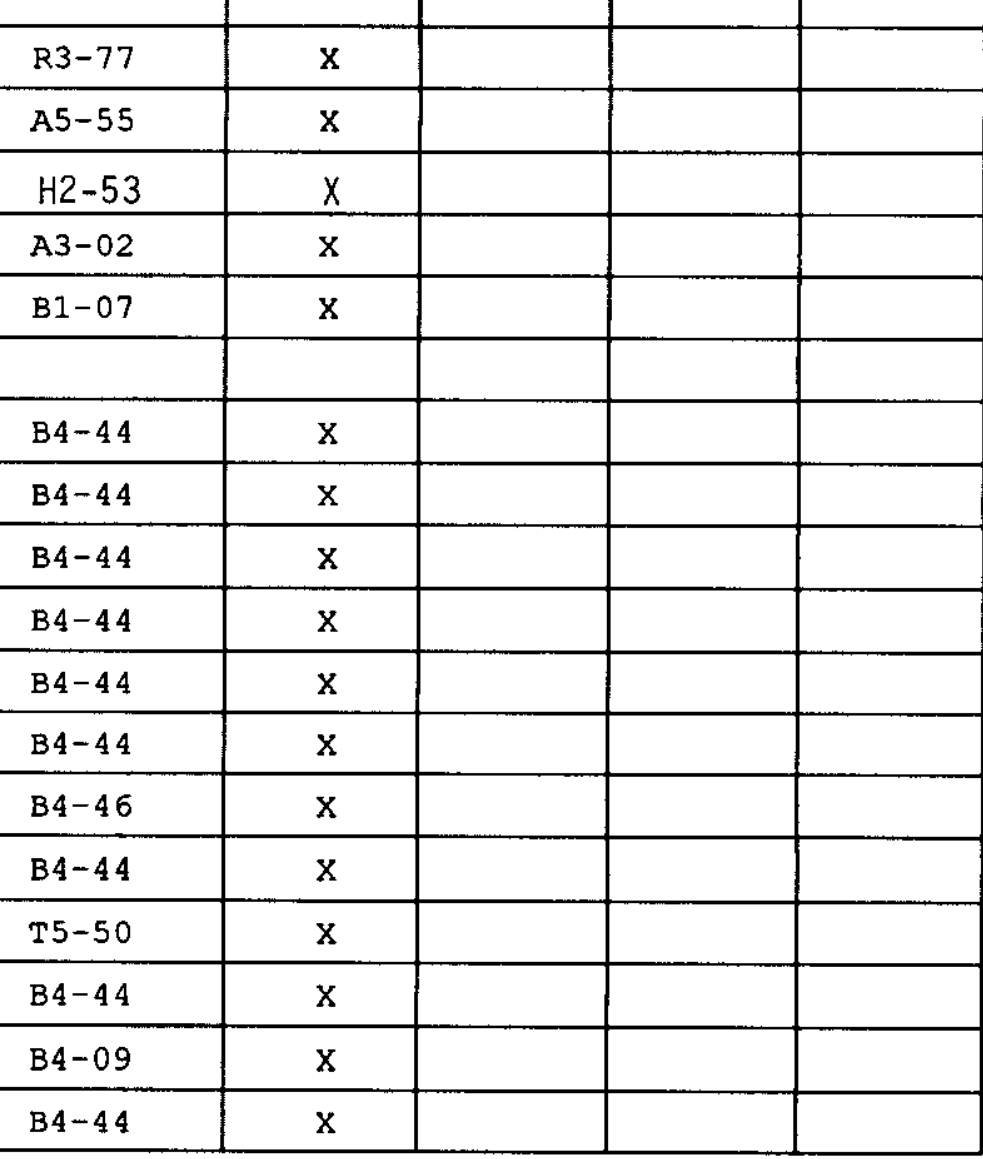




\section{INFORMATION CLEARANCE FORM}

\begin{tabular}{ll}
\multicolumn{2}{c|}{ A. Information Category } \\
$\square$ Abstract & $\square$ Joumal Article \\
$\square$ Summary & $\square$ Intemet \\
$\square$ Visual Aid & $\square$ Sotware \\
$\square$ Full Paper & $\square$ Report \\
$\square$ Other
\end{tabular}

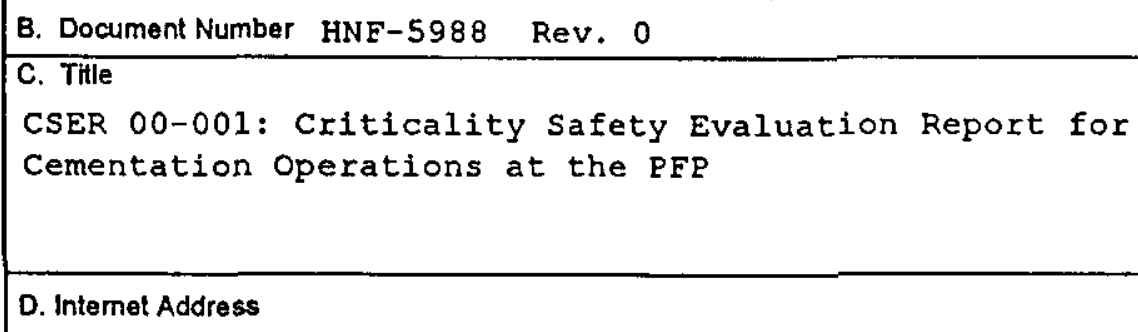

E. Required Information

1. Is document potentially Classified? ONo OYes (MANDATORY) Han Tolfur. Manager's Sighature Required

If Yes glolution ADC Signature Required

No OYes Classified

2. Internal Review Required? If Yes, Document Signatures Below

CNo OYes

Counsel

Program

3. References in the information are Applied Technology $O$ No OYes Export Controlled Information Ono Ores 4. Does Information Contain the Following: (MANDATORY)
a. New or Novel (Patentable) Subject Matter?
- No Ores

"Yes", Disclosure No.:

b. Information Received in Confidenco, Such as Propriatary andior Inventions?

ONo OYes if "Yes", Affix Appropriate Legends/Notices.

c. Copyrights? ONo OYes If "Yes", Attach Permission.

d. Trademarks? $\bigcirc$ No $O$ Yes "Yos", Identify in Document.

5. Is information requiring submlssion to OSTI? $\bigcirc$ No $\odot$ Yes

If Yes UC- SOCO and B\&R-EW 3130010

6. Release Level? $\bigcirc$ Public $\bigcirc$ Limited

7. Charge Code $110854 / \mathrm{AJ}_{6} \mathrm{C} \quad \mathrm{HmK} / 004.1$

F. Complete for a Joumal Article

1. Title of Journal $\mathrm{N} / \mathrm{A}$

G. Complete for a Presentation

1. Title for Conference or Meeting $\mathrm{N} / \mathrm{A}$

2. Group Sponsoring $N / A$

3. Date of Conference $N / A$

5. Will Informatlon be Published in Proceedings? ONo OYes

4. City/State $\mathrm{N} / \mathrm{A}$

H. Author/Requestor

6. Will Material be Handed Out? $O$ No O Yes

KD Dobbin KD Dobbin 3-3.00 (Print and Slgn)

Responsible Manager

\begin{tabular}{|c|c|c|c|c|}
\hline 1. Reviewers & Yes & Print & Signature & Public Y/N (If N, complete J) \\
\hline General Counsel & $\square$ & & & $Y / N$ \\
\hline Office of External Affalis & $\square$ & & - & $\mathrm{Y} / \mathrm{N}$ \\
\hline DOE-RL & $\square$ & & - & $\mathrm{Y} / \mathrm{N}$ \\
\hline Other & $\square$ & & & $Y / N$ \\
\hline Other & $\square$ & & & $Y / N$ \\
\hline
\end{tabular}

J. If Information Includes Sensitive Information and is not to be released to the Public indicate category below.

$\square$ Applied Technology $\square$ Protected CRADA

$\square$ Personal/Private $\quad \square$ Export Controlled

$\square$ Proprietary $\square$ Procurement-Sensitive

$\square$ Business-Sensitive $\square$ Patentable

$\square$ Predecisional $\square$ other (Specity)

$\square$ UCNI HANS TOFFER Theer iOfle- 411700

earance Approval

K. If Additional Comments, Please Attach Separate Sheet 


\section{CSER 00-001: Criticality Safety Evaluation Report for Cementation Operations at the PFP}

Prepared for the U.S. Department of Energy

Assistant Secretary for Environmental Management

Project Hanford Management Contractor for the

U.S. Department of Energy under Contract DE-AC06-96RL13200

Fluor Hanford

P.O. Box 1000

Richland, Washington 
HNF-5988

Revision 0

EDT 619995

\title{
CSER 00-001: Criticality Safety Evaluation Report for Cementation Operations at the PFP
}

\author{
K. D. Dobbin \\ D. W. Wootan \\ Fluor Federal Services
}

Date Published

March 2000

Prepared for the U.S. Department of Energy

Assistant Secretary for Environmental Management

Project Hanford Management Contractor for the

U.S. Department of Energy under Contract DE-AC06-96RL13200

Fluor Hanford

P.O. Box 1000

Richland, Washington
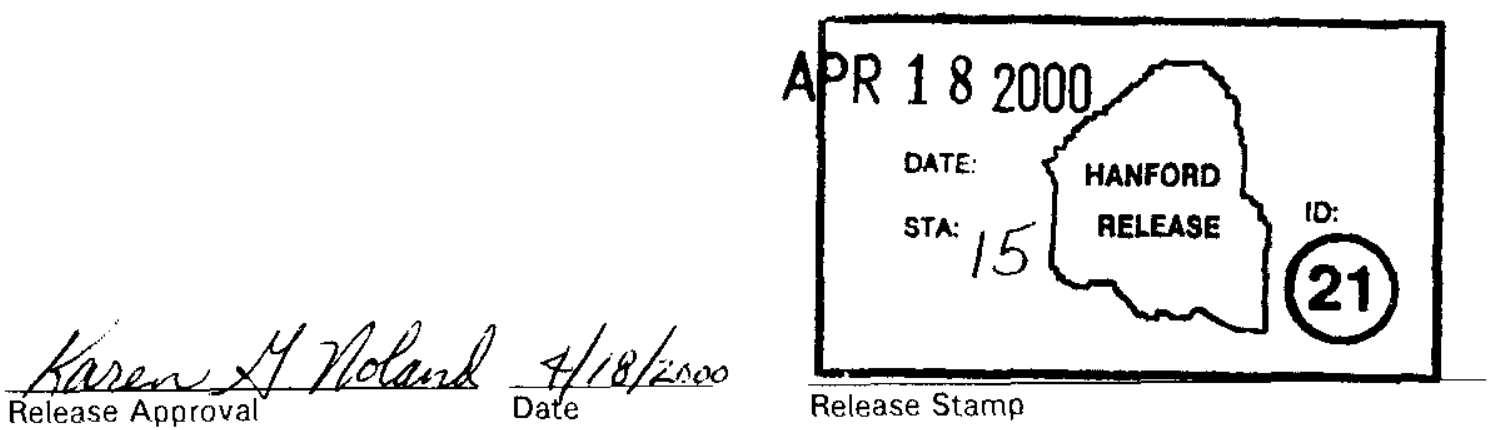
TRADEMARK DISCLAIMER

Reference herein to any specific commercial product, process,

or service by trade name, trademark, manufacturer, or

otherwise, does not necessarily constitute or imply its

endorsement, recommendation, or favoring by the United

States Government or any agency there of or its contractors or subcontractors.

This report has been reproduced from the best available copy.

Printed in the United States of America

Total Pages: $309 \mathrm{kN}$ 


\title{
CSER 00-001: \\ Criticality Safety Evaluation Report for Cementation Operations at the PFP
}

\author{
March 2000 \\ Prepared by \\ Fluor Federal Services \\ Richland, Washington \\ For \\ Fluor Hanford \\ In Support of \\ Task Order No. 5204
}

Prepared by: id 240 then

Date: $3-3-00$

K. D. Dobbin, Criticality and Shielding

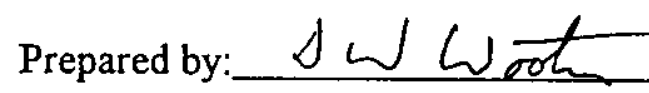

Date: $3-3-00$

D. W. Wootan, Environmental and Nuclear Initiatives

Reviewed by: $\frac{1 L_{1} n_{1} \text { Schwintem }}{\text { K. N. Schwinkendorf, Criticality and Shielding }}$

Date: $3 / 3 /$ ov

K.

Approved by:

H. Toffer, Manager

Date:

$3 / 3 / 00$

Criticality and Shielding 
HNF-5988 Rev. 0

This page intentionally left blank. 
HNF-5988 Rev. 0

\section{Executive Summary}

Glovebox HA-20MB is located in Room 235B of the 234-5Z Building at the Plutonium Finishing Plant. This enclosure contains mixers, mixer bowls, a crusher unit, an isolated inoperable conveyor unit, plutonium residue feed cans, cemented cans, and a feedwater container. Plutonium residue, not conducive to other forms of stabilization, is prepared for storage and ultimate disposal by cementation. The feed residue material cans can have plutonium contents of only a few grams or up to 200 grams. This evaluation accommodates this wide range of container fissile concentrations.

Two glovebox limit sets are supported by this document. One limit set is for residue in any form except solutions and allows up to $1200 \mathrm{~g}$ plutonium or fissile equivalent in the glovebox. Up to $500 \mathrm{~g}$ plutonium can be in feed or cement cans, $200 \mathrm{~g}$ plutonium in each of two mixing bowls, and $300 \mathrm{~g}$ plutonium as glovebox holdup. The second limit set is specifically for sand, slag, and crucible (SS\&C), ash, or oxide feed material and allows up to 2100 g plutonium or fissile equivalent. Up to $500 \mathrm{~g}$ plutonium can be in cemented billets, $900 \mathrm{~g}$ plutonium in cans as feed, $200 \mathrm{~g}$ plutonium in each of two mixing bowls, and $300 \mathrm{~g}$ plutonium as glovebox holdup.

Evaluation of this glovebox operation included normal, base cases, and contingencies. The base cases took the normal operations for each type of feed material and added the likely offnormal events. Each contingency is evaluated assuming the unlikely event happens to the conservative base case. A hazards assessment was conducted to assure that each credible unlikely event or set of correlated unlikely events was included in this analysis. The results of this evaluation show that the intended operation in Glovebox HA-20MB meets the double contingency requirement. That is, at least two unlikely, independent, and concurrent changes in process conditions are required before a criticality is possible. Therefore, this CSER meets the requirements for a criticality evaluation contained in the Hanford Site Nuclear Criticality Safety Manuals, HNF-PRO-334 (FDH 2000), HNF-PRO-537 (FDH 1997a), and HNF-PRO-539 (FDH 1997b), ANSI standards (ANSI 1998), and DOE Order 5480.24 (DOE 1992). This CSER also follows Fluor Federal Services, Inc. Practice 134.290.1121 (FFS 1999). 
HNF-5988 Rev. 0

This page intentionally left blank. 
HNF-5988 Rev. 0

Table of Contents

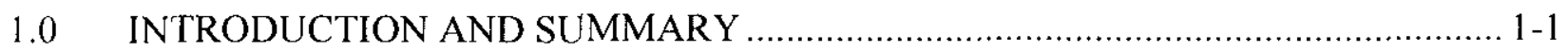

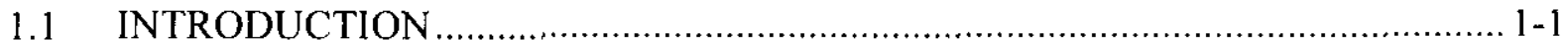

1.2 DOUBLE CONTINGENCY DOCUMENTATION ….................................... 1-2

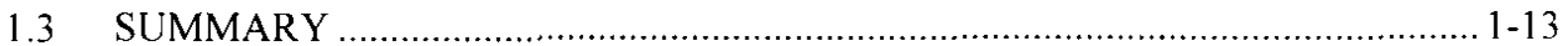

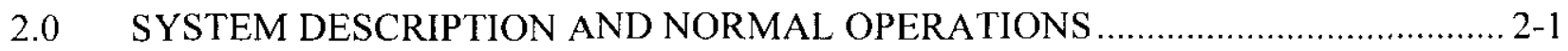

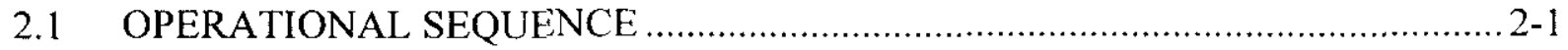

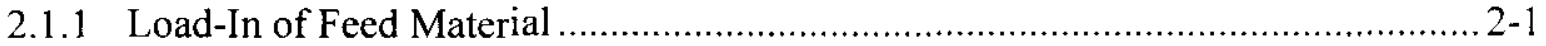

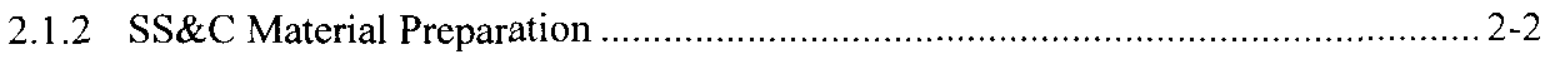

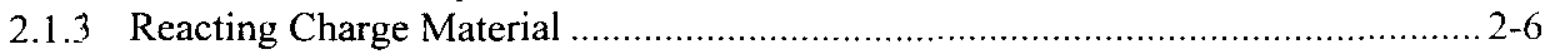

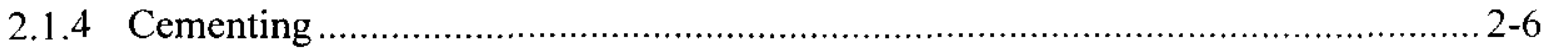

2.2 FACILITY AND EQUIPMENT DESCRIPTION ...................................... $2-6$

2.2.1 Glovebox HA-20MB Description............................................................... 2-8

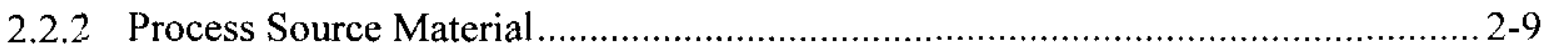

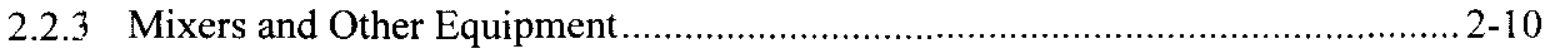

2.2.4 Containers for SS\&C Material and Slurries.................................................. 2-11

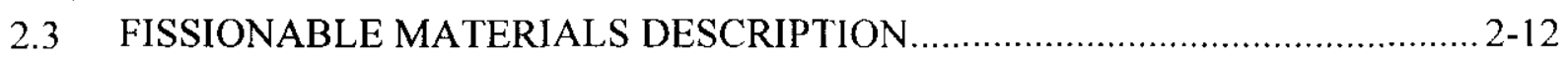

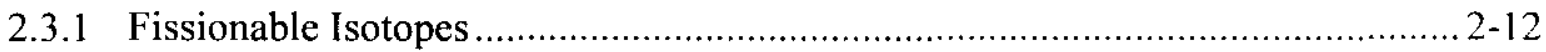

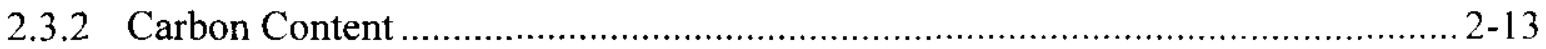

2.3.3 Residual Pu Contamination of the HA-20MB Glovebox ................................... 2-13

2.4 FISSIONABLE MATERIAL HANDLING ................................................ $2-13$

2.4.1 Receipt of Fissionable Material ................................................................. 2-13

2.4.2 Waste Packages ........................................................................................ 2-14

3.0 LIMITS AND CONTROLS …....................................................................... 3

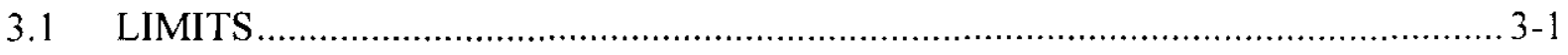

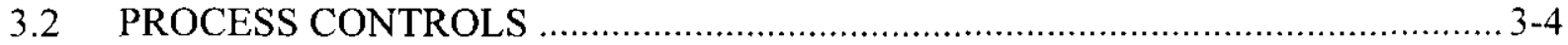

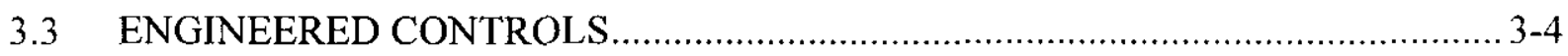

3.4 ADMINISTRATIVE CONTROL IMPLEMENTATION .................................. 3-5

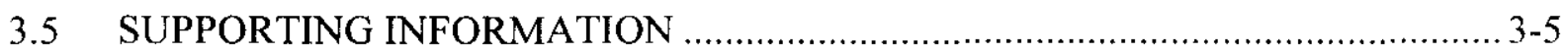

3.6 EVALUATION ASSUMPTIONS …........................................................... $3-5$

4.0 METHODOLOGY ..................................................................................... 4

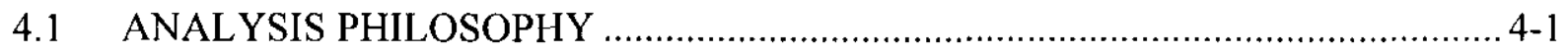

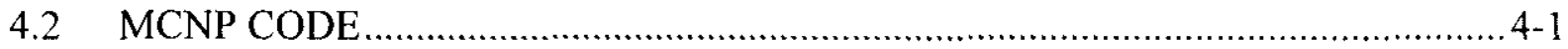

4.3 SUBCRITICALITY LIMIT ........................................................................... $4-1$

4.4 APPLICATION OF DOUBLE CONTINGENCY PRINCIPLE ............................ 4-2

4.5 HAZARDS ASSESSMENT ....................................................................... $4-2$

$5.0 \quad$ EVALUATION AND RESULTS .......................................................................

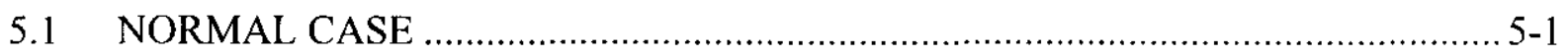

5.2 BASE CASE .............................................................................................. $5-1$

5.2.1 Base Case Model for Limit Set A: $1200 \mathrm{~g}$ Plutonium Limit Set ......................... 5-1

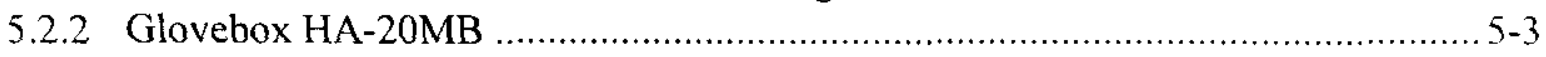

5.2.3 Feed and Cement Container .......................................................................... 5-3

5.2.4 Mixer Bowl .......................................................................................... 5 
HNF-5988 Rev. 0

5.2.5 HA-28 Conveyor Fissile Movement Past HA-20MB Glovebox ........................... 5-4

5.2.6 Glovebox Filter Holdup for HEPA Filter Replacement Operation....................... 5-4

5.2.7 Base Cases Results for Limit Set A …........................................................... 5-5

5.2.8 Base Case Model for Limit Set B: $2100 \mathrm{~g}$ Plutonium Total Glovebox ............... 5-7

5.2.9 Base Case Model Differences from Limit Set A .............................................. 5-9

5.2.10 Base Case Results for Limit Set B .................................................................. 5-9

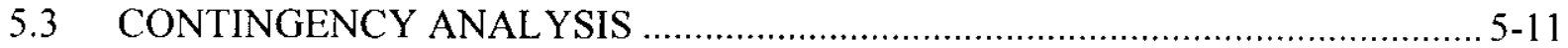

5.3.1 Contingencies for Limit Set A ….......................................................... 5-13

5.3.2 Seismic Event......................................................................................... $5-13$

5.3 .3 Major Fire ....................................................................................... $5-14$

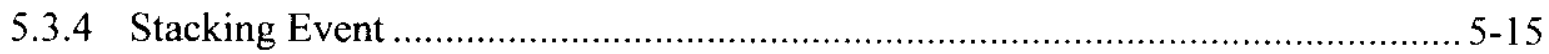

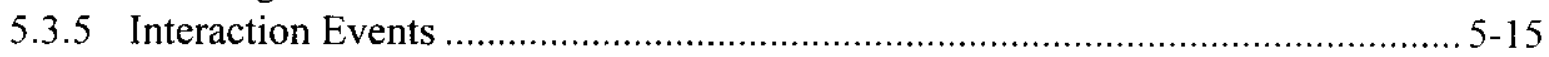

5.3.6 Other Contingencies for Limit Set A ...................................................... 5-17

5.3.7 Contingencies for Limit Set B .............................................................. 5-17

5.3.8 Seismic Event.......................................................................................... $5-18$

5.3 .9 Major Fire ........................................................................................ $5-19$

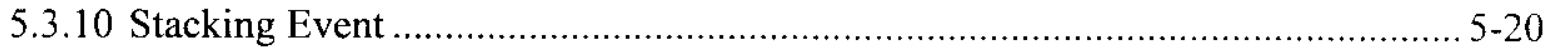

5.3.11 Interaction Events ................................................................................... 5-20

5.3.12 Other Contingencies for Limit Set B ........................................................ 5-21

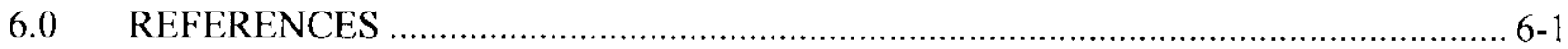

APPENDIX AINDEPENDENT REVIEW COMMENTS AND CHECKLIST ..................... A-1 APPENDIX B MCNP COMPUTER CODE VALIDATION ..............................................

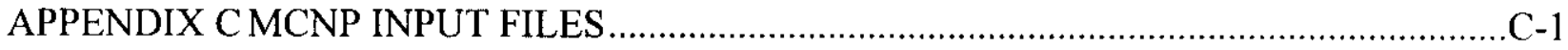

APPENDIX DPRELIMINARY HAZARDS ANALYSIS .............................................. D-1 APPENDIX E MCNP MODEL FIGURES ….............................................................. E-1

APPENDIX F SAND, SLAG, AND CRUCIBLE CEMENTATION PROCESS

FLOW AND STABILIZATION CEMENTATION DOCUMENTS ................. F-1

APPENDIX GGENERAL DESCRIPTION OF HANFORD RESIDUE CATEGORIFS:

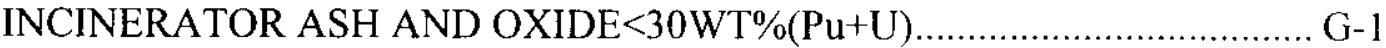

APPENDIX H WASTE PACKAGE DATA ….................................................................

APPENDIX I FIREFIGHTING WATER DENSITY …................................................. I-

APPENDIX J MAXIMUM WATER CONTENT IN SS\&C - CEMENT MATRIX .................... 


\section{List of Tables}

Table 1-1. Glovebox HA-20MB - Limit Set A Base Case Limits Summary .......................... 1-4

Table 1-2. Glovebox HA-20MB - Limit Set A Contingency Summary .............................. 1-6

Table 1-3. Glovebox HA-20MB - Limit Set B Base Case Limits Summary ........................... 1-9

Table 1-4. Glovebox HA-20MB - Limit Set B Contingency Summary .............................. 1-11

Table 3-1. Controls on Parameters Related to Criticality in Glovebox HA-20MB .................. 3-1

Table 3-2. Limit Set A: $1200 \mathrm{~g}$ Total Glovebox Fissile Mass ......................................... 3-2

Table 3-3. Limit Set B: $2100 \mathrm{~g}$ Total Glovebox Fissile Mass ............................................. 3-3

Table 5-1. Base Case Model for $1200 \mathrm{~g}$ Plutonium Limit Set ....................................... 5-2

Table 5-2. MCNP Calculational Results of Base Cases in Glovebox HA-20MB for Limit Set A: $1200 \mathrm{~g}$ Plutonium Glovebox Total............................................. 5-6

Table 5-3. Base Case Model 2100 g Plutonium Limit Set ............................................... 5-8

Table 5-4. MCNP Calculational Results of Base Cases in Glovebox HA-20MB for Limit Set B: $2100 \mathrm{~g}$ Plutonium Total Glovebox........................................ 5-10

Table 5-5. MCNP Calculational Results of Seismic Cases in Glovebox HA-20MB for

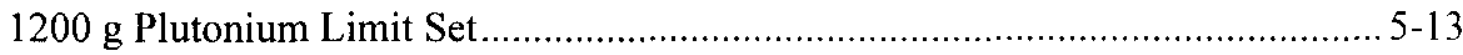

Table 5-6. MCNP Calculational Results of Flooding Cases in Glovebox HA-20MB for

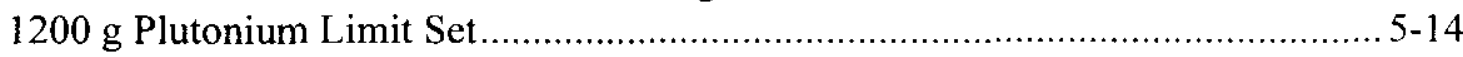

Table 5-7. MCNP Calculational Results of Stacking Cases in Glovebox HA-20MB for $1200 \mathrm{~g}$ Plutonium Limit Set.

Table 5-8. MCNP Calculational Results of Interaction Cases in Glovebox HA-20MB for $1200 \mathrm{~g}$ Plutonium Limit Set.

Table 5-9. MCNP Calculational Results of Seismic Cases in Glovebox HA-20MB for $2100 \mathrm{~g}$ Plutonium Limit Set.

Table 5-10. MCNP Calculational Results of Flooding Cases in Glovebox HA-20MB for $2100 \mathrm{~g}$ Plutonium Limit Set.

Table 5-11. MCNP Calculational Results of Stacking Cases in Glovebox HA-20MB for 2100 g Plutonium Limit Set....

Table 5-12. MCNP Calculational Results of Interaction Cases in Glovebox HA-20MB for $2100 \mathrm{~g}$ Plutonium Limit Set.

\section{List of Figures}

Figure 1. Approximate Layout for Gloveboxes and Conveyors Utilized for Thermal Stabilization Activities $2-3$

Figure 2. Cutaway End View from North of Glovebox HA-20MB ................................... 2-4

Figure 3. Layout of Glovebox HA-20MB for Cementation Processing ................................ 2-5

Figure 4. Cementation Process Flow Diagram ........................................................... 2-7 
HNF-5988 Rev. 0

\section{List of Terms}

$\begin{array}{ll}\text { AIChE } & \text { American Institute of Chemical Engineers } \\ \text { ANSI } & \text { American National Standards Institute } \\ \text { ANS } & \text { American Nuclear Society } \\ \text { CSER } & \text { Criticality Safety Evaluation Report } \\ \text { DOE } & \text { United States Department of Energy } \\ \text { GB } & \text { glovebox } \\ \text { ID } & \text { Identification Number } \\ \text { MCM } & \text { Minimum Critical Mass } \\ \text { NC } & \text { No Controls } \\ \text { NDA } & \text { Nondestructive Analysis } \\ \text { PFP } & \text { Plutonium Finishing Plant } \\ \text { PHA } & \text { Preliminary Hazards Analysis } \\ \text { SS\&C } & \text { Sand, Slag, and Crucible }\end{array}$

\section{List of Definitions}

Container - Any vessel that is in a position to hold solids or liquids (e.g., a pan turned upside down is not a container).

Contingency - A possible but unlikely change in a condition/control important to the nuclear criticality safety of a fissionable material operation that would, if it occurred, reduce the number of barriers (either administrative or physical) that are intended to prevent an accidental nuclear criticality. 


\subsection{INTRODUCTION AND SUMMARY}

\subsection{INTRODUCTION}

The plutonium stabilization program at the Plutonium Finishing Plant (PFP) involves treatment of the residual inventory of plutonium at the plant by various means, dependent on the material form and makeup, to convert it into forms amenable to long term storage at PFP or for disposition elsewhere. There is a significant quantity of scrap plutonium-bearing materials stored in cans in various vaults and gloveboxes. Some of the scrap is in the form of sand, slag and crucible (SS\&C), ash, or oxide. These materials, along with other fissile residues that could be stabilized by the cementation process, are addressed by this criticality safety evaluation report (CSER).

It has been decided that the most expeditious means for storage and disposal of stabilized SS\&C scrap will be cementation by mixing granulized SS\&C with portland cement to form contaminated concrete billets. The Glovebox HA-20MB in Room $235 \mathrm{~B}$ has been selected for this operation, and the equipment therein is to be converted to the special requirements for the cementation process. As opposed to the other stabilization process gloveboxes (for furnace firing). the HA-20MB activities involve Pu mixed with water, and at a dilution that full moderation of the fissile material is the norm. The Pu-bearing slurry containers will include $4.73 \mathrm{~L}(5 \mathrm{qt})$ mixing bowls and $2.73 \mathrm{~L}$ cementing cans. Ash, oxide, and other less characterized fissile scrap may also undergo this process.

Criticality safety control is achieved with plutonium inventory limitations of $2100 \mathrm{~g}$ plutonium or fissile equivalent total in the glovebox for the limit set when the feed material is characterized as SS\&C, ash, or oxide. When the feed is not one of these materials, only $1200 \mathrm{~g}$ plutonium or fissile equivalent is allowed. No more than $200 \mathrm{~g}$ of this fissile material is allowed in any one container and no more than $300 \mathrm{~g}$ of this fissile material can be holdup and it must be evenly distributed throughout the glovebox.

Holdup is analyzed separately from the process material in this CSER, contrary to the standard practice of combining it with the other fissile material in the most reactive arrangement. Normally, the holdup is a small percentage of the fissile mass allowed in the glovebox and can be conservatively combined with the process mass, not significantly impacting glovebox operation. However, for cementation operations, the holdup is a significant portion of the allowable fissile mass so it must be analyzed separately as a distributed mass. A spill is considered part of the process mass and must be cleaned up prior to continuing operation, so that the holdup does not become concentrated.

When cured, the 14-cm (5.5-in.) diameter by $17.78 \mathrm{~cm}(7 \mathrm{in}$.) tall cans of hardened cement will be loaded out of the glovebox for eventual disposition in special 55 gallon drums, which will accommodate up to three of these cemented cans. A loading limit of $200 \mathrm{~g}$ is imposed per drum, so that a cement can loaded to the container limit would still be acceptable by itself. 
The evaluation shows that under the controls specified, assurance of subcriticality under normal and plausible upset conditions is provided which satisfies the double contingency criterion set forth in the Hanford Site Nuclear Criticality Safety Manuals. That is, at least two unlikely, independent, and concurrent changes in process conditions are required before a criticality is possible.

There is a pre-existing holdup of $\mathrm{Pu}$ as surface contamination of the walls and floor in Glovebox HA-20MB. Although the total NDA value of $179 \mathrm{~g}$ of plutonium for the present quatity of holdup is on the order of a third of a Minimum Critical Mass (MCM), the material is so thinly distributed to be of minor consequence to the criticality safety controls.

\subsection{DOUBLE CONTINGENCY DOCUMENTATION}

This section presents a summary description of expected operations, expected normal conditions, base case of normal condition plus anticipated off-normal conditions for cementation operations and results of the contingency analyses.

\section{Expected Operation:}

Sand, slag, and crucible (SS\&C) scrap is processed through a crusher to prepare a particle size to expedite reaction of residual calcium. A sieve may be used to sort out pieces that require further grinding. The resultant material is reacted in $4.73 \mathrm{~L}$ mixing bowls containing approximately $1.5 \mathrm{~L}$ of chilled water. After reacting the calcium, cement powder and water are added to create a cement mud that is poured into $14 \mathrm{~cm}(5.5 \mathrm{in}$.) diameter, $17.8 \mathrm{~cm} \mathrm{(7} \mathrm{in.)} \mathrm{tall}$ cans. After curing, the cans are transferred out of the glovebox to 55 gallon drums for storage. Incinerator ash, oxides, and other residues could also be stabilized by this cementation process and may not use the crusher. There will be no liquid feed material.

The criticality safety of this operation depends upon the characterization of the neutron moderation possible for these materials. It is assumed that the mixing bowls can contain fully moderated plutonium and the cement mud could be up to $90 \%$ water. Two limit sets are developed to accommodate either fully moderated feed material or SS\&C, ash, or oxide (feed material that fits the description of Appendices F and G). One limit set allows unrestricted moderation feed. The second limit set allows more fissile mass in the glovebox but requires the operator to examine each container as it is brought into the glovebox if the material is ash or oxide to verify contents and assure no free liquid in the container. SS\&C does not require operator verification because it is not credible to have $H / X>20$, free liquid, or to confuse container with other material types. 
HNF-5988 Rev. 0

\subsubsection{LIMIT SET A: 1200 G LIMIT WHEN FEED MATERIAL TYPE OR MODERATION DOES NOT SATISFY REQUIREMENTS OF LIMIT SET B}

\section{Expected Normal Conditions:}

For limit set A, Glovebox HA-20MB may contain general scrap materials with plutonium and/or uranium in metal, alloy, or oxide form with unrestricted moderation. The glovebox total fissile mass, including holdup, is limited to $1200 \mathrm{~g}$ plutonium or fissile equivalent with the uranium ${ }^{235} \mathrm{U}$ enrichment less than or equal to $50 \%$. This mass is limited to $200 \mathrm{~g} \mathrm{Pu}$ in each mixing bowl, $500 \mathrm{~g} \mathrm{Pu}$, total, in the other containers, and $300 \mathrm{~g} \mathrm{Pu}$ evenly distributed around the glovebox as holdup. If the holdup is predominately in one location, such as a spill, then the holdup must be considered part of the mass limit for the containers it spilled from. Therefore, spills should be promptly cleaned up. Each container can contain up to $200 \mathrm{~g}$ Pu or fissile equivalent and is limited to a height of $17.8 \mathrm{~cm}(7 \mathrm{in}$.) when resting on the glovebox floor. Normally, material enters the glovebox in containers with about $60 \mathrm{~g} \mathrm{Pu}$ and leaves the glovebox in cement billets with up to $180 \mathrm{~g} \mathrm{Pu}$. Container volumes are limited to $4.73 \mathrm{~L}$ for mixing bowls and $2.76 \mathrm{~L}$ for other containers, except for the sieve assembly that can be $4.9 \mathrm{~L}$ and the auger/conveyor unit that can be $2.83 \mathrm{~L}$. Minimum spacing of $25.4 \mathrm{~cm}(10 \mathrm{in}$.) is required between mixing bowls and between mixing bowls and other containers except when transferring material into or out of a mixing bowl. Minimum spacing of $25.4 \mathrm{~cm}$ is also maintained to fissile items in Conveyor Glovebox HA-28. No spacing is required among the other containers inside Glovebox HA-20MB. Transition and storage spacing of $45.7 \mathrm{~cm}$ (18 in.) and $91.4 \mathrm{~cm} \mathrm{(36} \mathrm{in.),}$ respectively, for fissile material outside of Glovebox HA-20MB apply with one exception. Waste drums containing up to $200 \mathrm{~g}$ of plutonium or fissile equivalent are allowed to pass by the north end of Glovebox HA-20MB with $15.2 \mathrm{~cm}$ (6 in.) spacing to fissile containers inside the glovebox. A five-gallon feedwater container is allowed, but it is prohibited to add fissile material to this container. Any opening to the feedwater container must be configured such that there is no credible accidental means of introducing fissile-bearing material.

\section{Base Case Model for Limit Set A:}

The base case encompasses the normal and worst-case likely off-normal events. Two mixing bowls each contain $200 \mathrm{~g}$ Pu homogeneously mixed with water. The other $500 \mathrm{~g}$ of $\mathrm{Pu}$ is modeled conservatively as $18 \mathrm{~cm}(7.1 \mathrm{in}$.) tall, $2.76 \mathrm{~L}$ containers. The most reactive arrangement of these containers is to place the $500 \mathrm{~g}$ in seven containers completely surrounded by containers of cement or water and the two mixing bowls placed adjacent to each other in the corner of the glovebox and spaced $25.4 \mathrm{~cm}$ (10 in.) from the other containers. For the mixing bowls, the corner of the glovebox surrounded by $30.5 \mathrm{~cm}$ of water provides the maximum neutron reflection for containers that must be spaced $25.4 \mathrm{~cm}$ (10 in.) from other fissile-bearing containers. On the other hand, cement cans or cans of water, close packed, provide the greatest reflection for other fissile material that can be grouped without spacing. The mixing bowls are placed together to allow containers to be brought together for material transfer, for mixing, crushing, and conveying into the mixing bowl, or to simulate the likely loss of spacing between two containers. This arrangement is more reactive than if the containers were at the other end of the glovebox with a 4.7 L container with $400 \mathrm{~g}$ of fully moderated Pu on Conveyor HA-28 spaced $25.4 \mathrm{~cm}$ (10 in.) 
from these containers. A $2.76 \mathrm{~L}$ volume containing $200 \mathrm{~g}$ of $\mathrm{Pu}$ representing a waste drum passing just $15.2 \mathrm{~cm}$ ( 6 in.) past the north end of the glovebox in the normal case is less reactive than the $30.5 \mathrm{~cm}$ (12 in.) water reflection that surrounds the entire glovebox. Water reflection of $2.54 \mathrm{~cm}$ ( 1 in.) is placed around non-adjacent containers to represent hands, rags, and plastic waste packages and structural components that may be present in the glovebox. A $2.54 \mathrm{~cm}$ (1 in.) of water reflection is placed on top of all containers. The $300 \mathrm{~g} \mathrm{Pu}$ as holdup is distributed uniformly on the floor of the glovebox including under the fissile containers with $30.5 \mathrm{~cm}$ water reflection under that. The $\mathrm{k}_{\text {eff }}$ for this base case is $0.8647 \pm 0.0009$ (case c0001 $\mathrm{flb}$ b).

Table 1-1. Glovebox HA-20MB - Limit Set A Base Case Limits Summary

\begin{tabular}{|c|c|c|}
\hline Controlled Parameter & Limit & $\begin{array}{l}\text { Abnormal but anticipated } \\
\text { conditions (conservatism for } \\
\text { analysis) }\end{array}$ \\
\hline Mass & $\begin{array}{l}\text { Maximum } 1200 \mathrm{~g} \mathrm{Pu} \& \text { fissile } \\
\text { equiv. Glovebox total including } \\
\text { holdup; } 200 \mathrm{~g} \mathrm{Pu} \text { per mixing } \\
\text { bowl; } 500 \mathrm{~g} \text { total in other } \\
\text { containers with no more than } \\
200 \mathrm{~g} \text { in any one container; } \\
300 \mathrm{~g} \mathrm{Pu} \text { holdup }\end{array}$ & All fissile modeled as ${ }^{239} \mathrm{Pu}$ \\
\hline Volume & $\begin{array}{l}\text { Two mixing bowls with } \\
\text { maximum } 4.73 \mathrm{~L} \text { per bowl; } \\
4.9 \mathrm{~L} \text { sieve pan assembly; } 50 \mathrm{ml} \\
\text { of lubricants; crusher/hopper } \\
1.1 \mathrm{~L} \text {; auger/hopper } 2.83 \mathrm{~L} \text {; other } \\
\text { containers with maximum height } \\
\text { of } 17.8 \mathrm{~cm} \text { and maximum } \\
\text { volume of } 2.76 \mathrm{~L} \text { except one } \\
\text { five-gallon feedwater container } \\
\text { into which it is not permitted to } \\
\text { introduce fissile material and no } \\
\text { credible accidental means of } \\
\text { adding fissile material exists }\end{array}$ & $\begin{array}{l}\text { Mixing bowls were modeled as } \\
4.8 \mathrm{~L} \text {; other containers as } 2.76 \mathrm{~L}\end{array}$ \\
\hline Moderation & NA & \\
\hline Interaction & $\begin{array}{l}\text { No stacking of containers; } \\
25.4 \mathrm{~cm}(10 \mathrm{in} \text {.) minimum } \\
\text { spacing between mixing bowls } \\
\text { and between mixing bowls and } \\
\text { other containers except during } \\
\text { material transfer; } 25.4 \mathrm{~cm} \\
\text { minimum spacing to fissile } \\
\text { material in Conveyor Glovebox } \\
\text { HA- } 28 ; 15.2 \mathrm{~cm} \text { minimum } \\
\text { spacing between waste drums on }\end{array}$ & $\begin{array}{l}\text { Two full mixing bowls are placed } \\
\text { next to each other and next to full } \\
\text { neutron reflection glovebox walls } \\
\text { to conservatively simulate } \\
\text { transfer of fissile material from } \\
\text { container to container. }\end{array}$ \\
\hline
\end{tabular}


HNF-5988 Rev. 0

\begin{tabular}{|c|c|c|}
\hline Controlled Parameter & Limit & $\begin{array}{l}\text { Abnormal but anticipated } \\
\text { conditions (conservatism for } \\
\text { analysis) }\end{array}$ \\
\hline & $\begin{array}{l}\text { the north side of the glovebox } \\
\text { and fissile material containers } \\
\text { inside glovebox }\end{array}$ & \\
\hline Reflection & $\begin{array}{l}\text { Dry fire suppression system } \\
\text { within glovebox }\end{array}$ & $\begin{array}{l}\text { Full water reflection around } \\
\text { glovebox }, 2.54 \mathrm{~cm}(1 \mathrm{in} .) \text { water } \\
\text { reflection around fissile } \\
\text { containers if not closely packed }\end{array}$ \\
\hline Geometry & $\begin{array}{l}\text { Pu in designated containers with } \\
\text { a maximum } 17.8 \mathrm{~cm} \text { ( } 7 \text { in.) } \\
\text { height except holdup uniformly } \\
\text { distributed on floor }\end{array}$ & Containers modeled $18 \mathrm{~cm}$ tall \\
\hline Isotopics & NA & $100 \%{ }^{239} \mathrm{Pu}$ \\
\hline Enrichment & Maximum $50 \%{ }^{235} \mathrm{U}$ in $\mathrm{U}$ & $\begin{array}{l}{ }^{235} \mathrm{U} \text { treated as }{ }^{239} \mathrm{Pu} \text { fissile } \\
\text { equivalent }\end{array}$ \\
\hline Density & NA & \\
\hline Concentration & $\mathrm{NA}$ & $\begin{array}{l}\text { Plutonium in the most reactive } \\
\text { arrangement among the } \\
\text { containers }\end{array}$ \\
\hline Poisons & NA & \\
\hline
\end{tabular}

The mass of fissile material in each feed container is determined before it is brought into Glovebox HA-20MB. Therefore, it is unlikely that the mass limits in the table above will be exceeded and subsequently no anticipated abnormal mass conditions are included in the base case.

\section{Contingency Summary for Limit Set A:}

Table 1-2 summarizes the analyses of the unlikely, independent, off-normal events (contingencies). Each event is assumed to occur with the glovebox configured as the described base case with the contingency added. The resultant computed reactivity is compared to the subcriticality target $\mathrm{k}_{\mathrm{eff}}$ of 0.932 for MCNP calculations of metal plutonium systems, as explained in Section 4.0. This table summarizes the results of the contingency evaluation found in Section 5.0. Specific $\mathrm{k}_{\mathrm{eff}}$ calculations were not made for contingencies in Table 1.2 that were bounded by other analyzed contingencies. 
HNF-5988 Rev. 0

Table 1-2. Glovebox HA-20MB - Limit Set A Contingency Summary

\begin{tabular}{|c|c|c|c|}
\hline $\begin{array}{l}\text { Contingency } \\
\text { Description }\end{array}$ & $\begin{array}{l}\text { Affected } \\
\text { Parameter } \\
\text { (s) }\end{array}$ & $\begin{array}{l}\text { Barriers that make contingency } \\
\text { unlikely }\end{array}$ & $\begin{array}{l}\mathbf{k}_{\text {eff }} \text { bounding } \\
\text { contingency } \\
\text { (case ID) }\end{array}$ \\
\hline $\begin{array}{l}\text { Seismic event with } \\
\text { container spill and } \\
\text { flooding that } \\
\text { washes fissile } \\
\text { material from } \\
\text { containers and } \\
\text { holdup to } \\
\text { accumulate in } \\
\text { conveyor housing }\end{array}$ & $\begin{array}{l}\text { Volume } \\
\text { Geometry }\end{array}$ & $\begin{array}{l}\text { Seismic event unlikely; requires severe } \\
\text { damage to glovebox, breaking windows } \\
\text { and seal to cover of conveyor housing } \\
\text { under glovebox, breaking of fire } \\
\text { suppression system piping, all } \\
\text { containers spilling and washing into } \\
\text { conveyor housing. }\end{array}$ & $\begin{array}{l}0.4344 \pm 0.0007 \\
(\mathrm{c} 0001 \mathrm{fl} \mathrm{q} 5)\end{array}$ \\
\hline $\begin{array}{l}\text { Seismic event with } \\
\text { containers } \\
\text { grouping together } \\
\text { with no spacing } \\
\text { surrounded by cans } \\
\text { of cement or water }\end{array}$ & Interaction & $\begin{array}{l}\text { Seismic event unlikely; requires severe } \\
\text { damage to glovebox, breaking windows } \\
\text { with all containers collecting together } \\
\text { in the most reactive arrangement, and } \\
\text { breaking of fire suppression system } \\
\text { piping; it is unlikely that interspersed } \\
\text { water from fire suppression system } \\
\text { would have as high of a density as } 0.1 \\
\text { g/cc }\end{array}$ & $\begin{array}{l}0.9226 \pm 0.0009 \\
(\mathrm{c} 0001 \mathrm{flq} \text { la })\end{array}$ \\
\hline $\begin{array}{l}\text { Fire with } \\
\text { interspersed water } \\
\text { and fissile material } \\
\text { washing out of } \\
\text { containers }\end{array}$ & $\begin{array}{l}\text { Geometry } \\
\text { Reflection }\end{array}$ & $\begin{array}{l}\text { Major building fire that melts glovebox } \\
\text { panels is unlikely; it is unlikely that } \\
\text { the fire sprinkler water would add as } \\
\text { high of an interspersed water density as } \\
0.1 \mathrm{~g} / \mathrm{cc} \text { and cause all the fissile } \\
\text { material to be washed from containers }\end{array}$ & $\begin{array}{l}0.8329 \pm 0.0008 \\
(\mathrm{c} 0001 \mathrm{f} 1 \mathrm{f} 2)\end{array}$ \\
\hline $\begin{array}{l}\text { Fire with } \\
\text { interspersed water } \\
\text { and material stays } \\
\text { in containers }\end{array}$ & Reflection & $\begin{array}{l}\text { Major fire that melts glovebox glass is } \\
\text { unlikely; it is unlikely that the fire } \\
\text { sprinkler water would add as high of an } \\
\text { interspersed water density as } 0.1 \mathrm{~g} / \mathrm{cc}\end{array}$ & $\begin{array}{l}0.8567 \pm 0.0009 \\
(\mathrm{c} 0001 \mathrm{flfl})\end{array}$ \\
\hline $\begin{array}{l}\text { Mixing bowl } \\
\text { stacked on } 2.76 \mathrm{~L} \\
\text { containers }\end{array}$ & Interaction & $\begin{array}{l}\text { Operator training, procedure, no } \\
\text { stacking anywhere at PFP }\end{array}$ & $\begin{array}{l}0.9296 \pm 0.0008 \\
(\mathrm{c} 0001 \mathrm{f} 1 \mathrm{~s} 3)\end{array}$ \\
\hline $\begin{array}{l}\text { Extra container with } \\
200 \mathrm{~g} \mathrm{Pu} \text { in } \\
\text { glovebox, stacked } \\
\text { on } 2.76 \mathrm{~L} \\
\text { containers }\end{array}$ & $\begin{array}{l}\text { Mass } \\
\text { Interaction }\end{array}$ & $\begin{array}{l}\text { Operator training, procedure, fissile } \\
\text { inventory control, posted limits }\end{array}$ & $\begin{array}{l}0.9078 \pm 0.0009 \\
(\mathrm{c} 0001 \mathrm{fls} 5)\end{array}$ \\
\hline $\begin{array}{l}\text { Wagon with max. } \\
\text { Pu loading under } \\
\text { glovebox }\end{array}$ & Interaction & Operator training, procedure & $\begin{array}{l}0.8451 \pm 0.0010 \\
(\mathrm{c} 0001 \mathrm{f} 1 \mathrm{w} 1)\end{array}$ \\
\hline
\end{tabular}


HNF-5988 Rev. 0

\begin{tabular}{|c|c|c|c|}
\hline $\begin{array}{l}\text { Contingency } \\
\text { Description }\end{array}$ & $\begin{array}{l}\text { Affected } \\
\text { Parameter } \\
\text { (s) }\end{array}$ & $\begin{array}{l}\text { Barriers that make contingency } \\
\text { unlikely }\end{array}$ & $\begin{array}{l}\mathbf{k}_{\text {eff }} \text { bounding } \\
\text { contingency } \\
\text { (case ID) }\end{array}$ \\
\hline $\begin{array}{l}\text { Mixing bowls } \\
\text { stacked }\end{array}$ & Interaction & Operator training, procedure & $\begin{array}{l}0.8674 \pm 0.0008 \\
(\mathrm{c} 0001 \mathrm{fls} 6)\end{array}$ \\
\hline $\begin{array}{l}\text { Loss of 15.24-cm } \\
\text { (6-in.) spacing } \\
\text { between drum } \\
\text { passing on north } \\
\text { end and contents of } \\
\text { glovebox }\end{array}$ & Interaction & Operator training, procedure & $\begin{array}{l}0.8687 \pm 0.0008 \\
(\mathrm{c} 0001 \mathrm{f} 1 \mathrm{~b} 7 \mathrm{~g})\end{array}$ \\
\hline $\begin{array}{l}\text { Loss of spacing to } \\
\text { item on Conveyor } \\
\text { Glovebox HA-28 } \\
(400 \mathrm{~g}, 4.7 \mathrm{~L}, \\
\mathrm{H} / \mathrm{X}>20)\end{array}$ & Interaction & $\begin{array}{l}\text { Operator training, procedure, unlikely } \\
\text { to have container greater than } 2.7 \mathrm{~L}\end{array}$ & $\begin{array}{l}0.9097 \pm 0.0009 \\
(\mathrm{c} 0001 \mathrm{f} 1 \mathrm{~b} 17)\end{array}$ \\
\hline $\begin{array}{l}\text { Extra mixing bowl } \\
\text { with some fissile } \\
\text { mass out of other } \\
\text { containers }\end{array}$ & Volume & $\begin{array}{l}\text { Operator training/procedure; more } \\
\text { likely to use smaller container to clean } \\
\text { up a mess }\end{array}$ & $\begin{array}{l}\text { Less reactive than } \\
\text { extra container } \\
\text { stacked }\end{array}$ \\
\hline $\begin{array}{l}\text { Excess holdup } \\
\text { exceeding glovebox } \\
\text { mass limit }\end{array}$ & Mass & $\begin{array}{l}\text { Operator training/procedure/inventory } \\
\text { control }\end{array}$ & $\begin{array}{l}\text { Less reactive than } \\
\text { extra container } \\
\text { stacked }\end{array}$ \\
\hline Container too large & Volume & Operator training/procedure & $\begin{array}{l}\text { Less reactive than } \\
\text { bowls stacked }\end{array}$ \\
\hline Extra oil or plastic & Moderation & Operator training/procedure & $\begin{array}{l}\text { Less reactive than } \\
\text { fire analysis for } \\
\text { reasonable } \\
\text { quantities of } \\
\text { plastic present }\end{array}$ \\
\hline
\end{tabular}

The hazards assessment determined that it is not credible to have uranium with ${ }^{235} \mathrm{U}$ enrichment exceeding $50 \%$ in this glovebox. Therefore, no contingency was evaluated for enrichment.

\subsubsection{LIMIT SET B: 2100 G LIMIT FOR SS\&C, INCINERATOR ASH, AND OXIDE}

\section{Expected Normal Conditions:}

For limit set B, feed material into Glovebox HA-20MB shall contain SS\&C, incinerator ash, or oxide described in Appendices F and G, provided there is no free liquid inside the feed containers. Each container of ash and oxide will be examined upon entry into the glovebox to verify contents and that there is no free liquid. SS\&C does not need examination. The material 
in Appendices $\mathrm{F}$ and $\mathrm{G}$ can be characterized as having $\mathrm{H} / \mathrm{X}$ less than or equal to 20 . Unlike limit set $\mathrm{A}$, a distinction must be made between the feed containers with limited moderation and the fully moderated cemented fissile containers. The feed material must be spaced at least $25.4 \mathrm{~cm}$ away from the cemented fissile material containers as well as the mixing bowls, except when transferring material into the mixing bowls, or crushing, mixing and conveying feed into the mixing bowls. The glovebox total fissile mass, including holdup, is limited to $2100 \mathrm{~g}$ plutonium or fissile equivalent with the uranium ${ }^{235} \mathrm{U}$ enrichment less than or equal to $50 \%$. This mass is limited to $200 \mathrm{~g} \mathrm{Pu}$ in each mixing bowl with unrestricted moderation, $500 \mathrm{~g} \mathrm{Pu}$, total, in other containers as cement with unrestricted moderation, $900 \mathrm{~g} \mathrm{Pu}$ in other containers as feed material with no free liquid, and $300 \mathrm{~g}$ Pu evenly distributed around the glovebox as holdup. Only feed material with plutonium content of up to $200 \mathrm{~g}$ in any number of containers can be open at a time. Spills must be promptly cleaned up or considered part of the mass of the group of containers from which it was spilled. Each individual container can contain up to $200 \mathrm{~g} \mathrm{Pu}$ or fissile equivalent and must be limited to $17.8 \mathrm{~cm}$ (7 in.) in height when resting on the glovebox floor. Normally, material enters the glovebox in containers with about $60 \mathrm{~g} \mathrm{Pu}$ and leaves the glovebox in cement billets with up to $180 \mathrm{~g} \mathrm{Pu}$. Much of the feed material fissile mass will enter as less than $60 \mathrm{~g}$ Pu per container, but no cemented billet will contain more than $200 \mathrm{~g} \mathrm{Pu}$. Container volumes are limited to $4.73 \mathrm{~L}$ for mixing bowls and $2.76 \mathrm{~L}$ for other containers, except for the sieve assembly that can be $4.9 \mathrm{~L}$. Minimum spacing of $25.4 \mathrm{~cm}$ (10 in.) is required between mixing bowls and between mixing bowls and other containers except when transferring material into or out of a mixing bowl. Minimum spacing of $25.4 \mathrm{~cm}$ is also maintained to fissile items in Conveyor Glovebox HA-28. No spacing is required among the other containers inside Glovebox HA-20MB. Transition and storage spacing of $45.7 \mathrm{~cm}$ (18 in.) and $91.4 \mathrm{~cm}$ (36 in.), respectively, for fissile material outside of Glovebox HA-20MB apply with one exception. Waste drums containing up to $200 \mathrm{~g}$ of plutonium or fissile equivalent are allowed to pass by the north end of Glovebox HA-20MB with $15.2 \mathrm{~cm}(6 \mathrm{in}$.) spacing to fissile containers inside the glovebox. A five-gallon feedwater container is allowed, but it is prohibited to add fissile material to this container. Any opening to the feedwater container must be configured such that there is no credible accidental means of introducing fissile-bearing material.

\section{Base Case Model for Limit Set B:}

The base case for limit set B includes the normal and worst-case likely off-normal events. Two mixing bowls each contain $200 \mathrm{~g}$ Pu homogeneously mixed with water and placed adjacent to each other in the corner of the glovebox. Cement containing $500 \mathrm{~g}$ of Pu is modeled as $90 \%$ water and $10 \%$ plutonium and silicon oxide in seven adjacent, close packed $2.76 \mathrm{~L}, 14 \mathrm{~cm}$ diameter, $18 \mathrm{~cm}$ high containers completely surrounded by containers filled with cement. Feed material is placed in 7 containers with $900 \mathrm{~g}$ of $\mathrm{Pu}$ with $\mathrm{H} / \mathrm{X}=20$ and the remaining volume filled with $33 \%$ carbon and $67 \%$ silicon oxide. These seven containers are also completely surrounded by containers of cement because neutron reflection is greater than if surrounded by containers of water or next to the $30.5 \mathrm{~cm}$ of water reflection modeled around the glovebox. Glovebox holdup of $300 \mathrm{~g} \mathrm{Pu}$ is distributed on the floor of the glovebox, including under each of these containers, with $30.5 \mathrm{~cm}$ of water under that. The glovebox is completely surrounded by $30.5 \mathrm{~cm}$ thick, full neutron reflection water to simulate operators standing close by. The mixing bowls are placed together to allow containers to be brought together for material transfer, for 
mixing, grinding, and conveying into the mixing bowl, or to simulate the likely loss of spacing between two containers. This arrangement is more reactive than if the material was placed within $25.4 \mathrm{~cm}$ ( $10 \mathrm{in}$.) of a $2.76 \mathrm{~L}$ container with $400 \mathrm{~g}$ of fully moderated $\mathrm{Pu}$ that is allowed on the conveyor. A $2.76 \mathrm{~L}$ volume containing $200 \mathrm{~g}$ of Pu representing a waste drum passing just $15.2 \mathrm{~cm}$ ( $6 \mathrm{in}$.) past the north end of the glovebox in the normal case is replaced with a more reactive full water reflection wall. Water reflection of $2.54 \mathrm{~cm}(1 \mathrm{in}$.) is placed around the containers that are not close packed to represent hands, rags, and plastic waste packages that may be present in the glovebox. A $2.54 \mathrm{~cm}$ ( $1 \mathrm{in}$.) of water is modeled on top of all containers. Table 1-3 summarizes the base case for Limit Set B. The $k_{\text {eff }}$ for this base case is $0.8607 \pm 0.0009$ (case c0001f2b4).

Table 1-3. Glovebox HA-20MB - Limit Set B Base Case Limits Summary

\begin{tabular}{|c|c|c|}
\hline Controlled Parameter & Limit & $\begin{array}{l}\text { Abnormal but anticipated } \\
\text { conditions (conservatism for } \\
\text { analysis) }\end{array}$ \\
\hline Mass & $\begin{array}{l}\text { Maximum } 2100 \mathrm{~g} \text { Pu \& fissile } \\
\text { equiv. Glovebox total including } \\
\text { holdup; } 200 \mathrm{~g} \mathrm{Pu} \text { per mixing } \\
\text { bowl; } 500 \mathrm{~g} \mathrm{Pu} \text { total in cement } \\
\text { containers, } 900 \mathrm{~g} \mathrm{Pu} \text { total with } \\
200 \mathrm{~g} \mathrm{Pu} \text { per container in feed } \\
\text { material, containers and crusher/ } \\
\text { hopper, auger/hopper; } 300 \mathrm{~g} \mathrm{Pu} \\
\text { holdup }\end{array}$ & All fissile modeled as ${ }^{239} \mathrm{Pu}$ \\
\hline Volume & $\begin{array}{l}\text { Two mixing bowls with } \\
\text { maximum } 4.73 \mathrm{~L} \text { per bowl; } \\
4.9 \mathrm{~L} \text { sieve pan assembly; } 50 \mathrm{ml} \\
\text { of lubricants; crusher/hopper } \\
1.1 \mathrm{~L} \text {, auger/hopper } 2.83 \mathrm{~L} \text {; other } \\
\text { containers with maximum height } \\
\text { of } 17.8 \mathrm{~cm} \text { and maximum } \\
\text { volume of } 2.76 \mathrm{~L} \text { except one } \\
\text { five-gallon feedwater container } \\
\text { into which it is not permitted to } \\
\text { introduce fissile material and no } \\
\text { credible accidental means of } \\
\text { adding fissile material exists }\end{array}$ & $\begin{array}{l}\text { Mixing bowls were modeled as } \\
4.8 \mathrm{~L} \text {; other containers as } 2.76 \mathrm{I} \text {. }\end{array}$ \\
\hline Moderation & $\begin{array}{l}\text { No free liquid in feed containers: } \\
\text { no more than } 200 \mathrm{~g} \mathrm{Pu} \text { in open } \\
\text { feed containers, auger, crusher, } \\
\text { or hopper at a time }\end{array}$ & \\
\hline
\end{tabular}


HNF-5988 Rev. 0

\begin{tabular}{|c|c|c|}
\hline Controlled Parameter & Limit & $\begin{array}{l}\text { Abnormal but anticipated } \\
\text { conditions (conservatism for } \\
\text { analysis) }\end{array}$ \\
\hline Interaction & $\begin{array}{l}\text { No stacking of containers; } \\
25.4 \mathrm{~cm}(10 \mathrm{in} \text {.) minimum } \\
\text { spacing between mixing bowls } \\
\text { and between mixing bowls and } \\
\text { other containers and between } \\
\text { feed material and cement } \\
\text { containers with fissile material } \\
\text { except during material transfer; } \\
\text { spacing is not required among } \\
\text { feed containers or among cement } \\
\text { containers with fissile material, }\end{array}$ & $\begin{array}{l}\text { Two mixing bowls placed next to } \\
\text { each other to simulate fissile } \\
\text { material transfer. }\end{array}$ \\
\hline Interaction (continued) & $\begin{array}{l}25.4 \mathrm{~cm} \text { minimum spacing to } \\
\text { fissile material in Conveyor } \\
\text { Glovebox HA-28; } 15.2 \mathrm{~cm} \\
\text { minimum spacing between waste } \\
\text { drums on the north side of the } \\
\text { glovebox and fissile material } \\
\text { containers inside glovebox }\end{array}$ & \\
\hline Reflection & $\begin{array}{l}\text { Dry fire suppression system } \\
\text { within glovebox }\end{array}$ & $\begin{array}{l}\text { Full reflection around glovebox } \\
\text { and } 2.54 \mathrm{~cm}(1 \mathrm{in} .) \text { water } \\
\text { reflection on top of and around } \\
\text { fissile containers not close packed }\end{array}$ \\
\hline Geometry & $\begin{array}{l}\text { Pu in designated containers with } \\
\text { a maximum } 17.8 \mathrm{~cm}(7 \mathrm{in} .) \\
\text { height except uniformly } \\
\text { distributed holdup }\end{array}$ & Containers modeled $18 \mathrm{~cm}$ tall \\
\hline Isotopics & NA & $100 \%{ }^{239} \mathrm{Pu}$ \\
\hline Enrichment & Maximum $50 \%{ }^{235} \mathrm{U}$ in $\mathrm{U}$ & $\begin{array}{l}{ }^{235} \mathrm{U} \text { treated as }{ }^{239} \mathrm{Pu} \text { fissile } \\
\text { equivalent }\end{array}$ \\
\hline Density & $\mathrm{NA}$ & \\
\hline Concentration & NA & $\begin{array}{l}\text { Pu concentration to maximize } \\
\text { reactivity }\end{array}$ \\
\hline Poisons & NA & \\
\hline
\end{tabular}

The mass of fissile material in each feed container is determined before it is brought into Glovebox HA-20MB. Therefore, it is unlikely that the mass limits in the table above will be exceeded and subsequently no anticipated abnormal mass conditions are included in the base case. 
HNF-5988 Rev. 0

\section{Contingency Summary for Limit Set B:}

Table 1-4 summarizes the analyses of the unlikely, independent, off-normal events (contingencies). Each event is assumed to occur with the glovebox configured as the described base case with the contingency added. The resultant computed reactivity is compared to the subcriticality target $\mathrm{k}_{\mathrm{eff}}$ of 0.942 for MCNP calculations of plutonium non-metal systems, conservative for the combination of materials in the limit set, as explained in Section 4.0. This table summarizes the results of the contingency evaluation found in Section 5.0. Specific $k_{\text {eff }}$ calculations were not made for contingencies in Table 1.4 that were bounded by other analyzed contingencies.

Table 1-4. Glovebox HA-20MB - Limit Set B Contingency Summary

\begin{tabular}{|c|c|c|c|}
\hline $\begin{array}{l}\text { Contingency } \\
\text { Description }\end{array}$ & $\begin{array}{l}\text { Affected } \\
\text { Parameter(s) }\end{array}$ & $\begin{array}{l}\text { Barriers that make contingency } \\
\text { unlikely }\end{array}$ & $\begin{array}{l}\mathbf{k}_{\text {eff }} \text { bounding } \\
\text { contingency } \\
\text { (case ID) }\end{array}$ \\
\hline $\begin{array}{l}\text { Seismic event } \\
\text { with container } \\
\text { spill and } \\
\text { flooding that } \\
\text { washes fissile } \\
\text { material from } \\
\text { containers and } \\
\text { holdup to } \\
\text { accumulate in } \\
\text { conveyor } \\
\text { housing }\end{array}$ & $\begin{array}{l}\text { Volume } \\
\text { Geometry }\end{array}$ & $\begin{array}{l}\text { Seismic event unlikely; requires severe } \\
\text { damage to glovebox, breaking windows } \\
\text { and seal to cover of conveyor housing } \\
\text { under glovebox and breaking of fire } \\
\text { suppression system piping }\end{array}$ & $\begin{array}{l}0.7199 \pm 0.0008 \\
(c 0001 f 2 q 4 a)\end{array}$ \\
\hline $\begin{array}{l}\text { Seismic event } \\
\text { with containers } \\
\text { grouping } \\
\text { together with } \\
\text { no spacing } \\
\text { surrounded by } \\
\text { close packed } \\
\text { cans of cement } \\
\text { or water }\end{array}$ & Interaction & $\begin{array}{l}\text { Seismic event unlikely; requires severe } \\
\text { damage to glovebox, breaking windows } \\
\text { with all containers collecting together in } \\
\text { the most reactive arrangement, and } \\
\text { breaking of fire suppression system } \\
\text { piping; it is unlikely that interspersed } \\
\text { water from fire suppression system } \\
\text { would have as high of a density as } 0.1 \\
\text { g/cc }\end{array}$ & $\begin{array}{l}0.9413 \pm 0.0009 \\
(\mathrm{c} 000112 \mathrm{q} 1)\end{array}$ \\
\hline $\begin{array}{l}\text { Fire with } \\
\text { interspersed } \\
\text { water and } \\
\text { fissile material } \\
\text { washed out of } \\
\text { containers }\end{array}$ & $\begin{array}{l}\text { Geometry } \\
\text { Reflection }\end{array}$ & $\begin{array}{l}\text { Major building fire that melts glovebox } \\
\text { panels is unlikely; it is unlikely that the } \\
\text { fire sprinkler water would add as high of } \\
\text { an interspersed water density as } 0.1 \mathrm{~g} / \mathrm{cc} \\
\text { and cause all the fissile material to be } \\
\text { washed from containers }\end{array}$ & $\begin{array}{l}0.6569 \pm 0.0009 \\
(\mathrm{c} 0001 \mathrm{f} 2 \mathrm{f} 3)\end{array}$ \\
\hline $\begin{array}{l}\text { Fire with } \\
\text { interspersed } \\
\text { water and no }\end{array}$ & Reflection & $\begin{array}{l}\text { Major fire that melts glovebox glass is } \\
\text { unlikely; it is unlikely that the fire } \\
\text { sprinkler water would add as high of an }\end{array}$ & $\begin{array}{l}0.8515 \pm 0.0009 \\
(\mathrm{c} 0001 \mathrm{f} 2 \mathrm{f} 5 \mathrm{a})\end{array}$ \\
\hline
\end{tabular}


HNF-5988 Rev. 0

\begin{tabular}{|c|c|c|c|}
\hline $\begin{array}{l}\text { Contingency } \\
\text { Description }\end{array}$ & $\begin{array}{l}\text { Affected } \\
\text { Parameter(s) }\end{array}$ & $\begin{array}{l}\text { Barriers that make contingency } \\
\text { unlikely }\end{array}$ & $\begin{array}{l}\mathbf{k}_{\text {efr bounding }} \text { contingency } \\
\text { (case ID) }\end{array}$ \\
\hline $\begin{array}{l}\text { fissile material } \\
\text { washed out of } \\
\text { containers; one } \\
\text { feed container } \\
\text { open }\end{array}$ & & interspersed water density as $0.1 \mathrm{~g} / \mathrm{cc}$ & \\
\hline $\begin{array}{l}\text { One feed } \\
\text { container with } \\
\text { unrestricted } \\
\text { moderation } \\
\text { brought into } \\
\text { glovebox }\end{array}$ & Moderation & $\begin{array}{l}\text { Feed container contents are from } \\
\text { processes with } \mathrm{H} / \mathrm{X} \leq 20 \text { and stored in } \\
\text { vaults where this moderation limit is } \\
\text { imposed, so unlikely to get a more } \\
\text { moderated container; visual inspection } \\
\text { and removal of container from glovebox } \\
\text { assures a second moderation violation is } \\
\text { not credible }\end{array}$ & $\begin{array}{l}\text { Less reactive than } \\
\text { fire with one feed } \\
\text { container open }\end{array}$ \\
\hline $\begin{array}{l}\text { Feed container } \\
\mathrm{H} / \mathrm{X}=200, \\
\text { representing } \\
\text { more } \mathrm{H} \\
\text { associated with } \\
\text { carbon content }\end{array}$ & Moderation & $\begin{array}{l}\text { From contents of Appendices F \& G, not } \\
\text { likely to have that much material with } \\
\text { carbon and hydrogen }\end{array}$ & $\begin{array}{l}0.8601 \pm 0.0008 \\
(\mathrm{c} 0001 \mathrm{f} 2 \mathrm{~b} 7)\end{array}$ \\
\hline $\begin{array}{l}\text { Mixing bowl } \\
\text { stacked on } 2.76 \\
\text { L containers }\end{array}$ & Interaction & $\begin{array}{l}\text { Operator training, procedure, no stacking } \\
\text { anywhere at PFP }\end{array}$ & $\begin{array}{l}0.9236 \pm 0.0009 \\
(\mathrm{c} 0001 \mathrm{f} 2 \mathrm{~s} 1)\end{array}$ \\
\hline $\begin{array}{l}\text { Extra container } \\
\text { with } 200 \mathrm{~g} \mathrm{Pu} \\
\text { in glovebox, } \\
\text { stacked on } 2.76 \\
\mathrm{~L} \text { containers }\end{array}$ & $\begin{array}{l}\text { Mass } \\
\text { Interaction }\end{array}$ & $\begin{array}{l}\text { Operator training, procedure, fissile } \\
\text { inventory control, posted limits }\end{array}$ & $\begin{array}{l}0.9022 \pm 0.0009 \\
(\mathrm{c} 0001 \mathrm{f} 2 \mathrm{~s} 3)\end{array}$ \\
\hline $\begin{array}{l}\text { Wagon with } \\
\text { max. } \mathrm{Pu} \\
\text { loading under } \\
\text { glovebox }\end{array}$ & Interaction & Operator training, procedure & $\begin{array}{l}0.8427 \pm 0.0009 \\
(\mathrm{c} 0001 \mathrm{f} 2 \mathrm{wl})\end{array}$ \\
\hline $\begin{array}{l}\text { Mixing bowls } \\
\text { stacked }\end{array}$ & Interaction & Operator training, procedure & $\begin{array}{l}0.8584 \pm 0.0008 \\
(\mathrm{c} 0001 \mathrm{f} 2 \mathrm{~s} 2)\end{array}$ \\
\hline $\begin{array}{l}\text { Loss of } \\
15.24-\mathrm{cm} \\
\text { (6-in.) spacing } \\
\text { between drum } \\
\text { passing on } \\
\text { north end and } \\
\text { contents of } \\
\text { glovebox }\end{array}$ & Interaction & Operator training, procedure & $\begin{array}{l}0.8602 \pm 0.0008 \\
(\mathrm{c} 0001 \mathrm{f} 2 \mathrm{bh} 4)\end{array}$ \\
\hline
\end{tabular}


HNF-5988 Rev. 0

\begin{tabular}{|l|l|l|l|}
\hline $\begin{array}{l}\text { Contingency } \\
\text { Description }\end{array}$ & $\begin{array}{l}\text { Affected } \\
\text { Parameter(s) }\end{array}$ & $\begin{array}{l}\text { Barriers that make contingency } \\
\text { unlikely }\end{array}$ & $\begin{array}{l}\text { keff bounding } \\
\text { contingency } \\
\text { (case ID) }\end{array}$ \\
\hline $\begin{array}{l}\text { Loss of spacing } \\
\text { to item on } \\
\begin{array}{l}\text { Conveyor } \\
\text { Glovebox } \\
\text { HA-28 }(400 \mathrm{~g}, \\
4.7 \mathrm{~L}, \mathrm{H} / \mathrm{X}>20)\end{array}\end{array}$ & $\begin{array}{l}\text { Interaction } \\
\text { have container greater than 2.7 L }\end{array}$ & $\begin{array}{l}\text { Operator training, procedure, unlikely to } \\
\text { (c0001 f2b9) }\end{array}$ \\
\hline $\begin{array}{l}\text { Extra mixing } \\
\text { bowl with } \\
\text { some fissile } \\
\text { mass out of } \\
\text { other } \\
\text { containers }\end{array}$ & Volume & $\begin{array}{l}\text { Operator training/procedure; more likely } \\
\text { to use smaller container to clean up a } \\
\text { mess }\end{array}$ & $\begin{array}{l}\text { Less reactive than } \\
\text { extra container } \\
\text { stacked }\end{array}$ \\
\hline $\begin{array}{l}\text { Excess holdup } \\
\text { exceeding } \\
\text { glovebox mass } \\
\text { limit }\end{array}$ & Mass & $\begin{array}{l}\text { Operator training/procedure/inventory } \\
\text { control }\end{array}$ & $\begin{array}{l}\text { Less reactive than } \\
\text { extra container } \\
\text { stacked }\end{array}$ \\
\hline $\begin{array}{l}\text { Container too } \\
\text { large }\end{array}$ & Volume & Operator training/procedure & $\begin{array}{l}\text { Less reactive than } \\
\text { bowls stacked }\end{array}$ \\
\hline $\begin{array}{l}\text { Extra oil or } \\
\text { plastic }\end{array}$ & Moderation & Operator training/procedure & $\begin{array}{l}\text { Less reactive than } \\
\text { fire analysis for } \\
\text { reasonable } \\
\text { quantities of } \\
\text { plastic present }\end{array}$ \\
\hline
\end{tabular}

The hazards assessment determined that it is not credible to have uranium with ${ }^{2.35} \mathrm{U}$ enrichment exceeding 50\% in this glovebox. Therefore, no contingency was evaluated for enrichment.

\subsection{SUMMARY}

Glovebox HA-20MB is located in Room 235B of the 234-5Z Building at the Plutonium Finishing Plant. This enclosure contains mixers, mixer bowls, a crusher unit, an isolated inoperable conveyor unit, plutonium residue feed cans, cemented cans, and a feedwater container. Plutonium residue, not conducive to other forms of stabilization, is prepared for storage and ultimate disposal by cementation. The feed residue material cans can have plutonium contents of only a few grams or up to 200 grams. This evaluation accommodates this wide range of container fissile concentrations.

Two glovebox limit sets are supported by this document. One limit set is for residue in any form except solutions and allows up to $1200 \mathrm{~g}$ plutonium or fissile equivalent in the 
glovebox. Up to $500 \mathrm{~g}$ plutonium can be in feed or cement cans, $200 \mathrm{~g}$ plutonium in each of two mixing bowls, and $300 \mathrm{~g}$ plutonium as glovebox holdup. The second limit set is specifically for sand, slag, and crucible (SS\&C), ash, or oxide feed material and allows up to 2100 g plutonium or fissile equivalent. Up to $500 \mathrm{~g}$ plutonium can be in cemented billets, $900 \mathrm{~g}$ plutonium in cans as feed, $200 \mathrm{~g}$ plutonium in each of two mixing bowls, and $300 \mathrm{~g}$ plutonium as glovebox holdup.

This criticality safety evaluation controls mass, volume, spacing, reflection, and geometry for both limit sets. For limit set B, moderation for the feed material is also controlled by feed material type and operator inspection to assure no free liquids. No fissile material can be allowed in the feedwater tank. Noticeable accumulations of fissile material, such as from spills, must be cleaned up before continuing operation. The cement content of the plutonium, water and cement mix must be adequate to assure that the moisture content of the cement does not exceed 90 volume percent. A ratio of at least $1500 \mathrm{~g}$ cement in $4.73 \mathrm{~L}$ is sufficient to displace 10 volume percent water. Cementation procedures require more than this ratio of cementation to water mixed prior to placing the mixture in the cement billet containers. During HEPA filter changeouts, all fissile-bearing containers must be removed from the glovebox. For limit set $\mathrm{B}$, a maximum of $200 \mathrm{~g}$ of plutonium can be in open containers, auger, crusher, or hopper at one time. The other feed material must be in closed containers. Also, for limit set B, each ash and oxide feed container must be inspected when loaded into HA-20MB to assure that it contains no free liquids. SS\&C containers need not be inspected. No containers can be stacked and PFP transition and storage spacing applies to fissile-bearing containers outside of the glovebox except for waste drums passing by the north side of HA-20MB where a minimum spacing of $15.2 \mathrm{~cm}(6$ in.) to material inside the glovebox is required.

Evaluation of this glovebox operation included normal, base cases, and contingencies. The base cases took the normal operations for each type of feed material and added the likely off-normal events. Each contingency is evaluated assuming the unlikely event happens to the conservative base case. A hazards assessment was conducted to assure that each credible unlikely event or set of correlated unlikely events was included in this analysis. The results of this evaluation show that the intended operation in Glovebox HA-20MB meets the double contingency requirement. That is, at least two unlikely, independent, and concurrent changes in process conditions are required before a criticality is possible. Therefore, this CSER meets the requirements for a criticality evaluation contained in the Hanford Site Nuclear Criticality Safety Manuals, HNF-PRO-334 (FDH 2000), HNF-PRO-537 (FDH 1997a), and HNF-PRO-539 (FDH 1997b), ANSI standards (ANSI 1998), and DOE Order 5480.24 (DOE 1992). This CSER also follows Fluor Federal Services, Inc. Practice 134.290.1121 (FFS 1999). 
HNF-5988 Rev. 0

\subsection{SYSTEM DESCRIPTION AND NORMAL OPERATIONS}

Glovebox HA-20MB will be used to process plutonium scrap material by cementation. The normal operational sequence relating to criticality safety is given in Section 2.1 below. Figure 1 shows a sketch of the approximate layout of the glovebox in relation to the other gloveboxes and conveyors used for thermal stabilization activities at the PFP. Figures 2 and 3 are sketches showing equipment and containers to be used, but not necessarily in the specific glovebox locations.

The following sections describe the facilities, fissionable materials, and technical practices and process features of the handling processes.

\subsection{OPERATIONAL SEQUENCE}

Plutonium residue for cementation in Glovebox HA-20MB can be SS\&C, ash, oxide, or other less characterized material. A glovebox limit of $2100 \mathrm{~g}$ plutonium or fissile equivalent is allowed as described in Section 3.0 if the feed material is SS\&C, ash, or oxide as characterized by the material described in Appendices F and G. If not, then the glovebox fissile mass limit is $1200 \mathrm{~g}$. The SS\&C feed contains calcium that is reacted before cementation. The other scrap material can be directly cemented.

Material enters Glovebox HA-20MB through Conveyor Glovebox HA-28, the airlock, or through a port. Mixing bowls are used for the calcium reaction process and for combining the plutonium material with cement. The contents of the bowls are stirred by electric mixers or by hand. A feedwater container provides water for these processes. Cans of cemented material are stored while curing and then transferred out of the glovebox through the HA-28 conveyor.

A minimum separation of $25.4 \mathrm{~cm}$ (10 in.) is required between mixing bowls, between mixing bowls and other containers, and between feed containers and cemented containers with two exceptions. A mixing bowl can be brought together with another mixing bowl or be brought next to a feed or cement container for the transfer of material. Also, for limit set A, $1200 \mathrm{~g}$ of plutonium or fissile equivalent, there is no separation requirement between feed and cement containers.

\subsubsection{Load-In of Feed Material}

Processing of feed material begins with load-in of cans through a sphinter port, bag port, the Conveyor Glovebox HA-28, or the airlock cell. Allowed fissile mass and required minimum spacing depend upon which limit set is posted. Logistics and space availability may limit the can count. For limit set $\mathrm{B}(2100 \mathrm{~g} \mathrm{Pu})$, ash and oxide containers must be opened upon entry into Glovebox HA-20MB to assure that the type of feed material is consistent with Appendix G material and that there is no free liquid in the container. If these conditions are not met, then the container must be removed before another feed container is brought into the glovebox. For SS\&C, 
as described in Appendix F, it is not credible to have an $\mathrm{H} / \mathrm{X}>20$, to have free liquid, or be confused with another container because of the process used to create the SS\&C and can it (Roemer 1986).

When feed containers are opened and the material removed, these containers and any plastic bagging are rendered into "non-containers" and processed for disposal in the usual manner for glovebox waste. For limit set B, only $200 \mathrm{~g}$ of plutonium or fissile equivalent in feed material may be in open containers, auger, crusher or hopper at a time. A lid replaced on a slip lid can is no longer considered open, whether or not it is taped. The analysis requires that the feed containers not fill with water under the contingencies involving glovebox glass damage and sprinkler water entry into the glovebox. For limit set A, a $200 \mathrm{~g}$ fissile mass is allowed in each mixing bowl and $500 \mathrm{~g}$ fissile mass is allowed in the other containers. For limit set B, $200 \mathrm{~g}$ fissile mass is allowed in each mixing bowl, $900 \mathrm{~g}$ fissile mass is allowed in feed containers, and $500 \mathrm{~g}$ fissile mass is allowed in cemented containers. For both limit sets, $300 \mathrm{~g}$ fissile mass is allowed as distributed holdup throughout Glovebox HA-20MB and spills must be expeditiously cleaned up.

\subsubsection{SS\&C Material Preparation}

One container, at a time, is opened in the process area and weighed. Pu is tracked through a running inventory. The SS\&C is sieved to separate out the large pieces, which are then transferred to a size reduction unit (crusher) and re-sieved through an 8-mesh screen. An optimum particle size of 8 mesh was determined through laboratory testing and assures that the Ca metal oxidation reaction with water will proceed to completion. Following this pre-cementing activity, the SS\&C is transferred into a hopper and fed via a variable speed auger to the mixing bowl containing water. This step is necessary to assure a controlled reaction of the calcium with water. After this stage the material should be a relatively homogeneous blend of calcium fluoride $\left(\mathrm{CaF}_{2}\right)$, calcium iodide $\left(\mathrm{Cal}_{2}\right)$, unreacted calcium, magnesium oxide $(\mathrm{MgO})$ sand, plutonium fluoride $\left(\mathrm{PuF}_{4}\right)$, plutonium oxide $\left(\mathrm{PuO}_{2}\right)$ and silicon oxide $\left(\mathrm{SiO}_{2}\right)$ as powder grains and/or chips and grains as well as metallic $\mathrm{Pu}$ (and possibly other compounds of $\mathrm{Pu}$ in minute amounts). Then, batches of up to $2000 \mathrm{~g}$ total SS\&C will be transferred into the hopper of the auger for subsequent slow metering into a mixer bowl.

Due to WIPP requirements each SS\&C can will be processed on a one to one basis so the output can would retain the same Pu mass and assay accuracy as the original input can. This would simplify tracking of the area Pu inventories. On occasion the bulk cemented mixture may not fit in one cement can. In this case, Pu mixture will be assumed to be homogeneous and the $\mathrm{Pu}$ accounting for split batches would be determined using the gross weight ratios for the granulized and blended SS\&C charge portions. Charges will not be combined. 
HNF-5988 Rev. 0

Figure 1. Approximate Layout for Gloveboxes and Conveyors Utilized for Thermal Stabilization Activities

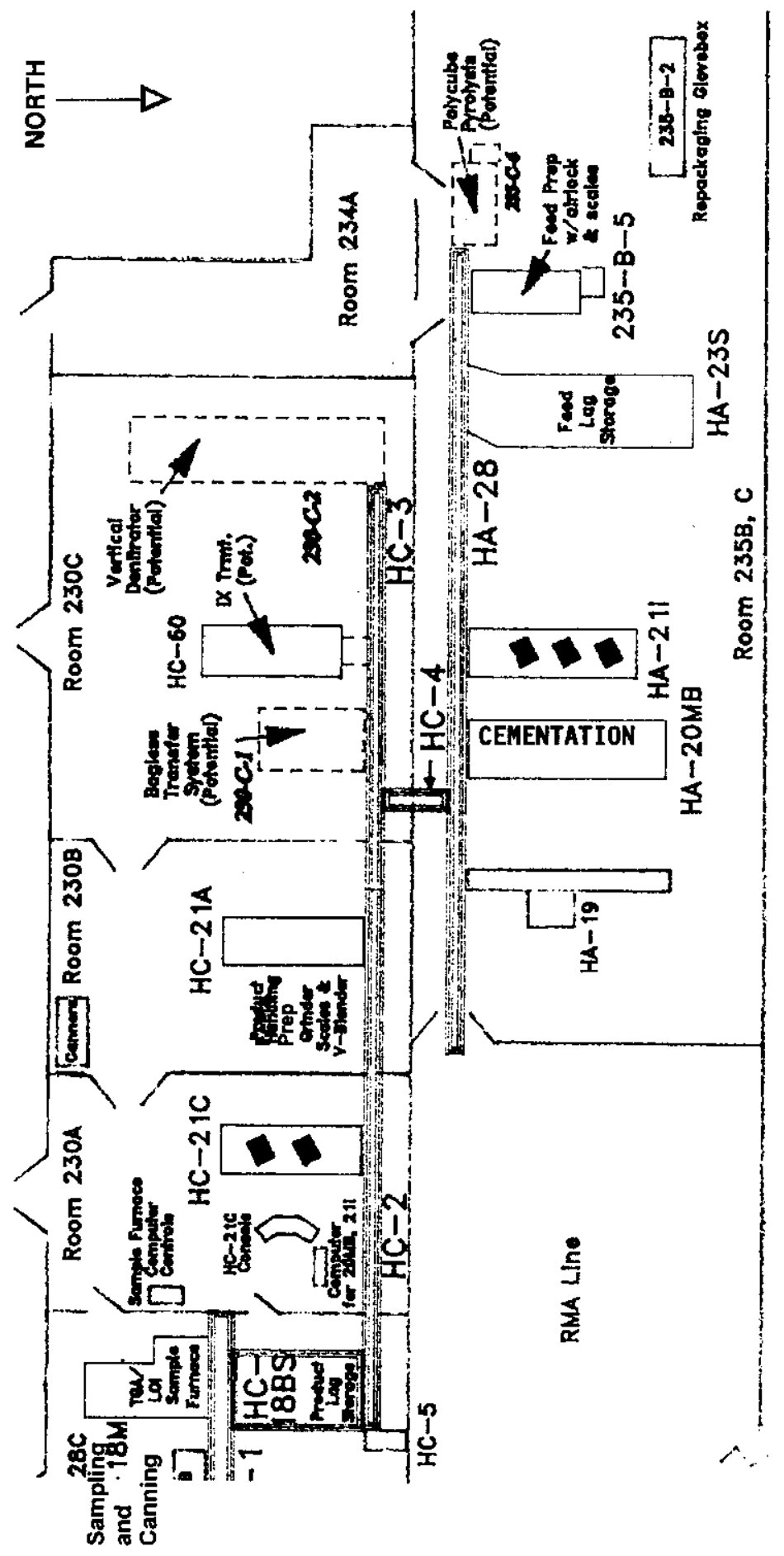


Figure 2. Cutaway End View from North of Glovebox HA-20MB

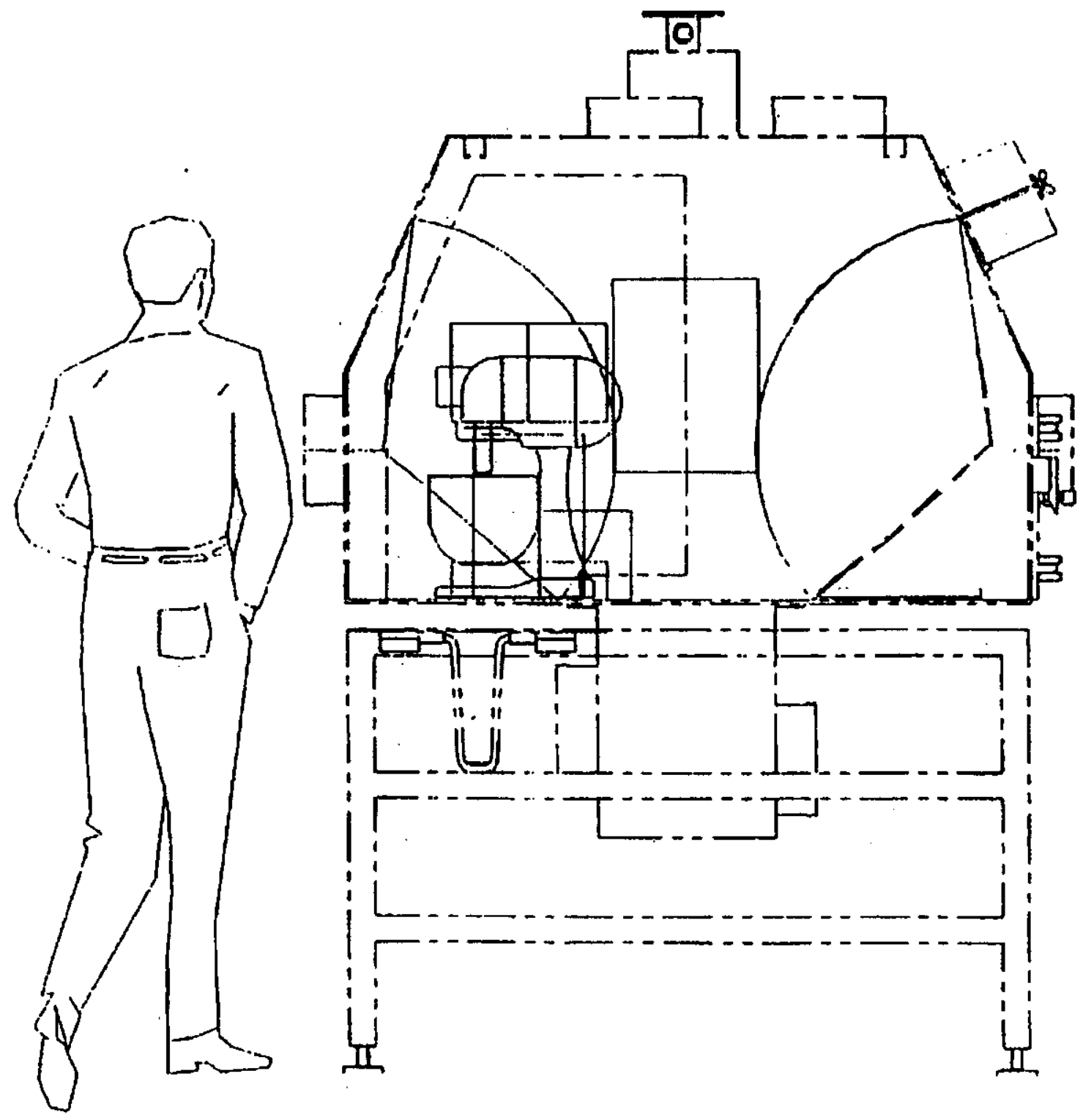


HNF-5988 Rev. 0

Figure 3. Layout of Glovebox HA-20MB for Cementation Processing

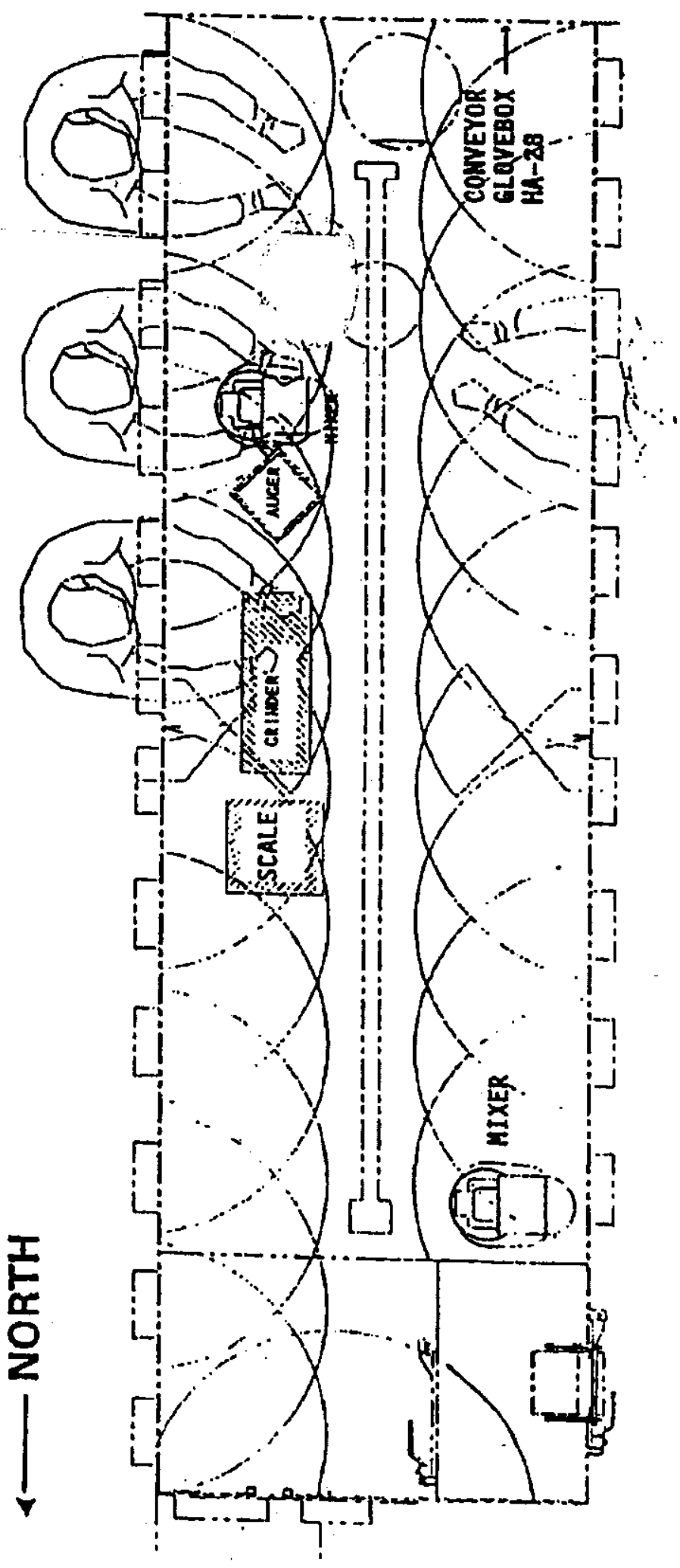


HNF-5988 Rev. 0

\subsubsection{Reacting Charge Material}

The SS\&C feed will require its calcium to be reacted with water. A $4.73 \mathrm{~L}, 5$ quart mixing bowl loaded with $1.4 \mathrm{~L}$ to $1.5 \mathrm{~L}$ of water (from the chilled water tank), will be prepared for reacting the new charge. Infrared thermocouples are affixed to the mixer arms for monitoring the fluid temperature. With the mixer beaters activated, the SS\&C material is slowly fed from the auger into the bowl of water, at a rate to limit the slurry temperature heatup caused by the residual free calcium reacting with water.

Once the bowl contains a designated charge of SS\&C material (up to $2000 \mathrm{~g}$ ), the auger is stopped and the mixing is continued for about 20 minutes, or until the temperature stabilization indicates no further reaction is occurring. Excess material in the auger, if any, would be transferred to a dry slip lid can for use in another charge.

\subsubsection{Cementing}

For cementing, approximately $1500 \mathrm{~g}$ of cement is added to the water and SS\&C or other feed material slurry mixing bowl. The maximum water content of the cement to have the cement setup with no liquid standing on top, as required by PFP cementation procedures, is 44 volume percent as explained in Appendix J (Greenhalgh 1996). The bowl is set under mixer beaters for stirring. Appropriate quantities of water and additional dry cement powder are added to the bowl as required to achieve a proper consistency for the cement mud. Loading of the cementing cans is done directly by hand from the mixing bowl. It may turn out that the bowl of wet cement volume exceeds the desired can fill volume, in which case the excess is poured into either another can as a partial fill or as a smaller can. PFP operations tracks Pu contents on the basis of totalweight ratios. Loaded cement cans will remain in the glovebox for at least 24 hours to cure. After curing, any free liquid is poured back into a mixer bowl for use in the next batch. The cement cans are sealed out of the glovebox in vented PVC bags.

\subsection{FACILITY AND EQUIPMENT DESCRIPTION}

The glovebox and the equipment within it are described in this section. Figure 3 shows Glovebox HA-20MB equipment layout and Figure 4 shows the cementation process, but not necessarily in the specific glovebox locations. 
HNF-5988 Rev. 0

Figure 4. Cementation Process Flow Diagram

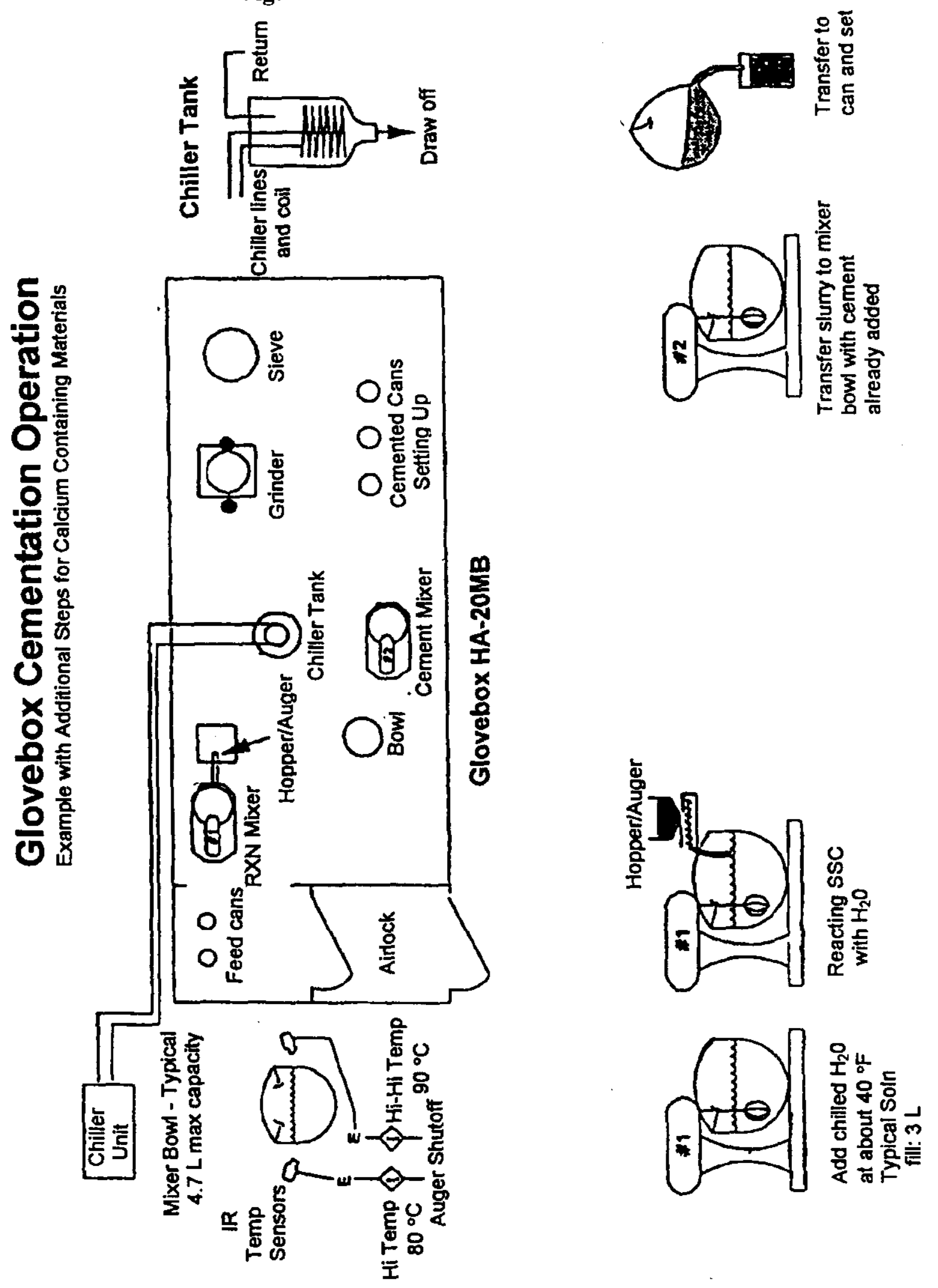




\subsubsection{Glovebox HA-20MB Description}

Glovebox HA-20MB, located in the main PFP Building 234-5Z in Room 235B next to Glovebox HA-21I, will be used for cementation processing. Glovebox HA-20MB has access to the conveyor box system through its connection at the south end to Conveyor Glovebox HA-28. Materials are brought into HA-20MB via HA-28, an airlock, a sphincter port or bag port. Items can be taken out via Conveyor Glovebox HA-28 or bag port, but no containers will be transferred out through the airlock

HA-20MB is a conventional glovebox with a $132.1 \mathrm{~cm}$ (52 in.) wide by $472.4 \mathrm{~cm}(15.5$ $\mathrm{ft}$ ) long floor supported $91.4 \mathrm{~cm}$ (36 in.) above the room floor by a table frame. It has an inside height of $91.4 \mathrm{~cm} \mathrm{(} 3 \mathrm{ft})$, and as shown by the end view in Figure 2 the long walls slope inward somewhat starting about midway from floor to ceiling. Running beneath the floor of the box is a $30.5 \mathrm{~cm}$ (12 in.) wide by $35.6 \mathrm{~cm}$ (14 in.) deep by $350.5 \mathrm{~cm}$ (11.5 ft) long conveyor trough, down the middle and about centered lengthwise; this channel has been covered and sealed. The Conveyor Glovebox HA-28 connects to Glovebox HA-20MB at the south end, opposite the end with the airlock.

Figure 3 shows a possible layout of equipment in Glovebox HA-20MB for the cementing operations. As indicated in this diagram, the northwest (lower left) portion of the glovebox has an air isolation chamber for staging the input SS\&C cans from storage. The semicircles evident on the drawing express the extent of gloved hand reaches, which through ports on either side give complete coverage for ease of container movements.

The CPS equipment list is to include as "equipment" the crusher, scale, mixers and auger, which include their hoppers. Under allowed containers, beside the liquid-loading types cited above, will be the sieve pans and cans of the source material. Dry SS\&C material may be distributed among one or more of the allowed containers. Not more than $200 \mathrm{~g} \mathrm{Pu}$ is to be included in any one container.

A summary of the process equipment and containers expected in Glovebox HA-20MB for operations is given below.

The equipment available in Glovebox HA-20MB are:

- one crusher unit

- one hopper/auger unit

- two mixers

- two electronic scales

The containers available in Glovebox HA-20MB are:

- feed cans $1.1 \mathrm{~L}$ or $1.5 \mathrm{~L}$, up to $2.73 \mathrm{~L}$ 
- mixer bowls

- crusher/hopper

- sieve catch pans

- hopper/auger

- cemented cans

- slip-lid cans

- graduated cylinder

- feedwater tank
$4.73 \mathrm{~L}$

$0.6 \mathrm{~L}$

$1.65 \mathrm{~L}$

$2.83 \mathrm{~L}$

$2.725 \mathrm{~L}$

$1.2 \mathrm{~L}$

$0.200 \mathrm{~L}$

$18.9 \mathrm{~L}$

Other materials available in Glovebox HA-20MB are:

- infrared thermocouples

- auger lidded metal box

- electronic scales

A 94.6 L (25 gal.) makeup water tank for the glovebox is located outside the glovebox.

Glovebox HA-20MB is listed as a "seismically qualified" glovebox.

\subsubsection{Process Source Material}

The SS\&C scrap materials input for cementation are the leftovers from the button making process whereby plutonium fluoride was mixed with calcium in a magnesium oxide crucible and fired at high temperature in an electromagnetic furnace. In a fully efficient operation, all of the $\mathrm{Pu}$ would be converted to metal, leaving a Pu metal button (up to $2.5 \mathrm{~kg}$ mass allowed), plus calcium fluoride slag, calcium iodate, unreacted calcium, and the $\mathrm{MgO}$ crucible fragments from breaking out the button. However, usually not all of the $\mathrm{PuF}_{4}$ was converted to metal, and sometimes metal chips may have been carried away with the slag and crucible (SS\&C) residues.

The process for making a Pu button of up to $2500 \mathrm{~g}$ Pu mass, which is $10.5 \mathrm{~mol}$., would thus provide up to $42 \mathrm{~mol}$. ( $798 \mathrm{~g}$ ) of fluorine. Full conversion (to $\mathrm{Pu}+\mathrm{CaF}_{2}$ ) would require then at least $21 \mathrm{~mol}$. (842 $\mathrm{g}$ of calcium) for each batch - - and likely much more. Typical analyses of SS\&C material indicate about equal parts by weight of $\mathrm{CaF}_{2}$ and $\mathrm{MgO}$, so that each batch will also include about $1600 \mathrm{~g}$ of $\mathrm{MgO}$ sand. However, for most of the relevant past button production runs, the typical crucible charge had less than $2000 \mathrm{~g} \mathrm{Pu}$, and the inventory of SS\&C compounds in a storage can could be as low as $50 \%$ of the masses cited above. Process flow documentation for $\mathrm{SS} \& \mathrm{C}$ is presented in Appendix F.

The SS\&C residues are in multiple-can storage containers, the primary containers of which are untinned cans of up to $1.5 \mathrm{~L}$ volume (meant to be fed to a SS\&C dissolver in the PRF). Assay records for the inventory of these SS\&C scrap containers indicate Pu contents of up to $200 \mathrm{~g}$ per can.

Ash material is a mixture of combustible residues that was generated in plutonium processing and recovery operations and processed in incinerators. The residues were burned to 


\section{HNF-5988 Rev. 0}

reduce volume, destroy volatile constituents, and recover plutonium. Oxide is generally the most stable form of metals and is expected to be the main species formed as a result of incineration.

Oxide material is plutonium oxides/mixed oxides of $<30 \mathrm{wt} \% \mathrm{Pu}$ or $\mathrm{Pu}+\mathrm{U}$, and are typically oxide and mixed oxide residues recovered from glovebox processes. All oxides were thermally stabilized prior to placing into vault storage.

Other materials that may be processed for cementation include sludges, reactive scrap, nitrates, oxalates, oxycarbonates, and others. Ash and oxide are described further in Appendix G. Other feed materials may have undetermined diluent matter along with the plutonium.

\subsubsection{Mixers and Other Equipment}

The items inside Glovebox HA-20MB for the cementation process considered as fixed equipment (as opposed to containers) include two mixers, a crusher, electronic scales, an auger (for controlled material feed rates), and a chilled feedwater tank. A larger tank for water supply and a chiller unit to supply the cooling coil in the inside feedwater tank are located on the mezzanine to the northeast of the glovebox.

\subsubsection{Mixers}

Conventional beater style mixers (industrial strength) are used for two stages of the operation, 1) reaction of residual calcium in the SS\&C scrap, and 2) mixing of the granulated scrap slurry with cement prior to transferring to the $14-\mathrm{cm}(5.5-\mathrm{in}$.) diameter cementing can. The proportions in the Figure 2 diagram indicate an overall height of $48 \mathrm{~cm}$ (19 in.) for the mixer units.

\subsubsection{Crusher}

A crusher placed in HA-20MB is for size reduction of the feed material. The hopper for this crusher has a capacity of $0.6 \mathrm{~L}$.

\subsubsection{Auger}

The auger unit is all enclosed in a $21.6 \times 21.6 \times 17.8 \mathrm{~cm}(8.5 \times 8.5 \times 7$ in. $)$ tall, lidded metal box, procured from AccuRateтм. According to manufacturers specifications, the feed hopper in the unit has a volume of $2.83 \mathrm{~L}\left(0.1 \mathrm{ft}^{3}\right)$, or about a third of the overall auger box volume. Material is metered out of the auger through a $9.14 \mathrm{~cm}$ (3.6 in.) long pipe extending out horizontally from a bottom corner of the box. Normal operating feed rate will be $24 \mathrm{~g} / \mathrm{min}$. The maximum operating limit of the auger is $46 \mathrm{~g} / \mathrm{min}$.

\subsubsection{Scales}

One or two electronic scales are available to check weights of SS\&C material accumulations in cans at various stages of the processing, as needed. The portland cement charges AccuRate is a trademark of Schmeck Corporation of Whitewater Wisconsin. 
to the cementing cans will already be properly weighed out and put in the cans before transfer into the glovebox.

\subsubsection{Feedwater Tank}

The interior feedwater tank for the HA-20MB process is an open top vessel of $18.9 \mathrm{~L}$ ( 5 gal.) capacity, formed from an inverted polypropylene carbuoy jug with its bottom cut off. Its diameter is $27.9 \mathrm{~cm}$ ( $11 \mathrm{in}$.), and the full height from the outlet to the base is $38.1 \mathrm{~cm}(15 \mathrm{in}$.). This interior tank is fed by gravity through piping from a $94.6 \mathrm{~L} \mathrm{(25}$ gal.) makeup water tank located on the mezzanine to the northeast of the glovebox. As Figure 4 shows, water is drawn by gravity out of the conical lower end of the tank to charge the mixer bowls. The cooling coils inside of the tank are supplied in a closed loop circuit from a $4.5 \mathrm{~L}(1.2 \mathrm{gal}$.) chiller unit outside of the glovebox. It is prohibited to introduce fissile material to this tank and its opening must be configured such that it is not credible to have fissile material accidentally enter this tank.

\subsubsection{Makeup Water Tank Outside Glovebox}

The 94.6 L ( 25 gal.) outside makeup water tank for the glovebox is also open on top, and is filled by hand using a bucket from a tap on the plant sanitary water line. Thus, replenishing the chiller tank can be accomplished by gravity flow without any threat of unrestricted accidental flow due to line pressure from the plant water system. The geometry of this outside source tank is not important because it is not credible that plutonium would get into it. Glovebox flooding from this tank is no more severe than from the fire or seismic events.

\subsubsection{Instrumentation}

Instrumentation for the processing will include the infrared thermocouples attached to the mixer.

\subsubsection{Containers for SS\&C Material and Slurries}

Containers intended to hold the SS\&C residues include the storage cans, the mixer bowls, the cementing cans, and possibly other small cans for transfer or cleanup purposes. It is intended that the mixer bowls and cement cans will be the only allowed container types to hold SS\&C residues-plus-water slurries or sludge (perhaps also a slip lid can of up to $1.2 \mathrm{~L}$ capacity for cleanup).

\subsubsection{SS\&C Containers}

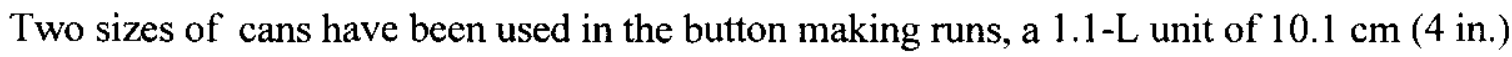
diameter and $14.0 \mathrm{~cm}(5.5 \mathrm{in}$.) height, and a $1.5 \mathrm{~L}$ unit which is $11.3 \mathrm{~cm}(4.5 \mathrm{in}$.) diameter by 15.2 $\mathrm{cm}(6$ in.) high. As brought into the glovebox though a sphincter port or bag-in port, the cans are crimped sealed and enclosed in a sealed, tight fitting plastic bag. Containers are limited to a height of $17.8 \mathrm{~cm}(7 \mathrm{in}$.) when resting on the glovebox floor. 


\subsubsection{Sieve Pans}

The sieve pans and catch pans are the same as for the sieve-shaker equipment described also in CSER 96-003 (Hess 1996), where each $20.3 \mathrm{~cm}$ (8 in.) diameter by $5.1 \mathrm{~cm}$ ( 2 in.) tall sieve or catch pan can hold as much as $1.65 \mathrm{~L}$.

\subsubsection{Slip-Lid Cans}

Dry SS\&C residues will be transferred during the preparations, grinding, splitting, and weighing operations in these pans, or in $1.2 \mathrm{~L}$ slip-lid cans. These " $2 \mathrm{lb}$ " slip-lid cans, $10.8 \mathrm{~cm}$ (4.25 in.) in diameter by $14.0 \mathrm{~cm}$ ( $5.5 \mathrm{in}$.) tall, may also be used for cleanup of spills.

\subsubsection{Mixer Bowls}

The mixer bowls (or beater vessels) are conventional, rounded bottom, $4.73 \mathrm{~L}$ (5-quart) stainless steel bowls, $20.3 \mathrm{~cm}$ ( 8 in.) in diameter by $17.8 \mathrm{~cm}$ (7 in.) deep.

\subsubsection{Cementing Cans}

The cementing cans are $14.0 \mathrm{~cm}(5.5$-in.) diameter by $17.8 \mathrm{~cm}$ ( 7 in.) tall, for a volume of $2.725 \mathrm{~L}$, and these are equipped with a slip-lid style cover. Load in of these cans into the glovebox may be with the charges of dry cement powder needed for the operations. After curing and loadout, the cemented SS\&C cans will be loaded into 55 gallon waste drums.

\subsubsection{Graduated Cylinder}

The allowed container list also includes a $0.2 \mathrm{~L}$ graduated cylinder for accurate measurement of the water charge required for the cement mixtures.

\subsection{FISSIONABLE MATERIALS DESCRIPTION}

The fissionable material handled in Glovebox HA-20MB is plutonium in the forms of SS\&C, metal, oxide, ash, sludge, scrap, and other compounds. The fissionable isotope content and physical forms are discussed below.

\subsubsection{Fissionable Isotopes}

Each container is labeled with the mass of plutonium or fissile material. The plutonium and other fissile mass is assumed to be ${ }^{239} \mathrm{Pu}$. This simplification is conservative for the plutonium with more ${ }^{240} \mathrm{Pu}$ than ${ }^{241} \mathrm{Pu}$, which is the case for the reactor produced plutonium at PFP. The ${ }^{239} \mathrm{Pu}$ assumption also applies to the fissile atoms in depleted or natural uranium or 
mixed oxides of plutonium and uranium that may be present. For uranium, the ${ }^{235} \mathrm{U}$ enrichment must not exceed 50 weight percent in order for the ${ }^{239} \mathrm{Pu}$ to conservatively model this uranium.

\subsubsection{Carbon Content}

The carbon content of the feed material may vary. For the materials described in Appendices $\mathrm{F}$ and $\mathrm{G}$, the carbon could be as high as $33 \%$ of the material. For other material, the carbon content is assumed to be $10 \%$, maximum.

\subsubsection{Residual Pu Contamination of the HA-20MB Glovebox}

Glovebox HA-20MB was used in the past for other plutonium handling operations which have resulted in some residual Pu contamination on the wall and floor surfaces in the glovebox. Appendix $\mathrm{H}$ reports on the NDA determinations of this holdup made after the most recent cleanup efforts and prior to installation of the cementation equipment. An NDA high-side estimate of $179 \mathrm{~g}$ Pu was obtained for the total distribution throughout the glovebox proper which included the installed HEPA filter. The NDA also showed no particular hot-spots for the material. It is not visually evident where the old deposits are, so that it can be assumed the contamination is as a very thin film spread out on the majority of interior surfaces. The average areal density is on the order of $10.8 \mathrm{~g} \mathrm{Pu} / \mathrm{m}^{2}\left(1 \mathrm{~g} \mathrm{Pu} / \mathrm{ft}^{2}\right)$, and not likely to exceed $53.8 \mathrm{~g} / \mathrm{m}^{2}$ $\left(5 \mathrm{~g} / \mathrm{ft}^{2}\right)$ in more than a few locations. If additional material is spilled, it must be expeditiously cleaned up or its mass must be included in the limit set for the type of material from the container it spilled from. Periodic NDA measurements will confirm glovebox holdup changes over time.

\subsection{FISSIONABLE MATERIAL HANDLING}

Fissionable material will be inventoried as containers enter and leave the type of container controlled by the posted limit set. Controls include multiple levels of protection of a safe batch such as limits on fissionable mass, maximum container volume, elimination of moderation, and separation distance from other fissionable materials. The multiple levels of protection will assure that criticality safety will not be jeopardized by the inadvertent failure of a single control.

In addition, processing will be stopped as necessary to clean up visible accumulations of fissionable materials from spills or processing.

\subsubsection{Receipt of Fissionable Material}

Material will be received in Glovebox HA-20MB in cans. Two sizes of cans had been used in the button making runs, a $1.1-\mathrm{L}$ unit of $10.1 \mathrm{~cm}$ (4 in.) diameter and $14.0 \mathrm{~cm}(5.5 \mathrm{in}$.) height, and a $1.5 \mathrm{~L}$ unit which is $11.4 \mathrm{~cm}(4.5 \mathrm{in}$.) diameter by $15.2 \mathrm{~cm}(6 \mathrm{in}$.) high. The maximum container mass will be $200 \mathrm{~g} \mathrm{Pu}$ or fissile equivalent and maximum container volume will be $2.76 \mathrm{~L}$ except for mixing bowls and sieve shaker. 
HNF-5988 Rev. 0

\subsubsection{Waste Packages}

Glovebox waste is generated from PFP plutonium stabilization operations. It is placed into plastic bags, transferred to Isolated Transport Containers, assayed, then placed into waste drums. This waste consists of gloves, bags, rags, containers used to port-in items, etc. Prior to bagging, all noticeable fissile material is shaken or brushed from these items and no fissile item is intentionally placed in these packages. Inspection of historical assay data shows that normally these packages contain only 1 or $2 \mathrm{~g}$ of fissile material. Appendix $\mathrm{H}$ documents this inspection and supports the conclusion that it is not credible for the packages to contain more than a few tens of grams of fissile material except for the upset of a fissile item in the waste package, which is bounded by other upset conditions (reflection).

Waste packages are allowed in Glovebox HA-20MB and would result from glovebox cleaning operations. Waste packages created in this glovebox would only contain the fissile material already inventoried and resultant neutron reflection/moderation is already conservatively modeled by water in the base calculations.

It is unlikely that a waste package containing fissile material from another glovebox would be transferred to HA-20MB because it is not a destination glovebox for waste packages. This event is not forbidden and is bounded by the analysis of upset conditions for Glovebox HA-20MB. 
HNF-5988 Rev. 0

\subsection{LIMITS AND CONTROLS}

Table 3-1 lists each of the parameters of concern for criticality safety, and discusses whether these parameters are necessary.

Table 3-1. Controls on Parameters Related to Criticality in Glovebox HA-20MB

\begin{tabular}{|c|c|c|}
\hline Parameter & Controlled & Discussion (Limit or Process Control if Yes, Reason if No) \\
\hline Mass & Yes & $\begin{array}{l}\text { Maximum mass limit per container, per group of feed containers, } \\
\text { per group of cement containers (combined with feed containers in } \\
\text { limit set A), and glovebox holdup }\end{array}$ \\
\hline Volume & Yes & $\begin{array}{l}\text { Volume limit on mixing bowls, sieve pan assembly, lubricants, } \\
\text { and other containers }\end{array}$ \\
\hline Spacing & Yes & $\begin{array}{l}\text { Minimum spacing between mixing bowls and other containers, } \\
\text { containers on the HA- } 28 \text { conveyor, and waste drums on north } \\
\text { side of glovebox, otherwise, general transition and storage } \\
\text { spacing requirements outside of glovebox; no stacking }\end{array}$ \\
\hline Moderator & No/Yes & $\begin{array}{l}\text { Optimum moderation in analysis for limit Set A/feed must be } \\
\text { SS\&C, ash, or oxide with no free liquids for limit Set B. }\end{array}$ \\
\hline Reflector & Yes & Dry fire suppression system within glovebox \\
\hline Poisons & No & Poisons were not used in this analysis. \\
\hline Concentration & No & Worst credible concentrations were analyzed. \\
\hline Enrichment & $\begin{array}{l}\text { Plutonium, } \\
\text { no; } \\
\text { Uranium, } \\
\text { yes }\end{array}$ & $\begin{array}{l}\text { Plutonium was assumed to be } 100 \mathrm{wt} \%{ }^{2.39} \mathrm{Pu} \text {. This } \\
\text { conservatively encompasses all allowed fissionable materials } \\
\text { including uranium enriched to } 50 \%{ }^{2.35} \mathrm{U} \text {. }\end{array}$ \\
\hline Density & No & Most reactive credible densities were used for all materials. \\
\hline Geometry & Yes & $\begin{array}{l}\text { Plutonium in designated containers with a maximum height of } \\
17.8 \mathrm{~cm} \text { ( } 7 \text { in.) except holdup uniformly distributed on floor }\end{array}$ \\
\hline
\end{tabular}

\subsection{LIMITS}

The operations in Glovebox HA-20MB are defined in Section 2.0. Operations are performed in the main glovebox area. There are two fissionable material mass limit sets for cementation glovebox operation. Tables 3-2 and 3-3 show the parameter limits for the $1200 \mathrm{~g}$ fissile unrestricted feed and $2100 \mathrm{~g}$ fissile SS\&C, ash, and oxide limit sets, respectively. 
HNF-5988 Rev. 0

Table 3-2. Limit Set A: $1200 \mathrm{~g}$ Total Glovebox Fissile Mass

\begin{tabular}{|c|c|}
\hline Mass & $\begin{array}{l}\text { Max. } 1200 \mathrm{~g} \text { plutonium or fissile equivalent in glovebox } \\
\text { Max. } 200 \mathrm{~g} \text { plutonium or fissile equivalent per mixing bowl } \\
\text { Max. } 500 \mathrm{~g} \text { plutonium or fissile equivalent in feed and cement } \\
\text { containers, crusher, auger, hopper with a maximum } 200 \mathrm{~g} \\
\text { plutonium or fissile equivalent in any one container, crusher, } \\
\text { auger, or hopper } \\
\text { Max. } 300 \mathrm{~g} \text { plutonium or fissile equivalent glovebox holdup }\end{array}$ \\
\hline Volume & $\begin{array}{l}\text { Two mixing bowls, each } 4.73 \mathrm{~L} \text {, max. } \\
\text { Sieve pan assembly, } 4.9 \mathrm{~L} \text {, max. } \\
\text { Lubricants, } 50 \mathrm{ml} \text {, max. } \\
\text { Crusher/hopper, } 1.1 \mathrm{~L} \\
\text { Auger/hopper, } 2.83 \mathrm{~L} \\
\text { Other containers, } 2.76 \mathrm{~L} \text {, max. except one } 18.9 \mathrm{~L} \text { (five-gallon) } \\
\text { feedwater container in which fissile material not permitted and no } \\
\text { credible accidental means of adding fissile material exists }\end{array}$ \\
\hline Spacing & $\begin{array}{l}\text { Minimum spacing of } 25.4 \mathrm{~cm}(10 \mathrm{in} \text {.) between mixing bowls and } \\
\text { mixing bowls and other containers except during material } \\
\text { transfer; } 25.4 \mathrm{~cm} \text { minimum spacing from fissile material in } \\
\text { glovebox to that in Conveyor Glovebox HA-28; } 15.2 \mathrm{~cm}(6 \mathrm{in} .) \\
\text { minimum spacing between fissile material containers in glovebox } \\
\text { to that in waste drums on the north side of the glovebox; no } \\
\text { stacking }\end{array}$ \\
\hline Moderator & None \\
\hline Reflector & Dry fire suppression system within glovebox \\
\hline Poisons & Poisons were not used in this analysis. \\
\hline Concentration & Worst credible concentrations were analyzed. \\
\hline Enrichment & $\begin{array}{l}\text { Plutonium was assumed to be } 100 \mathrm{wt} \%{ }^{239} \mathrm{Pu} \text {. This } \\
\text { conservatively encompasses all allowed fissionable materials } \\
\text { including uranium enriched to } 50 \%{ }^{235} \mathrm{U} \text {. }\end{array}$ \\
\hline Density & Most reactive credible densities were used for all materials. \\
\hline Geometry & $\begin{array}{l}\text { Plutonium in designated containers with a maximum height of } \\
17.8 \mathrm{~cm} \text { ( } 7 \text { in.) except holdup uniformly distributed on floor }\end{array}$ \\
\hline
\end{tabular}


Table 3-3. Limit Set B: 2100 g Total Glovebox Fissile Mass

Allowed Material Type: SS\&C, Ash, and Oxide

\begin{tabular}{|c|c|}
\hline Mass & $\begin{array}{l}\text { Max. } 2100 \mathrm{~g} \text { plutonium or fissile equivalent in glovebox } \\
\text { Max. } 200 \mathrm{~g} \text { plutonium or fissile equivalent per mixing bowl } \\
\text { Max. } 900 \mathrm{~g} \text { plutonium or fissile equivalent in feed containers, } \\
\text { crusher, auger, hopper with a maximum } 200 \mathrm{~g} \text { plutonium or } \\
\text { fissile equivalent in any one container, crusher, auger, or hopper } \\
\text { Max. } 500 \mathrm{~g} \text { plutonium or fissile equivalent in cement containers } \\
\text { Max. } 300 \mathrm{~g} \text { plutonium or fissile equivalent glovebox holdup }\end{array}$ \\
\hline Volume & $\begin{array}{l}\text { Two mixing bowls, each } 4.73 \mathrm{~L}, \text { max. } \\
\text { Sieve pan assembly, } 4.9 \mathrm{~L}, \max . \\
\text { Lubricants, } 50 \mathrm{ml} \text {, max. } \\
\text { Crusher/hopper, } 1.1 \mathrm{~L} \\
\text { Auger/hopper, } 2.83 \mathrm{~L} \\
\text { Other containers, } 2.76 \mathrm{~L} \text {, max. except one } 18.9 \mathrm{~L} \text { (five-gallon) } \\
\text { feedwater container in which fissile material not permitted and no } \\
\text { credible accidental means of adding fissile material exists }\end{array}$ \\
\hline Spacing & $\begin{array}{l}\text { Minimum spacing of } 25.4 \mathrm{~cm} \text { ( } 10 \text { in.) between mixing bowls and } \\
\text { mixing bowls and other containers and between feed containers } \\
\text { and fissile material bearing cement containers except during } \\
\text { material transfer; } 25.4 \mathrm{~cm} \text { minimum spacing from fissile material } \\
\text { in glovebox to that in Conveyor Glovebox HA-28; } 15.2 \mathrm{~cm}(6 \\
\text { in.) minimum spacing between fissile material containers in } \\
\text { glovebox to that in waste drums on the north side of the } \\
\text { glovebox; spacing is not required among feed containers or } \\
\text { among fissile bearing cement containers no stacking }\end{array}$ \\
\hline Moderator & Feed material must be SS\&C, ash, or oxide with no free liquid \\
\hline Reflector & Dry fire suppression system within glovebox \\
\hline Poisons & Poisons were not used in this analysis. \\
\hline Concentration & Worst credible concentrations were analyzed. \\
\hline Enrichment & $\begin{array}{l}\text { Plutonium was assumed to be } 100 \mathrm{wt} \%{ }^{239} \mathrm{Pu} \text {. This } \\
\text { conservatively encompasses all allowed fissionable materials } \\
\text { including uranium enriched to } 50 \%{ }^{235} \mathrm{U} \text {. }\end{array}$ \\
\hline Density & Most reactive credible densities were used for all materials. \\
\hline Geometry & $\begin{array}{l}\text { Plutonium in designated containers with a maximum height of } \\
17.8 \mathrm{~cm} \text { ( } 7 \text { in.) except holdup uniformly distributed on floor }\end{array}$ \\
\hline
\end{tabular}


HNF-5988 Rev. 0

\subsection{PROCESS CONTROLS}

To assure continued criticality safety during operations, the following process controls are required.

- A maximum of $200 \mathrm{~g}$ of plutonium feed material in open containers, auger, crusher, or hoppers at a time for limit set B.

- Each feed container will be opened and examined for free liquid before another container is brought into the glovebox for limit set $\mathrm{B}$.

- No fissile material will be placed into the feedwater tank.

- Containers shall not be stacked.

- Noticeable accumulations of fissionable materials, such as from spills, are not allowed to remain in Glovebox HA-20MB, and are to be cleaned up before continuing operating.

- During HEPA filter change out, all containers with fissile material shall be removed from the glovebox.

- Fire fighting category $\mathrm{C}$.

- Waste packages minimized to those required for cleanup of HA-20MB.

- No waste packages, generated outside HA-20MB, shall be brought into glovebox HA-20MB.

- At least $15.2 \mathrm{~cm}$ (6 in.) spacing must be maintained between fissile material in HA-20MB and waste drums passing by the north end of this glovebox (this spacing can be either inside or outside HA-20MB).

- PFP transition and storage spacing shall be maintained on the east and west sides of HA-20MB and on the north side for fissile containers other than waste drums.

- Cement brought into HA-20MB must be in containers no larger than $2.76 \mathrm{~L}$ or 7 in. tall.

- Contents of only one container can be transferred to another at one time.

- No liquids shall be added to feed containers for limit set B.

- Rags (maximum 6 sq. ft. total) allowed for cleaning.

\subsection{ENGINEERED CONTROLS}

Engineered controls are the primary means of preventing a criticality in the Glovebox HA-20MB. These controls include the following:

- Containers limit height of fissile material to $17.8 \mathrm{~cm}(7 \mathrm{in}$.$) .$

- Glovebox seismically qualified to remain upright during an earthquake.

- Cover seal over old conveyor housing under the glovebox so that fissile material does not enter during a fire.

- Old conveyor equipment remains in the housing to prevent fissile material containers from falling into conveyor during earthquake, if cover comes loose.

- Potential liquid depth around containers limited to $5.08 \mathrm{~cm}\left(2^{\prime \prime}\right)$ because elevation of HA-20MB only $5.08 \mathrm{~cm} \mathrm{(2")} \mathrm{lower} \mathrm{than} \mathrm{HA-28}$ 
HNF-5988 Rev. 0

\subsection{ADMINISTRATIVE CONTROL IMPLEMENTATION}

Criticality Prevention Specifications (CPS), postings and procedures provide limits and controls for handling fissionable materials, moderators, and other conditions that will assure criticality safety. These controls will address the limit sets of Tables 3-2 \& 3-3 and process controls of Section 3.2 .

The criticality analysis in this document demonstrates that a single failure of any administrative control will not result in a $\mathrm{k}_{\mathrm{eff}}$ that will exceed the criticality prevention criterion.

\subsection{SUPPORTING INFORMATION}

Operations within Glovebox HA-20MB require:

Fire Fighting Category: $\quad$ C.

This allows mists or fogs during fire fighting, but no directed solid streams of water are allowed (that may move or upset containers of fissionable materials).

\subsection{EVALUATION ASSUMPTIONS}

The important assumptions of this criticality safety evaluation are:

- The only operation analyzed is cementation.

- Glovebox holdup is evenly distributed throughout glovebox.

- It is not credible for significant quantities of fissile mass to get into the five gallon feedwater tank.

- Glovebox is seismically qualifed and remains upright and horizontal during earthquake.

- Neutron reflection from people and other objects external to glovebox is conservatively modeled as $30.5 \mathrm{~cm}$ of water.

- Neutron reflection from hands and other objects internal to glovebox is conservatively modeled as $2.54 \mathrm{~cm}$ of water around single containers and around the outside of close-packed groups of containers.

- Fissile material is conservatively modeled as ${ }^{239} \mathrm{Pu}$.

- It is not credible to have uranium with enrichment greater than $50 \%{ }^{235} \mathrm{U}$.

- It is unlikely that SS\&C, ash, or oxide, as described in Appendices F and G has $\mathrm{H} / \mathrm{X}>20$.

- Maximum water content in cemented billets is 90 volume percent. A ratio of at least $1500 \mathrm{~g}$ cement in $4.73 \mathrm{~L}$ is sufficient to displace 10 volume percent water. 


\section{HNF-5988 Rev. 0}

Cementation procedures require more than this ratio of cement to water mixed prior to placing the mixture in cement billet containers.

- The auger/conveyor and crusher units are part of the feed material when determining quantity of plutonium in open feed containers.

- Internal glovebox fire suppression is dry so that a major fire or earthquake is required to get water into glovebox. 
HNF-5988 Rev. 0

\subsection{METHODOLOGY}

\subsection{ANALYSIS PHILOSOPHY}

It is desired to both maximize the quantity of SS\&C, ash, or oxide to be processed and allow any non-solution plutonium residue to be cemented in Glovebox HA-20MB. Therefore, two limit sets are evaluated. One set limits the glovebox to $1200 \mathrm{~g}$ fissile based upon plutonium and water conservatively representing any plutonium or uranium $\left({ }^{235} \mathrm{U}\right.$ enrichment less than or equal to $50 \%$ ) compounds. The second set allows up to $2100 \mathrm{~g}$ fissile in the glovebox if the feed material is characterized as SS\&C, ash, or oxide as described in Appendices F and $\mathrm{G}$ and there is no free liquid in the feed container.

The computer code, MCNP 4B, is used to calculate the $\mathrm{k}_{\mathrm{eff}}$ of the allowed limit sets and credible upset events. Validation of this code was performed by evaluation of benchmark experiments involving the materials that will be used in this glovebox. As described in Section 4.2 , Erickson evaluated plutonium and uranium in systems involving water and concrete as reflectors and water as a moderator. Because Glovebox HA-20MB will be mixing cement with the fissile material, another benchmark experiment using concrete as a moderator was evaluated as reported in Appendix B.

\subsection{MCNP CODE}

The Monte Carlo code MCNP Version 4B, was certified (Schwinkendorf 1998) and validated (Erickson 1998a and Lan 1999) for plutonium systems such as the operation in this glovebox. Because that validation did not include concrete or cement as a moderator, an additional validation was performed and reported in Appendix B, MCNP 4B Computer Code Validation. Room temperature cross sections were used for the MCNP calculations. In Appendix B, a maximum allowable $\mathrm{k}_{\text {eff }}$ value of 0.932 was established for calculations for limit Set $\mathrm{A}$ that could contain metal chunks large enough to warrant the metal limit. For limit set B, the material charaterized by the descriptions of Appendices $\mathrm{A}$ and $\mathrm{F}$ can be considered non-metal for purposes of setting a $\mathrm{k}_{\mathrm{eff}}$ bias with a maximum allowable $\mathrm{k}_{\mathrm{eff}}$ value of 0.942 . These values are for calculations with statistical uncertainties $\leq 0.002$ and assure subcriticality with an acceptable margin, including the uncertainties in the analytical methods and benchmark experimental data.

\subsection{SUBCRITICALITY LIMIT}

For the purposes of this report, the principal criticality prevention criterion or parameter is that the effective neutron multiplication (or criticality) factor $\left(\mathrm{k}_{\mathrm{eff}}\right)$ shall not exceed 0.95 (i.e., $\mathrm{k}_{\mathrm{eff}} \leq 0.95$ ) for all permitted normal configurations of materials, containers, etc., and for any credible off-normal event. This criterion is based on implementing the applicable DOE Orders, ANSI standards, and HNF-PROs. The subcriticality criterion is used to judge the acceptability of a calculated $\mathrm{k}_{\mathrm{eff}}$ value for fissionable material configuration. This criterion must account for

*MCNP \& Monte Carlo are trademarks of the Regents of the University of California, Los Alamos National Laboratory. 
the bias inherent in the code and cross sections used, any uncertainties in the physical problem being analyzed, and the uncertainties in both the bias determination (the experimental basis) and the calculational methods.

\subsection{APPLICATION OF DOUBLE CONTINGENCY PRINCIPLE}

This analysis must meet the requirements of HNF-PRO-334, Criticality Safety General Requirements, (FDH 2000), HNF-PRO-537, Criticality Safety Control of Fissionable Material, (FDH 1997a) and HNF-PRO-539, Criticality Safety Evaluations (FDH 1997b). HNF-PRO-539 states that for all new operations and changes pertinent to criticality safety issues in existing operations, the CSER is required to demonstrate that there is an acceptable margin of subcriticality for all normal and credible abnormal conditions. To demonstrate the Double Contingency Principle is satisfied, this CSER must show that there are sufficient factors of safety in the operation of Glovebox HA-20MB such that at least two unlikely, independent, and concurrent changes in process conditions are required before a criticality accident is possible.

\subsection{HAZARDS ASSESSMENT}

Identification of the contingencies for the operation described in Section 2.0 and evaluated in Section 5.0 used a hazards assessment technique called a Preliminary Hazard Assessment (PHA). The goal of this effort is to identify deviations from the planned operation that may pose a challenge to criticality safety. Analysis is performed as necessary to demonstrate that each identified condition satisfies the criticality safety criteria.

In a PHA, an interdisciplinary team uses a disciplined, systematic approach to identify hazards and deviations that could lead to undesirable consequences. Because the criticality safety concerns usually arise from deviations from the process design, an experienced team leader systematically guides the team through the planned operation. Off-normal events are identified and separated into likely and unlikely to happen during the lifetime of the operation. The likely events become part of the base case and the unlikely events are the contingencies of Section 5.0. The detailed results of this assessment are presented in Appendix D. 
HNF-5988 Rev. 0

\subsection{EVALUATION AND RESULTS}

\subsection{NORMAL CASE}

Normally, this glovebox receives containers with $60 \mathrm{~g}$ or less plutonium and mixes these together in bowls to prepare containers that contain on the order of $180 \mathrm{~g}$ of plutonium for disposal. However, the feed containers could contain just a few grams or $200 \mathrm{~g}$ of plutonium each. Because of the variability of the plutonium content of this residue, it would be hard to define what the normal case would be. In fact, such a model would add very little value over the base case, except to conclude that the reactivity would be less if the fissile material was not in the worst concentration assumed in the base case. Also, one spacing violation is assumed in the base case that also covers the quasi-normal condition of a container or auger/conveyor with the maximum $200 \mathrm{~g}$ of plutonium being used to top off a mixing bowl with nearly $200 \mathrm{~g}$ in it.

The models used for this criticality safety evaluation are described in Section 5.2 as base cases. There will be one for limit set A, $1200 \mathrm{~g}$ plutonium and one for limit set B, $2100 \mathrm{~g}$ plutonium glovebox limit. Contingencies are described in Section 5.3. Input files can be found in Appendix $\mathrm{C}$ and model figures can be found in Appendix $\mathrm{E}$.

\subsection{BASE CASE}

This section presents the standard model of the HA-20MB Glovebox under base conditions of operations. The base case is composed of the normal operation with all parameters at their limiting values and likely abnormal conditions. This model includes two adjacent mixing bowls to represent either one spacing violation or the transfer of material from one container to another. Fissionable, moderating, and reflecting materials are modeled in the most conservative arrangement to represent the highest neutron multiplication for the glovebox.

Base cases for Limit Set A (1200 g plutonium) and Limit Set B (2100 g plutonium) are described in detail in the sections below. The items modeled within the glovebox are the mixer bowls, cement billet cans, and feed cans. A $2.54 \mathrm{~cm}(1 \mathrm{in}$.) of water is placed around containers or groups of containers in the model to represent neutron reflection from operator hands and other objects within the glovebox. A full neutron reflecting, $30.5 \mathrm{~cm}$ water jacket is placed around, under, and over the glovebox to allow operators and technicians to approach the glovebox from any angle. Details of the base model for Limit Sets A and B are summarized in Table 5-1, and Table 5-3, respectively.

\subsubsection{Base Case Model for Limit Set A: $1200 \mathrm{~g}$ Plutonium Limit Set}

The base case model for the unrestricted moderation feed had a $\mathrm{k}_{\text {eff }}$ of $0.8647 \pm 0.0009$ (case $\mathrm{c} 0001 \mathrm{flb} 7 \mathrm{~b}$ ). This value is well below the allowable $\mathrm{k}_{\mathrm{eff}}$ of 0.932 . Description of this model is as follows. 
Table 5-1. Base Case Model for $1200 \mathrm{~g}$ Plutonium Limit Set

\begin{tabular}{|c|c|}
\hline Glovebox Assumptions & $\begin{array}{l}\text { Glovebox is surrounded with a minimum of } 30.48 \mathrm{~cm} \text { (12 in.) of } \\
\text { water for neutron reflection. } \\
\text { Rectangular transverse cross-section instead of actual slanted-side } \\
\text { outlines. } \\
2.54 \mathrm{~cm} \text { ( } 1 \text { in.) water reflection representing hands around each } \\
\text { container group. } \\
\text { Array of close packed triangular pitched } 2.76 \mathrm{~L} \text { cans filled with } \\
\text { cement or water surround each group of cans. } \\
\text { Pu holdup in glovebox included in total glovebox mass limit. } \\
\text { Modeled as } 300 \mathrm{~g} \mathrm{Pu} \mathrm{in} \mathrm{thin} 0.001 \mathrm{~cm} \text { layer over entire floor of } \\
\text { glovebox. }\end{array}$ \\
\hline Glovebox dimensions & $\begin{array}{l}132.1 \mathrm{~cm}(52 \mathrm{in} \text {.) deep, } 91.44 \mathrm{~cm}(36 \mathrm{in} .) \text { high, } 518.16 \mathrm{~cm} \\
(204 \mathrm{in} .) \text { long. The length is } 45.7 \mathrm{~cm}(18 \mathrm{in} .) \text { longer than the } \\
\text { actual glovebox to include the adjoining Conveyor Glovebox HA- } \\
28 .\end{array}$ \\
\hline Mixer bowls & $\begin{array}{l}\text { Two } 4.80 \mathrm{~L} \text { bowl shape } 20.3 \mathrm{~cm}(8 \mathrm{in} \text {.) diameter and } 18.0 \mathrm{~cm} \\
\text { ( } 7.1 \mathrm{in} \text {.) deep. Lower part of bowl is hemispherical with flattened } \\
\text { bottom. The height is modeled slightly greater than the actual } \\
\text { height of } 17.8 \mathrm{~cm} \text { ( } 7 \text { in.) so the volume is larger than the actual } \\
\text { volume of } 4.73 \mathrm{~L} \text {. } \\
\text { Each bowl contains } 200 \mathrm{~g} \mathrm{Pu} \text { as } \mathrm{PuO}_{2} \text { mixed with water to the full } \\
\text { volume. The two bowls are touching to represent a single spacing } \\
\text { violation, and are located in a corner of the glovebox spaced } \\
25.4 \mathrm{~cm}(10 \text { in.) from other containers. }\end{array}$ \\
\hline Feed cans and Billet cans & $\begin{array}{l}2.76 \mathrm{~L} \text { cylinder } 14.0 \mathrm{~cm}(5.5 \mathrm{in} .) \text { diameter and } 18.0(7.1 \mathrm{in} .) \text { high. } \\
\text { The height is modeled slightly greater than the actual height of } \\
17.8 \mathrm{~cm}(7 \mathrm{in} .) \text { so the volume is larger than the actual volume of } \\
2.73 \mathrm{~L} \text {. } \\
500 \mathrm{~g} \mathrm{Pu} \text { in } 7 \text { cans filled with } 90 \text { vol\% water, } 10 \text { vol\% carbon } \\
\text { represents both unrestricted moderation feed cans and cement } \\
\text { filled cans. }\end{array}$ \\
\hline Sieve Pan Assembly & Not explicitly modeled since covered by feed and billet cans. \\
\hline Crusher Unit & Not explicitly modeled since covered by feed and billet cans. \\
\hline Auger/Conveyor Unit & Not explicitly modeled since covered by feed and billet cans. \\
\hline Feedwater tank & $\begin{array}{l}\text { Not explicitly modeled since covered by external water reflection } \\
\text { and cement cans reflection. }\end{array}$ \\
\hline Maintenance fluids & Not explicitly modeled since covered by water reflection. \\
\hline Sweeps container & $\begin{array}{l}\text { Not included since more reactive to have all } \mathrm{Pu} \text { in billet cans, feed } \\
\text { cans, and bowls. }\end{array}$ \\
\hline Room Assumptions & $\begin{array}{l}\text { One } 2.76 \mathrm{~L} \text { cylindrical can } 15.2 \mathrm{~cm}(6 \mathrm{in} \text {.) from glovebox wall } \\
\text { with } 200 \mathrm{~g} \mathrm{Pu} \text { with water representing waste barrel moving past } \\
\text { north end of glovebox. }\end{array}$ \\
\hline
\end{tabular}


HNF-5988 Rev. 0

\subsubsection{Glovebox HA-20MB}

A Glovebox HA-20MB model for the MCNP problems was established based on dimensions in the drawings from which the Figures 2 and 3 were derived. A rectangular transverse cross-section was adopted in the model instead of the slanted-side outline shown in Figure 2. The metal glovebox walls, floor, and ceiling were not modeled, but were surrounded by $30.48 \mathrm{~cm}$ ( $12 \mathrm{in}$.) full water reflection.

Only the mixer bowls, cementing cans, and feed cans were modeled inside the HA-20MB Glovebox. Volumes of the various equipment items that would hold feed materials such as the auger hopper and crusher hopper were not explicitly modeled, but assumed to be part of the group of feed containers with mass within that limit. Cemented fissile-bearing cans were modeled in a close cluster surrounded by close packed cans of cement. Clusters of fully filled mixer bowls were modeled up against the glovebox wall in a corner.

For all cases the plutonium involved was assumed to be entirely ${ }^{2.39} \mathrm{Pu}$. Also, none of the calculations accounted for the iodine constituent of the real SS\&C residues, a conservative omission because of the high neutron absorption properties for the element ( 7 barns at thermal energies, a factor of 20 times the absorption for hydrogen). For the cement mix, iron oxide, as sometimes present in concrete, was excluded.

\subsubsection{Feed and Cement Container}

Feed and cement containers were modeled as cylinders with a volume of $2.76 \mathrm{~L}$ as the interior cylinder of $14.0 \mathrm{~cm}(5.5 \mathrm{in}$.) diameter by $18.0 \mathrm{~cm}(7.1 \mathrm{in}$.) height. They contain either feed material with fissile material, cement with fissile material, or cement without fissile material. For mixtures of cement and fissile material, the cement acts as a moderator and the most reactive container is one with the most water. Cementation procedures require more cement than required to displace 10 volume percent water. Therefore, 90 volume percent water content was used for those containers. For limit set B the rest of the cement container is filled with the specified mass of plutonium as plutonium oxide and silicon oxide to fill the $2.76 \mathrm{~L}$ per container. The silicon oxide, water, and plutonium oxide mixture bonds the cement for limit set B. Cement containers without fissile material act as reflectors where the greatest neutron reflectivity occurs with $9 \%$ water in the cement and close packing around the containers with fissile material.

Feed and cement containers are modeled differently for limit set $\mathrm{A}$ than for limit set B. For limit set $\mathrm{A}$, the feed and cement container is 90 volume percent water with the remaining 10 volume percent containing both the specified plutonium as plutonium oxide and carbon which is the most reactive constituent along with the plutonium oxide. The carbon, water, and plutonium oxide mixture bounds both the feed material and cement for limit set $\mathrm{A}$. For limit set B, the material in the feed containers is characterized by Appendices $F$ and $G$ and has an effective maximum moderation $\mathrm{H} / \mathrm{X}<20$. That feed material is modeled as the plutonium as plutonium 
oxide, sufficient water to make $\mathrm{H} / \mathrm{X}=20$ with the rest of the volume of the container filled with $67 \%$ silicon oxide and $33 \%$ carbon.

\subsubsection{Mixer Bowl}

A detailed model of the curved bottom mixer bowl was created. For the feed material charged to the bowl, concentrations of $\mathrm{Pu}$ and water were assumed, in a full volume of water. Two $4.80 \mathrm{~L}$ bowls, each $20.3 \mathrm{~cm}$ ( $8 \mathrm{in}$.) diameter and $18.0 \mathrm{~cm}$ ( $7.1 \mathrm{in}$.$) deep are included in the model.$ The lower part of the bowl is hemispherical with a flattened bottom. The height is modeled slightly greater than the actual height of $17.8 \mathrm{~cm}(7 \mathrm{in}$.) so the volume is larger than the actual volume of $4.73 \mathrm{I}$. F Fach bowl contains $200 \mathrm{~g} \mathrm{Pu}$ as $\mathrm{PuO}_{2}$ mixed with water to the full volume. The two bowls are touching to represent a single spacing violation, and are located in a corner of the glovebox spaced $25.4 \mathrm{~cm}$ (10 in.) from other containers.

\subsubsection{HA-28 Conveyor Fissile Movement Past HA-20MB Glovebox}

Glovebox HA-20MB is open to the HA-28 conveyor, providing a path for fissile material movement to, from, and past HA-20MB. The PFP conveyor CPS (CPS-Z-165-80031) requires an edge-to-edge spacing limit of $25.4 \mathrm{~cm}$ (10 in.) between a container on a conveyor and a loaded container in a connecting glovebox. It is more reactive to have the containers in Glovebox HA-20MB fully reflected than to be spaced $25.4 \mathrm{~cm}$ (10 in.) from allowed fissile containers in Conveyor Glovebox HA-28. Therefore, the base case was reflected. A variation of the base case was created with one $4.7 \mathrm{~L}$ can containing $400 \mathrm{~g}$ plutonium of unrestricted $\mathrm{H} / \mathrm{X}$ from conveyor HA-28 inside the glovebox with $25.4 \mathrm{~cm}$ (10 in.) spacing from other containers. For the loss of spacing contingency, the conveyor can was brought into contact with the plutonium cans while maintaining reflective cement cans on the other sides of the plutonium cans.

\subsubsection{Glovebox Filter Holdup for HEPA Filter Replacement Operation}

PFP gloveboxes have in-place High Efficiency Particulate Air (HEPA) filters in the exhaust lines to remove plutonium dust and other particulate. The nominal $20.3 \mathrm{~cm} \mathrm{x} 20.3 \mathrm{~cm} \mathrm{x}$ $15.2 \mathrm{~cm}(8 \mathrm{in} . \times 8$ in. $x 6$ in.) filter is normally located in a recess in the glovebox roof. $\mathrm{A}$ glovebox would only have one significantly contaminated filter since experience has shown that even if there are two filters in sequence, only the first is contaminated with sufficient fissile material to be of any concern for criticality safety. The second filter will be contaminated but only with milligram quantities of plutonium (unless the first filter has been physically broken through).

CSAR 80-014 shows that over the credible range of plutonium particle densities, criticality in an optimally moderated filter is not credible at either full or nominal water reflection. In Glovebox HA-20MB with water lines, nominal reflection is considered normal. Per CSAR 80-014, dozens of filters are needed to approach criticality at low plutonium densities; at higher densities, tens of $\mathrm{kg}$ of plutonium are needed; and in between, both the number and 
HNF-5988 Rev. 0

mass required for criticality is incredible. Clearly the HEPA filter alone is not a threat to criticality safety.

The HEPA filter is made of material that is considered a moderator, so the HEPA filter is classified as having unrestricted moderation. CSER 80-014 shows that for a critical configuration at an optimal moderation of $30 \mathrm{~g} \mathrm{Pu} / \mathrm{L}$ and full water reflection, the $111 \mathrm{~g}$ of plutonium contained in the $3.72 \mathrm{~L}$ media volume of the $20.3 \mathrm{~cm} \times 20.3 \mathrm{~cm} \mathrm{x} 15.2 \mathrm{~cm}(8 \mathrm{in}$. 8 in. $x 6$ in.) HEPA filter at $30 \mathrm{~g} / \mathrm{L}$ is about $21 \%$ of the minimum critical mass. Glovebox holdup is limited to $300 \mathrm{~g}$ and includes the fissile material in the HEPA filter. Even if all this holdup was in the filter, not a credible scenario, the result is only $60 \%$ of a MCM. No containers of fissionable material are allowed in the glovebox while removing a HEPA filter. Floor accumulations are minimized by the requirement to expeditiously clean up spills. Therefore, reactivity would not be increased significantly above that for the filter by itself, which is well within allowables for credible accumulations in the filter.

\subsubsection{Base Cases Results for Limit Set A}

Base case evaluations were conservatively modeled to represent the operations defined in Section 4.4. The results for all of the base case evaluations are given in Table 5-2. These $\mathrm{k}_{\mathrm{eff}} \mathrm{s}$ are all significantly less than the criticality safety limit of 0.932 . The criticality safety criterion has been met for the base situation with unrestricted moderation feed.

The base case (case $\mathrm{c} 0001 \mathrm{flb} 7 \mathrm{~b}$ ) had a $\mathrm{k}_{\text {eff }}$ of $0.8647 \pm 0.0009$. The other cases in Table 5-2 are sensitivity studies that were used to develop this base case. These cases addressed issues of fissile material location, reflection, moderation, composition, and interaction.

Case $\mathrm{c} 0001 \mathrm{f} 1 \mathrm{~b} 7 \mathrm{c}$ showed that it is more reactive to have the fissile cans surrounded by close packed cement cans than to have the cans located in a corner of the glovebox with full water reflection on two sides. Case $\mathrm{c} 0001 \mathrm{flb} 7 \mathrm{e}$, with water in the close packed cans surrounding the fissile containers, had essentially the same $k_{\text {eff }}$ as the base case $0001 \mathrm{f} 1 \mathrm{~b} 7 \mathrm{~b}$, with cement in the surrounding containers.

The set of cases c0001f1b3a, c0001f1b4a, c0001f1b1a, c0001f1b6a, c0001f1b8a, $\mathrm{c} 0001 \mathrm{flbl0b}$, and c0001flbl la varied the number of fissile cans from three to ten, with the same $500 \mathrm{~g} \mathrm{Pu}$ fissile content. This showed that concentrations higher or lower than the base case of seven cans would have lower reactivity.

The $\mathrm{k}_{\mathrm{eff}}$ for Case $\mathrm{c} 0001 \mathrm{flb} 13 \mathrm{a}$ was lower than the base case $\mathrm{c} 0001 \mathrm{fl} \mathrm{b} 7 \mathrm{~b}$, showing that it is more reactive to have close packed cement cans reflection surrounding the fissile cans (with nominal $5.1 \mathrm{~cm}$ water reflection on top of the containers) than to have the fissile containers against the fully reflecting glovebox wall along with nominal $5.1 \mathrm{~cm}$ water reflection around the containers. 
Comparing case c0001f1b18 with the base case c0001f1b7b showed that it is more reactive to have close packed cement can reflection surrounding the fissile containers than to have the most reactive container that could be on the HA-28 conveyor ( $400 \mathrm{~g} \mathrm{Pu}$ in $4.7 \mathrm{~L}$ fully moderated with water) spaced at $25.4 \mathrm{~cm}$ from the glovebox fissile containers.

Cases c0001f1b23, c0001f1b21, c0001f1b22, together with the base case c0001f1b $7 \mathrm{~b}$, showed that displacing ten percent of the container volume with carbon is more reactive than substituting silicon oxide or cement for the water. The fissile cans represent both feed and cemented product containers. The $90 \%$ water content covers hydrogeneous materials as well as water in the feed and cement containers.

Case c0001f1b20 illustrates that the two adjacent bowls in the corner of the glovebox alone provide a $\mathrm{k}_{\text {eff }}$ of $0.8081 \pm 0.0008$. Adding the container with $200 \mathrm{~g}$ Pu representing a drum outside the north wall of the glovebox at $15.2 \mathrm{~cm}$ (6 in.) spacing (case c0001 flb $19 \mathrm{a}$ ) provides a negligible decrease in reactivity. The impact of the outside container at $15.2 \mathrm{~cm}$ spacing was also evaluated by comparing the base case $c 0001 \mathrm{f} 1 \mathrm{~b} 7 \mathrm{~b}$ with case $\mathrm{c} 0001 \mathrm{f} 1 \mathrm{~b} 7 \mathrm{f}$, which located the drum container near the two bowls and indicated a negligible increase in $\mathrm{k}_{\mathrm{eff}}$. The impact of the outside container at $15.2 \mathrm{~cm}$ spacing was also evaluated by comparing the case $\mathrm{c} 0001 \mathrm{f} 1 \mathrm{~b} 7 \mathrm{c}$ (with the fissile cans in the glovebox corner without the outside drum container) with case c0001flb $7 \mathrm{~d}$ (with the drum container at $15.2 \mathrm{~cm}$ from the cans), which had identical $\mathrm{k}_{\mathrm{eff}}$ 's. The net result of these studies was that the outside drum container spaced $15.2 \mathrm{~cm}$ from the fissile containers in the glovebox has a negligible impact on the glovebox reactivity.

Table 5-2. MCNP Calculational Results of Base Cases in Glovebox HA-20MB for Limit Set A: 1200 g Plutonium Glovebox Total

\begin{tabular}{|c|c|c|c|}
\hline Case & Description & $\mathbf{K}_{\text {calc }}$ & $1 \sigma$ \\
\hline $\mathrm{c} 0001 \mathrm{f} 1 \mathrm{~b} 7 \mathrm{~b}$ & $\begin{array}{l}500 \mathrm{~g} \mathrm{Pu} \text { in } 7 \text { cans } 90 \% \text { by volume water, } 10 \% \text { carbon } \\
400 \mathrm{~g} \mathrm{Pu} \text { in } 2 \text { bowls filled with water. } \\
300 \mathrm{~g} \mathrm{Pu} \text { holdup on floor. } \\
\text { Close packed cans surrounded by cement cans( } 9 \% \text { water }) \text {. }\end{array}$ & 0.8647 & 0.0009 \\
\hline $\mathrm{c} 0001 \mathrm{flb} 7 \mathrm{e}$ & Same as c0001flb7b except water cans reflection & 0.8641 & 0.0010 \\
\hline $\mathrm{c} 0001 \mathrm{f} 1 \mathrm{~b} 7 \mathrm{c}$ & Same as c0001f1b7b except cans in corner of glovebox & 0.8540 & 0.0008 \\
\hline $\mathrm{c} 0001 \mathrm{flb} 7 \mathrm{~d}$ & $\begin{array}{l}\text { Same as c0001flb7c except } 200 \mathrm{~g} \text { in } 2.76 \mathrm{~L} \text { can } 15.2 \mathrm{~cm} \\
(6 \mathrm{in} \text {.) outside glovebox close to cans }\end{array}$ & 0.8540 & 0.0008 \\
\hline $\mathrm{c} 0001 \mathrm{f} 1 \mathrm{~b} 7 \mathrm{f}$ & $\begin{array}{l}\text { Same as c0001flb7b except } 200 \mathrm{~g} \text { in } 2.76 \mathrm{~L} \text { can } 15.2 \mathrm{~cm} \\
(6 \mathrm{in} \text {.) outside glovebox close to bowls }\end{array}$ & 0.8665 & 0.0008 \\
\hline $\mathrm{c} 0001 \mathrm{flb} 18$ & $\begin{array}{l}\text { Same as c0001f } 1 \mathrm{~b} 7 \mathrm{~b} \text { except } 400 \mathrm{~g} \text { in } 4.7 \mathrm{~L} \text { can representing } \\
\text { container on conveyor } 25.4 \mathrm{~cm}(10 \mathrm{in} \text {.) from cans }\end{array}$ & 0.8510 & 0.0008 \\
\hline $\mathrm{c} 0001 \mathrm{f} 1 \mathrm{~b} 3 \mathrm{a}$ & Same as c0001flb7b except $500 \mathrm{~g}$ in 3 cans & 0.8324 & 0.0009 \\
\hline
\end{tabular}


HNF-5988 Rev. 0

\begin{tabular}{|c|c|c|c|}
\hline Case & Description & $\mathbf{K}_{\text {calc }}$ & $1 \sigma$ \\
\hline $\mathrm{c} 0001 \mathrm{f} 1 \mathrm{~b} 4 \mathrm{a}$ & Same as c0001flb7b except $500 \mathrm{~g}$ in 4 cans & 0.8572 & 0.0009 \\
\hline c000lflbla & Same as c0001f $1 \mathrm{~b} 7 \mathrm{~b}$ except $500 \mathrm{~g}$ in 5 cans & 0.8590 & 0.0009 \\
\hline c0001f1b6a & Same as c0001flb7b except $500 \mathrm{~g}$ in 6 cans & 0.8591 & 0.0009 \\
\hline c0001f1b8a & Same as c0001f1b7b except $500 \mathrm{~g}$ in 8 cans & 0.8510 & 0.0009 \\
\hline $\mathrm{c} 0001 \mathrm{f} 1 \mathrm{~b} 10 \mathrm{~b}$ & Same as c0001f1b7b except $500 \mathrm{~g}$ in 9 cans & 0.8371 & 0.0008 \\
\hline $\mathrm{c} 0001 \mathrm{f} 1 \mathrm{~b} 11 \mathrm{a}$ & Same as c0001flbla except $500 \mathrm{~g}$ in 10 cans & 0.8256 & 0.0008 \\
\hline c0001flb13a & $\begin{array}{l}\text { Same as c0001 flb7b except } 2.54 \mathrm{~cm}(1 \mathrm{in} .) \text { water around } \\
\text { sides of cans as well as top, no close packed cement cans for } \\
\text { reflection. Container groupings } 25.4 \mathrm{~cm}(10 \mathrm{in} \text {.) apart. } \\
400 \mathrm{~g} \text { Pu in } 4.7 \mathrm{~L} \text { spaced } 25.4 \mathrm{~cm}(10 \mathrm{in} \text {.) from cans } \\
\text { representing container on conveyor }\end{array}$ & 0.8603 & 0.0008 \\
\hline $\mathrm{c} 0001 \mathrm{f} 1 \mathrm{~b} 7 \mathrm{i}$ & $\begin{array}{l}\text { Same as c0001f1b } 7 \mathrm{~b} \text { except } 18 \% \text { water content cement cans } \\
\text { reflection }\end{array}$ & 0.8721 & 0.0008 \\
\hline $\mathrm{c} 0001 \mathrm{f} 1 \mathrm{~b} 20$ & Only 2 bowls, full water reflection from glovebox walls & 0.8081 & 0.0008 \\
\hline $\mathrm{c} 0001 \mathrm{f} 1 \mathrm{~b} 19 \mathrm{a}$ & $\begin{array}{l}\text { Only } 2 \text { bowls plus } 200 \mathrm{~g} \text { Pu can located } 6 \text { " from bowls } \\
\text { outside glovebox }\end{array}$ & 0.8046 & 0.0009 \\
\hline $\mathrm{c} 0001 \mathrm{f} 1 \mathrm{~b} 22$ & $\begin{array}{l}\text { Same as c } 0001 \mathrm{flb} 7 \mathrm{~b} \text { except } 7 \text { cans with } 10 \% \mathrm{SiO}_{2} \text { rather } \\
\text { than Carbon }\end{array}$ & 0.8590 & 0.0008 \\
\hline $\mathrm{c} 0001 \mathrm{fl} 1 \mathrm{~b} 21$ & Same as c0001flb $7 \mathrm{~b}$ except 7 cans with $\mathrm{Pu}+$ water & 0.8867 & 0.0008 \\
\hline $\mathrm{c} 0001 \mathrm{f} 1 \mathrm{~b} 23$ & $\begin{array}{l}\text { Same as c0001f1b7b except } 7 \text { cans with } 10 \% \text { cement rather } \\
\text { than Carbon }\end{array}$ & 0.8487 & 0.0008 \\
\hline
\end{tabular}

\subsubsection{Base Case Model for Limit Set B: $2100 \mathrm{~g}$ Plutonium Total Glovebox}

The base case model for the feed, restricted to the compositions of SS\&C, ash, or oxides documented in Appendices $\mathrm{F}$ and $\mathrm{G}$ and a physical inspection by operators that the feed containers have no free liquid had a $k_{\text {eff }}$ of $0.8607 \pm 0.0009$ (case c0001 $f 2 b 4$ ). This value is well below the allowable $\mathrm{k}_{\mathrm{eff}}$ of 0.942 . 
Table 5-3. Base Case Model 2100 g Plutonium Limit Set

\begin{tabular}{|c|c|}
\hline Glovebox Assumptions & $\begin{array}{l}\text { Glovebox is surrounded with a minimum of } 30.48 \mathrm{~cm}(12 \mathrm{in} \text {.) of } \\
\text { water for neutron reflection. } \\
\text { Rectangular transverse cross-section instead of actual slanted-side } \\
\text { outlines. } \\
2.54 \mathrm{~cm} \text { ( } 1 \text { in.) water reflection representing hands around each } \\
\text { container group. } \\
\text { Array of close packed triangular pitched } 2.76 \mathrm{~L} \text { cans filled with } \\
\text { cement or water surround each group of cans. } \\
\text { Pu holdup in glovebox included in total glovebox mass limit. } \\
\text { Modeled as } 300 \mathrm{~g} \mathrm{Pu} \text { in thin } 0.001 \mathrm{~cm} \text { layer over entire floor of } \\
\text { glovebox. }\end{array}$ \\
\hline Glovebox dimensions & $\begin{array}{l}132.1 \mathrm{~cm}(52 \mathrm{in} .) \text { deep, } 91.44 \mathrm{~cm}(36 \mathrm{in} .) \text { high, } 518.16 \mathrm{~cm} \\
(204 \mathrm{in} .) \text { long. The length is } 45.7 \mathrm{~cm}(18 \mathrm{in} .) \text { longer than the } \\
\text { actual glovebox to include the adjoining Conveyor Glovebox HA- } \\
28 \text {. }\end{array}$ \\
\hline Mixer bowls & $\begin{array}{l}\text { Two } 4.80 \mathrm{~L} \text { bowls } 20.3 \mathrm{~cm}(8 \mathrm{in} .) \text { diameter and } 18.0 \mathrm{~cm}(7.1 \mathrm{in} .) \\
\text { deep. Lower part of bowl is hemispherical with flattened bottom. } \\
\text { The height is modeled slightly greater than the actual height of } \\
17.8 \mathrm{~cm}(7 \mathrm{in} \text {.) so the volume is larger than the actual volume of } \\
4.73 \mathrm{~L} \text {. } \\
\text { Each bowl contains } 200 \mathrm{~g} \mathrm{Pu} \text { as PuO } 2 \text { mixed with water to the full } \\
\text { volume. The two bowls are touching to represent a single spacing } \\
\text { violation, and are located in a corner of the glovebox spaced } 25.4 \\
\mathrm{~cm}(10 \text { in.) from other containers. }\end{array}$ \\
\hline Feed cans & $\begin{array}{l}2.76 \mathrm{~L} \text { cylinder } 14.0 \mathrm{~cm}(5.5 \mathrm{in} .) \text { diameter and } 18.0(7.1 \mathrm{in} \text {.) high. } \\
\text { The height is modeled slightly greater than the actual height of } \\
17.8 \mathrm{~cm}(7 \mathrm{in} .) \text { so the volume is larger than the actual volume of } \\
2.73 \mathrm{~L} \text {. } \\
900 \mathrm{~g} \mathrm{Pu} \text { as } \mathrm{PuO} 2 \text { with } \mathrm{H} / \mathrm{X}=20 \text { in } 7 \text { cans filled with } 33 \mathrm{wt} \% \\
\text { carbon, } 67 \mathrm{wt} \% \text { silicon dioxide representing restricted moderation } \\
\text { feed cans containing one of the identified feed materials ( ash, } \\
\text { oxide scrap, or sand, slag and crucible material). These cans are } \\
\text { grouped together and surrounded close packed by other cement } \\
\text { filled cans, but are spaced } 25.4 \mathrm{~cm}(10 \mathrm{in} .) \text { from the Pu containing } \\
\text { billet cans. }\end{array}$ \\
\hline Billet cans & $\begin{array}{l}2.76 \mathrm{~L} \text { cylinder } 14.0 \mathrm{~cm}(5.5 \mathrm{in} .) \text { diameter and } 18.0 \mathrm{~cm}(7.1 \mathrm{in} .) \\
\text { high. } \\
\text { The height is modeled slightly greater than the actual height of } \\
17.8 \mathrm{~cm}(7 \mathrm{in} \text {.) so the volume is larger than the actual volume of } \\
2.73 \mathrm{~L} . \\
500 \mathrm{~g} \text { Pu in } 7 \text { cans filled with } 90 \mathrm{vol} \% \text { water, } 10 \text { vol } \% \text { silicon } \\
\text { dioxide represents unrestricted moderation cement filled cans. } \\
\text { These cans are grouped together and surrounded close packed by }\end{array}$ \\
\hline
\end{tabular}


HNF-5988 Rev. 0

\begin{tabular}{|l|l|}
\hline & $\begin{array}{l}\text { other cement filled cans, but are spaced } 20.5 \mathrm{~cm} \text { (10 in.) from other } \\
\text { Pu containing containers. }\end{array}$ \\
\hline Sieve Pan Assembly & Not explicitly modeled since covered by feed and billet cans. \\
\hline Crusher Unit & Not explicitly modeled since covered by feed and billet cans. \\
\hline Auger/Conveyor Unit & Not explicitly modeled since covered by feed and billet cans. \\
\hline Feedwater tank & $\begin{array}{l}\text { Not explicitly modeled since covered by external water reflection } \\
\text { and cement cans reflection. }\end{array}$ \\
\hline Maintenance fluids & Not explicitly modeled since covered by water reflection. \\
\hline Sweeps container & $\begin{array}{l}\text { Not included since more reactive to have all Pu in billet cans, feed } \\
\text { cans, and bowls. }\end{array}$ \\
\hline Room Assumptions & $\begin{array}{l}\text { One } 2.76 \mathrm{~L} \text { cylindrical can } 15.2 \mathrm{~cm} \text { (6 in.) from glovebox wall } \\
\text { with } 200 \mathrm{~g} \text { Pu with water representing waste barrel moving past } \\
\text { north end of glovebox. }\end{array}$ \\
\hline
\end{tabular}

\subsubsection{Base Case Model Differences from Limit Set A}

To increase the glovebox mass limit to $2100 \mathrm{~g}$ plutonium or fissile equivalent, less than optimum moderation must be assumed for the feed material. The mass limit is increased by separating the feed material from the cemented billets and requiring that the feed be material characterized as SS\&C, ash, or oxide. Appendixes F and G describe the composition of that material. Also, the feed containers must be inspected as they are brought into the glovebox to assure that there is no free liquid and only one container at a time can have its cover off.

Feed containers are then restricted in moderation due to the nature of the material and the requirements of where it is stored. SS\&C, ash, or oxides must have an $\mathrm{H} / \mathrm{X} \leq 20$, so using $\mathrm{H} / \mathrm{X}=20$ in these calculations is conservative. Vigilance must be exercised to maintain this restricted moderation level by inspecting each container brought into the glovebox for free liquid. Also, only one feed container can be uncovered at a time to not allow the cans to fill with water if an event breaks the glovebox windows and actuates the fire suppression water.

A minimum $25.4 \mathrm{~cm}$ spacing is maintained between the feed containers and the cemented billet cans. This requirement is in addition to the spacing required between the mixing bowls and the bowls and cement cans of limit set $\mathrm{A}$.

\subsubsection{Base Case Results for Limit Set B}

Base case evaluations were conservatively modeled to represent the operations for the $2100 \mathrm{~g}$ plutonium total glovebox limit. The results for these base case evaluations are given in Table 5-9. These $\mathrm{k}_{\mathrm{eff}} \mathrm{s}$ are all significantly less than the criticality safety limit. The criticality safety criterion has been met for the base situation with SS\&C, ash, or oxide feed.

The base case (case c0001f $2 \mathrm{~b} 4$ ) had a $\mathrm{k}_{\text {eff }}$ of $0.8607 \pm 0.0009$. The other cases in Table 54 are sensitivity studies that were used to develop this base case. These cases addressed issues of 
HNF-5988 Rev. 0

fissile material location, reflection, moderation, composition, and interaction.

Case c0001 2 b5 with water in the close packed cans surrounding the fissile containers, had a $k_{\text {eff }}$ of $0.8579 \pm 0.0008$ which is negligibly smaller than the $k_{\text {eff }}$ for the base case c0001f $2 \mathrm{~b} 4$ with cement in the surrounding containers.

The set of cases c0001f2b3, c0001f2bh3, c0001f2bh1, and c0001f $2 \mathrm{bh} 4$ varied the number of fissile limited moderation feed cans from five to ten, with the same $900 \mathrm{~g} \mathrm{Pu}$ fissile content. The number of fissile cans was also varied in cases c0001f $2 \mathrm{~b} 1$ and $c 0001 \mathrm{f} 2 \mathrm{~b} 2$. These cases showed that concentrations higher or lower than the base case of seven cans would have lower reactivity.

Sensitivity to the number of feed cans was demonstrated in the sensitivity studies for the Limit Set A base case in Section 5.2.7. As a check, the case c0001f $2 \mathrm{~b} 3$ reduced the number of fissile cement feed cans from seven to five, with the same $500 \mathrm{~g} \mathrm{Pu}$ fissile content. The resulting lower $\mathrm{k}_{\text {eff }}$ showed that concentrations higher than the base case of seven cans would have lower reactivity and indicated that the most reactive configuration would be the same .

The $\mathrm{k}_{\text {eff }}$ for case $\mathrm{c} 0001 \mathrm{f} 2 \mathrm{~b} 6 \mathrm{a}$ was lower than the base case $\mathrm{c} 0001 \mathrm{f} 2 \mathrm{~b} 4$, showing that it is more reactive to have close packed cement cans reflection surrounding the fissile cans (with nominal $5.1 \mathrm{~cm}$ water reflection on top of the containers) than to have the fissile containers against the fully reflecting glovebox wall along with nominal $5.1 \mathrm{~cm}$ water reflection around the containers.

Comparing case $\mathrm{c} 0001 \mathrm{f} 2 \mathrm{~b} 8$ with the base case $\mathrm{c} 0001 \mathrm{f} 2 \mathrm{~b} 4$ showed that it is more reactive to have close packed cement can reflection surrounding the fissile containers than to have the most reactive container that could be on the HA-28 conveyor $(400 \mathrm{~g}$ Pu in $4.7 \mathrm{~L}$ fully moderated with water) spaced at $25.4 \mathrm{~cm}$ from the glovebox fissile containers. Case c0001 2 b 8 located the conveyor container $25.4 \mathrm{~cm}$ from both feed and cement product container groupings.

Table 5-4. MCNP Calculational Results of Base Cases in Glovebox HA-20MB for Limit Set B: $2100 \mathrm{~g}$ Plutonium Total Glovebox

\begin{tabular}{|c|c|c|c|}
\hline Case & Description & $\mathbf{k}_{\text {calc }}$ & $1 \sigma$ \\
\hline $\mathrm{c} 0001 \mathrm{f} 2 \mathrm{~b} 4$ & $\begin{array}{l}500 \mathrm{~g} \mathrm{Pu} \text { in } 7 \text { cans } 90 \% \text { by volume water, } 10 \% \text { silicon oxide } \\
400 \mathrm{~g} \mathrm{Pu} \text { in } 2 \text { bowls } 100 \% \text { water touching. } \\
900 \mathrm{~g} \mathrm{Pu} \text { in } 7 \text { cans } \mathrm{H} / \mathrm{X}=2033 \% \text { carbon } 67 \% \text { silicon oxide } \\
300 \mathrm{~g} \mathrm{Pu} \text { holdup on floor. } \\
200 \mathrm{~g} \mathrm{Pu} \text { in } 2.7 \mathrm{~L} \text { outside glovebox at } 15.24 \mathrm{~cm}(6 \mathrm{in} .) \\
\text { spacing from glovebox wall next to bowls representing drum } \\
\text { passing by. } \\
\text { Close packed cans surrounded by cement cans. } \\
2.54 \mathrm{~cm}(1 \mathrm{in} .) \text { water reflection on top of cans. }\end{array}$ & 0.8607 & 0.0009 \\
\hline
\end{tabular}


HNF-5988 Rev. 0

\begin{tabular}{|c|c|c|c|}
\hline Case & Description & $\mathbf{k}_{\text {calc }}$ & $1 \sigma$ \\
\hline $\mathrm{c} 0001 \mathrm{f} 2 \mathrm{~b} 3$ & Same as c0001f $2 \mathrm{~b} 4$ except $900 \mathrm{~g}$ in 5 cans, $H / X=20$. & 0.8591 & 0.0009 \\
\hline $\mathrm{c} 0001 \mathrm{f} 2 \mathrm{~b} 1$ & $\begin{array}{l}\text { Same as c0001f } 2 \mathrm{~b} 3 \text { except } 500 \mathrm{~g} \text { in } 5 \text { cans, } 90 \% \text { water, } 10 \% \\
\text { silicon oxide, } 900 \mathrm{~g} \text { in } 5 \text { cans, } \mathrm{H} / \mathrm{X}=20 .\end{array}$ & 0.8530 & 0.0009 \\
\hline $\mathrm{c} 0001 \mathrm{f} 2 \mathrm{~b} 2$ & Same as c0001 f2b1 except $900 \mathrm{~g}$ in 6 cans, $\mathrm{H} / \mathrm{X}=20$. & 0.8535 & 0.0008 \\
\hline $\mathrm{c} 0001 \mathrm{f} 2 \mathrm{~b} 5$ & Same as c0001f2b4 except water cans reflection. & 0.8579 & 0.0008 \\
\hline $\mathrm{c} 0001 \mathrm{f} 2 \mathrm{~b} 8$ & $\begin{array}{l}\text { Same as c0001 f } 2 \mathrm{~b} 4 \text { except } 4.7 \mathrm{~L} \text { can with } 400 \mathrm{~g} \mathrm{Pu}, 25.4 \mathrm{~cm} \\
(10 \mathrm{in} \text {.) from other cans representing container on HA- } 28 \\
\text { conveyor. }\end{array}$ & 0.8456 & 0.0008 \\
\hline $\mathrm{c} 0001 \mathrm{f} 2 \mathrm{~b} 6 \mathrm{a}$ & $\begin{array}{l}\text { Same as c0001 } \mathrm{f} 2 \mathrm{~b} 4 \text { except } 2.54 \mathrm{~cm} \text { ( } 1 \text { in.) water around } \\
\text { sides of cans as well as top, next to walls, no close packed } \\
\text { cement cans for reflection. } 400 \mathrm{~g} \text { in } 4.7 \mathrm{~L} \text { can representing } \\
\text { conveyor container. Container groupings } 25.4 \mathrm{~cm}(10 \mathrm{in} \text {.) } \\
\text { apart. }\end{array}$ & 0.8553 & 0.0008 \\
\hline $\mathrm{c} 0001 \mathrm{f} 2 \mathrm{bh} 2$ & $\begin{array}{l}\text { Same as c0001f } 2 \mathrm{~b} 4 \text { except no } 500 \mathrm{~g} \mathrm{Pu} \text { in } 7 \text { cans, } \\
900 \mathrm{~g} \text { in } 5 \text { cans } \mathrm{H} / \mathrm{X}=20 .\end{array}$ & 0.8074 & 0.0008 \\
\hline $\mathrm{c} 0001 \mathrm{f} 2 \mathrm{bh} 3$ & $\begin{array}{l}\text { Same as c0001f } 2 \mathrm{~b} 4 \text { except no } 500 \mathrm{~g} \mathrm{Pu} \text { in } 7 \text { cans, } \\
900 \mathrm{~g} \text { in } 6 \text { cans } \mathrm{H} / \mathrm{X}=20 \text {. }\end{array}$ & 0.8088 & 0.0008 \\
\hline $\mathrm{c} 0001 \mathrm{f} 2 \mathrm{bh} 1$ & $\begin{array}{l}\text { Same as c0001f } 2 \mathrm{~b} 4 \text { except no } 500 \mathrm{~g} \text { Pu in } 7 \text { cans, } \\
900 \mathrm{~g} \text { in } 7 \text { cans } \mathrm{H} / \mathrm{X}=20 \text {. }\end{array}$ & 0.8094 & 0.0009 \\
\hline $\mathrm{c} 0001 \mathrm{f} 2 \mathrm{bh} 4$ & $\begin{array}{l}\text { Same as c0001f } 2 \mathrm{~b} 4 \text { except no } 500 \mathrm{~g} \mathrm{Pu} \text { in } 7 \text { cans, } \\
900 \mathrm{~g} \text { in } 10 \text { cans } \mathrm{H} / \mathrm{X}=20 \text {. }\end{array}$ & 0.8076 & 0.0009 \\
\hline
\end{tabular}

\subsection{CONTINGENCY ANALYSIS}

The contingency analysis section addresses the effect of various unlikely, off-normal events on the critical parameters and their associated controls to confirm the double contingency criterion has been met.

Mass is controlled administratively by measurement. The total fissile mass of the glovebox is limited to $1200 \mathrm{~g}$ plutonium or fissile equivalent for limit set $\mathrm{A}$ and $2100 \mathrm{~g}$ plutonium or fissile equivalent for limit set $\mathrm{B}$. These mass limits were determined by the maximum mass that would satisfy the criticality safety limits on $k_{\text {eff }}$ for the limiting conditions of the seismic contingency analysis. Sections 5.3.4, 5.3.5, 5.3.10, and 5.3.11 address the contingency of exceeding the glovebox mass limit as well as the container limit of $200 \mathrm{~g}$ plutonium or equivalent.

Volume and Geometry are physically controlled by restrictions on container volume and height. It is important in an unrestricted moderation glovebox not to allow large, low neutron 
leakage arrangement of containers. This is accomplished by limiting the height of the containers in the base case and the size of container that could be mistakenly stacked. Container height is limited to $17.8 \mathrm{~cm}$ and the volume of containers other than mixing bowls, sieve pan assembly, and crusher/auger is $2.76 \mathrm{~L}$. Sections 5.3.4 and 5.3.10 address the contingency of exceeding the volume limits.

Density is not controlled. The most reactive credible densities were used for all materials.

Moderation is not controlled for limit set A. For limit set B, the feed material must be SS\&C, ash, or oxide as described in Appendices F and G, cannot have free liquid in the feed containers, or more than one feed container open at one time. Sections 5.3.9 and 5.3.11 address the contingency of the $\mathrm{H} / \mathrm{X}$ ratio being too high in the feed material.

Reflection is controlled by a dry fire suppression system within the HA-20MB Glovebox but not controlled by the volume of water or number of water-bearing containers within the glovebox. Sections 5.3.1, 5.3.2, 5.3.8, and 5.3.9 explain the contingencies where an earthquake or major fire causes the glovebox windows to melt or break and the fire suppression system to rain water down on the glovebox contents.

Interaction is controlled administratively by a minimum $25.4 \mathrm{~cm}$ (10 in.) spacing requirement between mixing bowls and between mixing bowls and the other containers of fissile material for both limit sets. For limit set B, the feed material and cemented fissile containers shall be separated by $25.4 \mathrm{~cm}$. One spacing violation is included in the base case. Sections 5.3 .4 and 5.3.10 address the contingency of container stacking. Firefighting Category $\mathrm{C}$ is specified to restrict solid streams of water that could cause significant loss of interaction control. Stacking bounds a second spacing violation.

Enrichment, Concentration, and Isotopes are not controlled for plutonium which was assumed to be $100 \mathrm{wt} \%{ }^{239} \mathrm{Pu}$. This conservatively encompasses all allowed fissionable materials including uranium enriched to $50 \%{ }^{235} \mathrm{U}$. The hazards assessment, Appendix D, states that it isn't credible to exceed this uranium enrichment in Glovebox HA-20MB.

Neutron Absorption is not controlled.

The off-normal situations of fissionable material handling for the operations in Glovebox HA-20MB are listed in Tables 1-2 and 1-4. The following discussions in this section give a description of the off-normal conditions and the calculational results. Each of the unlikely off-normal events results from a loss of one or more controls, and is therefore considered to be a contingency. For each contingency, the model assumed the most limiting allowed conditions for criticality controls shown in Section 3.0 including likely off-normal events. 


\subsubsection{Contingencies for Limit Set A}

Contingencies for the $1200 \mathrm{~g}$ plutonium or equivalent fissile mass limit set are evaluated by imposing the unlikely event upon the base case described in Section 5.2.1. Each of these events are described below.

\subsubsection{Seismic Event}

The seismic contingency is the limiting event for setting the glovebox fissile mass limits. The Plutonium Finishing Plant Final Safety Analysis Report (FDH 1999) states that Glovebox HA-20MB is seismically qualified. The glovebox will remain upright but the contents can move around during an earthquake. The worst case is for the feed, cement billets, and mixing bowls to group together, thus losing the $25.4 \mathrm{~cm}$ spacing control between these groups of containers and then flooding.

The source of possible, but highly unlikely, flooding during a seismic event would be breakage of the room fire sprinkler pipes or heads combined with breakage of the glovebox windows to allow entry of water to the glovebox and contents. Open containers could collect water and free liquid could accumulate to a depth of $5.08 \mathrm{~cm}(2 \mathrm{in}$.) on the floor before draining into the HA-28 conveyor. Analysis with water to this depth adequately covers the potential flooding depth caused by this elevation difference. Table 5-5 shows the seismic event for several arrangements of the base case containers where $k_{\text {eff }}$ does not exceed 0.923 for sprinkler spray densities up to $0.1 \mathrm{~g} / \mathrm{cc}$.

Water spray densities from the sprinkler system was evaluated as described in Appendix I. Fire suppression water densities will be on the order of $0.01 \mathrm{~g} / \mathrm{cc}$ or less for contingencies that could actuate or break the water lines. Table 5-5 shows a parametric study of interspersed water through the credible range of sprinkler water densities for the seismic contingency for limit set A. The reactivity steadily rises with no intermediate peak. It is assumed in this evaluation that unlikely water densities could range up to $0.1 \mathrm{~g} / \mathrm{cc}$ and greater water densities are not credible.

Table 5-5. MCNP Calculational Results of Seismic Cases in Glovebox HA-20MB for $1200 \mathrm{~g}$ Plutonium Limit Set

\begin{tabular}{|c|l|c|c|}
\hline \multicolumn{1}{|c|}{ Case } & \multicolumn{1}{|c|}{ Description } & \multicolumn{1}{|c|}{$\mathbf{k}_{\text {calc }}$} & \multicolumn{1}{|c|}{$\mathbf{1} \sigma$} \\
\hline c000lflq1a & $\begin{array}{l}500 \mathrm{~g} \text { Pu in 5 cans 90\% by volume water, 10\% carbon } \\
400 \mathrm{~g} \text { Pu in 2 bowls filled with water. } \\
300 \mathrm{~g} \mathrm{Pu} \text { holdup on floor. }\end{array}$ & 0.9226 & 0.0009 \\
& $\begin{array}{l}\text { All containers grouped together with close packed cement } \\
\text { cans surrounding all Pu cans and bowls. } \\
\text { Glovebox flooded to 5.08 cm (2 in.), rest of glovebox filled } \\
\text { with 10\% dense water spray. }\end{array}$ & & \\
\hline
\end{tabular}


HNF-5988 Rev. 0

\begin{tabular}{|c|l|c|c|}
\hline Case & \multicolumn{1}{|c|}{ Description } & \multicolumn{1}{|c|}{$\mathbf{k}_{\text {calc }}$} & $1 \sigma$ \\
\hline c0001flq1 & Same as c0001flq1a but 4 cans & 0.9152 & 0.0009 \\
\hline c0001flq4 & Same as c0001flqla but 7 cans & 0.9120 & 0.0009 \\
\hline c0001flq3 & $\begin{array}{l}\text { Same as c0001flqla but 7 cans (same can arrangement as } \\
\text { base case c0001flb7b) }\end{array}$ & 0.9015 & 0.0009 \\
\hline c0001flq5 & $1200 \mathrm{~g}$ Pu in slab on floor of conveyor housing at $150 \mathrm{~g} / \mathrm{L}$ & 0.4344 & 0.0007 \\
\hline c0001flqle & Same as c0001flqla except $0.001 \mathrm{~g} / \mathrm{cc}$ water spray & 0.8789 & 0.0008 \\
\hline c0001flqlb & Same as c0001flqla except $0.01 \mathrm{~g} / \mathrm{cc}$ water spray & 0.8840 & 0.0009 \\
\hline c0001flq1c & Same as c0001flqla except $0.05 \mathrm{~g} / \mathrm{cc}$ water spray & 0.9004 & 0.0009 \\
\hline c0001f1q1d & Same as c0001flq1a except $0.15 \mathrm{~g} / \mathrm{cc}$ water spray & 0.9398 & 0.0009 \\
\hline
\end{tabular}

\subsubsection{Major Fire}

It is unlikely that the PFP will have a major structural fire that will melt the glovebox windows and actuate the fire suppression sprinklers. That contingency is evaluated two ways. One is to assume that open containers fill with water but don't overflow in such a way as to wash out fissile material. The other evaluation assumes that all the fissile material in open containers washes out onto the floor of the glovebox that fills to a $5.08-\mathrm{cm}(2-\mathrm{in}$.) depth before draining into the HA-28 conveyor. This depth adequately covers the potential flooding caused by the elevation difference between the two gloveboxes. Table 5-6 shows the results of these calculations with the $\mathrm{k}_{\text {eff }} \mathrm{s}$ less than 0.86 .

Table 5-6. MCNP Calculational Results of Flooding Cases in Glovebox HA-20MB for 1200 g Plutonium Limit Set

\begin{tabular}{|c|c|c|c|}
\hline Case & Description & $\mathbf{k}_{\text {calc }}$ & $1 \sigma$ \\
\hline $\mathrm{c} 0001 \mathrm{flfl}$ & $\begin{array}{l}\text { Same as base case c0001flb7b except glovebox flooded to } \\
5.08 \mathrm{~cm}(2 \mathrm{in} .) \text {, rest of glovebox filled with } 10 \% \text { dense water } \\
\text { spray. }\end{array}$ & 0.8567 & 0.0009 \\
\hline $\mathrm{c} 0001 \mathrm{f} 1 \mathrm{f} 2$ & $\begin{array}{l}\text { Same as base case c0001flb13a (no close packed cement } \\
\text { cans for reflection) except flooded to } 5.08 \mathrm{~cm}(2 \mathrm{in} \text {.), rest of } \\
\text { glovebox filled with } 10 \% \text { dense water spray }\end{array}$ & 0.8329 & 0.0008 \\
\hline $\mathrm{c} 0001 \mathrm{flf} 3$ & $\begin{array}{l}1200 \mathrm{~g} \mathrm{Pu} \text { mixed with water in } 5.08 \mathrm{~cm} \mathrm{(2} \mathrm{in.)} \mathrm{layer} \mathrm{on} \\
\text { glovebox floor }\end{array}$ & 0.2047 & 0.0003 \\
\hline $\mathrm{c} 0001 \mathrm{flf} 4$ & $\begin{array}{l}1200 \mathrm{~g} \mathrm{Pu} \text { in water in } 0.13 \mathrm{~cm} \text { thick slab on glovebox floor } \\
\text { at } 150 \mathrm{~g} / \mathrm{L}\end{array}$ & 0.6571 & 0.0011 \\
\hline
\end{tabular}




\subsubsection{Stacking Event}

Stacking is prohibited at the PFP. Also, operators are trained not to move one container over another. However, it is credible, but unlikely, that either a mixing bowl or another fissile container is moved over the top of another. For this contingency, a mixing bowl is analyzed stacked on top of another mixing bowl or on the top of the most reactive arrangement of other fissile containers. Also, an additional $2.76 \mathrm{~L}$ container with $200 \mathrm{~g}$ of plutonium is stacked on top of the most reactive arrangement of other fissile containers. These results are presented in Table 5-7 with $\mathrm{k}_{\mathrm{eff}}$ not exceeding 0.93 .

Table 5-7. MCNP Calculational Results of Stacking Cases in Glovebox HA-20MB for 1200 g Plutonium Limit Set

\begin{tabular}{|c|l|c|c|}
\hline Case & \multicolumn{1}{|c|}{ Description } & $\mathbf{k}_{\text {calc }}$ & $1 \sigma$ \\
\hline c0001f1s3 & $\begin{array}{l}\text { Same as base case c0001f1b7b except one bowl with } 200 \mathrm{~g} \\
\text { Pu stacked on top of seven 2.76 L cans containing } 500 \mathrm{~g} \mathrm{Pu} \\
\text { in center of glovebox with cement can reflection. }\end{array}$ & 0.9296 & 0.0008 \\
\hline c0001f1s4 & $\begin{array}{l}\text { Same as base case c0001flb7c except one bowl with } 200 \mathrm{~g} \\
\text { Pu stacked on top of seven 2.76 L cans containing } 500 \mathrm{~g} \mathrm{Pu} \\
\text { in corner of glovebox with cement can reflection. }\end{array}$ & 0.9223 & 0.0009 \\
\hline c0001f1s1 & $\begin{array}{l}\text { Same as base case c0001f1b7b except one bowl with 200 g } \\
\text { Pu stacked on top of five 2.76 L cans containing 500 g Pu in } \\
\text { center of glovebox with cement can reflection. }\end{array}$ & 0.9276 & 0.0009 \\
\hline c0001f1s2 & $\begin{array}{l}\text { Same as base case c0001f1b7b except one bowl with 200 g } \\
\text { Pu stacked on top of five 2.76 L cans containing 500 g Pu in } \\
\text { corner of glovebox with cement can reflection. }\end{array}$ & 0.9214 & 0.0009 \\
\hline c0001f1s6 & $\begin{array}{l}\text { Same as base case c0001flb7b except one bowl stacked on } \\
\text { top of other bowl. }\end{array}$ & 0.8674 & 0.0008 \\
\hline c0001f1s5 & $\begin{array}{l}\text { Same as base case c0001f1b7b except one extra 2.76 L can } \\
\text { with 200 g Pu stacked on top of seven cans containing 500 g } \\
\text { Pu. }\end{array}$ & 0.9078 & 0.0009 \\
\hline
\end{tabular}

\subsubsection{Interaction Events}

Minimum spacing is required for certain fissile containers within the glovebox and between these containers and fissile containers in Conveyor Glovebox HA-28, and to waste drums and wagons in Room 235B. One spacing violation inside the glovebox is likely and is included in the base case. The other spacing violations are unlikely and are analyzed as contingencies. The seismic event conservatively bounds the loss of spacing within the glovebox. Loss of the $25.4 \mathrm{~cm}$ minimum spacing to containers in Conveyor Glovebox HA-28, the $15.2 \mathrm{~cm}$ 
HNF-5988 Rev. 0

minimum spacing to the waste drums passing the north side of the glovebox, and the wagons allowed in the room are reported in Table 5-8. No $\mathrm{k}_{\mathrm{eff}}$ exceeds 0.91 .

The sensitivity cases described in Section 5.2.1 showed that the drum container would have a negligible impact on the glovebox reactivity as long as the $15.2 \mathrm{~cm}$ spacing is maintained to the containers in the glovebox. Interaction contingencies were evaluated to assess the impact of losing this spacing. The $\mathrm{k}_{\text {eff }}$ for case $\mathrm{c} 0001 \mathrm{f} 1 \mathrm{~b} 7 \mathrm{~g}$ of $0.8687 \pm 0.0008$, with the outside can against the glovebox wall next to the two bowls, can be compared directly to the base case c0001 flb7b k $\mathrm{eff}_{\text {of }}$ o.8647 \pm 0.0009 . The $\mathrm{k}_{\mathrm{eff}}$ for case $\mathrm{c} 0001 \mathrm{flb} \mathrm{h}$ of $0.8669 \pm 0.0008$, with the outside can against the glovebox wall next to the fissile cans in the corner of the glovebox, can be compared directly to the case $\mathrm{c} 0001 \mathrm{f} 1 \mathrm{~b} 7 \mathrm{c} \mathrm{k}_{\mathrm{eff}}$ of $0.8540 \pm 0.0008$, with the fissile cans in the corner of the glovebox. This comparison indicated an increase in $\mathrm{k}_{\mathrm{eif}}$ of 0.013 associated with losing the $15.2 \mathrm{~cm}$ spacing. While the $\mathrm{k}_{\mathrm{eff}}$ ' $\mathrm{s}$ calculated for this contingency are well below the $\mathrm{k}_{\mathrm{eff}}$ limit of 0.932 for this system, the increase in $\mathrm{k}_{\text {eff }}$ associated with the loss of spacing could impact other contingencies, such as stacking and seismic, if the loss of spacing was included as part of the base case. To illustrate this impact, case c0001f1s 8 was constructed as a duplicate of the stacking contingency case c0001f1s 4 with the fissile cans and a stacked bowl in the glovebox corner, with the addition of the outside drum container adjacent to the glovebox wall next to the cans. The $\mathrm{k}_{\mathrm{eff}}$ of case $\mathrm{c} 0001 \mathrm{f} 1 \mathrm{~s} 8$ was $0.9351 \pm 0.0009$, which is 0.013 higher than the case $\mathrm{c} 0001 \mathrm{f} 1 \mathrm{~s} 4 \mathrm{k}_{\text {eff }}$ of $0.9223 \pm 0.0009$, and exceeds the $\mathrm{k}_{\text {eff }}$ limit of 0.932 . A similar increase would be expected on seismic contingencies, which would also exceed the $\mathrm{k}_{\mathrm{eff}}$ limit. Therefore, the 15.2 $\mathrm{cm}$ spacing limit is required for the current analysis assumptions.

Table 5-8. MCNP Calculational Results of Interaction Cases in Glovebox HA-20MB for 1200 g Plutonium Limit Set

\begin{tabular}{|c|l|c|c|}
\hline Case & \multicolumn{1}{|c|}{ Description } & \multicolumn{1}{|c|}{$\mathbf{k}_{\text {calc }}$} & $1 \sigma$ \\
\hline c0001f1w1 & $\begin{array}{l}\text { Same as base case c0001f1b7c except one wagon with max } \\
\text { Pu loading under glovebox directly under cans. }\end{array}$ & 0.8451 & 0.0010 \\
\hline c0001f1b7h & $\begin{array}{l}\text { Same as base case c0001f1b7b except 2.76 L container with } \\
\text { 200 g Pu representing drum outside glovebox located against } \\
\text { glovebox wall adjacent to seven 2.76 L cans containing 500 } \\
\text { g Pu in corner. }\end{array}$ & 0.8669 & 0.0008 \\
\hline c0001f1b7g & $\begin{array}{l}\text { Same as base case c0001flb7b except 2.76 L container with } \\
\text { 200 g Pu representing drum outside glovebox located against } \\
\text { glovebox wall adjacent to two 4.8 L bowls containing 400 g } \\
\text { Pu in corner. }\end{array}$ & 0.8687 & 0.0008 \\
\hline c0001f1b17 & $\begin{array}{l}\text { Same as base case c0001f1b7b except 400 g in 4.7 L can } \\
\text { adjacent to other cans }\end{array}$ & 0.9097 & 0.0009 \\
\hline
\end{tabular}


HNF-5988 Rev. 0

\begin{tabular}{|c|l|c|c|}
\hline Case & \multicolumn{1}{|c|}{ Description } & \multicolumn{1}{|c|}{$\mathbf{k}_{\text {calc }}$} & $1 \sigma$ \\
\hline c0001flbs8 & $\begin{array}{l}\text { Same as stacking case c0001f1s4 except 2.76 L container } \\
\text { with 200 g Pu representing drum outside glovebox located } \\
\text { against glovebox wall adjacent to seven 2.76 L cans } \\
\text { containing 500 g Pu in corner. }\end{array}$ & $0.9351^{(\mathrm{a})}$ & 0.0009 \\
\hline
\end{tabular}

(a) This case includes two contingencies, a stacking violation and a spacing violation, and was only included to illustrate why the spacing violation was not part of the base case configuration.

\subsubsection{Other Contingencies for Limit Set A}

\section{Extra Mixing Bowl with Some Fissile Mass Out of Other Containers}

The additional $200 \mathrm{~g} \mathrm{Pu}$ container stacked on the other containers (case c0001f1s 3 ) covers the contingency of an extra mixing bowl with some of the fissile mass outside the other containers with a $\mathrm{k}_{\text {eff }}$ of $0.9296 \pm 0.0008$.

\section{Excess Glovebox Holdup Exceeding the Glovebox Mass Limit}

The additional $200 \mathrm{~g} \mathrm{Pu}$ container stacked on the other containers (case c0001f $1 \mathrm{~s} 3$ ) covers the contingency of excess holdup exceeding the glovebox mass limit by up to $200 \mathrm{~g}$ since it is more reactive to have the excess Pu concentrated in one container on top of the other containers than to have the Pu distributed around the glovebox as holdup.

\section{Container too Large}

The stacking of two $4.8 \mathrm{~L}$ mixing bowls, each containing $200 \mathrm{~g}$ of $\mathrm{Pu}$ with unrestricted moderation (case c0001f1 s6) provides a bounding reactivity for up to $400 \mathrm{~g} \mathrm{Pu}$ in a total of $9.6 \mathrm{~L}$, which is much larger than any container that could be introduced into the glovebox. Therefore the contingency of having a container larger than the $4.8 \mathrm{~L}$ mixing bowl is covered.

\section{Extra Oil or Plastic}

The fire case $0001 \mathrm{fl} f 1$ is an analysis of the base case configuration with $5 \mathrm{~cm}$ of water flooding on the floor and $10 \%$ dense water spray filling the glovebox. The $\mathrm{k}_{\text {eff }}$ for this case was $0.8567 \pm 0.0009$, which was lower than the $0.8647 \pm 0.0009 \mathrm{k}_{\text {efr }}$ for the base case with nominal reflection (case c0001flb7b). Extra oils or plastics in the glovebox would have to be very extensive in order to exceed the hydrogen content of the water in either of these cases.

\subsubsection{Contingencies for Limit Set B}

Contingencies for the $2100 \mathrm{~g}$ plutonium or equivalent fissile mass limit set are evaluated by imposing the unlikely event upon the base case described in Section 5.2.2. Each of these events is described below. 
HNF-5988 Rev. 0

\subsubsection{Seismic Event}

The seismic contingency is the limiting event for setting the glovebox fissile mass limits. The Plutonium Finishing Plant Final Safety Analysis Report (FDH 1999) states that Glovebox HA-20MB is seismically qualified. The glovebox will remain upright but the contents can move around during an earthquake. Worst case is for the feed, cement billets, and mixing bowls to group together, thus losing the $25.4 \mathrm{~cm}$ spacing control between these groups of containers and then flooding.

The source of possible, but highly unlikely, flooding during a seismic event would be breakage of the room fire sprinkler pipes or heads combined with breakage of the glovebox windows to allow entry of water to the glovebox and contents. Open containers could collect water and free liquid could accumulate to a depth of $5.08 \mathrm{~cm} \mathrm{(2} \mathrm{in.)} \mathrm{on} \mathrm{the} \mathrm{floor.} \mathrm{Flooding} \mathrm{of} \mathrm{the}$ glovebox with more than $5.08 \mathrm{~cm}$ ( 2 in.) of water is not credible due to drainage out the conveyor glovebox. Table 5-9 shows the seismic event for several arrangements of the base case containers where $k_{\text {eff }}$ does not exceed 0.942 for sprinkler water densities up to $0.1 \mathrm{~g} / \mathrm{cc}$.

Water spray densities from the sprinkler system was evaluated as described in Appendix I. Fire suppression water densities will be on the order of $0.01 \mathrm{~g} / \mathrm{cc}$ or less for contingencies that could actuate or break the water lines. Table 5-9 shows a parametric study of interspersed water through the credible range of sprinkler water densities for the seismic contingency for limit set $B$. The reactivity steadily rises with no intermediate peak. It is assumed in this evaluation that unlikely water densities could range up to $0.1 \mathrm{~g} / \mathrm{cc}$ and greater water densities are not credible.

Table 5-9. MCNP Calculational Results of Seismic Cases in Glovebox HA-20MB for $2100 \mathrm{~g}$ Plutonium Limit Set

\begin{tabular}{|c|c|c|c|}
\hline Case & Description & $\mathbf{k}_{\text {calc }}$ & $1 \sigma$ \\
\hline $\mathrm{c} 0001 \mathrm{f} 2 \mathrm{q} 1$ & $\begin{array}{l}500 \mathrm{~g} \mathrm{Pu} \text { in } 4 \text { cans } 90 \% \text { by volume water, } 10 \% \text { silicon oxide } \\
400 \mathrm{~g} \mathrm{Pu} \text { in } 2 \text { bowls } 100 \% \text { water. } \\
900 \mathrm{~g} \mathrm{Pu} \text { in } 7 \text { cans, } \mathrm{H} / \mathrm{X}=2033 \% \text {, carbon, } 67 \% \text { silicon oxide. } \\
300 \mathrm{~g} \mathrm{Pu} \text { holdup on floor. } \\
\text { All containers grouped together with close packed cement } \\
\text { cans surrounding all Pu cans and bowls. } \\
\text { Glovebox flooded to } 5.08 \mathrm{~cm}(2 \mathrm{in} \text {.), rest of glovebox filled } \\
\text { with } 10 \% \text { dense water spray. }\end{array}$ & 0.9413 & 0.0009 \\
\hline $\mathrm{c} 0001 \mathrm{f} 2 \mathrm{q} 2$ & Same as c0001f2q1 except water cans reflection & 0.9410 & 0.0010 \\
\hline $\mathrm{c} 0001 \mathrm{f} 2 \mathrm{q} 1 \mathrm{a}$ & $\begin{array}{l}\text { Same as c0001 } 2 \mathrm{q} 1 \text { except } \\
500 \mathrm{~g} \mathrm{Pu} \text { in } 5 \mathrm{cans}, 90 \% \text { by volume water, } 10 \% \text { silicon oxide } \\
900 \mathrm{~g} \mathrm{Pu} \text { in } 5 \text { cans, } \mathrm{H} / \mathrm{X}=2033 \% \text {, carbon } 67 \% \text {, silicon oxide. }\end{array}$ & 0.9387 & 0.0008 \\
\hline $\mathrm{c} 0001 \mathrm{f} 2 \mathrm{q} 4$ & $2100 \mathrm{~g} \mathrm{Pu}$ in water layer in under-floor conveyor region. & 0.6553 & 0.0009 \\
\hline
\end{tabular}


HNF-5988 Rev. 0

\begin{tabular}{|c|l|c|c|}
\hline \multicolumn{1}{|c|}{ Case } & \multicolumn{1}{|c|}{ Description } & $\mathbf{k}_{\text {calc }}$ & $1 \sigma$ \\
\hline $\mathrm{c} 0001 \mathrm{f} 2 \mathrm{q} 4 \mathrm{a}$ & $\begin{array}{l}\text { 2100 } \mathrm{g} \mathrm{Pu} \text { in } 6.55 \mathrm{~cm} \text { water layer in under-floor conveyor } \\
\text { region }(30 \mathrm{~g} / \mathrm{L}) .\end{array}$ & 0.7199 & 0.0009 \\
\hline $\mathrm{c} 0001 \mathrm{f} 2 \mathrm{q} 4 \mathrm{~b}$ & $\begin{array}{l}2100 \mathrm{~g} \mathrm{Pu} \text { in } 1.3 \mathrm{~cm} \text { water layer in under-floor conveyor } \\
\text { region }(150 \mathrm{~g} / \mathrm{L}) .\end{array}$ & 0.6582 & 0.0009 \\
\hline $\mathrm{c} 0001 \mathrm{f} 2 \mathrm{q} 1 \mathrm{~b}$ & Same as c0001f2q1 except $0.01 \mathrm{~g} / \mathrm{cc}$ water spray & 0.8991 & 0.0010 \\
\hline $\mathrm{c} 0001 \mathrm{f} 2 \mathrm{q} 1 \mathrm{c}$ & Same as c0001f2q1 except $0.05 \mathrm{~g} / \mathrm{cc}$ water spray & 0.9199 & 0.0009 \\
\hline $\mathrm{c} 0001 \mathrm{f} 2 \mathrm{q} 1 \mathrm{~d}$ & Same as c0001f2q1 except $0.15 \mathrm{~g} / \mathrm{cc}$ water spray & 0.9612 & 0.0010 \\
\hline $\mathrm{c} 0001 \mathrm{f} 2 \mathrm{qle}$ & Same as c0001f2q1 except $0.001 \mathrm{~g} / \mathrm{cc}$ water spray & 0.8938 & 0.0009 \\
\hline $\mathrm{c} 0001 \mathrm{lf2q5a}$ & $\begin{array}{l}\text { Same as c0001f2q1 except } 18 \% \text { water content cement } \\
\text { reflection }\end{array}$ & 0.9420 & 0.0010 \\
\hline
\end{tabular}

\subsubsection{Major Fire}

It is unlikely that the PFP will have a major structural fire that will melt the glovebox windows and actuate the fire suppression sprinklers. That contingency is evaluated two ways. One is to assume that open containers fill with water but don't overflow in such a way as to wash out fissile material. The other evaluation assumes that all the fissile material in open containers washes out onto the floor of the glovebox that fills to a $5.08-\mathrm{cm}$ (2-in.) depth before draining into the HA-28 conveyor. Table $5-10$ shows the results of these calculations where $k_{\mathrm{eff}}$ does not exceed 0.85 .

Table 5-10. MCNP Calculational Results of Flooding Cases in Glovebox HA-20MB for 2100 g Plutonium Limit Set

\begin{tabular}{|c|c|c|c|}
\hline Case & Description & $\mathbf{k}_{\text {calc }}$ & $1 \sigma$ \\
\hline $\mathrm{c} 0001 \mathrm{f} 2 \mathrm{fl}$ & $\begin{array}{l}\text { Same as base case c0001f } 2 \text { b } 4 \text { except glovebox flooded to } \\
5.08 \mathrm{~cm}(2 \mathrm{in} .) \text {, rest of glovebox filled with } 10 \% \text { dense water } \\
\text { spray. }\end{array}$ & 0.8494 & 0.0009 \\
\hline $\mathrm{c} 0001 \mathrm{f} 2 \mathrm{f} 2 \mathrm{a}$ & $\begin{array}{l}\text { Same as base case c0001f } 2 \mathrm{~b} 5 \text { (no close cement reflection } \\
\text { around cans) except glovebox flooded to } 5.08 \mathrm{~cm}(2 \mathrm{in} \text {.), rest } \\
\text { of glovebox filled with } 10 \% \text { dense water spray. }\end{array}$ & 0.8283 & 0.0009 \\
\hline $\mathrm{c} 0001 \mathrm{f} 2 \mathrm{f} 3$ & $\begin{array}{l}2100 \mathrm{~g} \mathrm{Pu} \text { mixed with water in } 5.08 \mathrm{~cm}(2 \mathrm{in} .) \text { layer on } \\
\text { glovebox floor }\end{array}$ & 0.6569 & 0.0009 \\
\hline $\mathrm{c} 0001 \mathrm{f} 2 \mathrm{f} 4$ & $\begin{array}{l}2100 \mathrm{~g} \mathrm{Pu} \text { mixed with water at } 150 \mathrm{~g} / \mathrm{L} \text { in } 0.22 \mathrm{~cm} \text { thick slab } \\
\text { covered by water to } 5.08 \mathrm{~cm}(2 \mathrm{in} \text {.) on glovebox floor }\end{array}$ & 0.6575 & 0.0011 \\
\hline $\mathrm{c} 0001 \mathrm{f} 2 \mathrm{f} 5 \mathrm{a}$ & $\begin{array}{l}\text { Same as c0001f } 2 \mathrm{f} 1 \text { except one } 2.76 \mathrm{~L} \text { can with } 200 \mathrm{~g} \mathrm{Pu} \\
\text { filled with water, } 6 \text { other cans with } 700 \mathrm{~g} \text { and } \mathrm{H} / \mathrm{X}=20\end{array}$ & 0.8515 & 0.0009 \\
\hline
\end{tabular}


HNF-5988 Rev. 0

\subsubsection{Stacking Event}

Stacking is prohibited at the PFP. Also, operators are trained not to move one container over another. However, it is credible, but unlikely, that either a mixing bowl or another fissile container is moved over the top of another. For this contingency, a mixing bowl is analyzed stacked on top of another mixing bowl or on the top of the most reactive arrangement of other fissile containers. Also, an additional $2.76 \mathrm{~L}$ container with $200 \mathrm{~g}$ of plutonium is stacked on top of the most reactive arrangement of other fissile containers. These results are presented in Table 5-11. The most reactive arrangement is for the mixing bowl to be stacked on top of the seven $2.7 \mathrm{~L}$ cans containing $500 \mathrm{~g} \mathrm{Pu}$ with reflection from close packed cement cans. The $\mathrm{k}_{\mathrm{etf}}$ for that case is less than 0.924 .

Table 5-11. MCNP Calculational Results of Stacking Cases in Glovebox HA-20MB for 2100 g Plutonium Limit Set

\begin{tabular}{|c|l|c|c|}
\hline Case & \multicolumn{1}{|c|}{ Description } & $\mathbf{k}_{\text {calc }}$ & $1 \sigma$ \\
\hline c0001f2s1 & $\begin{array}{l}\text { Same as base case c0001f2b4 except one bowl with 200 g Pu } \\
\text { stacked on top of seven 2.76 L cans containing 500 g Pu in } \\
\text { center of glovebox with cement can reflection. }\end{array}$ & 0.9236 & 0.0009 \\
\hline c0001f2s2 & $\begin{array}{l}\text { Same as base case c0001f2b4 except one bowl with 200 g Pu } \\
\text { stacked on top of other bowl. }\end{array}$ & 0.8584 & 0.0008 \\
\hline c0001f2s3 & $\begin{array}{l}\text { Same as base case c0001f2b4 except one extra 2.76 L can } \\
\text { with 200 g Pu stacked on top of seven cans containing 500 g } \\
\text { Pu. }\end{array}$ & 0.9022 & 0.0009 \\
\hline c0001f2s5 & $\begin{array}{l}\text { Same as base case c0001f2b4 except one extra 2.76 L can } \\
\text { with 200 g Pu stacked on top of seven cans containing 900 g } \\
\text { Pu, H/X=20. }\end{array}$ & 0.8591 & 0.0009 \\
\hline c0001f2s4 & $\begin{array}{l}\text { Same as base case c0001f2b4 except one bowl stacked on } \\
\text { top of seven 2.76 L cans containing 900 g Pu, H/X=20. }\end{array}$ & 0.8610 & 0.0008 \\
\hline
\end{tabular}

\subsubsection{Interaction Events}

Minimum spacing is required for certain fissile containers within the glovebox and between these containers and fissile containers in Conveyor Glovebox HA-28, and to waste drums and wagons in Room 235B. One spacing violation inside the glovebox is likely and is included in the base case. The other spacing violations are unlikely and are analyzed as contingencies. The seismic event conservatively bounds the loss of spacing within the glovebox. Loss of the $25.4 \mathrm{~cm}$ minimum spacing to containers in Conveyor Glovebox HA-28, the $15.2 \mathrm{~cm}$ minimum spacing to the waste drums passing the north side of the glovebox, and the wagons allowed in the room are reported in Table 5-12. The $\mathrm{k}_{\text {eff }} \mathrm{s}$ do not exceed 0.91 . 
HNF-5988 Rev. 0

Table 5-12. MCNP Calculational Results of Interaction Cases in Glovebox HA-20MB for 2100 g Plutonium Limit Set

\begin{tabular}{|c|c|c|c|}
\hline Case & Description & $\mathbf{k}_{\mathrm{calc}}$ & $1 \sigma$ \\
\hline $\mathrm{c} 0001 \mathrm{f} 2 \mathrm{w} 1$ & $\begin{array}{l}\text { Same as base case c0001f } 2 \text { b3 except one wagon with max } \\
\text { Pu loading under glovebox directly under } 7 \text { cans with } 500 \mathrm{~g} \\
\text { Pu. }\end{array}$ & 0.8427 & 0.0009 \\
\hline $\mathrm{c} 0001 \mathrm{f} 2 \mathrm{~b} 4 \mathrm{~h}$ & $\begin{array}{l}\text { Same as base case c0001f } 2 \mathrm{~b} 4 \text { except } 2.76 \mathrm{~L} \text { container with } \\
200 \mathrm{~g} \text { Pu representing drum outside glovebox located against } \\
\text { glovebox wall adjacent to two } 4.8 \mathrm{~L} \text { bowls containing } 400 \mathrm{~g} \\
\text { Pu in corner. }\end{array}$ & 0.8602 & 0.0008 \\
\hline $\mathrm{c} 0001 \mathrm{f} 2 \mathrm{~b} 9$ & $\begin{array}{l}\text { Same as base case c0001 } \mathrm{f} 2 \mathrm{~b} 4 \text { except } 400 \mathrm{~g} \text { in } 4.7 \mathrm{~L} \text { can } \\
\text { adjacent to other cans }\end{array}$ & 0.9048 & 0.0008 \\
\hline $\mathrm{c} 0001 \mathrm{f} 2 \mathrm{~b} 7$ & $\begin{array}{l}\text { Same as base case c0001f } 2 \mathrm{~b} 4 \text { except one } 200 \mathrm{~g} \text { can with } \\
\mathrm{H} / \mathrm{X}=200 \mathrm{in} \text { middle of } 6 \text { cans with } 700 \mathrm{~g} \mathrm{Pu}, \mathrm{H} / \mathrm{X}=20\end{array}$ & 0.8601 & 0.0008 \\
\hline $\mathrm{c} 0001 \mathrm{f} 2 \mathrm{~b} 11 \mathrm{a}$ & $\begin{array}{l}\text { Same as base case c } 0001 \mathrm{f} 2 \mathrm{~b} 4 \text { except } 200 \mathrm{~g} \text { in } 2.2 \mathrm{~L} \text { furnace } \\
\text { boat mixed with water adjacent to other cans }\end{array}$ & 0.8689 & 0.0009 \\
\hline $\mathrm{c} 0001 \mathrm{f} 2 \mathrm{~b} 13$ & $\begin{array}{l}\text { Same as base case c0001 } \mathrm{f} 2 \mathrm{~b} 4 \text { except } 200 \mathrm{~g} \text { in metal cubed } \\
2.2 \mathrm{~L} \text { furnace boat filled with water adjacent to other cans }\end{array}$ & 0.8583 & 0.0009 \\
\hline
\end{tabular}

\subsubsection{Other Contingencies for Limit Set B}

\section{Extra Mixing Bowl with Some Fissile Mass Out of Other Containers}

The additional $200 \mathrm{~g} \mathrm{Pu}$ container stacked on the other containers (case c0001 2 s 3 ) covers the contingency of an extra mixing bowl with some of the fissile mass outside the other containers with a k $\mathrm{eff}^{\text {eff }} 0.9022 \pm 0.0009$.

\section{Excess Glovebox Holdup Exceeding the Glovebox Mass Limit}

The additional $200 \mathrm{~g}$ Pu container stacked on the other containers (case c0001f $2 \mathrm{~s} 3$ ) covers the contingency of excess holdup exceeding the glovebox mass limit by up to $200 \mathrm{~g}$ since it is more reactive to have the excess Pu concentrated in one container on top of the other containers than to have the Pu distributed around the glovebox as holdup.

\section{Container too Large}

The stacking of two $4.8 \mathrm{~L}$ mixing bowls, each containing $200 \mathrm{~g}$ of $\mathrm{Pu}$ with unrestricted moderation (case c0001f $2 \mathrm{~s} 2$ ) provides a bounding reactivity of $0.8584 \pm 0.0008$ for up to $400 \mathrm{~g} \mathrm{Pu}$ in a total of $9.4 \mathrm{~L}$, which is much larger than any container that could be introduced into the glovebox. Therefore the contingency of having a container larger than the $4.8 \mathrm{~L}$ mixing bowl is covered. 
HNF-5988 Rev. 0

\section{Extra Oil or Plastic}

The fire case $\mathrm{c} 0001 \mathrm{f} 2 \mathrm{fl}$ is an analysis of the base case configuration with $5 \mathrm{~cm}$ of water flooding on the floor and $10 \%$ dense water spray filling the glovebox. The $\mathrm{k}_{\mathrm{eff}}$ for this case was $0.8494 \pm 0.0009$, which was lower than the $0.8607 \pm 0.0009 \mathrm{k}_{\text {eff }}$ for the base case with nominal reflection (case c0001 f $2 \mathrm{~b} 4$ ). Extra oils or plastics in the glovebox would have to be very extensive in order to exceed the hydrogen content of the water in either of these cases.

\section{One Feed Container with Unrestricted Moderation Brought into Glovebox}

The fire case $c 0001 \mathrm{f} 2 \mathrm{f} 5 \mathrm{a}$ provided a $\mathrm{k}_{\text {eff }}$ of $0.8515 \pm 0.0009$ for the configuration of one $2.76 \mathrm{~L}$ container with $200 \mathrm{~g}$ and unrestricted moderation surrounded by other $2.76 \mathrm{~L}$ containers with a total of $700 \mathrm{~g} \mathrm{Pu}$ as feed material with $\mathrm{H} / \mathrm{X}=20$. The interaction case $\mathrm{c} 0001 \mathrm{f} 2 \mathrm{~b} 7$ provided $\mathrm{a} \mathrm{k}_{\mathrm{eff}}$ of $0.8601 \pm 0.0008$ for the configuration of one $2.76 \mathrm{~L}$ container with $200 \mathrm{~g}$ and $\mathrm{H} / \mathrm{X}=200$ surrounded by other containers with a total of $700 \mathrm{~g} \mathrm{Pu}$ as feed material with $\mathrm{H} / \mathrm{X}=20$. 


\subsection{REFERENCES}

Altschuler, S. J., 1981, WHC-SD-SQA-CSA-20231, Rev. 0, CSAR 80-014: In-place Filters, Westinghouse Hanford Company, Richland, Washington.

ANSI/ANS-8.1-1983: R1998, Nuclear Criticality Safety in Operations with Fissionable Materials Outside Reactors, American Nuclear Society, La Grange Park, Illinois.

Carter, R. D., G. R. Kiel, and K. R. Ridgway, 1968, Criticality Handbook, ARH-600, 1980 Revision, Atlantic Richfield Hanford Company, Richland, Washington.

CPS-Z-165-80010, 1998, Rev/Mod C-4, General Limits, Plutonium Finishing Plant, Criticality Prevention Specification.

CPS-Z-165-80031, 1997, Rev/Mod B-0, Conveyor and Pass-Through Gloveboxes in Room 235-B, Plutonium Finishing Plant, Criticality Prevention Specification.

DOE, 1992, Nuclear Criticality Safety, DOE Order 5480.24, August 12, 1992, U. S. Department of Energy, Washington, D. C.

Erickson, D. G., 1998a, MCNP 4B Plutonium Validation, HNF-1905, Rev. 1, CCVR 97-001, Fluor Daniel Northwest, Inc., Richland, Washington.

Erickson, D. G., 1998b, CSER 98-003: Criticality Safety Evaluation Report for PFP Glovebox HC-21A with Button Can Opening, HNF-2705, Rev. 1, Fluor Daniel Northwest, Inc.. Richland, Washington.

FDH, 2000, Criticality Safety General, Requirements, HNF-PRO-334, Rev. 1, Fluor Daniel Hanford, Inc., Richland, Washington.

FDH, 1997a, Criticality Safety Control of Fissionable Material, HNF-PRO-537, Rev. 0, Fluor Daniel Hanford, Inc., Richland, Washington.

FDH, 1997b, Criticality Safety Evaluations, HNF-PRO-539, Rev. 0, Fluor Daniel Hanford, Inc., Richland, Washington.

FDH, 1999, Plutonium Finishing Plant Final Safety Analysis Report, HNF-SD-CP-SAR-021, Rev. 1, Fluor Daniel Hanford Inc., Richland, Washington.

FFS, 1999, Criticality Safety Evaluation Reports, Practice 1342901121.

Greenborg, J. 1999, CSER 98-008: Analysis of Plutonium Compounds as Applied to PFP Criticality Limits for Oxide and Metal Systems, HNF-3572, Rev. 0, Fluor Daniel Hanford, Richland, Washington. 
Greenhalgh, W. O., 1996, Results of The PFP Cementation Process, Internal Memo 8A400-96032, Westinghouse Hanford Company, Richland, Washington.

Hess, A. L., 1996, CSER 96-013: Cementation Process, Glovebox HA-20MB at PFP, WHC-SDSQA-CSA-513, Rev. 1, Westinghouse Hanford Company, Richland, Washington.

Lan, J. S., 1999, MCNP Version 4B Approval for Use Documentation \& Authorized User List, FDNW-DSL-99-004, January 12, 1999, Fluor Daniel Northwest, Inc., Richland, Washington.

Marusich, R. M., 1999, CSER 99-003: Criticality Mass of Uranium as Compared to Plutonium - Implications for PFP Processing Uranium, HNF-4436, Rev. 0, Fluor Daniel Hanford, Richland, Washington.

Pruvost, N. L. and Paxton, H. C., 1996, Nuclear Criticality Safety Guide, LA-12808, Los Alamos National Laboratory, Los Alamos, New Mexico.

Roemer, J. J., 1986, Remote Mechanical C Button Line, SD-CP-SAR-020, Rev. 0, March 1986, Rockwell Hanford Company, Richland, Washington.

Schwinkendorf, K. N., 1998, Software Certification Report for MCNP 4B, HNF-3316, Rev. 0 , October 14, 1998, Fluor Daniel Northwest, Inc., Richland, Washington. 
HNF-5988 Rev. 0

APPENDIX A

INDEPENDENT REVIEW COMMENTS AND CHECKLIST

A-1 
HNF-5988 Rev. 0

This page intentionally left blank 
Independent Peer Reviewer Comments: K. N. Schwinkendorf - 03/03/2000

This CSER was independently peer reviewed by K. N. Schwinkendorf, a qualified Criticality Safety Specialist in the Criticality and Shielding group of Fluor Federal Services. This technical review covered all aspects of this CSER with the exception of checking computer code input and output files. This phase of the review was carried out by S. R. Gedeon, also of the Criticality and Shielding group of Fluor Federal Services. As shown in the two Independent Review Checklists, taken together, this CSER has been reviewed with no gaps.

The construction of base case models using bounding, abnormal but credible conditions was well documented and is conservative. There were some analyzed cases that exceeded the criticality safety criterion, but these were determined not to be credible (for example, interspersed moderation in excess of $0.10 \mathrm{~g} / \mathrm{cm}^{3}$ ). One validation issue was raised. The sand, slag, and crucible (SS\&C) material, as defined in this CSER, may include Pu metal-phase material, so the metal system $k_{\text {eff }}$ limit of 0.932 was used for the "Limit Set A" materials (1200 g Pu limit set), instead of the 0.942 limit for non-metal systems, as per the Pu validation document. Use of the 0.942 limit was retained for the "Limit Set B" materials (2100 g Pu limit set) because these material are more well characterized, and will not contain large Pu metal pieces. Although some fine metal phase particles may still be present, they will be well-mixed with other materials such that the system may be considered "non-metal" from a neutronics perspective. Reducing the criticality safety criterion for Limit Set A did not impact any evaluated contingencies, as they were all below 0.932 .

No single contingency violated the criticality safety criterion, and so this reviewer concurs with the conclusion of this CSER, that this cementation process satisfies double contingency.

Finally, minor editorial comments were suggested, and were incorporated into the final version of the CSER.

Independent Peer Reviewer Comments: S. R. Gedeon - 03/03/2000

Computer inputs, outputs and spreadsheets were checked for consistency and reasonableness. Densities were checked with data in ARH-600 and found equal or conservative.

Input files were checked for model adequacy, material densities, geometry, and container volume. $\mathrm{K}_{\mathrm{eff}}$ values given in the report were verified against output files. Output files were reviewed for adequate convergence. Minor typographical errors were corrected. 
HNF-5988 Rev. 0

Practice 1342901112

Publication Date 22Nov99

Attuchment 02 - Sheet 1 of 1

FLUOR DANIEL NORTHWEST

TECHNICAL PEER REVIEWS

\section{CHECKLIST FOR TECHNICAL PEER REVIEW}

Document Reviewed: HNF-5988 Rev. 0

Title: $\quad$ CSER 00-001: Criticality Safety Evaluation Report for Cementation Operations At the PFP

Author: $\quad$ K. D. Dobbin and D. W. Wootan

Date: $\quad 3 / 3 / 00$

Scope of Review.

Yes No* NA

[4 I ] [ ] $]^{* *}$ Previous reviews complete and cover analysis, up to scope of this review, with no gaps.

[ 5 [ ] [ ] Problem completely defined.

[4 [ ] [ ] Accident scenarios developed in a clear and logical manner.

[4 [ ] [ ] Necessary assumptions explicitly stated and supported.

[ 4 [ ] [ ] Computer codes and data files documented.

[ ] [ ] [4 Data used in calculations explicitly stated in document.

[ ] [ ] [4 Data chocked for consistency with original source information as applicable.

[ ] [ ] [ ] Mathematical derivations chocked including dimensional consistency of results.

[L $[$ ] [ ] Models appropriate and used within range of validity or use outside range of establishod validity justified.

[ ] [ ] [ 4 Hand calculations chocked for errors. Spreadsheet results should be treated exactly the same as hand calculations.

[ ] [ ] [4 Software input correct and consistent with document reviewed.

[ ] [ ] [4 Software output consistent with input and with ressults reported in document reviewed.

[4 [ ] [ ] Limits/criteria/guidelines applied to analysis results are appropriate and referenced.

Limits/criteria/guidelines chocked against references.

[ 4 [ [ ] [ ] Safety margins consistent with good engincering practices.

[4 [ ] [ ] Conclusions consistent with analytical results and applicable limits.

[ 4 [ ] [ ] Results and conclusions address all points required in the problem statement.

[Y [ ] [ ] Format consistent with applicable guides or other standaris.

[4 [ ]** Review calculations, comments, and/or notes are attached.

[4 [ ] [ ] Document approved (i.e., the reviewer affirms the tochnical accuracy of the document).

K.N. Schwinkendorf 1kim N. Bchuinkendigy

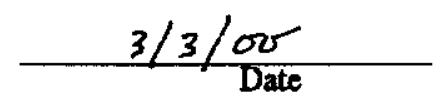

- All "NO" responses must be explained below or on an additional page.

** Any calculations, comments, of nota generitad as part of this reviow should be signed, dated and attuahed to this cheoklist. Such material should be labeled and rocorded in such a manner as to be intelligible to a technically qualified third party.

NUCLEAR ENGINEERING 
HNF-5988 Rev. 0

Practice 1342901112

Publlextion Date 22Nov99

Attachment 02 - Sheet 1 of 1

FLUOR DANIEL NORTHWEST

\section{TECHNICAL PEER REVIEWS}

\section{CHECKLIST FOR TECHNICAL PEER REVIEW}

Document Reviewed:

HNF-5988 Rev. 0

Title:

CSER 00-001: Criticality Safety Evaluation Report for Cementation Operations At the PFP

Author: $\quad$ K. D. Dobbin and D. W. Wootan

Date: $\quad 3 / 3 / 00$

Scope of Review:

Yes No* NA

[ ] [ ] $y^{* *}$ Previous reviews complete and cover analysis, up to scope of this review, with no gaps.

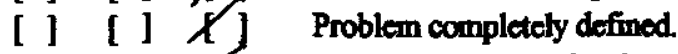

[ ] [ ] Z Accident scenarios developed in a clear and bogical manner.

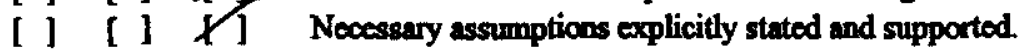

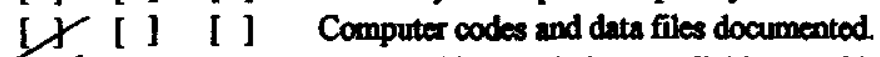

If [ ] I ] Data used in calculations explicitly stated in document.

I] [ ] [ ] Data chocked for consistency with original source information as applicable.

I] [ ] [ ] Mathematical derivations chocked including dimensional consistency of results.

I] [ ] [ ] Models appropriate and used within range of validity or use outside range of established validity justifiod.

I] [ ] [ ] Hand calculations checked for arors. Spreadshoct results should be treated exactly the same as hand calculations.

LT [ ] [ ] Software input correct and consistent with document reviewed.

I] [ ] [ ] Software cutput consistent with imput and with results reported in document reviewed.

[ ] [ ] f] Limits/criteria/guidelines applied to analysis results are appropriate and referenced.

Limits/criteria/guidelimes chocked against references.

[ ] [ ] 1] Safety margins consistent with good engineering practices.

[ ] [ ] XJ Conclusions consistent with anstytical results and applicable limits.

[ ] [ I X] Results and conclusions address all points required in the problem statement.

[ ] [ ] X T/ Format consistent with applicable guides or other standards.

[ 1 X F** Review calculations, comments, and/or notes are attached.

L] [ ] [ ] Document approved (i.e., the reviewer affirms the technical accuracy of the document).
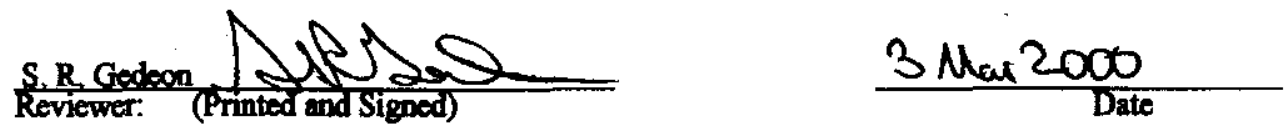

* All "NO" responses muat be explained below or on an additional page.

** Any calculations, comments, or notes generated as part of this review should be signed, dated and atteohod to this checklist. Such material should be labelod and rocarded in auch a mannor as to be intelligible to a tochnically qualified third party.

NUCLEAR ENGINERRING 


\section{Mohr and Associates}

\section{ENGINEERING - ANALYSIS - CONSULTING}

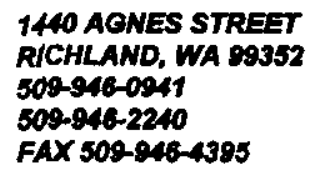

March 3, 2000

To:

Kenneth D. Dobbin, Fluor Federal Services, Inc.

From: Warner A. Blyckert

Subject: $\quad$ Review of CSER 00-001: Criticality Safety Evaluation Report for Cementation Operations at the PFP (HNF-5988 Rev 0)

Document HNF-5988, Rev. 0, CSER 00-001: Criticality Safety Evaluation Report for Cementation Operations at the PFP, was given an independent technical review. The approach to analyzing the proposed operations and the technique used were checked for suitability, accuracy and completeness. The input files were used to generate pictures of the calculation models used in the evaluation.

The material which was reviewed consisted of the draft of the final report. The output files of the computer calculations were not reviewed during the review and the results were accepted as recorded in the report. The correctness and results of the validation effort was not reviewed so that the limits used in the CSER were not checked for accuracy nor applicability other than the narrative account of the approach which is reported in an appendix. The referenced CSERs and CSARs were not reviewed and the statements concerning their results were accepted without verification.

Responses to the reviewer's comments have been incorporated into the final report and adequately address the comments.

The reviewer agrees with the conclusion of the report that the proposed cementation operations may be safely conducted with the postulated material under the limiting conditions of operation.

Very truly yours,

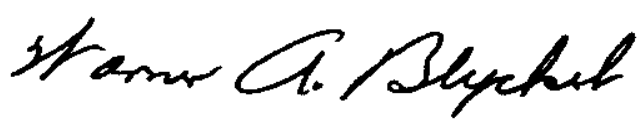

Warner A. Blyckert 
HNF-5988 Rev. 0

FLUOR DANIEL NORTHWEST

TECHNICAL PEER REVIEWS

\section{CHISCKLIST FOR TECHNICAL PEER REVIEW}

Document Reviewed:

Title:

Author:

Date:

Scope of Review:
HNF-5988 Rev. 0

CSER 00-001: Criticality Safety Evaluation Report for Cementation Operations At the PFP

K. D. Dobbin and D. W. Wootan

$3 / 3 / 00$

Yes Ne* NA

[ ] [ ] [ $\mathrm{x}]^{\text {t* }}$ Previous reviews complete and cover analysis, up to scope of this review, with no gaps.

[X] [ ] [ ] Problem completely defined.

[X] [ ] [ ] Accident scenarios developed in a clear and logical manner.

[X] [ ] [ ] Necessary assumptions explicitly stated and supported.

[ ] [ ] [X] Computer codes and data files documented.

[X] [ ] [ ] Data usod in calculations explicitly stated in document.

[ ] [ ] $[X]$ Data checked for consistency with original source information as applicable.

[ ] [ ] [X] Mathematical derivations checked including dimensional consistency of results.

[X] [ ] [ ] Models appropriate and used within range of validity or use outside range of establishod validity justified.

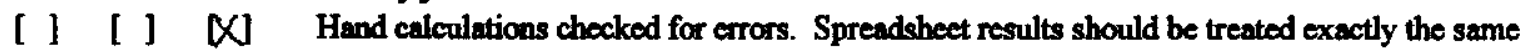
as hand calculations.

[X] [ ] [ ] Software input correct and consistent with document reviewed.

[X] [ ] [ ] Software output consistent with input and with results reported in document reviewed.

[X] [ ] [ ] Limits/criteria/guidelines applied to analysis results are appropriate and referenced.

Limits/criteria/guidelines checked against references.

[X] [ ] [ ] Safety margins consistent with good enginocring practices.

[X] [ ] [ ] Conclusions consistent with analytical results and applicable limits.

DX] [ ] [ ] Results and conclusions address all points required in the problem statement.

[X] [ ] [ ] Format consistent with applicable guides or other standards.

[X] [ ]** Roview calculations, comments, and/or notes are attached.

[X] [ ] [ ] Document approved (i.e., the reviewer affirms the technical accuracy of the document).

w. Blvckent SElyetert

Reviewer: (Printed afid Signed)

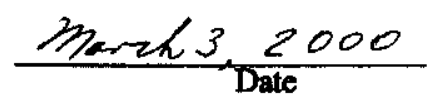

* All "NO" responses must be explainod below or on an additional page.

** Any celculations, comments, or notes peneruted a purt of this roview ahould be rigned, dated and attohed to this cheoklint. Such material should be labeled and recorded in such a manner as to be intelligible to a technioally qualifiod third party. 
HNF-5988 Rev. 0

This page intentionally left blank 
HNF-5988 Rev. 0

APPENDIX B

MCNP COMPUTER CODE VALIDATION

B-1 
HNF-5988 Rev. 0

This page intentionally left blank

B-2 


\section{B.1 VALIDATION PROCEDURE}

Validation of the computer code methods in this analysis consisted of testing the code and neutron cross sections on calculations of known critical configurations. These benchmark experiments have fissile isotopes in systems similar to that evaluated by this CSER. The computed and measured $\mathrm{k}_{\text {eff }} \mathrm{s}$ for the benchmark configurations were compared to establish a bias that includes the uncertainty in the calculational methods. A bias-adjusted $\mathrm{k}_{\mathrm{eff}}$ for the benchmark systems was defined to include both the deviations of the calculated from the measured $\mathrm{k}_{\text {eff }}$ 's, and experimental and calculational uncertainties along with the spread in the ability of the computer code to calculate similar systems. In addition, criticality safety criteria require that the bias-adjusted $\mathrm{k}_{\mathrm{eff}}$ for CSER analysis calculations not exceed the established $\mathrm{k}_{\text {eff }}$ safety limit at the $95 \%$ confidence level.

This method is illustrated in Figure B.1. Critical is defined as a $\mathrm{k}_{\mathrm{eff}}$ of unity, adjusted by the bias established from the comparison of calculations with benchmarks. The bias is combined with the safety margin of 0.05 (a safety limit that $\mathrm{k}_{\mathrm{eff}}$ must be less than or equal to 0.95 ) to compare with the calculated value and statistical uncertainty of the computer calculated $\mathrm{k}_{\mathrm{eff}}$ 's of this CSER analysis. The calculated target $\mathrm{k}_{\text {eff }}$ is established by adding the bias, 0.05 , and 1.645 times the one-sigma uncertainty of the calculated $\mathrm{k}_{\mathrm{eff}}$ for the particular CSER analysis and subtracting that value from 1.0. For the analyses in this CSER, all the computer statistical uncertainties were less than 0.002 , so this value was used to set the target $\mathrm{k}_{\mathrm{eff}}$ 's as described in Section B.2.

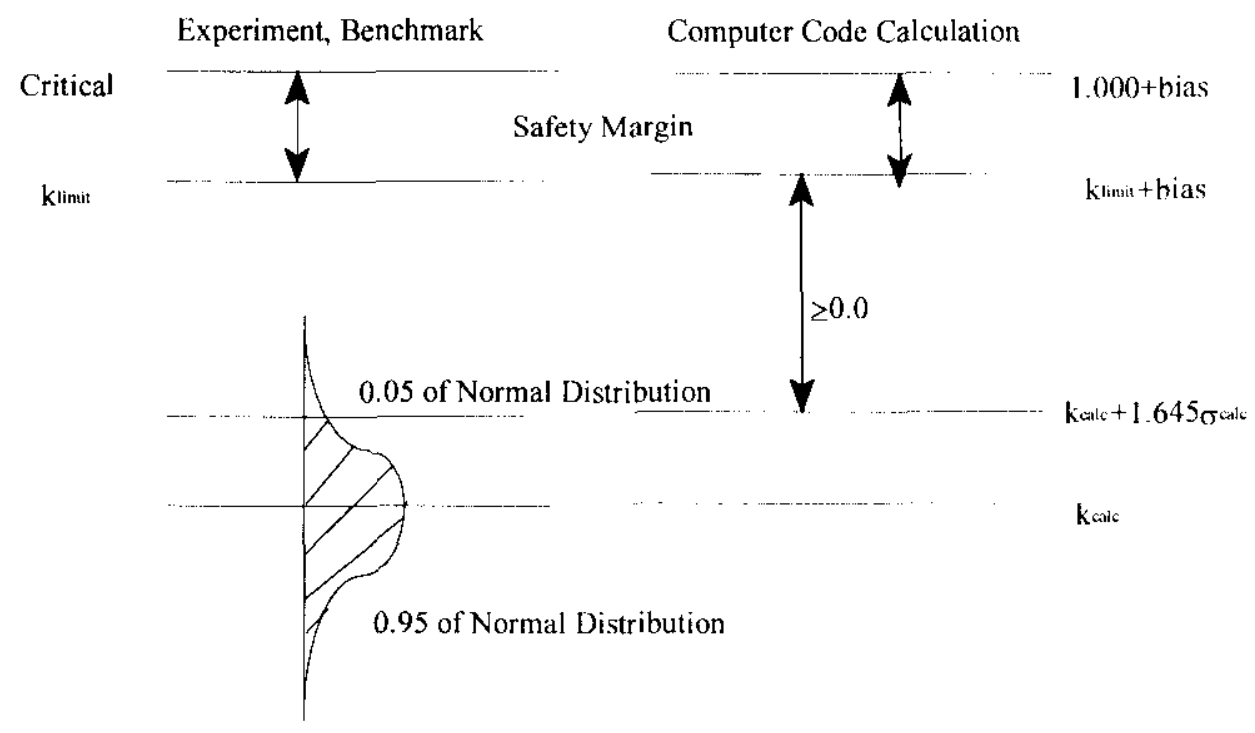

Figure B.1. Logic of Validation Procedure 
HNF-5988 Rev. 0

\section{B.2 GENERIC VALIDATION FOR PLUTONIUM SYSTEMS}

A report by J. S. Lan, MCNP Version 4B Approval For Use Documentation \& Authorized User List (Lan 1999), presents the results of calculations to determine a generic bias for plutonium configurations, as encountered in the Plutonium Finishing Plant. One hundred and forty three benchmark experiments were calculated. There were different material types that were considered in the plutonium validation calculations:

- $\quad$ Plutonium metal,

- Plutonium oxide,

- Plutonium solutions,

- $\quad$ Plutonium solutions with cadmium (a neutron poison),

- Water and polystyrene moderators, and

- Water, plexiglass, paraffin, polyethylene, and steel and concrete reflectors

The lower tolerance limit $b_{L}$ was calculated for the benchmark experiments such that there is $95 \%$ confidence that $95 \%$ of the benchmark calculated $k_{\mathrm{ef}}$ 's is above that limit. This is expressed by the following formula:

$$
\mathrm{b}_{\mathrm{I}}=\mathrm{k}_{\mathrm{avg}}-\mathrm{K}_{\mathrm{b}} * \sigma_{\mathrm{avg}}
$$

where: $b_{\mathrm{L}} \quad=$ lower tolerance limit for $95 \%$ confidence that $95 \%$ of the benchmark calculated $\mathrm{k}_{\text {eff }}$ 's is above this limit,

$\mathrm{k}_{\mathrm{avg}}=$ the average of the $\mathrm{k}_{\mathrm{eff}}$ 's calculated by MCNP 4B,

$\mathrm{K}_{\mathrm{b}} \quad=$ a multiplier found from statistical tables for non-central $\mathrm{t}$-distribution, and depends on number of degrees of freedom, and

$\sigma_{\text {avg }}=$ standard deviation of the MCNP $\mathrm{k}_{\mathrm{eff}}$ 's.

Bias is calculated by the following formula:

$$
\text { bias }=\mathrm{b}_{\mathrm{L}}-\mathrm{k}_{\mathrm{crit}}
$$

where:

$\mathrm{k}_{\text {crit }} \quad=$ the average of the $\mathrm{k}_{\text {eff }}$ 's for the critical experiments; for the plutonium experiments $\mathrm{k}_{\mathrm{crit}}=1.000$.

The bias for the plutonium metal group was significantly different than for all other groups. For this reason, it was concluded that separate bias values for metal and non-metal groupings would be appropriate. The lower tolerance limit for the metal group (17 benchmark critical experiments) calculated to be 0.9884 . The lower tolerance limit for the non-metal group (126 benchmark critical experiments) calculated to be 0.9991 . These lower tolerance limits yielded the bias appropriate for each material category:

- $\quad$ Plutonium metal

- Plutonium non-metal bias is -0.0116 ,

bias is -0.0009 . 
For conservatism, these calculated biases were recommended to be increased to:

- $\quad$ Plutonium metal

- $\quad$ Plutonium non-metal recommended bias is -0.0150 , recommended bias is -0.0050 .

The safety criteria for future calculations on undetermined systems requires that the bias-adjusted $\mathrm{k}_{\mathrm{eff}}$ does not exceed 0.95 at the $95 \%$ confidence level. This is expressed by the following formula:

$$
\mathrm{k}_{\mathrm{eff}}=\mathrm{k}_{\mathrm{calc}}-\text { bias }+1.645^{*} \sigma_{\mathrm{calc}} \leq \mathrm{k}_{\text {limit }}
$$

where: $\mathrm{k}_{\mathrm{calc}} \quad=\mathrm{k}$ value given by MCNP $4 \mathrm{~B}$ calculation for system in question,

bias $=-0.015$ for Pu metal, and -0.005 for Pu non-metal systems,

$1.645=$ a constant number of standard deviations for 0.95 of the distribution for a one-sided standard normal distribution

$\sigma_{\text {calc }}=$ standard deviation given by MCNP 4B calculation for system in question, and

$\mathrm{k}_{\text {limit }} \quad=0.95$ for plutonium systems, generally.

$\mathrm{k}_{\text {limit }}$ is generally taken to be 0.95 for plutonium systems.

For a standard deviation $\left(\sigma_{\text {calc }}\right)$ of 0.002 or less, the $k_{\text {eff }}$ value for plutonium metal systems is:

$$
\begin{gathered}
\mathrm{k}_{\text {calc }}-(-0.015)+1.645 * 0.002 \leq 0.95, \text { or } \\
\mathrm{k}_{\text {calc }} \leq 0.95+(-0.015)-1.645 * 0.002=0.932
\end{gathered}
$$

On this basis, it is determined that the true $\mathrm{k}_{\mathrm{eff}}$ of an analyzed configuration with plutonium will not exceed 0.95 with a $95 \%$ confidence level for plutonium metal systems if the calculated value $\left(\mathrm{k}_{\text {calc }}\right.$, and $\sigma \leq 0.002$ ) is limited to a maximum value of $\mathbf{0 . 9 3 2}$.

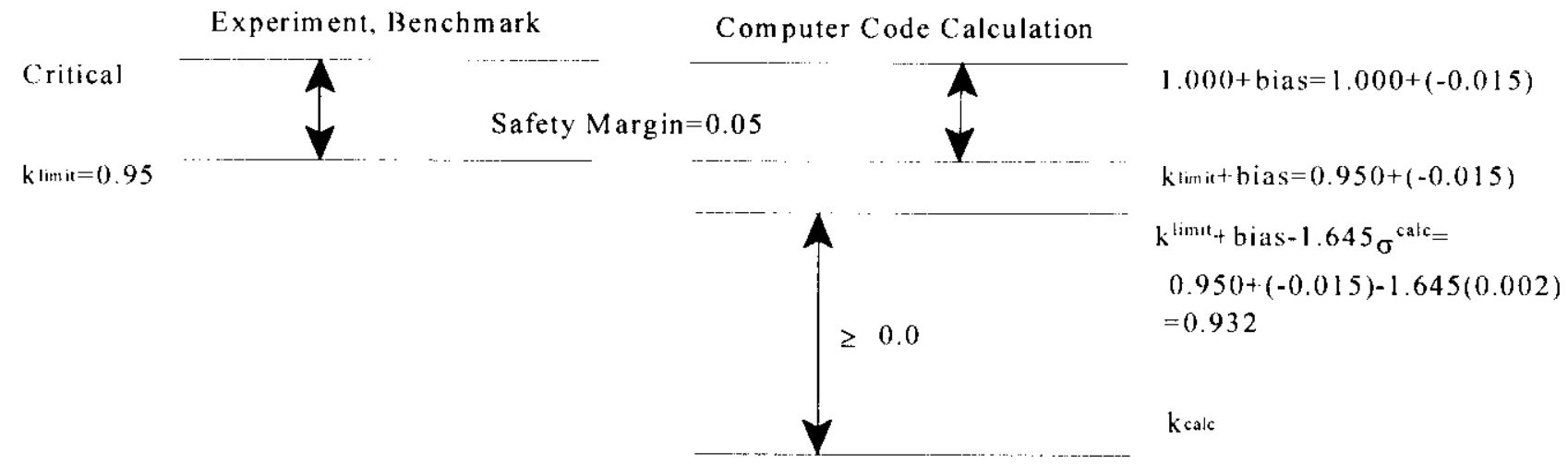

Figure B.2. Implementation of Validation Procedure 
For a standard deviation $\left(\sigma_{\text {calc }}\right.$ ) of 0.002 or less, the $k_{\text {eff }}$ value for non-metal systems is:

$$
\begin{gathered}
\mathrm{k}_{\text {calc }}-(-0.005)+1.645 * 0.002 \leq 0.95, \text { or } \\
\mathrm{k}_{\text {calc }} \leq 0.95+(-0.005)-1.645 * 0.002=0.942
\end{gathered}
$$

On this basis, it is determined that the true $\mathrm{k}_{\text {eff }}$ of an analyzed configuration with plutonium will not exceed 0.95 with a $95 \%$ confidence level for plutonium non-metal systems if the calculated value $\left(\mathrm{k}_{\text {calc }}\right.$, and $\sigma \leq 0.002$ ) is limited to a maximum value of $\mathbf{0 . 9 4 2}$.

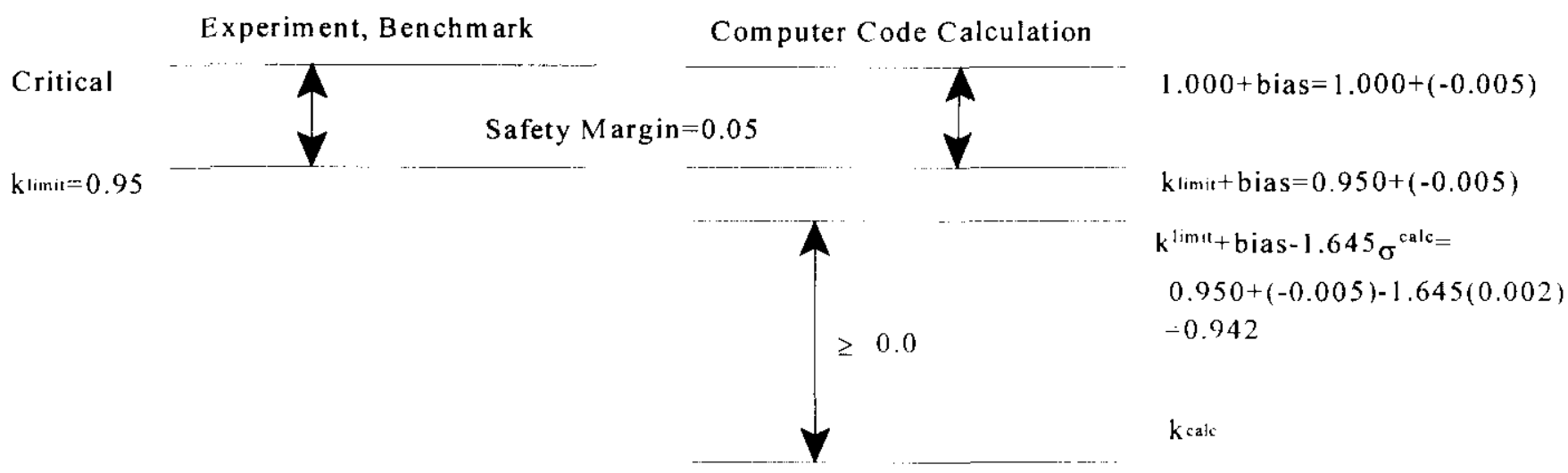

Figure B.3 Implementation of Validation Procedure 
HNF-5988 Rev. 0

\section{B.3 VALIDATION OF MCNP 4B}

The validation of the MCNP4B code on the new computing system, Intergraph ${ }^{\mathrm{TM}}$, $400 / 450 \mathrm{MHz}$ Pentium II, personal computers was documented in Lan, 1999. The essence of the validation was cross-correlation of calculational results obtained with this code version and results of critical experiments, as reported in MCNP Version 4B Approval for Use Documentation \& Authorized User List (Lan 1999).

\section{B.4 CONCRETE AS MODERATOR BENCHMARK}

\section{B.4.1 INTRODUCTION}

The MCNP Version 4B Monte Carlo code was certified (Schwinkendorf 1998) and validated (Erickson 1998a and Lan 1999) for plutonium systems. The benchmark configurations analyzed for the validation included plutonium solutions with concrete reflection. Some concerns were identified about the application of the documented calculational biases to configurations expected in the cementation process that involve mixing plutonium compounds with water and cement. To address these concerns, additional experimental configurations were identified that included both moderation and reflection by concrete. Calculation of these benchmark experiments with the MCNP code provides additional assurance that MCNP calculational biases can be applied to the cementation process configurations.

\section{B.4.2 EXPERIMENTAL CONFIGURATION}

Critical experiments were performed at the Pacific Northwest Laboratory - Critical Mass Laboratory from 1985 to 1987 with mixed $\mathrm{Pu}+\mathrm{U}$ nitrate solutions in annular geometry (Smolen 1994). Figure B.4 shows a schematic of the experimental configuration. The $25.4 \mathrm{~cm}$ diameter central region of the annular vessel contained various inserts, including a bottle containing fissile solution and annular concrete inserts. For the complete set of experiments, the fissile solution concentrations ranged from 47 to $226 \mathrm{~g} \mathrm{Pu} / \mathrm{L}$ with $\mathrm{Pu} / \mathrm{Pu}+\mathrm{U}$ ratios of $1.0,0.5$, and 0.2 . While these geometrical configurations and material compositions do not correspond closely to the configurations and materials involved in the HA-20MB cementation process, they do provide a means for identifying systematic calculational issues involving significant internal moderation and scattering from the constituents in concrete. Two of these experimental configurations were modeled in detail to evaluate the biases of the MCNP code for these types of calculations.

Table B.1 summarizes the important parameters for the two critical experiments selected for analysis. Experiment Run 091 consisted of a mixed $\mathrm{Pu}+\mathrm{U}$ nitrate solution with an annular concrete insert between the outer solution tank and the center solution bottle. This was the only experimental configuration with no $\mathrm{B}_{4} \mathrm{C}$ in the concrete insert. Experiment Run 095 consisted of Intergraph is a trademark of the Intergraph Corporation of Huntsville, Alabama. Pentium is a trademark of Intel Corporation, Santa Clara, Alabama. 
a primarily $\mathrm{Pu}$ nitrate solution with an annular $2 \mathrm{wt} \% \mathrm{~B}_{4} \mathrm{C}$ concrete insert. All of the primarily $\mathrm{Pu}$ solution configurations included this $2 \mathrm{wt} \% \mathrm{~B}_{4} \mathrm{C}$ concrete insert.

The critical experiments were performed in a Type $304 \mathrm{~L}$ stainless steel, $53.34 \mathrm{~cm}$ o.d. annular cylinder that had a $25.4 \mathrm{~cm}$ i.d. central region. The $13.82 \mathrm{~cm}$ thick annular region of the cylinder contained fissile solution. The average inside height of the annular solution vessel is $105.57 \mathrm{~cm}$. The side wall thickness is $0.074 \mathrm{~cm}$, and the thickness of the top and bottom plates are 0.953 and $0.653 \mathrm{~cm}$, respectively. The experiments were performed with various items located in the central region of the annular vessel. During the experiments, a $14.56 \mathrm{~cm}$ i.d. bottle was placed in the center of the vessel. The bottle was fabricated of Type 304L stainless steel, with a wall thickness of $0.074 \mathrm{~cm}$. The bottle was elevated so that the heights of the fissile solution in the bottle and annulus were equal. 


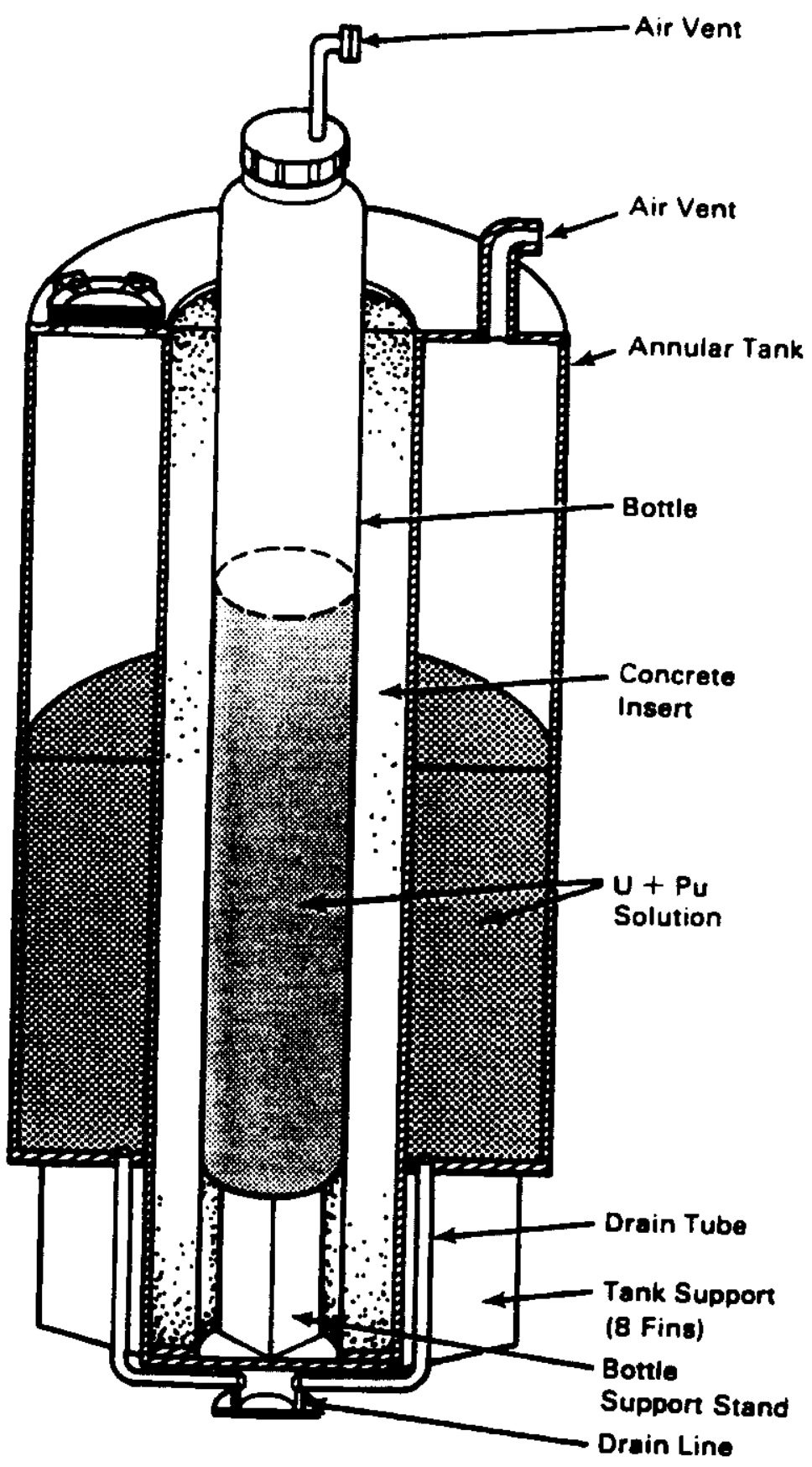

Figure B.4. Schematic of annular cylinder with concrete insert and bottle. 
HNF-5988 Rev. 0

Table B.1. Critical Parameters for Selected Experimental Configurations

\begin{tabular}{|l|l|c|c|c|c|c|c|}
\hline Run & $\begin{array}{c}\text { Water } \\
\text { height } \\
(\mathrm{cm})^{\mathrm{a}}\end{array}$ & $\mathrm{Pu}(\mathrm{g} / \mathrm{L})$ & $\mathrm{U}(\mathrm{g} / \mathrm{L})$ & $\begin{array}{c}\text { Density } \\
(\mathrm{g} / \mathrm{cm} 3)\end{array}$ & $\begin{array}{c}\text { Free } \\
\text { Acid } \\
(\mathrm{M})\end{array}$ & $\begin{array}{c}\text { Critical } \\
\text { Height } \\
(\mathrm{cm})\end{array}$ \\
\hline $\begin{array}{l}091 \\
0 \mathrm{wt} \% \\
\mathrm{~B}_{4} \mathrm{C} \\
\text { concrete } \\
\text { insert }\end{array}$ & Tank & 24.1 & 102.69 & 364.88 & 1.6780 & 0.77 & 48.99 \\
\cline { 2 - 8 } $\begin{array}{l}095 \\
2 \mathrm{wt} \% \\
\mathrm{~B}_{4} \mathrm{C} \\
\text { concrete } \\
\text { insert }\end{array}$ & Bottle B-2 & & 103.36 & 363.30 & 1.6777 & 0.77 & 59.4 \\
\cline { 2 - 8 } & Bottle B-3 & 24.1 & 195.61 & 6.5 & 1.4390 & 3.28 & 27.51 \\
\hline
\end{tabular}

${ }^{\text {a }}$ distance between top of water and top of annular vessel.

Annular concrete inserts were placed in the central region separating the annular tank and the bottle. These concrete inserts were $5.0 \mathrm{~cm}$ thick. The inserts were fabricated so that the elevation of their tops would be within $4 \mathrm{~mm}$ of the top of the annular vessel. The density of the concrete insert was determined to be $2.19 \pm 0.05 \mathrm{~g} / \mathrm{cm}^{3}$. The isotopic composition of the concrete inserts used in the two inserts is described in Table B.2. The analysis of the $\mathrm{B}_{4} \mathrm{C}$ used in the fabrication of some of the inserts disclosed that ${ }^{10} \mathrm{~B}$ constitutes $20.02 \pm 0.1$ at. $\%$, with the balance being " $\mathrm{B}$. The elemental composition of each insert was measured. The amount of water in the hardened concrete was measured as the total of free and chemically combined water. The estimated uncertainty in the actual water content for each insert is $\pm 1 \mathrm{wt} \%$.

Analysis of selected fissile solution samples indicated the average concentration of impurities shown in Table B.3 related to acidic corrosion products from the stainless steel storage tanks. As the plutonium concentration is diluted, the impurities would also be diluted.

Analysis of the fissile solution used in the critical experiments was periodically performed to assess the change in plutonium and uranium isotopic concentrations over time. Table B.4 shows the isotopic concentrations corresponding to the dates that the particular experiments were performed.

A summary of the estimated uncertainties on key experimental parameters is shown in Table B.5. The overall uncertainty in $\mathrm{k}_{\text {eff }}$ due to the experimental uncertainties was estimated to be on the order of \pm 0.0020 in Smolen 1994 . 
HNF-5988 Rev. 0

Table B.2. Elemental Composition of Concrete Inserts

\begin{tabular}{|l|c|c|}
\hline \multirow{2}{*}{ Element } & \multicolumn{2}{|c|}{ Insert Composition (wt\%) } \\
\cline { 2 - 3 } & $0 \mathrm{~B}_{4} \mathrm{C}$ & $2 \mathrm{~B}_{4} \mathrm{C}$ \\
\hline Aluminum & 4.82 & 4.82 \\
\hline Boron & 0.02 & 1.56 \\
\hline Barium & 0.07 & 0.07 \\
\hline Calcium & 15.4 & 13.9 \\
\hline Copper & 0.01 & 0.01 \\
\hline Iron & 4.39 & 4.35 \\
\hline Potassium & 0.54 & 1.52 \\
\hline Lithium & 0.02 & 0.02 \\
\hline Magnesium & 1.12 & 1.15 \\
\hline Manganese & 0.07 & 0.07 \\
\hline Sodium & 1.89 & 1.48 \\
\hline Silicon & 21.8 & 22.1 \\
\hline Strontium & 0.04 & 0.03 \\
\hline Titanium & 0.57 & 0.58 \\
\hline Zirconium & 0.04 & 0.10 \\
\hline Carbon & 0.0 & 0.43 \\
\hline Hydrogen & 0.95 & 0.87 \\
\hline Oxygen & 48.25 & 46.94 \\
\hline
\end{tabular}

Table B.3. Solution Impurity Concentrations

\begin{tabular}{|l|c|}
\hline Element & Specific Concentration $(\mu \mathrm{g} / \mathrm{g} \mathrm{Pu})$ \\
\hline Iron & 2935 \\
\hline Aluminum & 950 \\
\hline Chromium & 746 \\
\hline Calcium & 598 \\
\hline Nickel & 542 \\
\hline Titanium & 225 \\
\hline Manganese & 148 \\
\hline Cadmium & 57 \\
\hline Boron & 49 \\
\hline
\end{tabular}


HNF-5988 Rev. 0

Table B.4. Isotopic Composition of Mixed Pu+U Solutions

\begin{tabular}{|l|c|c|}
\hline \multirow{2}{*}{ Isotope } & \multicolumn{2}{|c|}{ Isotopic composition } \\
\cline { 2 - 3 } & Run 091 & Run 095 \\
\hline${ }^{238} \mathrm{Pu}(\mathrm{wt} \% \mathrm{Pu})$ & 0.029 & 0.027 \\
\hline${ }^{239} \mathrm{Pu}(\mathrm{wt} \% \mathrm{Pu})$ & 91.118 & 91.572 \\
\hline${ }^{240} \mathrm{Pu}(\mathrm{wt} \% \mathrm{Pu})$ & 8.310 & 7.940 \\
\hline${ }^{241} \mathrm{Pu}(\mathrm{wt} \% \mathrm{Pu})$ & 0.450 & 0.393 \\
\hline${ }^{242} \mathrm{Pu}(\mathrm{wt} \% \mathrm{Pu})$ & 0.093 & 0.068 \\
\hline${ }^{238} \mathrm{U}(\mathrm{wt} \% \mathrm{U})$ & 99.236 & 97.103 \\
\hline${ }^{236} \mathrm{U}(\mathrm{wt} \% \mathrm{U})$ & 0.053 & 0.467 \\
\hline${ }^{235} \mathrm{U}(\mathrm{wt} \% \mathrm{U})$ & 0.704 & 2.292 \\
\hline${ }^{234} \mathrm{U}(\mathrm{wt} \% \mathrm{U})$ & 0.007 & 0.138 \\
\hline${ }^{241} \mathrm{Am}(\mathrm{mg} / \mathrm{g} \mathrm{Pu})$ & 5.3 & 4.9 \\
\hline
\end{tabular}

Table B.5. Experimental Parameter Uncertainties

\begin{tabular}{|l|c|}
\hline Parameter & Uncertainty \\
\hline Pu concentration (\%) & \pm 0.2 \\
\hline U concentration (\%) & \pm 0.2 \\
\hline Density $\left(\mathrm{g} / \mathrm{cm}^{3}\right)$ & \pm 0.0003 \\
\hline Free acid concentration $(\mathrm{M})$ & \pm 0.04 \\
\hline Critical height $(\mathrm{cm})$ & \pm 0.16 \\
\hline
\end{tabular}

\section{B.4.5 CALCULATIONAL MODEL}

Computational models were developed for each of the experimental configurations using MCNP Version 4B. The models included the annular cylinder walls, bottom, and lid. The concrete inserts rested on the bottom of the annular vessel, and the full height of the inserts was modeled. The rebar in the concrete inserts was not modeled since the four $1.27 \mathrm{~cm}$ diameter rods were centrally located within the concrete and comprised only $1.6 \mathrm{vol} \%$. Although the bottles actually extended above the annular vessel, the height of the bottle in the model was truncated at the top of the annular vessel. The cruciform stainless steel bottle support stand was not included in the model. Full water reflection was included around the annular vessel, to model the actual water thickness of greater than $35.57 \mathrm{~cm}$ for the experiments analyzed. Full water reflection was also included below the annular cylinder. Figure B.5 shows a cross section of the model. Listings of the models have been included in this report. 
HNF-5988 Rev. 0

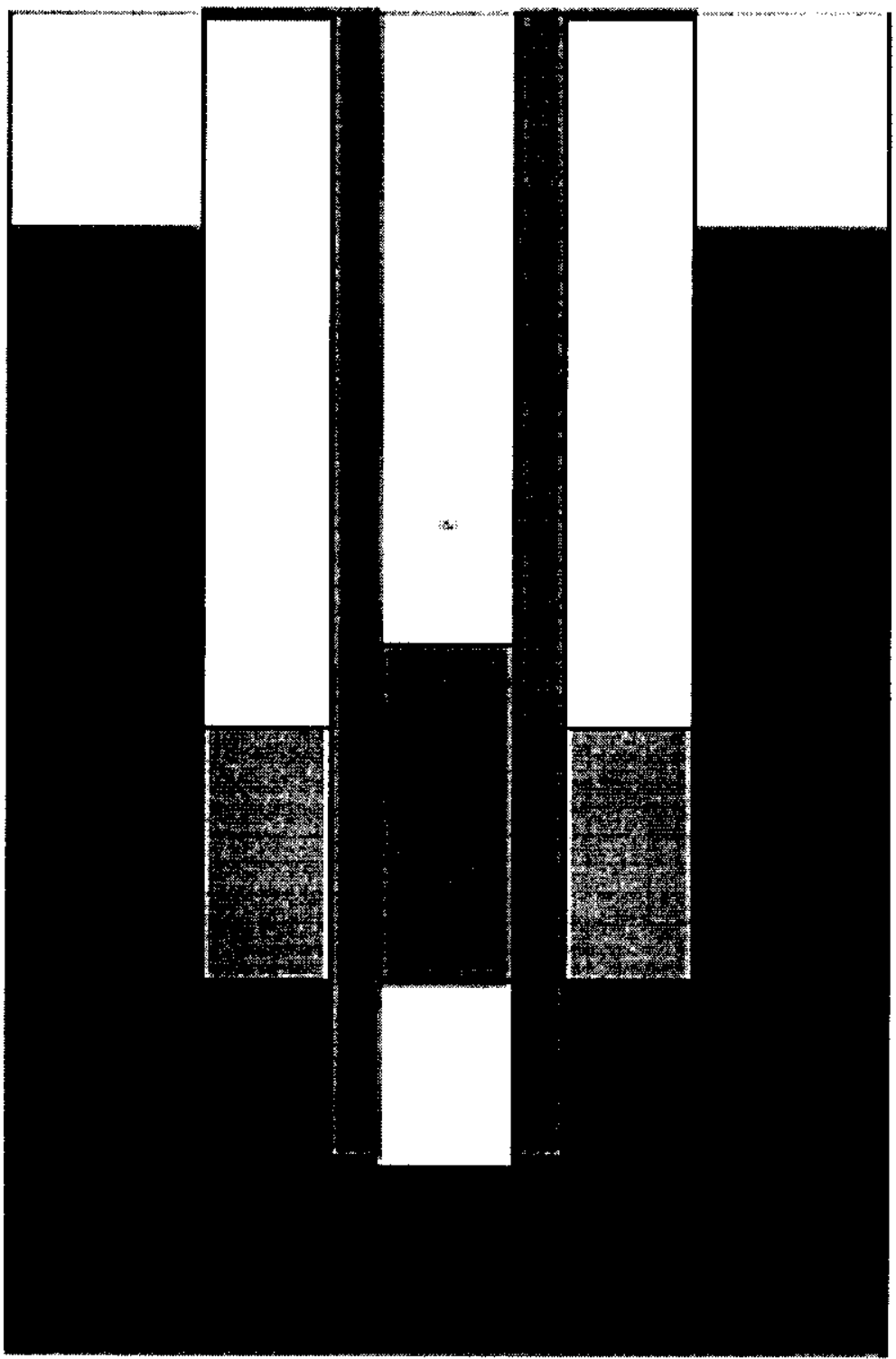

Figure B.5. Calculational Model of Annular Tank with Concrete Insert. 


\section{B.4.6 CALCULATIONAL RESULTS}

Table B.6 summarizes the results of the MCNP calculations for the two experimental configurations. The calculated $\mathrm{k}_{\text {eff }}$ for Case 'annulus2' with plutonium solution of 1.0050 \pm 0.0008 is consistent with the mean of 97 MCNP calculated plutonium benchmark solution cases of $1.0119 \pm 0.0056$ documented in Erickson 1998. Therefore, no change to the calculational bias for plutonium systems is justified. The calculated $k_{\text {eff }}$ for Case 'annulusl' of $0.9925 \pm 0.0007$ is lower than the mean $\mathrm{k}_{\mathrm{eff}}$ for non-metal plutonium benchmarks. However, the 'annulus1' configuration is not a plutonium system, but a mixed uranium+plutonium system. Marusich 1999 showed that the mean value of $k_{\text {eff }}$ calculated using MCNP for uranium solutions is approximately 0.02 lower than for plutonium solution benchmarks. The calculated $\mathrm{k}_{\mathrm{eff}}$ 's for case annulus 1 and case annulus 2 agree with the differences between uranium and plutonium solutions sytems observed in Marusich 1999. Thus, these results show that the presence of concrete moderation does not change the conclusions of Marusich 1999 that the calculational biases for plutonium and uranium systems allows for the presence of less than $50 \%$ enriched uranium in plutonium systems.

Case 'annulus1water' is a calculational variation of case 'annulus1' where the concrete insert was replaced with water. The $k_{\text {eff }}$ for this case, $1.0055 \pm 0.0007$, is higher than the $k_{\text {eff }}$ for case 'annulus 1 ' by $0.0130 \Delta \mathrm{k}$, which is significantly larger than the range of uncertainty in the calculated $\mathrm{k}_{\text {efr }} \mathrm{s}$ and the estimated uncertainty in $\mathrm{k}_{\text {eff }}$ due to the measurement uncertainties of 0.002 . This case illustrates that for this configuration water is more effective as a moderator than concrete and can be conservatively substituted for concrete.

Table B.6. Calculational Results

\begin{tabular}{|c|c|c|c|}
\hline Case & Description & $\mathbf{k}_{\text {calc }}$ & $1 \sigma$ \\
\hline Annulus1 & $\begin{array}{l}\text { Experiment } 091-\text { Part } 24 / \mathrm{B}-2 \\
\text { Tank: } 0.22 \mathrm{Pu} / \mathrm{Pu}+\mathrm{U} \\
103.37 \mathrm{~g} \mathrm{Pu} / \mathrm{L} \\
\mathrm{H} / \mathrm{X}=225 \\
\text { Bottle: } \mathrm{B}-2 \\
\text { Insert: Part } 24=\text { annular concrete } \\
\text { insert with } 0 \mathrm{wt} \% \mathrm{~B}_{4} \mathrm{C}\end{array}$ & 0.9925 & 0.0007 \\
\hline Annulus2 & $\begin{array}{l}\text { Experiment } 095-\text { Part } 26 / \mathrm{B}-3 \\
\text { Tank: } 0.97 \mathrm{Pu} / \mathrm{Pu}+\mathrm{U} \\
195.61 \mathrm{~g} \mathrm{Pu} / \mathrm{L} \\
\mathrm{H} / \mathrm{X}=126 \\
\text { Bottle: } \mathrm{B}-3 \\
\text { Insert: Part } 26=\text { annular concrete } \\
\text { insert with } 2 \mathrm{wt} \% \mathrm{~B} 4 \mathrm{C}\end{array}$ & 1.0050 & 0.0008 \\
\hline annulus I water & $\begin{array}{l}\text { Same as case annulus1 except } \\
\text { concrete insert replaced with water }\end{array}$ & 1.0055 & 0.0007 \\
\hline
\end{tabular}


HNF-5988 Rev. 0

\section{B.4.7 REFERENCES}

Erickson, D. G., 1998, MCNP 4B Plutonium Validation, HNF-1905, Rev. 1, CCVR 97-001, Fluor Daniel Northwest, Inc., Richland, Washington.

Lan, J. S., 1999, MCNP Version 4B Approval for Use Documentation \& Authorized User List, FDNW-DSL-99-004, January 12, 1999, Fluor Daniel Northwest, Inc., Richland, Washington.

Marusich, R. M., E. M. Miller, S. R. Gedeon, 1999, CSER 99-003: Critical Mass of Uranium As Compared to Plutonium-Implications For PFP Processing Uranium, HNF-4436, Rev. 0, Fluor Daniel Northwest, Inc., Richland, Washington.

Schwinkendorf, K. N., 1998, Software Certification Report for MCNP 4B, HNF-3316, Rev. 0, October 14, 1998, Fluor Daniel Northwest, Inc., Richland, Washington.

Smolen, G. R., R. C. Lloyd, and T. Koyama, 1994, "Criticality Data and Validation Studies of Plutonium-Uranium Nitrate Solutions in Annular Geometry", Nuclear Technology, Vol. 107, September 1994. 
HNF-5988 Rev. 0

\section{MCNP Models}

\section{annulus 1}

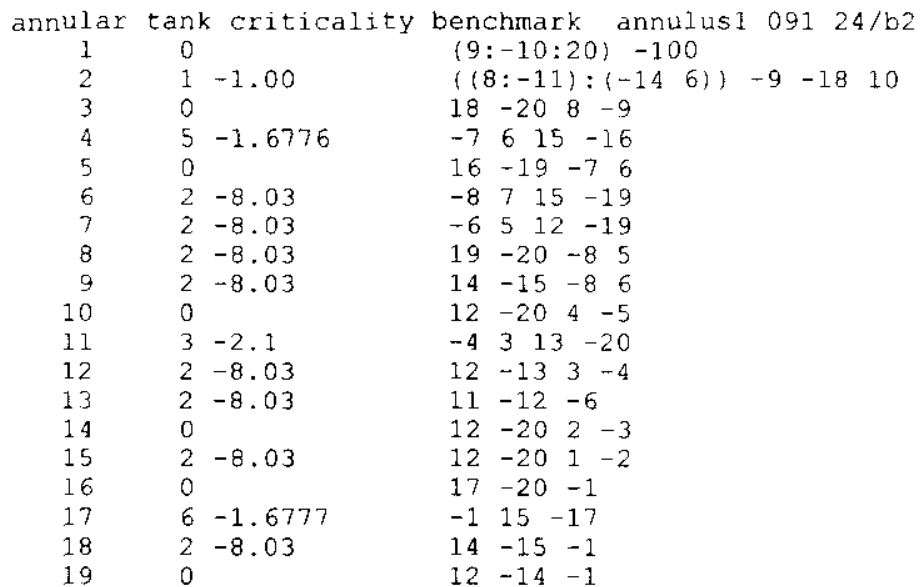
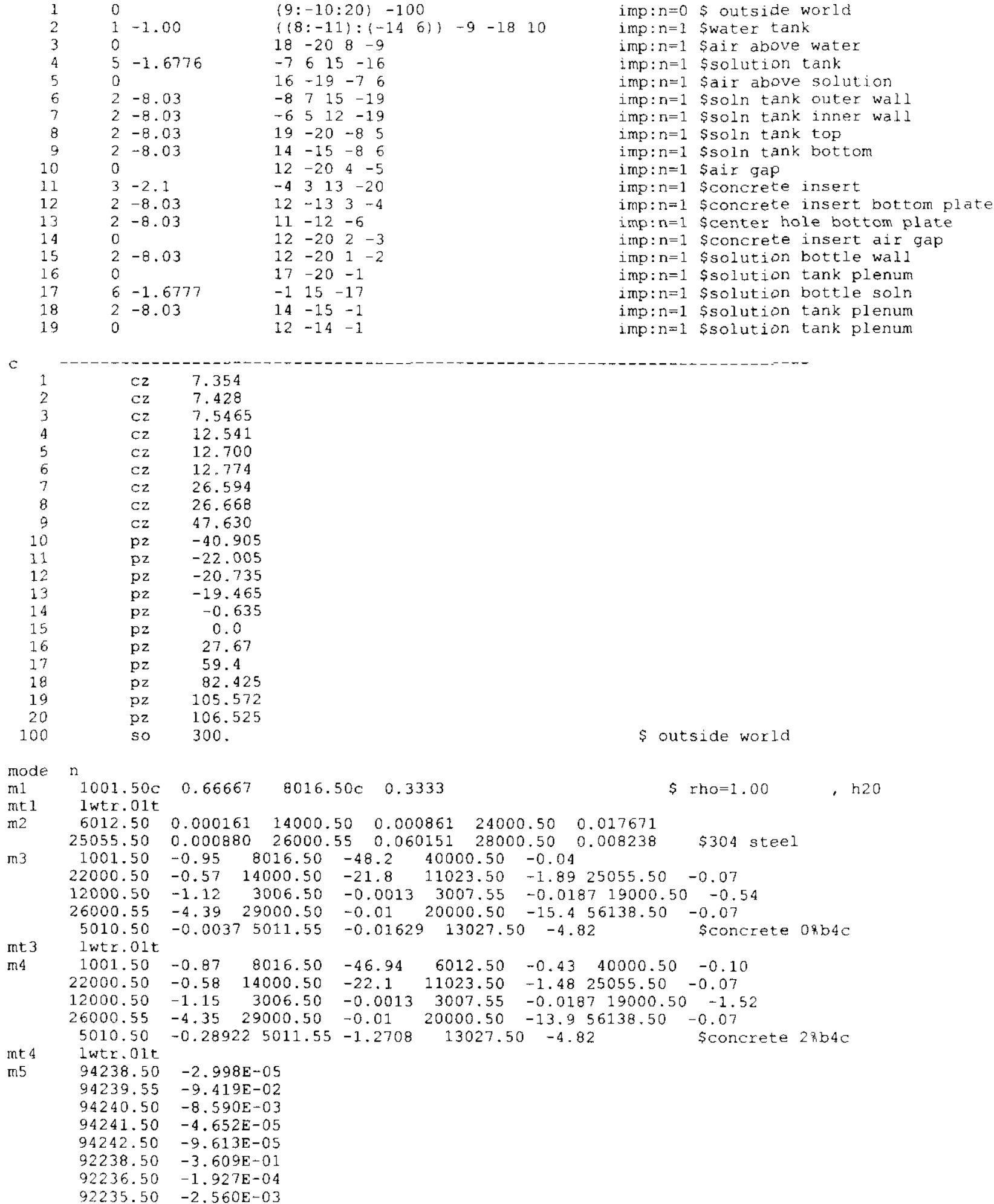
HNF-5988 Rev. 0

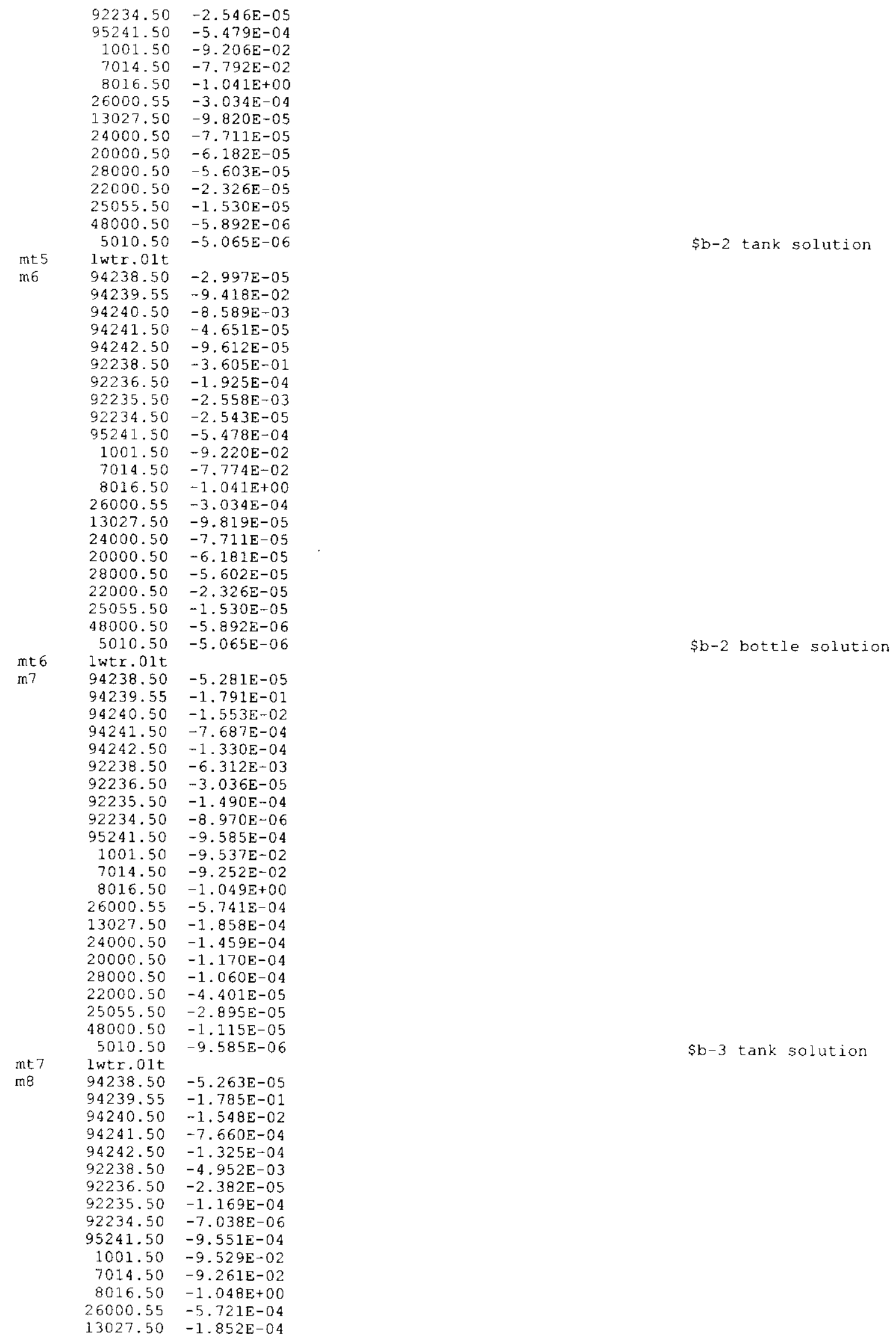

B-17 
HNF-5988 Rev. 0

\begin{tabular}{|c|c|c|}
\hline & $\begin{array}{r}24000.50 \\
20000.50 \\
28000.50 \\
22000.50 \\
25055.50 \\
48000.50 \\
5010.50\end{array}$ & $\begin{array}{l}-1.454 \mathrm{E}-04 \\
-1.166 \mathrm{E}-04 \\
-1.056 \mathrm{E}-04 \\
-4.386 \mathrm{E}-05 \\
-2.885 \mathrm{E}-05 \\
-1.111 \mathrm{E}-05 \\
-9.551 \mathrm{E}-06\end{array}$ \\
\hline nt 8 & lwtr.01t & \\
\hline rcode & 50001.0 & $10 \quad 300$ \\
\hline ksre & $\begin{array}{llll}0 & 0 & 15 & 0\end{array}$ & 1515 \\
\hline prdmp & j $\quad-300$ & 13 \\
\hline tnu & & \\
\hline int & & \\
\hline
\end{tabular}

\$b-3 bottle solution

\section{annulus2}

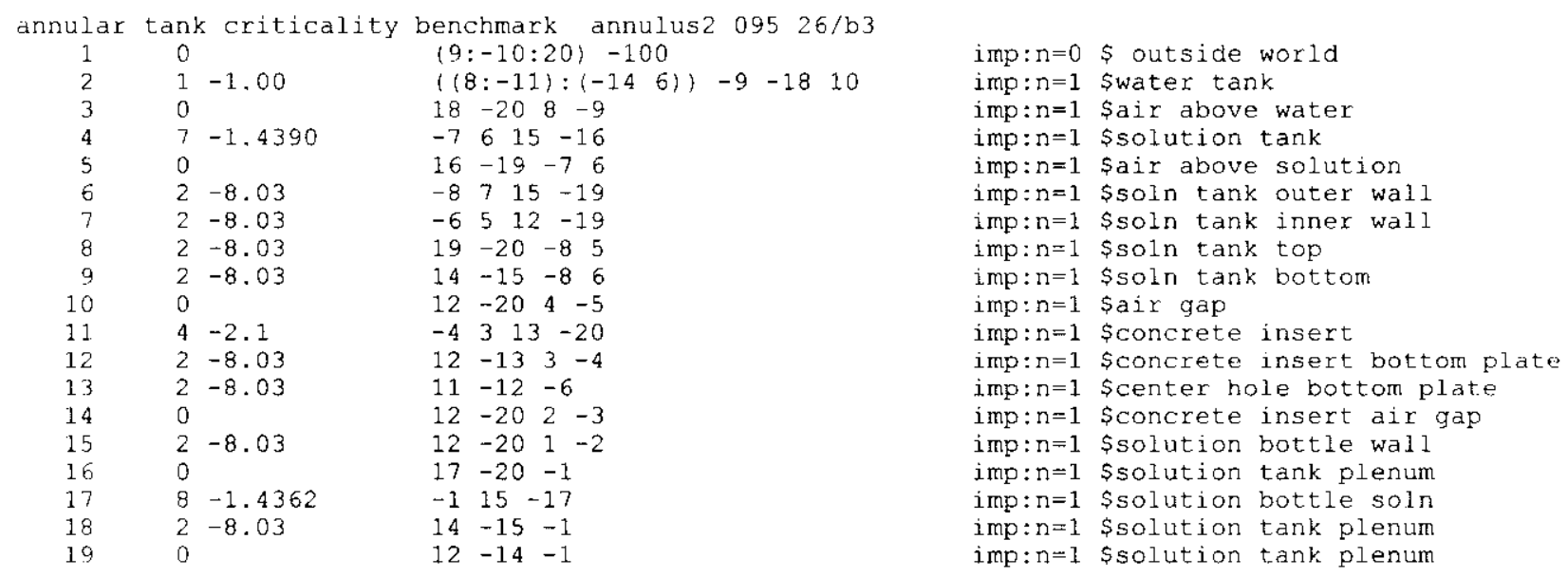

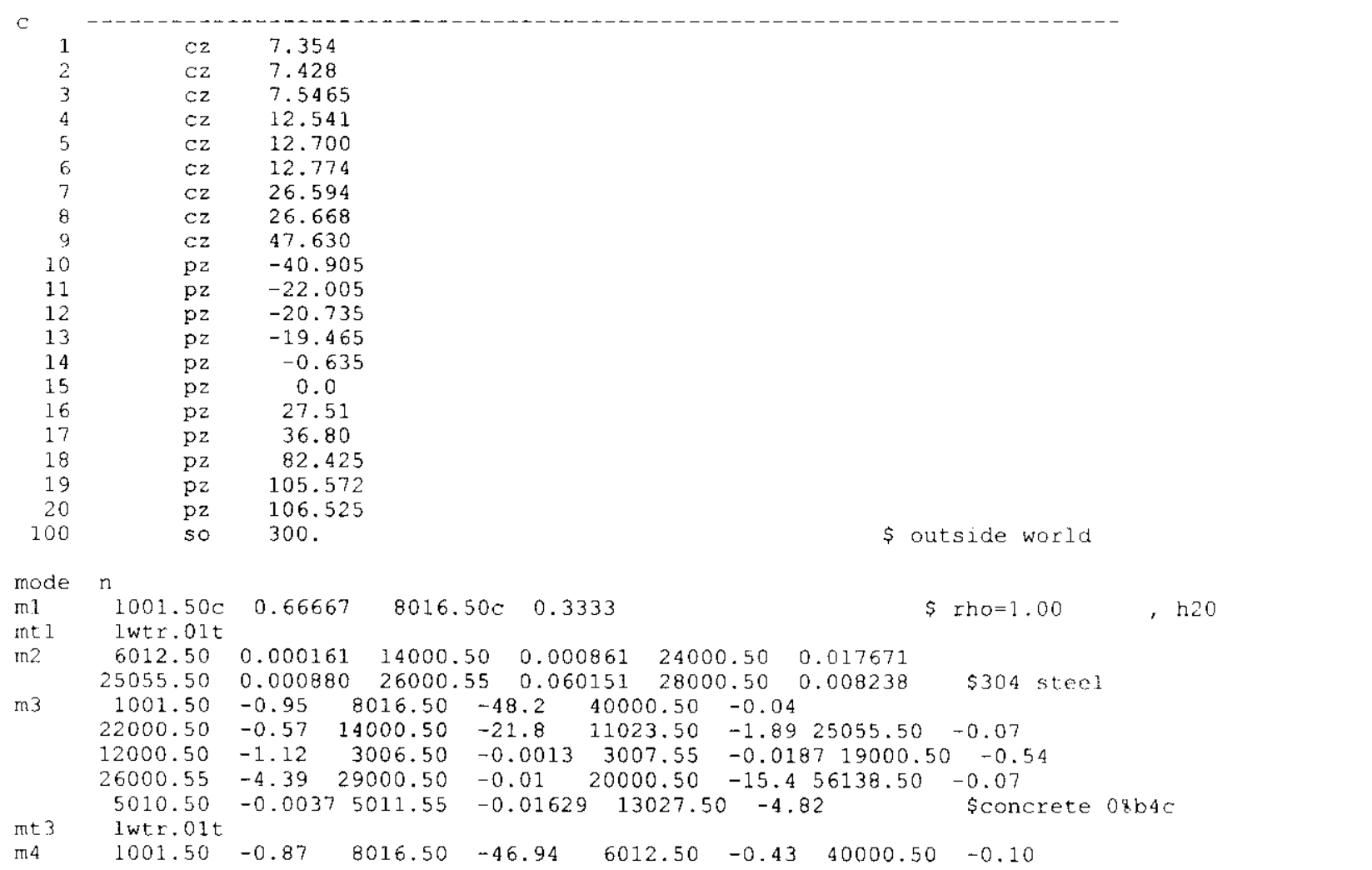




\section{HNF-5988 Rev. 0}

\begin{tabular}{|c|c|c|c|c|c|}
\hline & 22000.50 & 14000.50 & -22.1 & $11023.50-1.48 \quad 25055.50$ & -0.07 \\
\hline & 12000.50 & 3006.50 & -0.0013 & $\begin{array}{llll}3007.55 & -0.0187 & 19000.50\end{array}$ & -1.52 \\
\hline & 26000.55 & 29000.50 & -0.01 & -13.956138 .50 & -0.07 \\
\hline & 5010.50 & -0.289225011 .55 & -1.2708 & $13027.50-4.82$ & $\$$ concrete $28 \mathrm{~b} 4 \mathrm{c}$ \\
\hline \multirow{23}{*}{$\begin{array}{l}\text { mt } 4 \\
\text { m5 }\end{array}$} & lwtr.01t & & & & \\
\hline & 94238.50 & $-2.998 E-05$ & & & \\
\hline & 94239.55 & $-9.419 E-02$ & & & \\
\hline & 94240.50 & $-8.590 \mathrm{E}-03$ & & & \\
\hline & 94241.50 & $-4.652 E-05$ & & & \\
\hline & 94242.50 & $-9.613 E-05$ & & & \\
\hline & 92238.50 & $-3.609 \mathrm{E}-01$ & & & \\
\hline & 92236.50 & $-1.927 \mathrm{E}-04$ & & & \\
\hline & 92235.50 & $-2.560 \mathrm{E}-03$ & & & \\
\hline & 92234.50 & $-2.546 \mathrm{E}-05$ & & & \\
\hline & 95241.50 & $-5.479 \mathrm{E}-04$ & & & \\
\hline & 1001.50 & $-9.206 \mathrm{E}-02$ & & & \\
\hline & 7014.50 & $-7.792 \mathrm{E}-02$ & & & \\
\hline & 8016.50 & $-1.041 \mathrm{E}+00$ & & & \\
\hline & 26000.55 & $-3.034 \mathrm{E}-04$ & & & \\
\hline & 13027.50 & $-9.820 \mathrm{E}-05$ & & & \\
\hline & 24000.50 & $-7.711 E-05$ & & & \\
\hline & 20000.50 & $-6.182 E-05$ & & & \\
\hline & 28000.50 & $-5.603 E-05$ & & & \\
\hline & 22000.50 & $-2.326 E-05$ & & & \\
\hline & 25055.50 & $-1.530 \mathrm{E}-05$ & & & \\
\hline & 48000.50 & $-5.892 \mathrm{E}-06$ & & & \\
\hline & 5010.50 & $-5.065 E-06$ & & & \$b-2 tank solution \\
\hline \multirow{23}{*}{$\begin{array}{l}\mathrm{mt} 5 \\
\mathrm{~m} 6\end{array}$} & lwtr.01t & & & & \\
\hline & 94238.50 & $-2.997 \mathrm{E}-05$ & & & \\
\hline & 94239.55 & $-9.418 \mathrm{E}-02$ & & & \\
\hline & 94240.50 & $-8.589 E-03$ & & & \\
\hline & 94241.50 & $-4.651 \mathrm{E}-05$ & & & \\
\hline & 94242.50 & $-9.612 \mathrm{E}-05$ & & & \\
\hline & 92238.50 & $-3.605 E-01$ & & & \\
\hline & 92236.50 & $-1.925 \mathrm{E}-04$ & & & \\
\hline & 92235.50 & $-2.558 \mathrm{E}-03$ & & & \\
\hline & 92234.50 & $-2.543 \mathrm{E}-05$ & & & \\
\hline & 95241.50 & $-5.478 \mathrm{E}-04$ & & & \\
\hline & 1001.50 & $-9.220 \mathrm{E}-02$ & & & \\
\hline & 7014.50 & $-7.774 \mathrm{E}-02$ & & & \\
\hline & 8016.50 & $-1.041 \mathrm{E}+00$ & & & \\
\hline & 26000.55 & $-3.034 \mathrm{E}-04$ & & & \\
\hline & 13027.50 & $-9.819 E-05$ & & & \\
\hline & 24000.50 & $-7.711 \mathrm{E}-05$ & & & \\
\hline & 20000.50 & $-6.181 E-05$ & & & \\
\hline & 28000.50 & $-5.602 \mathrm{E}-05$ & & & \\
\hline & 22000.50 & $-2.326 \mathrm{E}-05$ & & & \\
\hline & 25055.50 & $-1.530 \mathrm{E}-05$ & & & \\
\hline & 48000.50 & $-5.892 E-06$ & & & \\
\hline & 5010.50 & $-5.065 \mathrm{E}-06$ & & & $\$ b-2$ bottle solution \\
\hline \multirow{22}{*}{$\begin{array}{l}\text { mt } 6 \\
m 7\end{array}$} & lwtr. $.01 \mathrm{t}$ & & & & \\
\hline & 94238.50 & $-5.281 E-05$ & & & \\
\hline & 94239.55 & $-1.791 E-01$ & & & \\
\hline & 94240.50 & $-1.553 E-02$ & & & \\
\hline & 94241.50 & $-7.687 \mathrm{E}-04$ & & & \\
\hline & 94242.50 & $-1.330 E-04$ & & & \\
\hline & 92238.50 & $-6.312 \mathrm{E}-03$ & & & \\
\hline & 92236.50 & $-3.036 \mathrm{E}-05$ & & & \\
\hline & 92235.50 & $-1.490 \mathrm{E}-04$ & & & \\
\hline & 92234.50 & $-8.970 \mathrm{E}-06$ & & & \\
\hline & $\begin{array}{r}95241.50 \\
1001.50\end{array}$ & $\begin{array}{l}-9.585 E-04 \\
-9.537 E-02\end{array}$ & & & \\
\hline & 7014.50 & $-9.252 \mathrm{E}-02$ & & & \\
\hline & 8016.50 & $-1.049 E+00$ & & & \\
\hline & 26000.55 & $-5.741 \mathrm{E}-04$ & & & \\
\hline & 13027.50 & $-1.858 \mathrm{E}-04$ & & & \\
\hline & 24000.50 & $-1.459 \mathrm{E}-04$ & & & \\
\hline & 20000.50 & $-1.170 E-04$ & & & \\
\hline & 28000.50 & $-1.060 \mathrm{E}-04$ & & & \\
\hline & 22000.50 & $-4.401 E-05$ & & & \\
\hline & 25055.50 & $-2.895 E-05$ & & & \\
\hline & 48000.50 & $-1.115 \mathrm{E}-05$ & & & \\
\hline & 5010.50 & $-9.585 E-06$ & & & $\$ b-3$ tank solution \\
\hline met 7 & $1 \mathrm{wtr} .01 \mathrm{t}$ & & & & \\
\hline \multirow[t]{2}{*}{ m8 } & 94238.50 & $-5.263 E-05$ & & & \\
\hline & 94239.55 & $-1.785 E-01$ & & & \\
\hline
\end{tabular}


HNF-5988 Rev. 0

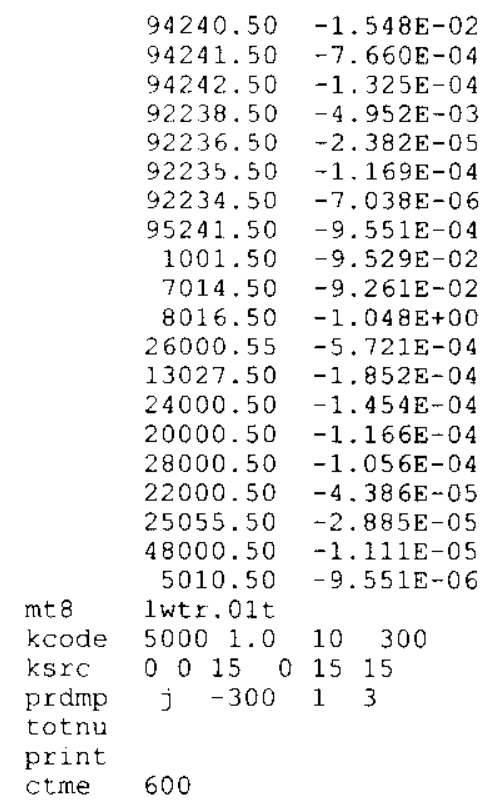

$\$ b-3$ bottle solution

annulus 1 water

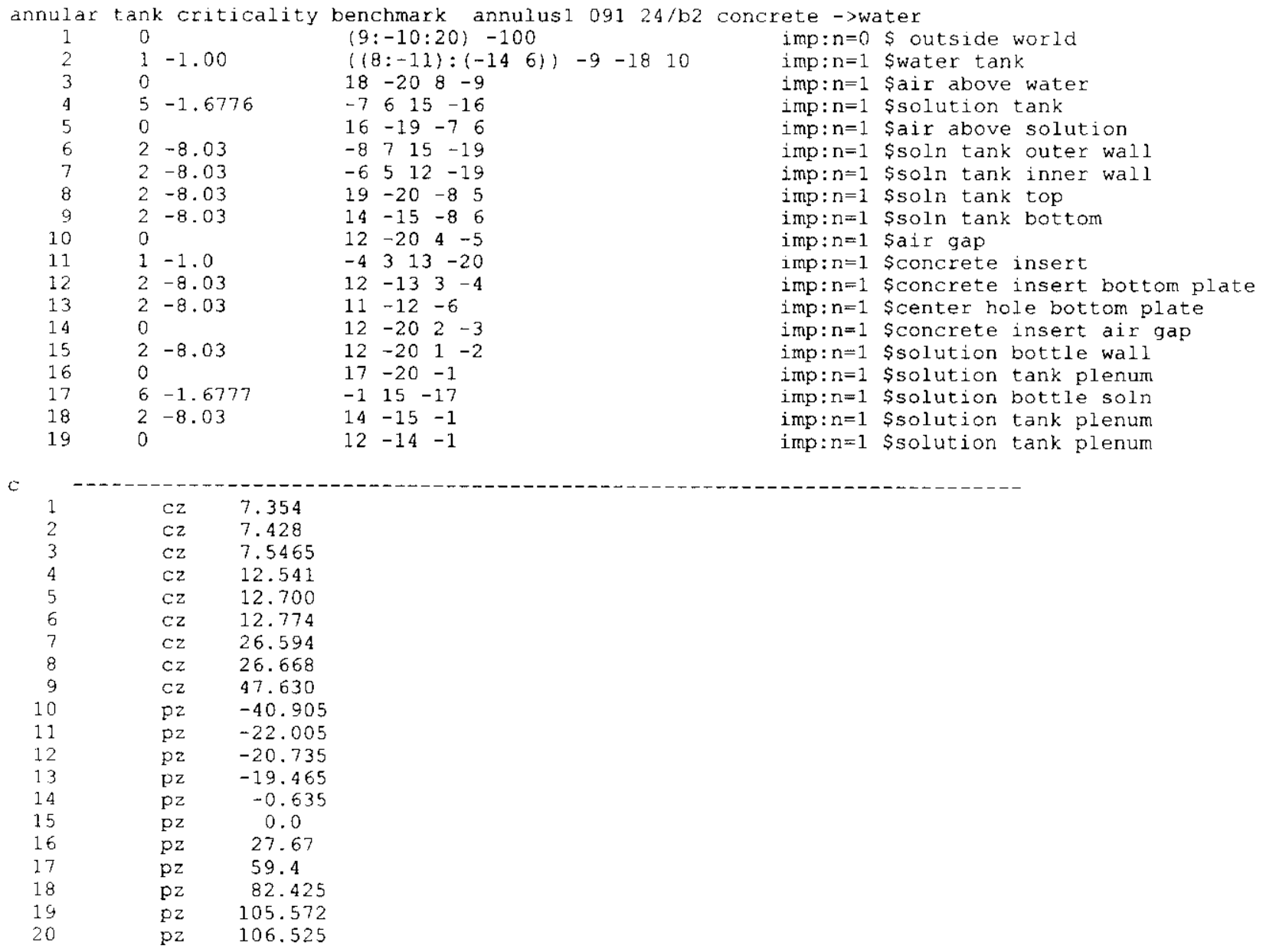




\section{HNF-5988 Rev. 0}

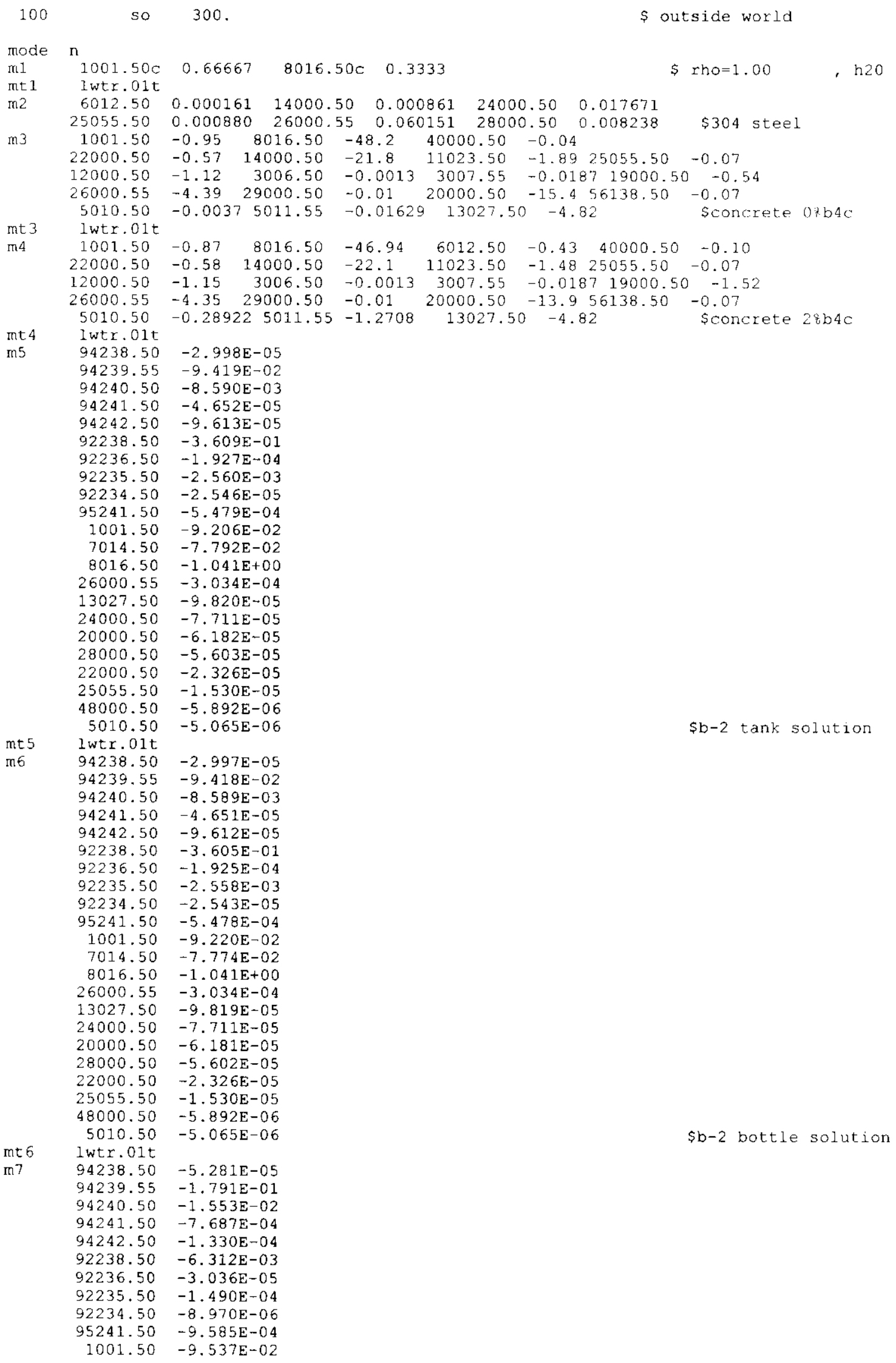


HNF-5988 Rev. 0

\begin{tabular}{|c|c|c|}
\hline & & \\
\hline & 7014.50 & $-9.252 \mathrm{E}-02$ \\
\hline & 8016.50 & $-1.049 E+00$ \\
\hline & 26000.55 & $-5.741 E-04$ \\
\hline & 13027.50 & $-1.858 \mathrm{E}-04$ \\
\hline & 24000.50 & $-1.459 \mathrm{E}-0$ \\
\hline & 20000.50 & $-1.170 \mathrm{E}-0$ \\
\hline & 28000.50 & $-1.060 \mathrm{E}-0$ \\
\hline & 22000.50 & $-4.401 E-0$ \\
\hline & 25055.50 & $-2.895 E-0$ \\
\hline & 48000.50 & $-1.115 E-0$ \\
\hline & 5010.50 & $-9.585 E-0$ \\
\hline$m+7$ & lwtr.01t & \\
\hline $\mathrm{m} 8$ & 94238.50 & $-5.263 \mathrm{E}-\mathrm{C}$ \\
\hline & 94239.55 & $-1.785 \mathrm{E}$ \\
\hline & 94240.50 & $-1.548 \mathrm{E}$ \\
\hline & 94241.50 & $-7.660 \mathrm{E}-0$ \\
\hline & 94242.50 & $-1.325 \mathrm{E}-0$ \\
\hline & 92238.50 & $-4.952 E-0$ \\
\hline & 92236.50 & $-2.382 E$ \\
\hline & 92235.50 & $-1.169 \mathrm{E}-0$ \\
\hline & 92234.50 & $-7.038 \mathrm{E}-0$ \\
\hline & 95241.50 & $-9.551 E-0$ \\
\hline & 1001.50 & $-9.529 \mathrm{E}-0$ \\
\hline & 7014.50 & $-9.261 \mathrm{E}-0$ \\
\hline & 8016.50 & $-1.048 \mathrm{E}+0$ \\
\hline & 26000.55 & $-5.721 E-0$ \\
\hline & 13027.50 & $-1.852 \mathrm{E}-0$ \\
\hline & 24000.50 & $-1.454 \mathrm{E}-0$ \\
\hline & 20000.50 & $-1.166 \mathrm{E}-0$ \\
\hline & 28000.50 & $-1.056 \mathrm{E}-0$ \\
\hline & 22000.50 & $-4.386 \mathrm{E}-0$ \\
\hline & 25055.50 & $-2.885 E-0$ \\
\hline & 48000.50 & $-1.111 \mathrm{E}-0$ \\
\hline & 5010.50 & $-9.551 \mathrm{E}-0$ \\
\hline$m t 8$ & lwtr.01t & \\
\hline kcode & 50001.0 & $10 \quad 300$ \\
\hline $\mathrm{ksrc}$ & $\begin{array}{llll}0 & 0 & 15 & 0\end{array}$ & $15 \quad 15$ \\
\hline prdmp & j -300 & 13 \\
\hline totnu & & \\
\hline pr & & \\
\hline & 600 & \\
\hline
\end{tabular}

\$b-3 tank solution 
HNF-5988 Rev. 0

APPENDIX C

MCNP INPUT FILES

C-1 
HNF-5988 Rev. 0

This page intentionally left blank

C-2 


\section{HNF-5988 Rev. 0}

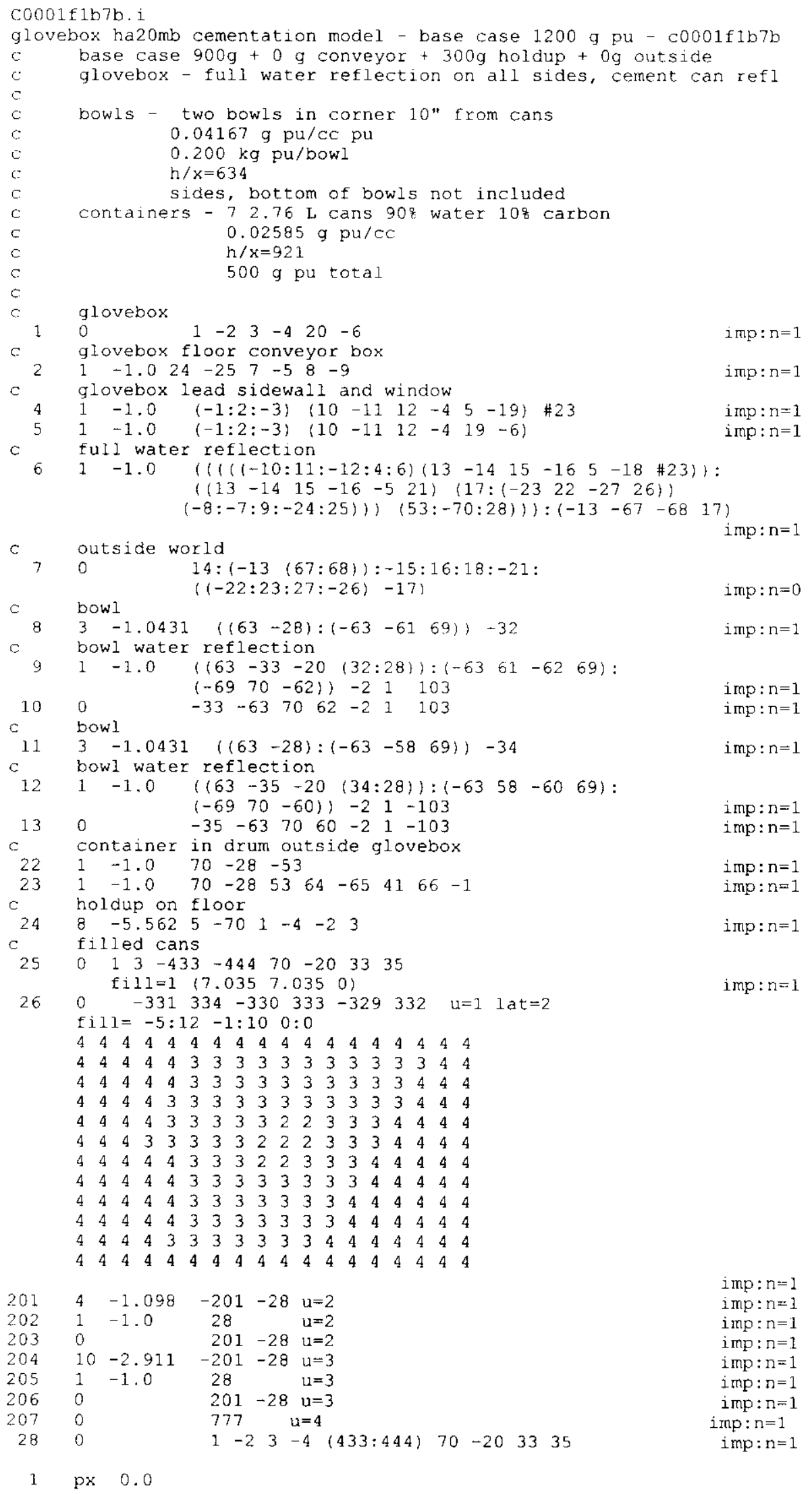


HNF-5988 Rev. 0

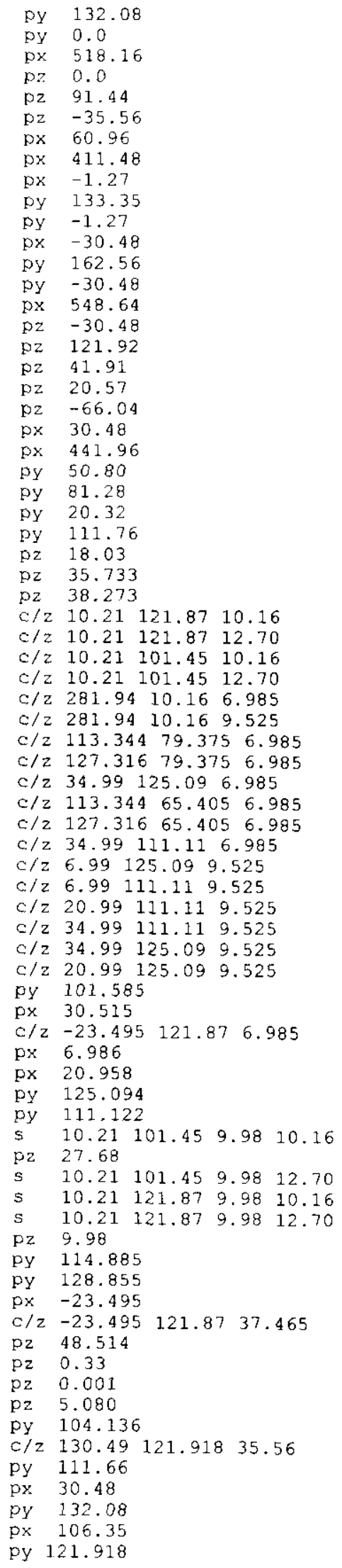




\section{HNF-5988 Rev. 0}

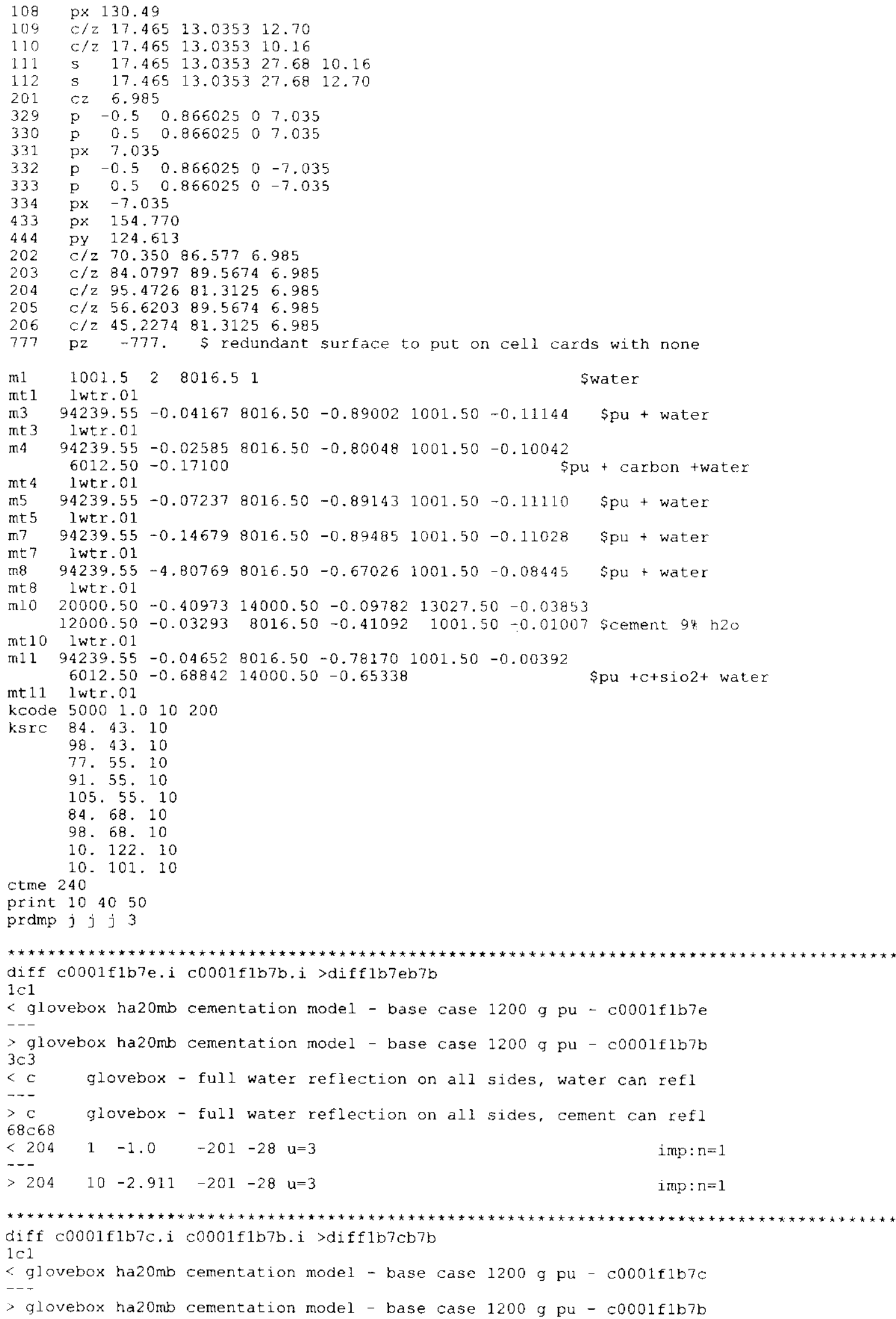




\section{HNF-5988 Rev. 0}

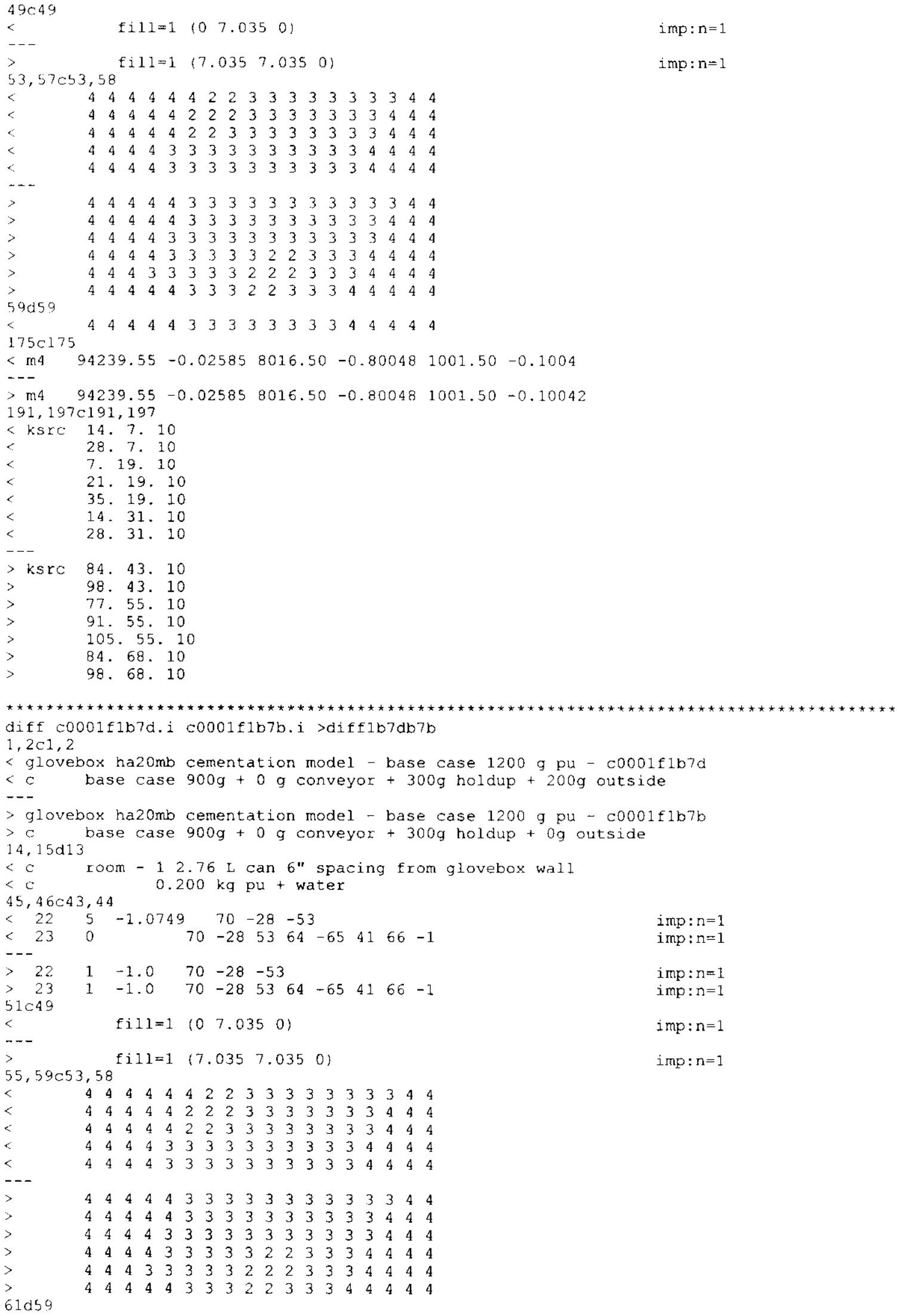


HNF-5988 Rev. 0

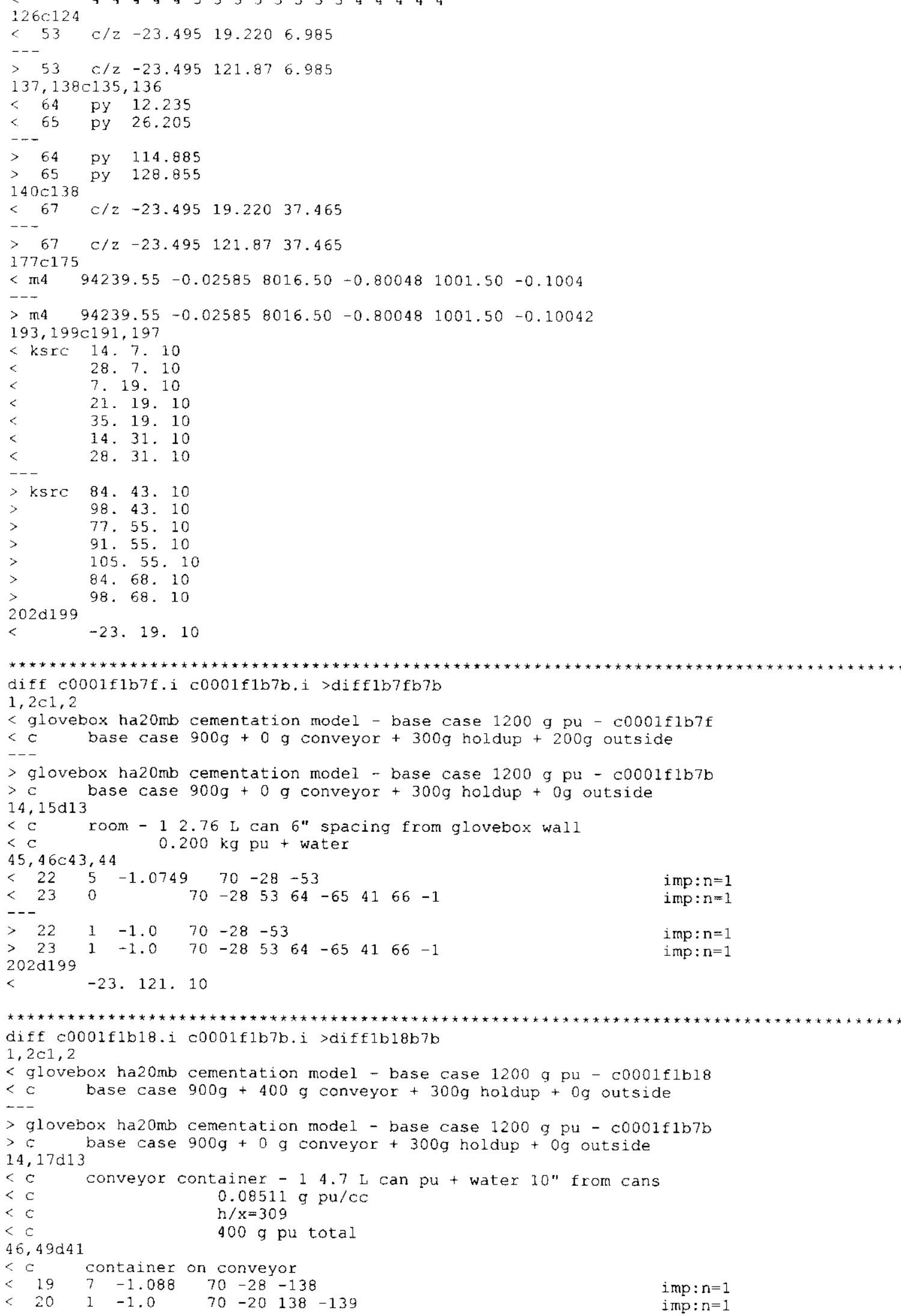


HNF-5988 Rev. 0

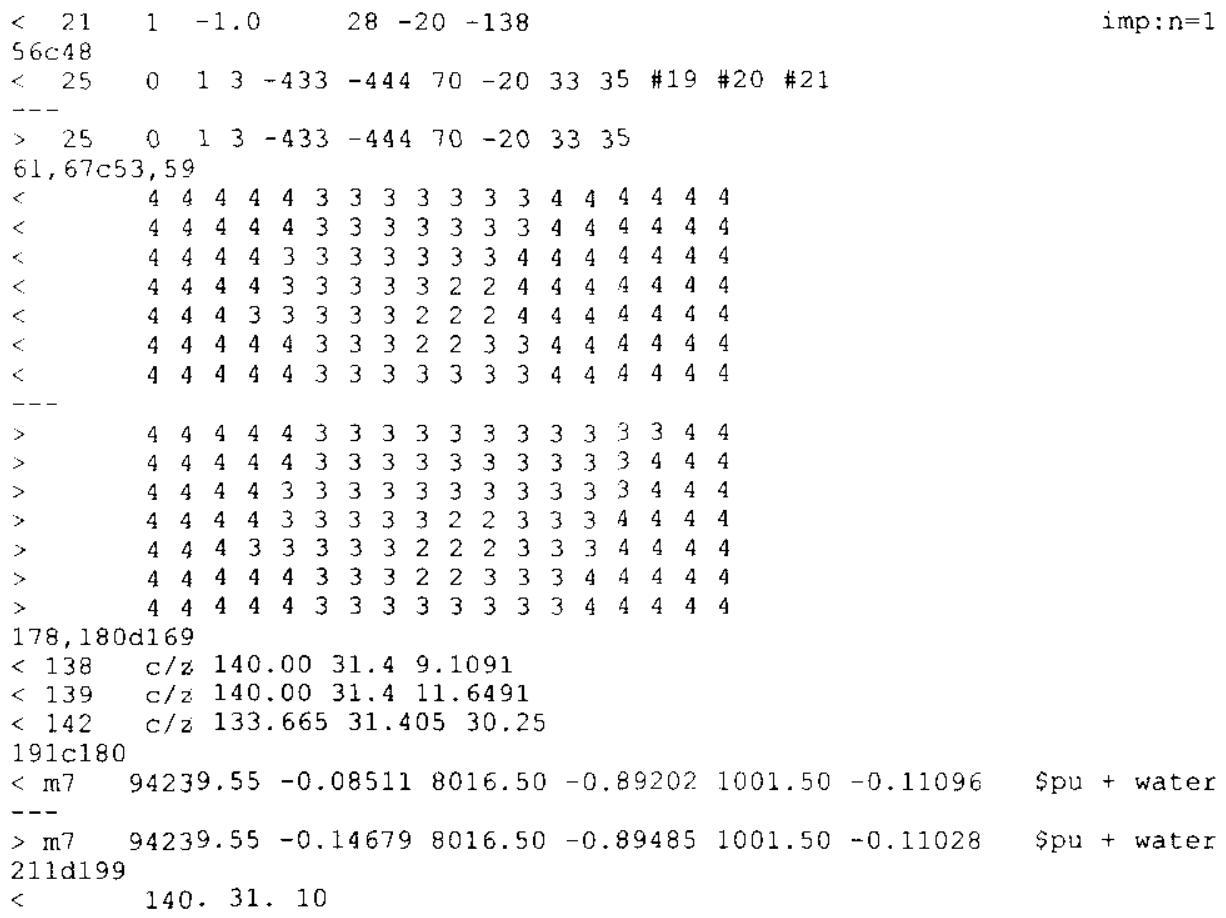




\section{HNF-5988 Rev. 0}

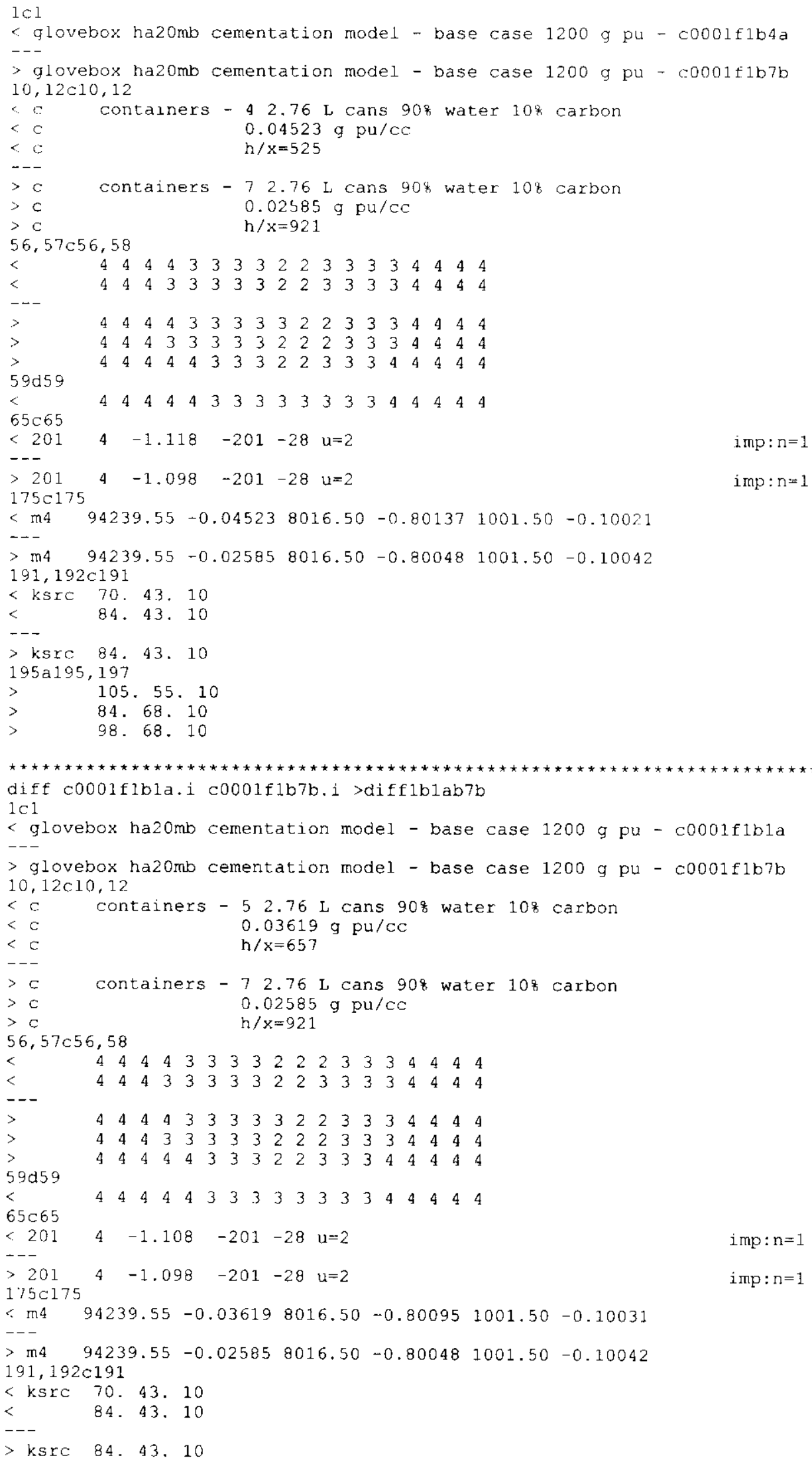




\section{HNF-5988 Rev. 0}

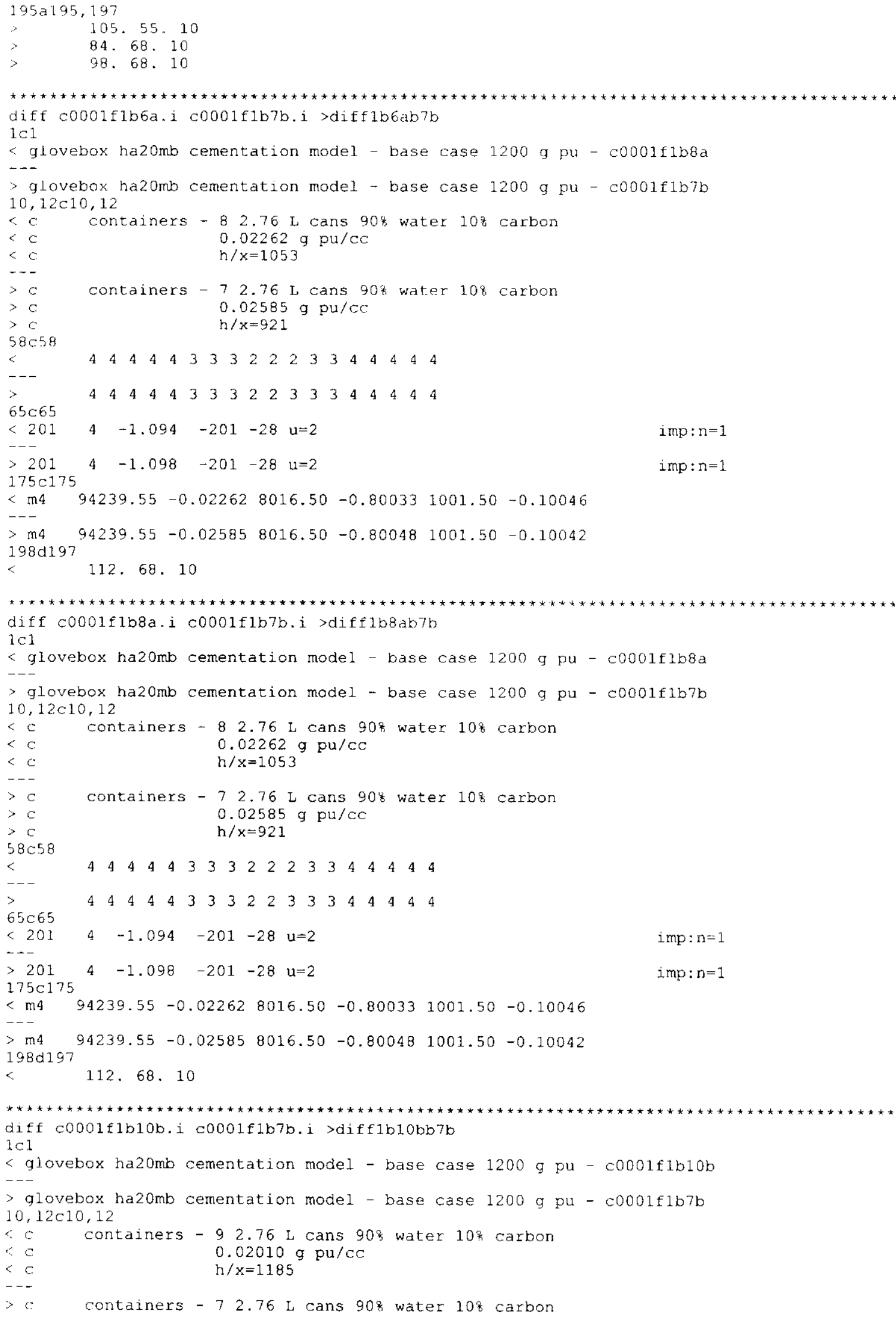




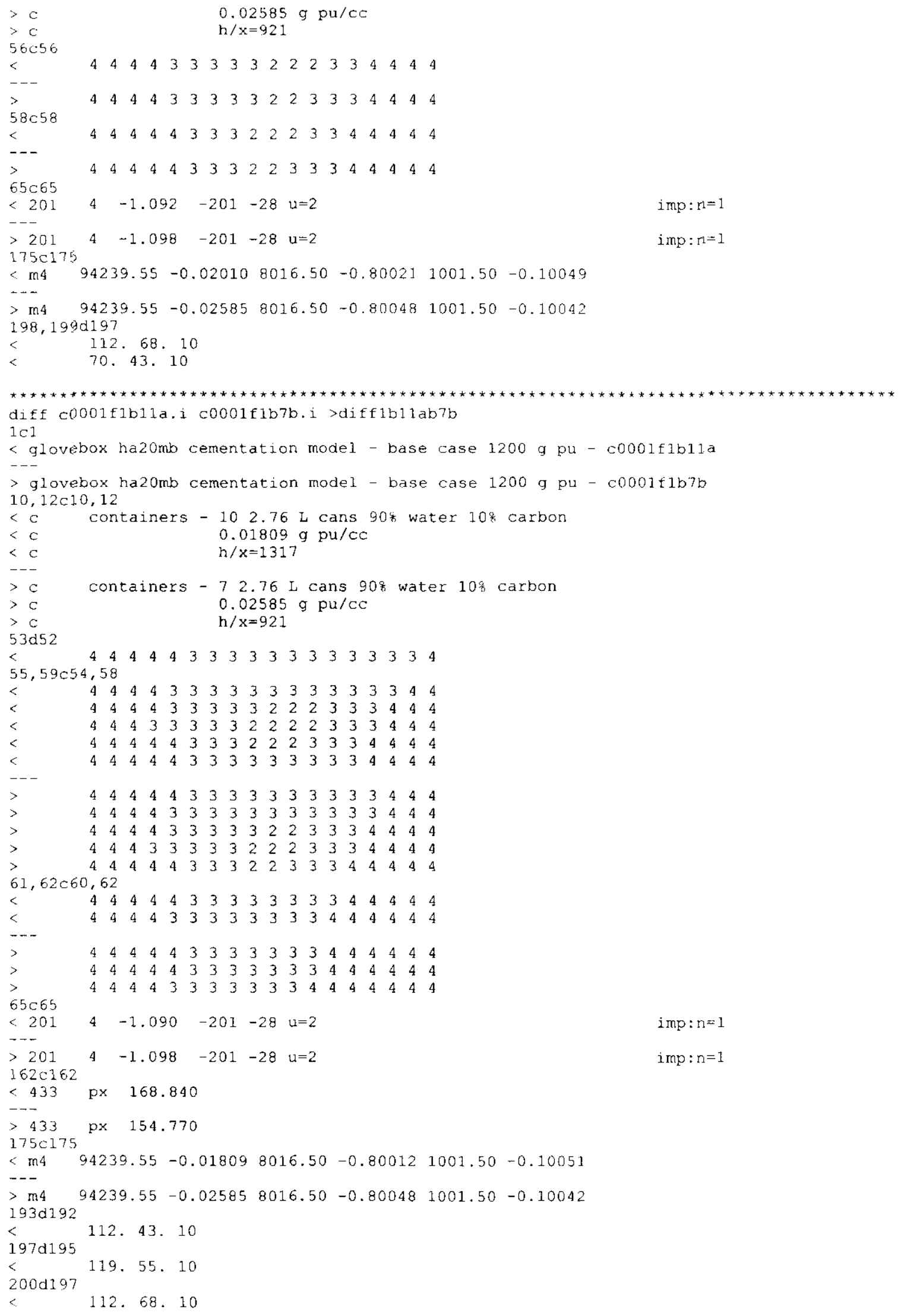


HNF-5988 Rev. 0

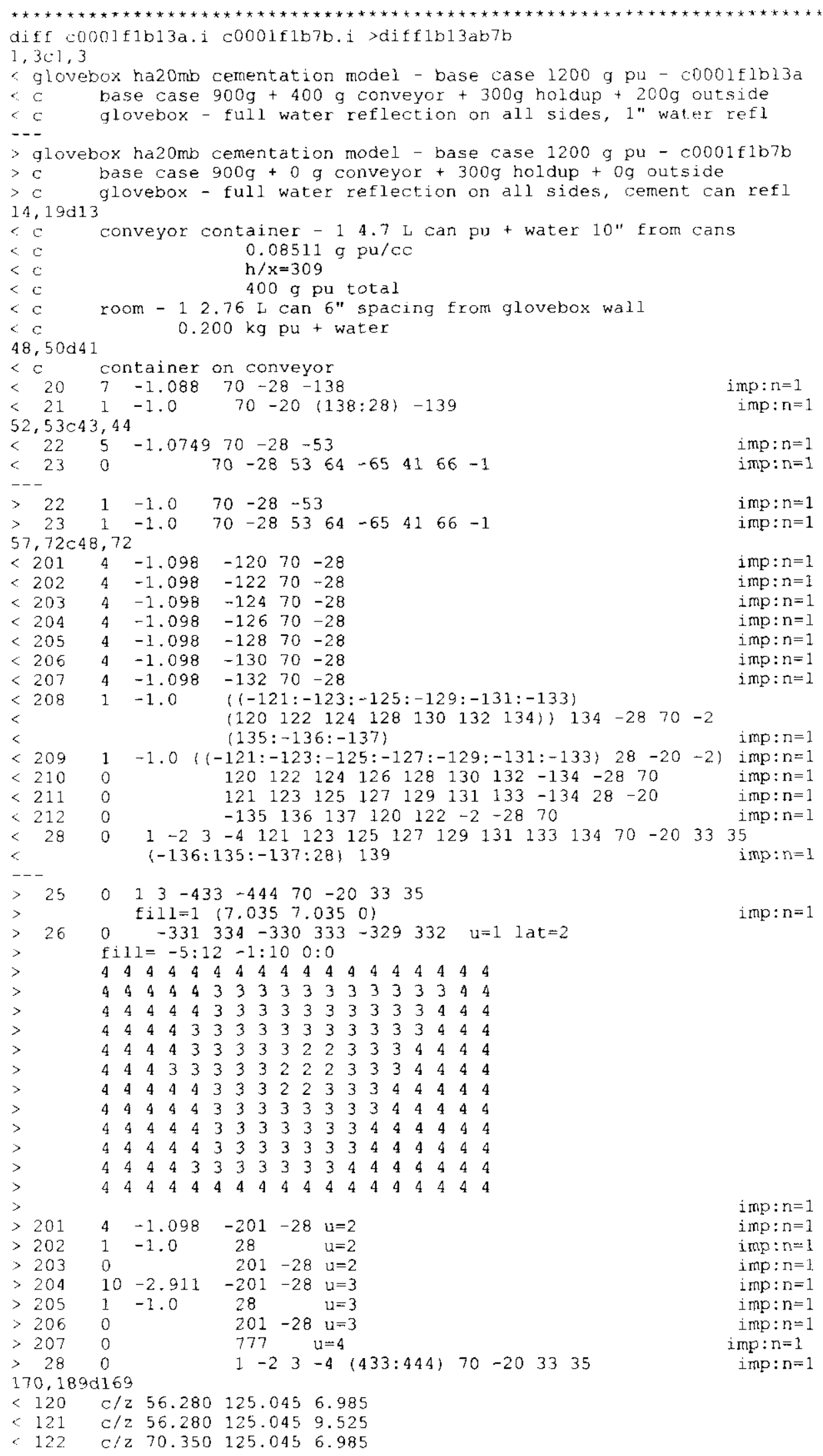


HNF-5988 Rev. 0

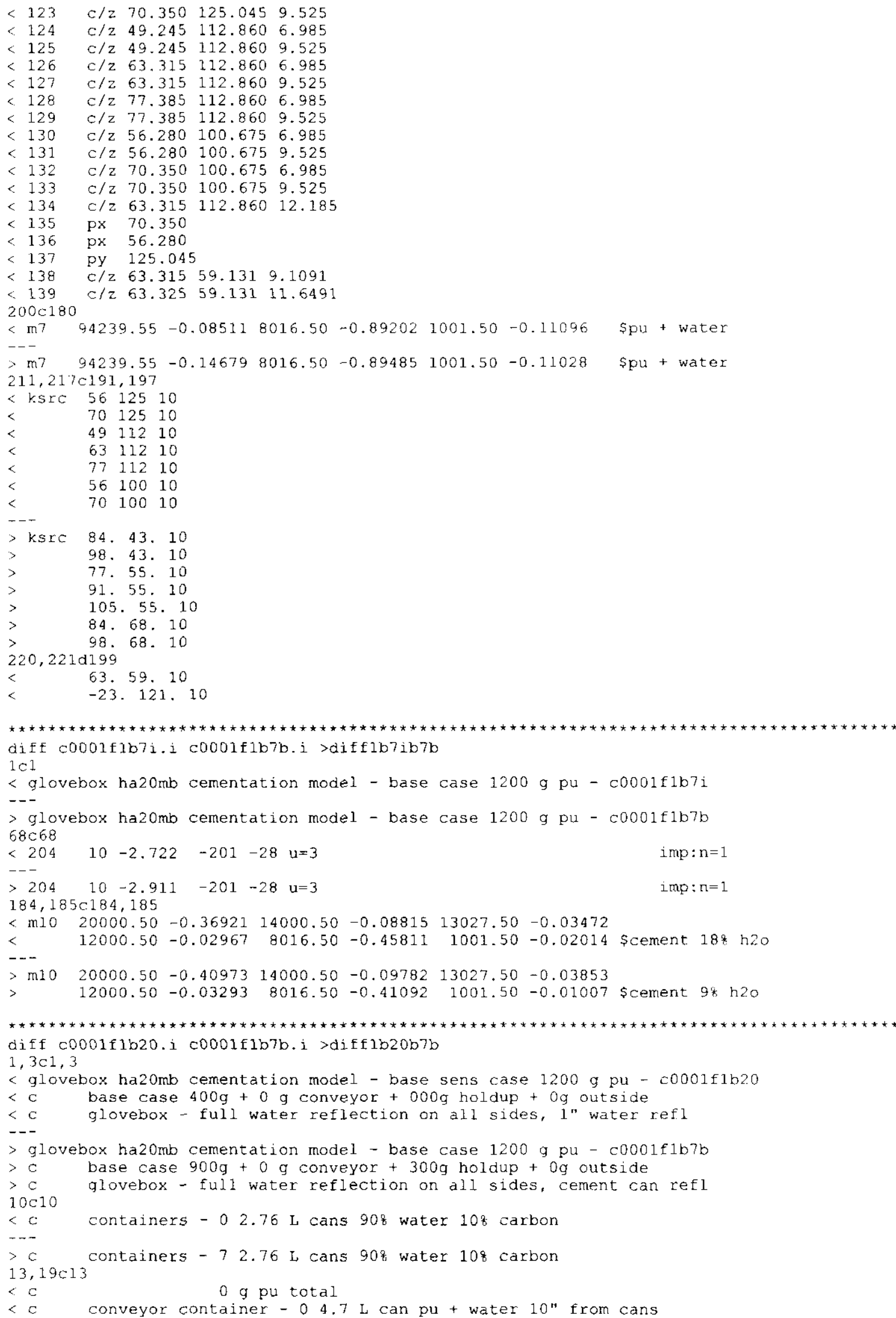




\section{HNF-5988 Rev. 0}

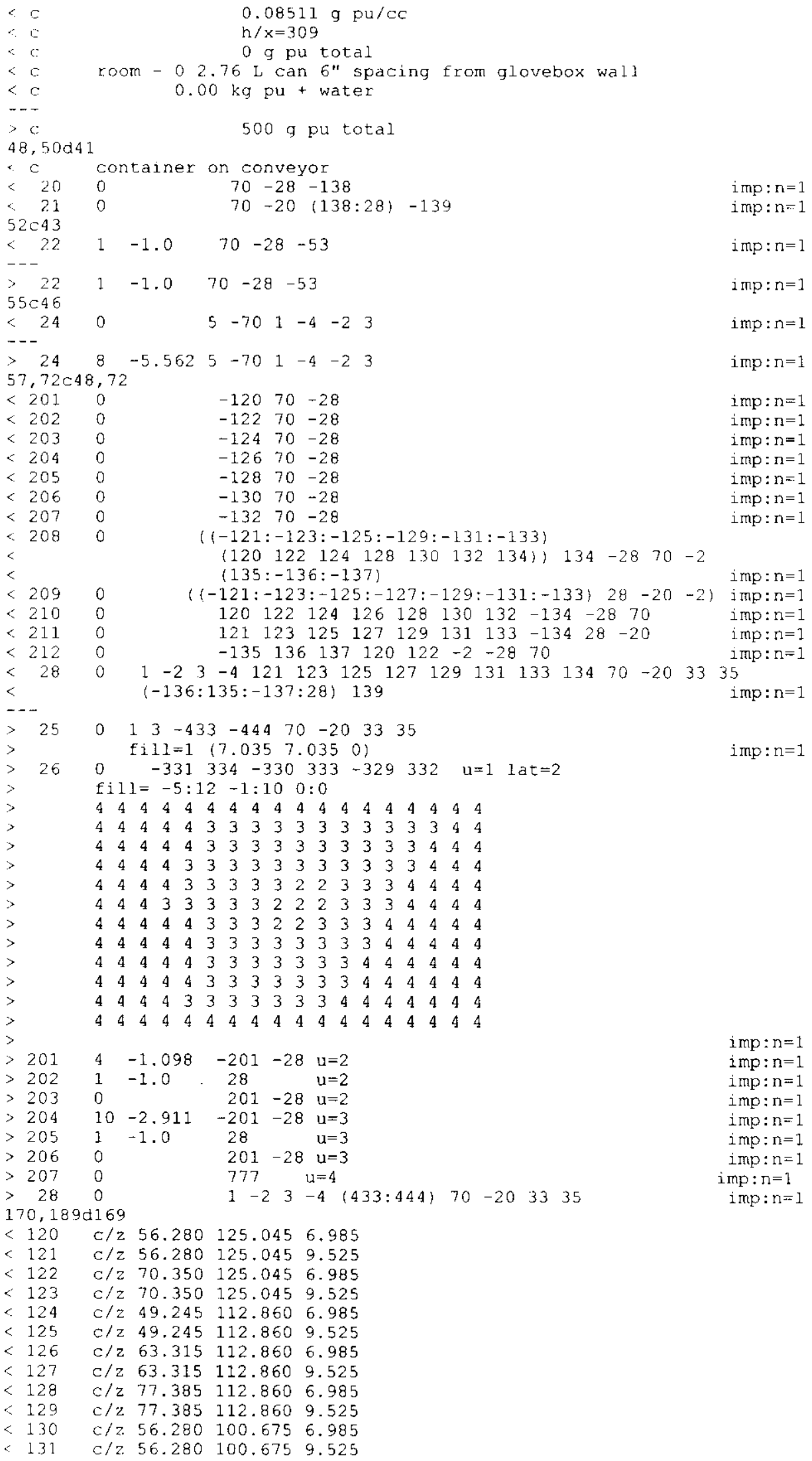




\section{HNF-5988 Rev. 0}

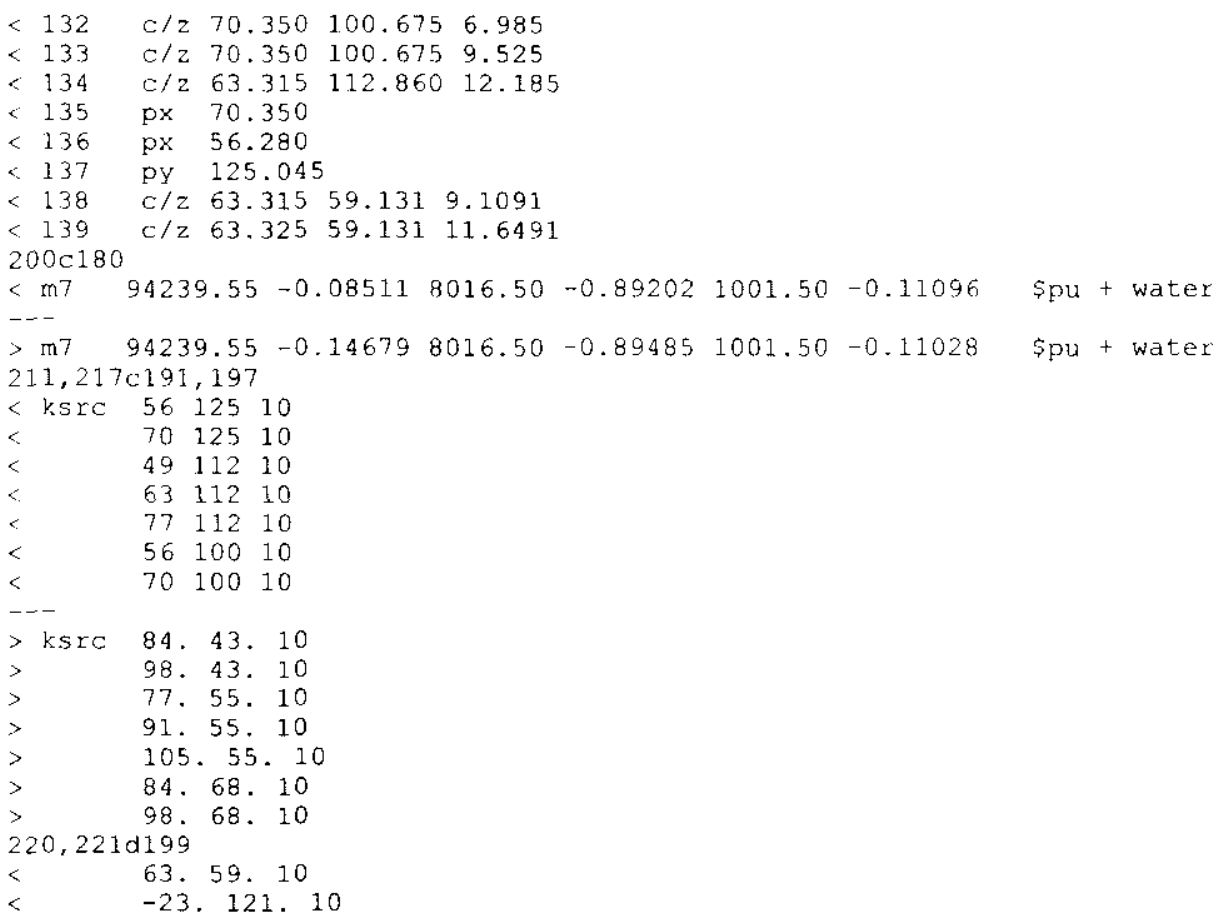




\section{HNF-5988 Rev. 0}

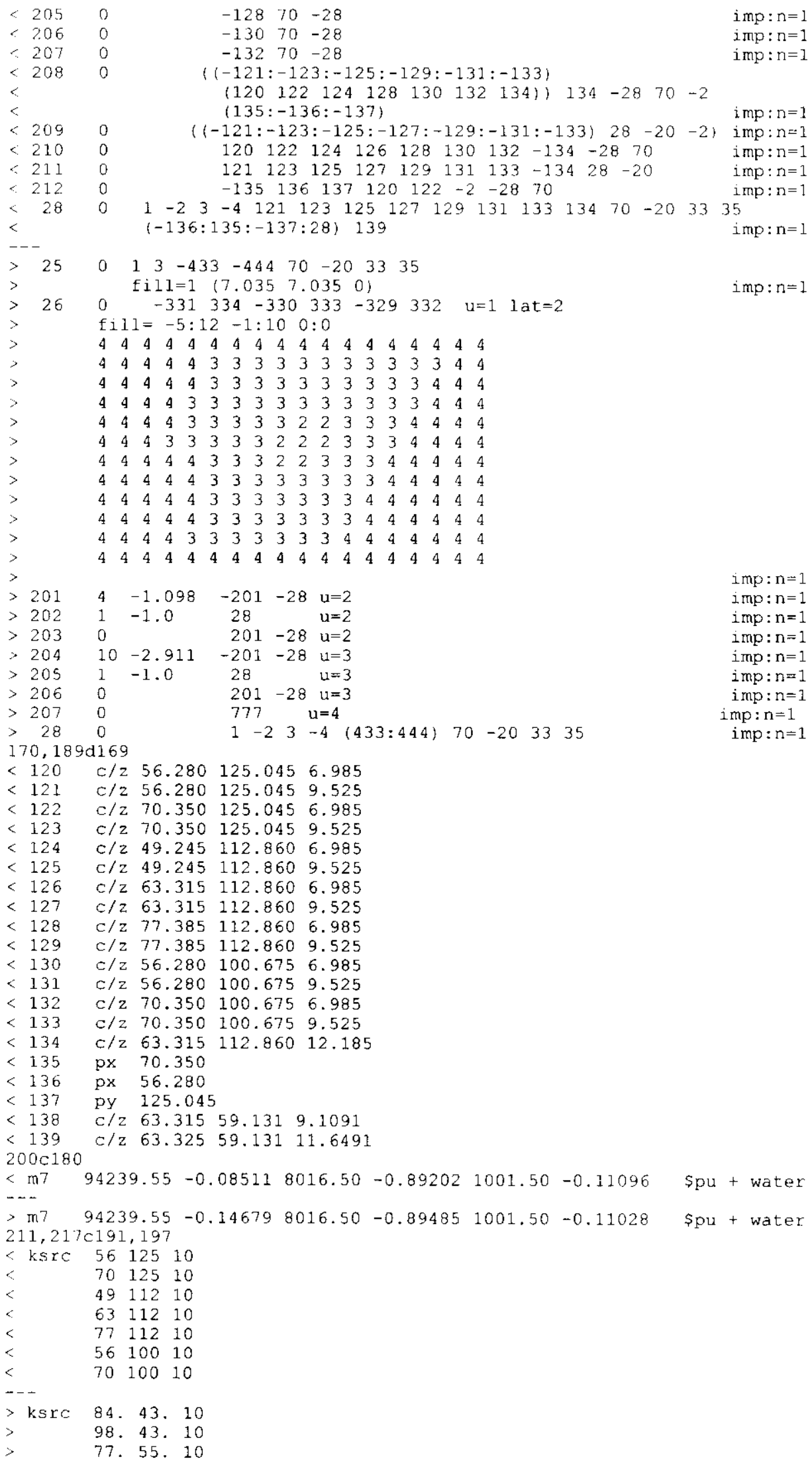


HNF-5988 Rev. 0

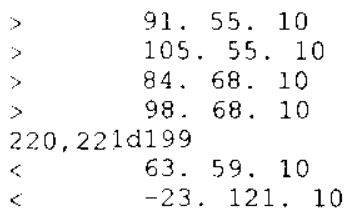


HNF-5988 Rev. 0

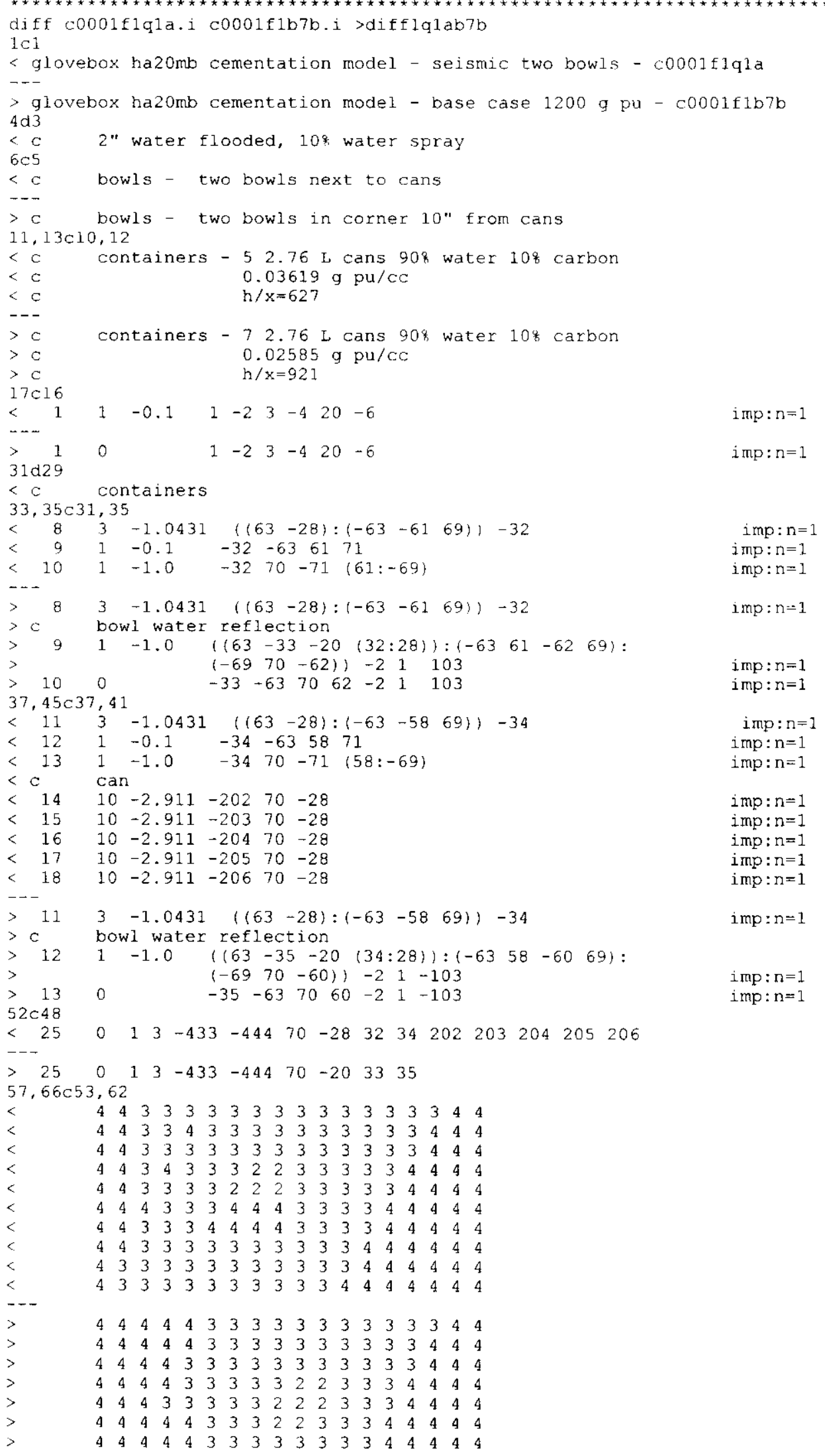


HNF-5988 Rev. 0

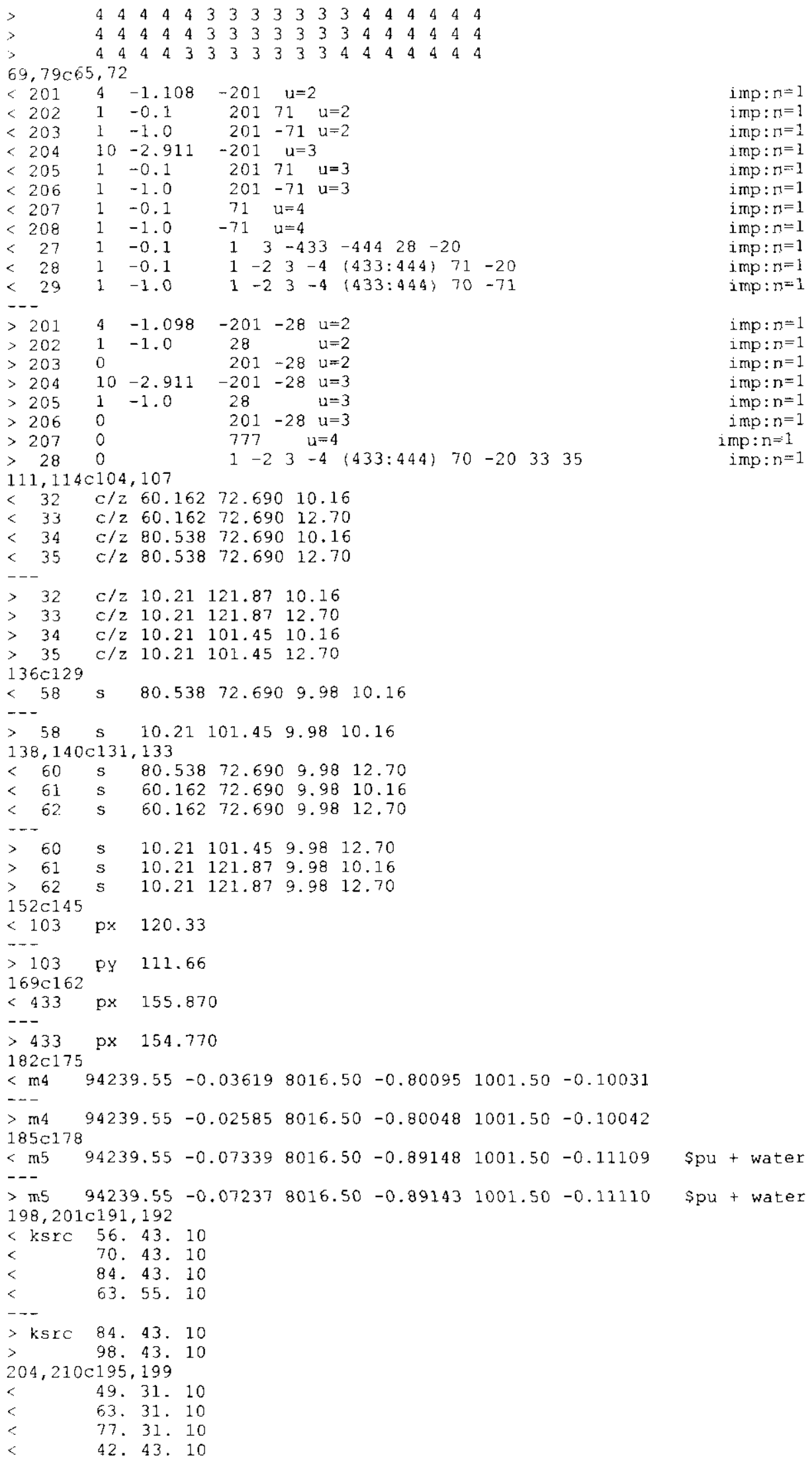




\section{HNF-5988 Rev. 0}

$\begin{array}{ll}< & 49 \cdot 55 \cdot 10 \\ < & 60 \cdot 72 \cdot 10 \\ < & 80 \cdot 72 \cdot 10 \\ --- & \\ > & 105 \cdot 55 \cdot 10 \\ > & 84 \cdot 68 \cdot 10 \\ > & 98 \cdot 68 \cdot 10 \\ > & 10 \cdot 122 \cdot 10 \\ > & 10 \cdot 101 \cdot 10\end{array}$


HNF-5988 Rev. 0

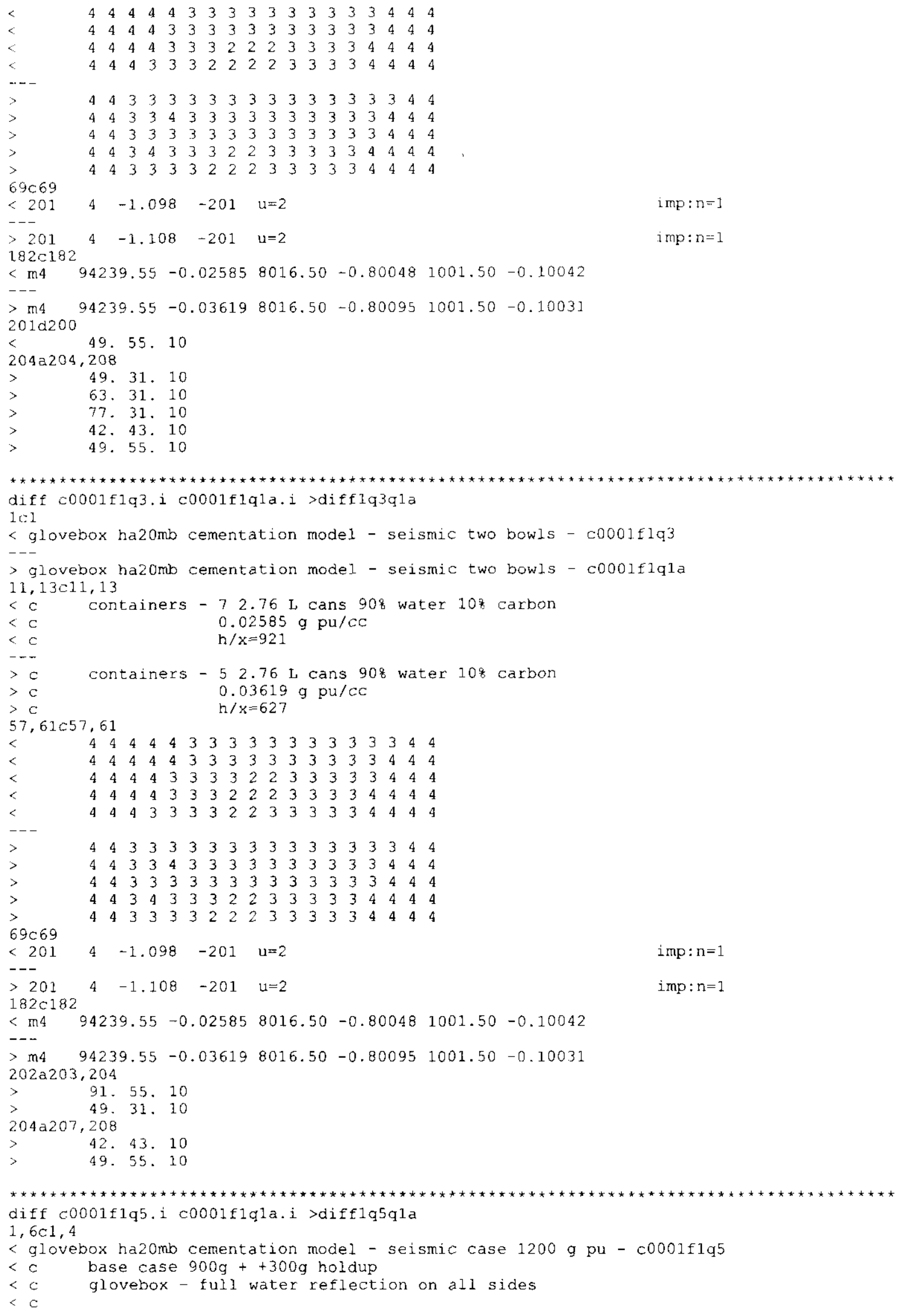


HNF-5988 Rev. 0

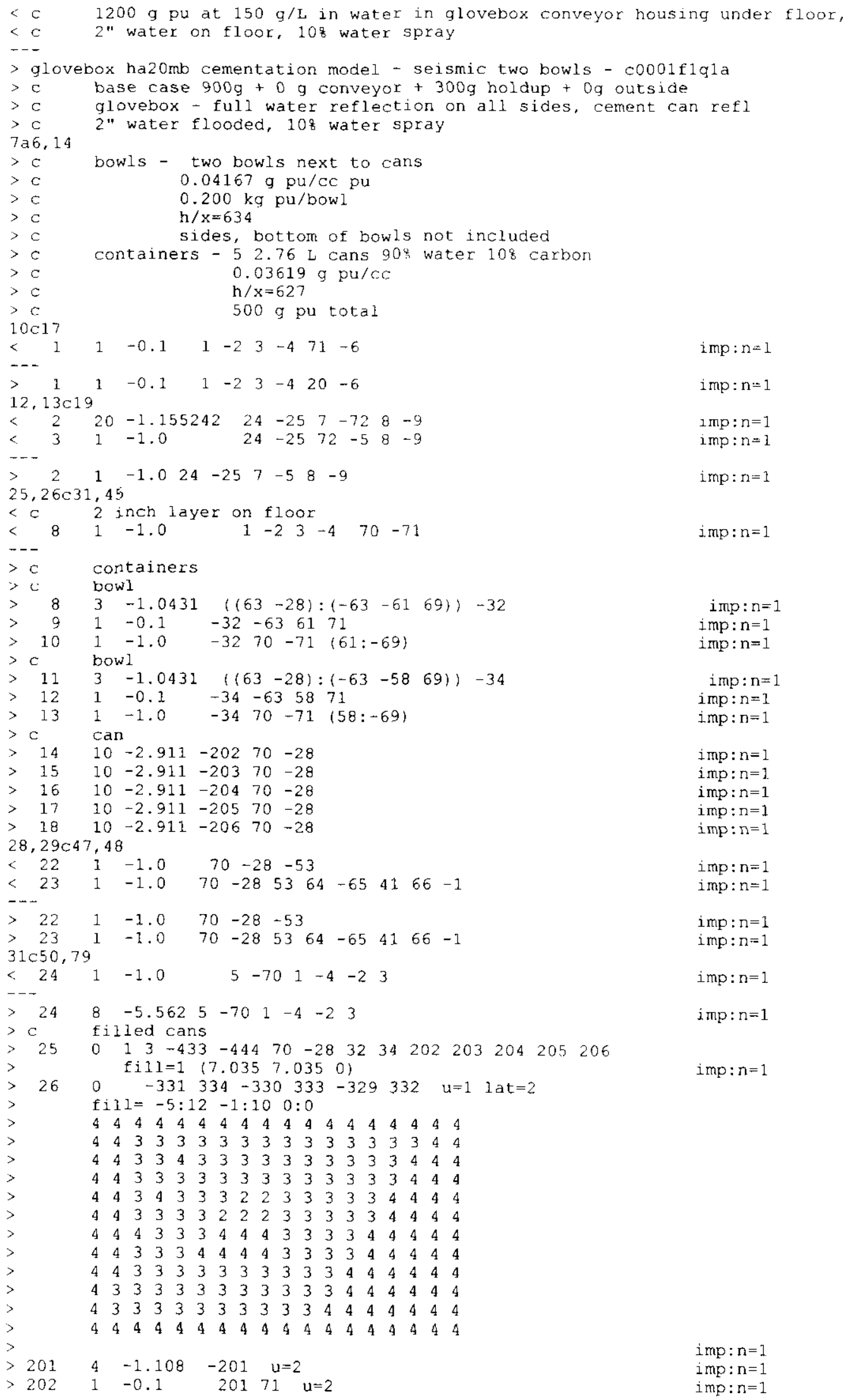


HNF-5988 Rev. 0

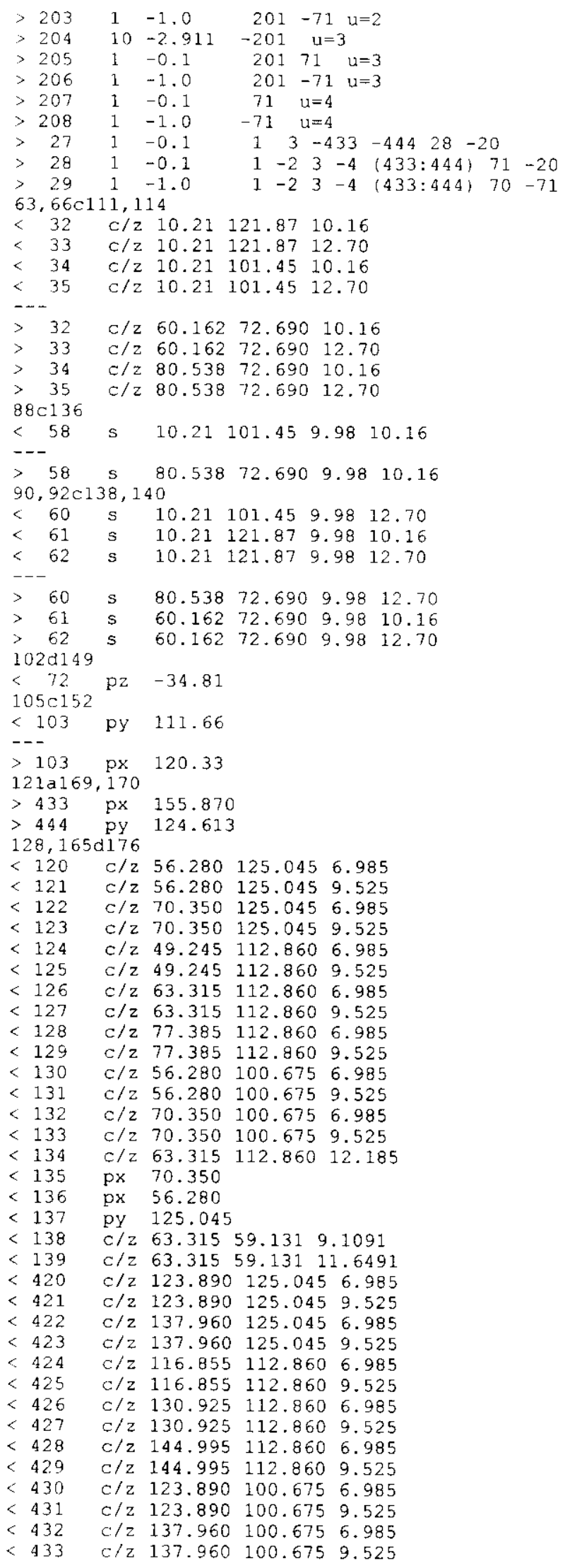

imp: $n=1$ imp: $n=1$ imp: $n=1$ imp: $n=1$ imp: $n=1$ imp: $n=1$. imp: $n=1$ i mp: $n=1$

imp: $n=1$ 
HNF-5988 Rev. 0

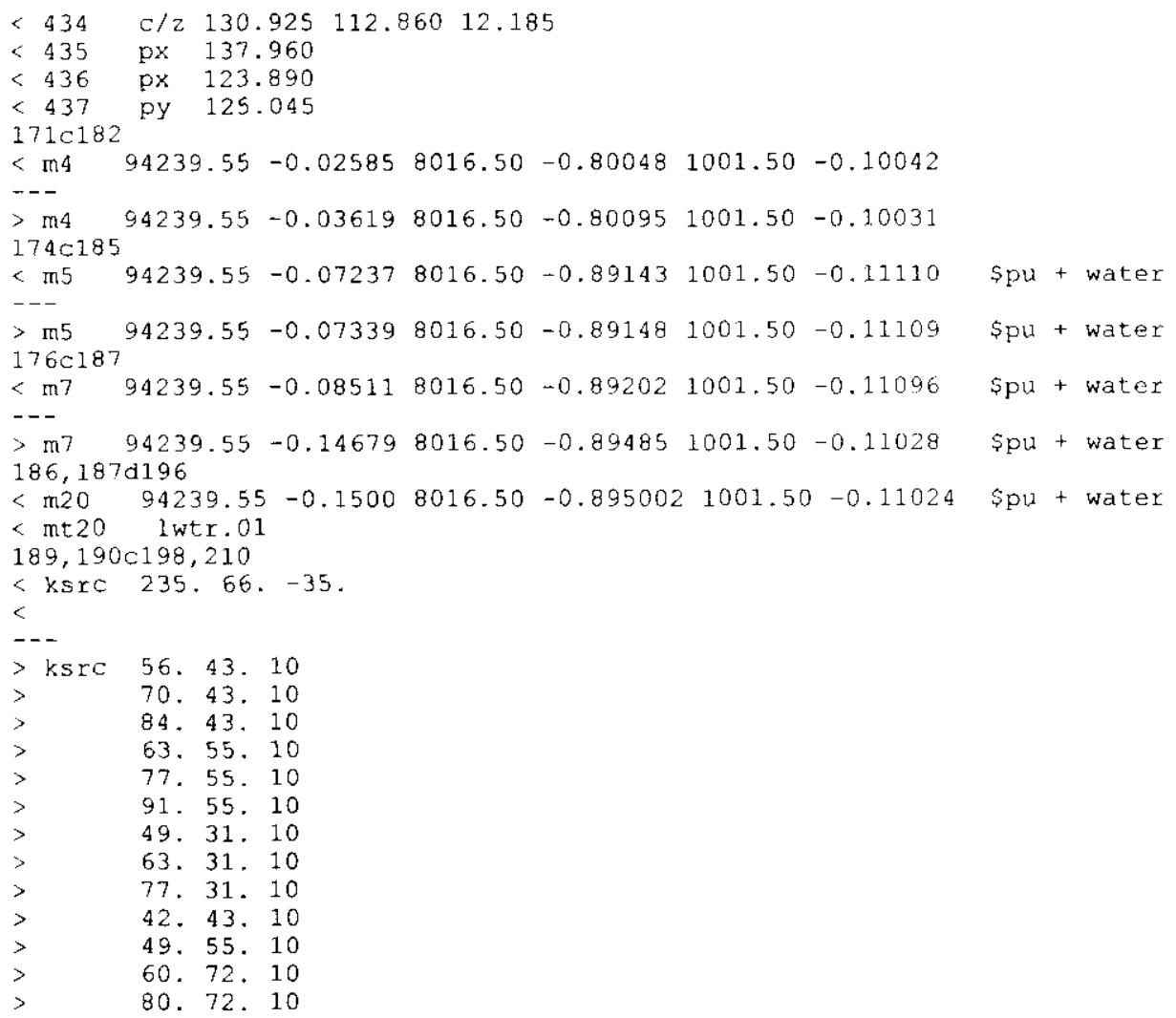


HNF-5988 Rev. 0

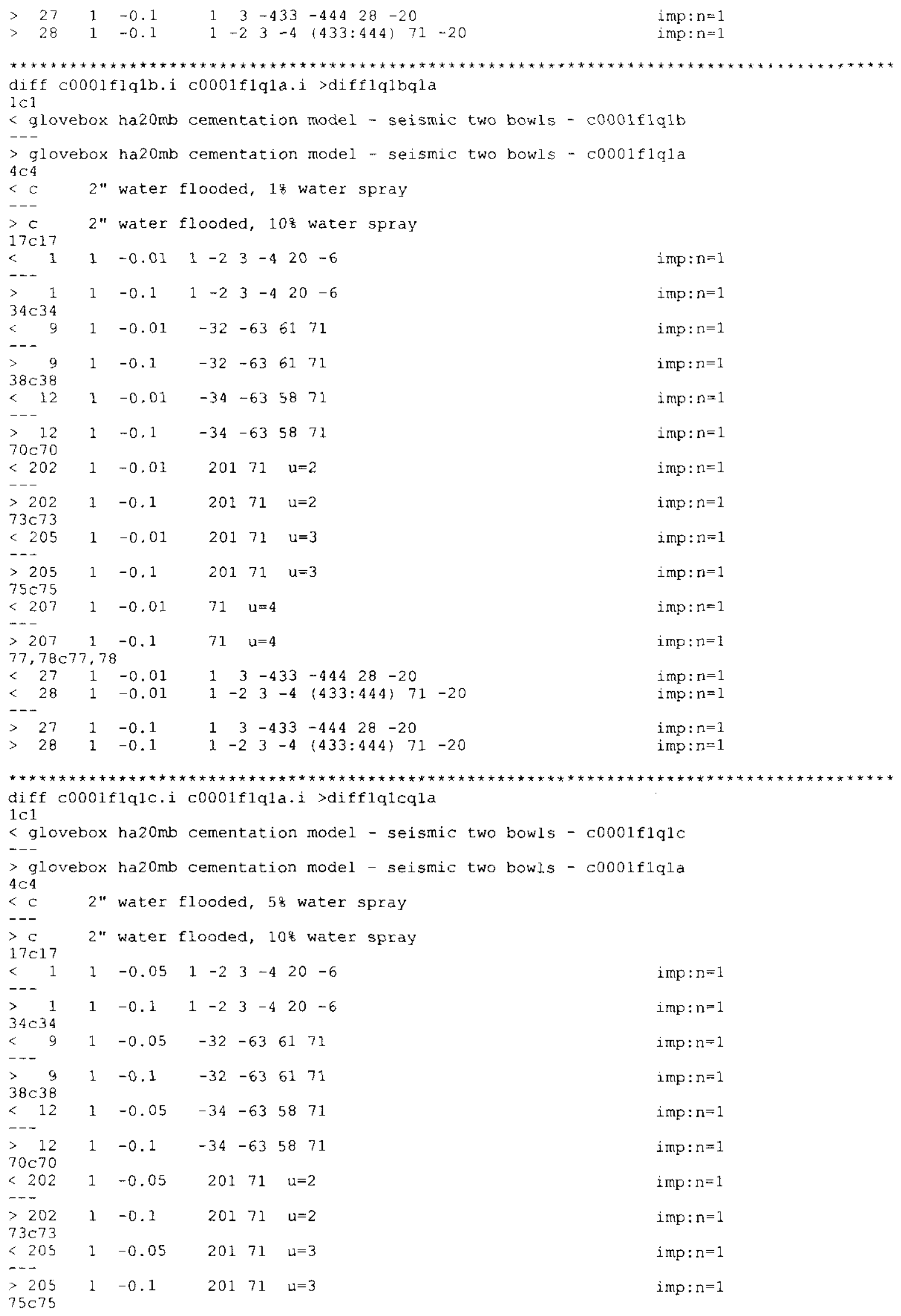




\section{HNF-5988 Rev. 0}

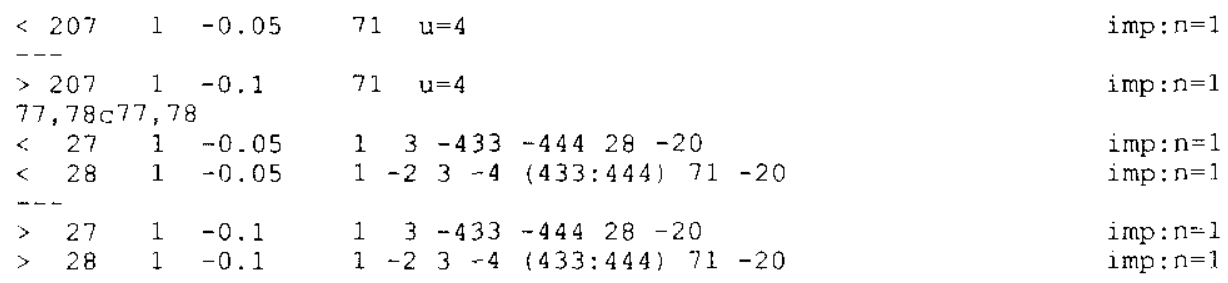

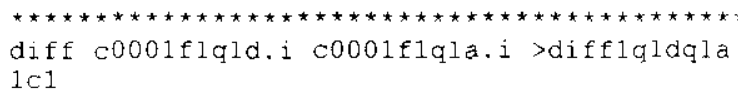

< glovebox ha20mb cementation model - seismic two bowls - c0001flqla

$---$

$>$ glovebox ha20mb cementation model - seismic two bowls - c000lflqla

$4 \mathrm{C} 4$

$<\mathrm{c} \quad 2$ " water flooded, $15 \%$ water spray

$---$

$>c \quad 2$ " water flooded, 10 s water spray

17017

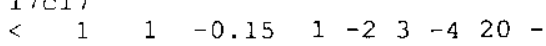

imp $: n=1$

$\begin{array}{lllllllllll}> & 1 & 1 & -0.1 & 1 & -2 & 3 & -4 & 20 & -6\end{array}$

imp: $n=1$

$\begin{array}{rrrrrrr}34034 & 1 & -0.15 & -32 & -63 & 61 & 71\end{array}$

imp: $n=1$

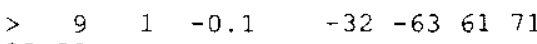

imp $: n=1$

$\begin{array}{llllllll}< & 12 & 1 & -0.15 & -34 & -63 & 58 & 71\end{array}$

imp: $n=1$

$\begin{array}{llllllll}> & 12 & 1 & -0.1 & -34 & -63 & 58 & 71\end{array}$

imp $: n=1$

70070

$<202$

$\begin{array}{lllll}-0.1 & -34 & -63 & 58 & 71\end{array}$

imp: $n=1$

$\begin{array}{lllll}7 & -0.1 & 20171 & \end{array}$

imp: $n=1$

73073

$<\begin{array}{llllll}205 & 1 & -0.15 \quad 20171 \quad u=3\end{array}$

imp $: n=1$

$>205 \quad 1-0.1 \quad 20171 \quad \mathrm{u}=3$

imp: $n=1$

75075

$<207 \quad 1-0.15 \quad 71 \quad u=4$

imp $: n=1$

$\begin{array}{lllll}207 & 1 & -0.1 & 71 & u=4\end{array}$

$77,78 \mathrm{c} 77,78$

$<\begin{array}{lllllllll}27 & 1 & -0.15 & 1 & 3 & -433 & -444 & 28 & -20\end{array}$

$<28 \quad 1-0.15 \quad 1-2 \quad 3-4 \quad(433: 444) \quad 71-20$

$\operatorname{imp}: n=1$

$---$

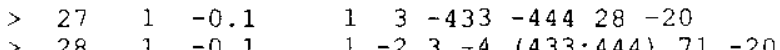

imp: $n=1$

$i m p: n=1$

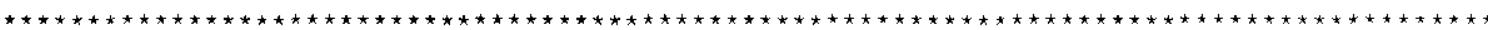

diff c0001fffl.i c0001flb7b.i >difflf1b7b

101

< glovebox ha20mb cementation model - fire case $1200 \mathrm{~g}$ pu - c0001fifl

$>$ glovebox ha20mb cementation model - base case $12.00 \mathrm{~g}$ pu - c0001flb7b

$6 c 6$

$<\mathrm{c}$

$0.04228 \mathrm{~g} \mathrm{pu} / \mathrm{cc} \mathrm{pu}$

$>\mathrm{c}$

$8 \mathrm{c} 8$

$<\mathrm{c}$

$0.04167 \mathrm{~g} \mathrm{pu} / \mathrm{cc} \mathrm{pu}$

$>\mathrm{C}$

$h / x$

$16 \mathrm{c} 16$

$h / x=634$

$<\begin{array}{lllllllll}1 & 1 & -0.1 & 1 & -2 & 3 & -4 & 20 & -6\end{array}$

imp: $n=1$

$\begin{array}{llllllllll}> & 1 & 0 & 1 & -2 & 3 & -4 & 20 & -6\end{array}$

imp: $n=1$

$30 \mathrm{~d} 29$

$<C$ containers

$33,35 \mathrm{c} 32,35$

$<\begin{array}{lllllll}3 & 9 & -0.1 & -32 & -63 & 61 & 71\end{array}$

$<101-1.0 \quad-3270-71 \quad(61:-69)$

$<\begin{array}{llllll}11 & 1 & -0.1 & -32 & 28 & -20\end{array}$

imp: $n=1$

imp: $n=1$

imp: $n=1$ 


\section{HNF-5988 Rev. 0}

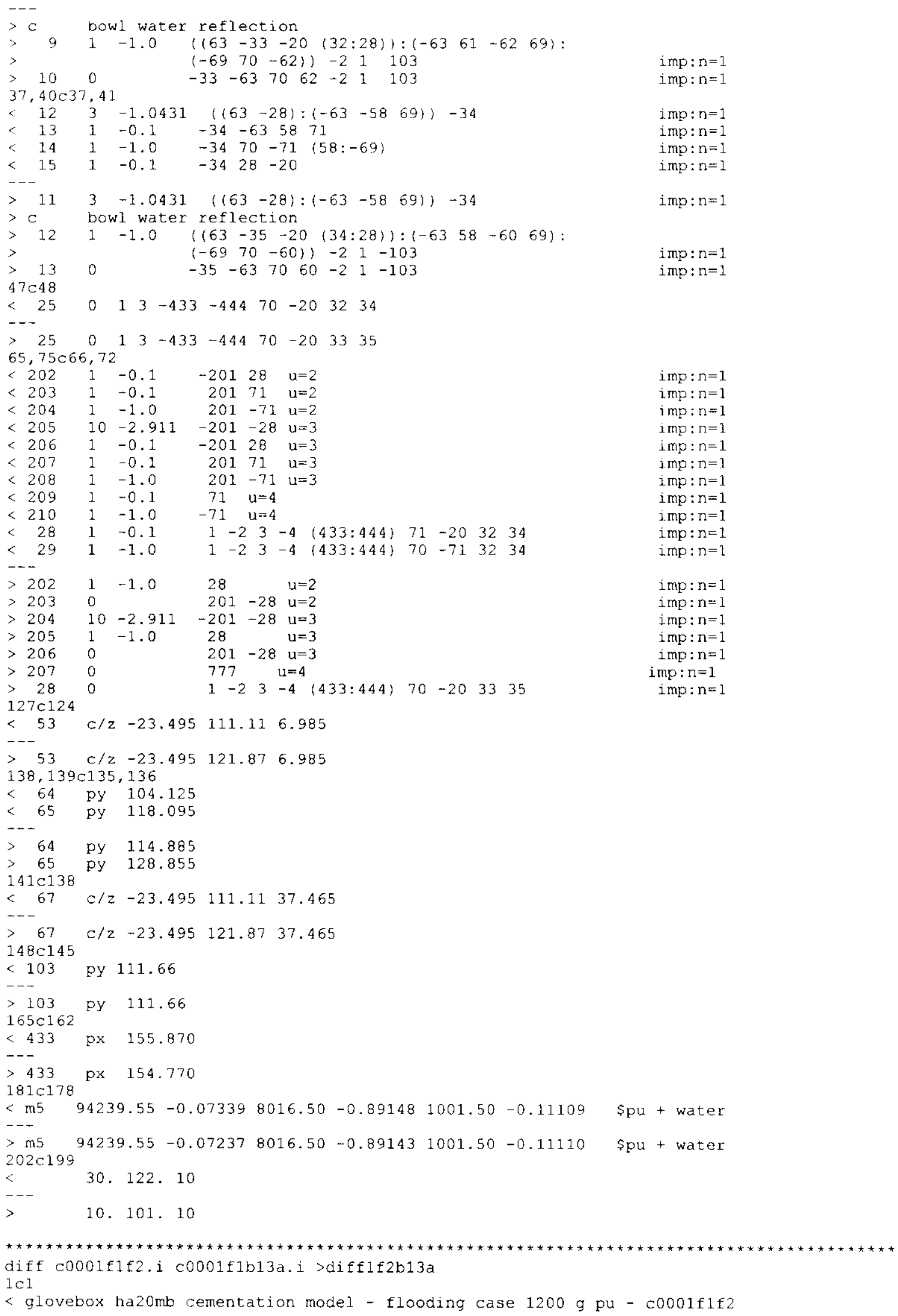




\section{HNF-5988 Rev. 0}

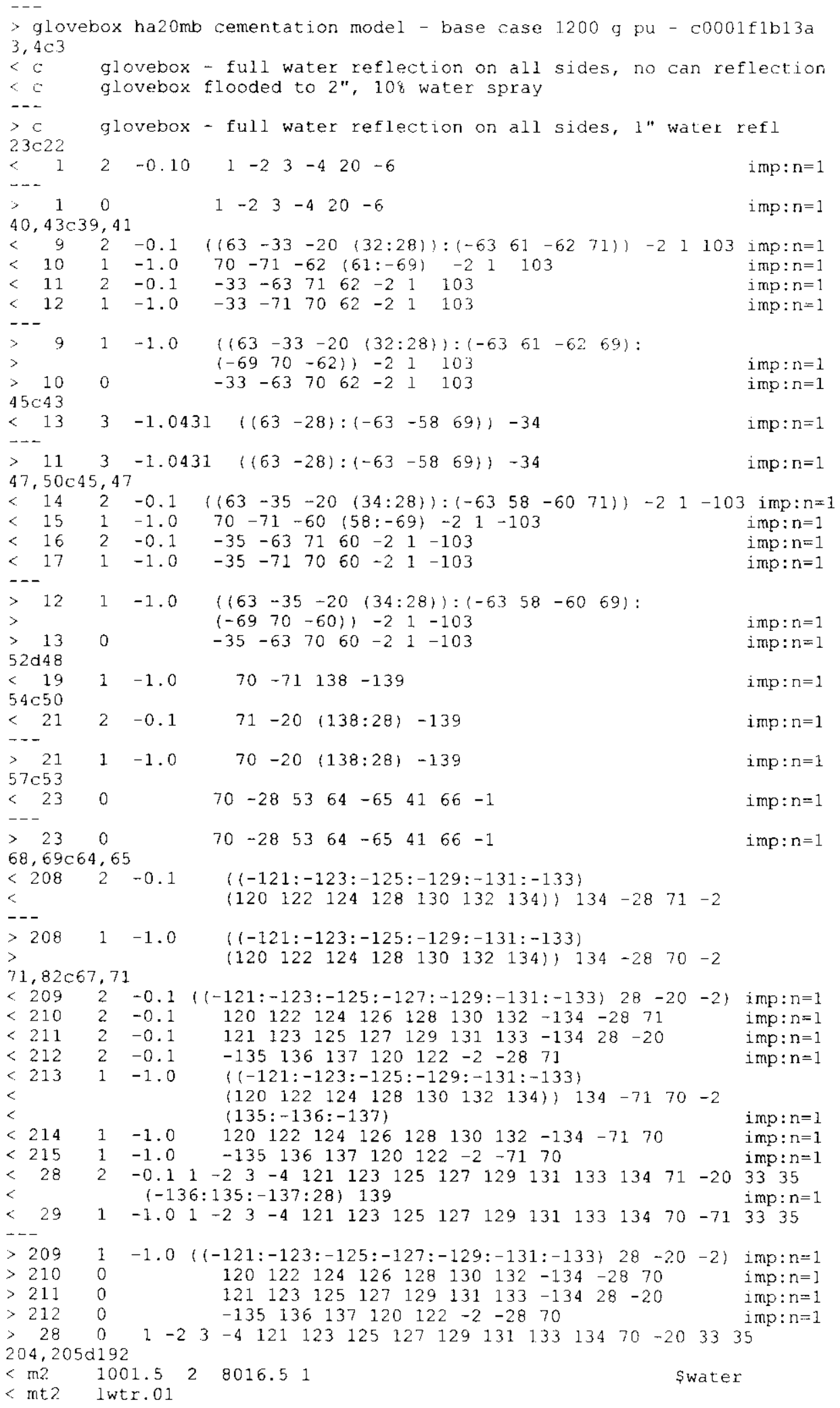


HNF-5988 Rev. 0

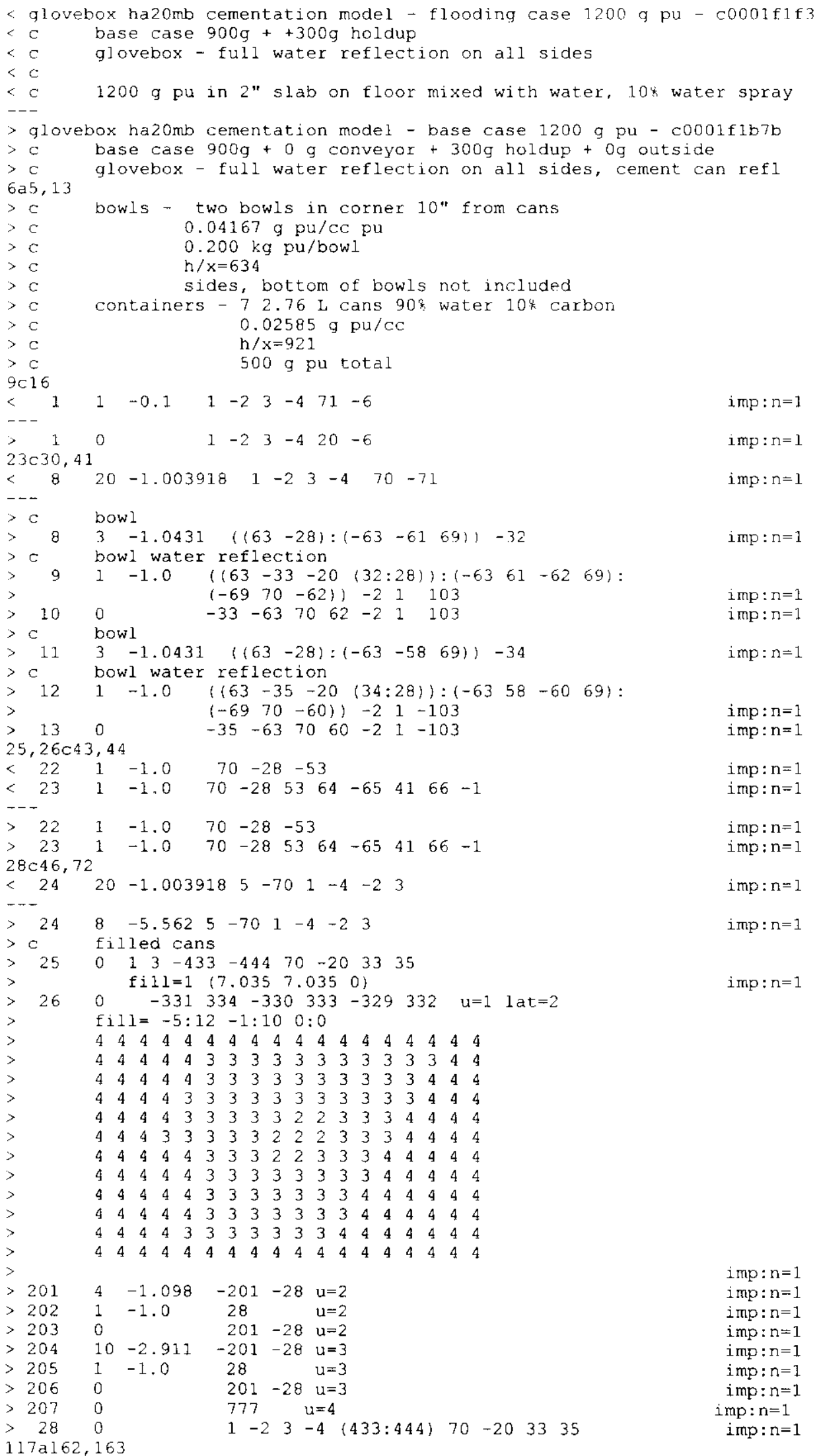


HNF-5988 Rev. 0

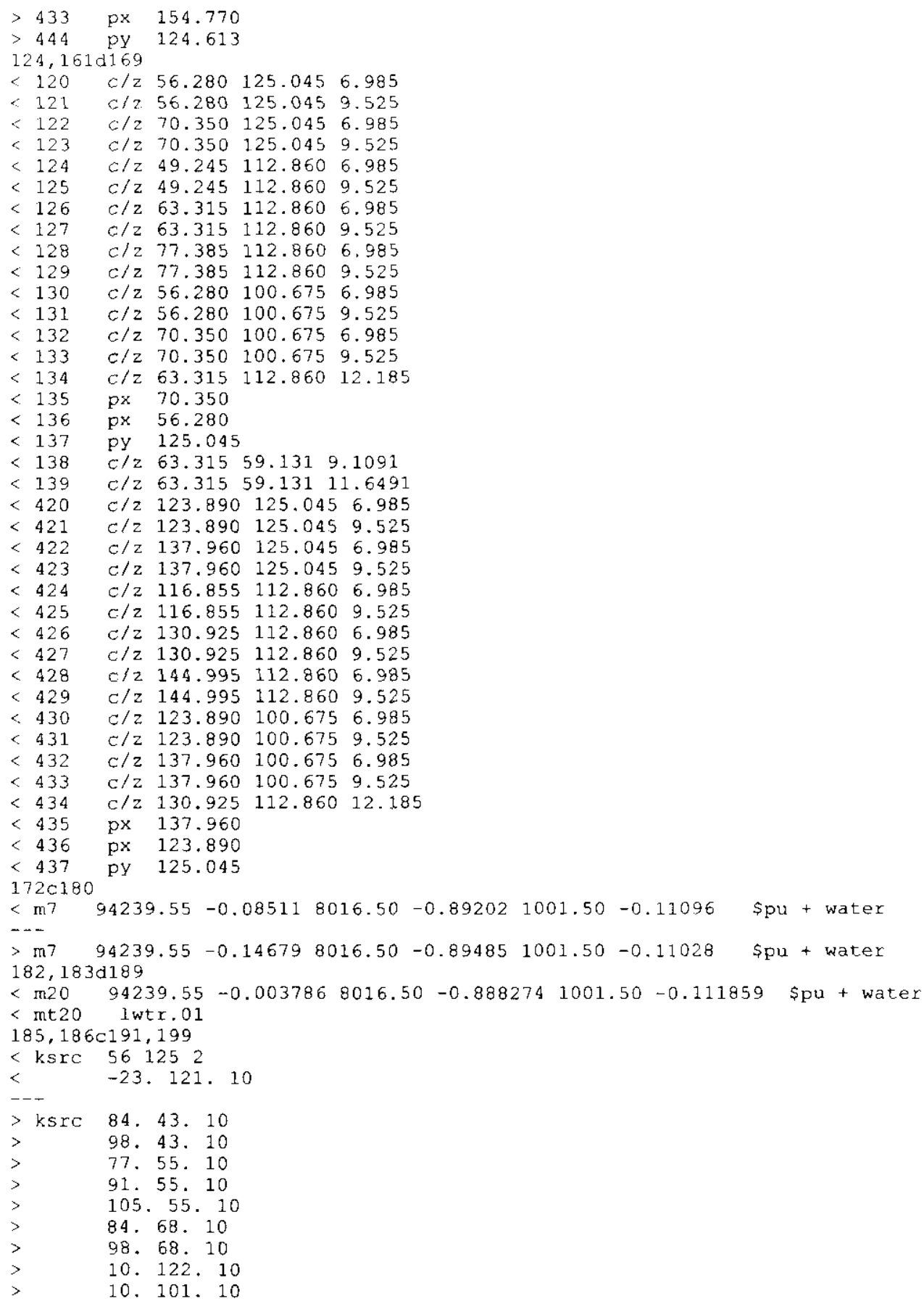

diff c0001flf4.i c0001flb7b.i $>$ difflf $4 b 7 b$

$1,6 \mathrm{cl}, 3$

$<$ glovebox ha20mb cementation model - flooding case $1200 \mathrm{~g}$ pu - co001flf 4

$<\mathrm{c}$ base case $900 \mathrm{~g}+300 \mathrm{~g}$ holdup

$<c$ glovebox - full water reflection on all sides

$<c \quad 1200 \mathrm{~g} \mathrm{pu}$ in $2 "$ slab on floor mixed with water, $10 \mathrm{~g}$ water spray

$<\mathrm{c} \quad 150 \mathrm{~g} / \mathrm{cc}$ pu with water above

$>$ glovebox ha20mb cementation model - base case $1200 \mathrm{~g}$ pu - c0001flb7b

$>c$ base case $900 \mathrm{~g}+0 \mathrm{~g}$ conveyor $+300 \mathrm{~g}$ holdup $+0 \mathrm{~g}$ outside

$>C$ glovebox - full water reflection on all sides, cement can refl 
HNF-5988 Rev. 0

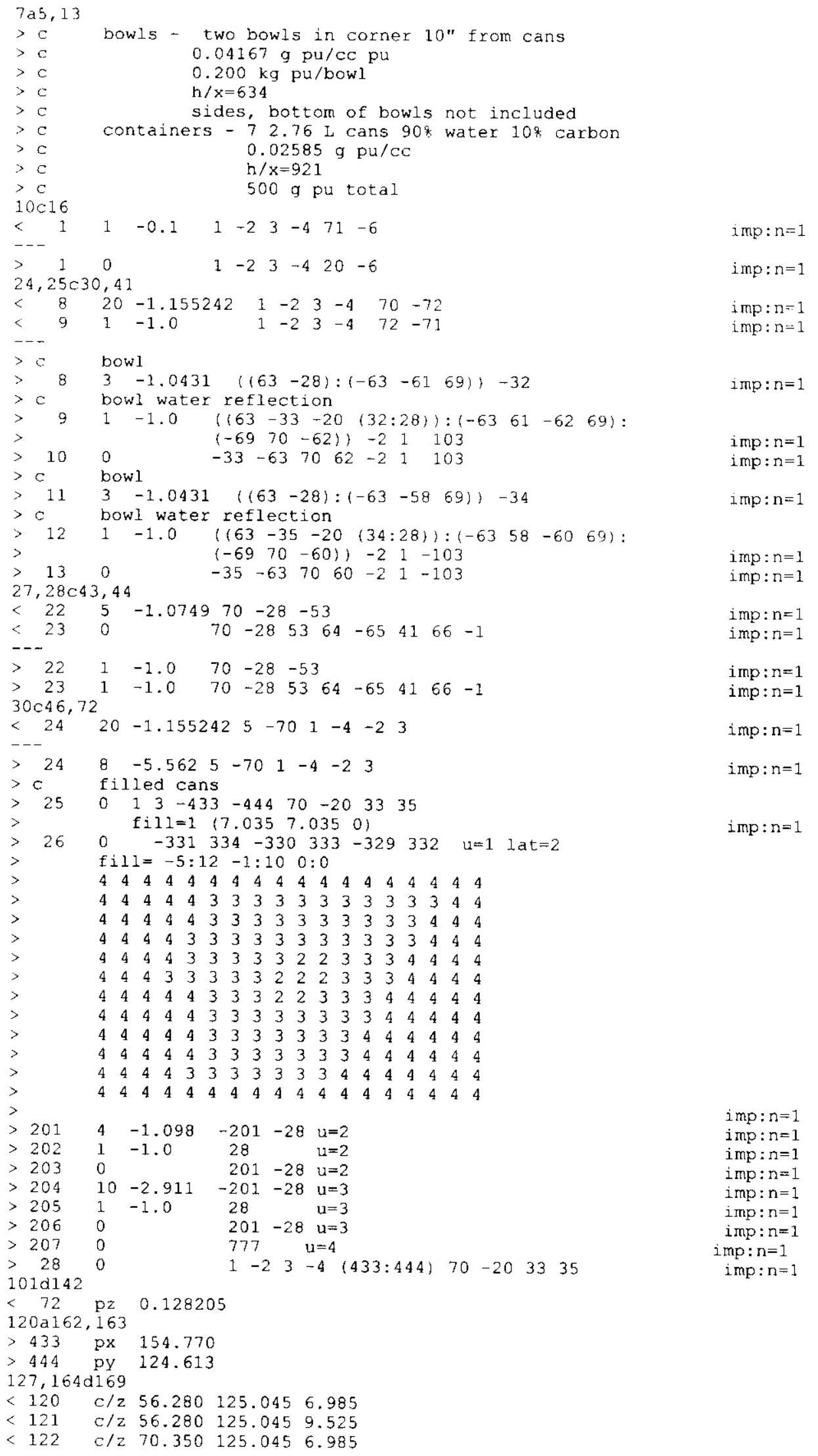


HNF-5988 Rev. 0

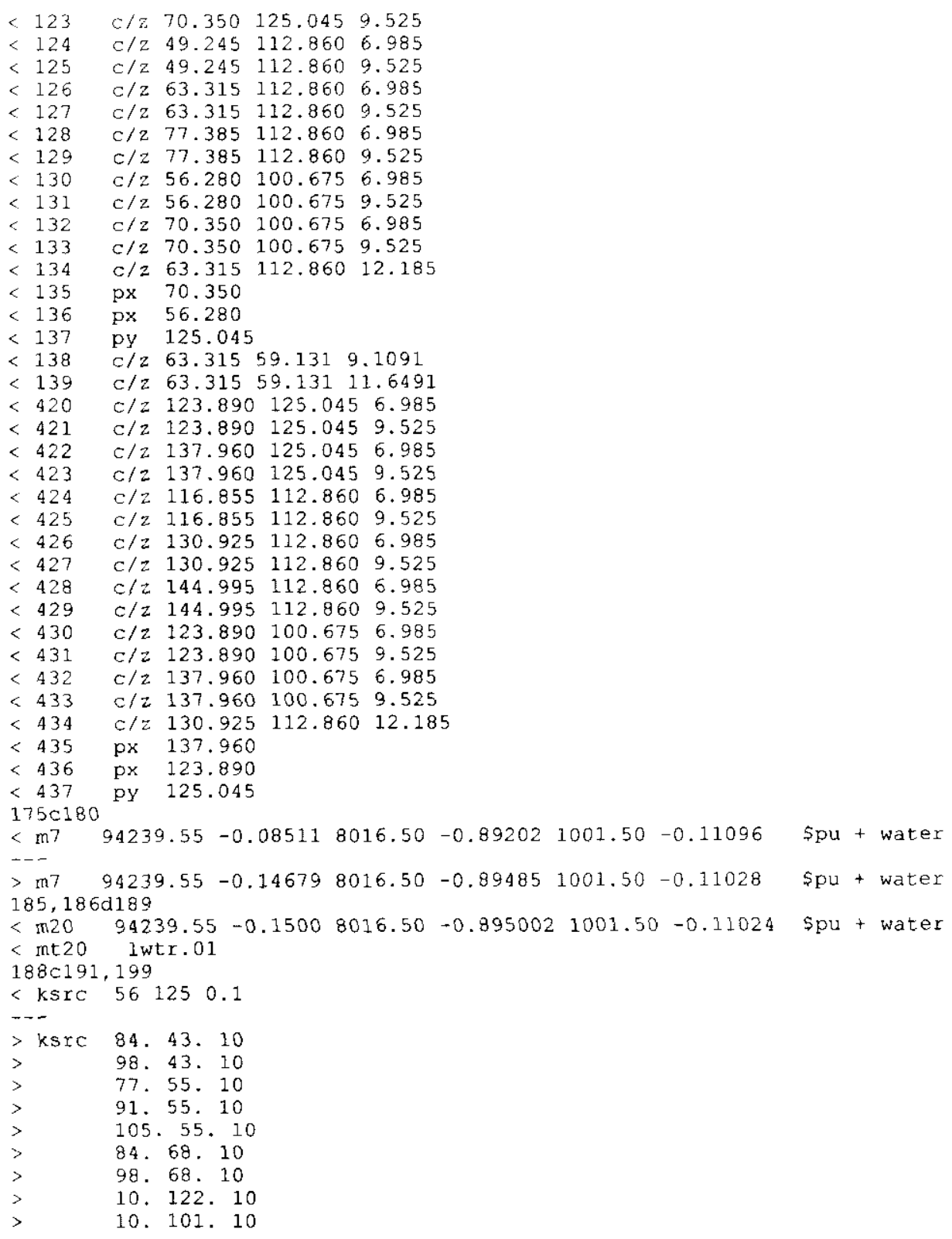

10. 101.

diff c0001fls3.i c0001f1b7b.i >diffls3b7b

$1 \mathrm{c} 1$

< glovebox ha20mb cementation model - base case $1200 \mathrm{~g}$ pu - c000lfls 3

-...

$>$ glovebox ha20mb cementation model - base case $1200 \mathrm{~g}$ pu - c0001f1b7b

$5,6 \mathrm{c5}$

$<C$ bowls - one bowl in corner 10" from cans

$<c$ one bowl stacked on cans

$>c$ bowls - two bowls in corner 10" from cans

$17 \subset 16$

$<10$

10

$35,36 \mathrm{c} 34,35$

$<10 \quad 0$

$<$

$>$

$\begin{array}{lllllllll}1 & -2 & 3 & -4 & 20 & -6 & \# 14 & \# 15\end{array}$

imp: $n=1$

$\begin{array}{llllll}1 & -2 & 3 & -4 & 20 & -6\end{array}$

imp $: n=1$

$(-6970-62))-2 \quad 1$

imp: $n=1$

$\begin{array}{llllll}-33 & -63 & 70 & 62 & -2 & 1\end{array}$

imp: $n=1$

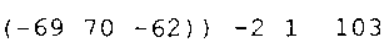

imp: $n=1$ 
HNF-5988 Rev. 0

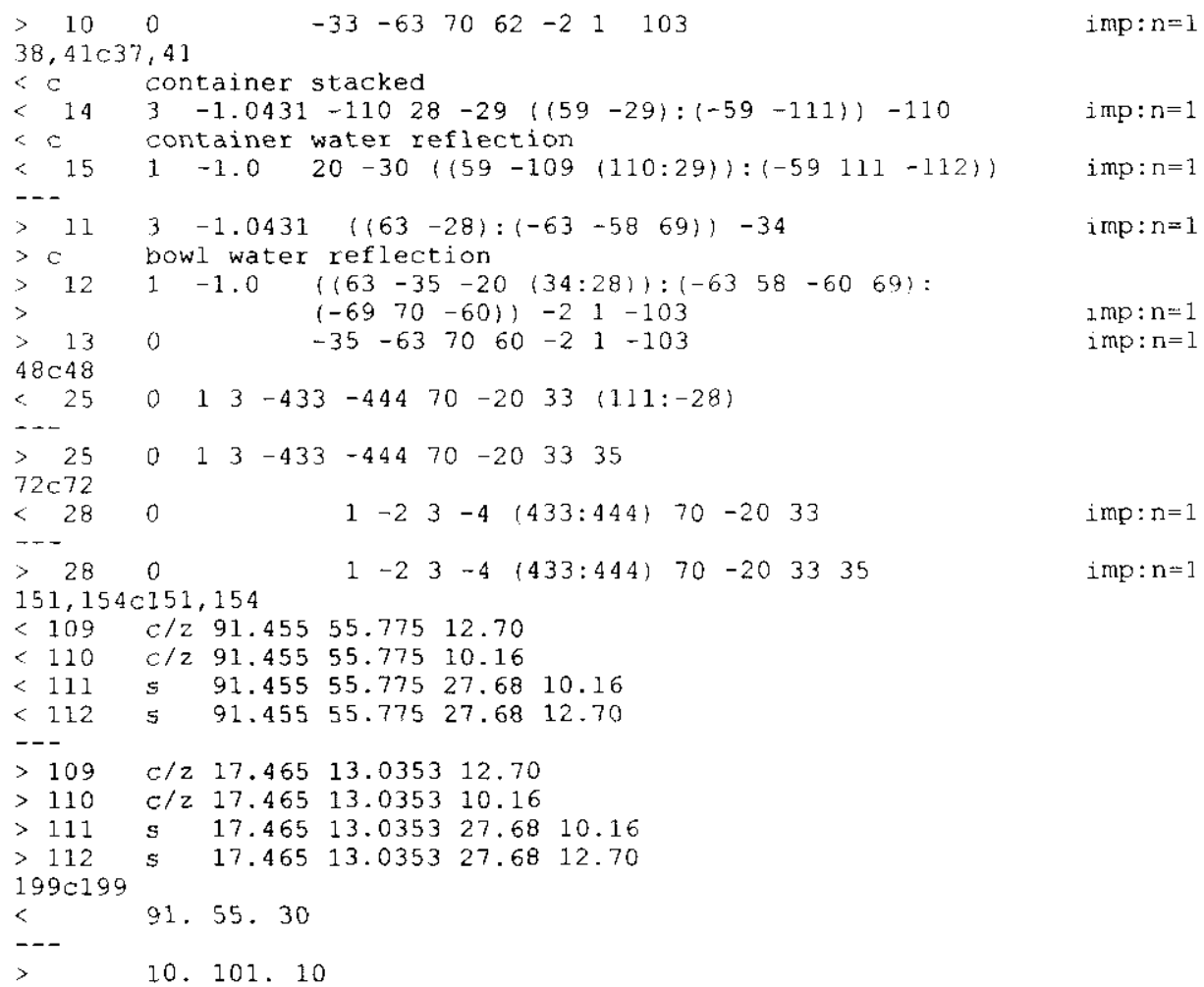


HNF-5988 Rev. 0

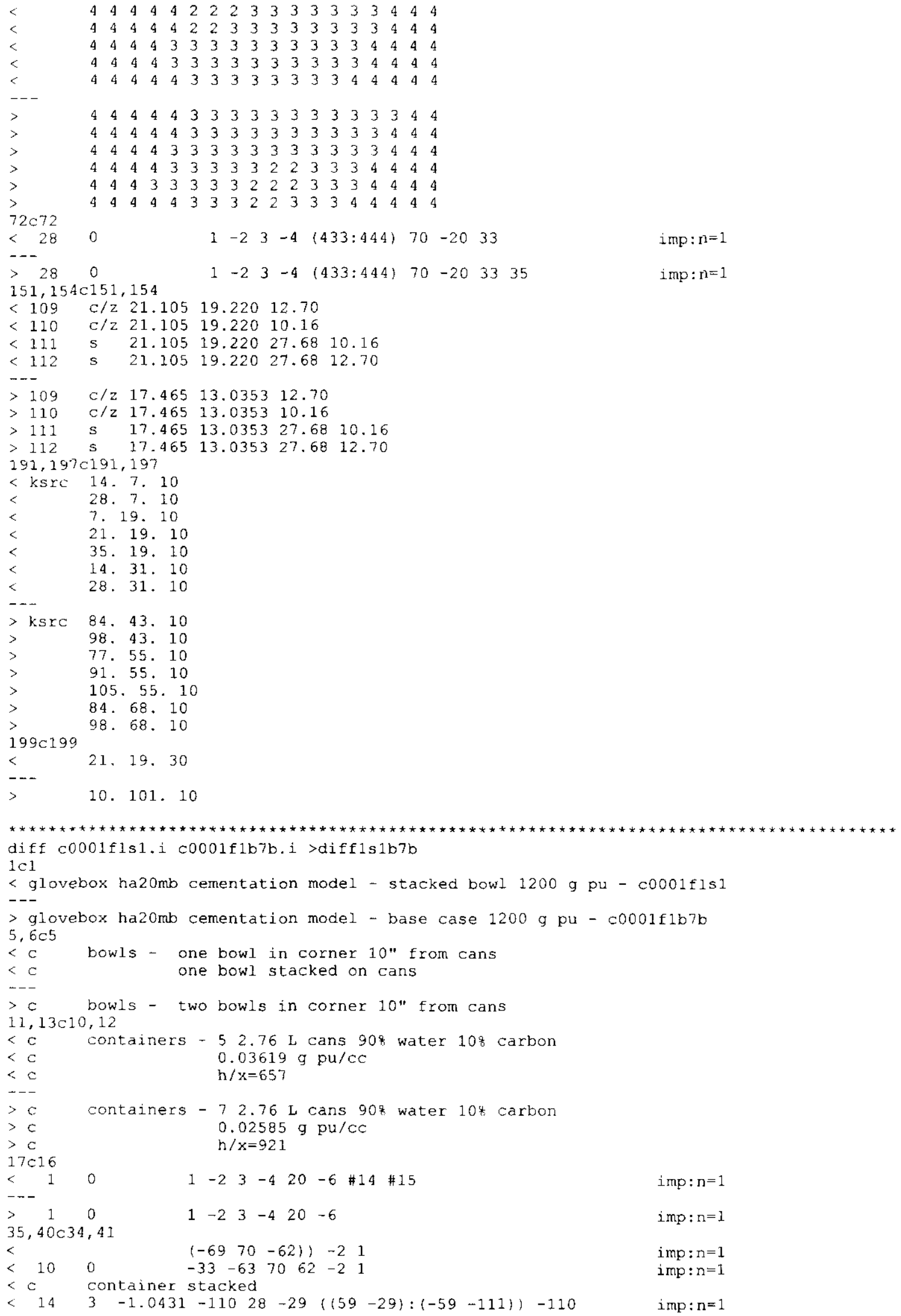




\section{HNF-5988 Rev. 0}

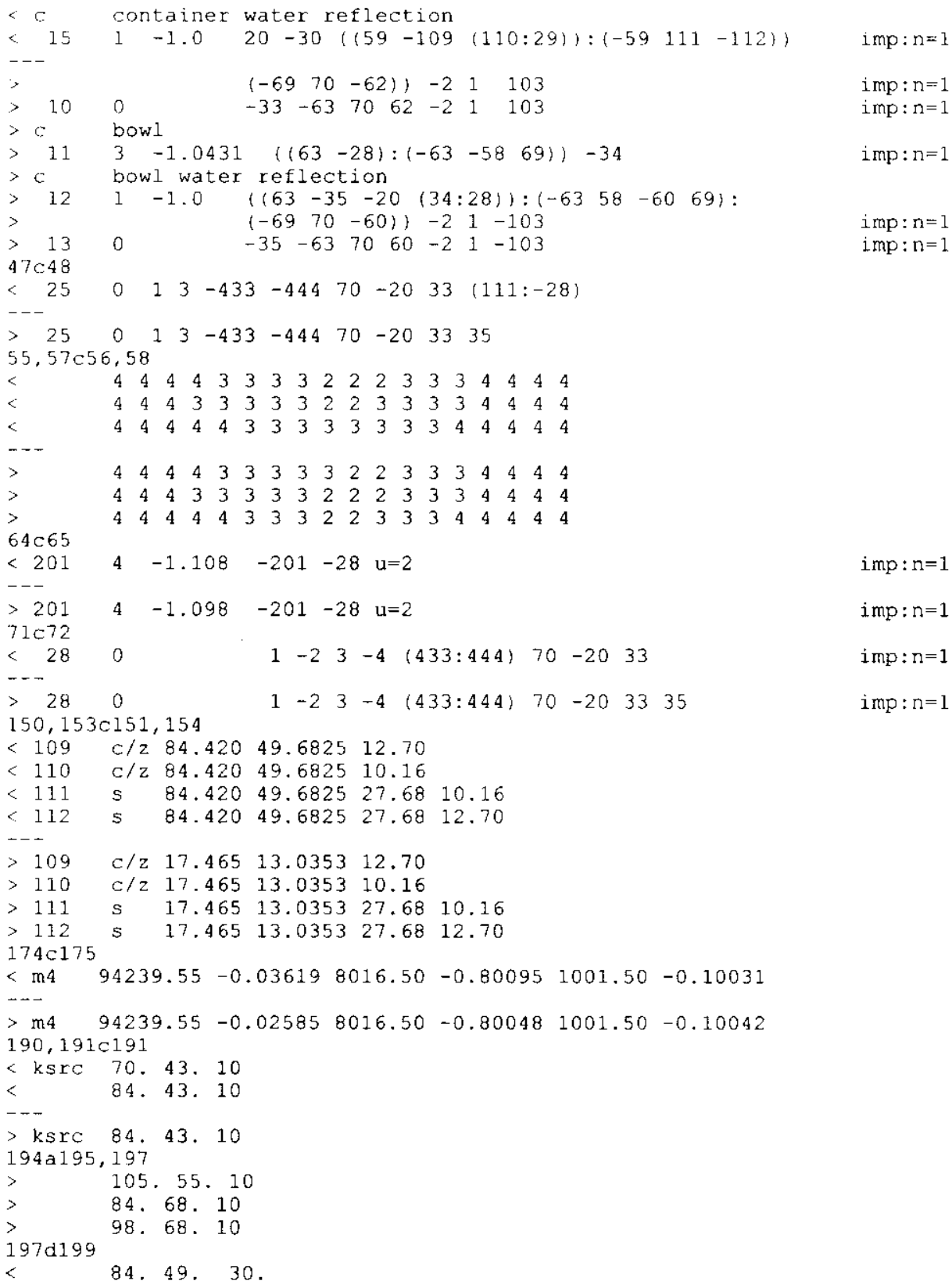




\section{HNF-5988 Rev. 0}

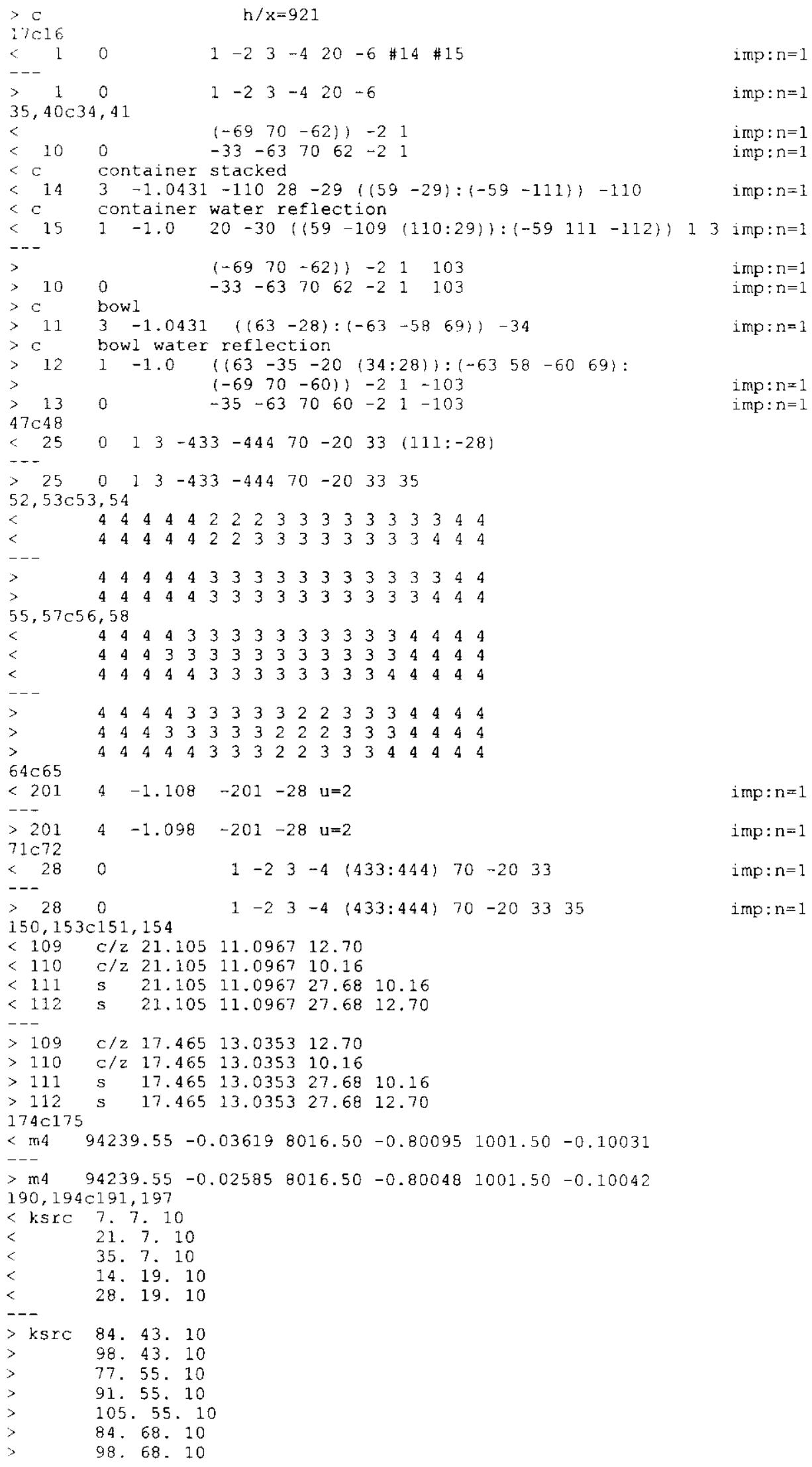




\section{HNF-5988 Rev. 0}

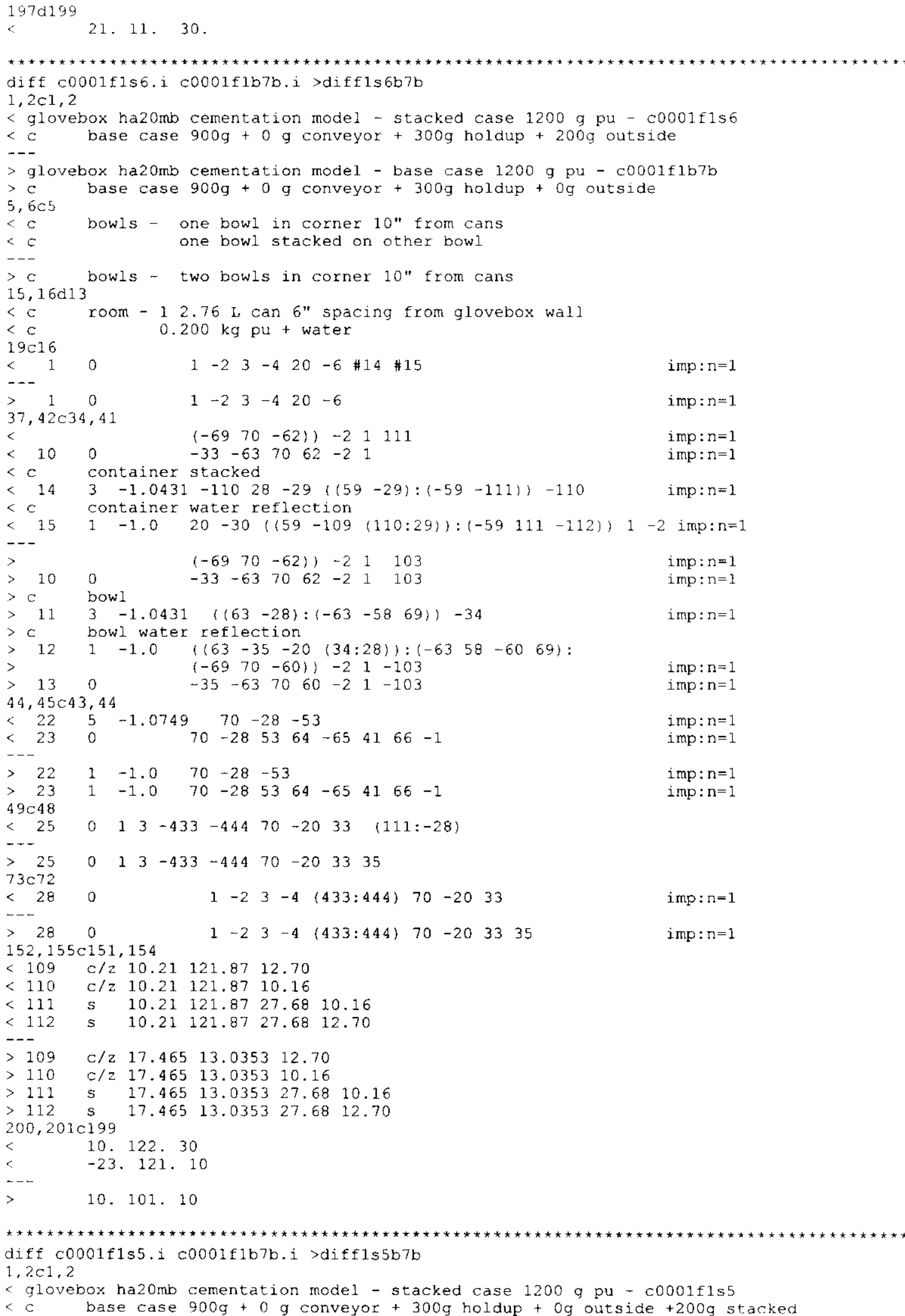


HNF-5988 Rev. 0

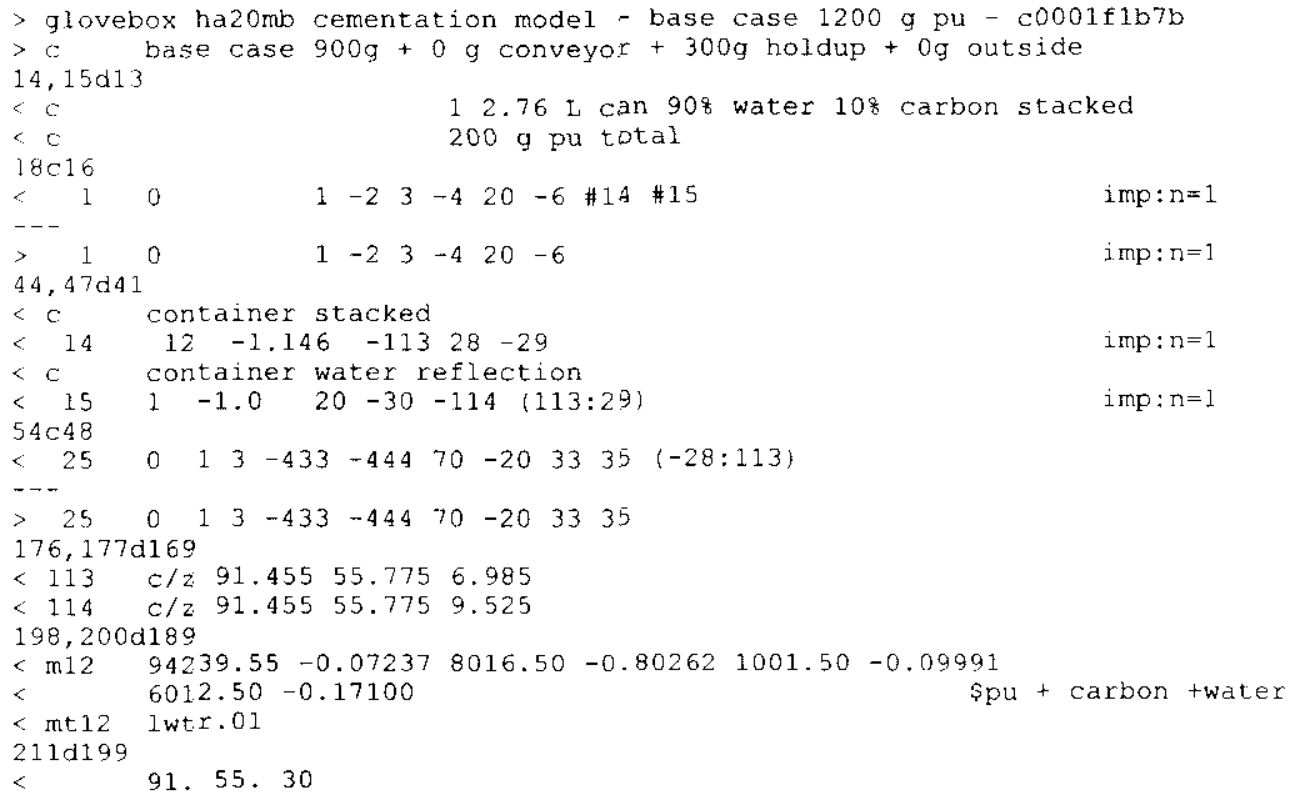

diff c0001flwl.i c0001f1b13a.i >difflw1b13a

$1,2 \mathrm{c} 1,2$

$<$ glovebox ha20mb cementation model - wagon case $1200 \mathrm{~g}$ pu - c000lflwl

$<$ b base case $900 \mathrm{~g}+400 \mathrm{~g}$ conveyor $+300 \mathrm{~g}$ holdup $+200 \mathrm{~g}$ outside

$>$ glovebox ha20mb cementation model - base case $1200 \mathrm{~g}$ pu - c0001f1b13a

$>$ b base case $900 \mathrm{~g}+400 \mathrm{~g}$ conveyor $+300 \mathrm{~g}$ holdup $+200 \mathrm{~g}$ outside

$20 d 19$

$<\mathrm{c} \quad-5$ position wagon with $52.7 \mathrm{t}$ cans $400 \mathrm{~g}$ pu + water

$30,34 c 29,32$

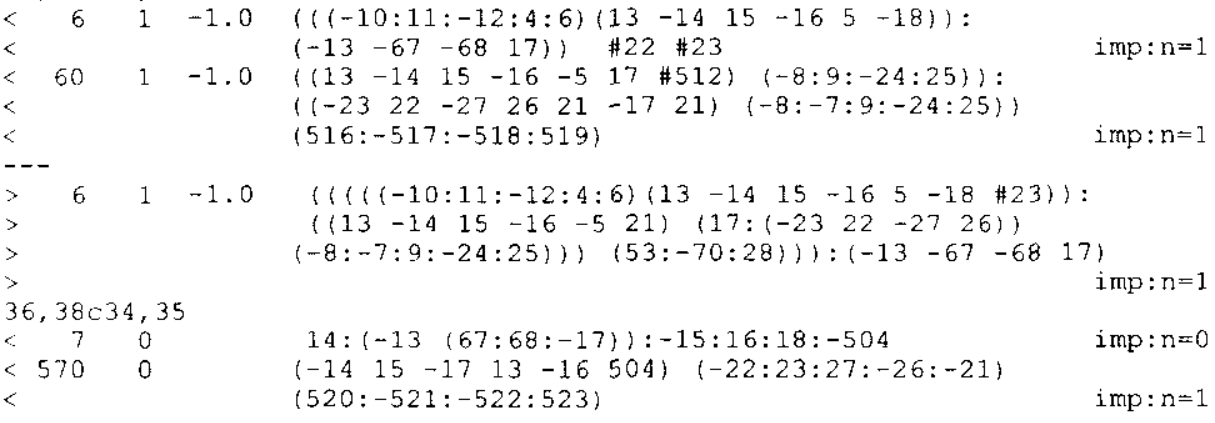

$>0 \quad 14:(-13(67: 68)):-15: 16: 18:-21:$

$>\quad(1-22: 23: 27:-26)-17) \quad$ imp: $n=0$

$<\begin{array}{lllllll}20 & 7 & -1.088 & 70 & -28 & -138 & \text { imp: } n=1\end{array}$

$>\begin{array}{lllllll}20 & 7 & -1.088 & 70 & -28 & -138 & i m p: n=1\end{array}$

$76,92 \mathrm{~d} 72$
$<\mathrm{C}$

$<0$

$<\begin{array}{llllll}501 & 50 & -1.153 & -505 & 503 & -502\end{array}$

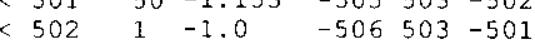

$<\begin{array}{llllll}503 & 50 & -1.153 & -507 & 503 & -502\end{array}$

$<\begin{array}{lllllll}504 & 1 & -1.0 & -508 & 503 & -501 & 1502: 507\end{array}$

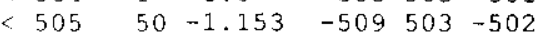

$\begin{array}{llllllll}<06 & 1 & -1.0 & -510 & 503 & -501 & (502: 509) & -519\end{array}$

$<507 \quad 50-1.153-511503-502$

$\begin{array}{lllllll}508 & 1 & -1.0 & -512 & 503 & -501 & (502: 511)\end{array}$

$<\begin{array}{llllll}509 & 50 & -1.153 & -513 & 503 & -502\end{array}$

$<\begin{array}{lllllll}510 & 1 & -1.0 & -514 & 503 & -501 & (502: 513)\end{array}$

$<5110 \quad 503-501-516517 \quad 518-519$

$506508 \quad 510512514$

imp: $\mathrm{n}=1$

imp: $n=1$

imp: $n=1$

imp: $n=1$

imp: $n=1$

imp: $n=1$

imp: $n=1$

imp: $n=1$

i $m p: n=1$

imp: $n=1$

imp: $n=1$

\section{C- 38}


HNF-5988 Rev. 0

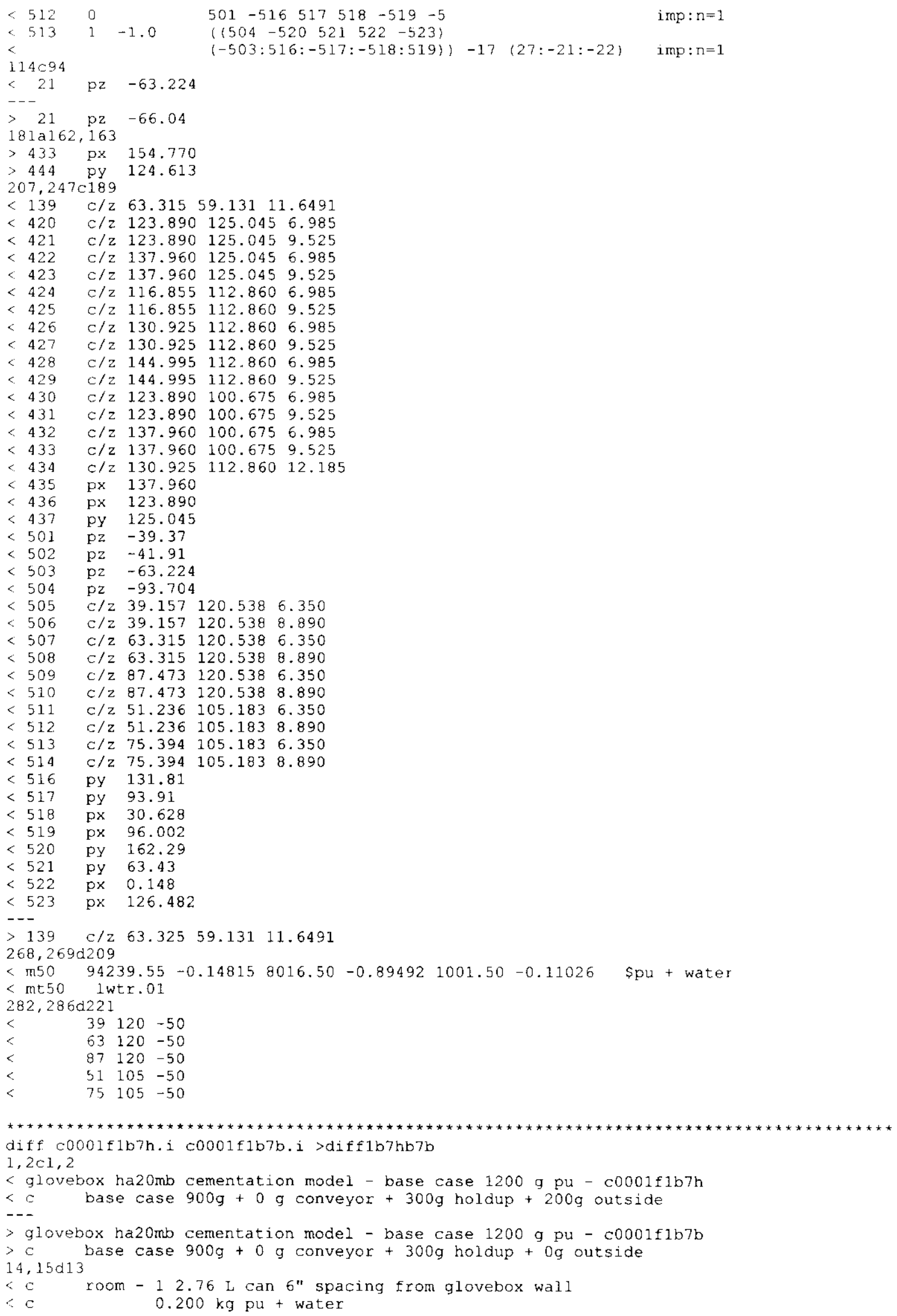


HNF-5988 Rev. 0

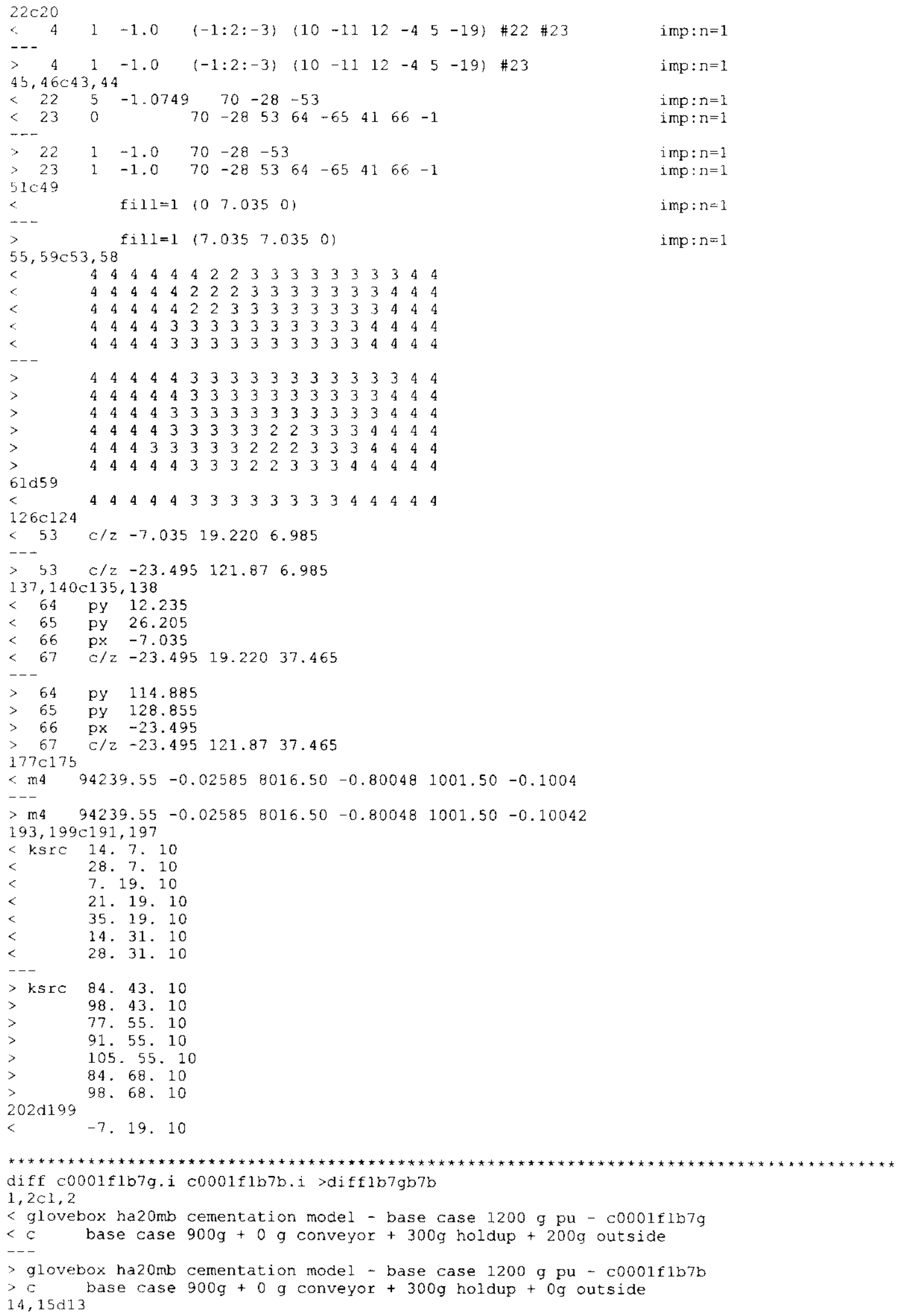




\section{HNF-5988 Rev. 0}

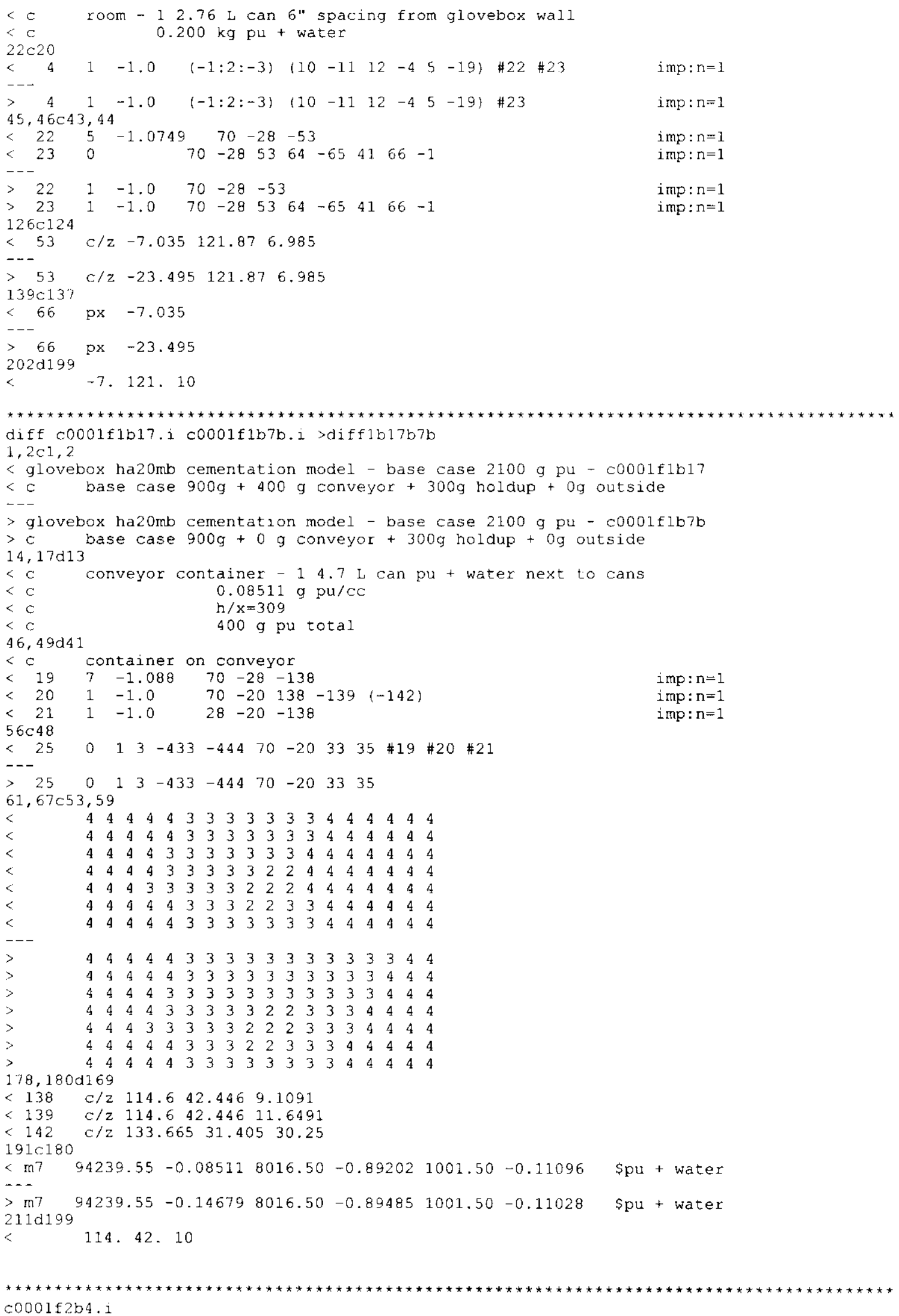


HNF-5988 Rev. 0

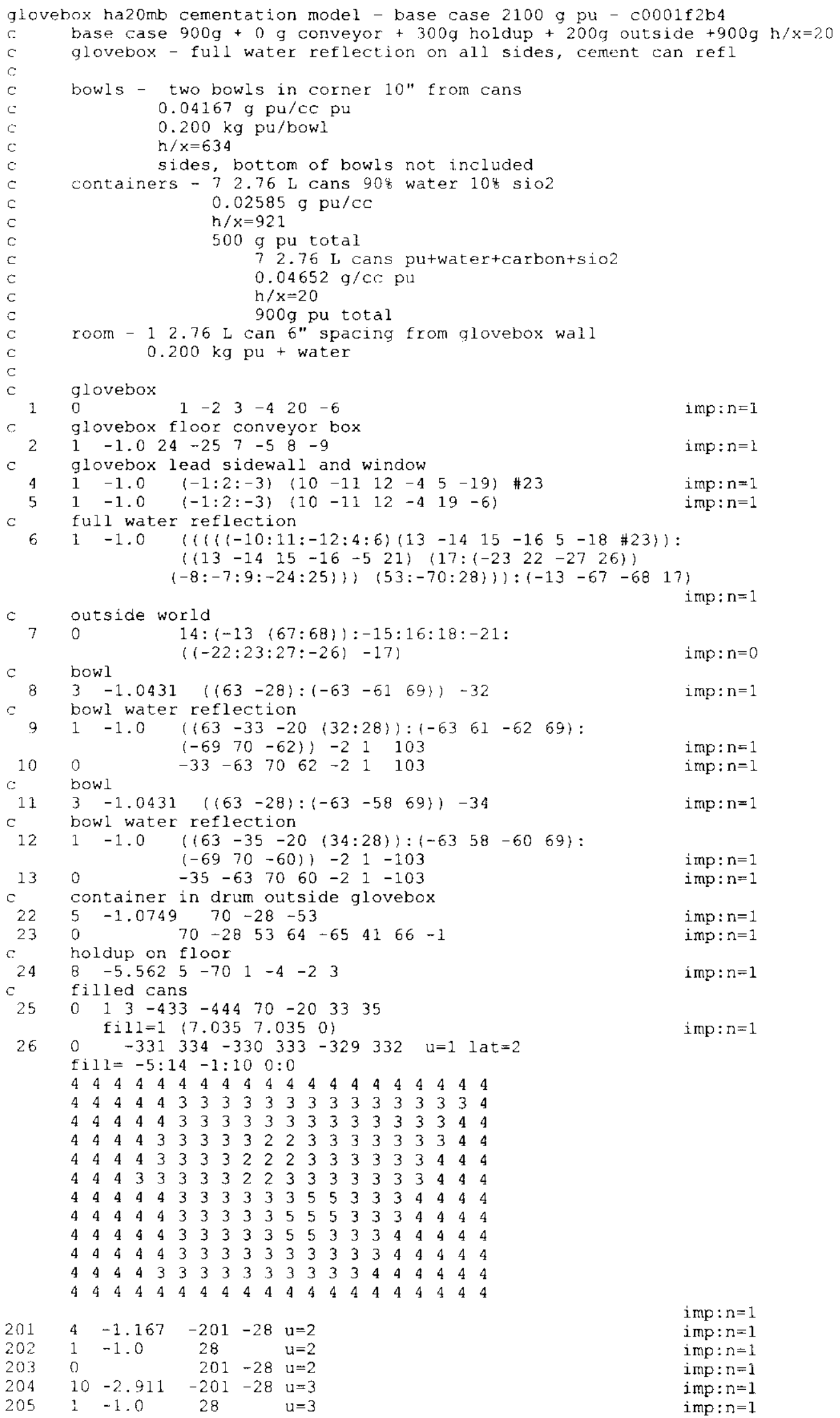


HNF-5988 Rev. 0

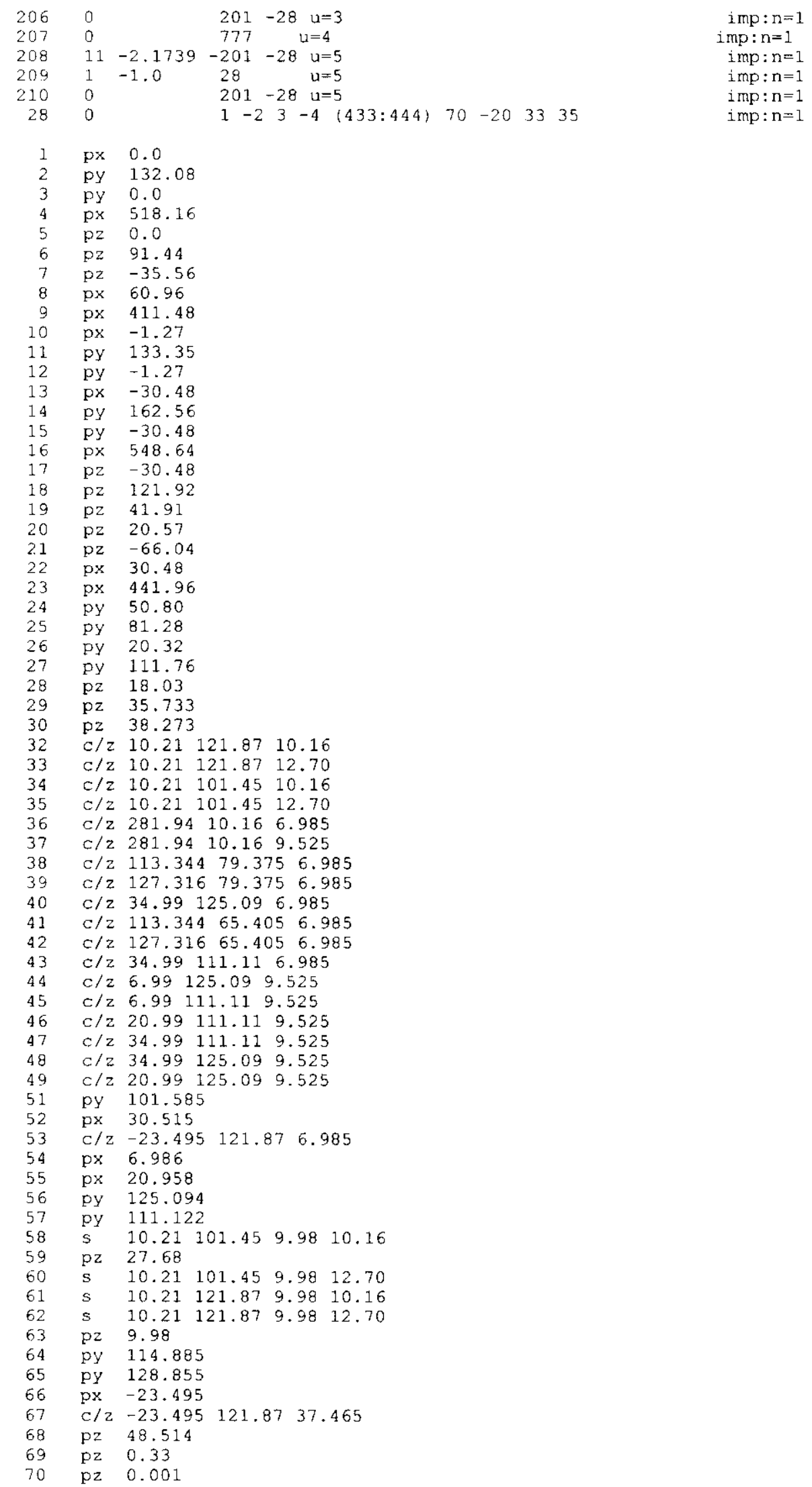




\section{HNF-5988 Rev. 0}

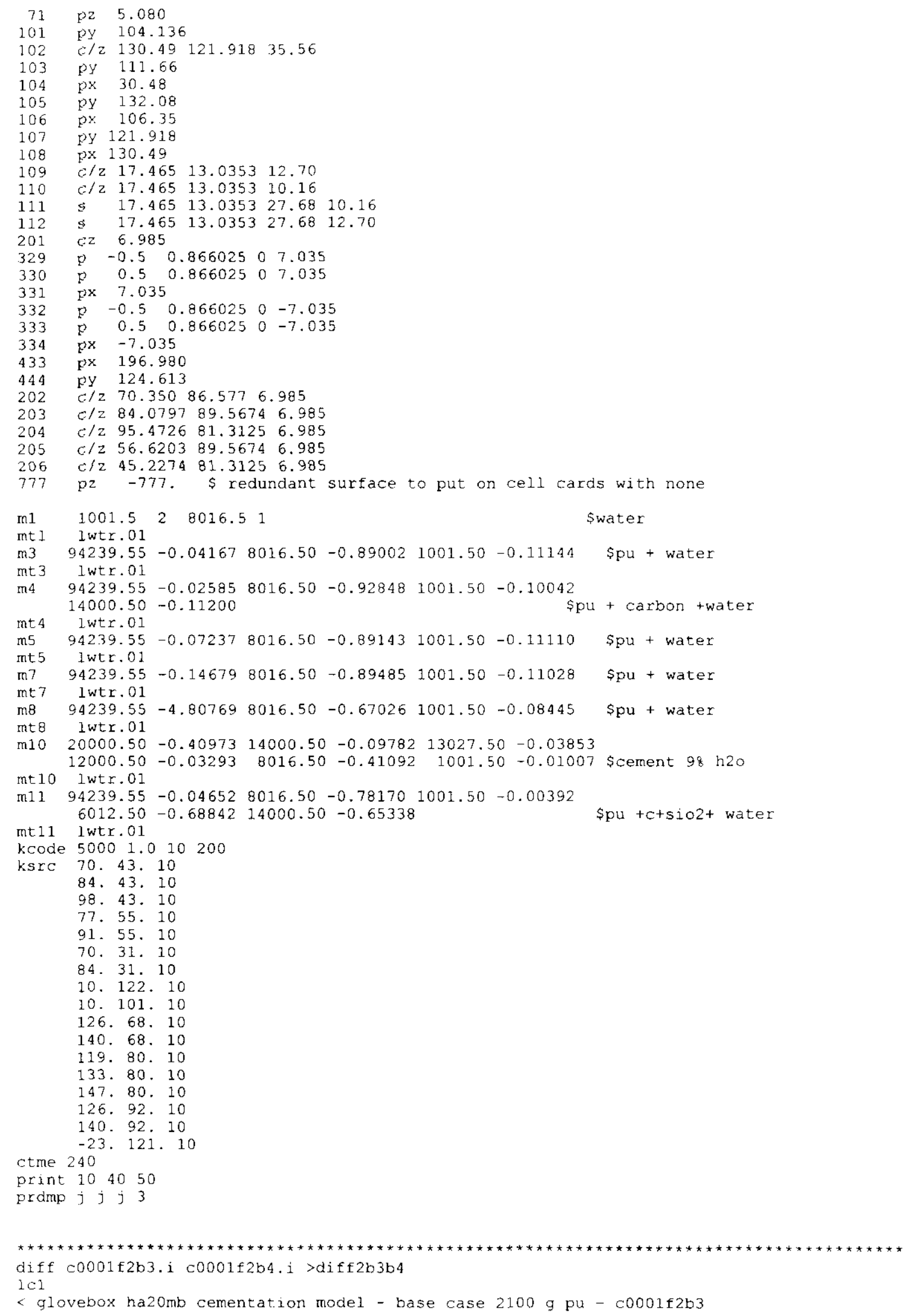


HNF-5988 Rev. 0

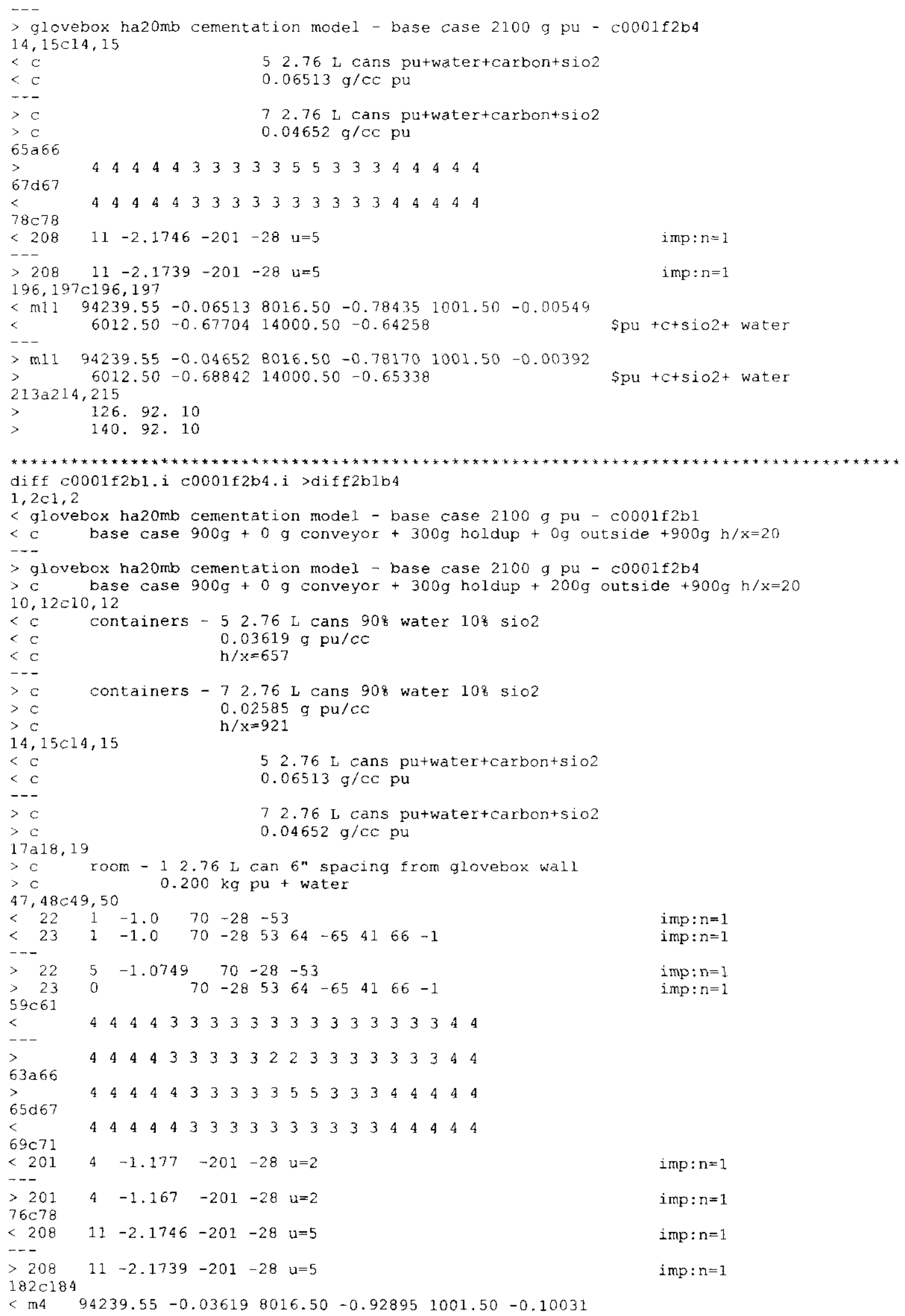




\section{HNF-5988 Rev. 0}

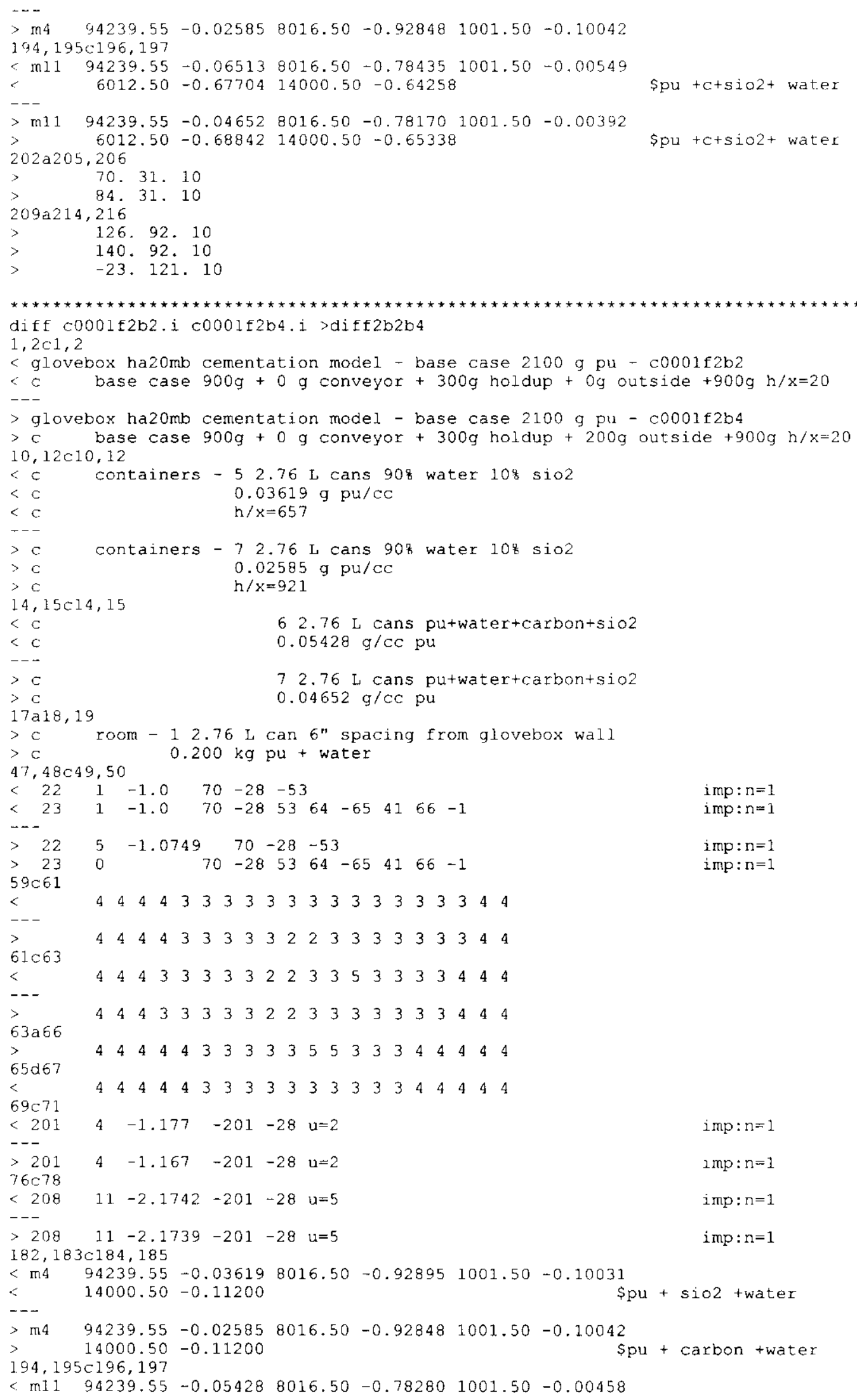


HNF-5988 Rev. 0

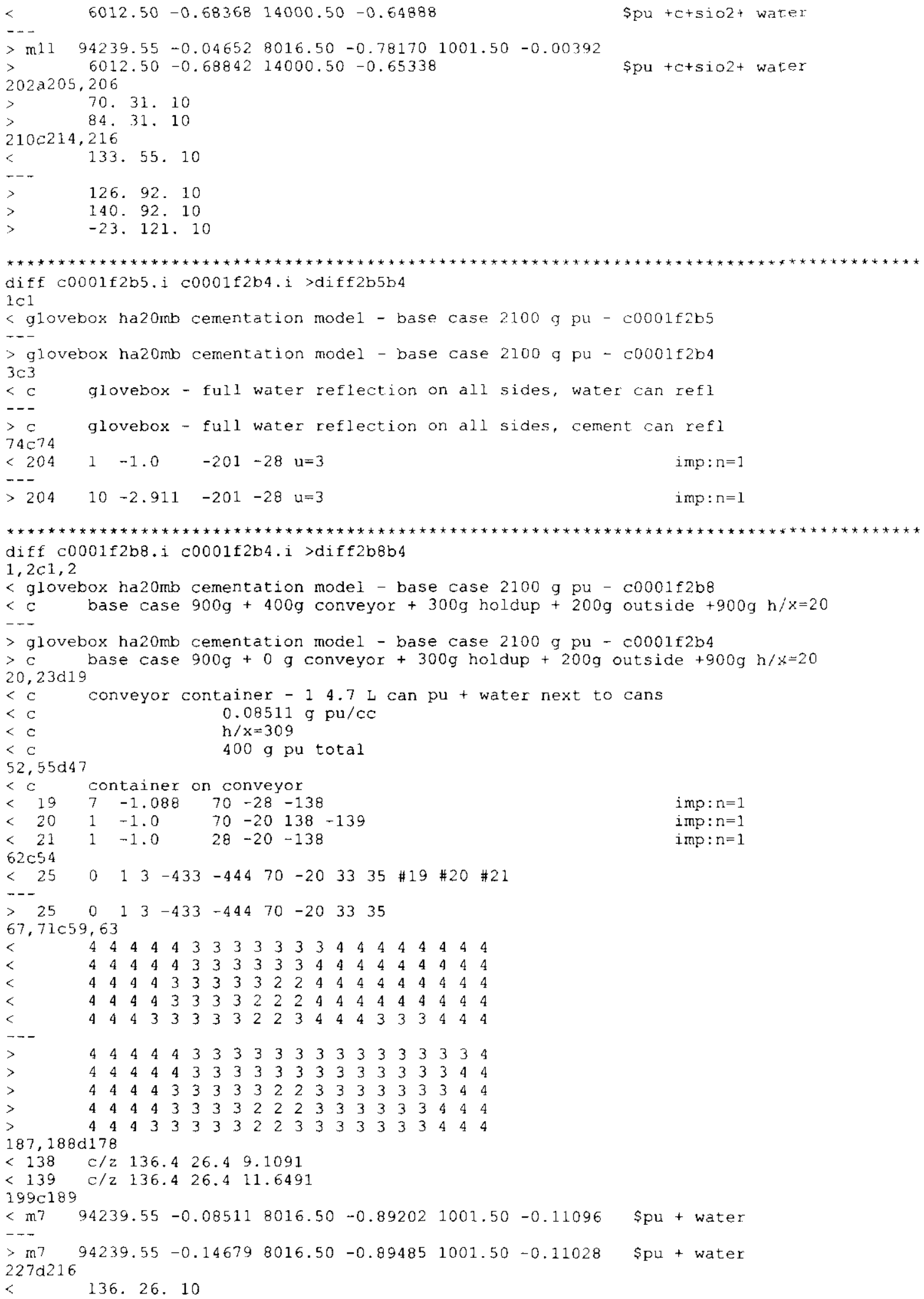


HNF-5988 Rev. 0

$1,3 c 1,3$

$<$ glovebox ha20mb cementation model - base case 2100 g pu - c0001f2b6a

$<\mathrm{c}$ base case $900 \mathrm{~g}+400 \mathrm{~g}$ conveyor $+300 \mathrm{~g}$ holdup $+200 \mathrm{~g}$ outside $+900 \mathrm{~g} \mathrm{~h} / \mathrm{x}=20$

c glovebox - full water reflection on all sides, 1 " water refl.

$>$ glovebox ha20mb cementation model - base case $2100 \mathrm{~g}$ pu - c0001f2b4

$>\mathrm{C}$ base case $900 \mathrm{~g}+0 \mathrm{~g}$ conveyor $+300 \mathrm{~g}$ holdup $+200 \mathrm{~g}$ outsjde $+900 \mathrm{~g} \mathrm{~h} / \mathrm{x}-20$

$>c$ glovebox - full water reflection on all sides, cement can refl

$18,21 \mathrm{~d} 17$

$<c$ conveyor container $-14.7 \mathrm{~L}$ can pu + water $10^{\prime \prime}$ from cans

$<\mathrm{c} \quad 0.08511 \mathrm{~g} \mathrm{pu} / \mathrm{cc}$

$h / x=309$

$<c \quad 400 \mathrm{~g} \mathrm{pu}$ total

$52,54 d 47$

$<\mathrm{c}$ container on conveyor

$<207-1.08870-28-138$

$\begin{array}{lllllll}21 & 1 & -1.0 & 70 & -20 & (138: 28) & -139\end{array}$

i mp: $n=1$

$56 c 49$

$<225-1.074970-28-53$

imp $: n=1$

$>22 \quad 5 \quad-1.0749 \quad 70-28 \quad-53$

imp $: n=1$

$61,92 \mathrm{c} 54,81$

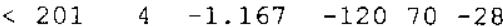

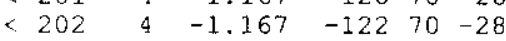

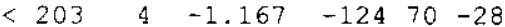

$\begin{array}{llllll}<204 & 4 & -1.167 & -126 & 70 & -28\end{array}$

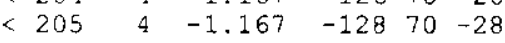

$<\begin{array}{llllll}206 & 4 & -1.167 & -130 & 70 & -28\end{array}$

$<\begin{array}{llllll}207 & 4 & -1.167 & -132 & 70 & -28\end{array}$

$<208 \quad 1-1.0 \quad((-121:-123:-125 ;-129:-131:-133)$

imp $: n=1$

$<2091-1.0((-121:-123:-125:-127:-129:-131:-133) 28-20-2)$

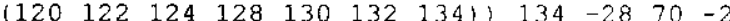
(135: $-136:-137)$

imp: $n=1$

imp: $n=1$

imp: $\mathrm{n}=1$

imp: $n=1$

imp: $n=1$

imp: $n=1$

imp: $n=1$

$<211$

$<212$

$<\mathrm{G}$

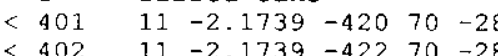

$<\begin{array}{llllll}403 & 11 & -2.1739 & -424 & 70 & -28\end{array}$

$<\begin{array}{llllll}404 & 11 & -2.1739 & -426 & 70 & -28\end{array}$

$\begin{array}{llllll}405 & 11 & -2.1739 & -428 & 70 & -28\end{array}$

$<406 \quad 11-2.1739-43070-28$

$<407 \quad 11-2.1739-43270-28$

$<408 \quad 1-1.0 \quad(1-421:-423:-425:-429:-431:-433)$

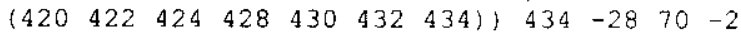
$(435:-436:-437)$

imp: $n=1$

mp: $n=1$

imp: $n=1$

imp: $n=1$

imp: $n=1$

imp: $n=1$

imp: $n=1$

imp: $n=1$

imp: $n=1$

$i m p: n=1$

imp: $n=1$

imp: $\mathrm{n}=1$

$(435:-436:-437)$
$<-1.0((-421:-423:-425:-427:-429:-431:-433) 28-20-2) \quad i m: n=1$
$i m p: n=1$

$<410$

$<411$

$\begin{array}{lllllllllll}420 & 422 & 424 & 426 & 428 & 430 & 432 & -434 & -28 & 70\end{array}$

$\begin{array}{lllllllllll}421 & 423 & 425 & 427 & 429 & 431 & 433 & -434 & 28 & -20 & \text { imp: } n=1\end{array}$

imp: $n=1$

\begin{tabular}{rlllllllllllllllllllllll}
412 & 0 & \multicolumn{1}{c}{-435} & 436 & 437 & 420 & 422 & -2 & -28 & 70 \\
28 & 0 & 1 & -2 & 3 & -4 & 121 & 123 & 125 & 127 & 129 & 131 & 133 & 134 & 70 & -20 & 33 & 35 &
\end{tabular}

$(-136: 135:-137: 28) \quad 139 \quad 421 \quad 423 \quad 425 \quad 427 \quad 429431433 \quad 434$

$(-436: 435:-437: 28)$

imp: $n=1$

$\begin{array}{lllllllllll}25 & 0 & 1 & 3 & -433 & -444 & 70 & -20 & 33 & 35\end{array}$

fill $=1 \quad(7.0357 .0350)$

$26 \quad 0 \quad-331 \quad 334-330 \quad 333-329 \quad 332 \quad u=1 \quad$ lat $=2$

imp: $\mathrm{n}=1$

fill $=-5: 14-1: 100: 0$

$\begin{array}{llllllllllllllllllll}4 & 4 & 4 & 4 & 4 & 4 & 4 & 4 & 4 & 4 & 4 & 4 & 4 & 4 & 4 & 4 & 4 & 4 & 4 & 4\end{array}$

$\begin{array}{llllllllllllllllllllll}4 & 4 & 4 & 4 & 4 & 3 & 3 & 3 & 3 & 3 & 3 & 3 & 3 & 3 & 3 & 3 & 3 & 3 & 3 & 4\end{array}$

$\begin{array}{llllllllllllllllllll}4 & 4 & 4 & 4 & 4 & 3 & 3 & 3 & 3 & 3 & 3 & 3 & 3 & 3 & 3 & 3 & 3 & 3 & 4 & 4\end{array}$

$\begin{array}{llllllllllllllllllll}4 & 4 & 4 & 4 & 3 & 3 & 3 & 3 & 3 & 2 & 2 & 3 & 3 & 3 & 3 & 3 & 3 & 3 & 4 & 4\end{array}$

$\begin{array}{llllllllllllllllllllll}4 & 4 & 4 & 4 & 3 & 3 & 3 & 3 & 2 & 2 & 2 & 3 & 3 & 3 & 3 & 3 & 3 & 4 & 4 & 4\end{array}$

$\begin{array}{llllllllllllllllllll}4 & 4 & 4 & 3 & 3 & 3 & 3 & 3 & 2 & 2 & 3 & 3 & 3 & 3 & 3 & 3 & 3 & 4 & 4 & 4\end{array}$

$\begin{array}{llllllllllllllllllll}4 & 4 & 4 & 4 & 4 & 3 & 3 & 3 & 3 & 3 & 3 & 5 & 5 & 3 & 3 & 3 & 4 & 4 & 4 & 4\end{array}$

$\begin{array}{llllllllllllllllllllll}4 & 4 & 4 & 4 & 4 & 3 & 3 & 3 & 3 & 3 & 5 & 5 & 5 & 3 & 3 & 3 & 4 & 4 & 4 & 4\end{array}$

$\begin{array}{llllllllllllllllllll}4 & 4 & 4 & 4 & 4 & 3 & 3 & 3 & 3 & 3 & 5 & 5 & 3 & 3 & 3 & 4 & 4 & 4 & 4 & 4\end{array}$

$\begin{array}{llllllllllllllllllll}4 & 4 & 4 & 4 & 4 & 3 & 3 & 3 & 3 & 3 & 3 & 3 & 3 & 3 & 3 & 4 & 4 & 4 & 4 & 4\end{array}$

$\begin{array}{llllllllllllllllllll}4 & 4 & 4 & 4 & 3 & 3 & 3 & 3 & 3 & 3 & 3 & 3 & 3 & 3 & 4 & 4 & 4 & 4 & 4 & 4\end{array}$

$\begin{array}{llllllllllllllllllll}4 & 4 & 4 & 4 & 4 & 4 & 4 & 4 & 4 & 4 & 4 & 4 & 4 & 4 & 4 & 4 & 4 & 4 & 4 & 4\end{array}$

$201 \quad 4 \quad-1.167-201-28 u=2$

$\begin{array}{lllll}202 & 1 & -1.0 & 28 & u=2\end{array}$

$\begin{array}{llll}203 & 0 & 201-28 u=2\end{array}$

imp: $n=1$

imp: $n=1$

imp: $n=1$

imp $: n=1$ 
HNF-5988 Rev. 0

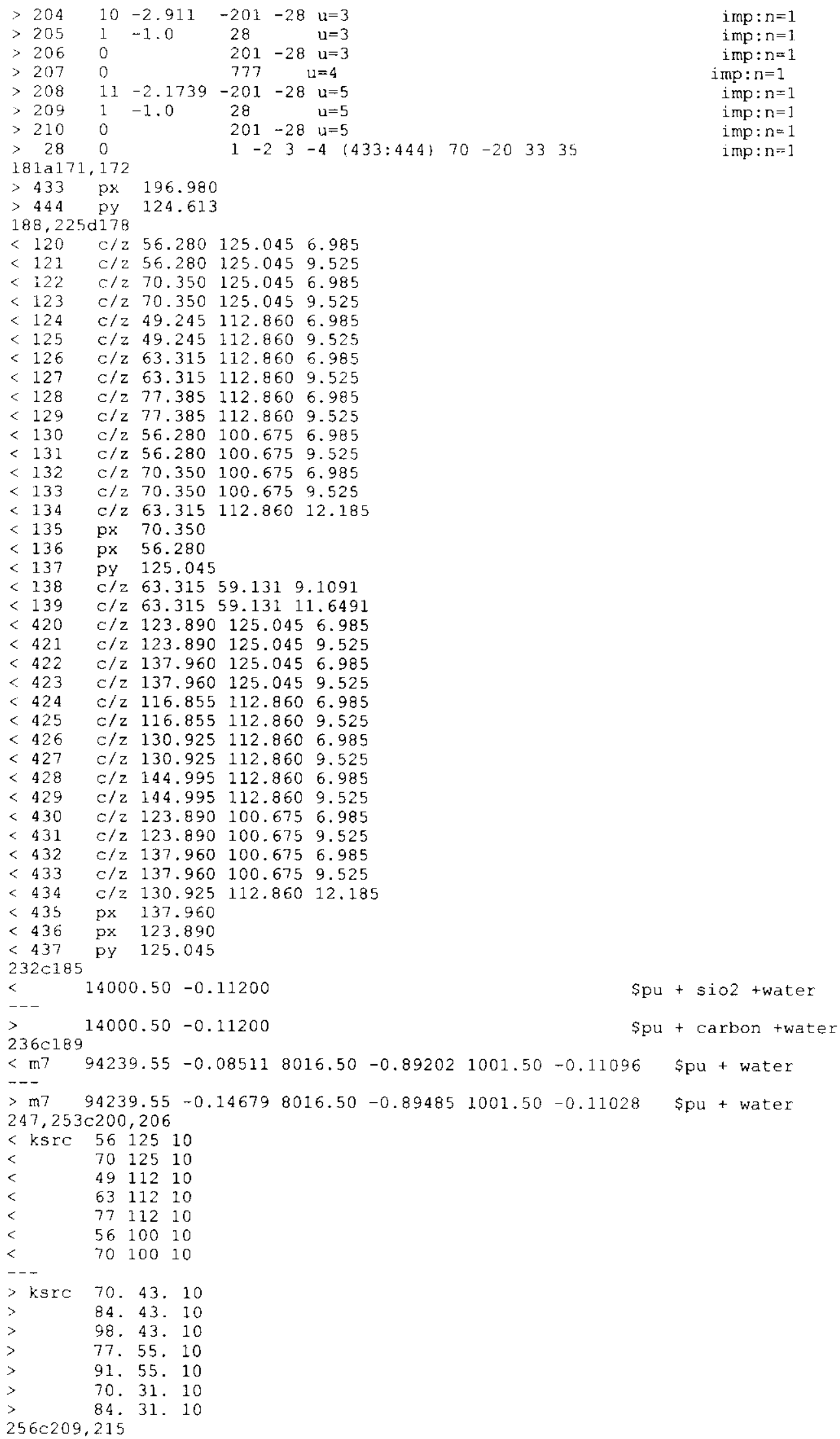




\section{HNF-5988 Rev. 0}

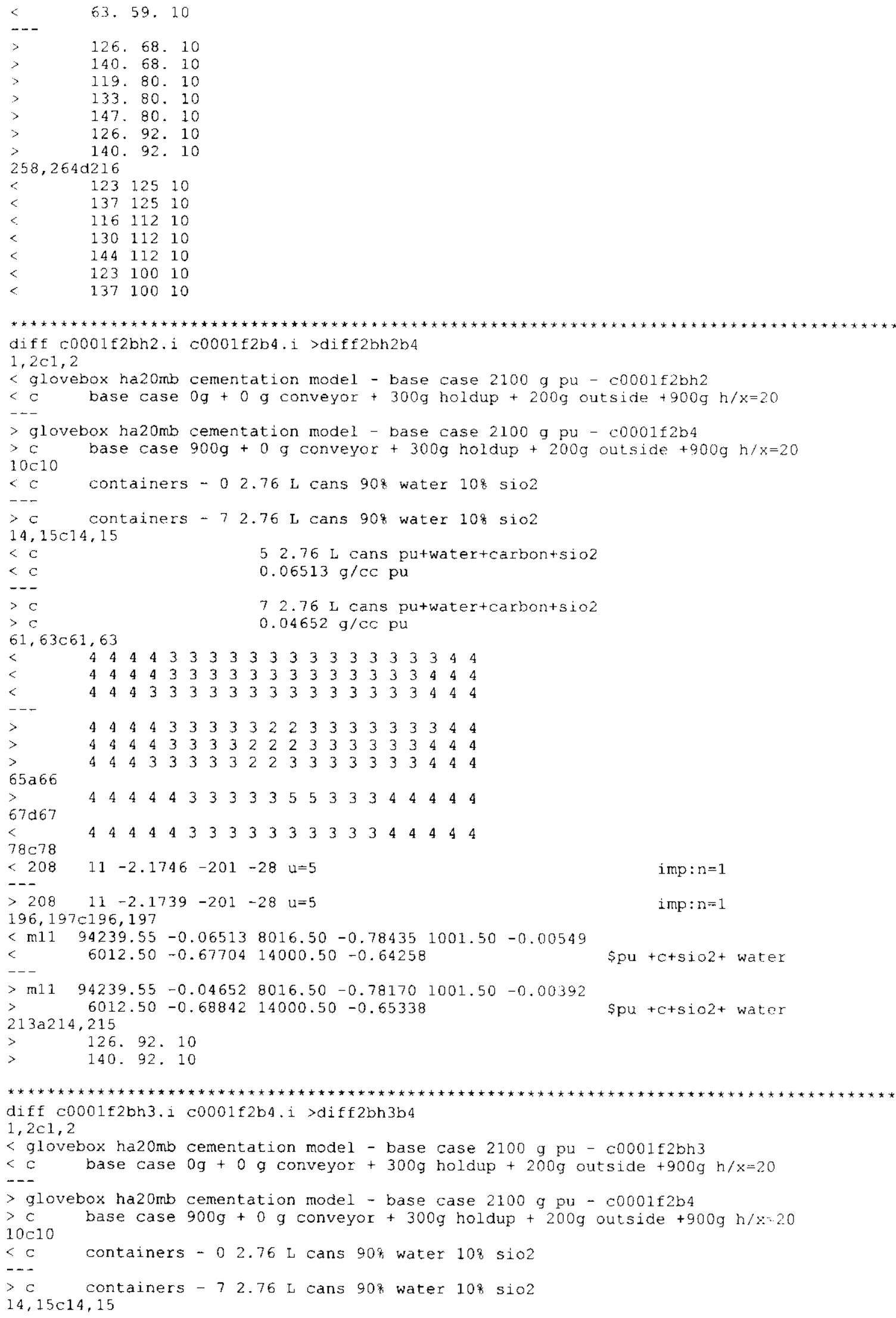




\section{HNF-5988 Rev. 0}

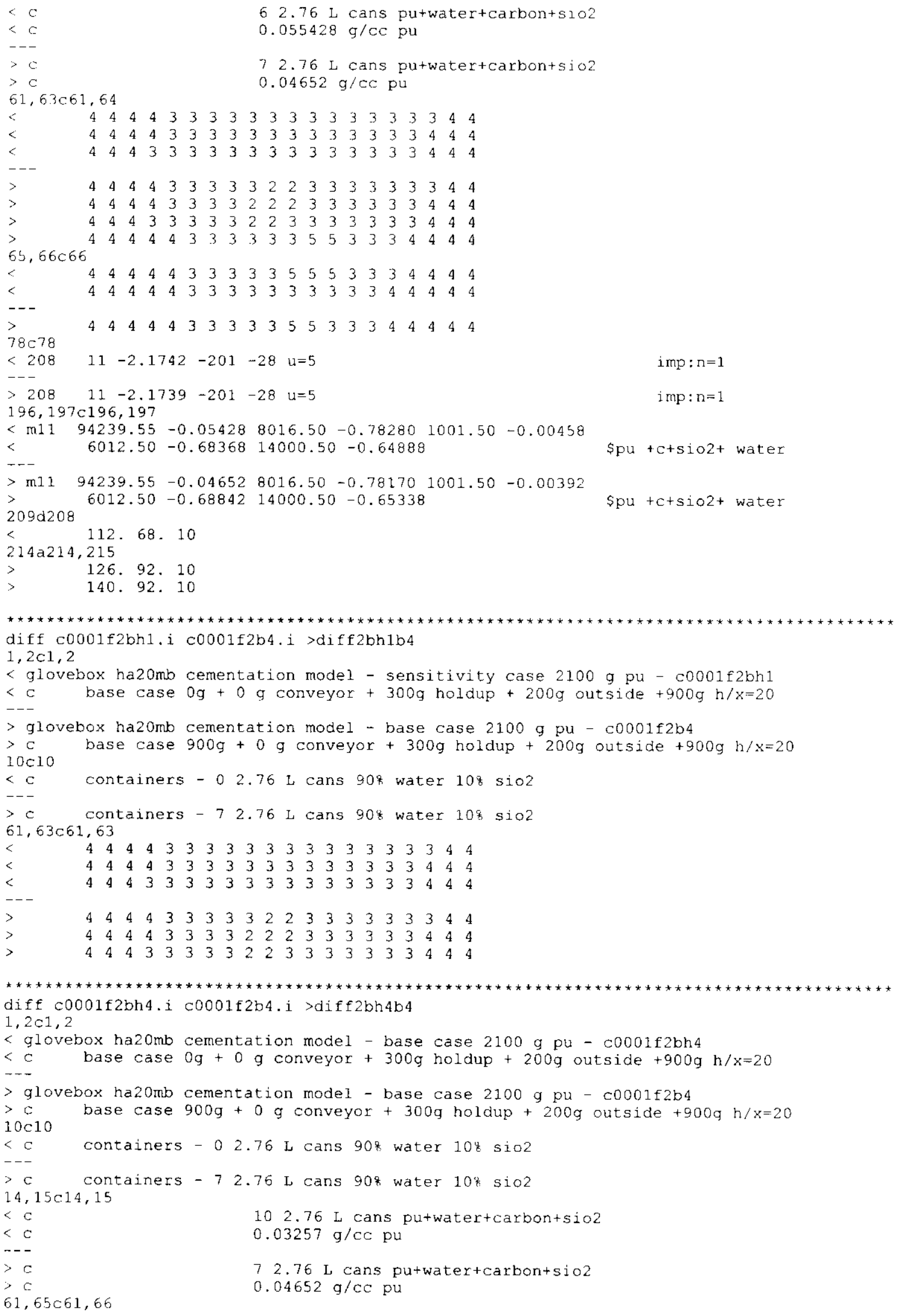




\section{HNF-5988 Rev. 0}

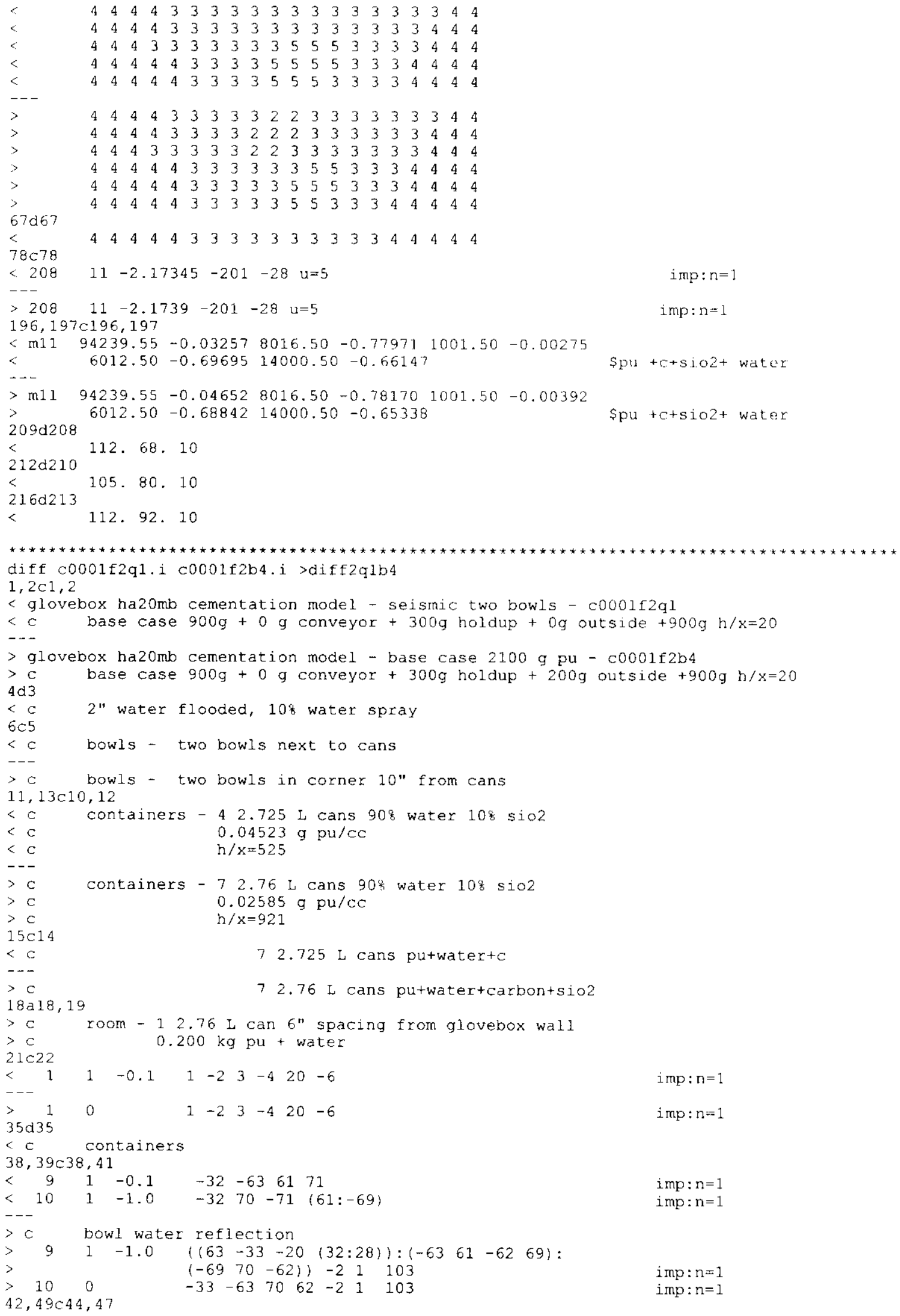


HNF-5988 Rev. 0

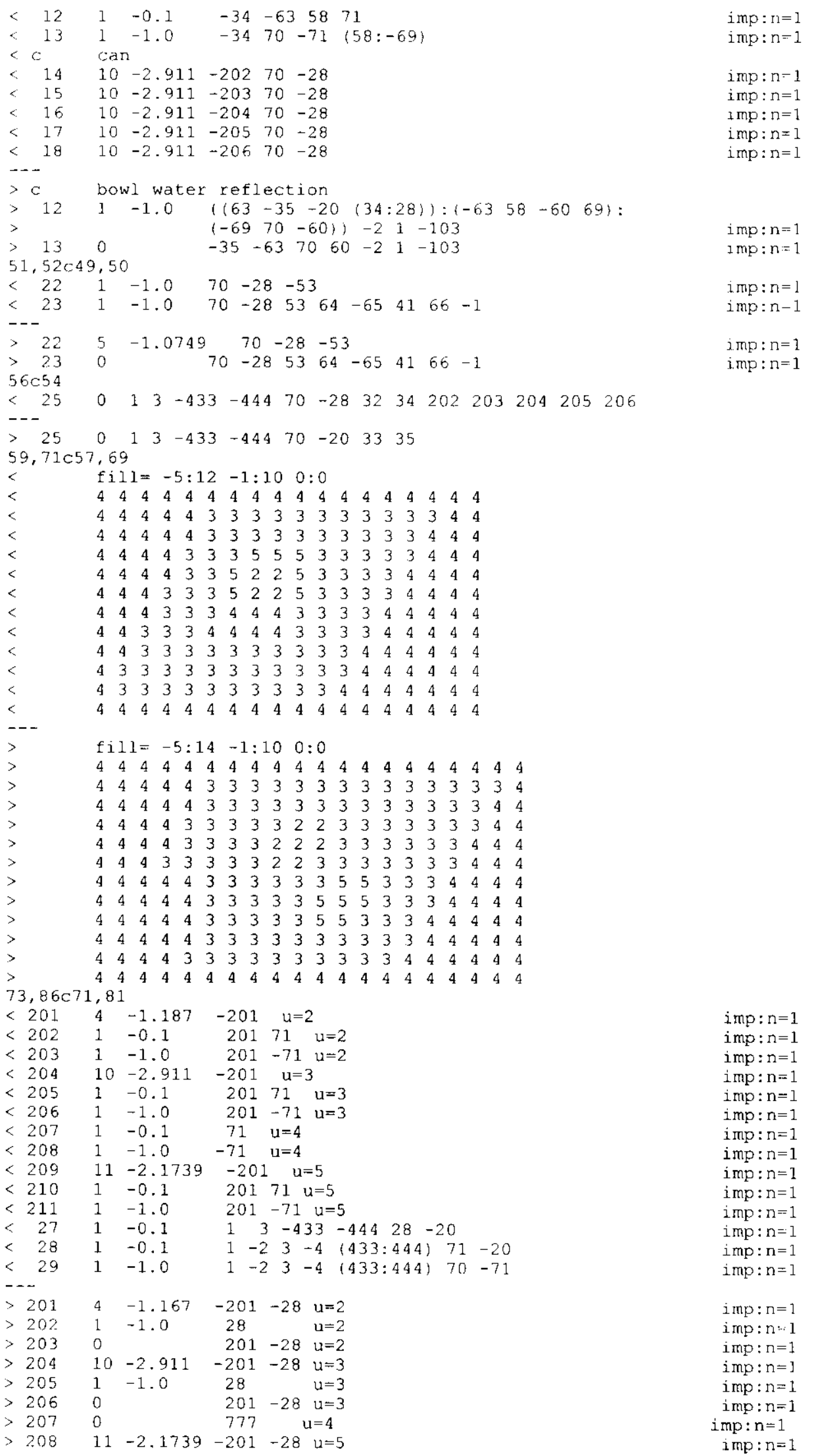




\section{HNF-5988 Rev. 0}

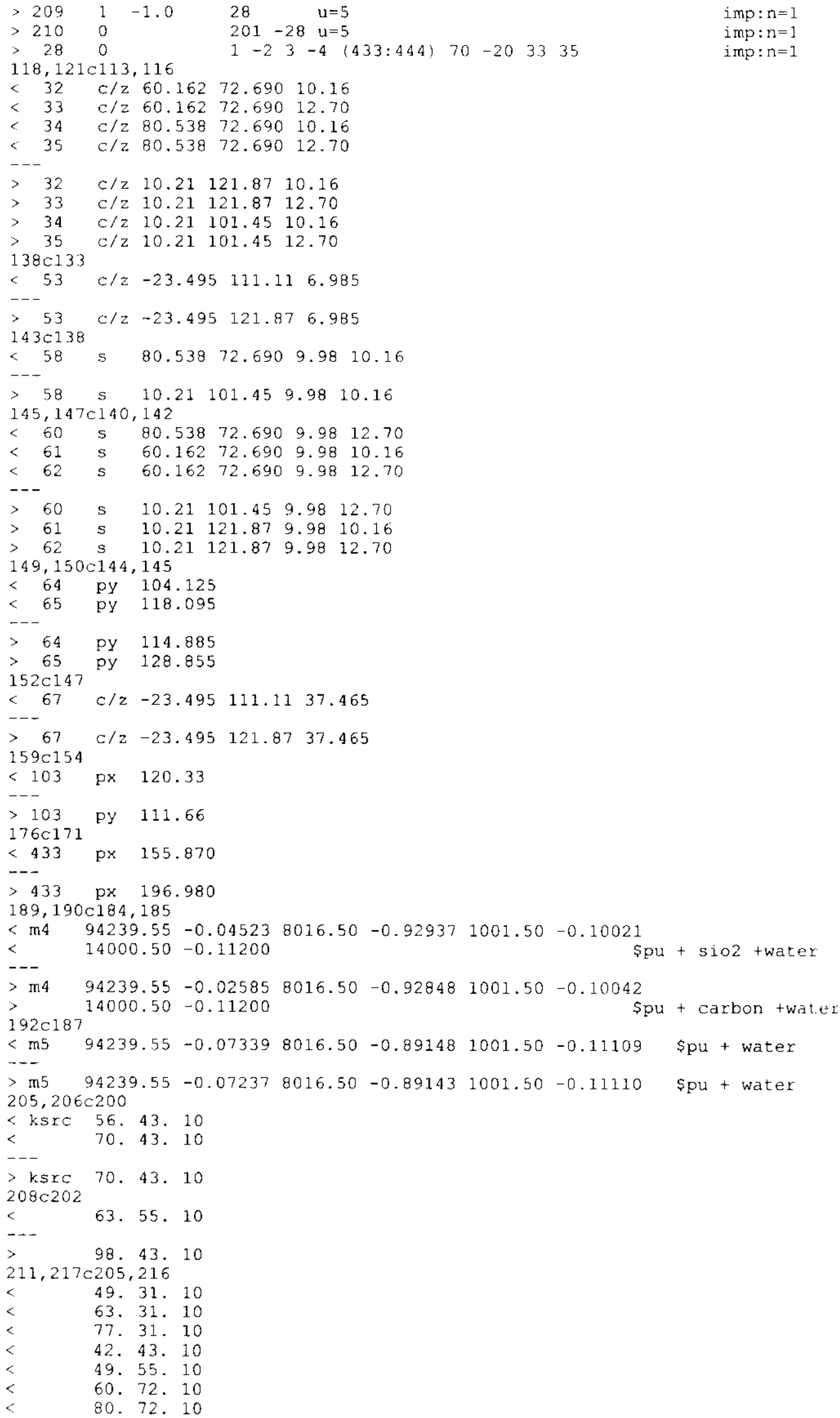




\section{HNF-5988 Rev. 0}

$$
\begin{aligned}
& \text { 70. 31. } 10 \\
& \text { 84. 31. } 10 \\
& 10.122 .10 \\
& \text { 10. } 101.10 \\
& \text { 126. } 68.10 \\
& \text { 140. 68. } 10 \\
& \text { 119. } 80.10 \\
& 133.80 .10 \\
& \text { 147. } 80.10 \\
& \text { 126. } 92.10 \\
& \text { 140.92. } 10 \\
& -23 \text {. 121. } 10
\end{aligned}
$$

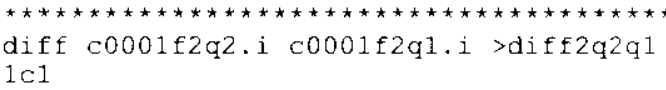

$<$ glovebox ha20mb cementation model - seismic two bowls - c0001f2q2

$---$

$>$ glovebox ha20mb cementation model - seismic two bowls - c0001f2q1

303

$<\mathrm{c}$ glovebox - full water reflection on all sides, water can refl

$>c$ glovebox - full water reflection on all sides, cement can refl $45,49045,49$

$<\begin{array}{lllllll}14 & 1 & -1.0 & -202 & 70 & -28 & \text { imp: } n=1\end{array}$

$<\begin{array}{llllllll}15 & 1 & -1.0 & -203 & 70 & -28 & \text { imp: } n=1\end{array}$

$\begin{array}{lllllll}16 & 1 & -1.0 & -204 & 70 & -28 & \text { imp: } n=1\end{array}$

$<\begin{array}{lllllll}17 & 1 & -1.0 & -205 & 70 & -28 & \text { imp: } \mathrm{n}=1\end{array}$

$<\begin{array}{lllllll}18 & 1 & -1.0 & -206 & 70 & -28 & \text { imp: } n=1\end{array}$

$>14 \quad 10-2.911-20270-28 \quad$ imp: $n=1$

$>15 \quad 10-2.911-20370-28 \quad$ imp: $n=1$

$\begin{array}{llllll}16 & 10 & -2.911 & -20470-28 & i m p: n=1\end{array}$

$>17 \quad 10-2.911-20570-28 \quad$ imp: $n=1$

$\begin{array}{rllllll}18 & 10 & -2.911 & -206 & 70 & -28 & \text { imp: } n=1\end{array}$

$<204 \quad 1-1.0 \quad-201 \quad u=3 \quad$ imp: $n=1$

$>204 \quad 10-2.911-201 \quad u=3 \quad$ imp: $n=1$

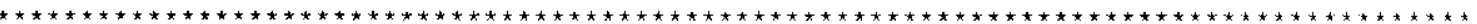

diff c0001f2q1a.i c0001f2q1.i >diff2q1aq1

101

< glovebox ha20mb cementation model - seismic two bowls - c0001f2q1a

$>$ glovebox ha20mb cementation model - seismic two bowls - c0001f2ql

$11,13 \mathrm{c} 11,13$

$<c$ containers - $52.76 \mathrm{~L}$ cans $90 \%$ water 108 sioz

$<\mathrm{c} \quad 0.03619 \mathrm{~g} \mathrm{pu} / \mathrm{cc}$

< $\quad \mathrm{h} / \mathrm{x}=627$

$>\mathrm{C}$ containers - $42.725 \mathrm{~L}$ cans 908 water $10 \%$ sio2

$>\mathrm{C} \quad 0.04523 \mathrm{~g} \mathrm{pu} / \mathrm{cc}$

$>\mathrm{C} \quad \mathrm{h} / \mathrm{x}=525$

$15,16015,16$

$<\mathrm{C}$

$<\mathrm{C}$

$-\cdots$

$>\mathrm{C}$

$>c$

$20 d 19$

$<c$

$<8 \quad 3-1.0431((63-28):(-63-6169))-32 \quad$ imp: $n=1$

$>\quad 3-1.0431((63-28):(-63-6169))-32 \quad i m p: n=1$

$\begin{array}{r}42041 \\ <11\end{array} \quad 3 \quad-1.0431 \quad((63-28):(-63-5869))-34 \quad$ imp: $n=1$

$>113-1.0431\left((63-28):\left(\begin{array}{llll}-63 & -5869\end{array}\right)-34 \quad\right.$ imp: $n=1$

$62,66 \mathrm{c} 61,65$

$\begin{array}{llllllllllllllllll}4 & 4 & 3 & 3 & 3 & 3 & 3 & 3 & 3 & 3 & 3 & 3 & 3 & 3 & 3 & 3 & 4 & 4\end{array}$

$\begin{array}{llllllllllllllllll}4 & 4 & 3 & 3 & 4 & 3 & 3 & 3 & 3 & 3 & 3 & 3 & 3 & 3 & 3 & 4 & 4 & 4\end{array}$

$\begin{array}{llllllllllllllllll}4 & 4 & 3 & 3 & 3 & 3 & 3 & 5 & 5 & 5 & 3 & 3 & 3 & 3 & 3 & 4 & 4 & 4\end{array}$

$\begin{array}{llllllllllllllllll}4 & 4 & 3 & 4 & 3 & 3 & 3 & 2 & 2 & 5 & 3 & 3 & 3 & 3 & 4 & 4 & 4 & 4\end{array}$ 


\section{HNF-5988 Rev. 0}

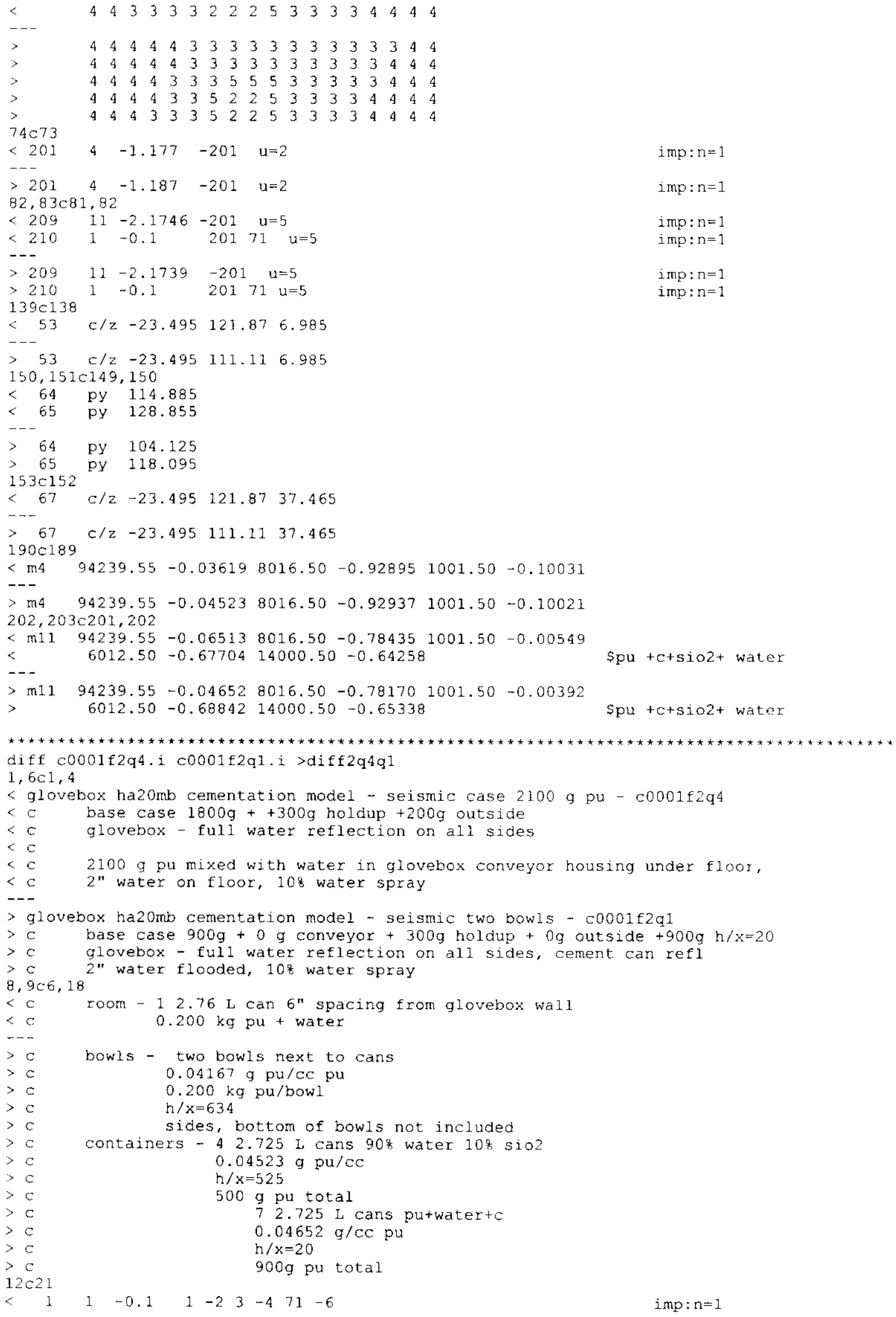


HNF-5988 Rev. 0

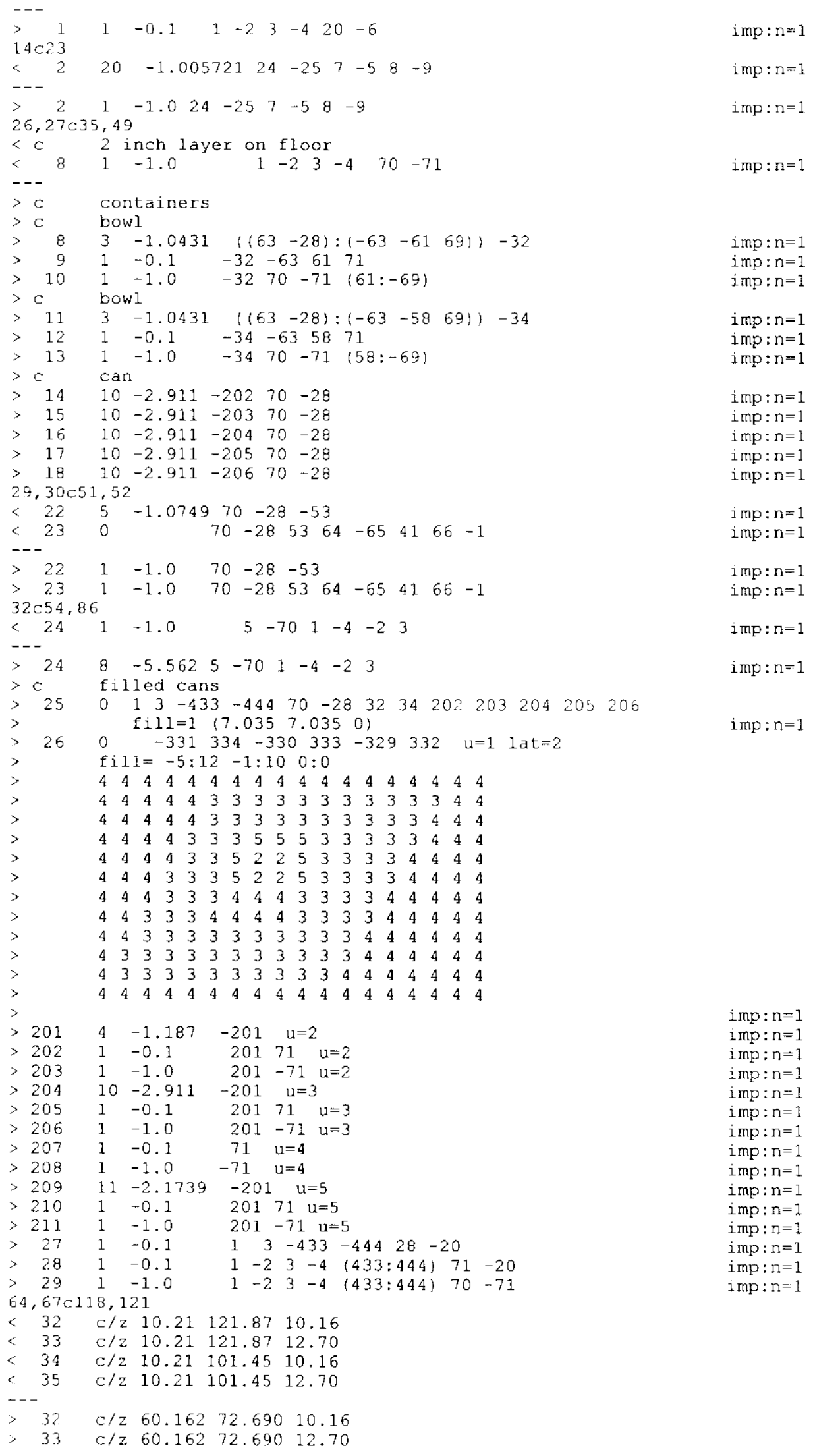




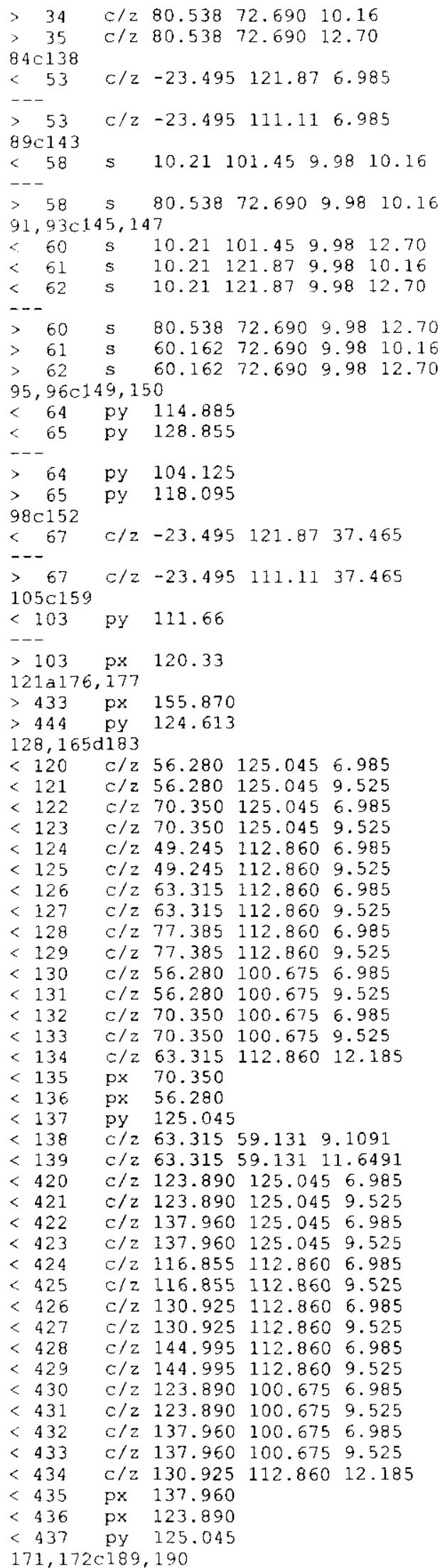


HNF-5988 Rev. 0
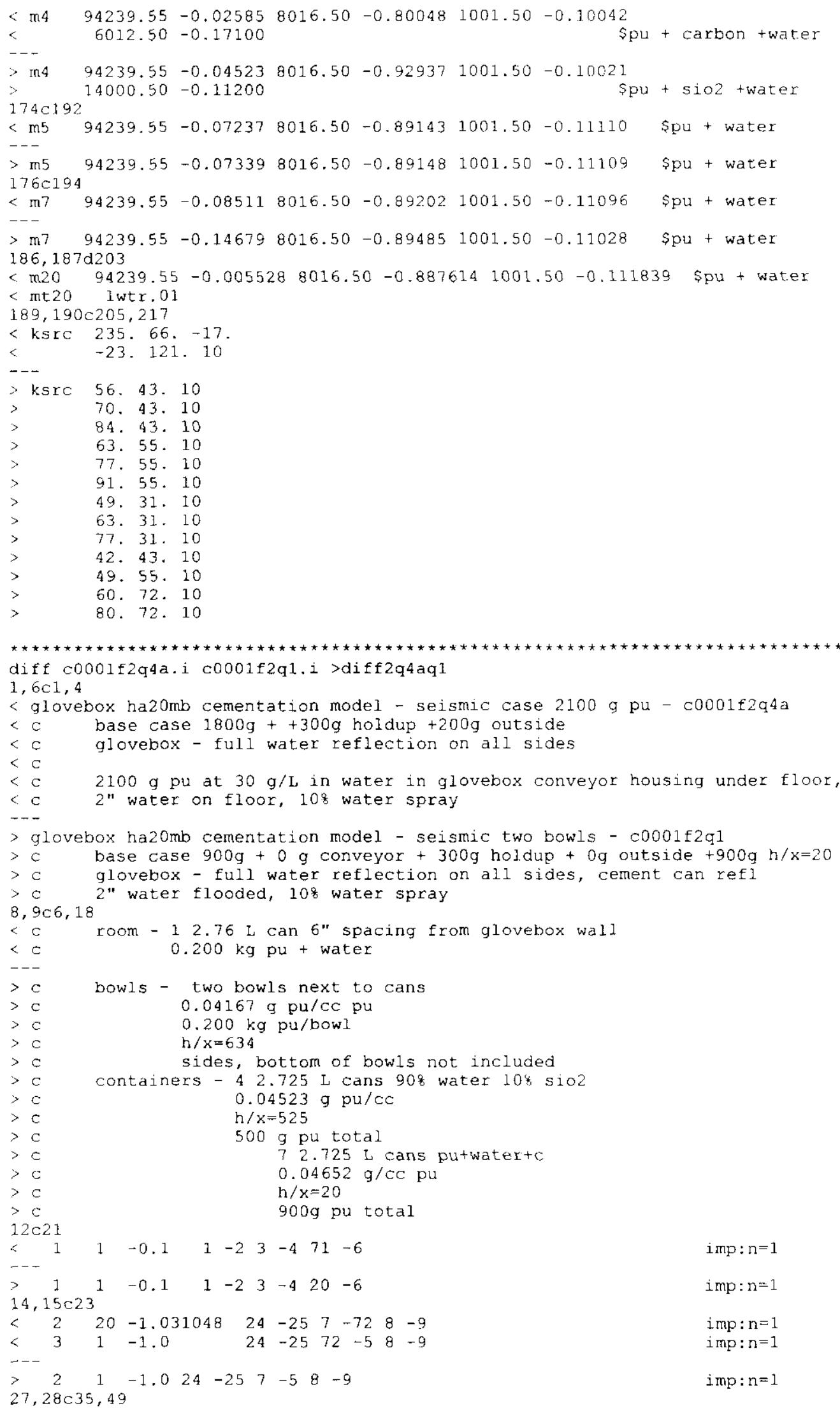
HNF-5988 Rev. 0

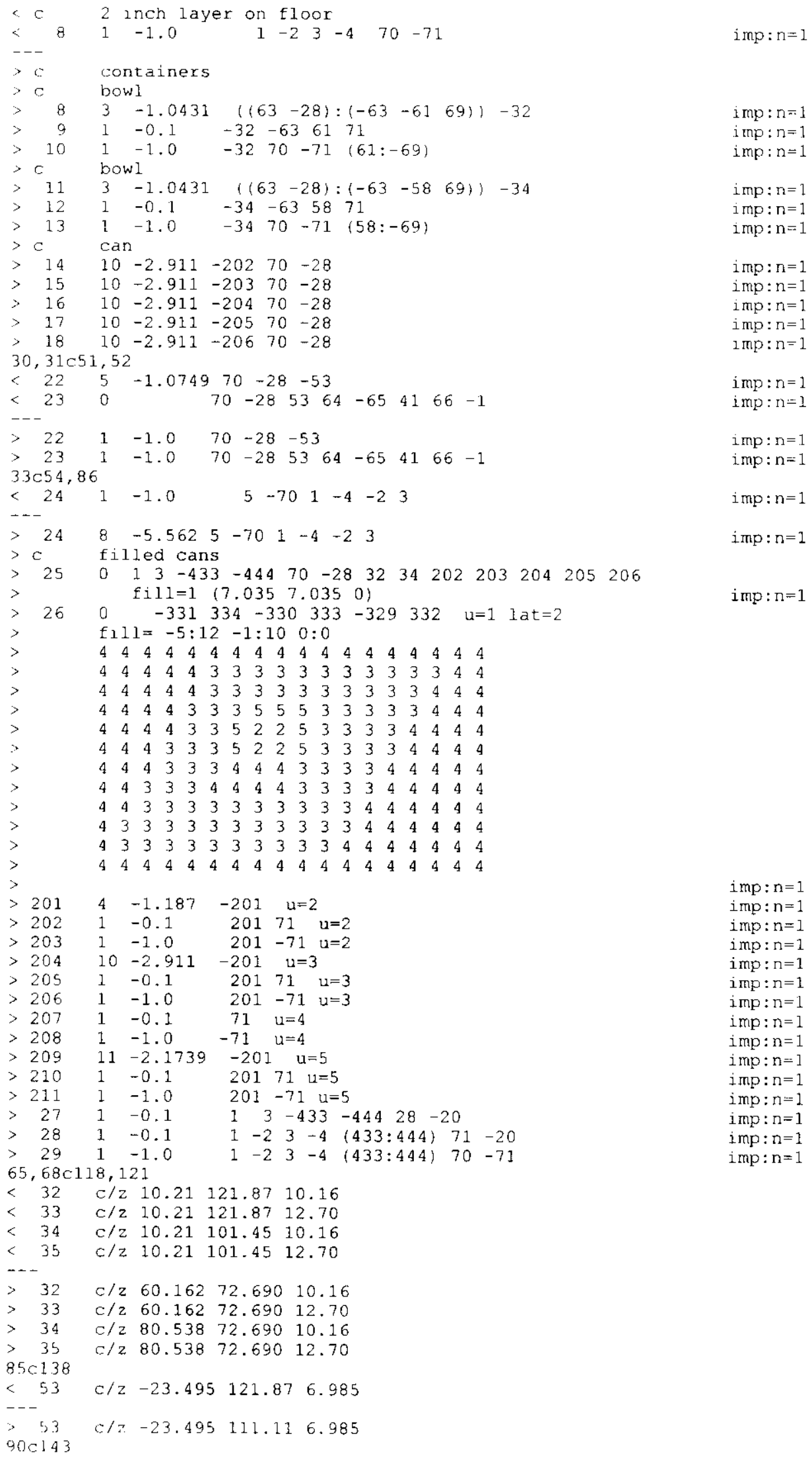


HNF-5988 Rev. 0

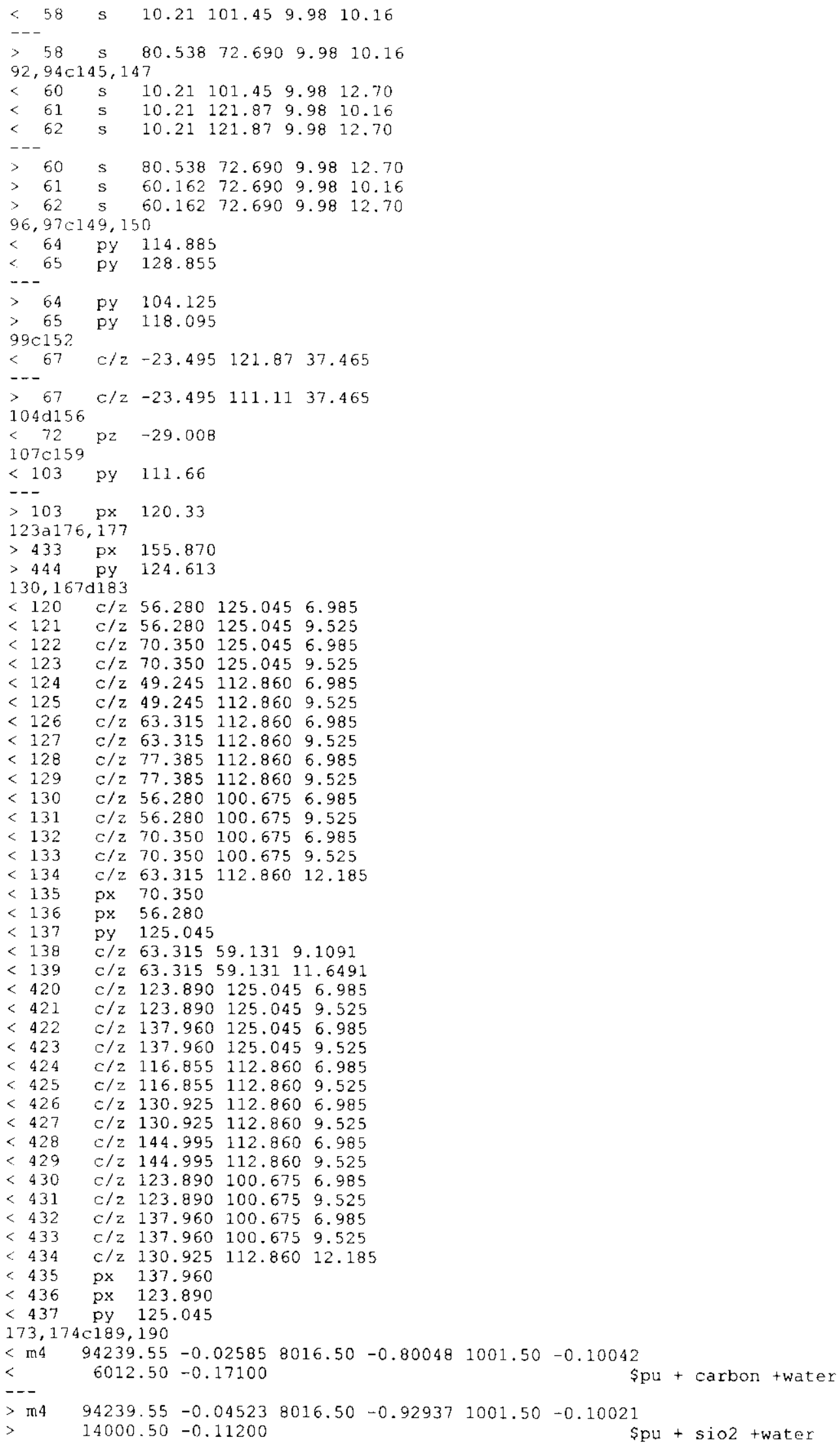




\section{HNF-5988 Rev. 0}

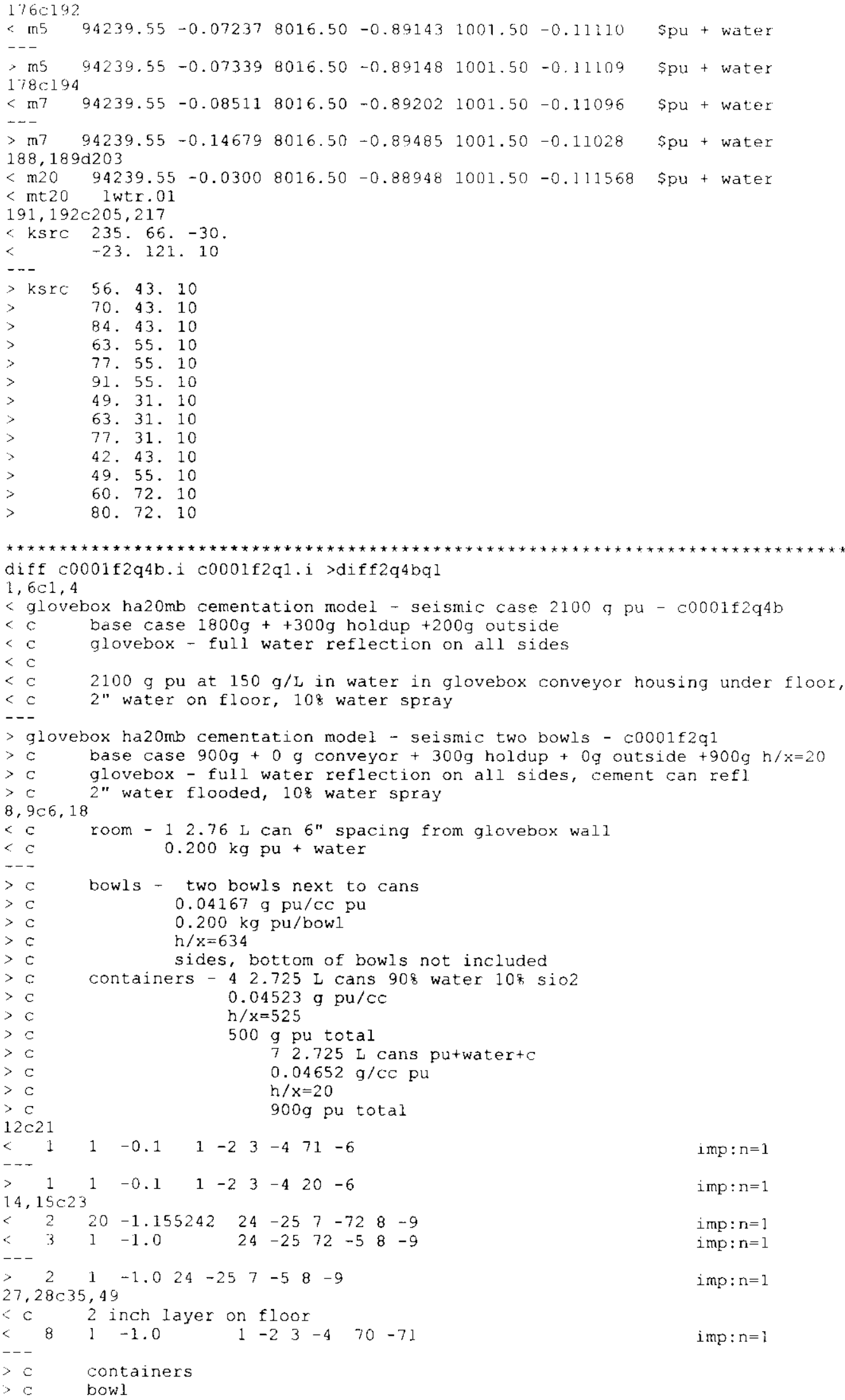


HNF-5988 Rev. 0

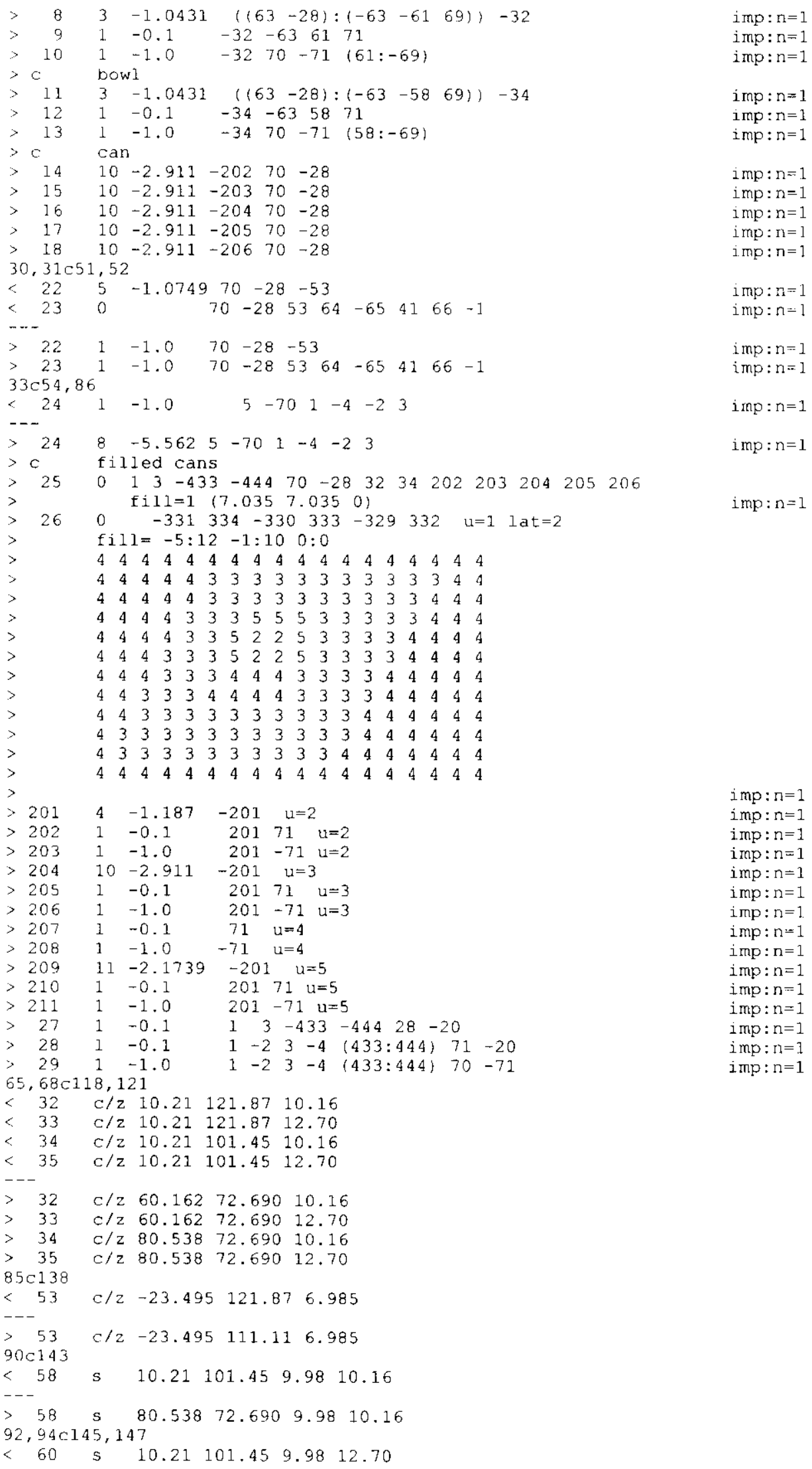




\section{HNF-5988 Rev. 0}

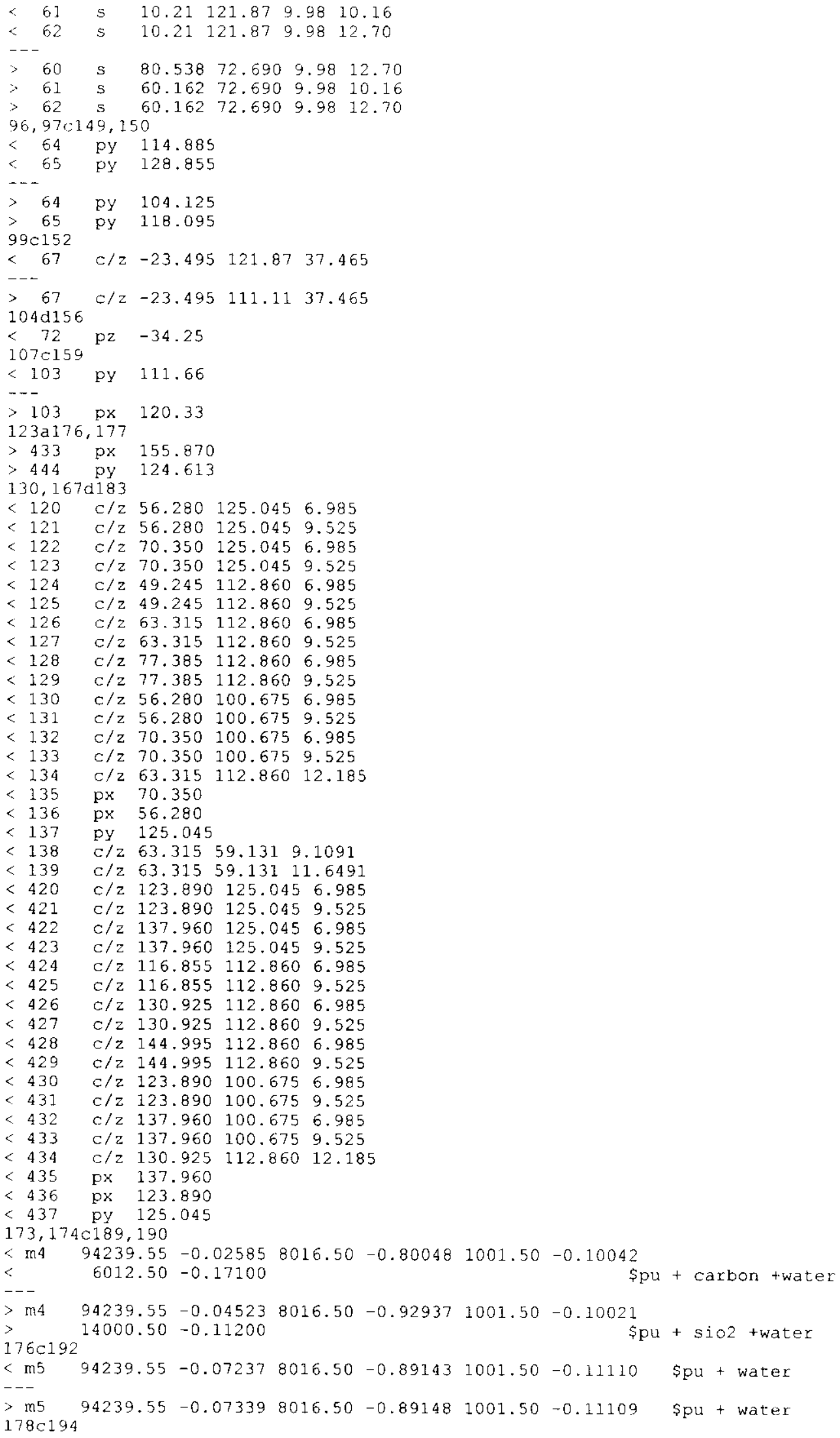




\section{HNF-5988 Rev. 0}

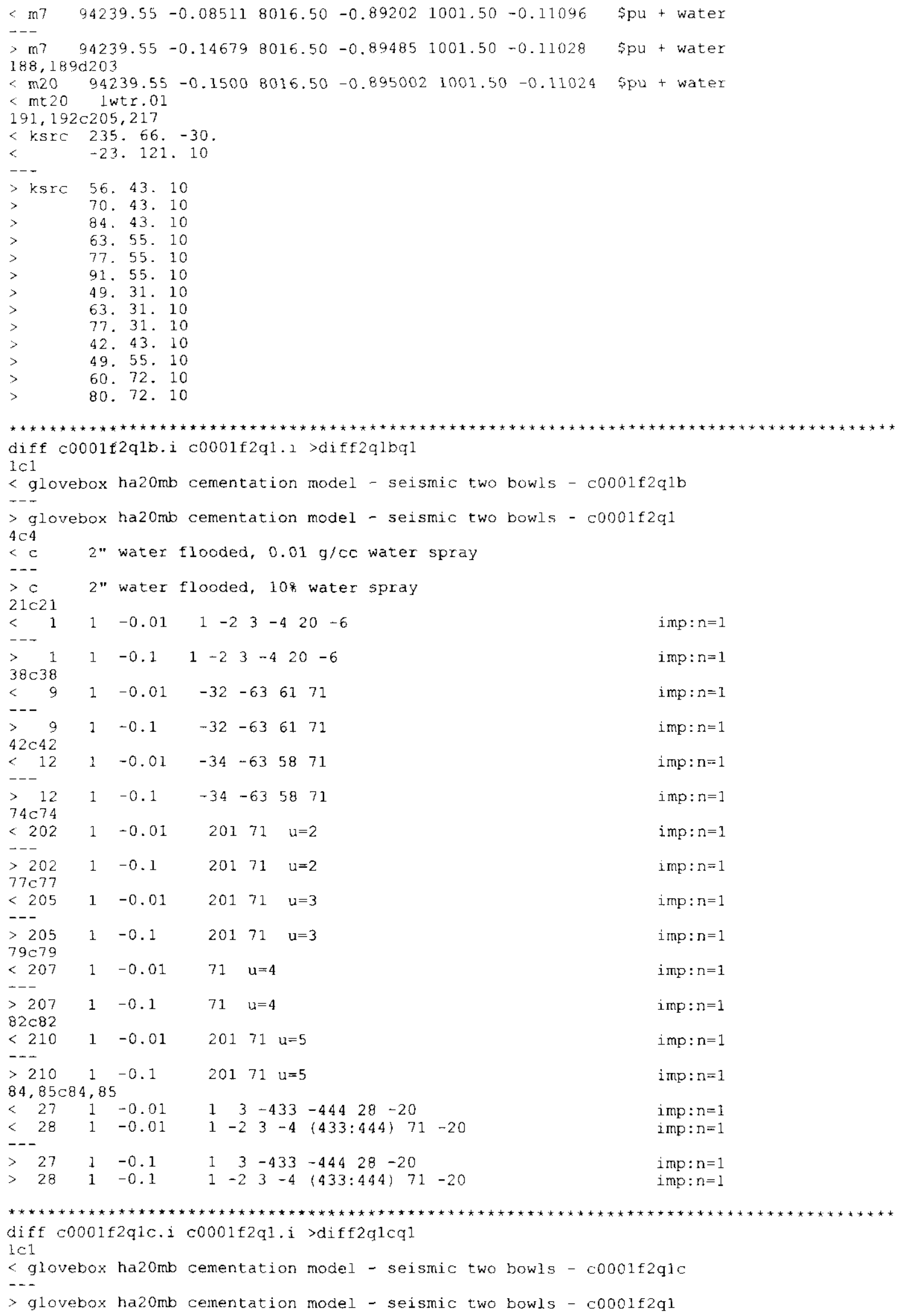

\section{C-65}


HNF-5988 Rev. 0

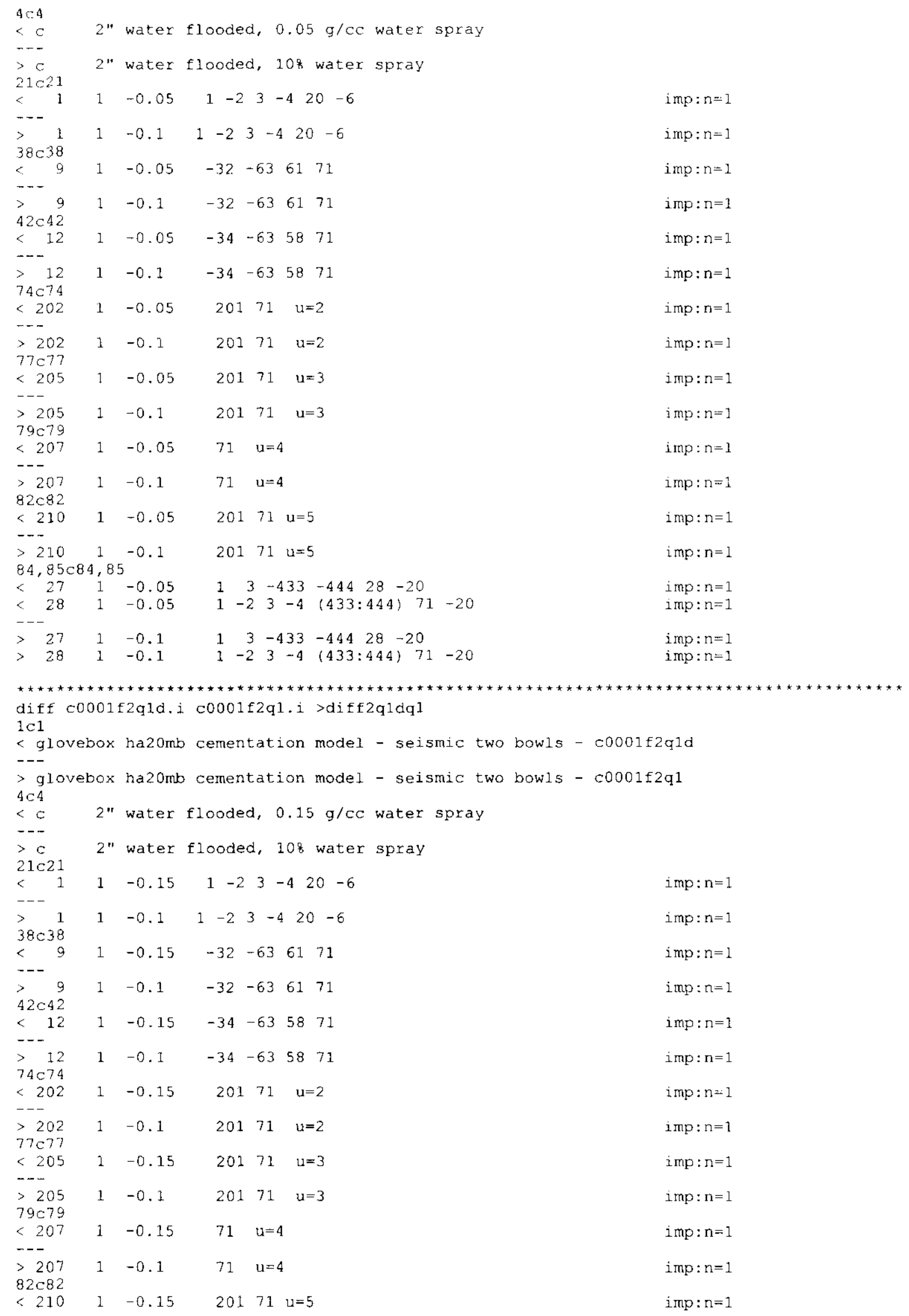


HNF-5988 Rev. 0

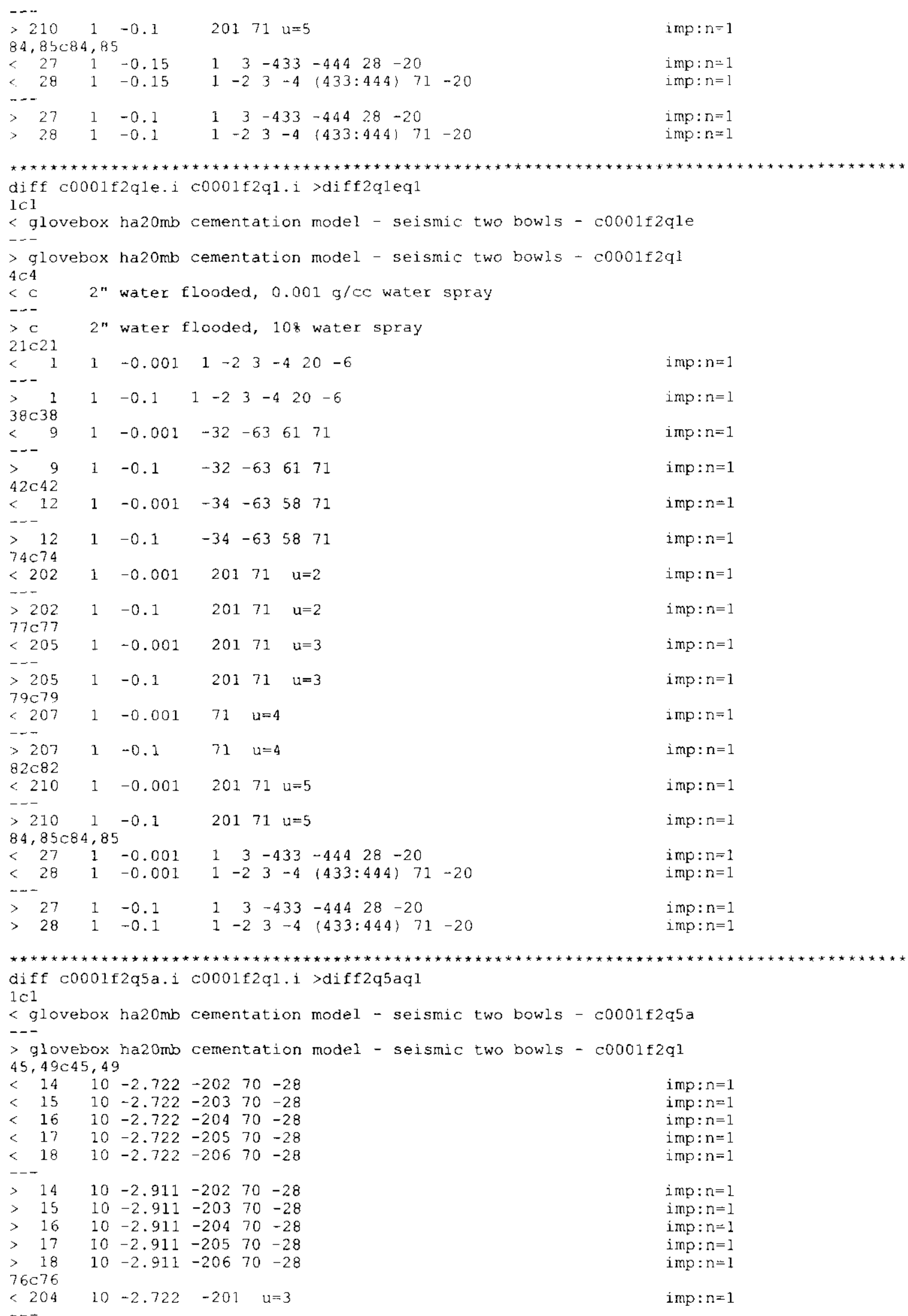


HNF-5988 Rev. 0

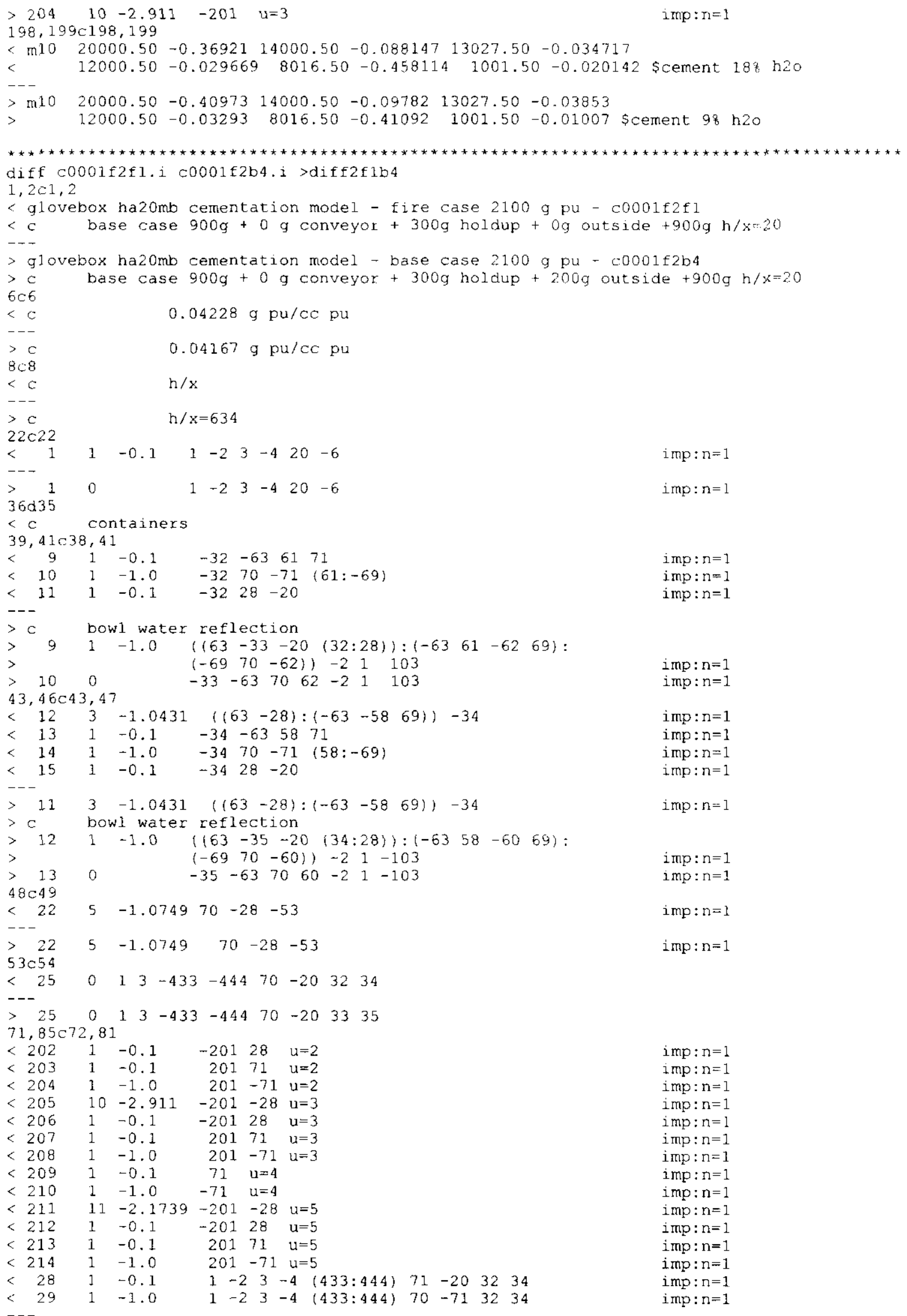


HNF-5988 Rev. 0

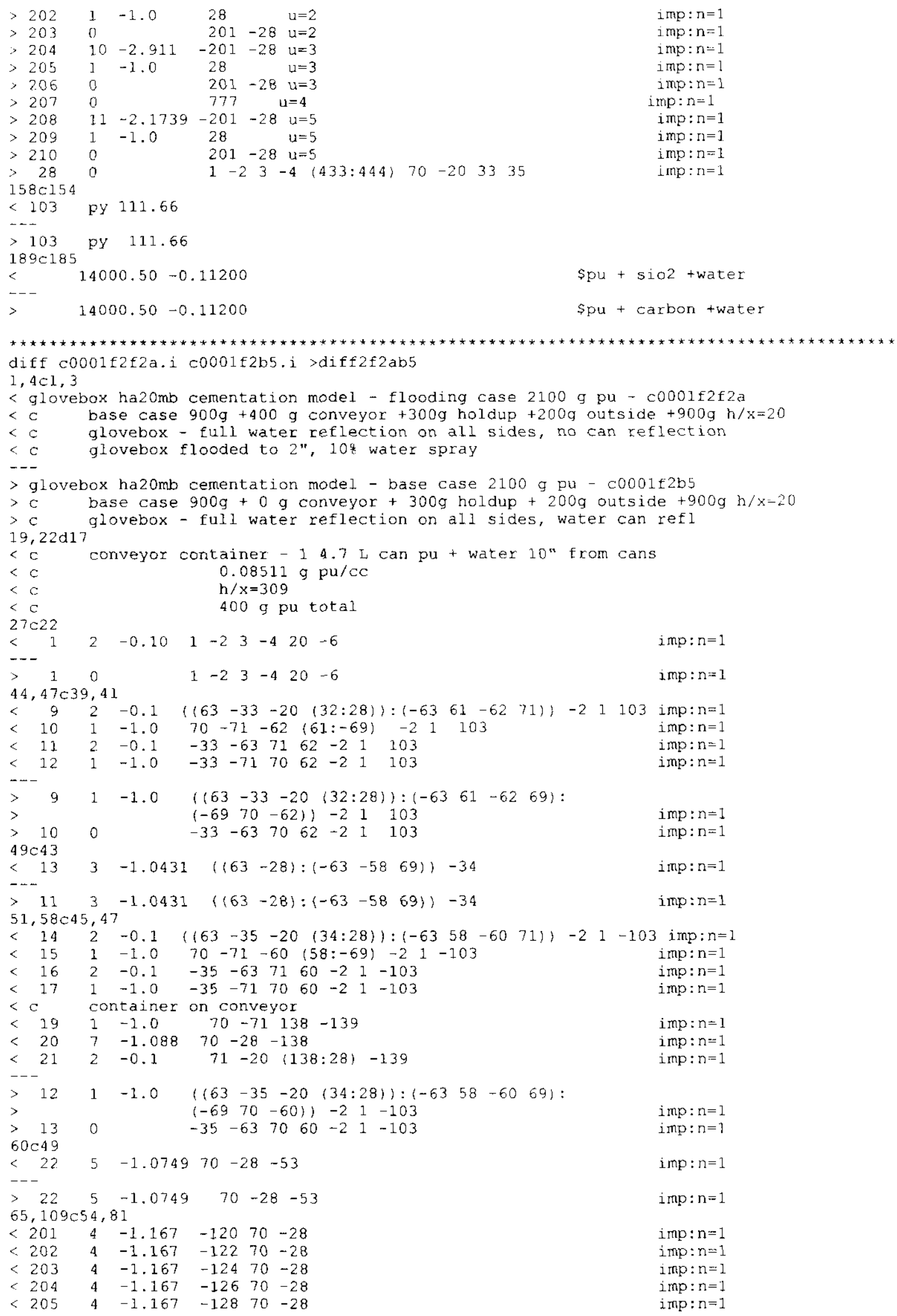




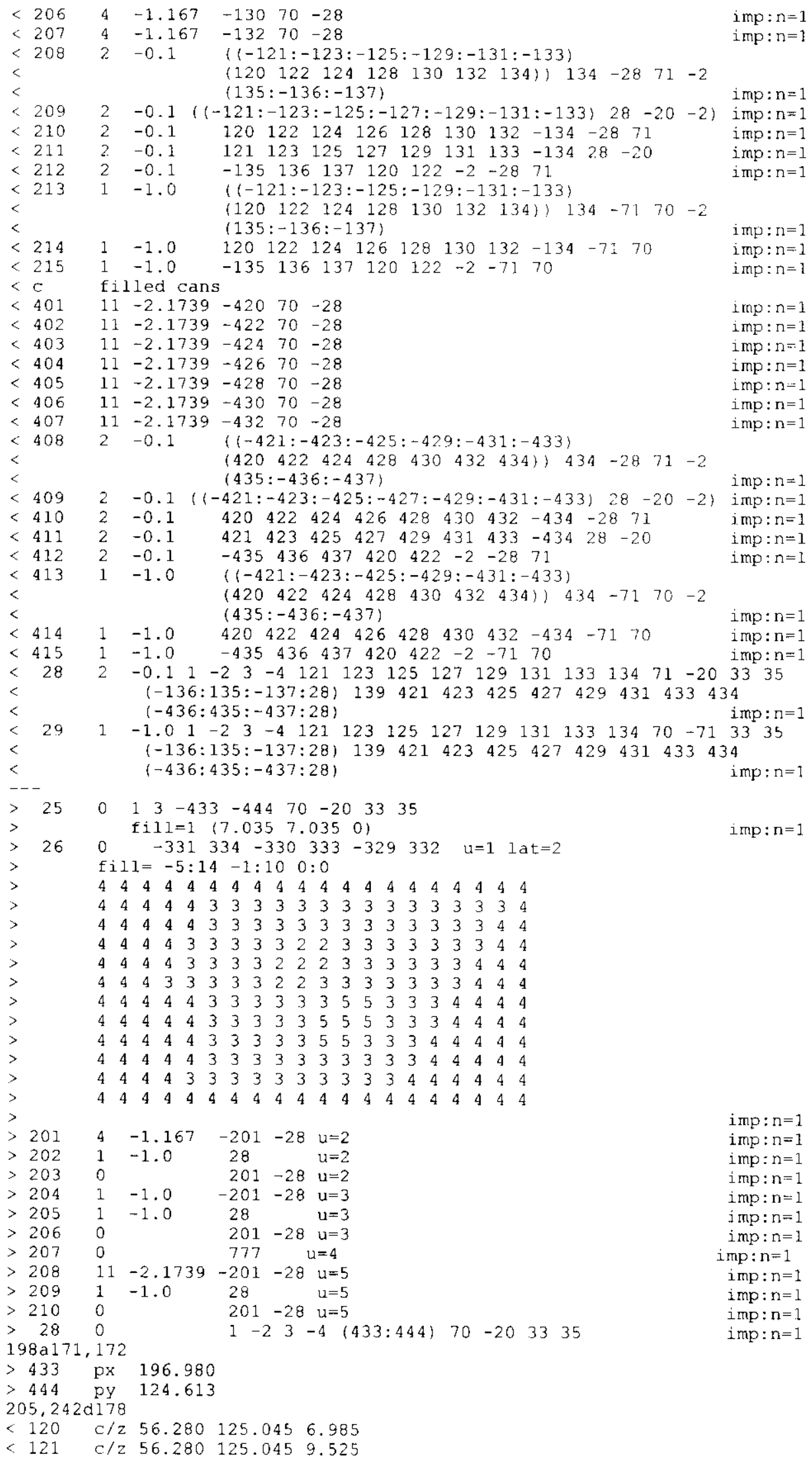


HNF-5988 Rev. 0

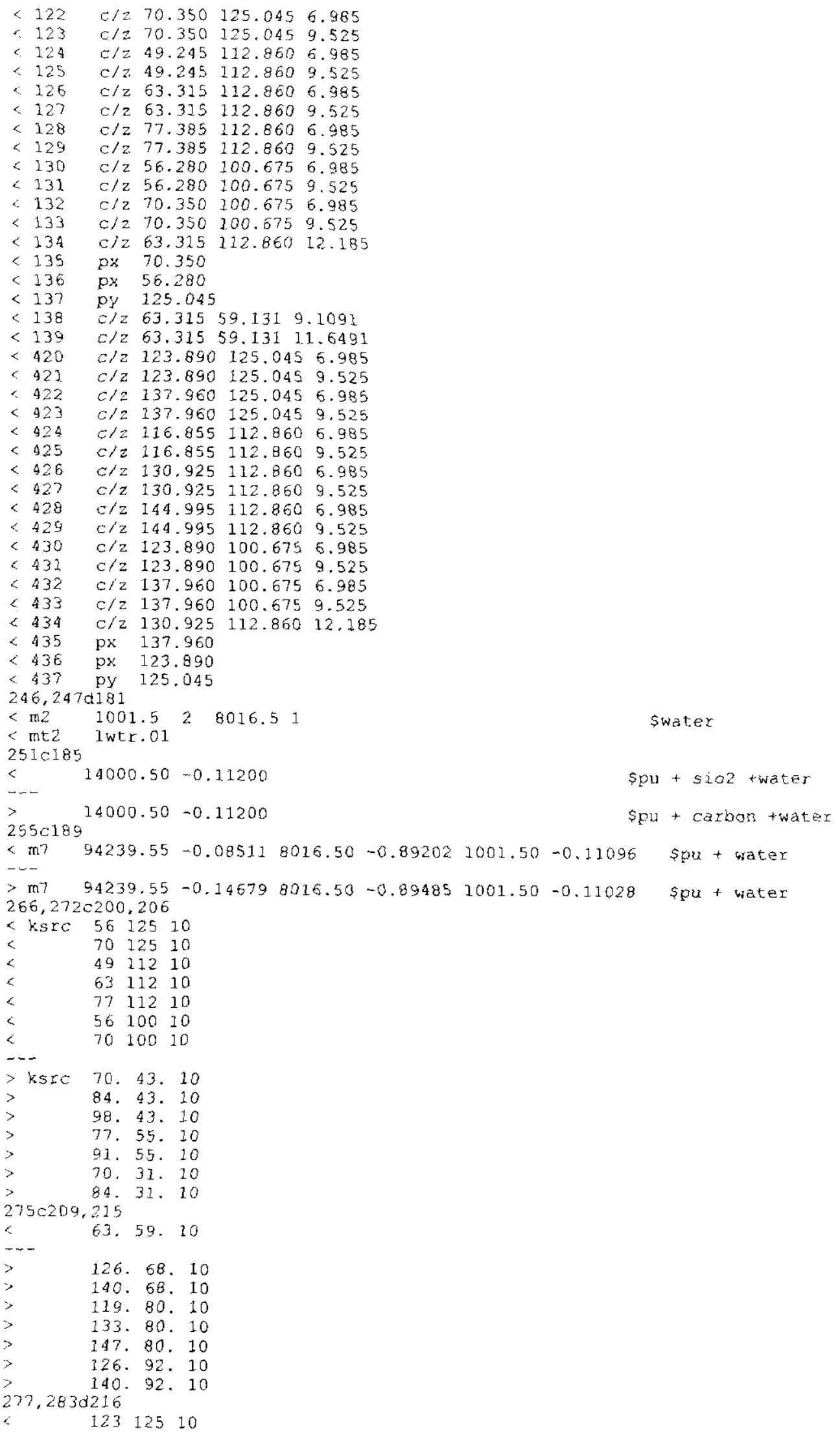


HNF-5988 Rev. 0

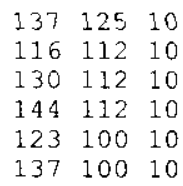

diff c0001f2f3.i c0001f2b4.i diff2f 3 b4

$1,5 c 1,3$

< glovebox ha20mb cementation model - flooding case $2100 \mathrm{~g}$ pu - c0001f2f3

$<\mathrm{c}$ base case $1800 \mathrm{~g}++300 \mathrm{~g}$ holdup $+200 \mathrm{~g}$ outside

$<\mathrm{c}$ glovebox - full water reflection on all sides

$<\mathrm{c} \quad 2100 \mathrm{~g}$ pu in $2^{\prime \prime}$ slab on floor mixed with water, 10* water spray

$>$ glovebox ha20mb cementation model - base case $2100 \mathrm{~g}$ pu - c0001f2b4

$>c$ base case 900g +0 g conveyor $+300 \mathrm{~g}$ holdup $+200 \mathrm{~g}$ outside $+900 \mathrm{~g} h / \mathrm{x}-20$

$>c$ glovebox - full water reflection on all sides, cement can refl

$6 a 5,17$

$>\mathrm{c}$

$>\mathrm{C}$

$>\mathrm{C}$

$>\mathrm{C}$

$>c$

$>\mathrm{C}$

$>C$

$>\mathrm{C}$

$>\mathrm{C}$

$>\mathrm{C}$

$>\mathrm{C}$

$>\mathrm{C}$

bowls - two bowls in corner 10" from cans

$0.04167 \mathrm{~g} \mathrm{pu} / \mathrm{cc} \mathrm{pu}$

$0.200 \mathrm{~kg} \mathrm{pu} / \mathrm{bow}$

$h / x=634$

sides, bottom of bowls not included

containers $-72.76 \mathrm{~L}$ cans 90 water $10 \%$ sio2

$0.02585 \mathrm{~g} \mathrm{pu} / \mathrm{Cc}$

$h / x=921$

$500 \mathrm{~g}$ pu total

$72.76 \mathrm{~L}$ cans pu+water+carbontsio2

$0.04652 \mathrm{~g} / \mathrm{Cc} \mathrm{pu}$

$h / x=20$

$900 \mathrm{~g}$ pu total

$11 \mathrm{c} 22$

$<$

$-\infty$

$>10 \quad 1-2 \quad 3-420-6$

$25,36,47$

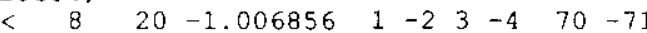

$+$

$>c$ bow 1

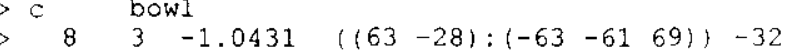

$>$ bowl water reflection

$>91-1.0 \quad\left(\begin{array}{lllll}63 & -33 & -20 & (32: 28)\end{array}\right):\left(\begin{array}{llll}-63 & 61 & -62 & 69\end{array}\right)$ :

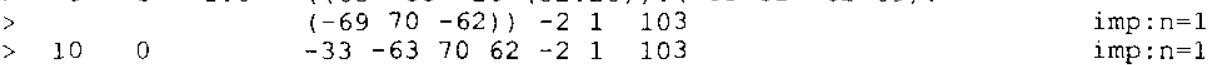

$>\mathrm{C}$ bowl

$313-1.0431+(63-28)=(-63-5869))-34$

$>$ bowl water reflection

$121-1.0 \quad\left((63-35-20(34: 28)):\left(\begin{array}{lllll}-63 & 58 & -60 & 69\end{array}\right)\right.$.

$>\quad(-6970-60))-2 \quad 1-103$

$>130 \quad-35 \quad-63 \quad 70 \quad 60-2 \quad 1 \quad-103$

$27,28 c 49,50$

$<225-1.074970-28-53$

$\begin{array}{lllllll}22 & 5 & -1.0749 & 70 & -28 & -53\end{array}$

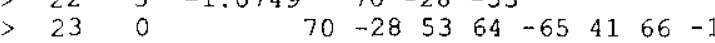

$30 c 52,81$

$\begin{array}{lllllllll}<4 & 20 & -1.006856 & 5 & -70 & 1 & -4 & -2 & 3\end{array}$

$i m p: n=1$

imp: $n=1$

imp: $n=1$

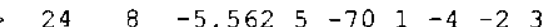

filled cans

$\begin{array}{llllllllll}25 & 0 & 1 & 3 & -433 & -444 & 70 & -20 & 33 & 35\end{array}$

fill $=1 \quad(7.035 \quad 7.0350)$

$26 \quad 0 \quad-331 \quad 334-330 \quad 333 \quad-329 \quad 332 \quad u=1 \quad$ lat $=2$

fill $=-5: 14-1: 100: 0$

$\begin{array}{lllllllllllllllllllll}4 & 4 & 4 & 4 & 4 & 4 & 4 & 4 & 4 & 4 & 4 & 4 & 4 & 4 & 4 & 4 & 4 & 4 & 4 & 4\end{array}$

$\begin{array}{llllllllllllllllllll}4 & 4 & 4 & 4 & 4 & 3 & 3 & 3 & 3 & 3 & 3 & 3 & 3 & 3 & 3 & 3 & 3 & 3 & 3 & 4\end{array}$

$\begin{array}{llllllllllllllllllll}4 & 4 & 4 & 4 & 4 & 3 & 3 & 3 & 3 & 3 & 3 & 3 & 3 & 3 & 3 & 3 & 3 & 3 & 4 & 4\end{array}$

$\begin{array}{llllllllllllllllllll}4 & 4 & 4 & 4 & 3 & 3 & 3 & 3 & 3 & 2 & 2 & 3 & 3 & 3 & 3 & 3 & 3 & 3 & 4 & 4\end{array}$

$\begin{array}{llllllllllllllllllll}4 & 4 & 4 & 4 & 3 & 3 & 3 & 3 & 2 & 2 & 2 & 3 & 3 & 3 & 3 & 3 & 3 & 4 & 4 & 4\end{array}$

$\begin{array}{llllllllllllllllllll}4 & 4 & 4 & 3 & 3 & 3 & 3 & 3 & 2 & 2 & 3 & 3 & 3 & 3 & 3 & 3 & 3 & 4 & 4 & 4\end{array}$

$\begin{array}{llllllllllllllllllll}4 & 4 & 4 & 4 & 4 & 3 & 3 & 3 & 3 & 3 & 3 & 5 & 5 & 3 & 3 & 3 & 4 & 4 & 4 & 4\end{array}$

$\begin{array}{llllllllllllllllllll}4 & 4 & 4 & 4 & 4 & 3 & 3 & 3 & 3 & 3 & 5 & 5 & 5 & 3 & 3 & 3 & 4 & 4 & 4 & 4\end{array}$ 
HNF-5988 Rev. 0

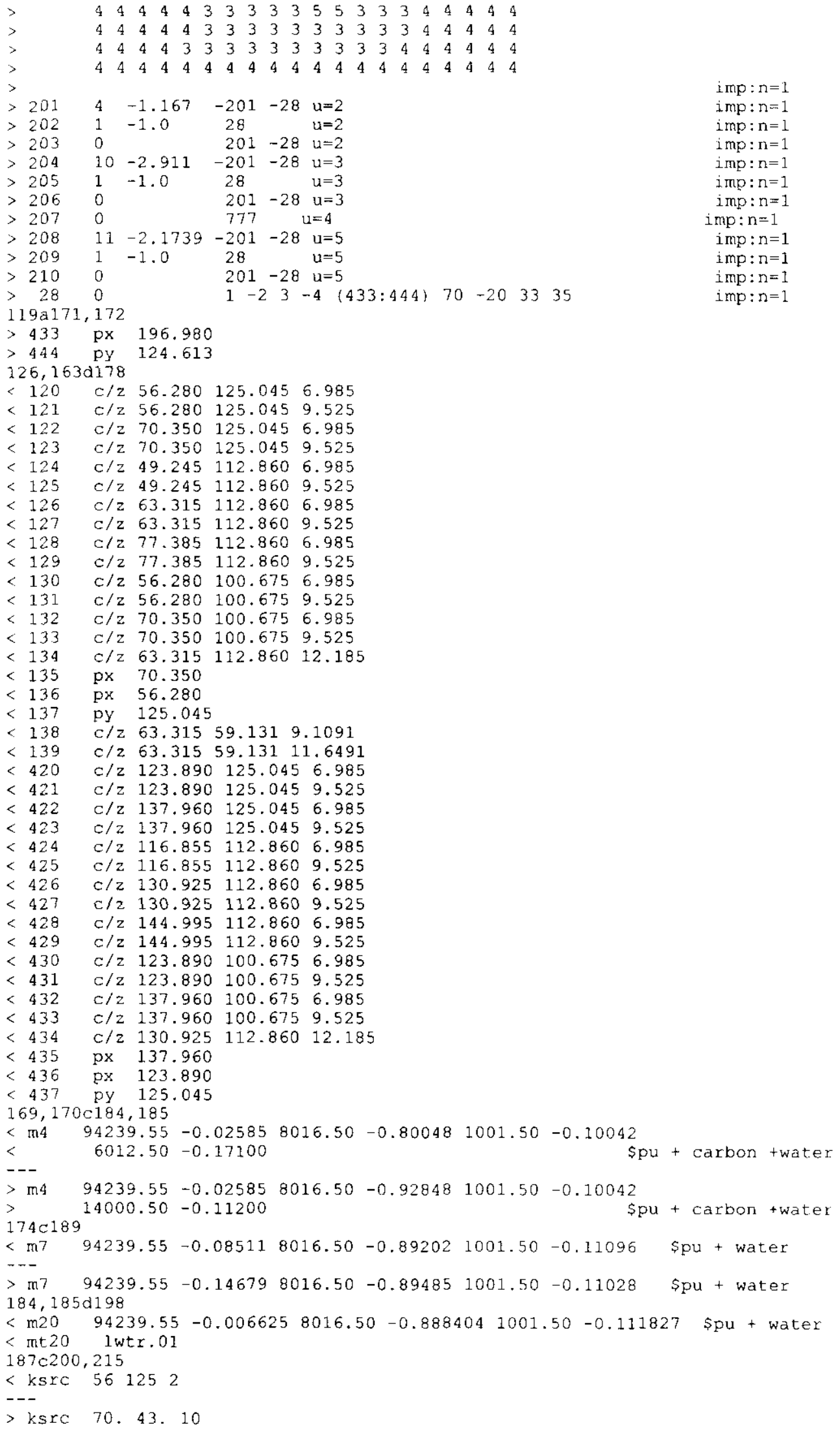


HNF-5988 Rev. 0

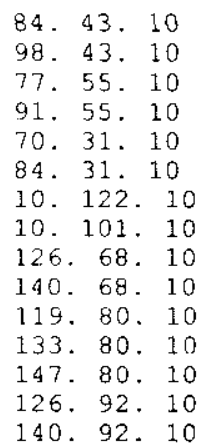

140.92 .10

diff c0001f2f4.i c0001f2b4,i >diff $2 f 4 b 4$

$1,6 \mathrm{cl}, 3$

$<$ glovebox ha20mb cementation model - flooding case $2100 \mathrm{~g} \mathrm{pu}$ - c0001f2f 4

$<$ c base case $1800 \mathrm{~g}++300 \mathrm{~g}$ holdup $+200 \mathrm{~g}$ outside

$<$ glovebox - full water reflection on all sides

$<\mathrm{c}$

$<\mathrm{c} \quad 2100 \mathrm{~g}$ pu in $2 "$ slab on floor mixed with water, 10 * water spray

$<$ c $\quad 150 \mathrm{~g} / \mathrm{cc}$ pu with water above

$>$ glovebox ha20mb cementation model - base case $2100 \mathrm{~g} \mathrm{pu}$ - c0001f2b4

$>c$ base case $900 \mathrm{~g}+0 \mathrm{~g}$ conveyor $+300 \mathrm{~g}$ holdup $+200 \mathrm{~g}$ outside $+900 \mathrm{~g} \mathrm{~h} / \mathrm{x}=20$

$>c$ glovebox - full water reflection on all sides, cement can refl

$7 a 5,17$

$>C$ bowls - two bowls in corner 10" from cans

$>c \quad 0.04167 \mathrm{~g} \mathrm{pu} / \mathrm{cc}$ pu

$>\mathrm{c} \quad 0.200 \mathrm{~kg}$ pu/bowl

$>\mathrm{C} \quad \mathrm{h} / \mathrm{x}=634$

$>c$ sides, bottom of bowls not included

$>\mathrm{C}$ containers $-72.76 \mathrm{~L}$ cans $90 \%$ water $10 \%$ sio2

$>\mathrm{C} \quad 0.02585 \mathrm{~g} \mathrm{pu} / \mathrm{cc}$

$>\mathrm{C} \quad \mathrm{h} / \mathrm{x}=921$

$>C \quad 500 \mathrm{~g} \mathrm{pu}$ total

$>\mathrm{C} \quad 72.76 \mathrm{~L}$ cans pu+watertcarbontsio2

$>\mathrm{c} \quad 0.04652 \mathrm{~g} / \mathrm{cc} \mathrm{pu}$

$>\mathrm{C} \quad \mathrm{h} / \mathrm{x}=20$

$>\mathrm{C} \quad 900 \mathrm{~g}$ pu total

$12 c 22$

$<\begin{array}{llllllllllll}1 & 1 & -0.1 & 1 & -2 & 3 & -4 & 71 & -6 & \text { imp: } \mathrm{n}=1\end{array}$

$>10 \quad 1-2 \quad 3-4 \quad 20-6 \quad$ imp: $n=1$

$26,27036,47$

$\begin{array}{llllllllll}8 & 20 & -1.155242 & 1 & -2 & 3 & -4 & 70 & -72 & \text { imp: } n=1\end{array}$

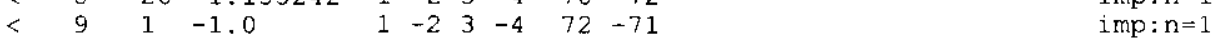

$>c \quad$ bowl

$>83^{3}-1.0431 \quad\left(\begin{array}{lll}(63 & -28\end{array}\right):\left(\begin{array}{lll}-63 & -61 & 69\end{array}\right)-32 \quad$ imp: $\mathrm{n}=1$

C bowl water reflection

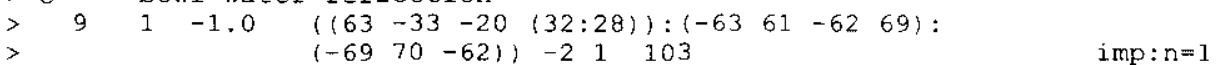

$\begin{array}{llllllllll}10 & 0 & -33 & -63 & 70 & 62 & -2 & 1 & 103 & \text { imp: } n=1\end{array}$

$>$ C bowl

$>113-1.0431\left((63-28):\left(\begin{array}{llll}-63 & -58 & 69\end{array}\right)-34 \quad\right.$ imp: $n=1$

$>$ C bowl water reflection

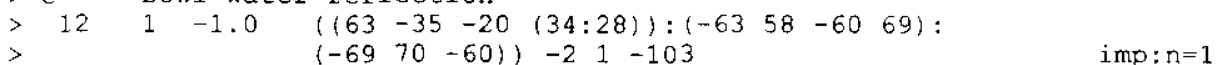

$>130 \quad-35-637060-21-103 \quad$ imp: $n=1$

$29,30 c 49,50$

$<225-1.074970-28-53$

$<230 \quad 70-28 \quad 53 \quad 64-654166-1 \quad$ imp: $n=1$

$\begin{array}{lllllll}-- & 52 & -1.0749 & 70 & -28 & -53\end{array}$

$\begin{array}{rrrrrrrrrrrrr}22 & 5 & -1.0749 & 70 & -28 & -53 & & & \\ 23 & 0 & & 70 & -28 & 53 & 64 & -65 & 41 & 66 & -1 & \text { imp: } n=1 \\ \text { imp: } n=1\end{array}$

$32 c 52,81$

$<2420-1.1552425-70 \quad 1-4 \quad-2 \quad 3$

imp: $n=1$

$\begin{array}{lllllllllll}> & 24 & 8 & -5.562 & 5 & -70 & 1 & -4 & -2 & 3\end{array}$

$>c \quad$ filled cans

imp: $n=1$ 
HNF-5988 Rev. 0

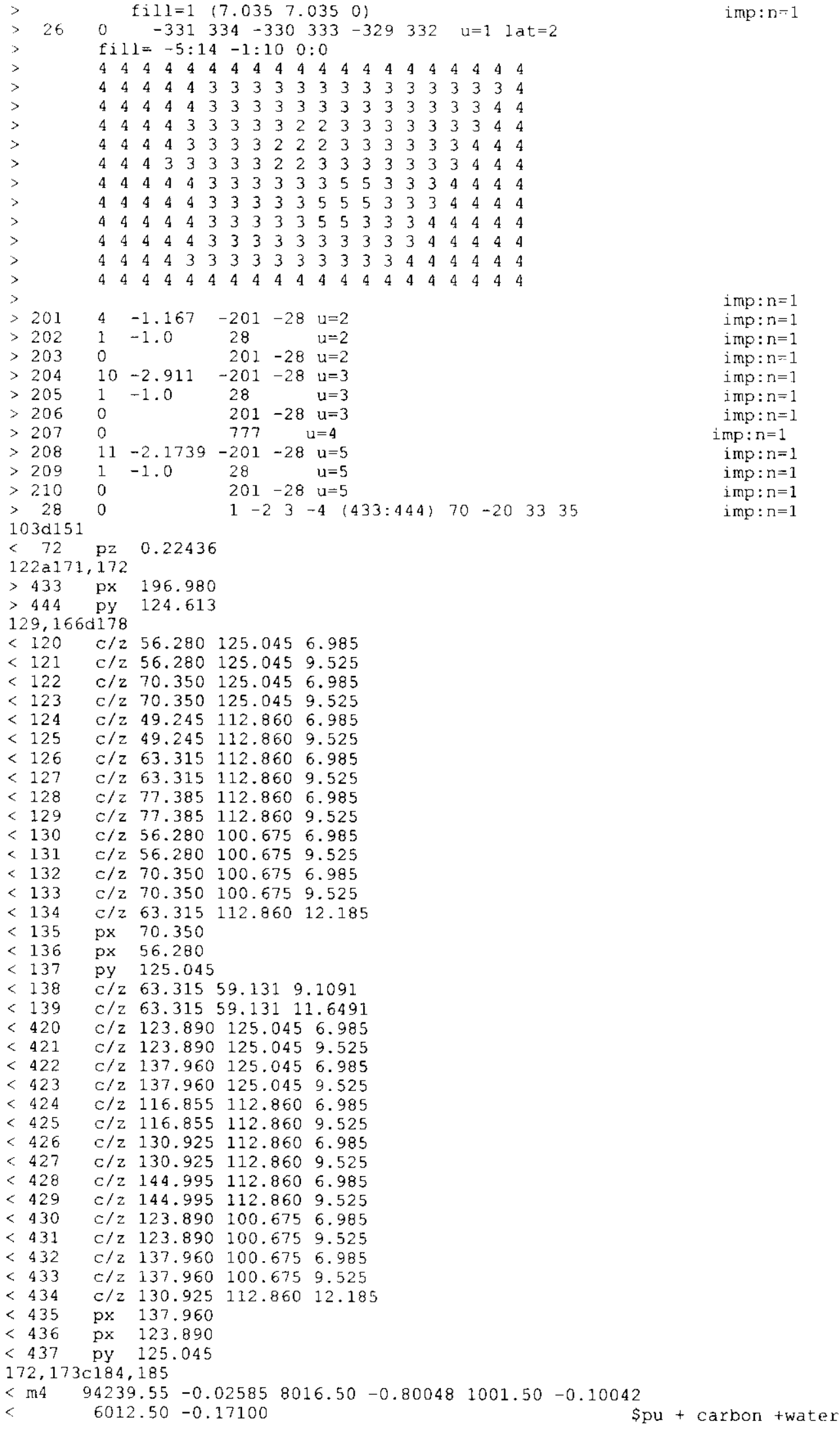




\section{HNF-5988 Rev. 0}

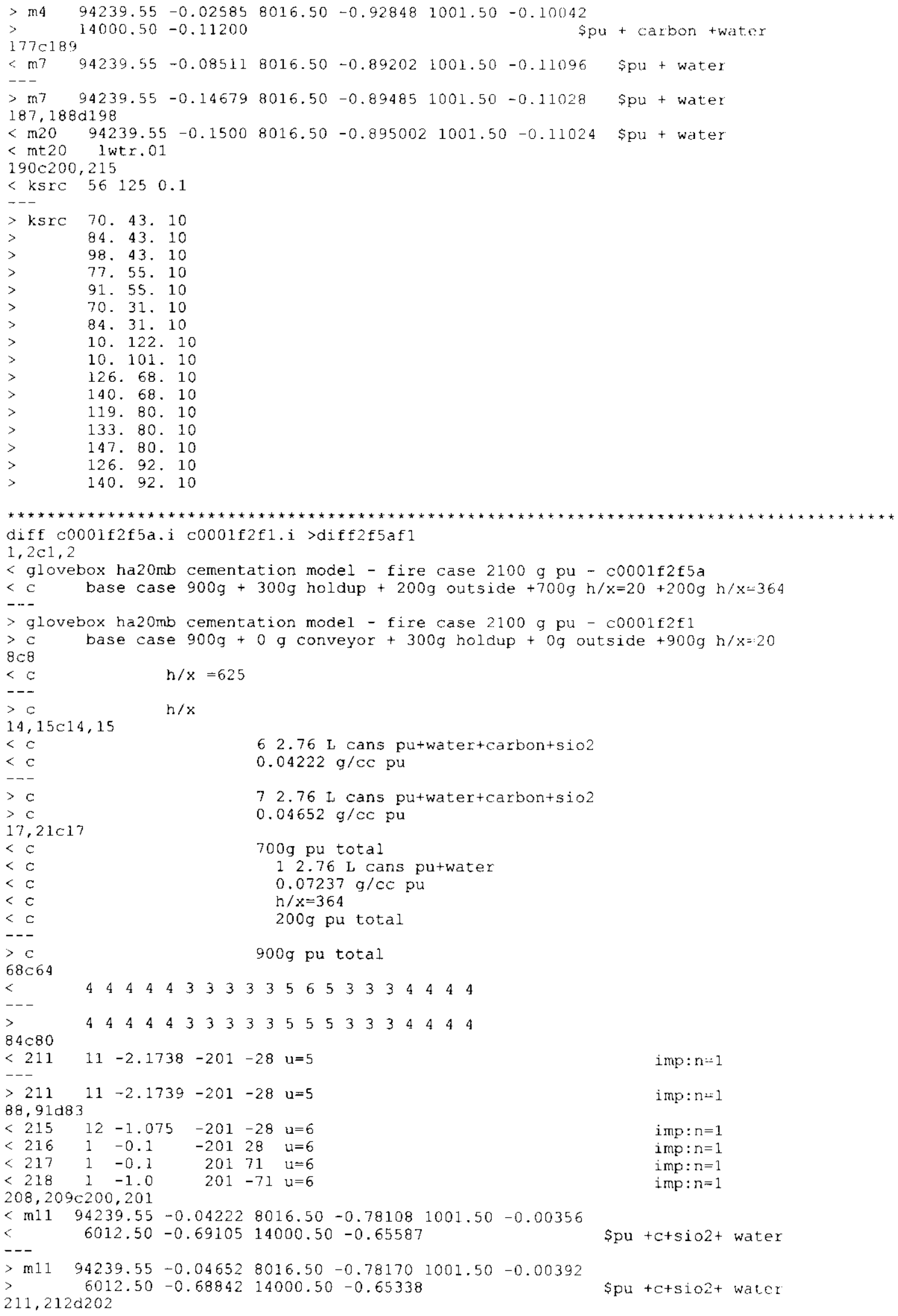


HNF-5988 Rev. 0

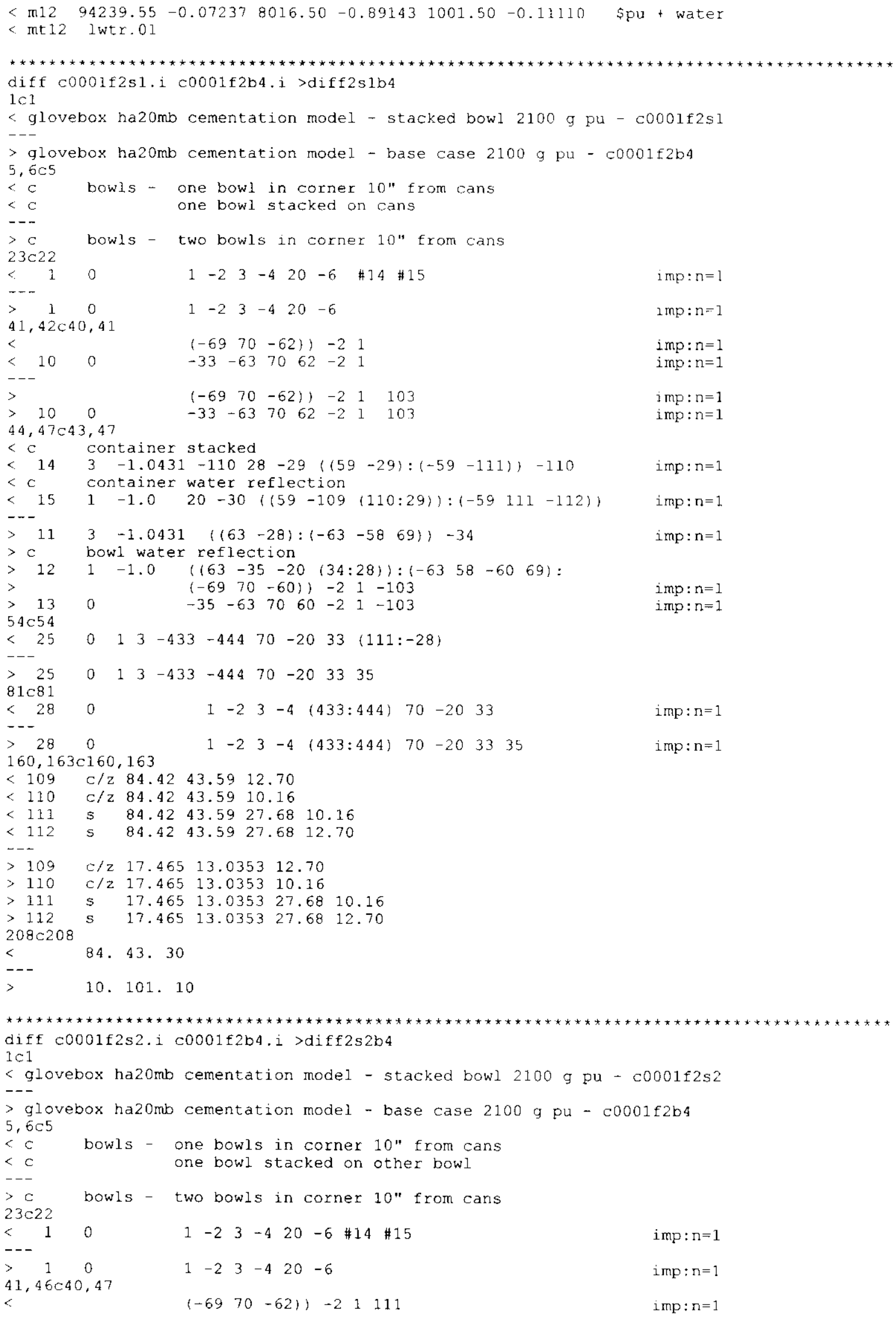


HNF-5988 Rev. 0

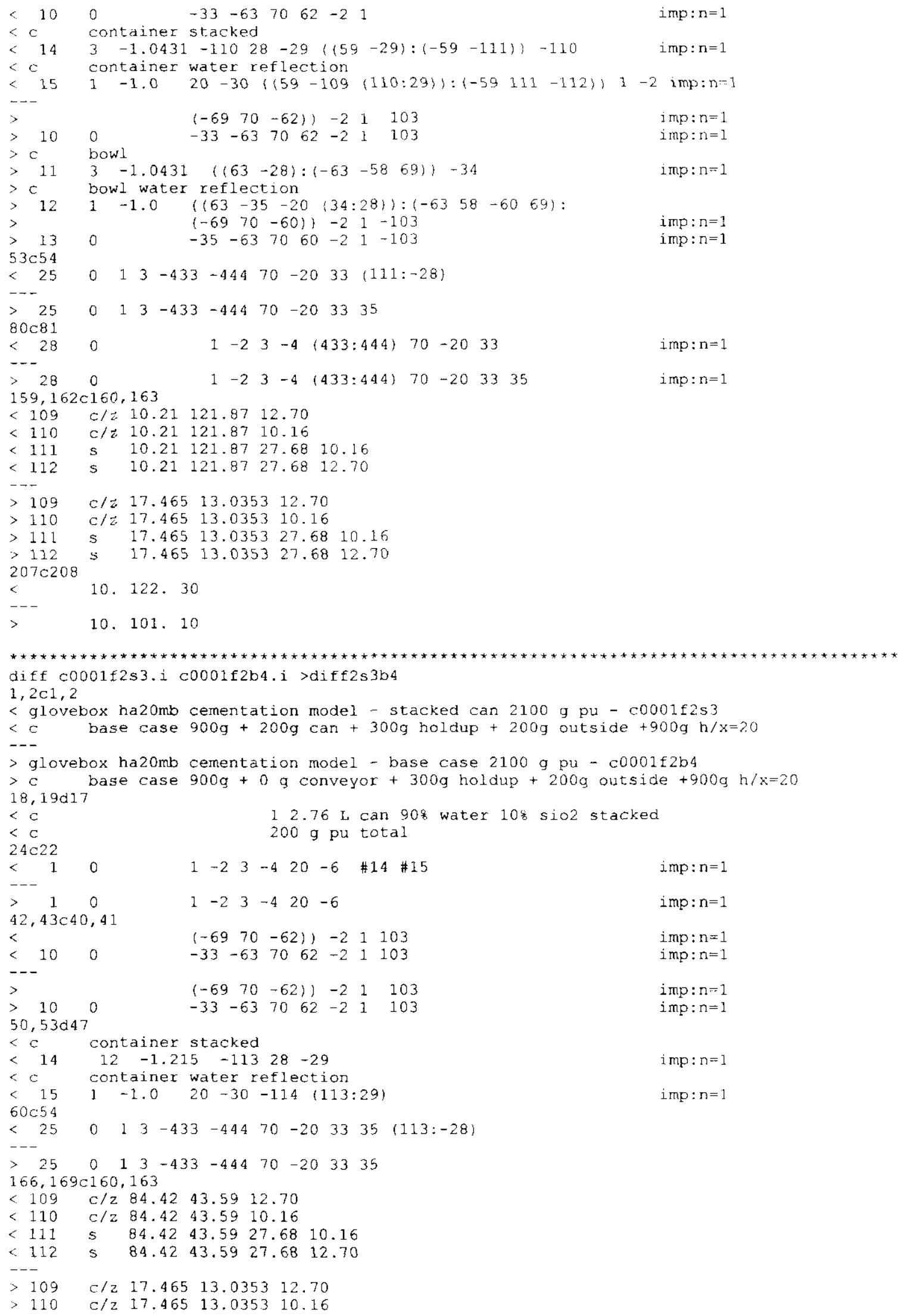




\section{HNF-5988 Rev. 0}

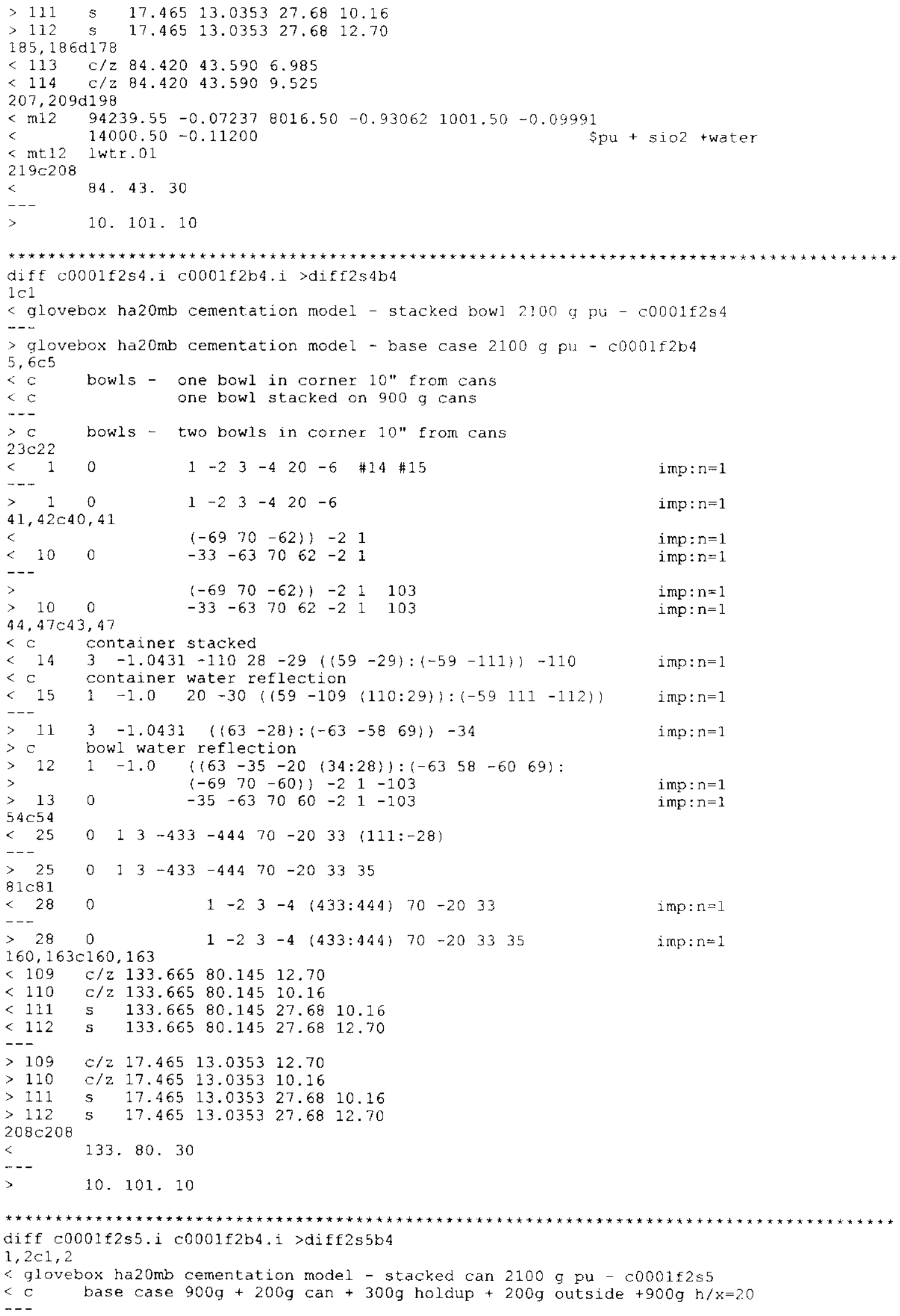




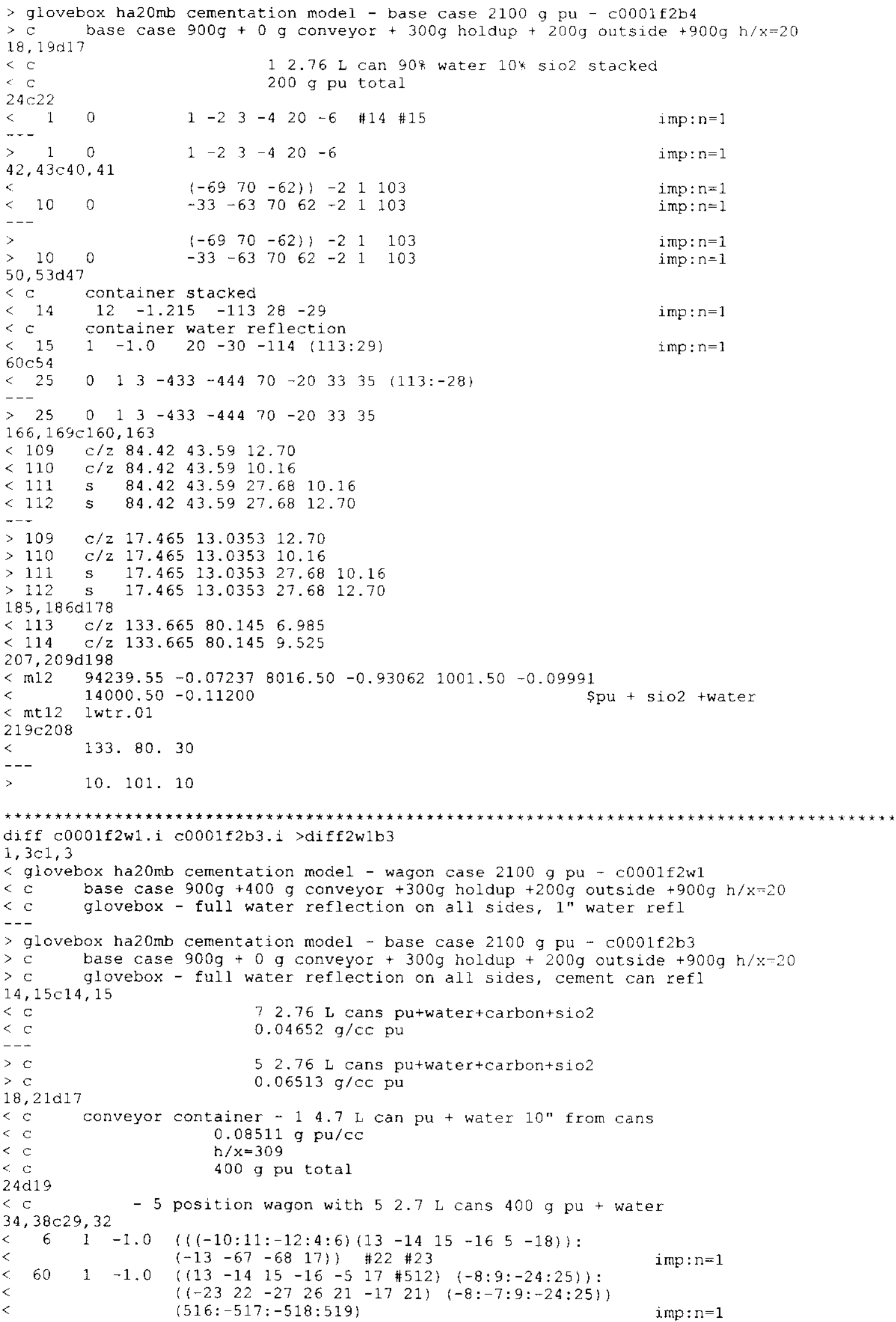


HNF-5988 Rev. 0

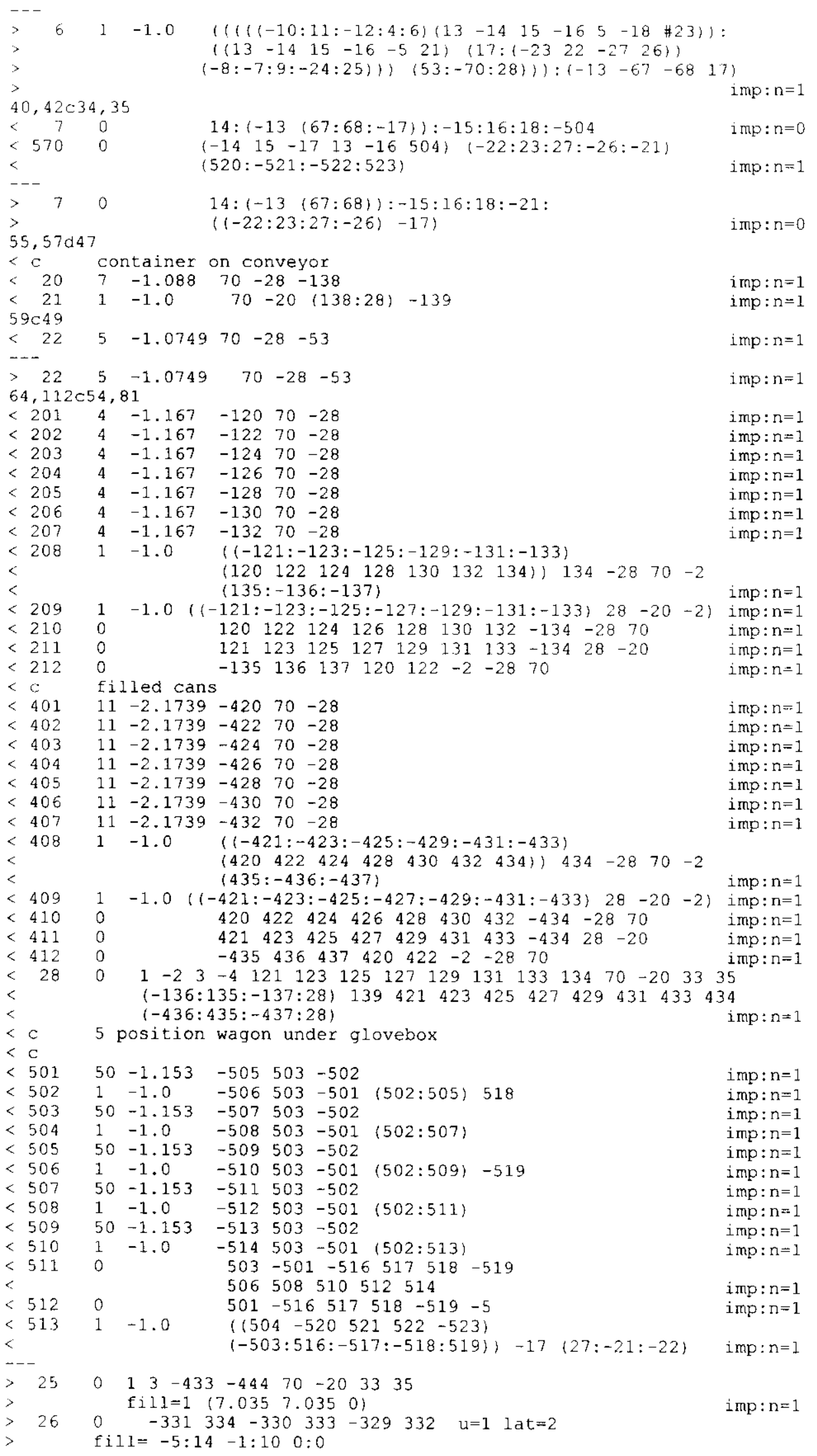

\section{C-81}


HNF-5988 Rev. 0

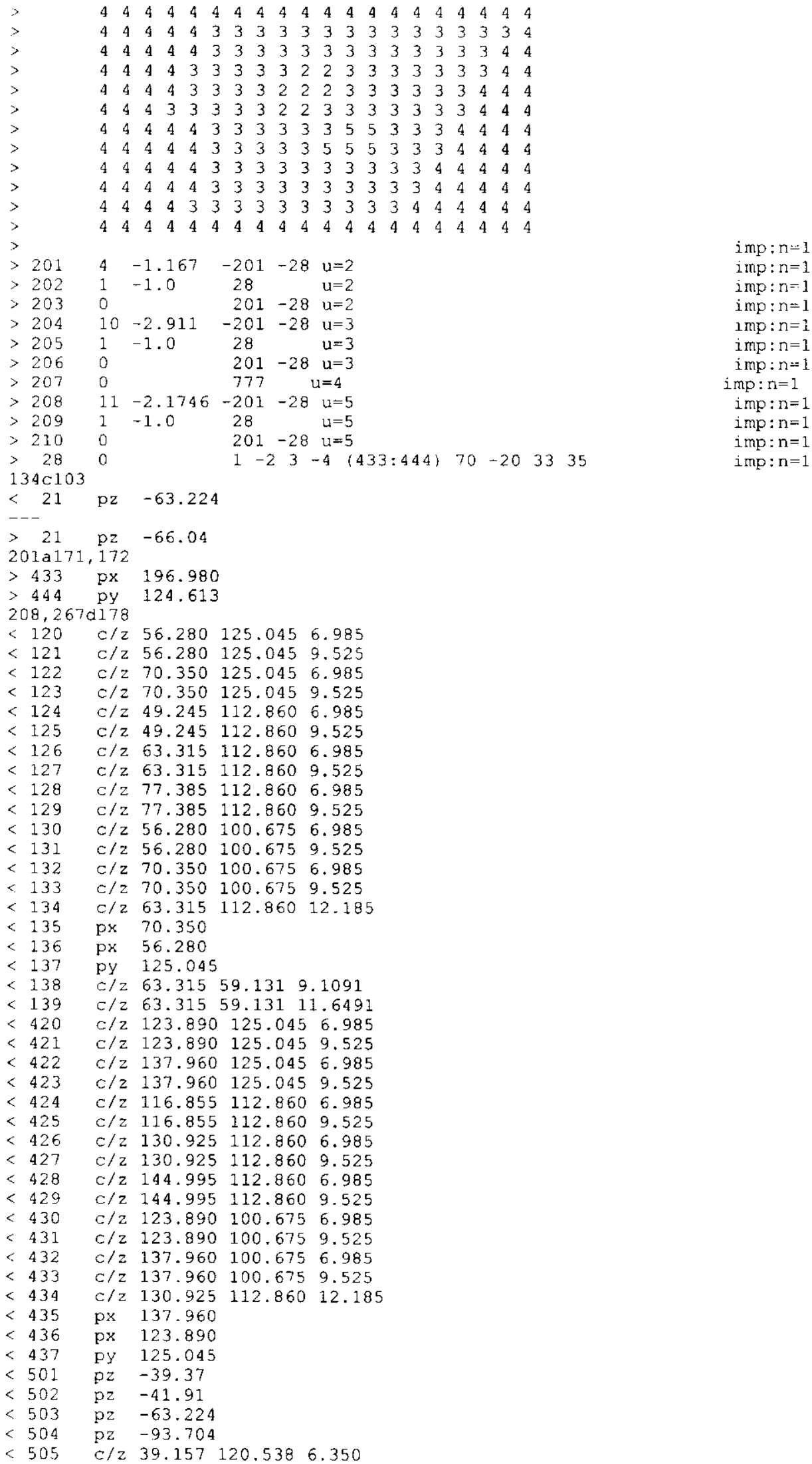




\section{HNF-5988 Rev. 0}

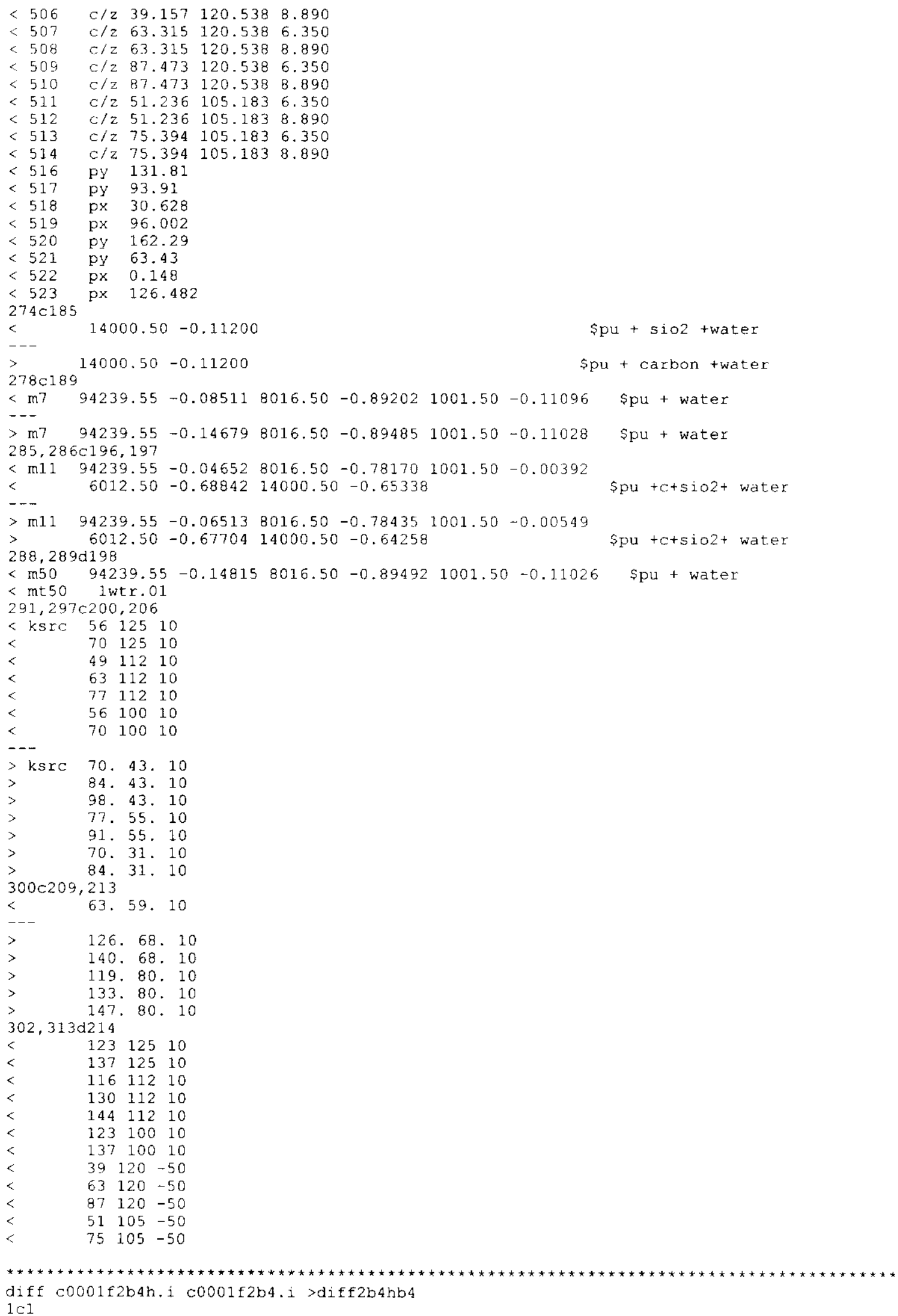


HNF-5988 Rev. 0

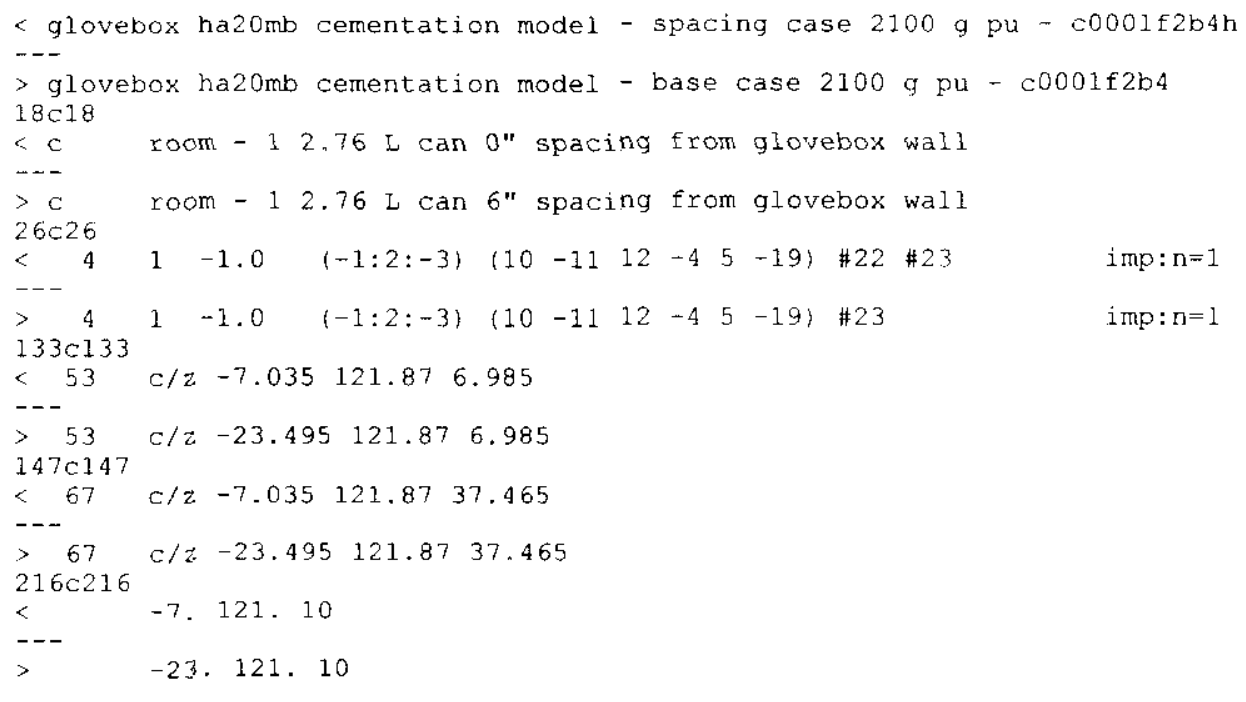

\section{C-84}




\section{HNF-5988 Rev. 0}

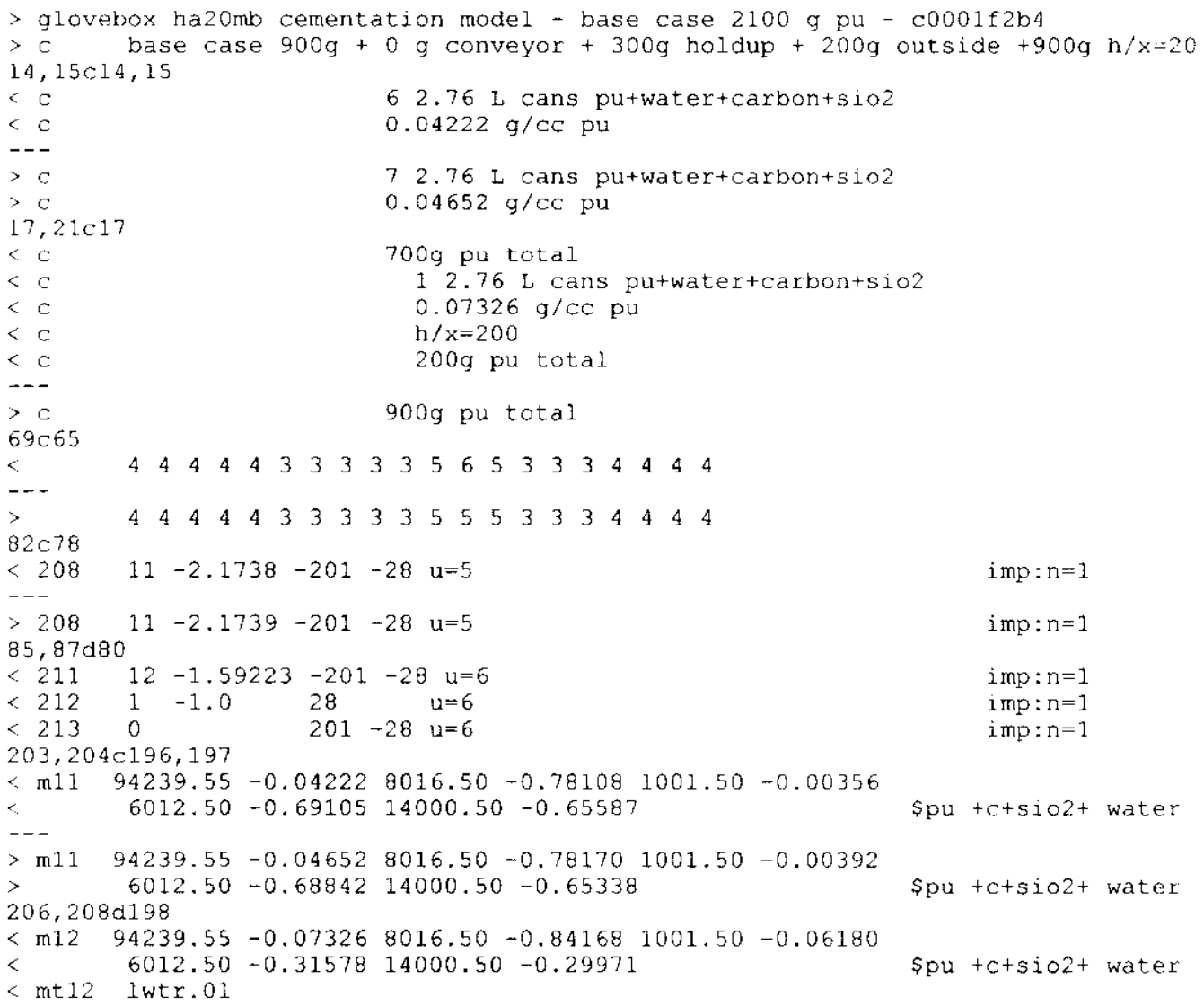




\section{HNF-5988 Rev. 0}

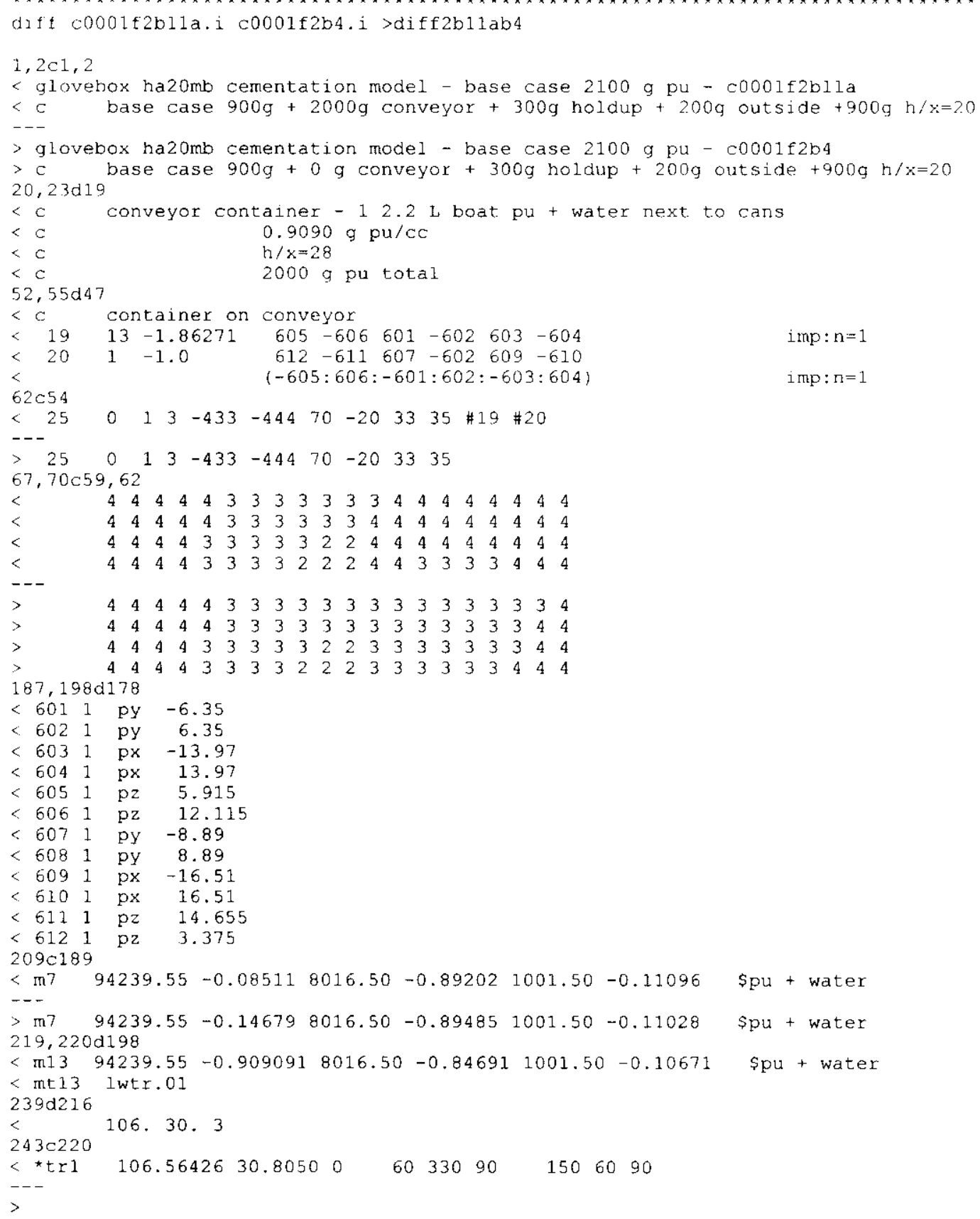


HNF-5988 Rev. 0

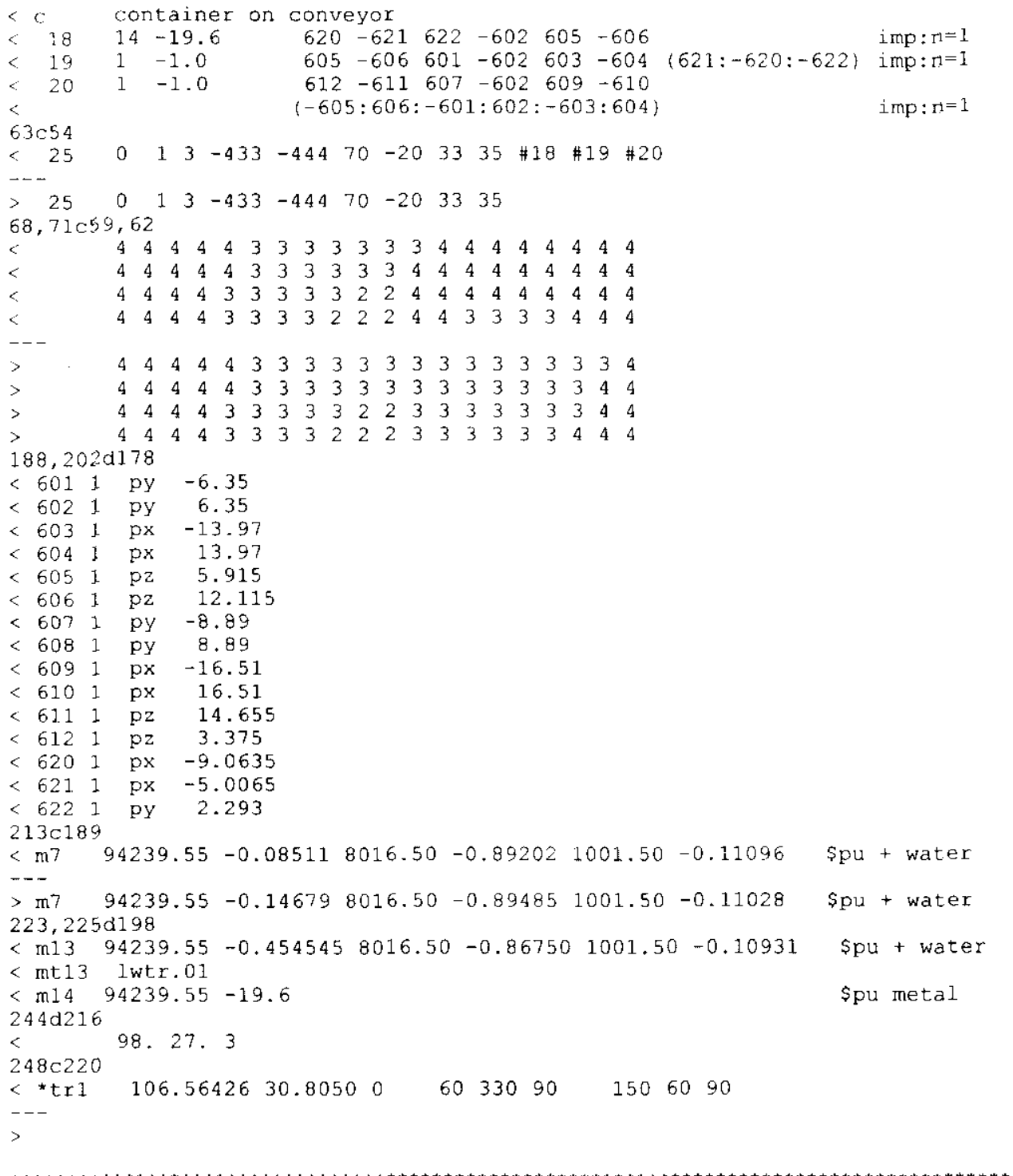

diff c0001f1s8.i c0001f1s4.i >diff2s8s4

$1,2 \mathrm{cl}, 2$

< glovebox ha20mb cementation model - base case $1200 \mathrm{~g}$ pu - c0001fls8

$<\mathrm{c}$ base case $900 \mathrm{~g}+0 \mathrm{~g}$ conveyor + $300 \mathrm{~g}$ holdup $+200 \mathrm{~g}$ outside

$>$ glovebox ha20mb cementation model - base case $1200 \mathrm{~g}$ pu - c0001fls 4

$>c$ base case $900 \mathrm{~g}+0 \mathrm{~g}$ conveyor + $300 \mathrm{~g}$ holdup + 0g outside

$15,16 \mathrm{~d} 14$

$<c$ room - $12.76 \mathrm{~L}$ can no spacing from glovebox wall

$<\mathrm{c} \quad 0.200 \mathrm{~kg} \mathrm{pu}+$ water

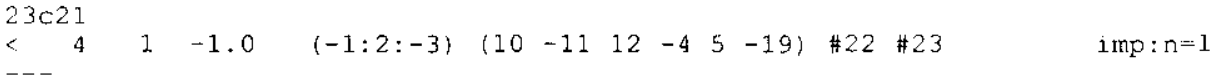

$>\quad 4 \quad 1-1.0 \quad(-1: 2:-3)\left(\begin{array}{lllllll}10 & -11 & 12 & -4 & 5 & -19\end{array}\right) \quad \# 23 \quad$ imp: $n=1$

$\left.\left.\left.\left.\begin{array}{l}28 c 26 \\ <\end{array}(-8:-7: 9:-24: 25)\right)\right)(53:-70: 28)\right)\right):(-15-67-6817)$

$<$

$--$

$31<29$

$(-8:-7: 9:-24: 25)))(53:-70: 28))):(-13-67-6817)$

$<70 \quad 14:(-15(67: 68)):-13: 16: 18:-21:$

$>70 \quad 14:(-13(67: 68)):-15: 16: 18:-21:$

$45,46043,44$ 
HNF-5988 Rev. 0

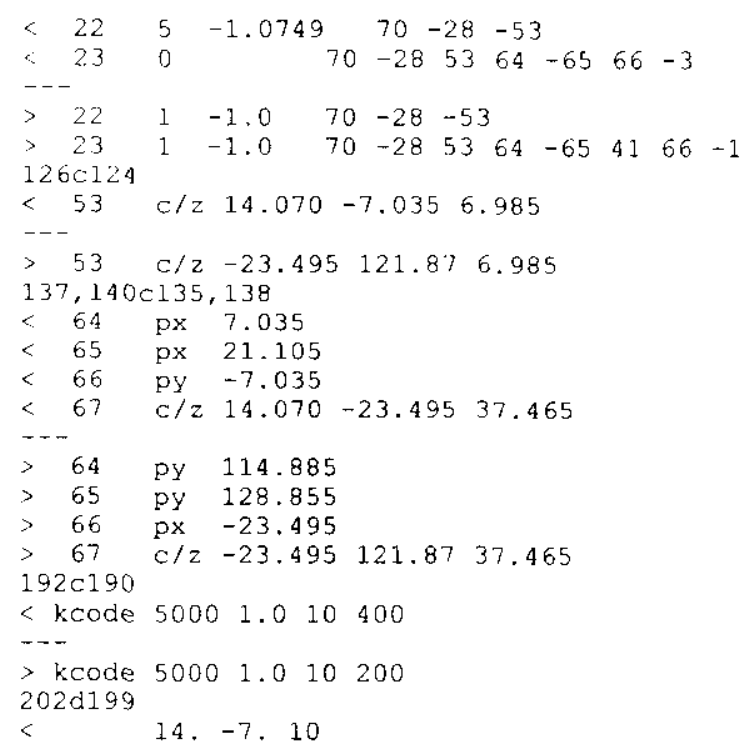


HNF-5988 Rev. 0

\section{APPENDIX D}

PRELIMINARY HAZARDS ANALYSIS

D-1 
HNF-5988 Rev. 0

This page left intentionally blank.

D-2 
HNF-5988 Rev. 0

\section{D1.0 HA-20MB CEMENTATION GLOVEBOX CRITICALITY PRELIMINARY AZARDS ANALYSIS}

\section{D1.1 PURPOSE}

The purpose of this Preliminary Hazard Analysis (PHA) is to identify the important process parameters and conditions that could impact the potential for the occurrence of a criticality in the PFP HA-20MB Glovebox. The results of this PHA will be used for input into the HA-20MB Glovebox Criticality Safety Evaluation Report (CSER).

\section{2.0 HAZARDS EVALUATION}

A PHA is a hazards identification/evaluation technique derived from the U.S. Military Standard System Safety Program Requirements (MIL-STD-882). A PHA is a structured discovery process involving a multi-disciplinary team and focuses on the hazardous materials and major process areas of a facility. The results of the PHA are recorded using a tabular format. Because of its military heritage, the PHA technique is useful for reviewing process areas where energy can be released in an uncontrolled manner. In general, the PHA formulates a list of hazards and hazardous situations by considering the following process characteristics:

- $\quad$ Raw materials, intermediate and final products, and their reactivity

- $\quad$ Plant equipment

- Facility layout

- Operating environment

- Operational activities (testing, maintenance, etc.)

- Interfaces among system components.

The American Institute of Chemical Engineers (AIChE) recognizes the PHA process as a creditable method of hazard evaluation. AIChE describes this process in their publication titled "Guidelines for Hazard Evaluation Procedures" (AIChE 1992).

The depth of a PHA is directly related to the experience and knowledge of the participants. A short resume of each team member is included (Section 3.0) to document the experience and knowledge of the PHA team. 
HNF-5988 Rev. 0

\section{D2.1 PHA EVALUATION STRUCTURE}

The hazardous condition of concern for this PHA is a nuclear criticality. Criticality events are prevented by establishing limits for specific parameters. These parameters are referred to as controlled parameters. This PHA was structured to address the following controlled parameters:

- Mass

- Volume

- Geometry

- Moderation

- Reflection

- Interaction

- Enrichment

- Density

- Concentration

- Poisons

The process occurring in the HA-20MB Glovebox involves stabilization of $\mathrm{Pu}$ bearing materials in a Portland cement matrix. The PHA considered the controlled parameters in the context of the process steps that occur in the glovebox during the $\mathrm{Pu}$ cementation operation.

\section{D2.2 PHA TABLE DESCRIPTION}

The PHA table (Table A-1) was structured to ensure a systematic and thorough evaluation of the controlled parameters. The PHA table captured the following information:

ID: Item Identification; used to record a unique identifier for the hazardous condition

Process Condition: The process condition for which deviations of controlled parameters are being evaluated for the potential to cause a criticality in the HA-20MB Glovebox.

Controlled Parameter: Parameters that are controlled to prevent the occurrence of criticality events. Ten parameters are used: mass, volume, moderation, interaction, reflection, geometry, enrichment, density, concentration, and poisons.

General Cause: The general cause leading to the hazardous condition. In many cases, multiple hardware or operational faults are required to produce the hazardous condition. This column, in conjunction with the following column, identifies the 
sequence of hardware or operational faults postulated to produce the hazardous condition.

Detailed Causes: Specific causes within the general group of causes identified in the preceding column that can lead to the hazardous condition. This column is used to capture details that may be important in the analysis that will define the controls to prevent a criticality.

Existing Eng Safety: Hardware items identified by the PHA team that have the potential to mitigate or prevent the hazardous condition of concern

Existing Admin Safety: Administrative controls such as facility worker training and safety procedures identified by the PHA team that have the potential to mitigate or prevent the hazardous condition

Freq Cat NC: Frequency Category, No controls - The frequency ranking is a qualitative estimate of whether the hazardous condition is considered credible or not.

Conditions considered not credible will not be evaluated further.

Remarks: Miscellaneous observations or clarifying comments for a given item. This column is also used to capture criticality analysis requirement decisions of the PHA team.

\section{D2.3 PHA RESULTS}

The results of this PHA are in the form of information to be considered as part of the Criticality Safety Evaluation Report (CSER). The raw data is presented in Table A1. The information contained in the PHA table is used to ensure that the CSER analysis addresses the appropriate conditions that may contribute to a criticality in the HA-20MB Glovebox. The following assumptions that are important to the CSER analysis were extracted from Table A1.

\section{PFP Glovebox HA-20MB Criticality PHA Assumptions and Dispositions Derived from the PHA:}

Assumptions Regarding Physical Configuration Outside Glovebox HA-20MB:

1. Assume lard can wagon, five position wagon, or waste drum can pass next to the north side of Glovebox HA-20MB. The criticality safety evaluation report (CSER) will assume that either are present as part of normal operations.

2. Only one waste drum at a time is allowed to be moved in Room $235 \mathrm{~B}$ during normal operations. 
3. The lard can or a five position wagon could pass underneath the glovebox. These will be considered as a contingency in the CSER.

4. Boats from HA-21I could, but would not normally, be moved past the glovebox on conveyor HA-28. The CSER will consider a container of $400 \mathrm{~g}$ of fully moderated material on the conveyor to bound this condition.

5. Material from Glovebox $23 \mathrm{~S}$ could, but would not normally go by the glovebox on conveyor HA-28. The CSER will consider a container of $400 \mathrm{~g}$ of fully moderated material on the conveyor to bound this condition.

6. It will be assumed that no Hanford Convenience Cans (HCCs) will be present on Conveyor Glovebox HA-28 or in Room 235B. This is based on the current HA-28 Criticality Prevention Specifications (CPS) which does not allow this. Operations does not anticipate using Conveyor Glovebox HA-28 for HCCs in the future.

Assumptions Regarding Internal Glovebox Operations:

1. Several operators may be present during the cementation operations. Full reflection around the glovebox will be analyzed.

2. Multiple operations within the glovebox are anticipated to take place concurrently. The limits established in the CPS will accommodate this mode of operation.

3. The current anticipated feed is sand, slag and crucible (SSC). However, the CSER will consider future feed materials of sludge, ashes, fluorides, oxides (floor sweeps), and oxides $<30 \%$ Pu. The CSER analysis will bound these future feed materials by analyzing optimally water moderated $\mathrm{Pu}$.

4. Moderators/reflectors better than water are not considered credible.

5. Access to the bottom of the glovebox is possible. This is bounded in the CSER by considering movement of material under the glovebox or personnel access under the glovebox.

6. Only 2 mixing bowls will be in use. It is anticipated that additional mixing bowls will be present but turned upside down so as not to be containers.

Assumptions Regarding Physical Configuration Inside Glovebox HA-20MB:

1. The glovebox is seismically qualified will remain upright and will not collapse during a seismic event (SE). 
HNF-5988 Rev. 0

2. Equipment mountings inside the glovebox are not seismically qualified. Thus, equipment contents could be spilled in a seismic event.

3. A sealed metal plate covers a conveyer belt at the bottom of the glovebox. However, the seal is not qualified as a safety barrier and could fail and allow water, powder, or slurry to accumulate in the conveyor housing. This material will be analyzed as distributed along the floor.

4. The glovebox has no criticality drain. However, the maximum liquid depth in the glovebox is $\sim 5.08 \mathrm{~cm}(\sim 2$ in.) due to a ledge between the glovebox and the HA-28 conveyor. Above this depth, liquids in HA-20MB drain into the HA-28 conveyor. The CSER will consider the ledge trapping water in the glovebox.

5. Liquid in the HA-28 conveyor drains into HA-21I which has a criticality drain.

6. It is desirable to simultaneously have in the glovebox at least 4 slip lid cans with a charge in them, a charge in reactor, a charge in mixer, an indeterminate number of feed cans, an indeterminate number of billet cans present, and material in the crusher and crusher pan. The Pu mass limit identified in the CSER will bound this condition.

7. When not in use the sieve assembly is turned upside down so that it is not a container.

8. $\mathrm{Pu}$ is assumed to be ${ }^{239} \mathrm{Pu}$; it is not credible for uranium to exceed $50 \%{ }^{235} \mathrm{U}$ enrichment in this glovebox.

9. Addition of fissile material into the glovebox feedwater tank will not be considered in the CSER. Purposeful introduction of fissile material into this tank will be procedurally prohibited. Accidental addition of fissile material into the tank is not credible based on the following considerations: storage of material is at a lower level than the tank; material movement does not occur over the tank; tubes block the opening of the tank; glovebox structural support blocks the opening in the top of the tank. 


\section{D3.0 PHA TEAM MEMBER BIOGRAPHIES}

LaPriel Dayley - Project Enhancement Corporation, Project Engineer. Ms. Dayley has 15 years of experience working at the Hanford Site. She spent about 4 years as technical support for $\mathrm{N}$ Reactor and 7 years as Process Engineer at PFP. She was the Cementation process cog engineer for initial process start up in 1996. Her experience includes specifying equipment, acting as PIC for equipment installation, developing procedures and technical basis documents and shift technical support. Ms. Dayley has a Bachelor of Science degree in Chemical Engineering from the University of Washington.

Ken Dobbin - Fluor Federal Services, Inc, Criticality Safety Engineer - Mr. Dobbin has 25 years experience as a nuclear engineer, 20 of these years analyzing reactor physics and fuel management and 5 years in criticality safety. He is qualified as a Criticality Safety Engineer at the Plutonium Finishing Plant and has 20 months experience with PFP systems. During his PFP tenure, he contributed criticality safety expertise for the successful completion of an Operational Readiness Review to resume thermal stabilization of plutonium. Mr. Dobbin has both undergraduate and masters degrees in nuclear engineering.

David G. Erickson - Fluor Federal Services, Criticality Safety Engineer. Mr. Erickson has a B.S. in Physics, and has been at the Hanford Site for 16 years performing analysis in the fields of reactor physics and 13 years in criticality safety. He is familiar with the codes used in criticality analysis and has performed analysis and reviews of other PFP operations. He is a qualified Criticality Safety Specialist with FFS, and is the Technical Peer Reviewer for this project.

Brit E. Hey, Fluor Federal Services, Inc - Scribe for PHA. Mr. Brit Hey has over 18 years of combined engineering and management experience in the commercial and DOE nuclear industries. For the last 10 years Mr. Hey has performed safety analysis for numerous Hanford facilities and activities including tank farms, the waste encapsulation and storage facility, B-Plant, and the plutonium finishing plant. Mr. Hey has successfully completed the Process Hazard Analysis Leader training course offered by the ABS Group, Inc. Mr. Hey has both undergraduate and masters degrees in nuclear engineering from North Carolina State University.

Alan Ramble - B\&W Hanford Company, PFP Facility Engineering - Mr. Ramble is currently the Criticality Safety Representative, the cognizant engineer for the Safety Analysis Report, and project manager for the Solution Stabilization Project at the Plutonium Finishing Plant. As Criticality Safety Representative, Mr. Ramble has responsibility for implementation of the criticality safety program at PFP, including approval of Criticality Safety Evaluation Reports, Criticality Prevention Specifications, operating procedures, initial training and annual retraining of fissile material handlers, and inspection for compliance with criticality safety requirements of PFP. 
Robert F. Richard, Fluor Federal Services, Inc., Criticality Safety Engineer - B.S. Nuclear Engineering. Thirteen years experience at Hanford performing nuclear engineering analyses in fuel management, reactor physics, radiation shielding, and seven years in criticality safety.

Maria E. Shaw - B\&W Federal Services - Nuclear Criticality Safety Representative Nuclear Engineer. Ms. Shaw has worked as an engineer since 1991 and has been at the Hanford site since 1998. She has worked at the Plutonium Finishing Plant as a criticality safety representative and is plant certified as a Criticality Safety Representative. She has worked on the PFP thermal stabilization project. Ms. Shaw holds a B.S. in Math from Idaho State and M.S. in Chemistry from Univ. of Idaho. Prior to Hanford, she worked in the criticality safety field at Idaho National Engineering Laboratory and at the Navel Nuclear Fuel Facility (Lynchburg, VA.)

Mílton V. Shultz, Jr. - Fluor Federal Services Inc., Safety Analysis and Risk Assessment. B.S. Nuclear Engineering Technology. Facilitator for Glovebox HA-20MB PHA. More than twenty-six years experience in a broad range of engineering and technical assignments at the Hanford Site. Experience includes leading PHAs and HAZOPs for a variety of TWRS and PFP projects, including several for the TWRS FSAR and BIO efforts, contributor to the hazards analysis work for the TWRS BIO. Has performed independent Nuclear Safety evaluations of reactor plant design and operation at Hanford's N Reactor.

Brian D. Skeels - Flour Hanford Company, PFP Stabilization Operations, Thermal Stabilization Support Team Leader. Mr. Skeels has 15 years experience at the Hanford Site. His experience has been at $100-\mathrm{KE} / \mathrm{KW}$ basins, $100 \mathrm{~N}$ and PFP. Mr. Skeels has been at PFP for 12 years with 9 years as a First Line Supervisor/Manager. Mr. Skeels is currently the Team Leader for the Thermal Stabilization Support Team (TSST). Prior to being assigned as the TSST Team Leader, Mr. Skeels was a Shift Manager in charge of both the Cementation and Thermal Stabilization Processes during their operating campaigns. Mr. Skeels is currently qualified on the Cementation process as it was operated during the last campaign.
Alan D. Wilkinson, Fluor Federal Services, Inc, Criticality Safety Engineer, - Mr. Wilkinson has a B.S. Nuclear Engineering and M.S. Nuclear Engineering with an emphasis on Nuclear Criticality Safety. He has five years experience at Rocky Flats performing nuclear criticality safety analysis, and is now supporting PFP as a nuclear criticality safety engineer.

David W. Wootan, Fluor Federal Services, Inc, Criticality Safety Engineer, - Mr. Wootan has a B.S. Nuclear Engineering and M.S. Nuclear Engineering. He has twenty years experience at Hanford performing nuclear engineering analyses in the areas of reactor physics, shielding, and characterizing radiation environments, with 4 years experience in criticality safety. 


\section{HNF-5988 Rev. 0}

\section{D4.0 REFERENCES}

AIChE, 1992, Guidelines for Hazard Evaluation Procedures, American Institute of Chemical Engineers, New York, New York.

MIL-STD-882B, 1977, System Safety Program Requirements, Department of Defense, Washington, DC 
HNF-5988 Rev. 0

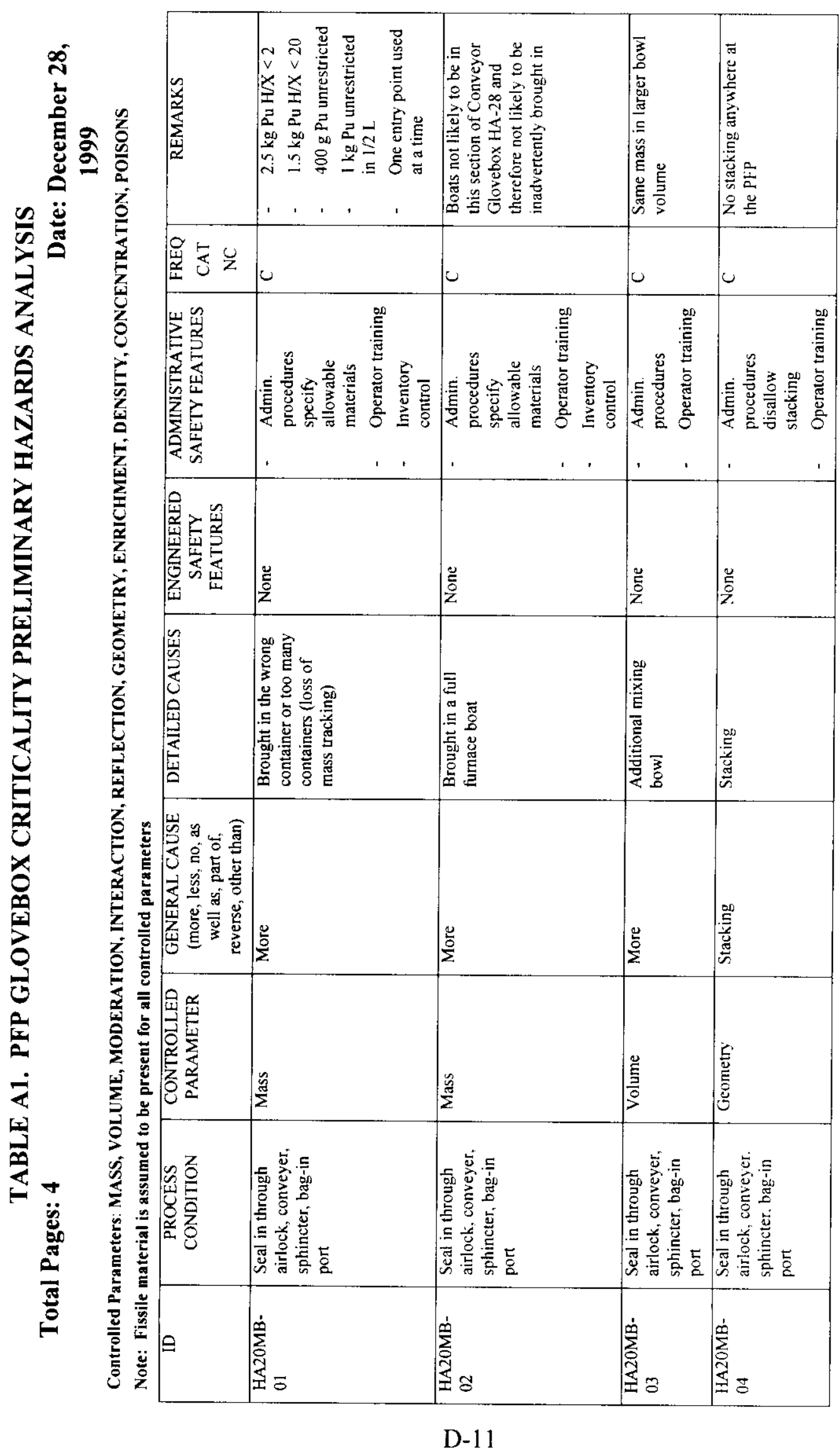


HNF-5988 Rev. 0

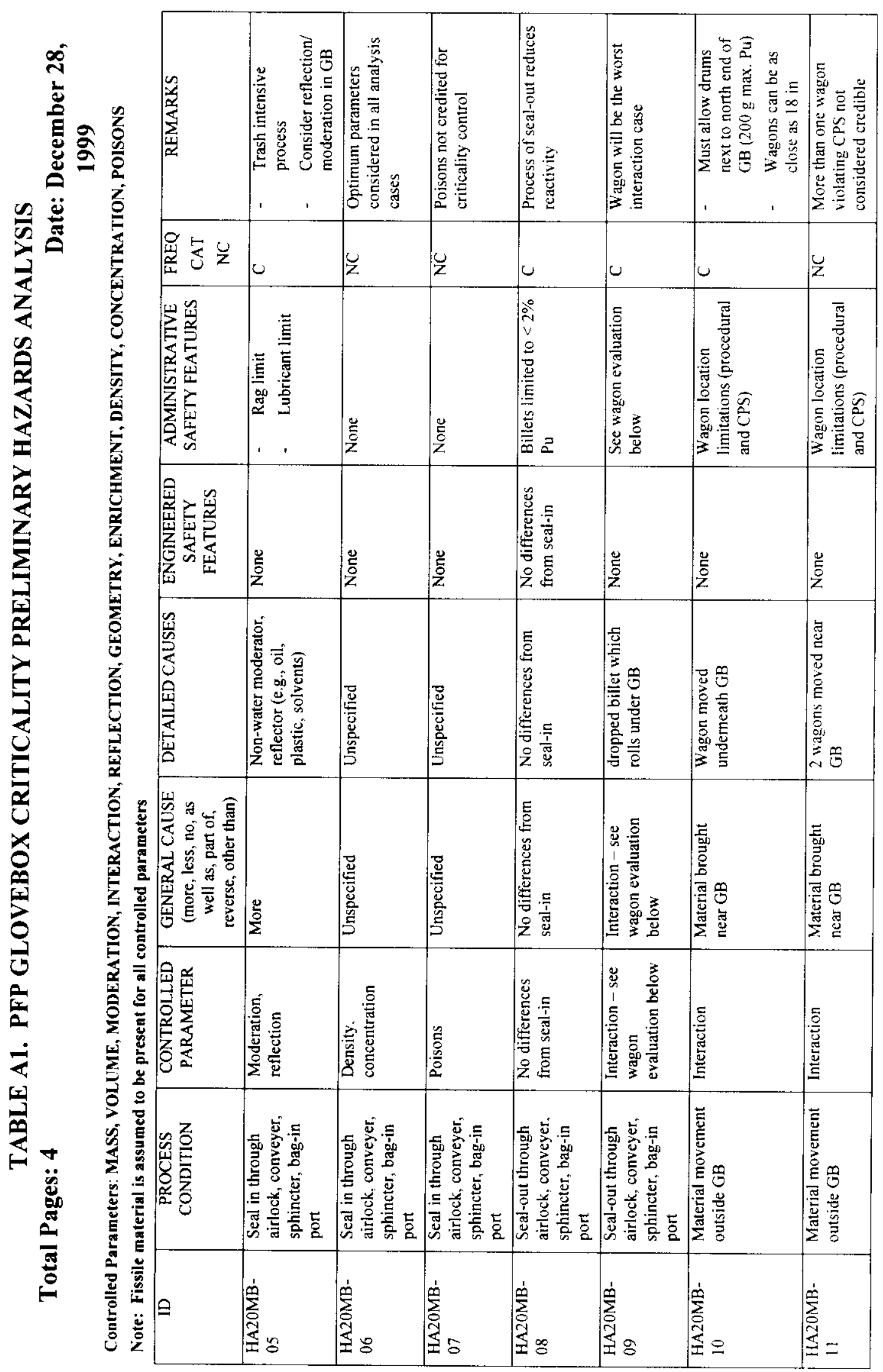

D-12 
HNF-5988 Rev. 0

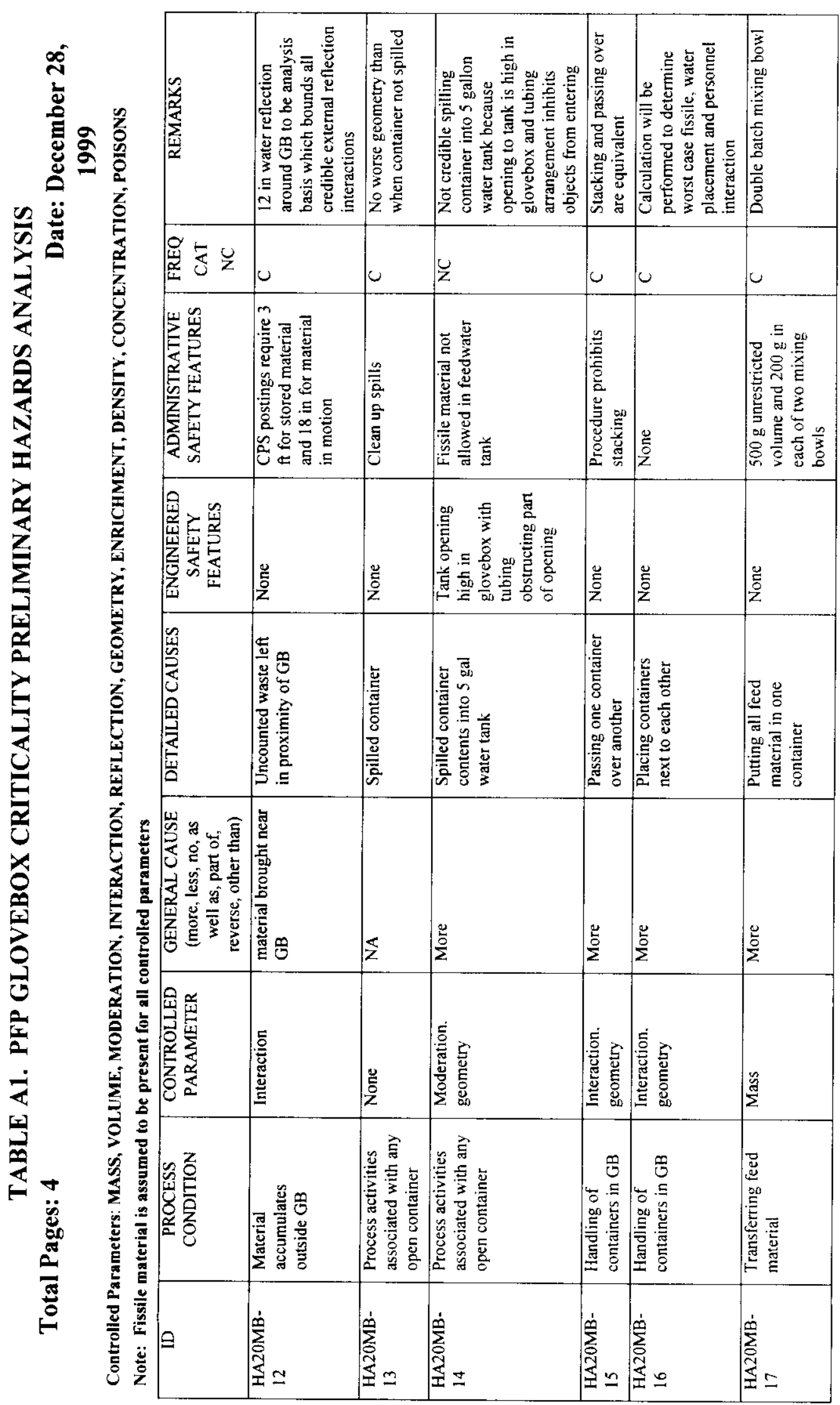

D-13 
HNF-5988 Rev. 0

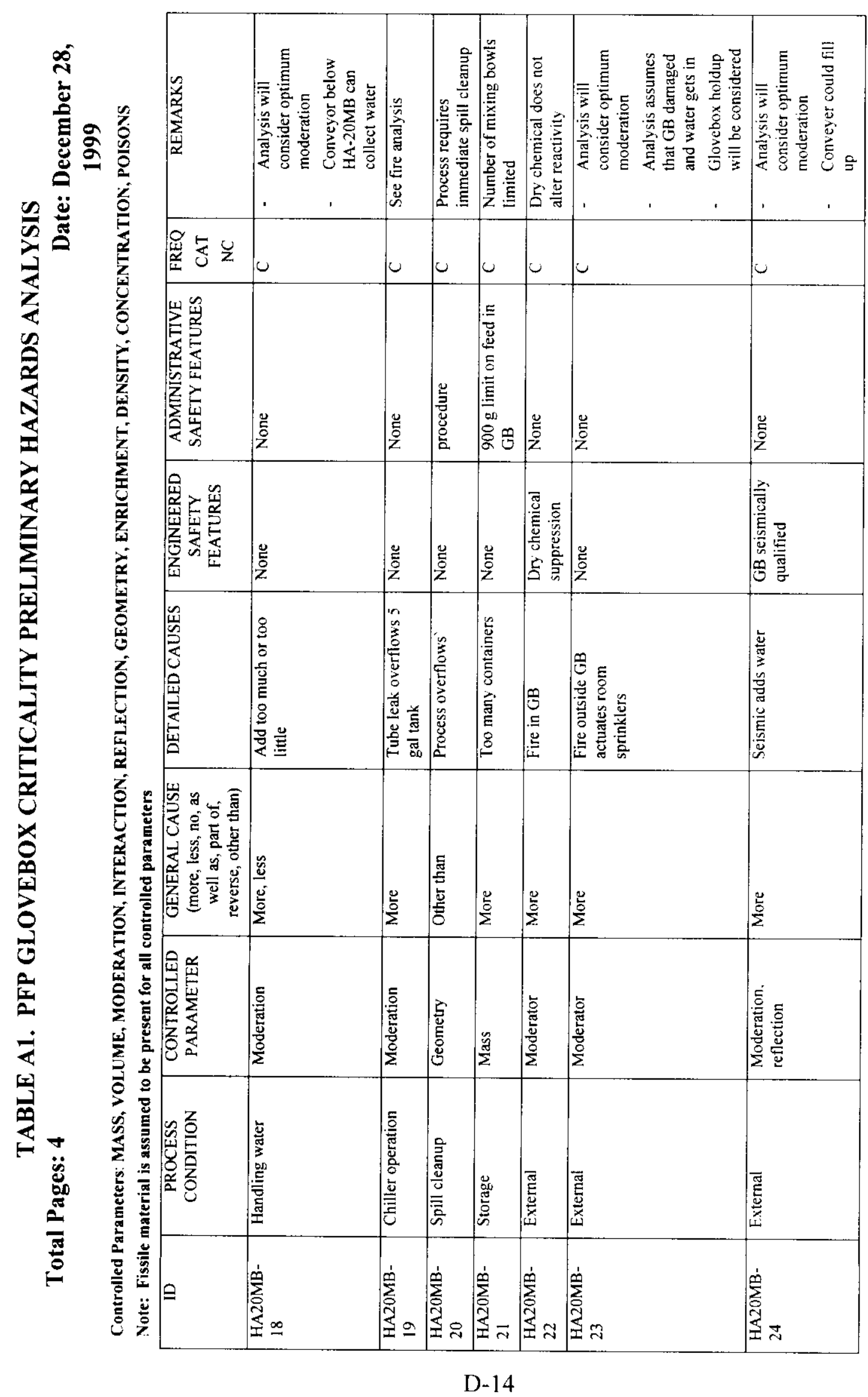


HNF-5988 Rev. 0

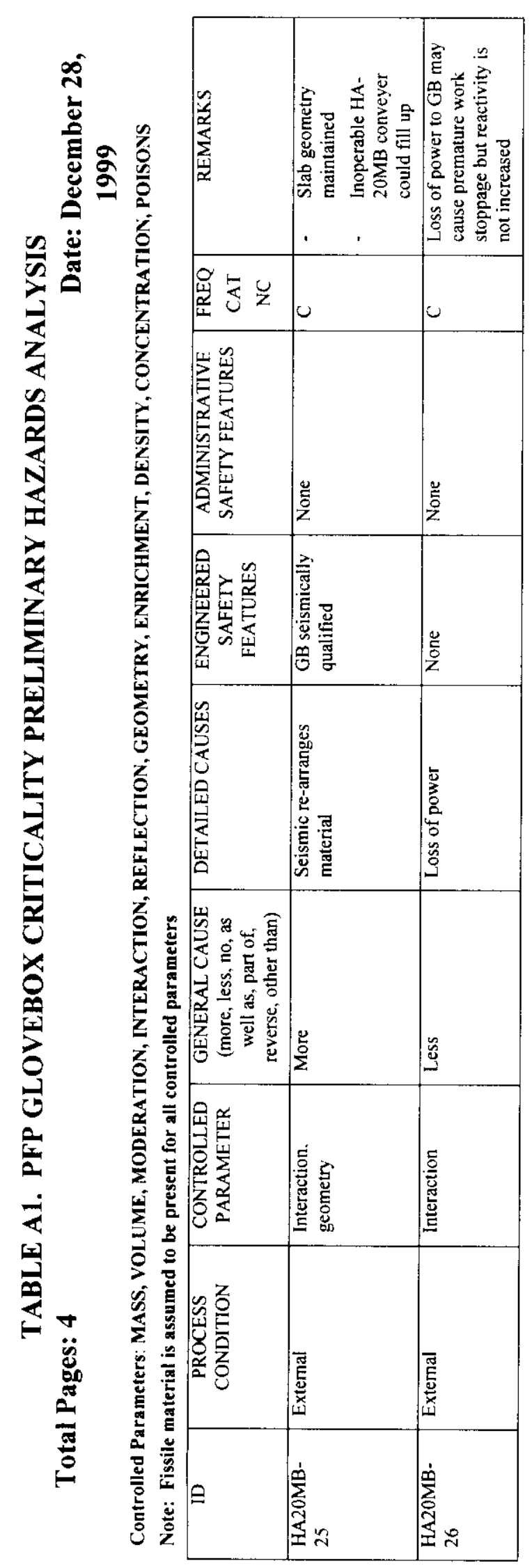

D-15 
HNF-5988 Rev. 0

This page intentionally left blank.

D-16 
HNF-5988 Rev. 0

APPENDIX E

MCNP MODEL FIGURES

E-1 
HNF-5988 Rev. 0

This page intentionally left blank.

E-2 


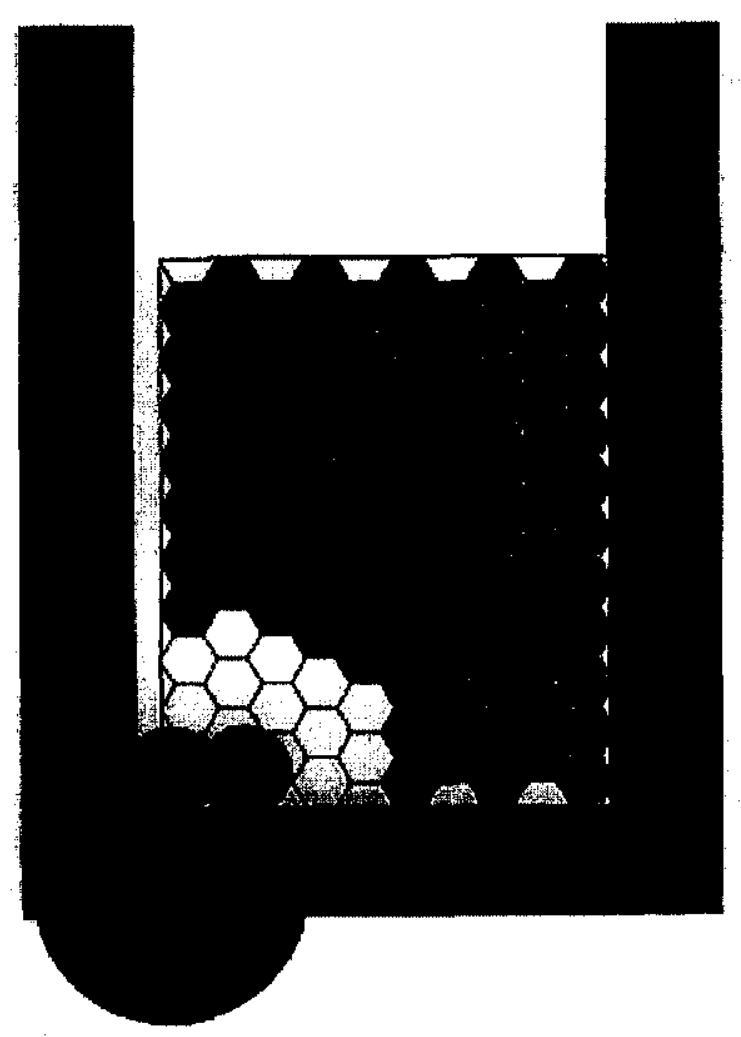

Figure $11200 \mathrm{~g}$ base case with cement can reflection Case c0001fib7b

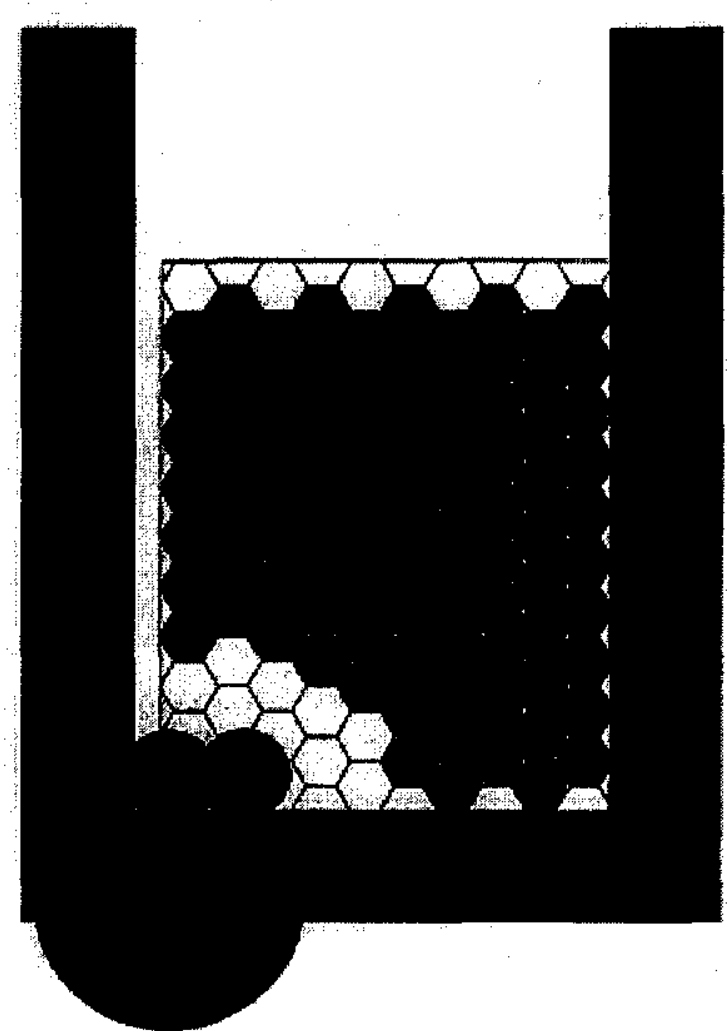

Figure $31200 \mathrm{~g}$ base case variation with cans in corner case $\mathrm{c0001 \textrm {flb }}$ 7c

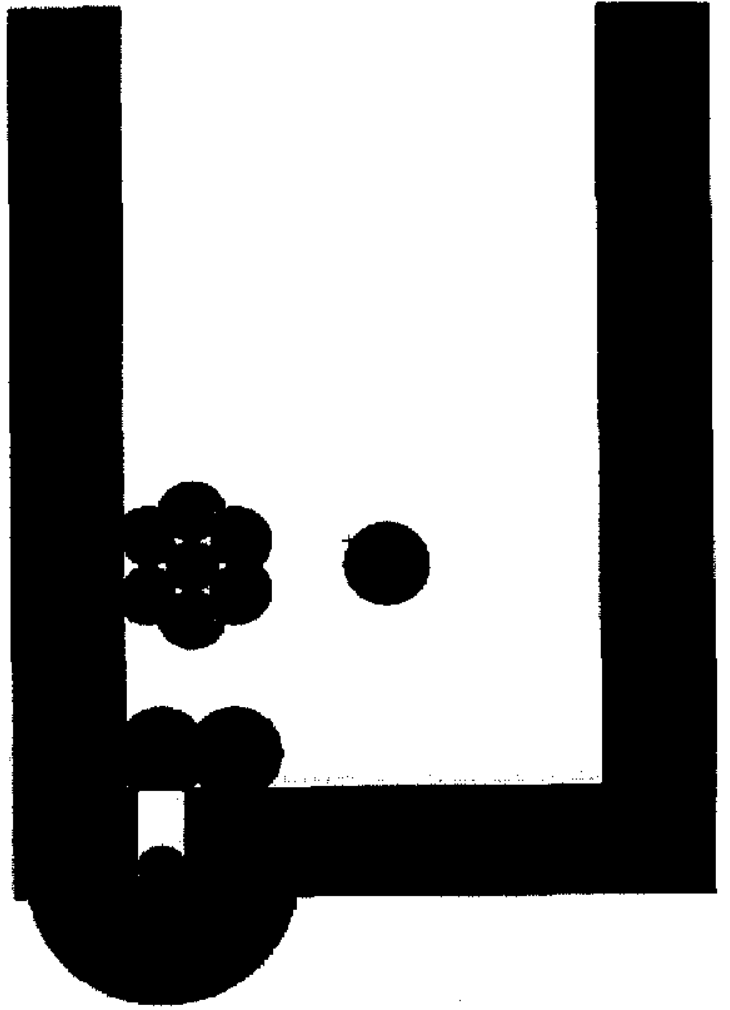

Figure $21200 \mathrm{~g}$ base case variation with nominal water reflection case $\mathrm{c0001}$ flb13a

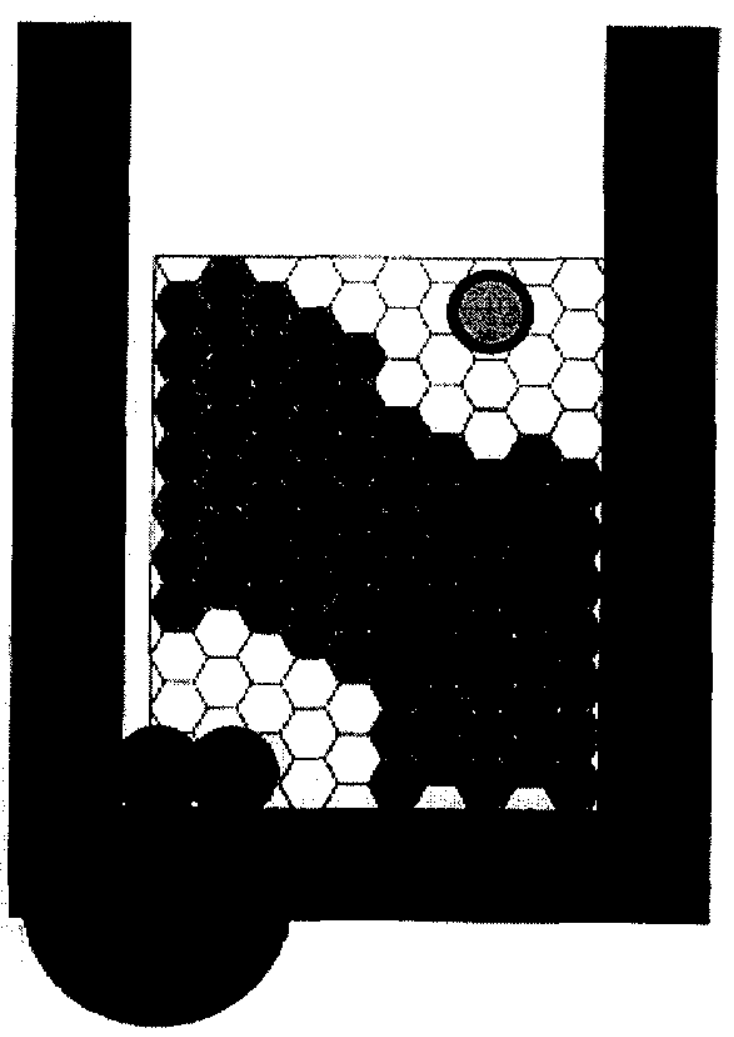

Figure $41200 \mathrm{~g}$ base case variation with conveyor container case c0001f1b18 


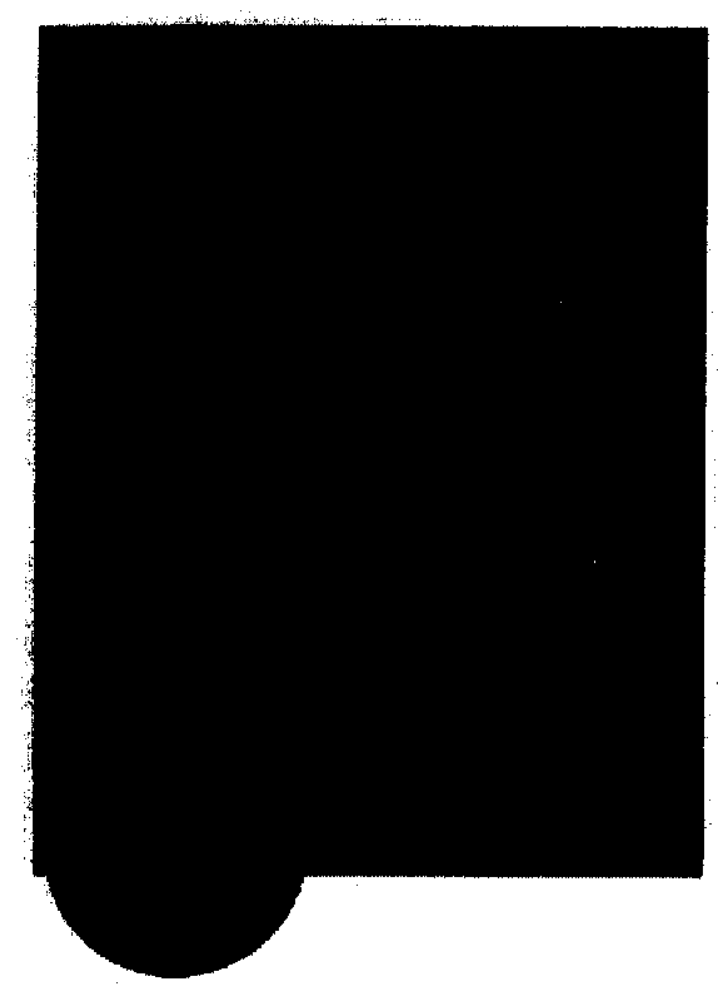

Figure 51200 g seismic case c0001f1q1a

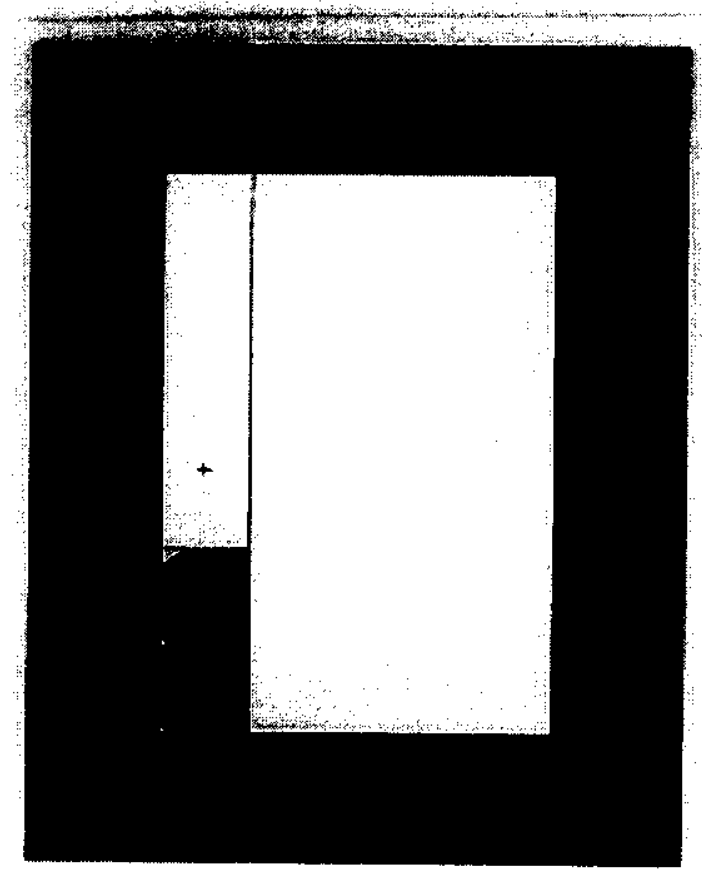

Figure 7 Verical Cross section of model showing two bowls

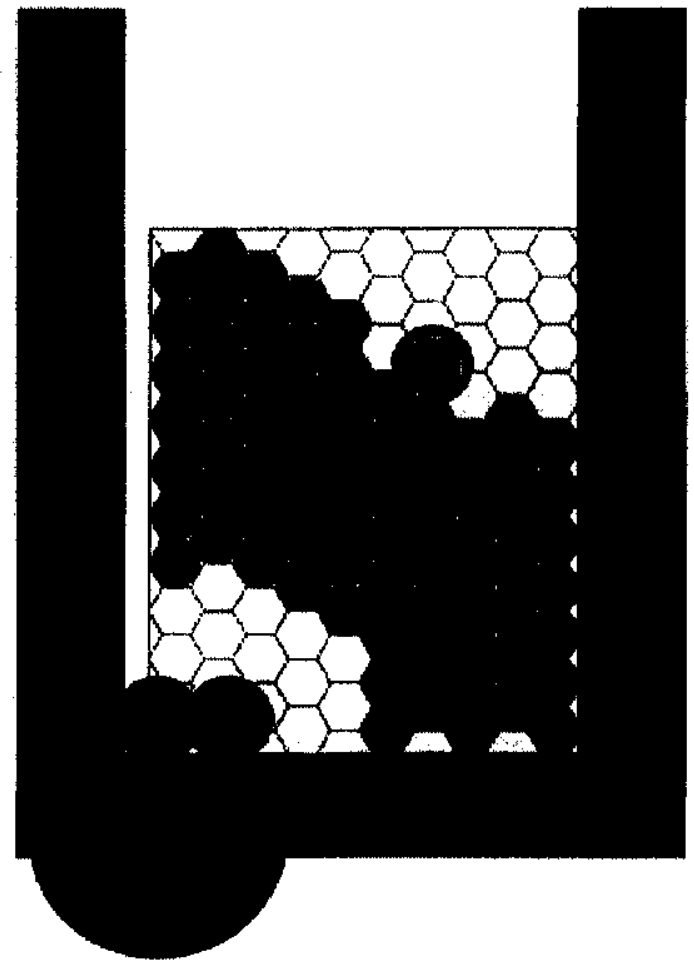

Figure $61200 \mathrm{~g}$ spacing case c0001f $1 \mathrm{b17}$

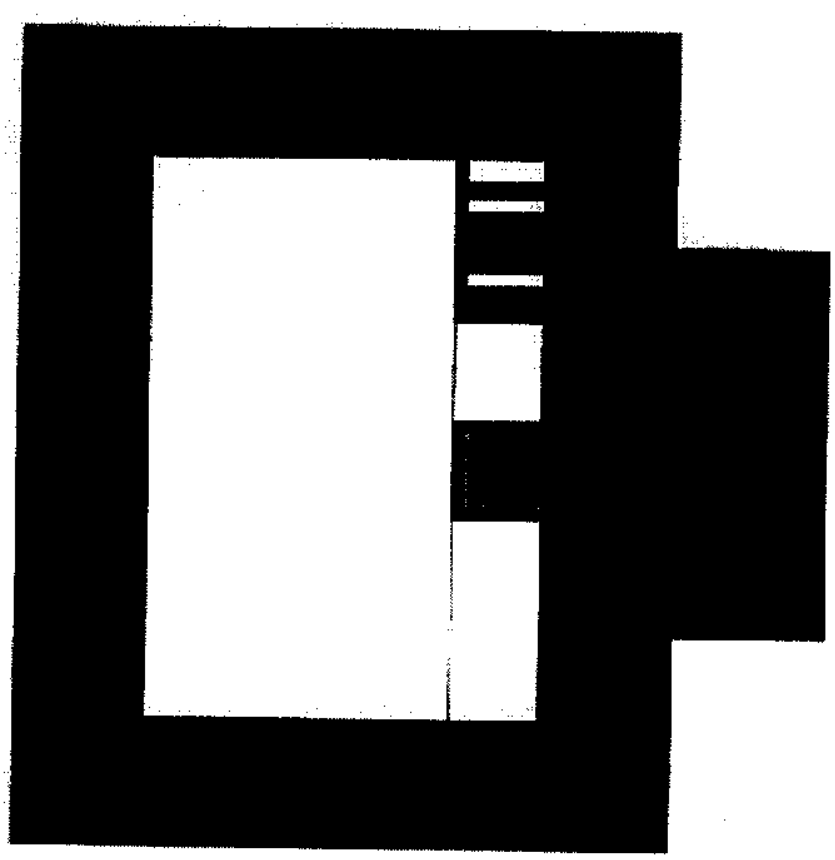

Figure 8 Vertical cross section showing cans and conveyor container case $\mathbf{c} 0001 \mathrm{fl}$ b13a 


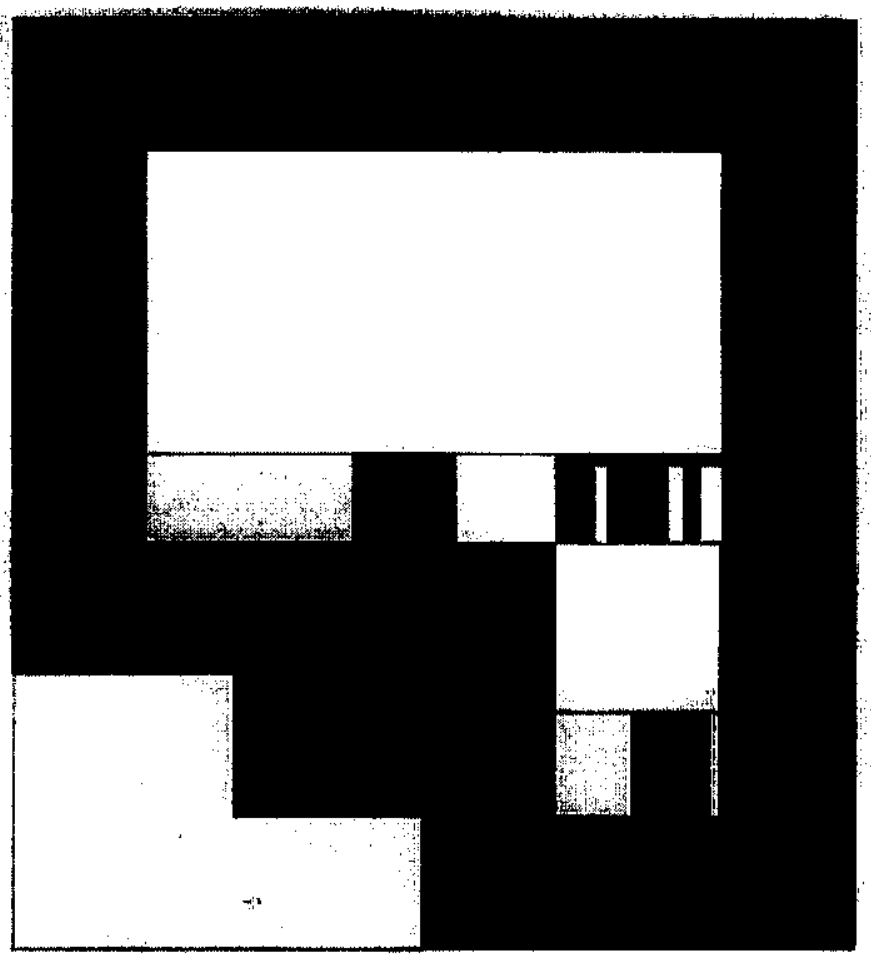

Figure 9 Verical cross ection showing canister in wagon under glovebox case c0001f w1

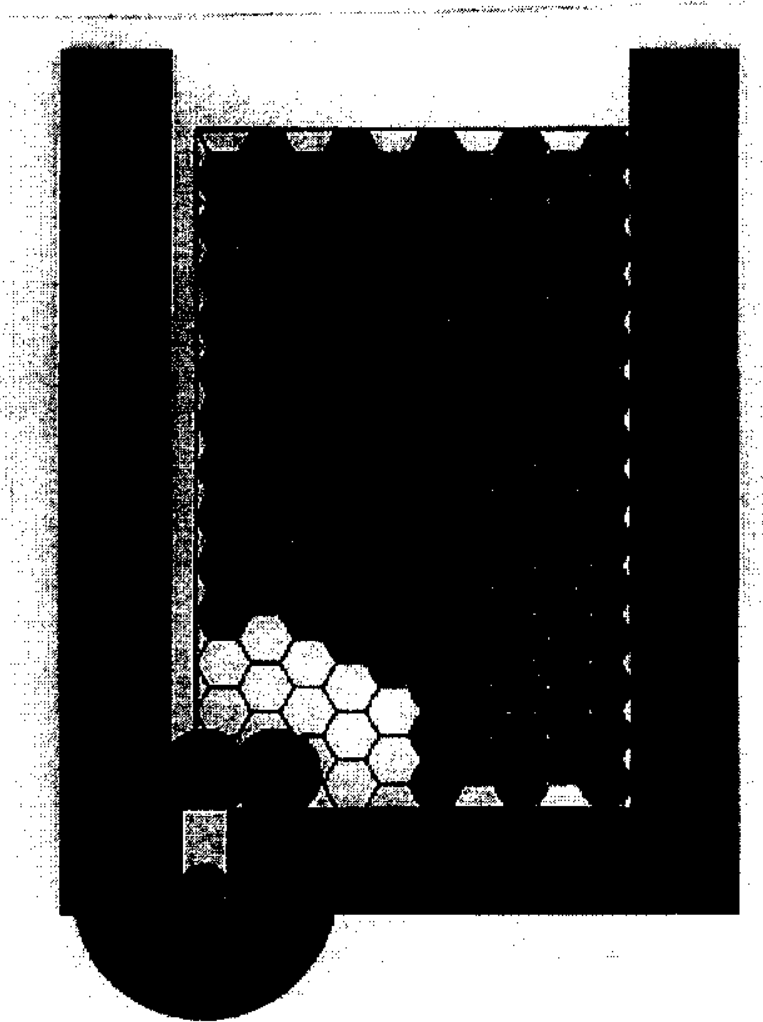

Figure $112100 \mathrm{~g}$ base case with cement can reflection Case c0001 2b4

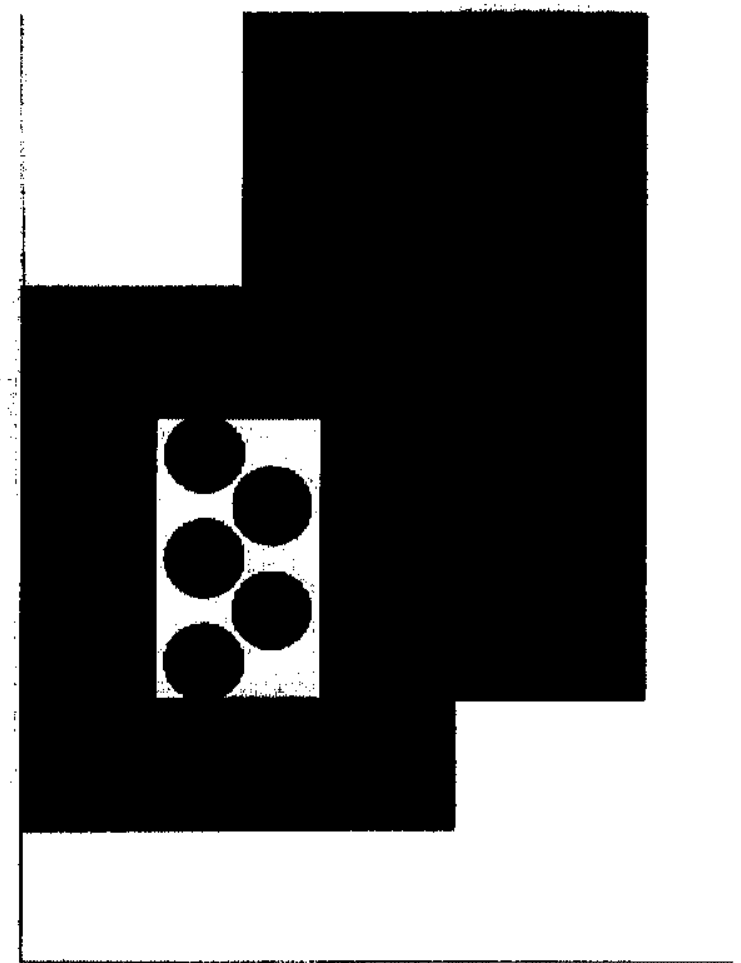

Figure 10 horizontal cross section showing wagon under glovebox case c0001f1w1

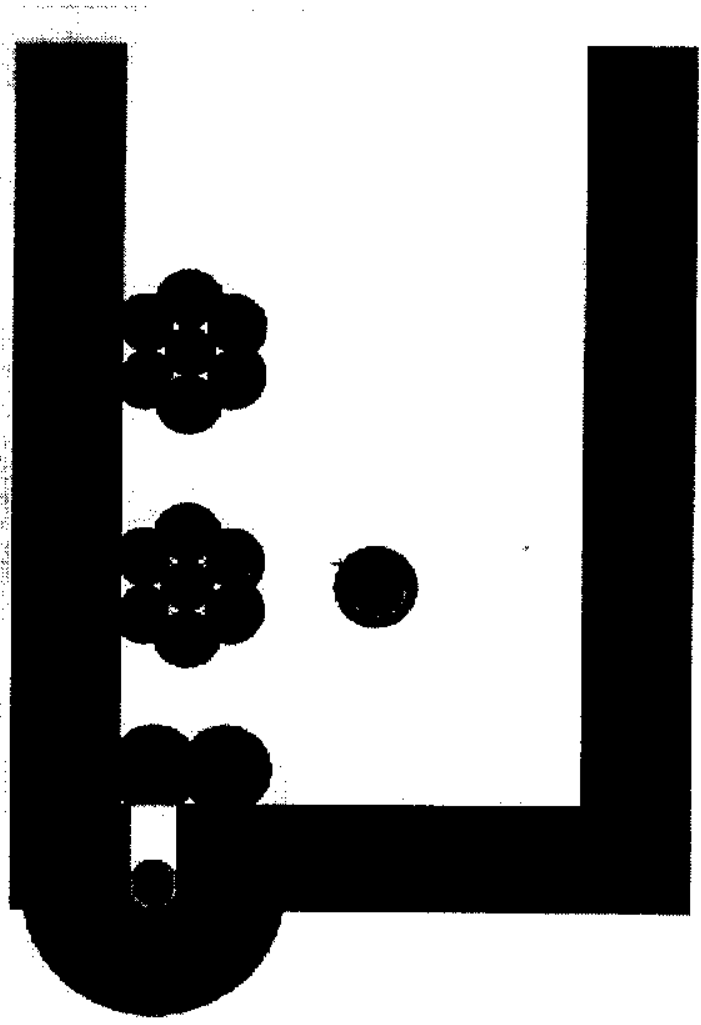

Figure $122100 \mathrm{~g}$ base case with nominal water reflectionCase c0001 f2b6a 
HNF-5988 Rev. 0

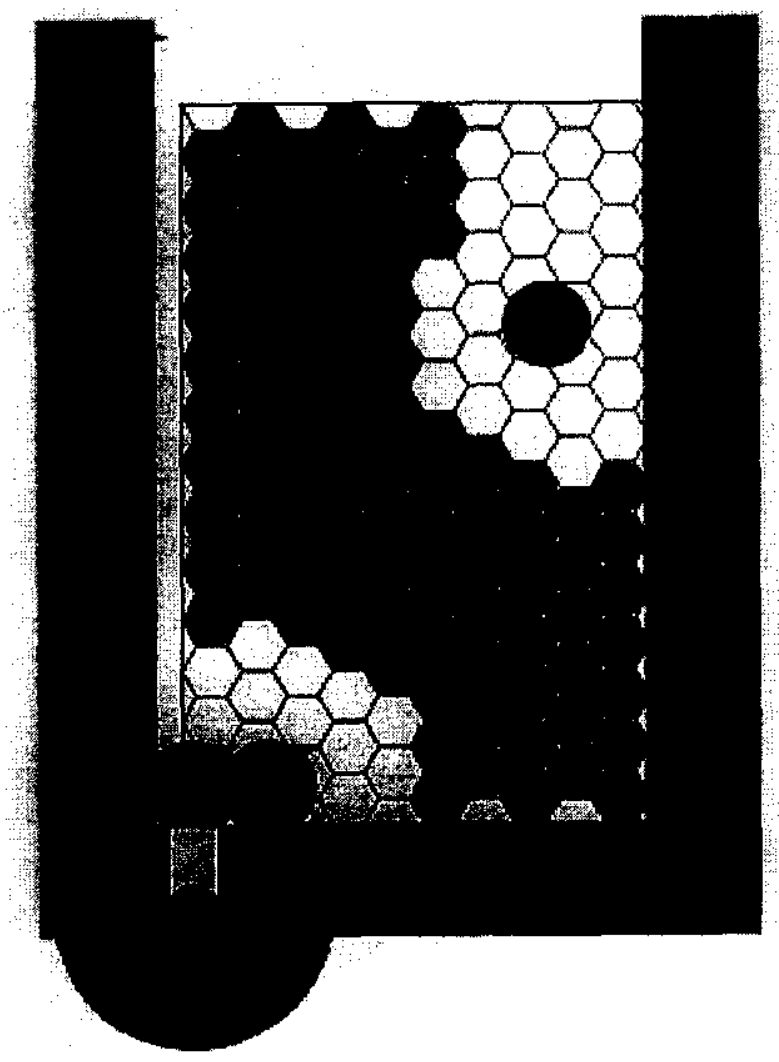

Figure $132100 \mathrm{~g}$ base case variation with conveyor container case $\mathbf{c 0 0 0 1}$ fb8

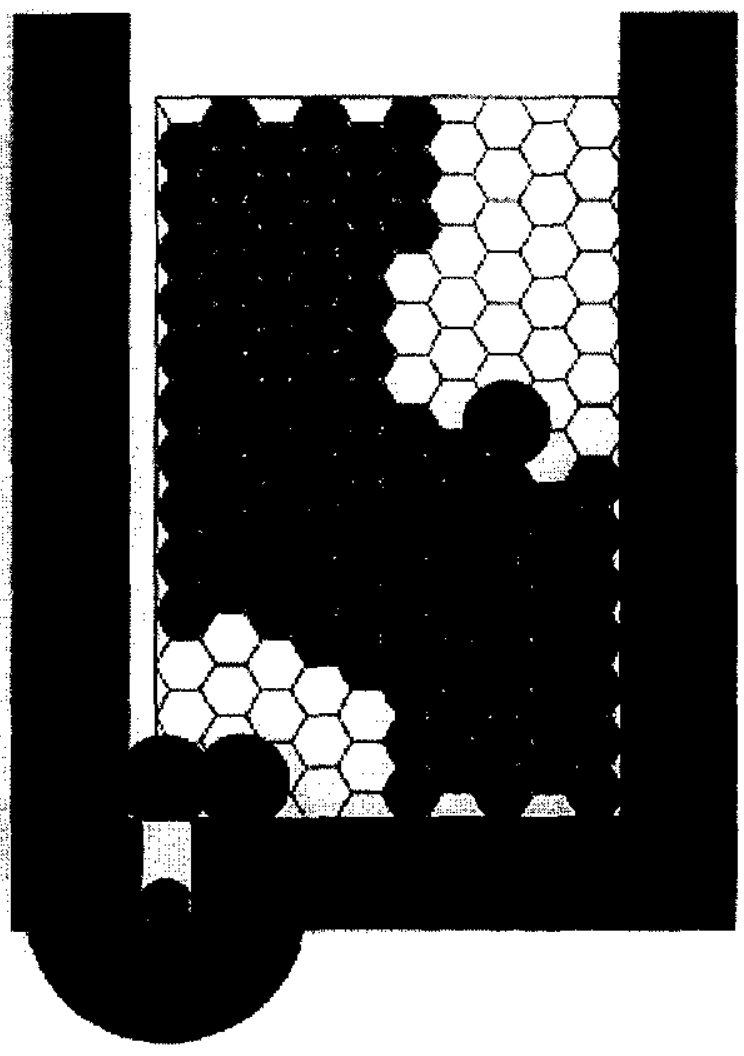

Figure $142100 \mathrm{~g}$ spacing case c0001 fab 
HNF-5988 Rev. 0

APPENDIX F

SAND, SLAG, AND CRUCIBLE CEMENTATION PROCESS FLOW AND STABILIZATION CEMENTATION DOCUMENTS 
HNF-5988 Rev. 0

This page intentionally left blank. 


\section{PLUTONIUM FINISHING PLANT PROCESS FLOW DOCUMENT}

SAND, SLAG, AND CRUCIBLE CEMENTATION PROCESS FLOW DOCUMENT

\section{PFD-Z-200-001}

Prepared By:

A. M. Stubbs

Engineer

PFP Process Engineering

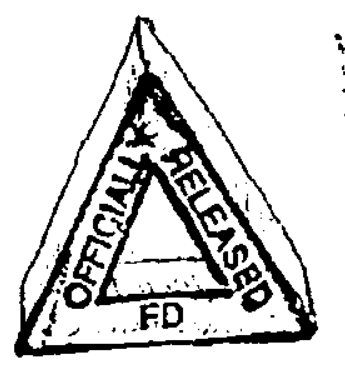


HNF-5988 Rev. 0

TABLE OF CONTENIS

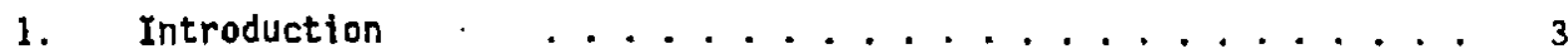

2. Process Summary ...................... 3

3. Process Description .................... 3

4. Process Technology ..................... 4

5. Process Control ................... 5

6. Off-standard conditions ................... 5

7. Equipment Description ................ 6

8. Safets ........................ . . 7

9. Essential Material ................... 8

10. References ....................... . . . 9

11. Figures......................... 10 


\section{Introduction}

A cementation process will be applied to immabilize material containing plutonium for eventual disnosal to the Waste Isolation Pilot Plant (WIPP). Sand, Slag, and crucible (SS\&C) items specified for cementation were generated from past PMC production runs. Since this material contains calcium, which is reactive, steps will be taken in the process to render tha material nonreactive before mixing with cenent. SS\&C items treated in this process will be packaged for WIPP/WAC and TRU requirements per the Hanford Site Solid haste Acceptance Criteria ${ }^{4}$. The cemented SS\&C will then be shlpped for long term storage. The PFP Stabilization Final Environmenta) Impact Statement (DOE/EIS-0244-F, APP-E) immobilization alternative evaluates the impacts of immobilizing this material ${ }^{2}$.

2. Process Summary

SS\&C which will be cemented is staged for introduction into the HA-20MB glovebox, where it is opened, weighed, sieved and processed through a particle size reduction unit. A measured amount of SSBC is mixed with chilled water in a mixer reactor to react residual calcium metal. This step will enable control of the exothermic reaction temperatures and hydrojen genaration. Following the calcium oxidation, cement, water, and SSSC are mixed to forr a cement matrix. When the cemented can is cured, it is sealeci cut, packaged, and shipped.

3. Process Description

SS\&C and other necessary cementation material is staged for introduction into glovebox HA-2ONB. One SS\&C container at a time is opened in the process area and weighed. Total unreacted SS\&C in the glovebox is Timited to $\leq 8,500$ grams and is tracked through a running inventory. The SS\&C is sieved to separate out the large pieces, then transferred to a size reduction unit to obtain an optinum particie size to assure reaction completeness. Optimum particle size was determined through labcratory testing to be $8 \mathrm{mesh}^{5}$. Following this precementing activity, the SS\&C is transferred into a hopper that feeds the variable speed auge, prior to further processing (Figure One).

A no: 1 nal 3 I iters of chilled process water is gravity fed into the mixer reactor bowl. SS\&C is fed into the mixer reactor torl under agitation at a rate ranginy from $0-45 \mathrm{~g} / \mathrm{min}$ to react calcium meta7. The mixer reactor temperature is monitored using redundant infrared thermocouples and digital ronitors. Additional chilled water may be added in 100 to $200 \mathrm{~mL}$ anounts during the addition of the $55 \& \mathrm{C}$ to offset any water loss from the hater/caicium reaction. When the temperature reaches $80^{\circ} \mathrm{C}$, the auger is autonatically shut off using a teciperature interlock to the auger. If the first interlock fails a redundant temperature interlock is activated at $90^{\circ} \mathrm{C}$ to stop the auger. When the calcium reaction is complete, the mixer reactor is manually stopped using switches located outside of the glovebox. The reactor bowt is removed from the mixer and a new reactor bowl is installed on the mixer and the process described above is repeated. 
The solids are transferred to a holding contalner until enough is accurulated for a cementation batch (Figure 2).

The accumulated SS\&C, cement, and water are mixed to form a cement matrix, allowed to cure, sealed out, and packaged for shipping. The proposed storage/shipping container is shown in figure 3.

\section{Process Technology}

\subsection{Feed Stock}

The SS\&C material being processed in the cementing operations was generated in the RMC button line operations. It consists of material left after the plutonium button was removed from the casting molo.

\subsubsection{SSQC From RHC Ogerations}

The SS\&C material being processed originated from RMC button casting operations. Plutonium metal production required the mixing of plutonium fluoride, calcium metal, and other reactants. The mixture was placed into a magnesium oxide crucible (mold) and heated to $1093^{\circ} \mathrm{C}$ using an induction furnace. The high temperature caused the plutonium fluoride to be reduced to plutonlum metal. The mold containing the plutonium was placed into the RMC line mold cutter. The mold cutter broke the mold, which released what was called a "button". The botton was then removed by hand from the adhering slag. The remaining solios were collected and processed through the hamer mill and placed into storage cans for future processing in PRF. The plutonium reduction process did not consume all the piutonium fluoride reduction reagents. A typical compasition of SS\&C is showin below.

$\begin{array}{lll}\text { Compound } & \text { Mole/Can } & \text { Wt\% } \\ & 18.36 & 46.42 \\ \mathrm{CaF}_{2} & 8.57 & 41.97 \\ \mathrm{Ca} & 3.49 & 8.78 \\ \mathrm{CaI}_{2} & 0.09 & 1.65 \\ \mathrm{Pu}_{\mathrm{PuF}_{4}} & 0.03 & 0.46 \\ \mathrm{PuO}_{2} & 0.01 & 0.20 \\ \mathrm{SiO}_{2} & 0.01 & 0.17 \\ & 0.12 & 0.45\end{array}$

\section{Calciug Metal}

Unreacted excess calcium metal jeftover from plutonium metal production is still present. Calcium metal is highly reactive and when mixed with a matrixing agent such as cement and water, will react with the water and generate excess heat and hydrogen. An Unreviewed Safety Question Evaluation (USQ) was performed to bound potential accidents per the current PFP FSAR. The USQ analysis showed that by restricting the amount of unreacted SS\&C to $\leq 8,500$ grams, keeping all dispersable material covered, and allowing no more than 100 grams dispersable Pu per contatner, the

PFD-Z-200-001 
process was bounded by the current PFP FSAR. The concentration of hydrogen in the glovebox during normal operation will be kept below flamablility limits by limiting the flow of SS\&C into the mixer reactor to $\leq 50$ grams/minute. This keeps the hydrogen concentration below the hydrogen flammability limit of $4 \%$ in the space. above the mixer bowl. This is conservative as the calculation doesn't take into consideration that $H A-2 O M B$ is ventilated at $59451 \mathrm{~L} / \mathrm{hr}$.

A material balance based on a feed rate of 50 grams/minute of SS\&C containing $20 \%$ calcium is shown in Table 1.

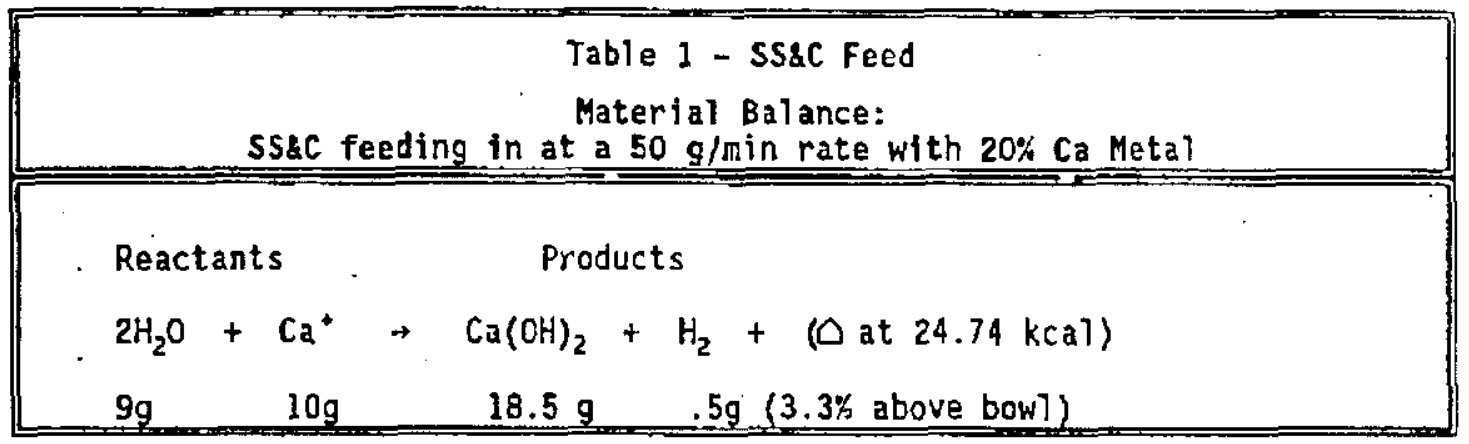

\section{Process Control}

The instrumentation and controls for the process are located in Room 235-B inside and outside of HA-2OMB.

\subsection{Mixer Reactor Temperature Control}

The mixer reactor operating teinperature wil] be noritored using a temperature sensor. SS\&C contains unreacted calcium metal from the reduction of plutonium fluoride to plutonivin metal. Calcium metal eacts with water producing heat and hydroger. The temperature of the mixer reactor will be monitored and is interlocked with the auger to stop feed addition when the reacting mixture reaches $80^{\circ} \mathrm{C}$. This will allow the water to cool and 1 init the generation of water vapor and hydrogen. If the first temperature interlock fails, a second interlock is set to stop the auger at $90^{\circ} \mathrm{C}$.

6. Off-standard Conditions

Loss of the E-4 ventilation syster would allow the possible build up of hydrogen within the glovebox. The operational procedures will instruct the operator to stop the 5S\&C auger feed. Ventilation loss during processing activities sti\}l would not generate hydrogen to the flamability limit of 4 percent. Hyorocen amounts calculated from average calcium arount weight concentrations in SS3C will produce 3.9 percent hydrogen in the glovebox even if the whole $2000 \mathrm{gram}$ charge is fed into the mixer bowl with no air flow in the glovebox. 


\section{Equipment Description}

The cementation process will be carried out in HA-2OMB. The glovebox is located in Rm 235B. This section describes the location and type of equipment used in the cementation process.

\subsection{Mixer Reactor}

The commerical mixer reactor is a Hobart ${ }^{\text {TM }}$ model number $\mathrm{N}-50$ or equal. The comerical mixer reactor is capable of operating at three speeds. The speed control will be set at the correct speed, the mixer will be set to the on position, and a remote on/off switch, located on the outside of the glovebox near the mixer, will be used to start and stop the mixer.

\subsection{Auger}

The process feed auger has variable speed and can feed material to the $\mathrm{m}$ ixer reactor at rates ranging from $0-45 \mathrm{~g} / \mathrm{min}$. Normal operating feed rate will be nominally $24 \mathrm{~g} / \mathrm{m} / \mathrm{n}$. Since the maximum allowable feed rate is $50 \mathrm{~g} / \mathrm{min}$, this represents an engineered control. The auger is interlocked with temperature controllers to stop operation when the temperature is above the specified 1 imit. The auger has a different plug and receptacle configuration to pravent overriding temperature interiocks.

\subsection{Chiller}

Process water cooler produces $3751 \mathrm{btu} / \mathrm{hr}$ of cooling to chill the water used to react the calcium metal and aid in process teicperature coritrol. The chiller unit is located on the mezzanine above the glovebax with the cooling coil tubing penetrating the glovebox wall and going into the process water reservoir.

Process water will be provided by a 94.51 iter capacity tank located on the mezzanine. Process viater vill] be hand loaded to control the amount of water that could potentialiy enter the glovebox.

\subsection{Scale}

The scales have digital readouts and will be located in HA-20MB. Scales will be used to measure out charges into slip lid containers and to verify percent $P_{u}$ in each cemented item.

\subsection{Terperature Control System}

The mixer reactor temperiture will1 be controlled using infrared thermocouples and digital monitors. The controller will be interlocked to the SS\&C auger. SS\&C addition to the mixer reactor is stopped at $80^{\circ} \mathrm{C}$ through this interlock. A redundant auger stop loop is in place to stop the auger at $90^{\circ} \mathrm{C}$ if loop one fails to operate. Process restart is done manualiy when the temperature falls below $60^{\circ} \mathrm{C}$.

Hobart is a trademark of the Hobart Corporation, Troy, Ohio. 
HNF-5988 Rev. 0

\subsection{Size Reduction}

The SS\&C will be reduced to the optimum particle size of 8 mesh using a general purpose crusher. The crusher is a standard 115VAC IPH unit.

\subsection{Sieve}

A standard 8 mesh sieve is used to remove any particles larger than 8 mesh. The sieve screen can be from bulk 8 mesh material cut to fit or of custom manufacture.

8. Safety.

The principle hazards associated with glovebox HA-2OMB operations are heat of reaction, off-gas flammability, criticality, and radiation. The following sections will address these items.

\subsection{Heat_of Reaction}

The reaction of calcium metal and water generates enough heat to boil water. Temperature controls are installed to control the amount of heat generated from the reaction by stopping the addition of SSAC. Further, the mixer reactor is continuously operatid to dissipate heat of reaction.

\subsection{Qff-gas Flammability}

Hydrogen is generated when calctum metal is reacted with water. Temperature controls are installed on the mixer reactor to limit the SS\&C feed. Controlling the SS\&C feed rate to $550 \mathrm{~g} / \mathrm{min}$ limits the hydrogen generated above the bow to $3 \%$ vichich is below the $4 \%$ flammability limit for hydrogen. Since the maximum auger feed rate is $45 \mathrm{~g} / \mathrm{min}$, this is a engineered control. Also, by 7imiting the charge sizes to $\leq 2000$ grans unreacted SS\&C, if the ventilation were to stop and all the material in the auger fed into t!.e mfxer reactor, the hydrogen level in the glovebox would be belo's the flamability limit ( $<4 \%$ hydrogen). 
HNF-5988 Rev. 0

\subsection{Glovebox Exhaust Fiow}

Glovebox ventilation is required to maintain glovebox airflow at specified values for prudent engineering control and defense in depth to prevent hydrogen buildup as discussed in section 8.2. The glovebox exhaust flow is maintained at greater than 20 scfm and is monitored on flow indicator FI-20MB-1.

The flow monitor is read as a prerequisite to startup and read periodically while processing per procedure 20-160-060. This specification is required when reacting SS\&C, other activities are permitted as long as glovebox to room of requirements are satisfied.

\subsection{Criticality}

Plutoniug is a fissile material and therefore, criticality limits are required. Criticality Prevention Specification CPS-Z-165-80030 (Glovebox HA-20MB in Room 235-B, 234-5Z Building) will be applicable during all operations in HA-20MB. Criticality specification limits fissile material to 500 grams in the airlock and 500 grams in the process area. Fissile materlal is 1 imited to 180 grims in a'y liquid-bearing container (mixing bowl or cement can). No direct water lines will be connected to the glovebox, therefore limiting the total water available. Spacing of the fissile material is not required.

\subsection{Radiation}

Remote operation of equipment through placenent of controls outside of the glovebox will reduce operator exposure. The mid-section of the glovebox has lead plates installed for dose reduction. However, this process is labor intensive and operations and maintenance activities in the glovebox will be rinimized using ALARA principles of tirie, distance, and shielding will be used in developing prccedures.

\section{Essential Materia\}}

No essential material is required for this process. It is desirable that the same cement manufacturer be used to ensure consistent product.

PFO-2-200-001 
10. References

(1) DOE, 1996a, Waste Acceptance Criterla for the Waste Isolation Pilot Plant, DOE/WIPP-069 Revision 5 Draft C, U.S. Department of Energy, Carlsbad Area Office, Carlsbad, New Mexico.

(2) DOE, 1996, Analys is of the Immobilization Alternative, DOE/EIS-0244-F, Appendix E Rev 3, U. S. Department Of Energy, Richland Area Office, Richland, Washington.

(3) Mortimer, Charles E., Chemistry, $5^{\text {th }}$ Edition, 1983 Wadsworth Inc.

(4) WHC, 1993, Hanford Site Solid Waste Acceptance Criteria, Chapter 5, Transuranic Waste, Westinghouse Hanford Company, Richland, Washingtor.

(5) Winstead, Michelle. L., July 1996, Internal Letter 15700-96-058, Results of Sand, Slag, and Cruible Testing for Cementation Process 
HNF-5988 Rev. 0

FIGURE 1 - CEMENTATION PROCESS PREPARATION FLOW SHEET

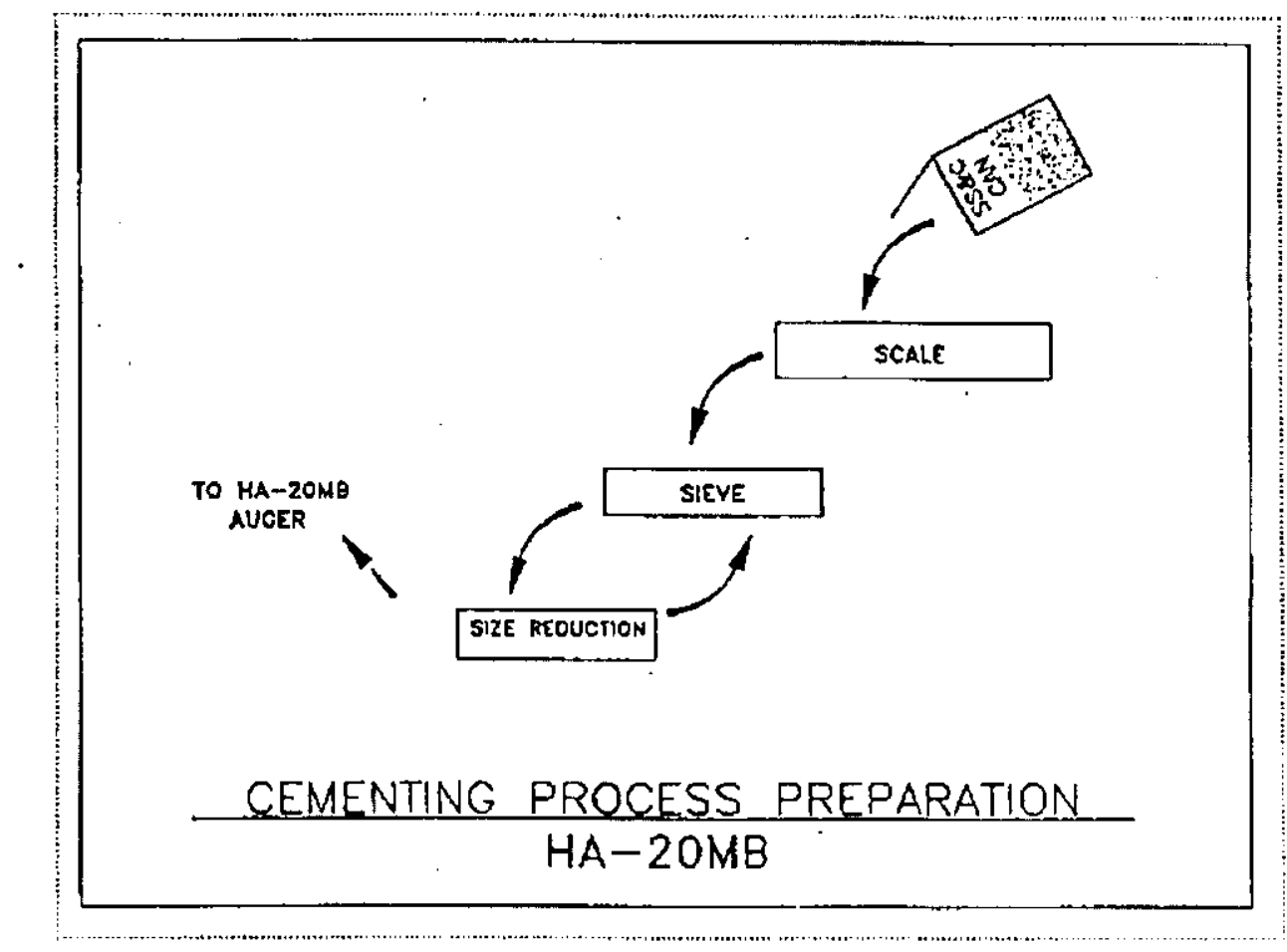


HNF-5988 Rev. 0

FIGURE 2 - SS\&C CEMENTATION FLOH SHEET

Figure 2 - SS\&C CEMENTATION FLOW SHEET

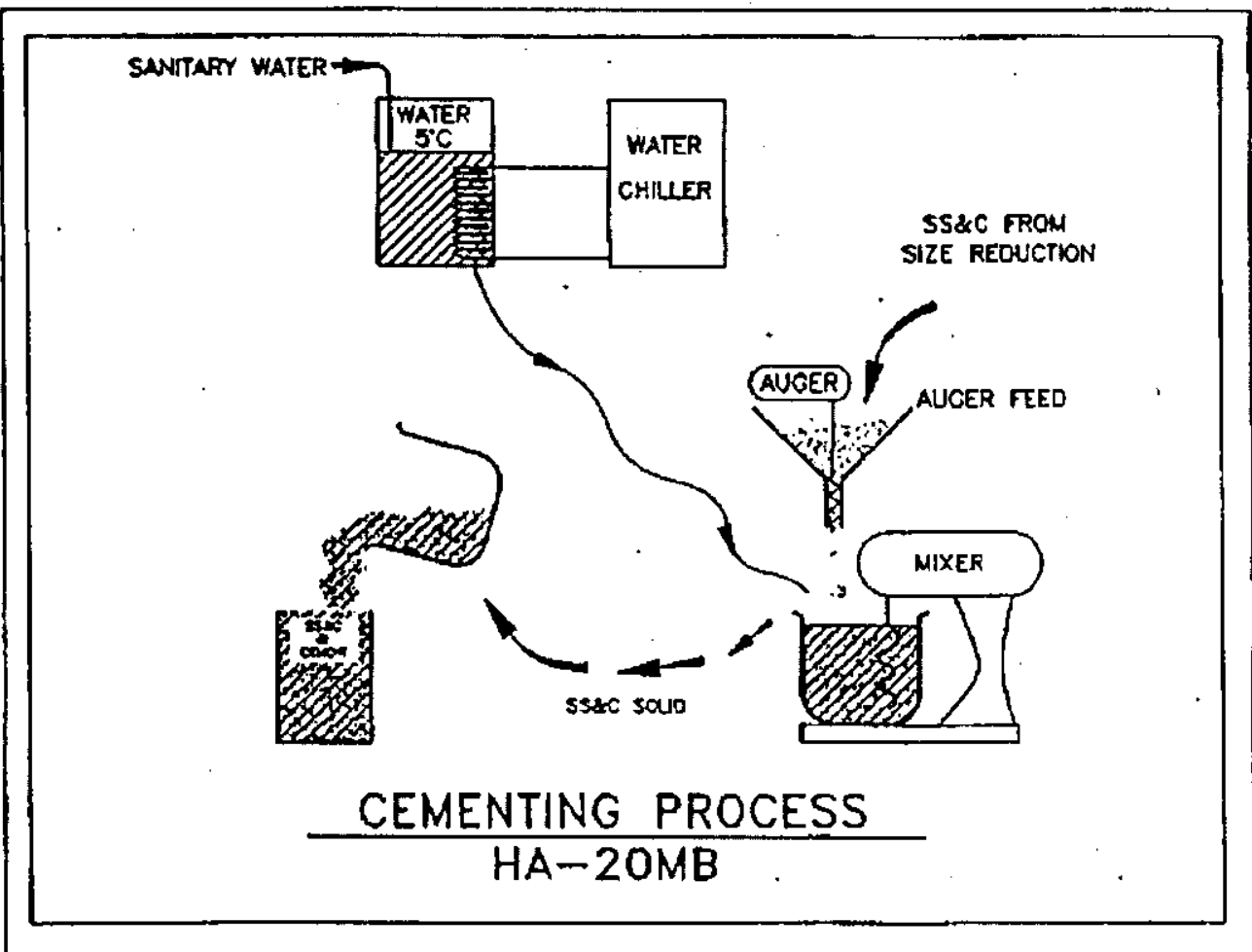

PFD-Z-200-001

Rev A-2

11 of 12 
HNF-5988 Rev. 0

Figure 3 - Pipe-container-in-drum

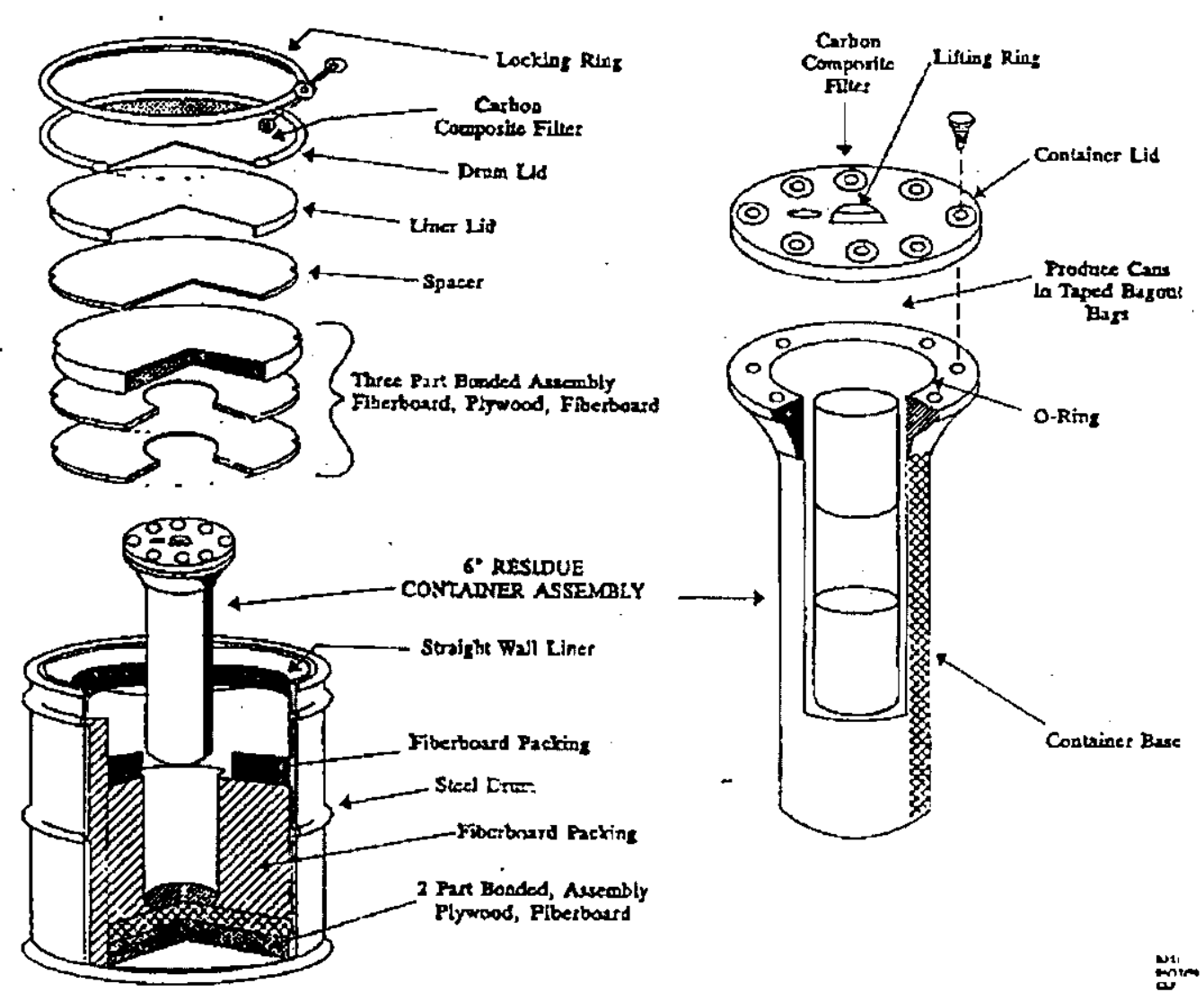




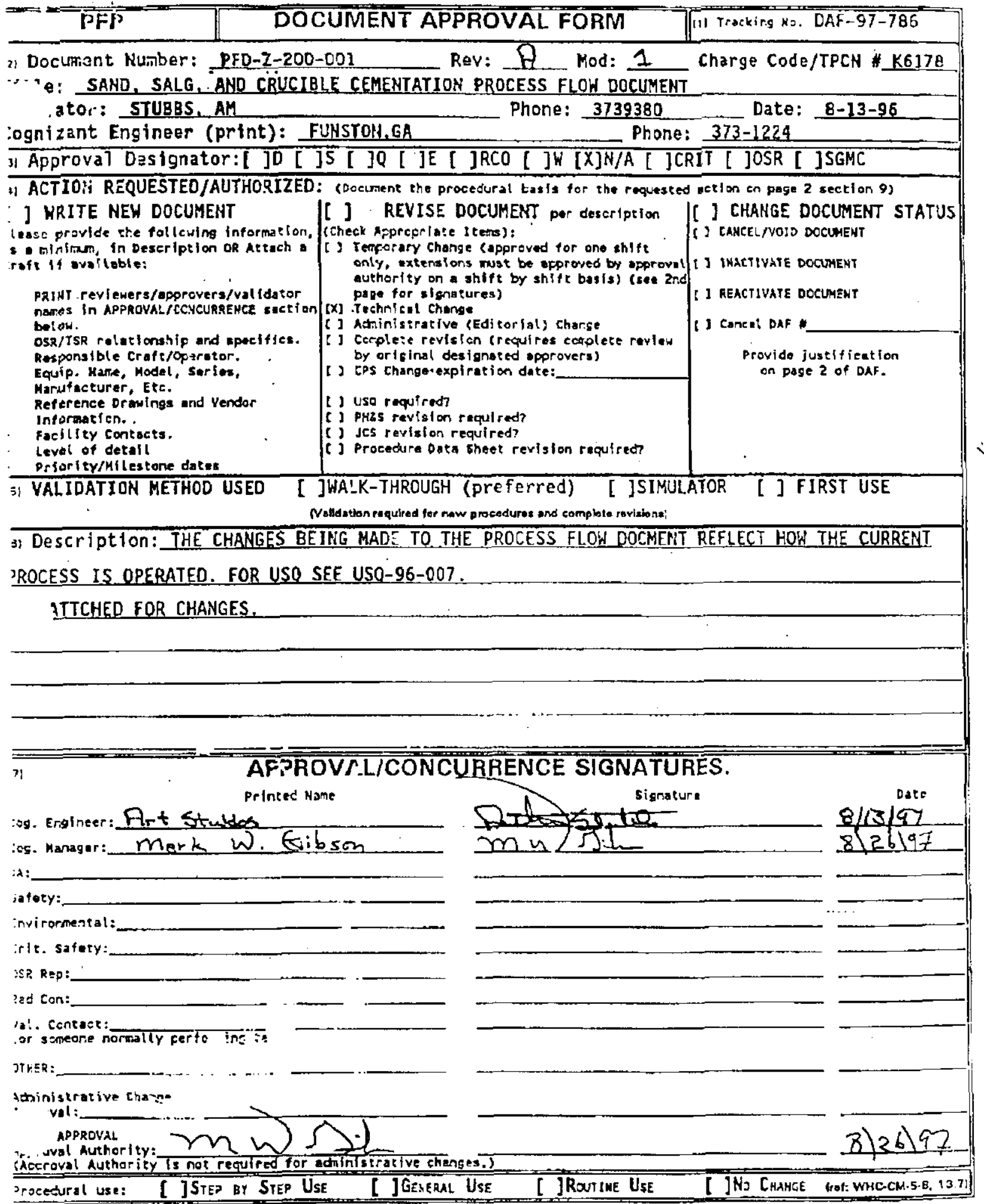


HNF-5988 Rev. 0

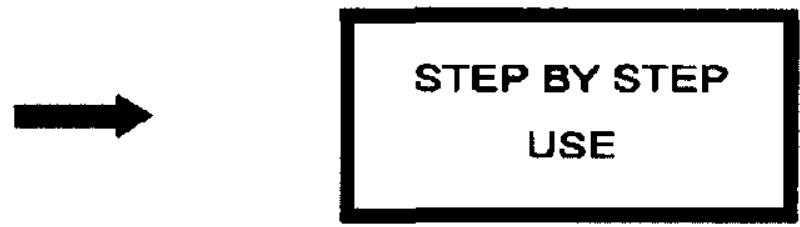

\section{PLUTONIUM FINISHING PLANT \\ STABILIZATION OPERATIONS}

\section{STABILIZATION CEMENTATION}

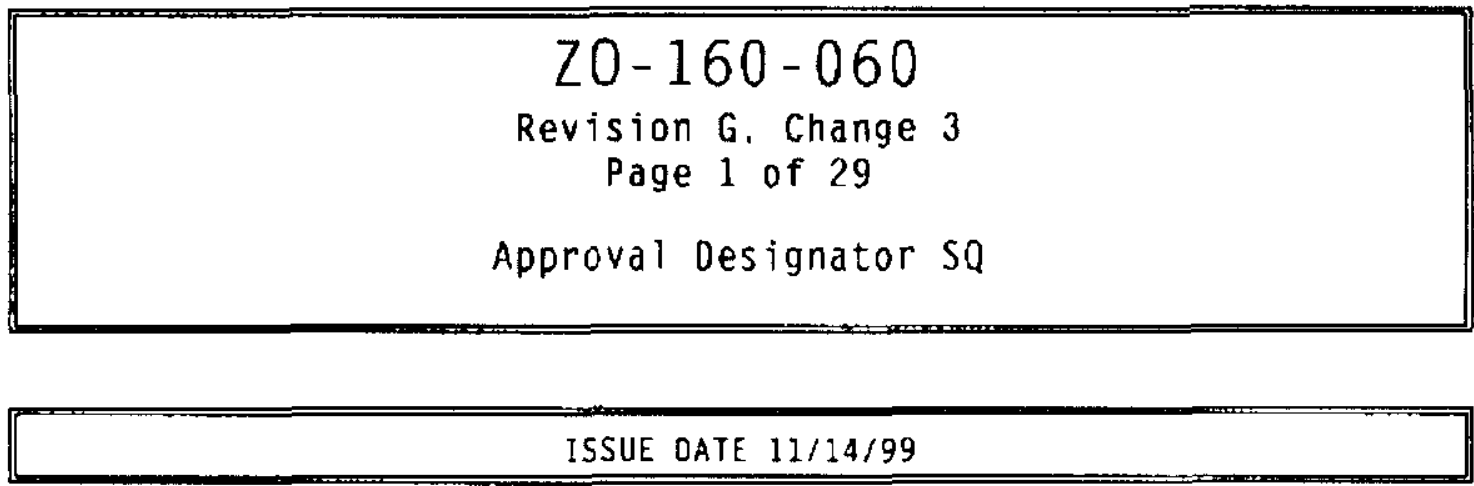

WORKING COPY VERIFIED BY: DATE: 
HNF-5988 Rev, 0

\begin{tabular}{l|l} 
STABI LI ZATI ON CEMENTATI ON & $\begin{array}{l}20-160-060 \\
\text { Rev. G. Chg. } 3 \\
\text { Page 2 of } 29\end{array}$ \\
\hline
\end{tabular}

\section{REVISION STATUS}

CHANGE PAGE(S) DESCRIPTION

REV. G-0 ALL COMPLETE REVISION

OAF- $97-0173$

MOD. G-1 7 IMPROVED WAY OF MEASURING OFF-GAS FLOW IN STEP

DAF-97-0464 6.1.1.

DATE $5 / 1 / 97$

MOD. G-2 16

DAF - $97-0851$

DATE $9 / 16 / 97$

17

27

STEP 6.6.14. a. ChANGed "6.10.1" TO " $5.11 .1 "$

STEP 6.5.16 CHANGED "6.5.19" TO "6.6.17"

ATTACHMENT 2 REMOVED "6.5.26" FROM ATTACHMENT

Change 3

DAF $-99-1284$

$11 / 14 / 99$

$1,2.5$.

13. 20 .

24. $26-28$

Administrative change to update personnel and group titles to reflect those in the redesigned organization.

VALIDATED ON 02/20/97 
HNF-5988 Rev. 0

STABI LI ZATI ON CEMENTATI ON

SECTION

DESCR I PTION

$\underline{\text { PAGE }}$

1. I NTRODUCTION ...................................... 4

1.1 Purpose . . . . . . . . . . . . . . . . . . . . . . 4

1.2 Scope . . . . . . . . . . . . . . . . . . . . . . . . . 4

1.3 Appl i cability . . . . . . . . . . . . . . . . . . . 4

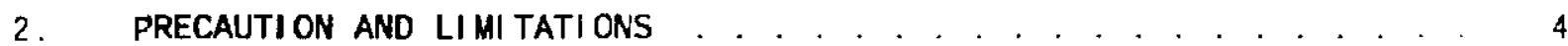

2.1 Cri ti cal i ty Statements . . . . . . . . . . . . . . . . . . . . 4

2.2 Warni ng Statements . . . . . . . . . . . . . . . . . . . . . 5

2.3 Cauti on Statements . . . . . . . . . . . . . . . . . . . . . 5

2.4 Admi ni strati ve . . . . . . . . . . . . . . . . . . . . . . . 5

3. PREREQUI SITES . . . . . . . . . . . . . . . . . . . . . . . . . . . 5

4. SPECI AL TOOLS, EQUI PMENT, AND MATERI ALS . . . . . . . . . . . . . . . 6

5. PERFORMANCE DOCUMENTS . . . . . . . . . . . . . . . . . . . . . . 6

5.1 Records . . . . . . . . . . . . . . . . . . . . 6

6. PERFORMANCE ........................... . . . . . 7

6.1 Prel i mi nary Instructi ons . . . . . . . . . . . . . . . . . . . . . . . 7

6.2 Val ve and Swi tch Li ne-up . . . . . . . . . . . . . . . . . . 7

6.3 Water Make-up . . . . . . . . . . . . . . . . . . . . . . 9

6.4 Chiller Operati on . . . . . . . . . . . . . . . . . . . . . . 10

6.5 Prepare Sol i ds For Cal ci um Reacting. . . . . . . . . . . . . 11

6.6 React Cal ci um . . . . . . . . . . . . . . . . . . . . . . . 15

6.7 Cement Reacted Sol ids . . . . . . . . . . . . . . . . . . . . 18

6.8 Billet Can Preparation . . . . . . . . . . . . . . . . . . . 20

6.9 Fill Bill et Cans . . . . . . . . . . . . . . . . . . 21

6.10 Respond to Materi al Spills . . . . . . . . . . . . . . . . . 23

6.11 Al arm/Emergency Responses . . . . . . . . . . . . . . . . . . 23

7. BI BLI OGRAPHY . . . . . . . . . . . . . . . . . . . . . . . . 25

Attachment 1 - CHARGE PREP DATA SHEET . . . . . . . . . . . . . . . . 26

Attachment 2 - CALCIUM REACTION/CEMENTATION DATA SHEET . . . . . . . . 27

Attachment 3 - BILLET CAN DATA SHEET . . . . . . . . . . . . . . . . . . 28

Attachment 4 - OPEN UNREACTED SS\&C INVENTORY SHEET . . . . . . . . . . . 29 
HNF-5988 Rev. 0

STABI LI ZATION CEMENTATI ON

$20-160-060$

Rev. G. Chg. 3

Page 4 of 29

\section{INTRODUCTION}

\subsection{Purpose}

Provide instructions for cementing Sand, Slag. and Crucible (SS\&C) in glovebox HA-2OMB. The cemented SS\&C shall be packaged in waste drum in preparation for shipment to waste Isolation Pilot Plant (WIPP).

\subsection{Scope}

This procedure applies to SS\&C with plutonium levels accepted for disposal. The SS\&C contains calcium metal which does not meet WIPP reactivity requirements and will be reacted with water prior to cementing.

\subsection{Appl i cabi l i ty}

Items with less than 60 grams plutonium that have been selected for disposal by this method. Sections are independent and may be performed simultaneously (except 6.1).

\section{PRECAUTION AND LI MI TATIONS}

\subsection{Critical ity Statements}

2.1.1 Amount of plutonium allowed in HA-2OMB process area is not to be more than 500 grams above HA-20MB hold-up.

2.1.2 Amount of plutonium allowed in HA-20MB airlock is not to exceed 500 grams.

2.1.3 No more than 180 grams of plutonium in any one liquid bearing container.

2.1.4 Maximum container volume not to exceed a nominal 5 quarts (4.73 liters).

2.1.5 Stacking of containers is not allowed. 


\section{STABI LI ZATI ON CEMENTATI ON}

\subsection{Warning Statements}

2.2.1 Total unreacted SS\&C in open containers (including material held in slip-lid cans) is limited to less than 8500 grams in HA-20MB.

2.2.2 To limit dispersible Pu to 100 grams, maximum $P u$ for individual containers with dry SS\&C is SlOO grams.

\subsection{Cauti on Statements}

2.3.1 Worknit. HD. Smitty or leather gloves shall be worn when opening cans and handling sharp edged ttems.

\subsection{Admi ni strative}

\subsubsection{Operating MODE}

The Main Facility AND Process Area 3 shall be in MODE 1 or MODE 2 and meet minimum staffing limits (two certified NCOs and one certified manager/Team Leader). If area is in MODE 2. LCOS 3.1.3.2, and 3.3 shall be met.

\section{PREREQUI SITES}

NONE. 
HNF-5988 Rev. 0

\section{STABI LI ZATI ON CEMENTATI ON}

$Z 0-160-060$

Rev. G, Chg. 3

Page 6 of 29

4. SPECIAL TOOLS, EQUI PMENT, AND MATERI ALS

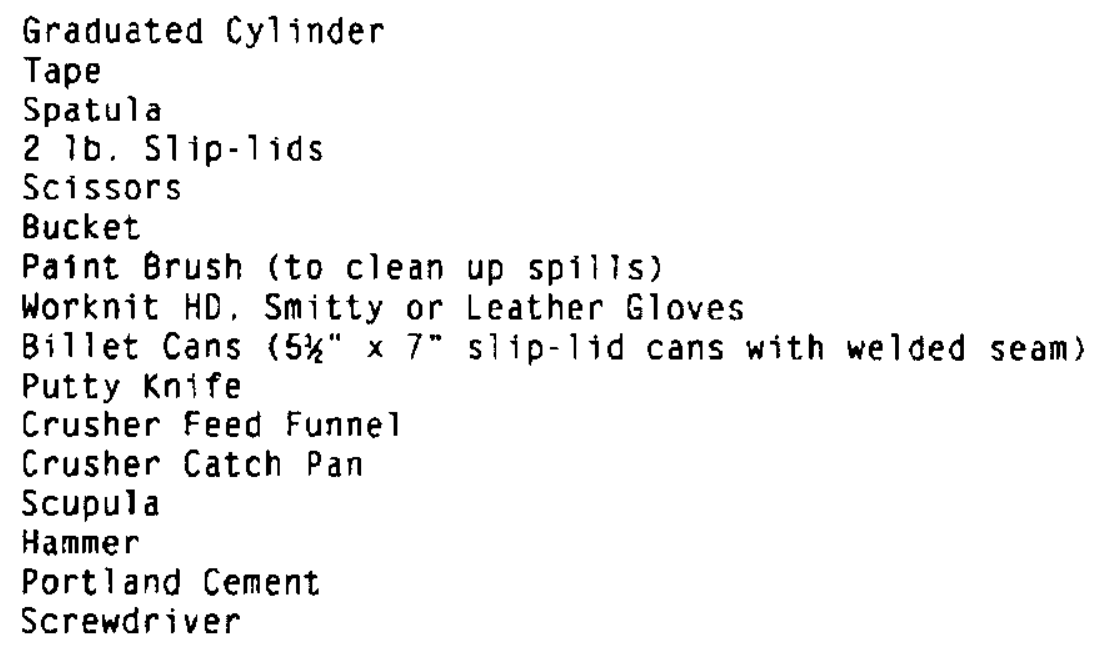

5. PERFORMANCE DOCUMENTS

20-170-299. Seal out

20-170-301, Seal In

20-200-101. Zero And Operate Mettler And Scientech Balances

\subsection{Records}

CHARGE PREP DATA SHEET

CALCIUM REACTION/CEMENTATION DATA SHEET

BILLED CAN DATA SHEET

OPEN UNREACTED SS\&C INVENTORY SHEET

CEMENTATION LOG BOOK 


\section{PERFORMANCE}

6.1 Prel i mi nary Instructions

6.1.1 VERIFY Flow Reading on FI-20MB-1 north of glove box HA-2OMB is greater than $20 \%$ and valve $V-28311-25 A$ is closed whenever performing section 6.5.

6.1.2 VERIFY glovebox negative pressure relative to room pressure is between 0.5 and $2.0 \mathrm{in}$. WG to ensure contamination containment.

6.1.3 ENSURE failed or expired gloves/bags have been replaced or covered with pie plate.

6.1.4 VISUALLy inspect electrical cords for damage PRIOR to using electrical equipment in glovebox HA-2OMB.

6.1.5 REPLACE equipment or complete repair of damaged cord PRIOR to equipment use.

6.2 Valve and Swi tch Line-up

6.2.1 ENSURE valves are posttioned as follows before initial weekly start-up.

\begin{tabular}{lll}
$V a l v e$ & Position & \multicolumn{1}{c}{ Location } \\
$V-20 M B-1$ & Close & North end of HA-2OMB \\
$V-20 M B-2$ & Close & Middle of HA-2OMB \\
$V-20 M B-3$ & Close & Middle of HA-20MB \\
$V-20 M B-4$ & Close & Narth end of HA-2OMB \\
$V-20 M B-5$ & Close & North end of HA-2OMB \\
$V-20 M B-6$ & Close & Middle of HA-2OMB
\end{tabular}


HNF-5988 Rev. 0

STABI LI ZATI ON CEMENTATION

$20-160-060$

Rev. G, Chg. 3

Page 8 of 29

6.2.2 ENSURE switches are positioned as follows before initial weekly start-up.

\begin{tabular}{lccc} 
Switch & Position & Switch & Positi \\
\hline HS-20MB-1 & OFF & HS-20MB-4 & OFF \\
HS-20MB-2 & OFF & HS -2OMB-5 & OFF \\
HS-20MB-3 & OFF & HS-2OMB-6 & OFF
\end{tabular}

6.2.3 ENSURE valves are positioned as follows after weekly shut down.

\begin{tabular}{lll} 
Valve & Position & Location \\
\hline$V-20 M B-1$ & Close & North end of $H A-20 M B$ \\
$V-20 M B-2$ & Close & Middle of HA-2OMB \\
$V-20 M B-3$ & Close & Middle of $H A-20 M B$ \\
$V-20 M B-4$ & Close & North end of HA-2OMB \\
$V-20 M B-5$ & Close & North end of HA-20MB \\
$V-20 M B-5$ & Close & Middle of HA-20MB
\end{tabular}

6.2.4 ENSURE switches are positioned as follows after weekly shut down.

\begin{tabular}{lccc} 
Switch & Position & Switch & Posit \\
\hline HS-2OMB-1 & OFF & HS-2OMB-4 & OFF \\
HS-2OMB-2 & OFF & HS - 20MB-5 & OFF \\
HS-2OMB-3 & OFF & HS-2OMB-6 & OFF
\end{tabular}


HNF-5988 Rev. 0

STABI LI ZATI ON CEMENTATI ON

$20-160-060$

Rev. G. Chg. 3

page 9 of 29

6.3 Water Make-up

6.3.1 If make-up water tank is at $\underline{O R}$ below low level. fill as follows:

a. PLACE transfer bucket under santtary water line by valve $V-2940-23 C$.

b. OPEN valve $V-2940-23 C$ to fill bucket. THEN CLOSE valve $V-2940-23 C$.

c. TRANSFER water from bucket into make-up water tank.

d. REPEAT Step 6.3.1 as necessary until water is between low level and high level.

6.3.2 If Chtllwater Tank is at oR below low level. fill as follows:

a. ENSURE level of make-up water tank is above low level.

D. OPEN valve $V-20 M B-1$.

C. OPEN valve $V-20 M B-2$.

d. WHEN Chillwater Tank is between low level and high level, CLOSE valves $V-20 M B-2$ and V-20MB-1.

e. REPEAT Step 6.3.2 as necessary. 
HNF-5988 Rev. 0

\section{STABI LI ZATI ON CEMENTATI ON}

\subsection{Chiller Operation}

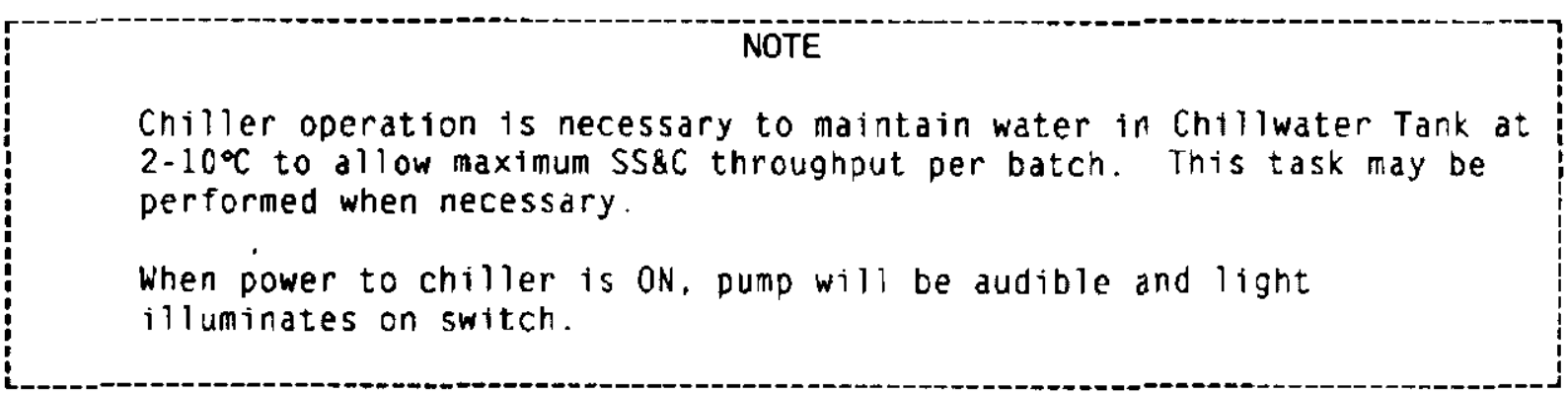

6.4.1 WHEN chiller is required, perform the following:

a. OPEN valves $V-20 M B-4$ and $V-20 M B-5$.

b. START chlller with power switch DS-20MB-1.

6.4.2 WHEN chiller is not required. perform the following:

a. STOP with power switch OS-2OMB-1.

b. CLOSE valves $V-20 M B-4$ and $V-20 M B-5$. 
HNF-5988 Rev. 0

STABILI ZATI ON CEMENTATIION

$20-160-060$

Rev. G, Chg. 3

Page 11 of 29

6.5 Prepare Sol i ds For Cal ci um Reacting

6.5.1 RECORD items to be processed in CEMENTATION LOG BOOK AND

CROSS reference items to those listed in daily operating Instructions.

\section{WARNI NG}

To 1 imit dispersible $P u$ to $100 \mathrm{grams.} \mathrm{maximum} P_{u}$ for individual containers with dry SS\&C is $\leq 100$ grams.

\section{CRI TI CALITY}

Amount of plutonium allowed in HA-2OMB process area is not to be more than 500 grams above HA-2OMB hold-up.

Amount of plutonfum allowed in HA-20MB airlock is not to exceed 500 grams.

Stacking of containers is not allowed.

6.5.2 SEAL IN SS\&C items per 20-170-301.

6.5.3 RECORD Item Number and Element Weight for item to be processed On CHARGE PREP DATA SHEET. 
HNF-5988 Rev. 0

\section{STABI LI ZATI ON CEMENTATI ON}

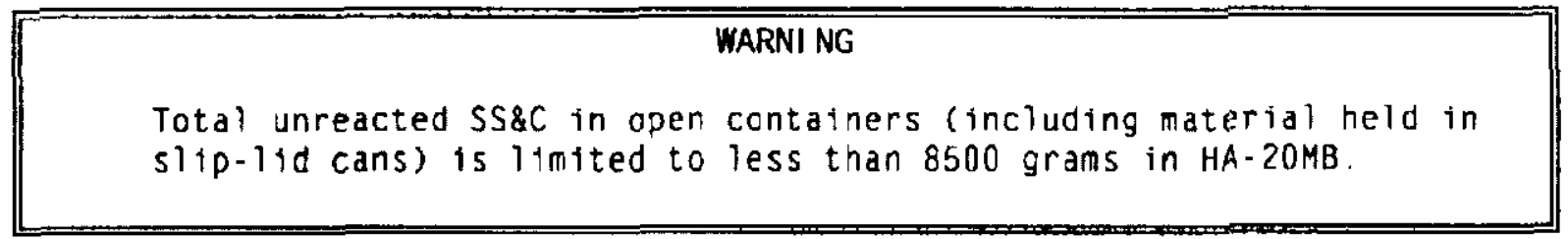

6.5.4 WEIGH item AND RECORD on CHARGE PREP DATA SHEET.

6.5.5 ENSURE addition of this weight will not cause running inventory on OPEN UNREACTED SS\&C INVENTORY SHEET to exceed 8500 grams of SS\&C before continuing.

\section{CAUTI ON}

Worknit. HD. Smitty or leather gloves shall be worn when opening cans and handing sharp edged items.

6.5.6 OPEN item AND TRANSFER to 4 -mesh and 8-mesh sieve trays with empty catch pan.

6.5.7 REMOVE foreign material AND PLACE into waste container. 
HNF-5988 Rev. 0

STABI LI ZATI ON CEMENTATION

$20-160-060$

Rev. G, Chg, 3

Page 13 of 29

\section{NOTE}

Multiple passes may be required to crush material. Material that appears to be larger than $/ \%$ in. shall be slowly dropped (1-2 pieces at a time) into crusher to keep from plugging. Materlal larger than $1 / 4$ in. may be placed in jaw crusher pan and gently struck with hammer to help identify calcium pieces so they may be individually fed into jaw crusher. Flattening of calcium pieces with hammer in jaw crusher pan is permitted for large calcium pieces prior to dropping into jaw crusher.

Crusher throat shall not be completely filled with material.

Crusher hopper shall be in place when feeding material.

6.5.8 CRUSH feed material greater than 8-mesh.

a. PLACE jaw crusher pan at outlet of crusher.

b. START crusher with switch HS-20MB-2.

c. FEEO material into crusher slowly.

d. IF crusher becomes jammed. STOP crusher with switch HS-20MB-2.

1. REMOVE debris as necessary to unjam crusher.

e. WHEN crusher pan is full. STOP crusher with switch HS- $20 M B-2$.

f. EMPTY crusher pan into catch pan with 8-mesh sieve.

g. REPEAT Step 6.5.8 with remainder of materia?.

h. MATERIAL larger than 8 -mesh shall be recycled through crusher per Step 6.5.8.

1. AFTER 2 passes through crusher. Team Leader may approve addition of $>8$-mesh material to slip-lid can. 
6.5.9 PLACE up to 2000 grams of material into a covered slip-lid can as follows:

a. RECORD Slip-lid Can Number on CHARGE PREP DATA SHEET.

b. WEIGH Empty Slip-lid Can with Lid AND RECORD on CHARGE PREP OATA SHEET.

\footnotetext{
NOTE

Final weight of SS\&C in slip-lid can shall not exceed 2000 grams.

c. TRANSFER material from catch pan to slip-lid can AND REPLACE IId.

d. WEIGH Covered Slip-lid Can with Material AND RECORD on CHARGE PREP DATA SHEET.

e. CALCULATE Weight of Matertal in Slip-lid Can AND RECORD ON CHARGE PREP DATA SHEET.

f. ADD slip-lid item to OPEN UNREACTED SS\&C INVENTORY SHEET.

g. REPEAT Step 6.5.9 until all material is removed from catch pan.

6.5.10 CALCULATE SIip-lid Can Element weight for each slip-lid Can AND RECORD on CHARGE PREP DATA SHEET.

6.5.11 SIGN AND DATE CHARGE PREP DATA SHEET.

6.5.12 REPEAT Steps 6.5.3 through 6.5.11 as needed.
} 
HNF-5988 Rev. 0

\section{STABI LI ZATI ON CEMENTATION}

$20-160-060$

Rev. G, Chg. 3

Page 15 of 29

\subsection{React Cal ci um}

6.6.1 ASSIGN next consecutive Reaction Batch Number AND RECORD ON CALCIUM REACTION/CEMENTATION DATA SHEET.

6.6.2 IF processing new slip-lid can.

THEN RECORD Slip-lid Can Number. SIip-lid Can Element Weight. and Weight of Material in Slip-lid Can from CHARGE PREP DATA SHEET ON CALCIUM REACTION/CEMENTATION DATA SHEET $\underline{O R}$

If processing a recycled slip-lid can.

THEN RECORD Slip-lid Can Number. Unreacted Material

Element Weight as Siip-lid Can Element Weight. and Unreacted Material Weight as Weight of Material in Slip-lid from previous CALCIUM REACTION/CEMENTATION DATA SHEET on current CALCIUM REACTION/ CEMENTATION DATA SHEET.

6.6.3 WEIGH Empty Mixing BOWI AND RECORD On CALCIUM REACTION/ CEMENTATION DATA SHEET.

6.6.4 PLACE mixing bowl onto reactor mixer.

6.6.5 FILL mixing bowl with chilled water from Chillwater Tank as follows:

a. OPEN valve $V-20 M B-6$.

b. FILL graduated cylinder by temporarily opening valve $V-20 M B-3$.

c. EMPTY into mixing bowl.

d. REPEAT 6.6.5.D. and 6.6.5.C. until $1400-1500 \mathrm{ml}$ of water is added to mixing bowl.

e. CLOSE valves $V-20 M B-3$ and $V-20 M B-6$. 
HNF-5988 Rev. 0

STABI LI ZATI ON CEMENTATI ON

$20-160-060$

Rev. G. Chg. 3

Page 16 of 29

\section{NOTE}

To reduce need to remove unreacted material from hopper, partial

transfers from a slip-lid may be utilized.

\section{CRI TI CALI TY}

No more than 180 grams of plutonium in any one liquid bearing container.

6.6.6 TRANSFER material into auger hopper from slip-lid can.

6.6.7 POSITION auger over mixing bowl.

6.6.8 ENSURE EMERGENCY STOP button is enabled.

6.6.9 ENSURE reactor mixer speed control lever is in speed (1) setting.

6.6.10 POSITION ON-OFF switch on side of reactor mixer to ON.

6.6.11 START reactor mixer with switch HS-20MB-4.

6.6.12 SET auger speed between 5 and 6 on speed control knob.

6.6.13 START auger with switch HS-2OMB-1.

6.6.14 PERIODICALLY monttor (every $10-15$ minutes) mixing bow: temperature as displayed on MIXER \#1 HIGH TEMPERATURE alarm switch and MIXER \#1 HIGH HIGH TEMPERATURE alarm switch during addition of material.

a. If mixing bowl temperature $15 \geq 80^{\circ} \mathrm{C}$. THEN RESPOND per Step 6.11.1.

6.6.15 ADJUST auger speed between 0 and 10 on speed control knob as necessary to control reaction. temperature, and foaming. 
HNF-5988 Rev. 0

STABI LI ZATION CEMENTATION

$20-160-060$

Rev. G, Chg. 3

Page 17 of 29

6.6.16 IF excessive foaming occurs. adjust feed rate or STOP addition of material from auger with switch HS-20MB-1 temporarlly unt 11 foaming subsides. THEN RESTART auger with Sw1tch HS-20MB-1 QR CONTINUE with Step 6.6.17.

6.6.17 IF excessive thickenting of reaction bow 1 material from heat and evaporation occurs.

IKEN ADD approximately $100.200 \mathrm{ml}$ of water from chillwater tank to reaction bowl as follows:

a. PLACE tubing from Chillwater Tank into graduated cylinder.

b. OPEN valves $V-20 \mathrm{MB}-6$ and $V-20 \mathrm{MB}-3$ unt $i$ desired amount of water is in graduated cylinder.

THEN CLOSE $v$ alves $V-20 M B-3$ and $V-20 M B-6$.

C. ADD water from graduated cylinder to mixing bowl AND RECORD amount in Comment section of CALCIUM REACTION/CEMENTATION DATA SHEET.

d. REPEAT Step 6.6.17 as necessary.

6.6.18 WHEN auger is empty. more material may be added into auger hopper by REPEATING Steps 6.6.2 and 6.6.6 unt il up to 2000 grams have been added to reaction batch. THEN STOP auger with switch HS-2OMB-1.

6.6.19 ALLOW material to continue mixing for approximately 20 minutes or until reaction is complete. (temperature STOPS increasing and additional foaming ceases). THEN STOP reactor mixer with switch HS-2OMB-4.

6.6.20 If required. TRANSFER any material remaining in auger into original silp-lid can.

6.6.21 RECORD Unreacted Materfal Weight on CALCIUM REACTION/ CEMENTATION DATA SHEET. 
HNF-5988 Rev. 0

STABI LI ZATI ON CEMENTATION

$20-160-060$

Rev. G. Chg. 3

Page 18 of 29

6.6.22 CALCULATE Unreacted Material Element Weight AND RECORD on CALCIUM REACTION/CEMENTATION OATA SHEET.

6.6.23 RECYCLE unreacted material through process per Section 6.6 .

6.6.24 CALCULATE Matertal Reacted wetght AND RECORD on CALCILIM REACTION/CEMENTATION DATA SHEET.

6.6.25 CALCULATE Element weight in Batch from slip-lid can AND RECORD ON CALCIUM REACTION/CEMENTATION DATA SHEET.

6.6.26 CALCULATE TOTalS AND RECORD ON CALCIUM REACTION/ CEMENTATION DATA SHEET.

6.6.27 REMOVE item matertal weight from OPEN UNREACTED SS\&C INVENTORY SHEET.

6.7 Cement Reacted Sol ids

NOTE

To reduce losses when adding cement into slurry, make multiple

additions to achieve required cement quantity.

\section{CRI TI CALITY}

No more than 180 grams of plutonium in any one liquid bearing container.

6.7.1 ADO approximately 1500 grams of dry cement to mixing bow?.

6.7.2 If mixer fatls or bowl is too full. cement may be manually mixed. 
6.7.3 WHEN mixing is complete, STOP cement mixer.

6.7.4 If needed, add additional cement as required to obtain desire mixture as follows:

a. ADD dry cement to mixing bow AND RECORD amount in Comment section of CALCIUM REACTION/CEMENTATION DATA SHEET.

b. If mixer falls or bowl is to full. cement may be manually mixed.

c. WHEN mixing is complete. STOP cement mixer.

d. REPEAT Step 6.7.4 as necessary.

6.7.5 If material is dry, add water to mixture as follows:

a. PLACE tubing from Chillwater Tank into graduated cylinder.

b. OPEN valves V-2OMB-6 and V-20MB-3 unt $i l$ desired amount of water is in graduated cylinder.

THEN CLOSE valves $V-20 M B-3$ and $V-20 M B-6$.

c. AOD water from graduated cylinder to mixing bowl AND RECORD amount in Comment section of CALCIUM REACTION/CEMENTATION DATA SHEET.

d. If mixer fails or bowl is too full. cement may be manually mixed.

e. WHEN mixing is complete. STOP cement mixer.

f. REPEAT Step 6.7 .5 as necessary. 
HNF-5988 Rev. 0

STABI LI ZATI ON CEMENTATI ON

$20-160-060$ Rev. G. Chg. 3

Page 20 of 29

6.7.6 POSITION ON-OFF switch an side of mixer to OFF.

6.7.7 REMOVE mixing bOW from mixer.

6.7.8 REMOVE excess material from B Flat Beater AND ADD to mixing bow $\mathrm{T}$.

6.7.9 WEIGH mixing DOWl AND RECORD as Final Cement Mixing Bowl Weight on CALCIUM REACTION/CEMENTATION DATA SHEET.

6.7.10 CALCULATE Percent PU in Cement AND RECORD On CALCIUM REACTION/CEMENTATION DATA SHEET.

6.7 .11 IF Percent Pu in Cement is $>2 \%$. THEN CONTACT Team Leader and Technica? Support before continuing.

6.7.12 SIGN AND DATE CALCIUM REACTION/CEMENTATION DATA SHEET.

6.8 Billet Can Preparation

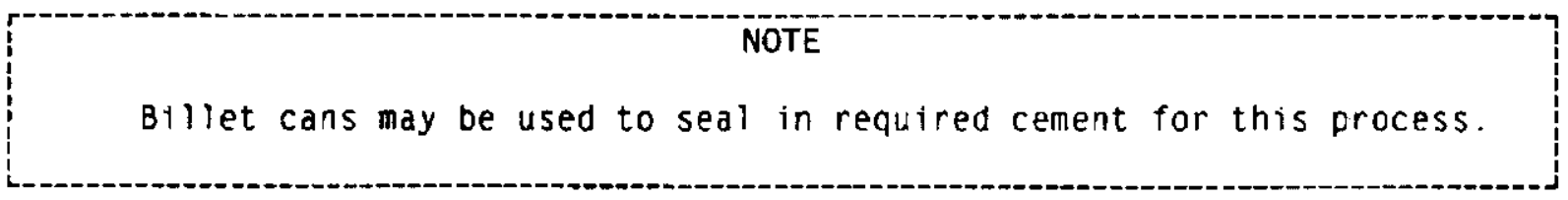

6.8.1 LABEL billet can(s) with I0 Number assigned by Special Nuclear Material (SNM) Specialist or Team Leader.

6.8.2 RECORD Billet Can Number on BILLET CAN DATA SHEET. 
HNF-5988 Rev. 0

STABI LI ZATI ON CEMENTATION

$20-160-060$

Rev. G. Chg. 3

Page 21 of 29

\section{NOTE}

Weight may be obtained after seal-in.

6.8.3 WEIGH empty Billet Can.

D RECORD as first Billet Can weight on BILLET CAN DATA SHEET.

- RECORD aS TARE WEIGHT On can.

D SEAL IN billet can per 20-170-301.

6.9 Fill Billet Cans

6.9.1 RECORD Reaction Batch Number and Percent Pu in Cement from CALCIUM REACTION/CEMENTATION DATA SHEET ON BILLET CAN DATA SHEET.

6.9.2 TRANSFER cement from mixing bowl until billet can(s) is within $3 / 4$ in. of top or mixing bowl is empty.

6.9.3 WEIGH Billet Can After Addition AND RECORD on BILLET CAN DATA SHEET.

6.9.4 REPEAT Steps 6.9.1 through 6.9.3 to fill billet cans and empty Mixing Bowls completely.

a. SCRAPE out mixing bowl using spatula.

6.9.5 CALCULATE Weight of Cement Added to Billet Can AND RECORO ON BILLET CAN DATA SHEET.

6.9.6 CALCULATE Element Weight Added to Billet Can AND RECORD on BILLET CAN DATA SHEET. 
HNF-5988 Rev. 0

STABILIZATION CEMENTATION

\section{CRI TI CALI TY}

Stacking of containers is not allowed.

6.9.7 REPLACE lid on billet cans,

THEN ALLOW cement in container to cure for 24 hours.

a. ENTER On BILLET CAN DATA SHEET TIME and DATE billet is filled.

6.9.8 INSPECT cement for free liquids.
a. FREE standing liquid shall be recycled into a subsequent reaction batch.
b. If water was removed. AlLow contents of container to cure as necessary.

\section{NOTE}

Scales shall be set up within 24 hours for accountability purposes.

6.9.9 WEIGH Dillet can per 20-200-101 AND RECORD Final Billet Can weight on BILLET CAN DATA SHEET.

\section{NOTE}

Contents of błllet can shall have no free liquids before placing inside waste drum.

Cemented SS\&C to be handied as mixed waste.

6.9.10 SEAL OUT billet cans from glovebox per 20-170-299 into a vented PVC bag.

6.9.11 SIGN AND DATE BILLET CAN DATA SHEET, 
HNF-5988 Rev. 0

STABI LI ZATI ON CEMENTATI ON

$20-160-060$

Rev. G. Chg. 3

Page 23 of 29

\subsection{Respond to Material Spi IIs}

6.10.1 If container holding unprocessed material is spilled. SWEEP UP spilled material AND REPLACE in container.

a. REWEIGH container and make changes to CHARGE PREP DATA SHEET as necessary.

6.10 .2 If abnormal solution sprllage occurs. SHUTDOWN process per Step 6.11.3 (EMERGENCY RESPONSE) AND CLEAN UP SP 111.

6.10 .3 If container holding cemented SS\&C is spilled. CLEAN up spilled materfal AND REPLACE in billet can.

a. REWEIGH container and make changes to BILLET CAN DATA SHEET as necessary.

\section{$6.11 \mathrm{Al}$ arm/Emergency Responses}

NOTE

The HIGH TEMPERATURE alarm is set at $80^{\circ} \mathrm{C}$ and is interlocked to shut down the feed auger.

6.11.1 RESPOND to MIXER \#1 HIGH TEMPERATURE alarm.

a. REMOVE power to feed auger with switch HS-20MB-1.

b. WHEN vessel temperature is less than $80^{\circ} \mathrm{C}$. RESET alarm Dy pressing \#1 HIGH RESET.

c. ALLOW temperature to cool to $<60^{\circ} \mathrm{C}$,

THEN GO TO Step 6.6.13. 
HNF-5988 Rev. 0

STABI LI ZATI ON CEMENTATI ON

Page 24 of 29

\section{NOTE}

The HIGH-HIGH TEMPERATURE alarm is set at $90^{\circ} \mathrm{C}$ and is inter locked to shutdown feed auger. This provides a back-up for HIGH TEMPERATURE al arm.

6.11.2 RESPONO to MIXER \#1 HIGH-HIGH TEMPERATURE alarm.

a. REMOVE power to feed auger with Swftch HS-20MB-1.

b. WHEN vessel temperature is less than $80^{\circ} \mathrm{C}$. RESET alarm by pressing \#1 HIGH HIGH RESET.

c. INITIATE investigation into failure of \#I HIGH TEMPERATURE interlock. If interlock failed.

d. WHEN interlock investigation is resolved, RESTART process per Step 6.6.13, after temperature has cooled to less than $60^{\circ} \mathrm{C}$.

6.11.3 EMERGENCY RESPONSE or other abnormal conditions occur.

d. SHUT OFF switches outside glovebox (HS-20MB-1. HS-20MB-2, HS-20MB-3. HS-2OMB-4, HS-2OMB-5, and HS - 2OMB-6).

b. SHUT OFF chiller with switch OS-2OMB-1.

c. PUSH EMERGENCY STOP button.

d. RESTART system per Technical Support and Team Leader direction. 
HNF-5988 Rev. 0

\section{STABI LI ZATI ON CEMENTATION}

$Z 0-160-060$

Rev. G, Chg. 3

Page 25 of 29

\section{BI BLI OGRAPHY}

7.1 OSD-2-184-00020. CH-TRU SOlid Waste Disposal

7.2 OS0-Z-184-00025. Glovebox Gloves \& Differential Pressure

7.3 CPS-Z-165-80634. Sand, Slag And Crucible Cementation Process. Glovebox HA-20MB 
HNF-5988 Rev. 0

STABI LI ZATI ON CEMENTATI ON

$Z 0-160-060$

Rev. G, Chg. 3

Page 26 of 29

Attachment 1 - CHARGE PREP DATA SHEET

\begin{tabular}{|c|c|c|c|c|c|}
\hline Step & & Formula & & & \\
\hline 6.5 .3 & Item Number & 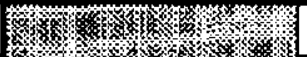 & & & \\
\hline 6.5 .3 & Element Weight & 每 & (A) & & $g$ \\
\hline 6.5 .4 & Item Weight & 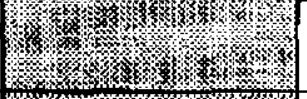 & $(B)$ & & 9 \\
\hline $6.5 .9 . a$ & Slip-lid Can Number & 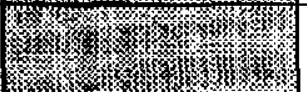 & & & \\
\hline $6.5 .9 . b$ & $\begin{array}{l}\text { Empty Slip-lid Can } \\
\text { with Lid Weight }\end{array}$ & $y_{1}$ & (C) & (D) & 9 \\
\hline $6.5 .9 . d$ & $\begin{array}{l}\text { Covered Sip-lid Can } \\
\text { with Material Weight }\end{array}$ & 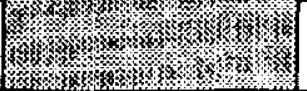 & $(E)$ & $(F)$ & $\mathrm{g}$ \\
\hline $6.5 .9 . e$ & $\begin{array}{l}\text { Weight of Material } \\
\text { in Slip-lid Can }\end{array}$ & $\begin{aligned} G & =E-C \\
& \text { or } \\
H & =F-D\end{aligned}$ & (G) & $(H)$ & $g$ \\
\hline 6.5 .10 & $\begin{array}{l}\text { STip-lid Can Element } \\
\text { Weight }\end{array}$ & $\begin{array}{c}G=\ldots .+A \\
G+H \\
\text { or } \\
H \\
J=\ldots \times A \\
G+H\end{array}$ & 7 & (j) & $g$ \\
\hline \multicolumn{6}{|c|}{ NCO: $\quad$ Date: } \\
\hline \multicolumn{2}{|c|}{ Team Leader: } & Date & & & \\
\hline
\end{tabular}

Comments: 
HNF-5988 Rev. 0

STABI LI ZATI ON CEMENTATI ON

$Z 0-160-060$

Rev. G, Chg. 3

Page 27 of 29

Attachment 2 - CALCIUM REACTION/CEMENTATION DATA SHEET

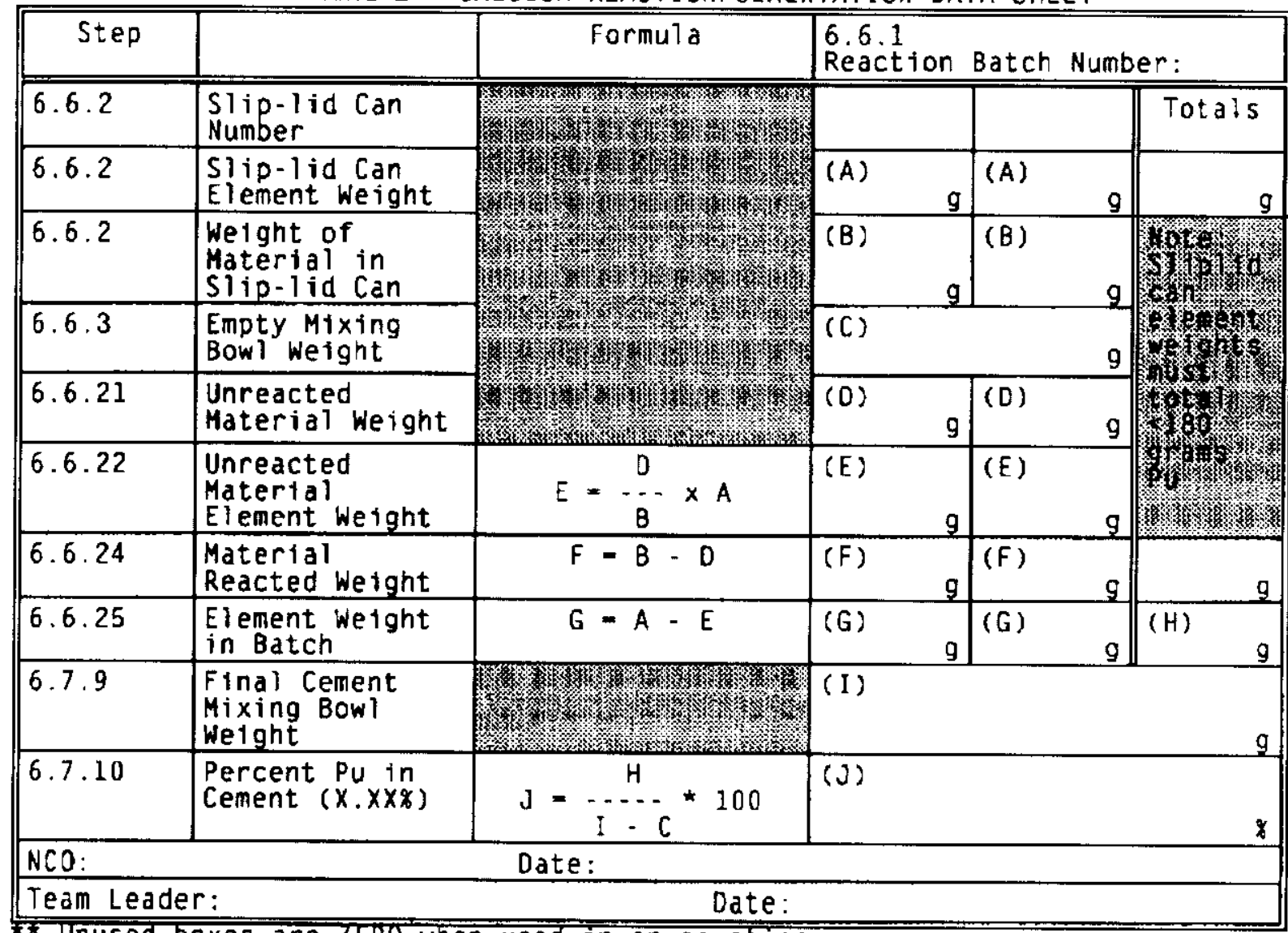

* Unused boxes are LERO when used in an equation.

Comments: 
HNF-5988 Rev. 0

STABI LI ZATI ON CEMENTATION

$20-160-060$

Rev. G. Chg. 3

Page 28 of 29

Attachment 3 - BILLET CAN DATA SHEET

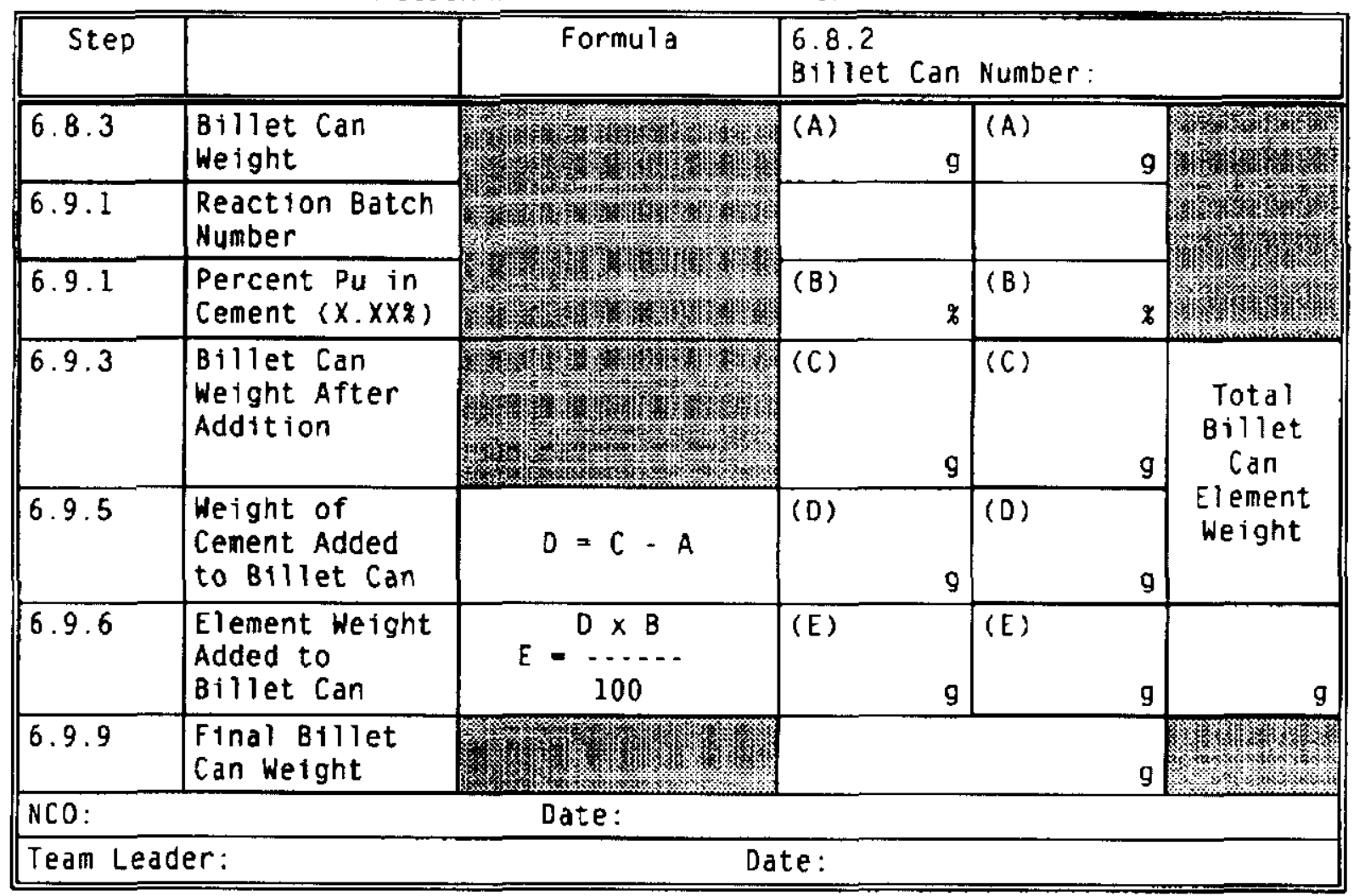

Comments:

6. 9.7.a. Billet can filled

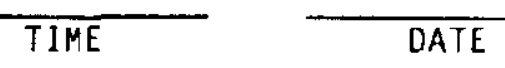


HNF-5988 Rev. 0

STABI LI ZATI ON CEMENTATION

$20-160-060$

Rev. G, Chg. 3

Page 29 of 29

Attachment 4 - OPEN UNREACTED SS\&C INVENTORY SHEET

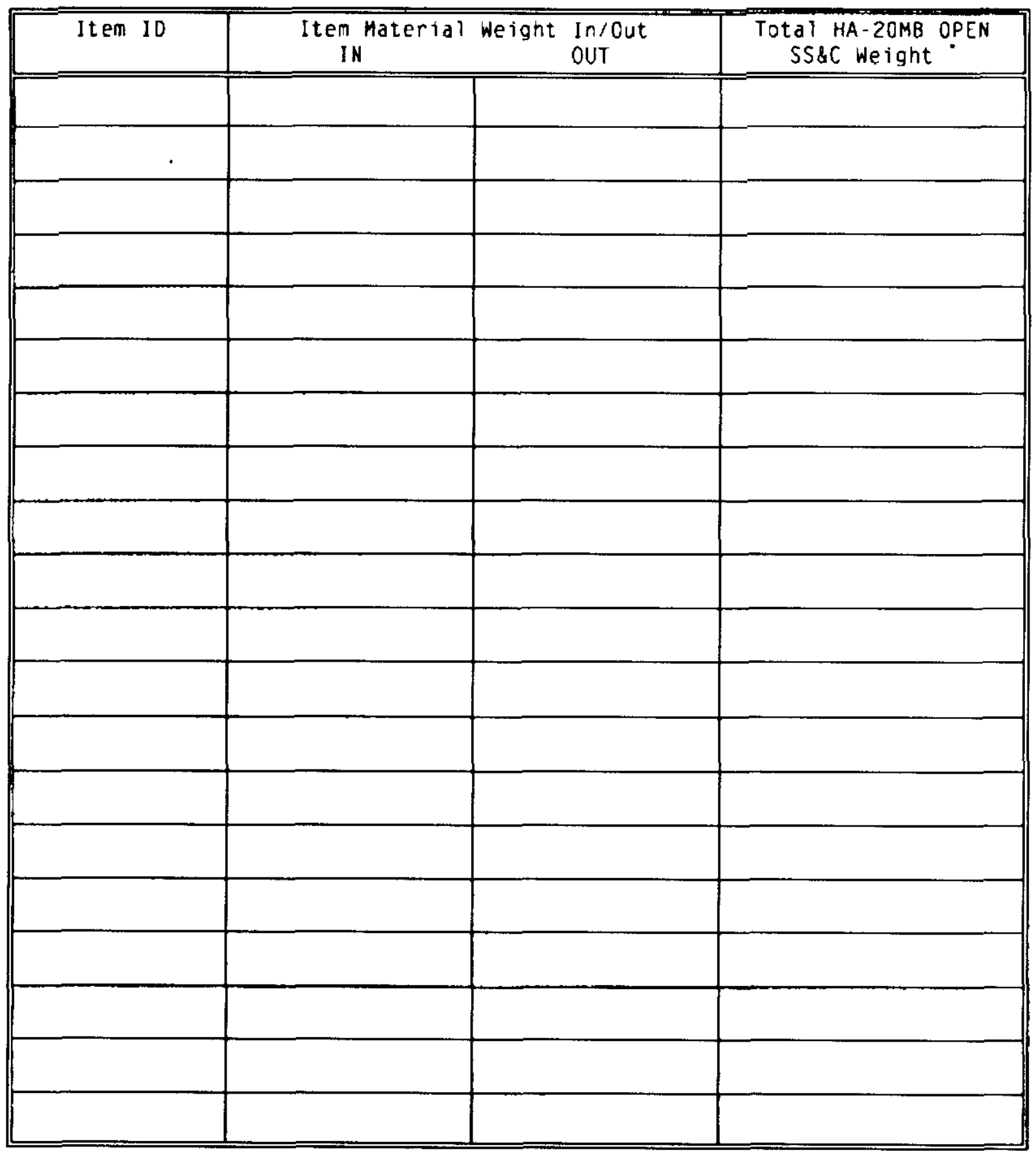

* Total running inventory of open SS\&C material shall be < 8500 grams 
HNF-5988 Rev. 0

This page intentionally left blank. 
HNF-5988 Rev. 0

APPENDIX G

GENERAL DESCRIPTION OF HANFORD RESIDUE CATEGORIES: INCINERATOR ASH AND OXIDE $<30 \mathrm{WT} \%(\mathrm{PU}+\mathrm{U})$ 
HNF-5988 Rev. 0

This page intentionally left blank.

G-2 


\section{FLUOR DANIEL HANFORD, INC.}

\section{INTEROFFICE CORRESPONDENCE}

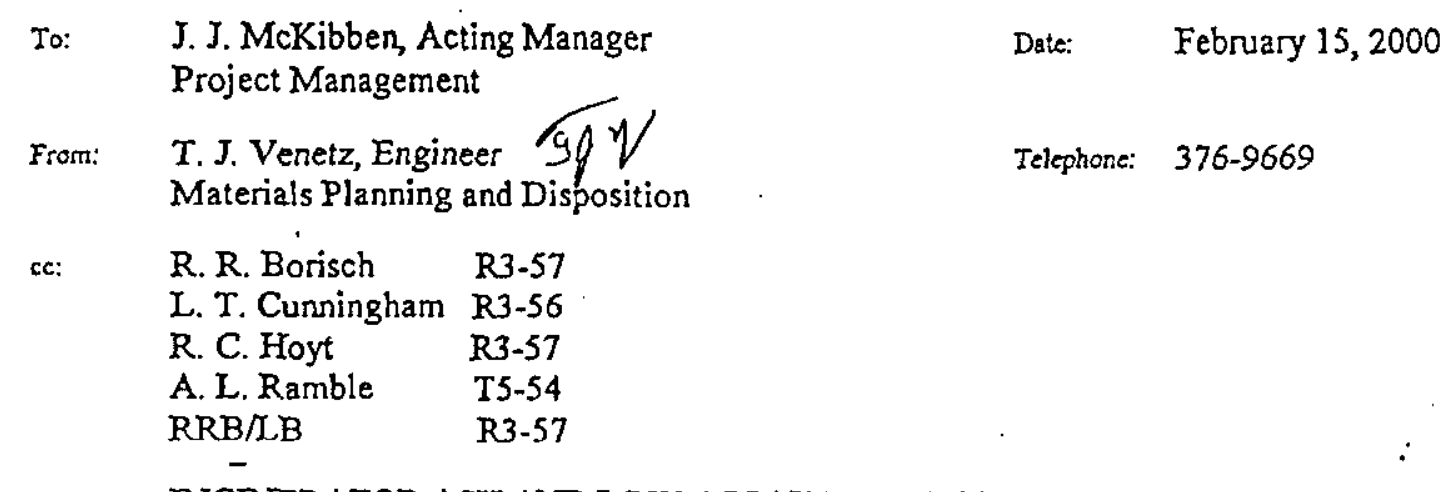

Subjec: INCINERATOR ASH AND LOW ASSAY PLUTONIUM OXIDE RESIDUES WHITE PAPER

The attached document contains information on incinerator ash and plutonium oxide residues that was compiled at the verbal request of Mr. R. R. Leugemors, BWXT.

If you need additional information on this matter, you may reach me at 373-9669.

Is

Attachment 
HNF-5988 Rev. 0

February 15, 2000.

ATTACHMENT

\section{General Description Of Hanford Residue Categories: Incinerator Ash And Oride $>0$ wt \% (Pu+U)}

\section{Purpose:}

The purpose of this paper is to provide general process knowledge and chemical and physical characterization information on two categories of plutonium bearing residues stored at the Plutonium Finishing Plant (PFP) that are under consideration for stabilization via a cementation process. The two residue categories are plutonium bearing incinerator ash and oxides with less than $30 \mathrm{wt} \%$ Special Nuclear Material (SNM) (i.e. $\mathrm{Pu}+\mathrm{U}$ )

\section{Incinerator Ash}

Ash is mixture of coarse, granular, fine and very fine particulate materials from the furnaces. The ash is not homogeneous and may contain bits of tramp metal, unburned feed materials and carbon from the incomplete oxidation of some feed materials. The . Hanford incinerator ash category contains about 530 items. These items consist of either individual cans of ash or large metal cans (industry-denoted as a 50 pound lard can) containing numerous individual cans of ash. Thus, the item number is not a count of the number of cans of ash. There are three broad components that comprise the incinerator ash category:

n ash which was generated at the Hanford $232-Z$ incinerator

- ash which was generated at Rocky Flats Plant (RFP) [site is currently called the Rocky Flats Environmental Technology Site (RFETS)]

- ash which was received from the Battelle Northwest National Laboratory (BNNL) [currently Pacific Northwest National Laboratory (PNNL)].

The majority of the Hanford incinerator ash inventory consists of about one hundred lard cans, each of which contains from 5 to 7 individual smaller cans. The incinerator ash items from RFP consist of about 410 items which are 7 inch food pack containers. The ash received from $B N N L$ consists of about 20 of the 7 inch food pack cans of ash. The average plutonium content of incinerator ash for which there is net weight data available is 12.3 weight per cent plutonium. Only 13 items are recorded as having a $\mathrm{Pu}^{240}$ content greater then 7 percent.

The incinerators were used to process combustible residues that were generated by plutonium processing and recovery operations. The combustible residues were burned to reduce volume, destroy volatile constituents and recover plutonium. Large quantities of ash were leached in boiling nitric acid to recover the plutonium, and some of this ash was re-bumed prior to dissolution. The items in the present inventory had not been processed when the Plutonium Finishing Plant (PFP) continuous dissolvers were shut down.

\section{Rocky Flats Incinerator Ash}

The RFP ash was produced in an oxygen-purged, hand-fed, self-sustaining incinerator maintained at about $700^{\circ}$ C. [Trip Report, 65454-83-134, C.H. Delegard, November 15, 1983]. The incinerator system included a ball mill that was generally used to pulverize 
the ash as it was generated. The ash was milled to pass through a 100-mesh screen, but may contain some of the particles that are retained on a 20 -mesh sieve.

Source combustibles which produced RFP ash consisted of plastic such as polyvinyl chloride (PVC) (45 percent feed) and polyethylene/polypropylene (35 percent feed), paper ( 5 percent feed), liquid ( 5 percent feed), drybox gloves ( 4 percent feed), filters with carbon ( 3 percent feed), metal ( 2 percent feed), and wood (lpercent feed).

The ash composition varies widely and was generally analyzed only for plutonium. The major ash components are silica ( 15 to 75 percent, but typically 45 percent) and carbon ( 5 to 40 percent, but generally about 20 percent); minor components such as aluminum oxide, calcium oxide, iron oxide, and sodium oxide can normally vary from 1 to 10 percent. [T. C. Johnson, RFP-250, Recovery of Plutonium from Incinerator Ash at Rocky Flats, 1976][C. H. Delegard, RHO-RE-SA-95P, Plutonium Dissolution from Rocky Flats Plant Incinerator Ash, June 1985[ [C. H. Delegard, SD-CP-DTR-005, Laboratory Tests on Plutonium Recovery from Rocky Flats Ash Using Nitric Acid-Fluoride Leaching, 3-30-84]. Table I shows the laboratory analysis for typical RFP incinerator ash received at PFP. Additional analyses are reported in Table 4 and 5.

Table 1. Typical RFP Incinerator Ash Composition*

\begin{tabular}{|c|c|}
\hline Constituent & Ash (Vt \%) \\
\hline Aluminum oxide & 3.3 \\
\hline Barium Oxide & 0.9 \\
\hline Boron Oxide & 1.8 \\
\hline Calcium Oxide & 4.0 \\
\hline Chromium Oxide & 0.7 \\
\hline Copper Oxide & 1.0 \\
\hline Iron Oxide & 5.7 \\
\hline Lead Oxide & 0.8 \\
\hline Magnesium Oxide & 4.6 \\
\hline Manganese Oxide & 0.1 \\
\hline Nickel Oxide & 0.5 \\
\hline Phosphorus Oxide & 0.0 \\
\hline Potassium Oxide & 0.7 \\
\hline Plutonium Oxide & 2.8 \\
\hline Silicon Oxide & 48.5 \\
\hline Sodium Oxide & 1.2 \\
\hline Tantalum Oxide & 0.4 \\
\hline Tin Oxide & 0.1 \\
\hline Titanium Oxide & 1.4 \\
\hline Carbon & 22.0 \\
\hline Total & 100.5 \\
\hline
\end{tabular}

* Data from RFP-2520 
HNF-5988 Rev. 0

The metal ions, except for carbon, are reported as oxides. Analyses did indicate that some incinerator ash contained an average of 0.6 wt percent fluoride and 2.5 wt percent chloride [J.L. Long, "Analysis of Incinerator Ash \& Heel, Internal Rocky Flats Job Report No. 1-74, DPA 950348, January 4, 1947]. The oxide is the thermodynamically stable form of most metais from an oxygen rich incineration process and is expected to be the predominant species formed as a result of incineration. However, under the incineration conditions, other species could have been formed such as chloride salts from the reaction with $\mathrm{HCl}$ generated from the decomposition of polyvinyl chloride (PVC), carbonates from the reaction with $\mathrm{CO}_{2}$, and silicates and aluminates depending on the initial source of the silicon and aluminum. The more reactive alkali and alkaline metals are not characteristically found in nature as the oxide and these metals would tend to form chlorides, carbonates and silicates. Delegard specifically mentioned the presence of calcium silicate and lead ferrate in ash received from RFP. He also mentioned that incinerator ash received from RFP contained pieces of glass, bits of metal and varying amounts of incompletely bumed carbonaceous materials.

The RFP incinerator ash will probably be characterized as Resource Conservation and Recovery Act (RCRA) hazardous by the derived-from rule. The hazardous constituents include F-listed wastes, chromium (D007) and lead (D008). It appears that leaded gloves must have been burned during early RFP campaigns because some "old" ash contains more than 50 ivt percent lead.

All of the RFP ash presently stored at Hanford was subsequently re-burned to meet PFP vault storage requirements. Most of the items were re-burned in oxygen-rich tube furnaces in Glovebox HA-40-F, located in Room 169 of the 234-5Z building [PFD-Z180-00005, Process Flowsheet for HA-40-F Calcination, May 25, 1984]. The procedure mandated that the "... ash shall be re-burned at $600^{\circ} \mathrm{C}$ for four hours with good oxygen contact. Heating rate shall be carefully controlled between $400^{\circ} \mathrm{C}$ to $600^{\circ} \mathrm{C}$, depending on fuel value. Air shall be supplied for dilution of oxygen, as may be required, for ash with high fuel value (i.e. large amounts of carbon)." The calciners were equipped with two paddles operating up to $12 \mathrm{rpm}$ to stir/agitate the ash and ensure good ash-oxygen contact. Those items that were not re-burned in the HA-40-F calciners were re-bumed in the furnace in glovebox HC-21C. This re-buming further reduced the carbon content. All the RFP items met the PFP Loss on Ignition (LOI) requirements for vault storage after re-buming. The LOI tests were performed at $450^{\circ} \mathrm{C}$ because there was volatilization of salts when the tests were carried out at $1000^{\circ} \mathrm{C}$.

As mentioned earlier, most of the resulting ash was treated to recover plutonium. Plutonium recovery was achieved by leaching ash in boiling $11 \mathrm{M}$ nitric acid containing 0.1 to $0.2 \mathrm{M}$ fluoride ion. Ash was processed in the continuous dissolvers in the Plutonium Reclamation Facility (PRF) that was used for sand, slag \& crucible (S\&C) dissolution. Several hundred cans of both RFP and $232-Z$ ash were processed at PFP. Laboratory tests were made on the recovery of plutonium from RFP incinerator ash (M. J. Rasmussen and H. W. Crocker, Recovery of Plutonium From Incinerator Ashes, HW72285, January 15, 1962) (C. H. Delagard, Laboratory Tests on Plutonium Recovery 
HNF-5988 Rev. 0

from Rocky Flats As Using Nitric Acid-Calcium Fluoride Leaching, SD-CP-DTR-005, March 30, 1984). There was no mention of unexpected, energetic reactions when RFP incinerator ash was contacted with boiling (about $115^{\circ} \mathrm{C}$ ) $11 \mathrm{M}$ nitric acid using $\mathrm{CaF}_{2}$ as the fluoride source.

\section{PFP Incinerator Ash}

The $232-Z$ incinerator was conceived as a way to reduce the volume of combustible wastes for recovery of plutonium from "various miscellaneous solid wastes" generated at both the 234-5Z Building and the 231-Z Building. The incinerator was a dualchambered, externally heated, muffle-type incinerator fed by chopped Pu-bearing waste that entered the incinerator glovebox via a continuous wire-mesh conveyor belt. Plant operations began in January 1962 and were shut down in 1973 . The system occasionally experienced operating problems due to equipment failures and various mechanical problems. Smoking, backfiring, and temperature differentials within the incinerator itself occurred as occasional problems, along with jamming of the chopper feed belt. The lack of good air flow control was a basic design flaw. [HNF-EP-0924, History and Stabilization of the PFP Complex, Hanford Site]. Typical operating conditions for the $232-Z$ incinerator furnace included primary combustion chamber temperature of $700^{\circ} \mathrm{C}$ to $800^{\circ} \mathrm{C}$ and about 20 minutes residence time in the furnace (full residence time range was from 6 to 60 minutes based on the belt speed capability of 2 to 20 inches per minute through a heated chamber that was 9 feet 10 inches long. Typical belt speed was 6 inches per minute).

Panesko [Internal Letter J.V. Panesko to D. G. Harlow, March 18, 1975, Information on Z Plant Incinerator] [ J.V. Panesko, ARH-1981, Batch Dissolution of Incinerator Ash, February 1971] indicated that 232-Z incinerator feed was mostly PVC plastic with 25 percent rags and paper (towels and cartons). Cardboard was added to achieve a 50-50 plastic-paper mix. He also indicated 5 percent asbestos in one feed material. Only the fingertips of leaded glovebox gloves were incinerated. Process oils absorbed onto paper towels were also incinerated. All material charged to the furnace was sorted and chopped. The $232-Z$ incinerator process operated such that feed was sent through the chopper into a bin from which it then exited via a rubber belt with cleats, it then fell onto the vibrating chute, and then moved onto the continuous wire mesh conveyor belt and into the furnace.

The PFP Safety Analysis Report (SAR) [WHC-SD-CP-SAR-021 Revision 0, page 9C11 ] indicates that the ash produced by the $232-Z$ incinerator routinely contained on the average $10 \%$ plutonium. The range of plutonium in ash varied from 3 to $20 \%$ plutonium.

In a process test conducted in 1970 to determine processing advantages gained by reburning the normal incinerator ash, [Evaluation of Process Test PRF-68-2, Re-burning of Incinerator Ash, dated July 6, 1970], it was reported that re-buming resulted in a 45 percent reduction in volume, a 36 percent reduction in the weight of the ash and a "reduction of tars and organic material in the ash." However, they also reported a 14 percent loss of plutonium which suggests that the weight and volume data is biased high. In later studies, Panesko reported "the average weight loss of the first three ashes was 
approximately 15.0 percent." The ash batches were described as ranging from homogeneous fines to coarse mixtures containing charcoal chunks and fibers.

The re-burning changed the color of the ash from a gray-black to a dark tan. The incinerator operating conditions for the 1970 process test were: nominal temperatures of primary inlet was $700^{\circ} \mathrm{C}$, primary outlet was $800^{\circ} \mathrm{C}$ and secondary stage was $800^{\circ} \mathrm{C}$. The incinerator belt speed was 6 inches/minute; air flows were $5 \mathrm{cfm}$ for the primary inlet, 7 $\mathrm{cfm}$ for the primary outlet, and $8 \mathrm{cfm}$ for the secondary. It was reported during laboratory dissolution experiments "of re-burned and control ash", that dissolution of reburned ash yielded a lighter colored and less tarry dissolver heal with smaller undissolved particles than that for regular ash. The regular ash foamed excessively during acid dissolution even after the addition of antifoam, while the re-burned ash foaming problem was easily controlled by the addition of antifoam." In a test to physically fractionate the ash [letter A. H. Case to L. A. Grande, Incinerator Ash, January 8, 1970], the ash was described as about 72.5 percent coarse and 27 percent fines. In one test, the ash was slurried in water and there was no mention of any heat generated from dissolution of any salts/oxides.

Data on the analysis of PFP generated incinerator ash is sparse compared to information on RFP incinerator ash. The result of an analysis on PFP incinerator ash can number 85 is shown in Table 2. The oxide compound is a calculated value resulting from an analysis of the element concentration.

Table 2. PFP Incinerator Ash Composition

\begin{tabular}{|c|c|}
\hline Constituent & Ash (Wt \%) \\
\hline Barium Oxide & 0.67 \\
\hline Calcium Oxide & 0.17 \\
\hline Chromium Oxide & 0.44 \\
\hline Chloride & 0.24 \\
\hline Iron Oxide & 10.01 \\
\hline Manganese Oxide & 0.09 \\
\hline Nickel Oxide & 0.10 \\
\hline Plutonium Oxide & 17.53 \\
\hline Silicon Oxide & 11.98 \\
\hline Zinc Oxide & 0.12 \\
\hline Carbon & 28.0 \\
\hline Total & 69.35 \\
\hline
\end{tabular}

The PFP SAR indicates that the major cations in ash include sodium, potassium, magnesium, calcium and iron, but references were not cited. The presence of chloride would suggest that some of the more reactive metals would be present as chloride salts. Analysis of incinerator slag [Letter, V.L. Schuelein to C. M. Peabody and R. E. Felt, Analysis of 232 Incinerator Slag, May 30, 1973] indicated the presence of a number of 
cations. Their concentration in decreasing order $(>10,000 \mathrm{ppm})$ were silicon, lead, aluminum, calcium, magnesium, zinc, gallium, iron, and nickel.

Consequently, Hanford generated incinerator ash is not expected to contain target levels of hazardous materials.

Other General Remarks relating to Ash and Cementation of Ash

There should be insignificant generation of gases during cementation of ash. The ash material was oxidized at temperatures of around $650^{\circ} \mathrm{C}$ or higher.

Any alkali/alkaline metals, i.e. $\mathrm{Na}$, would have been oxidized to the oxide. In the case of SS\&C there is a Ca metal that would be oxidized by water to form the oxide and hydrogen. There could be tramp metal, ie. Iron nuts and bolts, but they would not be oxidized by water.

There is the possibility of small particles of Pu metal in the ash which might not have been oxidized. These could react with water and liberate hydrogen. But the Pu would be widely-dispersed and in small concentration, so the rate of hydrogen generation would be slow and not lead to flammable mixture. SS\&C would contain more particulate Pu metal than the ash.

We do not have any heat of reaction data for ash. Sodium oxide is reported to dissolve in water with the liberation of considerable heat. The other alkai/alkaline metal oxides do not dissolve with the liberation of much, if any, heat, i.e. $\mathrm{BaO} \mathrm{MgO}, \mathrm{K}_{2} \mathrm{O}$. But the real issue is how much if any sodium oxide is there and what is its concentration. As we have stated there is no analytical data that indicates that the $\mathrm{Na}$ is present as the oxide. With the presence of chloride, carbonate, aluminate and silicate, the sodium oxide content would be small. If there were sodium oxide present, it would be well dispersed in the ash and entrapped in ash particles so the rate of dissolution would be slow and not generate much heat per unit of time. The heat generated from the reaction with $\mathrm{Ca}$ or the heat of hydration from the making of cement is probably greater that anything that could come from the dissolution of ash in water.

Cement is a mixture of calcium carbonate, silica, alumina, iron oxide, and calcium sulfate. It is not apparent that any of the components - anions or cations - of ash would cause energetic reactions with cement and water that would be greater than the nomal heat evolved from the hydration and setting of cement. The ash components could retard the curing time of the cement and affect the compressive strength of the cement. Ash should be less reactive that SS\&C since ash has been stabilized by burning and calcining at an elevated temperature.

Many hundreds of cans of Hanford source incinerator ash have been leached/dissolved in concentrated nitric in both batch and continous dissolvers at Hanford. Persons familiar with that work recall no remarkable heat or gas generation. We would expect less response to water or a mixture of Portland cement and water. We would expect similar behavior from lean plutonium oxide scraps that have been stabilized in a fumace with an air atmosphere. Review of Rocky Flats documentation on aqueous dissolution ash 
indicate that over 9,000 kilograms of ash have been processed in a continuous cascade dissolver system. No mention is made of reactivity problems; however, plugging of the offgas system with silica was cited as a major problem. Silica is formed by vapor deposition and hydrolysis of silicon tetrafluoride, which is formed by the nitric/HF acid used to dissolve the ash.

There is in the PFP history document, HNF-EP-0924, pages 12-9, reference made to a November 1968 event in which an explosion or implosion of glass vessel ash dissolver occurred. The document states that inspection of the system showed a restriction on the vent pipe. This could have been caused by over-pressurization due to vent line plugging with silca.

Plutonium Oxides/Mixed Oxides/Alloy $<30$ weight percent $\mathrm{Pu}$ or Pu+U There are less than 500 items in the plutonium oxides/mixed oxide/alloy $<30 \mathrm{Wt}$ percent $\mathrm{Pu}$ or Pu $+\mathrm{U}$ category. The items are in 35 different PFP category codes. They are typically oxide and mixed oxide residues and some low Pu content alloys, they are summarized in Table 3.

Table 3. Plutonium Oxides/Mixed Oxides/Alloy $<30$ weight percent $\mathrm{Pu}$ or $\mathbf{P u}+\mathrm{U}$

\begin{tabular}{|l|l|l|}
\hline Sub-category & Category Codes & Percent of total \\
\hline $\begin{array}{l}\text { Rocky Flats } \\
\text { Oxides }\end{array}$ & 102,900 & $10 \%$ \\
\hline $\begin{array}{l}\text { PFP generated } \\
\text { oxides }\end{array}$ & $5,6,19,20,30,41,61,62$, & $64 \%$ \\
\hline Mixed oxides and & 63,64 & \\
alloys & $17,67,70,73,74,77,78$, & $26 \%$ \\
& $436,439,224,404,411$, & \\
& $465,466,482,800,850$, & \\
& 950 & \\
\hline
\end{tabular}

\section{PFP Generated Oxide Residues}

PFP stabilized oxide residue comprises the majority of the material. The low grade oxide residue is plutonium oxide generated from the thermal stabilization of plutonium material recovered from the process gloveboxes that resulted from process spills and powders generated during process operations. The majority of the residue came from Remote Mechanical C (RMC) line operations and from PRF operations. Although some of this material could have contained reactive and organic chemical constituents (i.e., tri-butyl phosphate degradation products), thermal stabilization was required prior to placing the material into vault storage, effectively reducing these constituents to de-minimus levels. The non plutonium constituents remaining will consist of the flowsheet process chemicals (compounds of $\mathrm{Al}, \mathrm{Ca}, \mathrm{Mg}$, and $\mathrm{Mn}$ ) and iron, nickel and chromium from corrosion of process equipment. 


\section{Rocky Flats Oxide Oxides}

The RFP oxide residues (about 10 percent of the total) consist of plutonium oxide recovered from various pyrochemical operations and consequently contain high concentration of chlorides. However thermal stabilization of the materials would have removed all moisture, and reactive or gas generating components. These materials were stabilized to an LOI of less than 1 percent at $450 \mathrm{C}$, to meet shipping requirements.

Tests were conducted in the analytical laboratory on Rocky Flats plutonium oxides which included washing with dilute sodium hydroxide and/or acid dissolution (11 M nitric acid). [Letter, T. D. Cooper to M. J. Schliebe, Removal of Chloride from Plutonium Oxide Via Washing, May 24, 1988][Letter, C. H. Delegard and D. G. Bouse to K. S. Kalkofen, Characterization, Particle Size and Dissolution Tests of Three Rocky Flats Oxides, August 30, 1985]. There were no reported indications of any unexpected energetic reactions when the oxides were mixed with dilute base, water or nitric acid. . The salts were described as consisting of pebble sized particles, fine powder, and some contained black chunks like anthracite. Some of the black chunks were identified as graphite and others appeared to be parts of fractured crucibles. Also encountered were pieces of wire and broken bits of glass and plastic. In one test the scrap was sieved through a US series 20 mesh screen to remove large chunks. Small beads of metal also collected on the screen. The beads were characterized as containing plutonium.

\section{Mixed Oxide and Alloys}

Mixed oxide and alloy residues are scrap materials which resulted from 300 Area fuel fabrication research in support of commercial, research, and test reactors. As noted in Table 3 they comprise 23 different PFP category codes, but 62 percent of the items are listed as Pu-U or Pu-EU oxide. The materials vary widely in composition. Almost all the items contain uranium compounds. Aluminum and/or zirconium is also reported to be present in some of the items, which is expected, as these elements were commonly used in reactor fuel compositions. The low grade scrap (non alloy) can be expected to contain materials generated from fuel fabrication operations and glovebox sweepings, such as grinding media, typically tungsten carbide. Organic chemicals in the form of binders and dye lubricants were used in the fuel pelletizing process, but these materials were removed, by thermal stabilization to meet either vault storage or LOI shipping requirements. 
HNF-5988 Rev. 0

悹

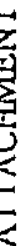

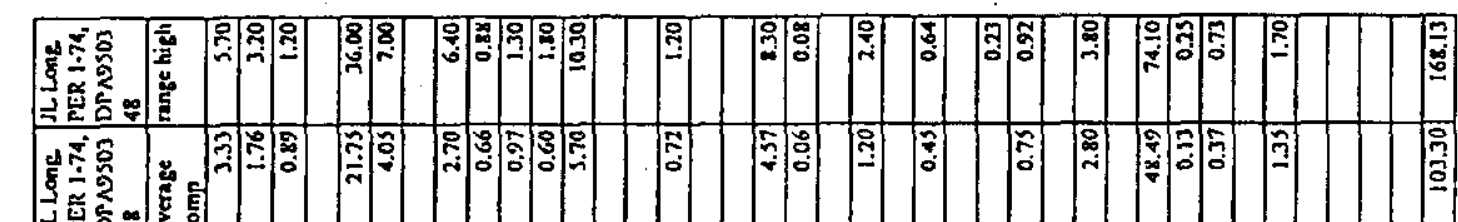

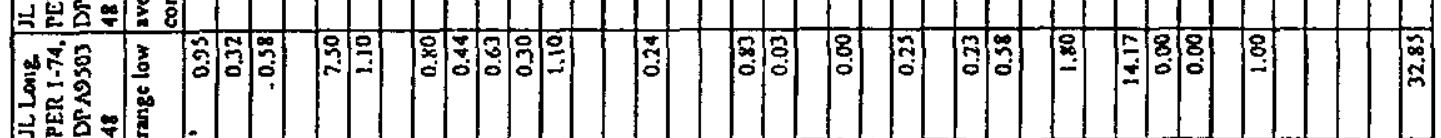

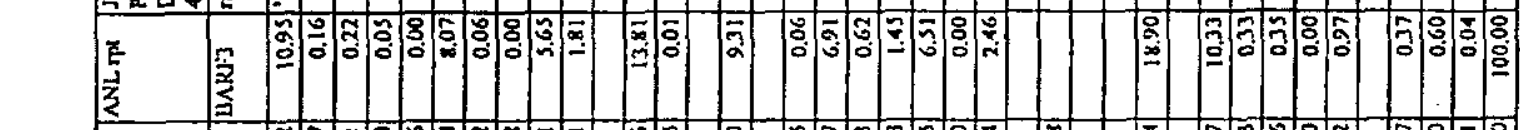

告倍

至㟥

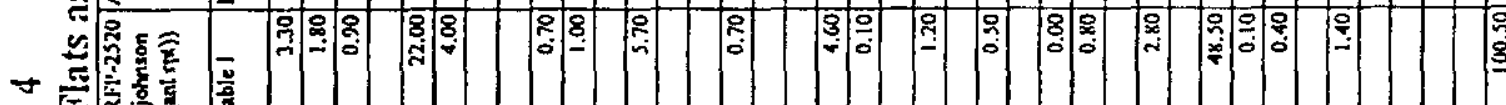

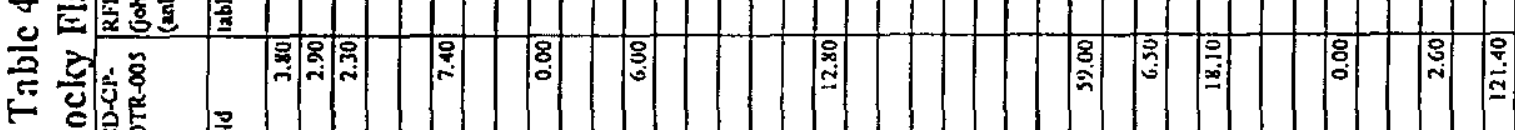

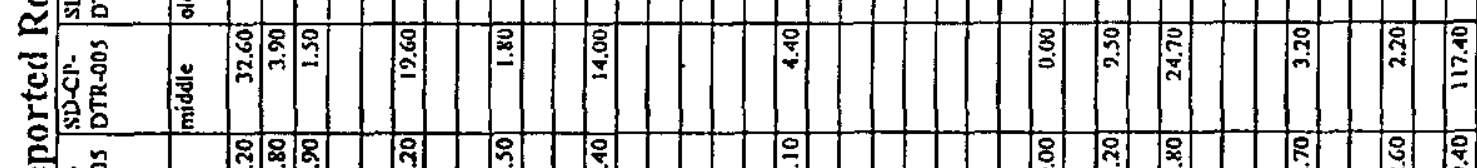

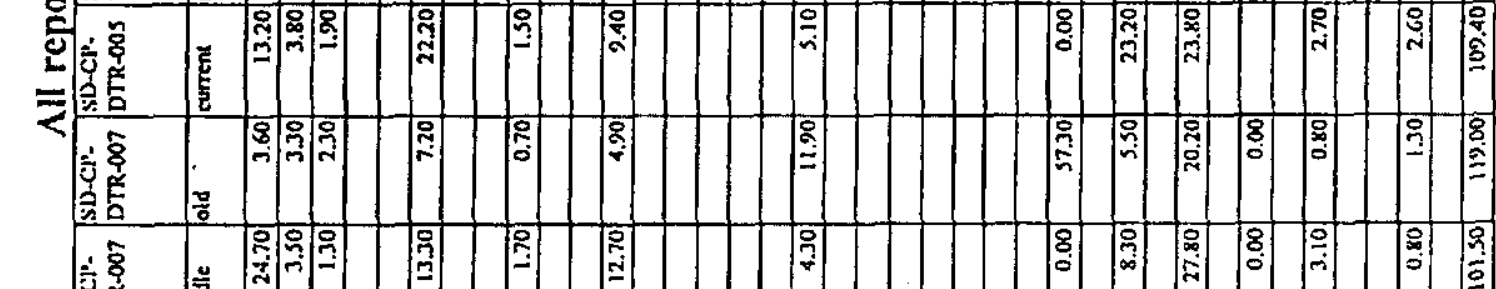

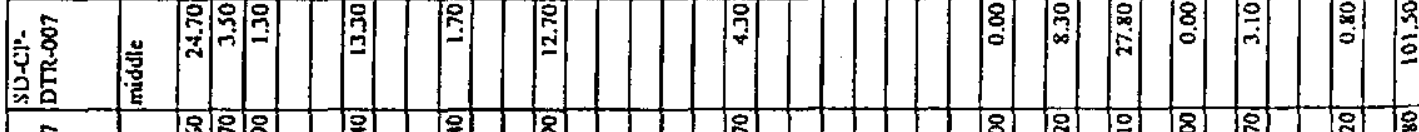

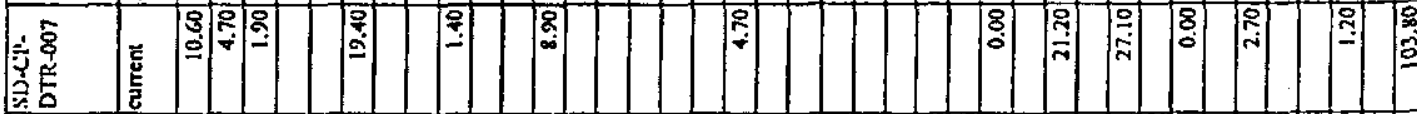

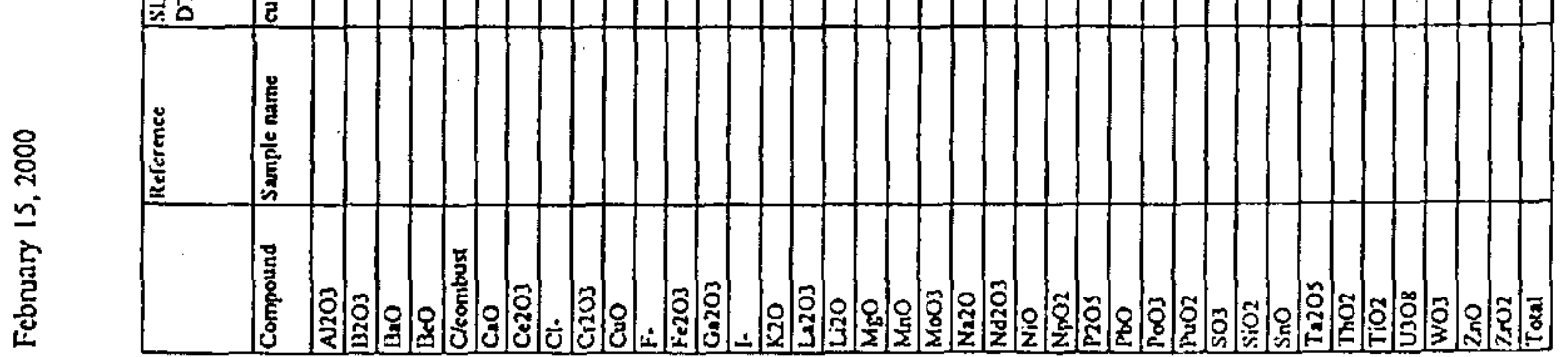


Table 5

Composite Rocky Flats ash composition based on all available analysis

\begin{tabular}{|c|c|c|c|c|}
\hline Oxide & $\min$ & nominal & $\max$ & Comments \\
\hline A 203 & 0.95 & 3.30 & 32.60 & low end average with spikes of high $\mathrm{Al}$ \\
\hline $\mathrm{B} 2 \mathrm{O}$ & 0.16 & 1.90 & 4.70 & \\
\hline $\mathrm{BaO}$ & 0.22 & 1.29 & 2.30 & \\
\hline BeO & 0.05 & 0.30 & 0.60 & \\
\hline $\mathrm{C} /$ combust & 0.00 & 18.00 & 36.00 & wide continuous variation \\
\hline $\mathrm{CaO}$ & 0.17 & 9.51 & 22.20 & \\
\hline $\mathrm{Ce} 2 \mathrm{O} 3$ & 0.02 & 0.03 & 0.06 & \\
\hline $\mathrm{Cl}-$ & 0.00 & 2.70 & 6.40 & Uncertainty in this range \\
\hline $\mathrm{C} 2 \mathrm{O3}$ & 0.00 & 1.46 & 5.65 & may also be found in the form of tramp metals \\
\hline $\mathrm{CuO}$ & 0.63 & 0.97 & 1.81 & \\
\hline$-F$ & 0.30 & 0.90 & 1.80 & Uncertainty in this range \\
\hline $\mathrm{Fe} 2 \mathrm{O} 3$ & 1.10 & 7.50 & 14.00 & may also be found in the form of tramp metals \\
\hline $\mathrm{Ga2O3}$ & 0.01 & 0.07 & 0.15 & \\
\hline I- & 0.00 & 0.00 & 0.00 & no data found \\
\hline $\mathrm{K} 2 \mathrm{O}$ & 0.24 & 0.72 & 17.40 & local spikes \\
\hline $\mathrm{L} 2203$ & 0.00 & 0.00 & 0.00 & \\
\hline $\mathrm{Li2O}$ & 0.05 & 0.06 & 0.06 & \\
\hline $\mathrm{MgO}$ & 0.83 & 5.33 & 12.80 & \\
\hline $\mathrm{MnO}$ & 0.03 & 0.51 & 2.16 & \\
\hline $\mathrm{MoO3}$ & 0.03 & 0.63 & 1.45 & \\
\hline $\mathrm{Na} 2 \mathrm{O}$ & 0.00 & 1.80 & 6.51 & \\
\hline $\mathrm{Nd2O3}$ & 0.00 & 0.00 & 0.00 & \\
\hline $\mathrm{NiO}$ & 0.10 & 1.05 & 2.46 & may also be found in the form of tramp metals \\
\hline $\mathrm{NpO} 2$ & 0.00 & 0.00 & 0.00 & \\
\hline P2O5 & 0.00 & 0.23 & 0.38 & \\
\hline $\mathrm{PbO}$ & 0.00 & 0.75 & 59.00 & spikes from lead glove incineration \\
\hline $\mathrm{PoO3}$ & 0.00 & 0.00 & 0.00 & \\
\hline $\mathrm{PuO2}$ & 1.80 & 7.83 & 23.20 & \\
\hline $\mathrm{SO} 3$ & 0.00 & 1.00 & 0.00 & reported values not likely \\
\hline $\mathrm{SiO} 2$ & 10.33 & 28.27 & 74.10 & wide continuous variation \\
\hline Sno & 0.00 & 0.17 & 0.33 & \\
\hline $\mathrm{Ta2O5}$ & 0.00 & 0.23 & 0.73 & \\
\hline ThO2 & 0.00 & 0.00 & 0.00 & \\
\hline $\mathrm{TiO} 2$ & 0.00 & 2.28 & 6.02 & \\
\hline U308 & 0.00 & 0.00 & 0.00 & \\
\hline WO3 & 0.21 & 0.28 & 0.37 & \\
\hline $\mathrm{ZnO}$ & 0.12 & 0.80 & 2.77 & \\
\hline $\mathrm{ZrO2}$ & 0.01 & 0.14 & 0.38 & \\
\hline Total & 17.3601 & 100 & 338.389 & \\
\hline
\end{tabular}


HNF-5988 Rev. 0

This page intentionally left blank.

G-14 
HNF-5988 Rev. 0

APPENDIX H

WASTE PACKAGE DATA 
HNF-5988 Rev. 0

This page intentionally left blank. 
Dobbin, Kenneth D

$\begin{array}{ll}\text { From: } & \text { Ramble, Alan L } \\ \text { Sent: } & \text { Friday, November 19, 1999 3:09 PM } \\ \text { To: } & \text { Dobbin, Kenneth D } \\ \text { Cc: } & \text { Shaw, Maria E; Ramble, Alan L } \\ \text { Subject: } & \text { FW: G Pu in Waste Packages }\end{array}$

Ken, some date. More to follow. Al

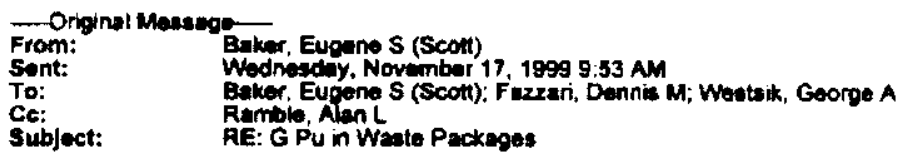

Al has asked for a little more information on what I have menticned below in my earlier message

There are two calibration curves thal everything in ITC's are counted on

- $\quad 25$ lbs., low density, both combustible and non-combustible (\#1)

- dense iterns or ITC's > 25 Ibs. (\#2)

Looking at the data below, and classifying the 100 analyses (down from $102 \mathrm{~d}$ le to some confusion in classification), the information can be grouped as follows:

$\begin{array}{lc}\text { Pu Content } & \text { \#fitems counted by } \# 1 \\ 0-2 \text { grams } & 53 \\ 2-10 \text { grams } & 15 \\ 10-20 \text { grams } & 1 \\ 20-30 \text { grams } & 0 \\ 30-40 \text { grams } & 1 \\ 40+\text { grams } & 0 \\ \text { Average value } & 2.16 \\ \text { High value } & 35.43\end{array}$

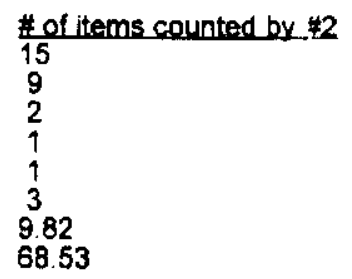

Based on this information, if you make the assumption that all of the items that would be considered "waste packages" are less than 25 lbs. and do not contain any dense metal items, your CSER evaluation of a waste package containing 2 grams as the "normal and base case condition" would be valid. You would also be correct in pointing out the 30 gram item identified as a contingency. I would feel a little uncomfortable in stating that item to be the " only contingency identified .... in assay data history. " however.

\section{Scott}

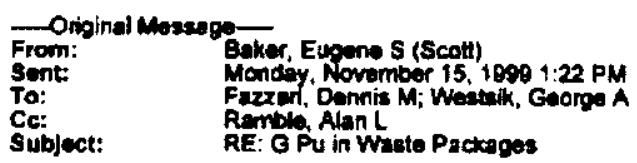

I agree with the comments Dennis makes. I have also looked at the ITC results from the Nal counter for $6 / 1 / 99$ to the present, and can make the following observations

Pu_content
$0-2$ grams
$2-10$ grams
$10-20$ grams
$20-30$ grams
$30-40$ grams
$40+$ grams

Total 102

Average gram Pu value, all items - 4.5 grams

Average gram value, $0-10$ gram items ( 93 items) -1.7 grams

Highest value for a single item - 68.53 grams

If you look only at items counted 9/1/99 to the present, the numbers change to: 


\begin{tabular}{|c|c|}
\hline $\begin{array}{l}\text { Pucontent } \\
0-2 \text { grams } \\
2-10 \text { grams } \\
10-20 \text { grams } \\
20-30 \text { grams } \\
30-40 \text { grams } \\
40+\text { grams }\end{array}$ & $\begin{array}{l}\text { 基 of itsms } \\
21 \\
15 \\
1 \\
1 \\
2 \\
1\end{array}$ \\
\hline Total & 41 \\
\hline
\end{tabular}

Average gram Pu value, all items - 6.0 grams

Average gram value, $0-10$ gram items ( 36 items) -2.4 grams

Highest value for a single item - 45.29 grams

\section{Scott}

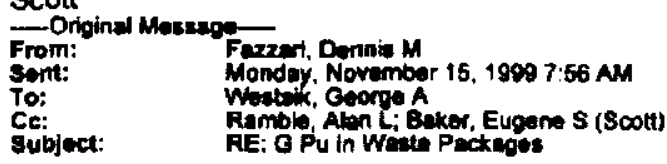

There is no way I can determine what items were waste, scrap, studge, etc... and, for that matter, what the average or maximum gram quantity might be. Operations does not identify items well and, as a result, the information you requested cannot be easily identifed. Most waste items are assayed on the Nal counter - which is Scott's (Baker) responsibility

I'm not sure where the 30 gram maximum came from. Based upon the measurement results I've reviewed, I doubt any reasonable statement can be made regarding average or maximum quantities.

Similar comments below

Dennis

\begin{tabular}{|c|c|}
\hline $\begin{array}{l}\text { Ooriginal Task- } \\
\text { Subjem: } \\
\text { Priorty: }\end{array}$ & $\begin{array}{l}\text { G Pu in Whate Peckaget } \\
\text { Normal }\end{array}$ \\
\hline Surt data: & $\begin{array}{l}\text { Mon 11/15/1999 } \\
\text { Mon 11/15/1999 }\end{array}$ \\
\hline $\begin{array}{l}\text { Stetus: } \\
\text { \% Completo: }\end{array}$ & $\begin{array}{l}\text { Not Stanted } \\
\text { d\% }\end{array}$ \\
\hline $\begin{array}{l}\text { Total work: } \\
\text { Actual work: }\end{array}$ & $\begin{array}{l}\text { O hours } \\
\text { O hours }\end{array}$ \\
\hline
\end{tabular}

Please look in your vast memories or backlog of papers and let Al Ramble (with a copy to me) know by COB $11 / 15$ if the average package quantity and the upper limil quantity are reasonable. Thank you

\section{George}

George could you confirm the 30 gram number. Mike this is the process upset for waste packages we are considering in glovebox 211

\section{Al Ramble}

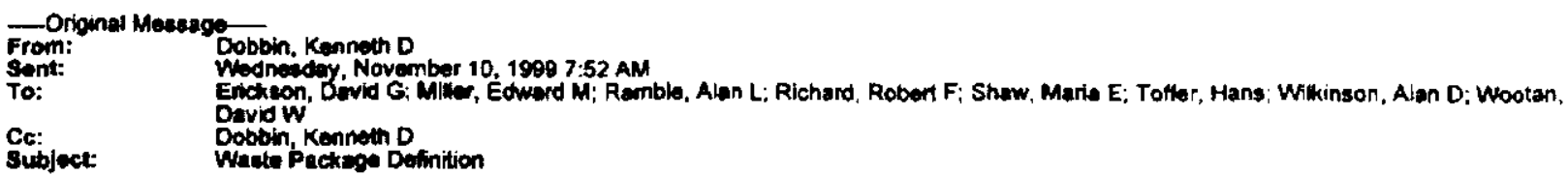

Yesterday aftemoon. we agreed upon the definition of a waste package to be used for CSERs associated with plutonium stabilization. The purpose of this message is to put that definition in writing and allow meteting participants a chance to comment. Untess I hear back today, the following definition will be used in these CSERs.

Glovebox waste is generated from PFP plutonium stabilization operations. It is placed into plastic bags, transferred to isolated Transport Containers, assayed, then placed into waste drums. This waste consists of gloves, rags, containers used to port-in items, etc. Prior to bagging, all noticable fissile material is brushed from these items [Fazzeri, Dennis M] I doubt this is true. I suspect the items are bagged and removed without brushing and no fissile item is intentionally placed 
HNF-5988 Rev. 0

in these packages. Inspection of historical assay data show that normally these packages contain only 1 or 2 grams of fissile material. [Fazzari, Donnis M] No. I don't believe there is any technical basis for this statement. The greatest quanlity found was one package that contained 30 grams of plutonium. (Fazzari, Dennis $M$ ) Where did this value come from?

This CSER evaluation includes a waste package containing 2 grams as the normal and base case conditions. For this fissile loading, the package acts as a refiector and possibły adds interspersed moderation between containers, however, no more so than already modeled in the base case. The only contingency identified is the excess fissile mass condition of 30 grams that was found once in the assay data history. (Fazzari, Dennis M] ??? Errors associated with loading fissile abjects into the waste package are not included because if loaded in this glovebox they would be already covered by evaluation, and if the bading error occurs in other gloveboxes and transferred to this glovebox. then two errors would be required. Waste packages are not normalty brought from other gloveboxes to this one. 
HNF-5988 Rev. 0

This page intentionally left blank.

H-6 
HNF-5988 Rev. 0

\section{APPENDIX I}

FIREFIGHTING WATER DENSITY 
HNF-5988 Rev. 0

This page intentionally left blank. 


\section{B \& W Hanford Co.}

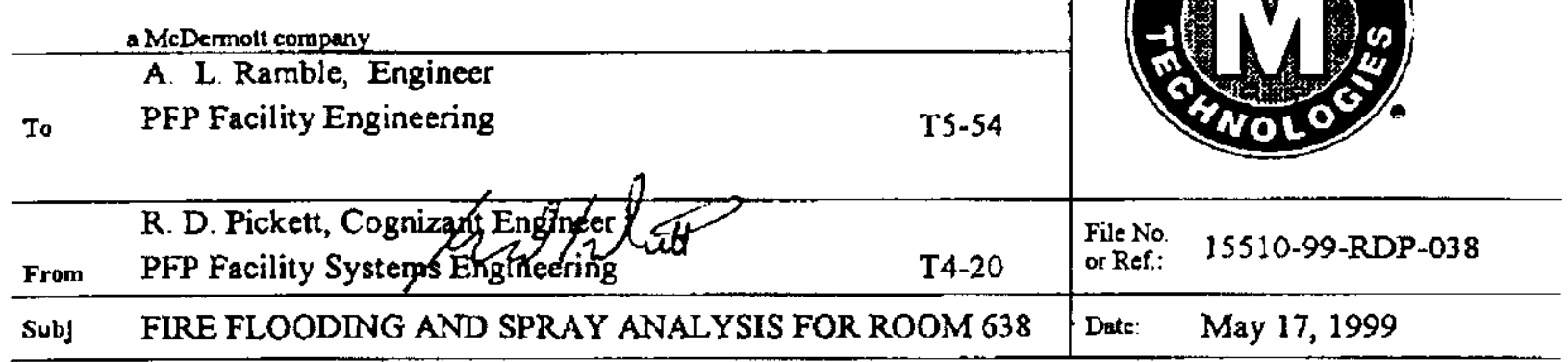

Reference: Telephone Request for Fire Water Flooding and Spray Analysis, dated May 7, 1999.

\section{ASSUMPTIONS}

- Fire department on scene within 40 minutes (see FSAR section 9.2.2A).

- 120 psi at each sprinkler head (this is very conservative since line losses and operation of other sprinkler heads would decrease this pressure)

- Fight a fire with two hoses for a total of $400 \mathrm{gpm}$ (one hose at $100 \mathrm{gpm}$ and second hose at $300 \mathrm{gpm}$ per information provided by the fire department). Note: these hoses are variable stream types so the pattern and flows are adjustable.

- For flooding, assume all sprinkler heads operate (this is worse than a shear of a $11 / 2$ " water line).

- 1 second of flow from a sprinkler head or hose will suspend the amount of water to achieve the maximum density.

- Assume 3 sprinkler heads worth of flow into the cage area.

- No leakage out of the room.

- There is $8 \mathrm{lb}$. Water in 1 gallon.

- Exclude floor space and volume of room 639 and 640.

\section{BACKGROUND}

- Area of the room floor $=130 \mathrm{ft2}$.

- 14 sprinkler heads in the room (see CVI 21097)

- Sprinklers have a $1 / 2^{n}$ orifice with a $5.62 \mathrm{~K}$-factor.

- There are 7.481 gallons per f 3 .

- Occupational Classification is Ordinary Hazard (see CVI 21097)

- Caged area has two sprinkler heads.

- Ceiling height is $9^{\prime} 6^{\prime \prime}$.

- Floor dimensions of caged area 7' $\times 18^{\prime} 3^{\prime \prime}$

- Probability of fire not being noticed and the fire department being delayed 30 minutes is discussed in section 9.2.2A of the FSAR

- Flooding cannot occur when a fire hose is used since the doors to the room have to be open along the hose route all the way to the outside of the building. There are no hose connections inside $2736-\mathrm{ZB}$ or $2736-\mathrm{Z}$. 
A. L. Ramble, et. al.

15510-99-RDP-038

Page 2

May 17, 1999

\section{CALCULATIONS}

Flow per sprinkler head $=\mathrm{Q}=\mathrm{K} \sqrt{\mathrm{P}}=5.62 \cdot \sqrt{120}=61.56 \mathrm{gpm}$

Sprinkler flow into cage area $=3 \bullet 61.56=185 \mathrm{gpm}$

Sprinkler flow into the whole room $=14 * 61.56=862 \mathrm{gpm}$

Volume of cage area $=7^{\prime} \bullet 18^{\prime} * 9.5^{\prime}=1200 \mathrm{cu} . \mathrm{ft}$.

\section{CAGE DENSITY CALCULATIONS}

Cage Density during fire fighting in cage area $=185 \mathrm{gpm}$ from sprinklers $+400 \mathrm{gpm}$ from fire hoses $=585 \mathrm{gpm}$ total flow.

Water released in 1 second of sprinklers and hoses $=\$ 85 \mathrm{gpm} *(1 \mathrm{~min} / 60 \mathrm{sec}) * 1 \mathrm{sec}=9.75$ gal.

Water density in cage area $=9.75 \mathrm{gal} / 1200 \mathrm{cu} . \mathrm{ft} .=0.0081225 \mathrm{gal} / \mathrm{cu}: \mathrm{ft}$.

\section{FLOODING CALCULATIONS}

Volume of water release in 40 minutes $=40 \mathrm{~min} \bullet 862 \mathrm{gpm} *(1 \mathrm{cu} . \mathrm{ft} . / 7.481 \mathrm{gal})=4609 \mathrm{cu} . \mathrm{ft}$.

Water level after $40 \mathrm{~min} .=4609 \mathrm{cu} . \mathrm{ft} . / 1340 \mathrm{sq}$. ft. floor area $=3.44 \mathrm{ft}$.

\section{CONCLUSIONS}

After 40 minutes of sprinkler flow, the water level in room 638 will be 3.44 feet. The maximum density of water suspended in the cage area is $0.008-\mathrm{gal} / \mathrm{cu}$. $\mathrm{ft}$.

$\mathrm{klm}$

Distribution

Fluor Daniel Northwest

K. D. Dobbin

B4-44

J. S. Lan

B4-44

J. A. Miller

B4-44

RDP File/LB 
HNF-5988 Rev. 0

APPENDIX $\mathbf{J}$

MAXIMUM WATER CONTENT IN SS\&C - CEMENT MATRIX 
HNF-5988 Rev. 0

This page intentionally left blank. 
From: $\quad$ Process Engineering

8A400-96-032

Phone: $\quad 376-9616$ L5-3]

Date: July 2, 1996

Subject: RESULTS OF THE PFP CEMENTATION PROCESS

To:

$\begin{array}{ll}\text { CC: D. M. Bogen } & \text { T5-50 } \\ \text { L. Dayley } & T 5-55 \\ \text { D. E. Gana } & \text { L6-33 } \\ \text { M. W. Gibson } & T 5-50\end{array}$

\section{J. A. Hunter}

G. L. Pippy

W. L. Winsted

WOG File/LB

L5-3]

T5-50

T5-55

References: (1) Letter, LaPriel Dayley, WHC, to W. 0. Greenhalgh, WHC, "Request Cost Estimate for Testing to Provide Data in Designing a Cementation Process, "15530-96-LD-042, dated April 18, 1996.

(2) WIPP-DOE-069, "TRU Waste Acceptance Criteria for the Waste Isolation Pilot Plant," latest Revision, Waste Isolation Division, Carlsbad, New Mexico.

(3) J. W. Phillips, "Qualification of Waste Forms to Meet the Requirements of $10 \mathrm{CFR}-61$," Waste Management '84, Vol. 2, dated March 11-15, 1984, pp. 183-187.

\section{INTRODUCTION}

This letter report contains a summary of the results of work requested in internal memo 15530-96-LD-042 (Reference 1). The internal memo requested the following technical support:

0 Determine the maximum ratio of PFP sand, slag, and crucible (SS\&C) waste to cement to obtain a product that meets WIPP/WAC requirements or optionally some other solidification agent that will meet the requirements of 10 CFR-61

- (definition of a solid which is interpreted as waste form exhibiting a compression strength o 50 psi after solidification. (Reference 3 )

- Determine the set times for cement/slag waste mixtures and admixture chemicals or techniques which could be use to increase or decrease these times.

- Develop a composition range diagram. 
G. A. Funston

$8 A 400-96-032$

Page 2

Ju7y 2, 1996

- Provide information to aid in the selection of mixer equipment to handle product cans roughly 5.5 inches in diameter by 6 to 8 inches high.

- Provide mixing instructions which can be used to develop training/procedure tasks for the process operation.

\section{WIPP-WAC}

The cement solidified SS\&C waste product will be a transuranic (TRU) waste because it contains residual plutonium and possibly other transuranic radionuclides. The solidified waste will have to be certified as to meeting specified criteria and then be shipped to the Waste Isolation Pilot Plant (WIPP) in New Mexico for disposal. The Waste Acceptance Criteria (WAC) for WIPP, or WIPP-WAC, as stated in, "WIPP-DOE-069," (Reference 2) that appear to be applicable to the proposed solidified SS\&C waste is as follows:

- "Powder, ashes, and similar particulate waste materials are immobilized if more than 1 wt.\% of the waste matrix in each package is in the form of particles below 10 microns in diameter; or if more that $15 \mathrm{wt} . \%$ is in the form of particles below 200 microns in diameter."

- "The TRU waste shall not be in free liquid form. Minor residual liquid remaining in well-drained inner packages shall not exceed 1 vol.\%, and the total liquid in the waste package shall not exceed 1 vol.\%."

The PFP plutonium SS\&C waste consist of a variety of powdered or particulate materials that require immobilization according to the WIPP-WAC. If cemented, it must be done in a manner that no free liquid is left over, or generated, by the immobilization process. The WIPP-WAC does not set any standard measurement for solids, such as compression strength. However, in the future, it is expected that the United States Nuclear Regulatory Commission (NRC) will take over regulatory requirements at WIPP. They are expected to require conformance with 10 CFR-61, which is currently viewed by NRC as being at least 500 psi for cement solidified nuclear waste rather than the lower 50 psi allowed for other solidification media. Therefore, the only waste solids considered as an acceptable waste product for this report are those cement products exhibiting a compression strength of 500 psi, or greater, having no free water, and essentially having no dispersable solids. Portland cement appeared to be very compatible with the simulated PFP SS\&C waste tested so no other solidification media was studied. 


\section{WATER/CEMENT/WASTE PHASE DIAGRAM}

The operable water, cement, and SS\&C waste parameters are generally best described or determined using a triangular ( 3 dimension) phase diagram. This phase diagram is listed as a compositional range diagram and is shown in Figure 1. (Attachment 5). The values for the diagram are listed in Tabie 1 (Attachment 1). The composition diagram gives the outer limit range of operation for the three components. The minimum water line represents the minimum water that can be added, and still be able to make a homogeneous, consistent, and smooth mix. This is typically thought of as that minimal amount of water required to allow the mixer to function properly and prepare a cementable mix.

The maximum water is the upper limit, where the addition of any further appreciabie water will result in a dual phase product consisting of cement solids, and a lighter aqueous liquid phase, generally on top of the cement.

A third broad line is based on compression strengths, and is a boundary limit where compression strength estimates, or actual measurements on representative cement/waste products would decrease below $500 \mathrm{psi}$, based on 7-day cured specimens. Cement/concrete compression strength samples are typically cured 28 days. The samples usually exhibit compression strength values that are significantiy higher $(>20 \%)$ for 28 day cure samples. Use of the 7-day cure test samples will provide an extra margin of reliance in meeting the $500 \mathrm{psi}$ minimum cement compression strength. The general procedure for the phase diagram and 7-day compression strength work is included in Appendix A. Compression strength values, as a function of wt.\% waste, are shown in Figures 2 and 3 . The compression strength as expected decreases with increasing waste content; these figures are used to predict how much waste can be added before the compression strengths values decrease below 500 psi.

\section{CEMENT SET RATES}

How long it takes for cement to set is of concern to the PFP cement process since they literally will have thousands of SS\&C waste cans to process. Typically, a cement immobilized waste form is allowed to set a minimum of 24 hours after mixing, to set up and cure. After the 24 hour period, the waste solid can normally be removed. At this time it is visually checked to see that it has completely hardened, has no "free 1 iquid", and is ready to be stored or packaged for subsequent disposal. However, if a cement set retarder material is added or is present in the waste it could take longer. In contrast, addition of a set accelerator or certain other modifications could allow the cement to set quicker allowing faster handling and processing. 
The PFP Process Engineering requested cement setting data for typical type mixes, as well as some information on cement modifiers. Table 2 has this information, where the "initial set" is based on a penetrometer penetration reading of $500 \mathrm{psi}$, and the "final set" is one of 4,000 psi. As mentioned earlier, a $500 \mathrm{psi}$ strength product is the value that is required to meet assumed NRC waste solidification requirements. Final sets (4,000 psi) are shown to provide an indication of a final set. However, it should be noted that this testing assumed penetration resistance values (Penetrometer readings) in psi to be equivalent to compression strength values, but they may not be, even though the same unit is used.

Table 2 (Attachment 2) provides the set times of a list of mixes at the same waste content along with their respective initial (500 psi), and final ( 4,000 psi) setting times. The list of set times includes set times for mixes containing some common cement modifiers.

Calcium chloride (sat. sol'n) at about $2 \%$ will hasten the overall set time, and give a good compression strength product. Fly ash, class $F$, will delay the initial set time, but the other retarders (glucose and Pozzolith ${ }^{\otimes}$ ) did not work well with this particular mix. However, adjustment of the water content appears to be the overall best method of adjusting set time, as is indicated for the first three runs at constant waste content, but varying water content. (See Figure 4). The initial set time is approximately proportional to the water content (wt.\%). The initial set time is reduced about $1.25 \mathrm{hr}$ for each $1 \%$ decrease in water content. The final set time curve is parabolic, but in the minimum water area, a $1 \%$ change in water content causes about $0.8 \mathrm{hr}$. change in set time. (See Figure 4)

The above effect will, of course, change in unit dimension with changes in composition. However, the values shown should give a good indication on how to modify similar mixes for higher or lower set times. A general procedure used for determining cement set times for this work is included in Appendix A (Attachment 3).

\section{MIXER INFORMATION}

What is the best mixer or type of mixers to use for mixing a large quantity of small cement mixes in a glove-box or similar type facility? The size of the mixes, $\sim 1 / 2$ to 1 gallon, provides an excellent opportunity to use the container itself as a mixer receptacle, and merely have to add the ingredients. Adding a metal marble (steelie) into the can help facilitate the mixing process. A brief survey of the commercial market found that the most commonly used self-contained mixers for this size of mix to be paint can mixers. Use of a highly agitator mixer, as opposed to a "roller, "or circular motion is thought to be better for cement solidification. Such a mixer is marketed by Red Devil, and is shown in Figure 5 . Several other types of paint type mixers are available at a moderate price. Approximately 2 to 3 weeks are required to obtain one using a credit card type purchase. Price information for the Red Devil mixers are also included in Appendix $B$ (Attachment 4). 
other options include a range of open mixers. These, of course, require frequent cleaning and some routine decontamination around the mixing area. Mixers of this type should be capable of $>150 \mathrm{rpm}$, and a torque of 90 foot-lbs., or an equivalent mixing capability. Several commercial, and a number of large home-type mixers would probably work all right. Kitchen Aid and similar mixers will work for this application.

The suggested mixing technique is to lightly blend all solids first, and then add the desired liquid to provide the smoothest mix. If dusting is a problem, you can add the solids to the liquid; but do it slowly, at a controlled rate for best results.

\section{OPTIMUM WASTE LOADINGS}

In general, the higher the waste loading, the lower the disposal costs. The highest waste loadings are on the right hand side of the diagram. The minimum water mixes exhibit higher waste loadings than maximum water mixes unless the water used is also a waste material. The highest waste loading values shown in Figure 1 that meet the WIPP-WAC and NRC requirements are about $50 \mathrm{Wt} . \%$. Bulk densities for the simulated waste were measured to be about $1.64 \mathrm{~g} / \mathrm{cc}$ compared to $1.29 \mathrm{gm}$. for bulk cement powder. The waste loading is rea lly equivalent to about 59 vol.\%. since waste volumes not weights are the units by which waste quantities are measured and tracked. More work could be done on optomizing waste loadings to reduce waste disposal costs. A 5 to $10 \%$ increase in waste loading is very likely with additional work. 


\section{CONCLUSIONS}

1. Minimum water composition values were fairly constant at about 24 to 25 wt.\% water for the Ashgrove type I-II cement used for these tests. The minimum water mixes exhibited essentially zero (no) slump.

2. Maximum water composition values increased slightly with waste content as shown in Figure 1 from a zero waste value of $32 \mathrm{wt. \%}$.

3. Compression strength limit line of $500 \mathrm{psi}$ is the other limiting parameter. The compression strength limiting values were estimated from strength measurements made on minimum and maximum water samples and the graphs in Figures 2 and 3.

4. Cement mix set times were fastest for minimum water mixes, and for mixes to which sat. calcium chloride liquid has been added to accelerate the set.

5. In-can mixing, using the waste container as the mixing receptacle, is recommended for solidifying the waste. Mixer clean-up and glove-box contamination would be minimal for this type of mixer processing.

6. Waste loading data is minimal, but efficiencies approaching $60 \%$ appear possible for waste products that will meet WIPP-WAC requirements. These solid waste products shall exhibit at least a 500 psi minimum compression strength.

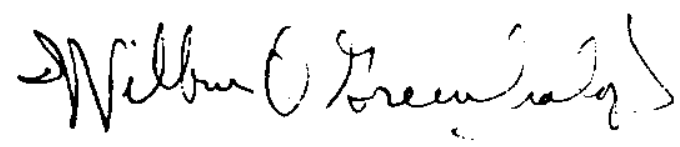

W. 0 Greenhalgh, Principal Chemist

Process Engineering

$\mathrm{cmr}$

Attachments 5 
HNF-5988 Rev. 0

8A400-96-032

ATTACHMENT 1

Table No. 1

\section{FINAL PHASE DIAGRAM COMPOSITION \\ AND \\ COMPRESSION STRENGTH MEASUREMENTS}

\begin{tabular}{|c|c|c|c|c|}
\hline \multirow[b]{2}{*}{ Sample } & \multicolumn{3}{|c|}{ Composition } & \multirow{3}{*}{$\begin{array}{c}\text { Average } \\
\text { Comp. Strength (psi) } \\
\end{array}$} \\
\hline & Water & Waste & Cement & \\
\hline Max. Water & & & & \\
\hline a. & 31.98 & 0.00 & 68.02 & 3900 \\
\hline b. & 32.25 & 5.94 & 61.80 & 3190 \\
\hline c. & 31.94 & 12.37 & 55.69 & 2240 \\
\hline d. & 32.70 & 19.43 & 47.87 & 1990 \\
\hline e. & 33.59 & 26.56 & 39.85 & 1200 \\
\hline f. & 34.77 & 34.70 & 30.54 & 510 \\
\hline
\end{tabular}

Min. Water

$\begin{array}{lrrrr}\text { g. } & 24.35 & 0.00 & 75.65 & 6620 \\ \text { h. } & 24.70 & 5.38 & 69.92 & 6560 \\ \text { i. } & 25.56 & 11.11 & 63.33 & 5450 \\ \text { j. } & 24.08 & 17.52 & 58.40 & 4650 \\ \text { k. } & 24.82 & 24.25 & 50.93 & 3810 \\ \text { l. } & 24.24 & 31.57 & 44.19 & 3790\end{array}$


HNF-5988 Rev. 0

8A400-96-032

Table No. 2

ATTACHMENT 2

\section{CEMENT/WASTE SET TIMES}

Penetrometer readings have been used to estimate the following set times for the listed compositions:

\section{Composition (Wt\%)}

Water Waste

a. 33.8

26.5

b. $\quad 29.0$

c. $\quad 24.0$

d. $\quad 29.0$

e. $\quad 29.0$

f. $\quad 29.0$

g. $\quad 29.0$

h. $\quad 29.0$

i. $\quad 29.0$

j. $\quad 29.0$

k. $\quad 29.0$

1. 29.0

m. 29.0

n. 22.0

o. 22.0

p. 22.0
26.5

26.5

26.5

26.5

26.5

26.5

26.5

26.5

26.5

26.5

26.5

26.5

26.5

26.5

26.5
Set Times (hrs)

Cement

39.7

44.5

49.5

39.5

39.5

39.5

39.5

43.0

39.5

42.5

42.5

42.5

42.5

49.5

49.5

49.5

Additive Initial Einal

$$
0
$$

15.9

26.6

0

9.2

16.9

0

3.6

12.4

5 - Sucrose No Final Set

5 -Flyash $14.5 \quad 25.2$

5 - Pozzolith No Set No Set

5 - Slag Cem. $15.6 \quad 28.3$

1.5 - Calcium $10.8 \quad 17.1$

Chloride liq.

5 - Calcium $3.1 \quad 17.9$ Chloride Liq.

2 - Sucrose $\quad 44.8 \quad 89.5$

$\begin{array}{lll}2 \text { - Flyash } & 12.7 & 17.0\end{array}$

2 - Pozzolith 365 No Set

2 - Slag Cement 8.4 18.3

2 - Sucrose Data Inconclusive

2 - Pozzolith $29.7 \quad 50.9$

2 - Calcium $\quad 4.9 \quad 9.2$

Chloride Liq. 
HNF-5988 Rev. 0

8A400-96-032

ATTACHMENT 3

\section{Appendix A}

Test Procedures

Procedure No. 1 consists of 6 pages

Procedure No. 2 consists of 3 pages 
HNF-5988 Rev. 0

8A400-96-032

ATTACHMENT 3

Page 7 of 6

\section{WASTE SOLIDIFICATION COMPOSITION DIAGRAM}

Procedure No. 1

Wilbur Greenhalgh - April 30, 1996

\section{INTRODUCTION:}

Plutonium contaminated residues and wastes are to be disposed at the Waste Isolation Pilot Plant (WIPP) in New Mexico. The Waste Acceptance Criteria for WIPP (WIPP-WAC) require that (1). "Powders, ashes, and similar particulate waste materials are immobilized if more than 1 wt\% of the waste matrix in each package is in the form of particles below 10 microns in diameter, or if more than $15 \mathrm{wt} \%$ is in the form of particles below 200 microns in diameter". (WIPP-DOE-069) (2). "The TRU waste shall not be in freeliquid form. Minor residual liquid remaining in well-drained inner packages shall not exceed 1 vol\% and the total liquid in the waste package shall not exceed 1 vol\%". (WIPP-DOE-069) These requirements mean that solidification procedures must be used that will fix any powders or dispersible materials, and any "free liquids".

Portland cement (type I-II) tested in these procedures is a hydraulic setting cement, which means it will set up even under water. This hydraulic setting property makes it easy to measure the excess water in test

compositions with a slight excess of water. As the cement sets, excess liquid comes to the top (less dense than cement), and the cement forms a solid product beneath the liquid. The excess liquid is removed and measured. The maximum cement-water composition is the original mix composition minus the excess water content. The cement mix composition is corrected for the amount that was determined to be in excess. The maximum cement-water compositions for a system can be determined by varying the ratio of cement to waste residue and then determining the maximum water.

The other working boundary of cement mixes is the minimum water boundary line. This line is not as well defined as the maximum water line and is primarily a function of the mixer. It is probably best understood as the boundary where just enough water has been added to the cement or cement/residue mix that a smooth (no lumps) water slurry or pourable sludge can be made. This mixture should exhibit a nearly constant, reproducible slump. A portable slump tester will be used to follow this concrete measurement.

METHOD FOR DETERMINING THE MAXIMUM WATER COMPOSITION LINE

Apparatus:

1. Utility cement mixer, 1 gal. capacity.

2. Top loading automatic $1000 \mathrm{gram}$ balance.

3. Automatic compression strength tester.

4. Portable $K$ slump tester or its equivalent.

5. Powder blender 
HNF-5988 Rev. 0

Page 2 of 6

Supplies:

1. Portland cement type (I-II) unless otherwise specifted.

2. Distilled or demineralized water.

3. Simulated or actual waste residue matrix.

4. Metal slip top tin cans, 1 pint or their equivalent.

5. Graduated glass cylinders for excess water measurement as a verification to weight measurements.

6. Test Log Book (official WHC numbered notebook)

Chemicals:

1. Magnesium oxide sand

2. Calcium fluoride powder

3. Calcium iodide powder

4. Calcium oxide powder

5. Iron filings or its equivalent

6. Silica oxide powder

Assumptions :

1. Plutonium is an actinide that exhibits many alkaline earth type properties. Calcium compounds will be used as a stand-in for the very small trace plutonium and plutonium compounds listed in the original button slag waste. Substitution of calcium compounds for the trace plutonium compounds is not expected to have any appreciable effect on the physical properties of the test cement products.

\section{PROCEDURES}

A. Prepare Simulated Crucible Slag Waste Matrix

1. Prepare one or more 1 kilogram batches of simulated crucible slag waste matrix (CSWM) by weighing in the hood the following proportions per $\mathrm{kg}$ of waste matrix: (Note: percentages have been adjusted for the substitution of calcium oxide for calcium metal.) 
Chemical

Mag. Oxide Sand

Calcium Fluoride

Iron Filings

Calcium Iodide

Silica Oxide

Calcium 0xide
WT\%

41.00

37.25

8.32

1.46

0.40

11.57
WT. (g)

410.0

372.5

83.2

14.6

4.0

115.7

2. Place all the ingredients in a powder blender and mix for at least 10 minutes and then place in a one-gallon wide mouth jar that can be sealed. Keep in a dry place.

3. Label and date the bottle and place a hazardous material communication label (NFPA sticker) that best reflects a composite of their MSDS's in regard to health, flamability, and reactivity risks.

Note: Calcium metal is the one remaining ingredient listed in the slag that is not present $(8.44 \%$ or $84.4 \mathrm{~g} / \mathrm{kg})$; calcium oxide will be used instead at the same mole ratio which amounts to 11.41 wt\%. The additional trace lime listed in the table above represents a trace of plutonium oxide present in the original waste matrix.

B. Determine the Maximum Water Composition Line

1. Visually check the portland cement before each use and screen out ( 8 mesh or finer) any lumps or large particles. Record the type and brand of cement in the test log book.

2. Prepare water rich cement mixes using the following approximate formulations and 250 grams total for each test sample required: (Note: Add dry materials first and then slowly add water).

\begin{tabular}{|c|c|c|c|}
\hline & Water & Waste (dry) & Cement \\
\hline $\begin{array}{l}\text { a. } \\
\text { b. } \\
\text { c. } \\
\text { d. } \\
\text { e. } \\
\text { f. }\end{array}$ & $\begin{array}{l}41 w t \% \\
43 \\
45 \\
48 \\
50 \\
53\end{array}$ & $\begin{array}{l}0 \text { wt\% } \\
5 \\
10 \\
15 \\
20 \\
25\end{array}$ & $\begin{array}{l}59 w t \% \\
52 \\
45 \\
37 \\
30 \\
22\end{array}$ \\
\hline
\end{tabular}

3. Perform steps B-4 through B-10 for each of the above compositions.

4. Mix formulation for at least 5 minutes and then pour the mix in a preweighed pint tin can or other pint size non-leaking container.

5. Weigh the contents to determine the weight of cement mix present and record the weight value. 
6. Put on the can lid and tape seal closed any air openings into the can.

7. Label the can and set it aside on a shelf to set-up for $24 \mathrm{hrs}$ at ambient temperature $(25 \pm 5 \mathrm{deg}$. C) and record the temperature.

8. After 24 hours, remove the tape seal and collect the free liquid in a pre-weighed 10 or $25 \mathrm{ml}$ graduated cylinder.

9. Measure and record both the weight and volume of the free liquid present in the can, retain all cement liquids. (haz. eval.)

10. Subtract the weight of "free liquid" (FL) from the applied formulation and calculate a "free liquid" corrected composition as shown below: (Example: assume $5 \mathrm{~g}$ " $F L^{\text {" measured for an initial }}$ 41 wt\% water composition)

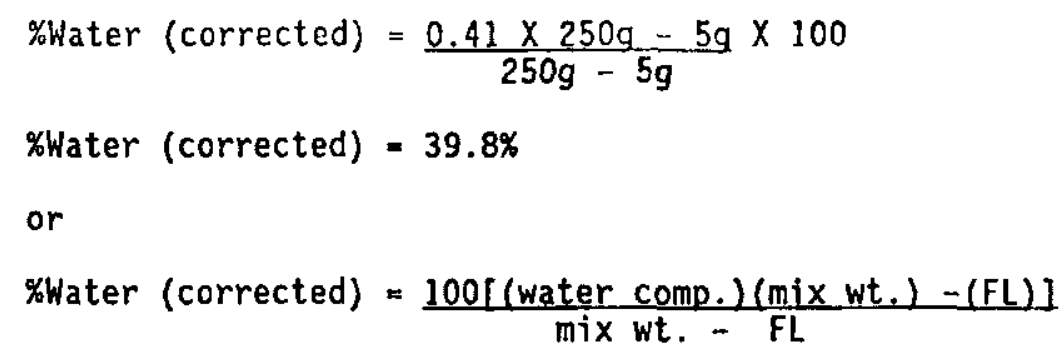

10. Record all corrected maximum water contents in a $\log$ book and then plot the values on a triangular phase diagram using cement, water, and waste matrix at the apexes (points of the triangle).

11. Adjust each succeeding formulation in Step 2 by adding or subtracting water based upon the results obtained for the previous formulation. If the "free liquid" is starting to exceed 2 to 3 wt\%, then reduce the quantity of water. If very little free liquid is observed then increase the water. If no free liquid was observed the maximum water line was not reached and the run must be repeated with a higher ratio of water.

C. Determine Compression Strengths for Maximum Water Samples

1. Schedule Standards Laboratory to calibrate one of the compression strength testers that meet ASTM specifications and provide written guidance as to the accuracy of the tester.

2. Repeat the preparation of the listed formulations using the corrected maximum water values. Prepare a triplicate ( 750 gram) size batch. Pour a third of the material into the pint can to check the maximum water correction and pour the other two portions into 2-inch cubes for compression strength samples.

3. Visualiy inspect for free liquid after 24 hours and record the results for the mix placed in the tin can. If appreciable water is present repeat steps B-8 through B-10. 
HNF-5988 Rev. 0

Page 5 of 6

4. Remove the two cubes (compression strength samples) after 24 hours, weigh, and seal in a plastic bag.

5. Compute a sample density by dividing the weight (g) of the 2inch cube sample by $131.1 \mathrm{cc}$ the volume of a 2-inch cube, this will give the density in $\mathrm{g} / \mathrm{cc}$.

6. Cure the compression strength samples (sealed in plastic bags) for seven days at room temperature $(25 \pm 5 \mathrm{deg}$. C).

7. Perform a compression strength measurement per ASTM C109-95 and reçord the values in $1 \mathrm{bs} / \mathrm{sq}$. in. (psi).

D. Determine the Minimum Water Composition Line

1. Prepare duplicate minimum water sample mixes for each formulation listed in Step $0-2$ using 300 grams mix per sample.

2. Prepare the mixes by adding the dry components first and then adding the water slowly until just enough water has been added to allow the cement to be entrained in a smooth mix (no lumps). Use the approximate wt.\% formulations listed below:

Water Waste (dry) Cement (dry)

$\begin{array}{llll}\text { a. } & 26 & 0 & 74 \\ \text { b. } & 30 & 5 & 65 \\ \text { c. } & 33 & 10 & 57 \\ \text { d. } & 35 & 15 & 50 \\ \text { e. } & 38 & 20 & 42 \\ \text { f. } \quad 40 & 25 & 35\end{array}$

If the mix appears to exceed the minimum water appearance (too thin o1 wet), then add additional waste and cement in the correct ratio for that specific formulation.

3. Perform Steps D-4 through D-9 for each of the above formulations.

4. Measure the mix slump using a portable "K-slump" tester and record the slump value.

5. Place the mix into two-inch cube forms and let it set-up for 24 hours to use as compression strength samples.

6. Remove the cube forms, weigh the cubes and compute a sample density as done previously in Procedure Step $\mathrm{C}-5$.

7. Place the cube forms into plastic bags, seal, and allow to cure at room temperature $(25 \pm 5 \mathrm{deg}$. C) for 7 days.

8. Measure and record the compression strengths per ASTM C109-95 method. 
9. Plot out the minimum water composition line on the triangular diagram used just previously, also plot compression strength as a function of the waste content.

E. Determine Bulk Densities for the Cement and Waste Matrix

1. Take two preweighed graduated $100 \mathrm{ml}$ cylinders. Fill one cylinder with bulk cement and other with bulk waste matrix powder. Manually vibrate and fill or adjust volume until the $100 \mathrm{ml}$ mark is reached and doesn't settle with continued vibration.

2. Reweigh the graduated cylinders and compute the bulk densities by dividing the bulk cement or waste matrix weight in gram units by $100 \mathrm{ml}(\mathrm{cc})$.

3. Record the bulk densities in the log book and use these values to compute volume percents for customer report needs.

F. Handling Test Matrix Wastes

The composition of the resultant cement test products have been submitted to Acceptance Services for designation. The test samples are nonregulated for all compositions where the percent calcium fluoride is less than 10 wt\% of the total. All of the compositions listed in these procedures are less that $10 \mathrm{wt} \%$ and are non-regulated. A copy of the predesignation is included with the procedure.

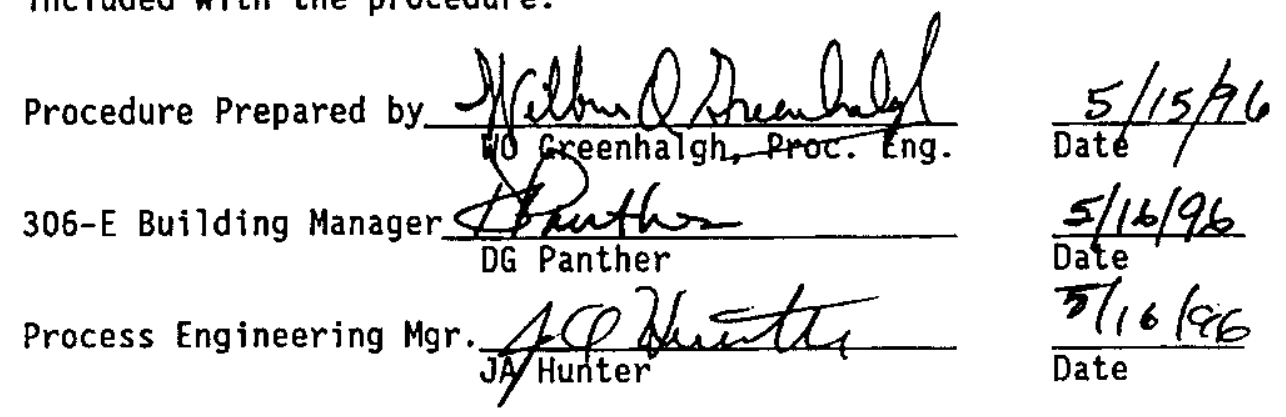




\section{CEMENT SOLIDIFICATION SET TIMES AND ADMIXTURES}

Procedure No. 2

Wilbur Greenhalgh - May 20, 1996

\section{INTRODUCTION:}

The PFP operation is planning on solidifying some of their plutonium button slag wastes in cement to make a product that meets Waste Isolation Pilot Plant (WIPP) disposal criteria. A cement solidification composition diagram is being prepared for the cement/water/waste parameters. Cement set times for the candidate mixtures are needed for planning processing procedures. In addition, general admixture set times might be useful to either slow down or speed up set times to optomize operations or perhaps ensure mixtures receive sufficient mixing before setting occurs.

METHOD FOR MEASURING SET TIMES:

\section{Apparatus:}

1. Penetrometer - built to ASTM standards or recommendations.

2. Penetrometer Needles - Sizes $1,1 / 2,1 / 4,1 / 10,1 / 20$, and $1 / 40 \mathrm{in.}^{2}$

3. Cement Mixer - lab size.

4. Portable K slump tester.

5. Watch or clock timer.

Supplies:

1. Portland cement type (I-II).

2. Distilled or demineralized water.

3. Simulated waste residue matrix material.

4. Cement sample containers, 3-in. min. dia. $\times 3-i n$. min. height.

Chemicals:

\section{Cement Admixtures:}

1. Glucose

2. Flyash, class $F$

3. Pozzolith $122 \mathrm{HE}$

4. Slag cement

5. Calcium chloride liquid 
HNF-5988 Rev. 0

Page 2 of 3

PROCEDURES

1. Set up the penetrometer apparatus so it is ready for operation.

2. Set-up to prepare duplicate $700 \mathrm{gm}$ samples of the following wt.\% compositions:

\begin{tabular}{|c|c|c|c|}
\hline Water & $\frac{\text { Waste }}{\text { (simu7ant) }}$ & Cement & $\frac{\text { Additive }}{\text { (specified) }}$ \\
\hline a. 33.8 & 26.5 & 39.7 & 0 \\
\hline b. 29.0 & 26.5 & 44.5 & 0 \\
\hline c. 24.0 & 26.5 & 49.5 & 0 \\
\hline d. 29.0 & 26.5 & 39.5 & 5 - Sucrose \\
\hline e. 29.0 & 26.5 & 39.5 & 5 - Flyash \\
\hline f. 29.0 & 26.5 & 39.5 & 5 - Pozzolith \\
\hline g. 29.0 & 26.5 & 39.5 & 5 - Slag Cement \\
\hline h. 29.0 & 26.5 & 43.0 & $\begin{array}{l}1.5 \text { - calcium chloride } 1 \text { iq. } \\
\text { (2 gal./yd concrete) }\end{array}$ \\
\hline
\end{tabular}

3. Perform procedure steps 4 through 8 for each composition above.

4. Prepare only one duplicate set of samples at a time, add all ingredients except water and add water last of all.

5. Start the timer as soon as water is added, and place timer where it can be readily read.

6. After mixing, measure the slump using the slump tester and then pour the mix into the cement container.

7. Make penetrometer readings using 3 needies per sample at approx. $30 \mathrm{~min}$. , 1 hour, 2 hours, 4 hours and 24 hours per Section 9.2 of ASTM C 403-95 (procedure attached).

8. Compute and record the penetration resistance in $1 \mathrm{bs} / \mathrm{in}^{2}$.

9. Plot penetration resistance versus elapsed time on $10 \mathrm{~g} / \mathrm{log}$ paper.

WASTE MANAGEMENT:

None of the admixtures are regulated, and there will not be any liquid formed so all test sample products and residues will be non-regulated. 
Page 3 of 3

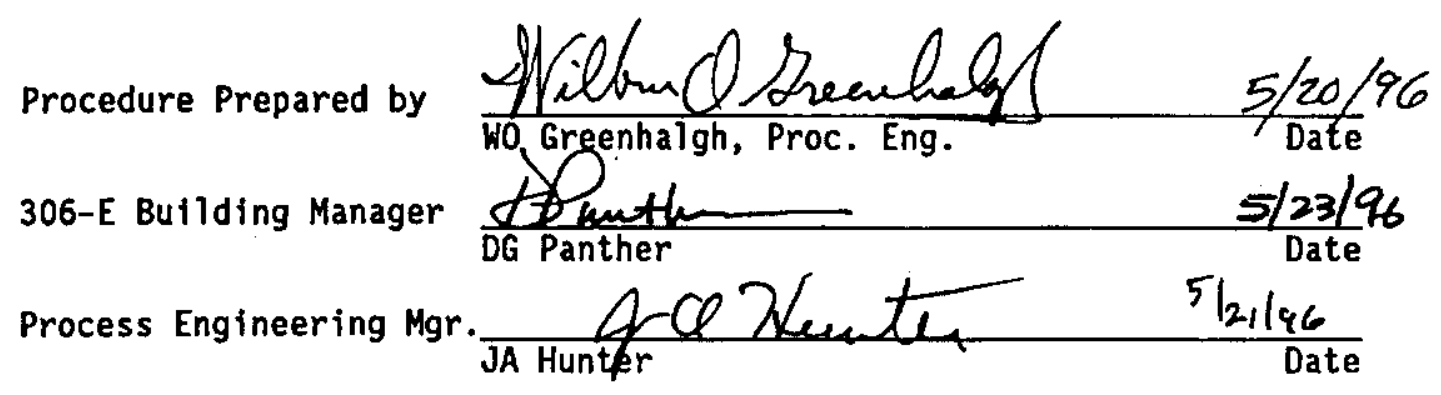


HNF-5988 Rev. 0

8A400-96-032

ATTACHMENT 4

Appendix B

Mixer Information

Consisting of 1 page 


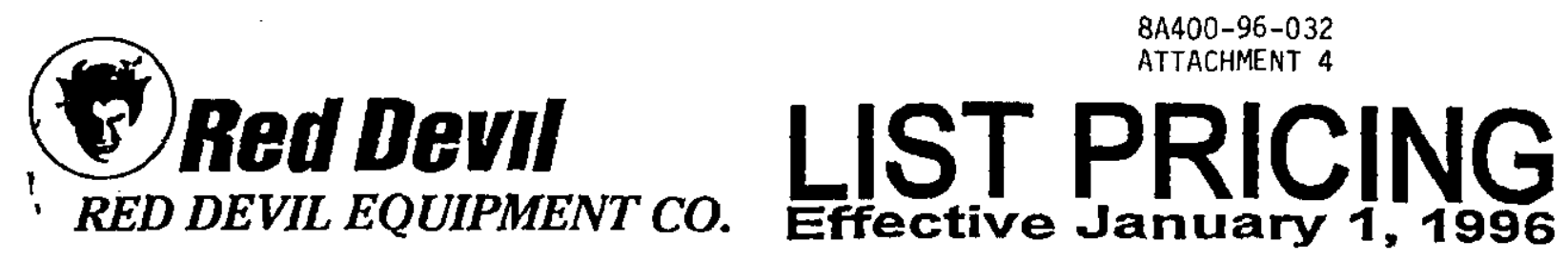

\begin{tabular}{|c|c|c|}
\hline \multicolumn{3}{|c|}{ ONE GALLON SHAKERS } \\
\hline $\begin{array}{l}\text { Model No. } \\
0-5400-02 \\
0-5400-O M \\
0-5400-O H \\
0-5400-32 \\
0-5400-M 3 \\
0-5400-\mathrm{H3} \\
0-5400-X 2 \\
0-5400-X 3 \\
0-5400-E 2 \\
0.5400-E M \\
0-5400-E H \\
0-5400-E 3 \\
0-5400-Y 2 \\
0-5400-Y 3 \\
0-5400-A 1\end{array}$ & $\begin{array}{l}400 \text { Twin One Gallon Shakers } \\
\text { Description } \\
6 \text { Minute Push Button Timer } \\
15 \text { Minute Mechanical Timer } \\
1 \text { Hour Mechanical Timer } \\
\text { Heavy-Duty, } 6 \text { Minute Timer } \\
\text { Heavy-Duty, } 15 \text { Minute Timer } \\
\text { Heavy-Duty, 1-Hour Timer } \\
\text { Explosion-Proof } \\
\text { Explosion-Proof, Heavy Duty } \\
6 \text { Minule Timer, } 220 \mathrm{~V} \\
15 \text { Minute Timer, } 220 \mathrm{~V} \\
1 \text { Hour Timer, } 22 \mathrm{CV} \\
\text { Heavy-Duty, 220V } \\
\text { Explosion-Procf, } 220 \mathrm{~V} \\
\text { Explosion-Proof, Heavy-Duty, } 220 \mathrm{~V} \\
\text { Air-Driven }\end{array}$ & $\begin{array}{l}\text { Price } \\
\$ 1,191 \\
\$ 1,109 \\
\$ 1,109 \\
\$ 1,310 \\
\$ 1,219 \\
\$ 1,219 \\
\$ 1,543 \\
\$ 1,669 \\
\$ 1,264 \\
\$ 1,176 \\
\$ 1,176 \\
\$ 1,340 \\
\$ 1,683 \\
\$ 1,790 \\
\$ 1,129\end{array}$ \\
\hline $\begin{array}{l}\quad 54 \\
\text { Model No. } \\
0-5410-02 \\
0-5410-\mathrm{OM} \\
0-5410-\mathrm{OH} \\
0-5410-32 \\
0-5410-\mathrm{M3} \\
0-5410-\mathrm{H3} \\
0-5410-\times 2 \\
0-5410-\mathrm{X3} \\
0-5410-\mathrm{E2} \\
0-5410-\mathrm{EM} \\
0-5410-\mathrm{EH} \\
0-5410-\mathrm{Y} 2 \\
0-5410-Y 3\end{array}$ & $\begin{array}{l}\text { 10 Single One Gailon Shakers } \\
\text { Description } \\
6 \text { Minute Push Butlon Timer } \\
15 \text { Minute Mechanical Timer } \\
1 \text { Hour Mechanical Timer } \\
\text { Heavy-Duty, } 6 \text { Minute Timer } \\
\text { Heavy-Duty, } 15 \text { Minute Timer } \\
\text { Heavy-Duty, } 1 \text { Hour Timer } \\
\text { Explosion-Proof } \\
\text { Explosion-Proof, Heavy-Duty } \\
6 \text { Minute Timer, } 220 \mathrm{~V} \\
15 \text { Minute Timer, } 220 \mathrm{~V} \\
1 \text { Hour Timer, } 220 \mathrm{~V} \\
\text { Explosion-Proof, } 220 \mathrm{~V} \\
\text { Explosion-Procf, Heavy-Duty, } 220 \mathrm{~V}\end{array}$ & $\begin{array}{r}\text { Price } \\
\$ 1,021 \\
\$ 948 \\
\$ 948 \\
\$ 1,123 \\
\$ 1,044 \\
\$ 1,044 \\
\$ 1,326 \\
\$ 1,434 \\
\$ 1,089 \\
\$ 1,011 \\
\$ 1,011 \\
\$ 1,448 \\
\$ 1,539\end{array}$ \\
\hline $0.5710-00$ & Air-Driven & $\$ 480$ \\
\hline $\begin{array}{l}\text { Model No. } \\
0.5153-00 \\
0.5151-00\end{array}$ & $\begin{array}{l}\text { Bases } \\
\text { Description } \\
\text { Counter Base } \\
\text { Pedestal Base }\end{array}$ & $\begin{array}{rr}\text { Price } \\
\$ & 104 \\
\$ & 196\end{array}$ \\
\hline $\begin{array}{l}\text { Model No. } \\
0-5600-01 \\
0-5600-E 1\end{array}$ & $\begin{array}{c}5600 \text { Auto Sperse }{ }^{\circledR} \text { Shaker } \\
\text { Description } \\
\text { Aulo Sperse } \\
\text { Auto Sperse }{ }^{\circ} \text {. High-Speed } \\
\text { Higeed. } 220 \mathrm{~V}\end{array}$ & $\begin{array}{l}\text { Price } \\
\$ 1,051 \\
\$ 1,156\end{array}$ \\
\hline
\end{tabular}

RED DEVIL EQUIPMENT CO. 7150 Boone Avenue North Minneapolis, MN 55428
Sales \& Service (US): $800 / 221-1083$ Sales \& Service (Int'l): $612 / 533-2969$

Fax: 612/533-0015

Auto Sperse is a trademark of Red Devil, Inc., of Union, New Jersey. 
HNF-5988 Rev. 0

8A400-96-032

ATTACHMENT 5

Appendix $\mathrm{C}$

Figures 1 through 5

Consisting of 1 page each 
HNF-5988 Rev. 0

8A400-96-032

ATTACHMENT 5

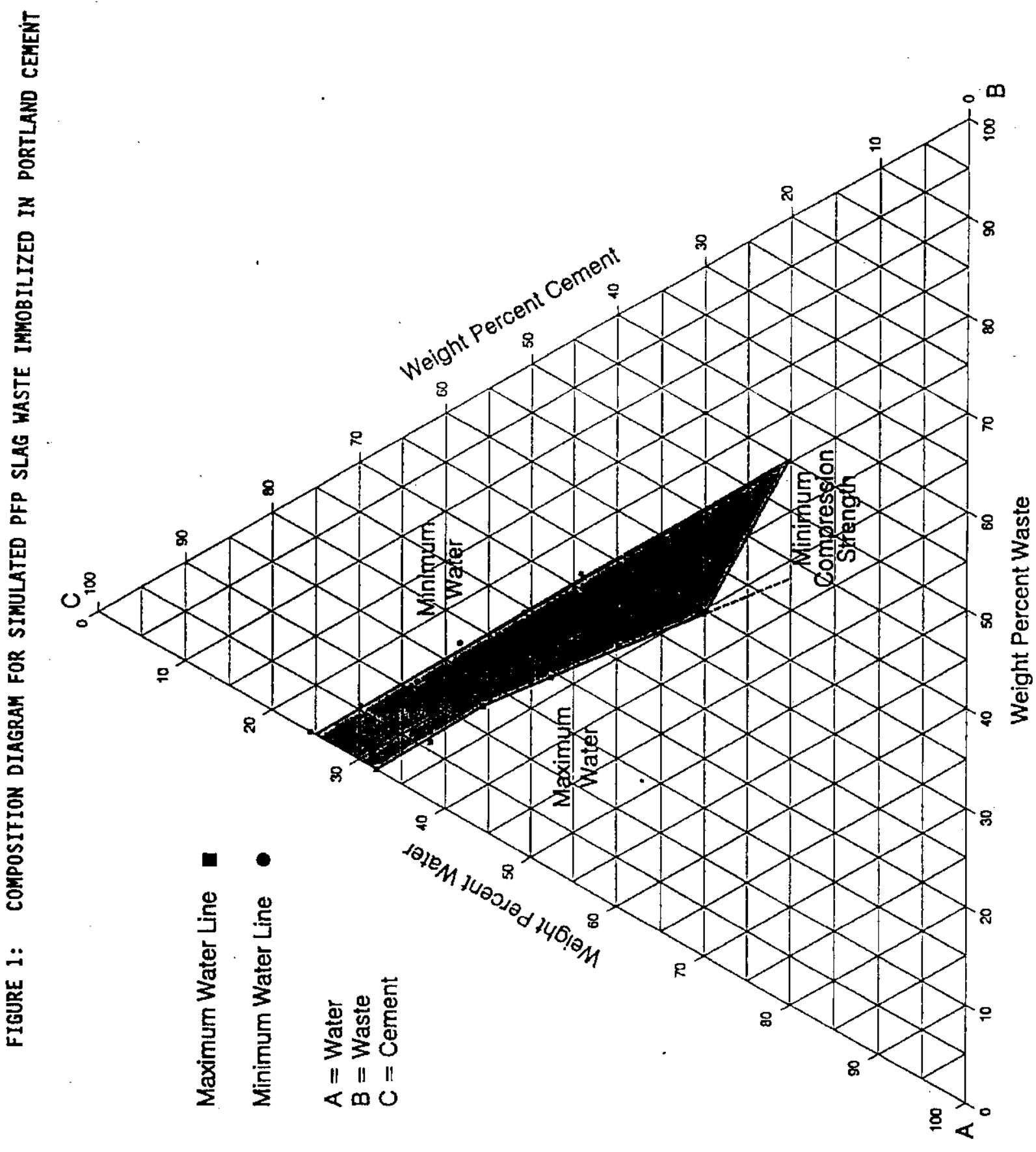


HNF-5988 Rev. 0

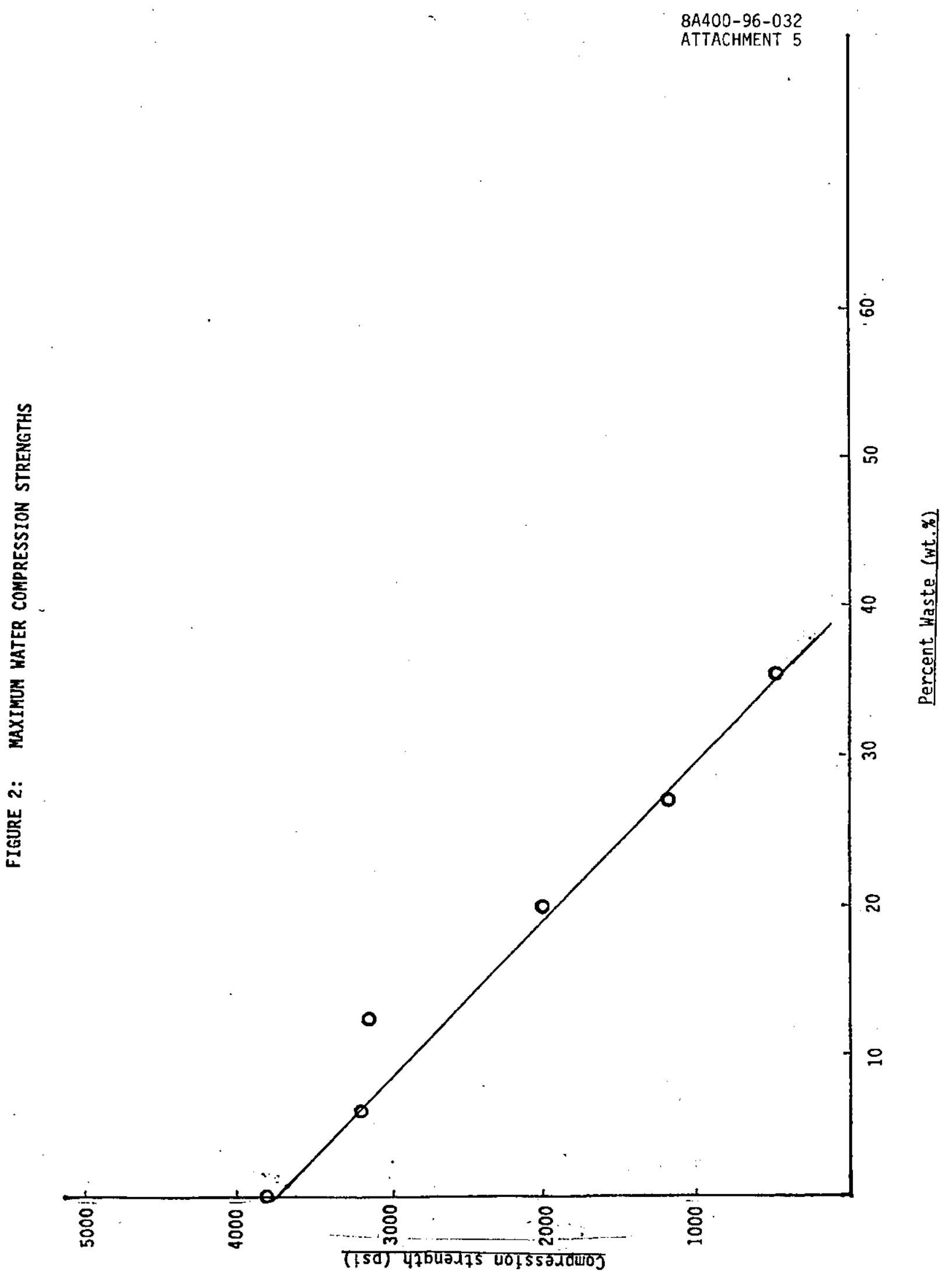


HNF-5988 Rev. 0

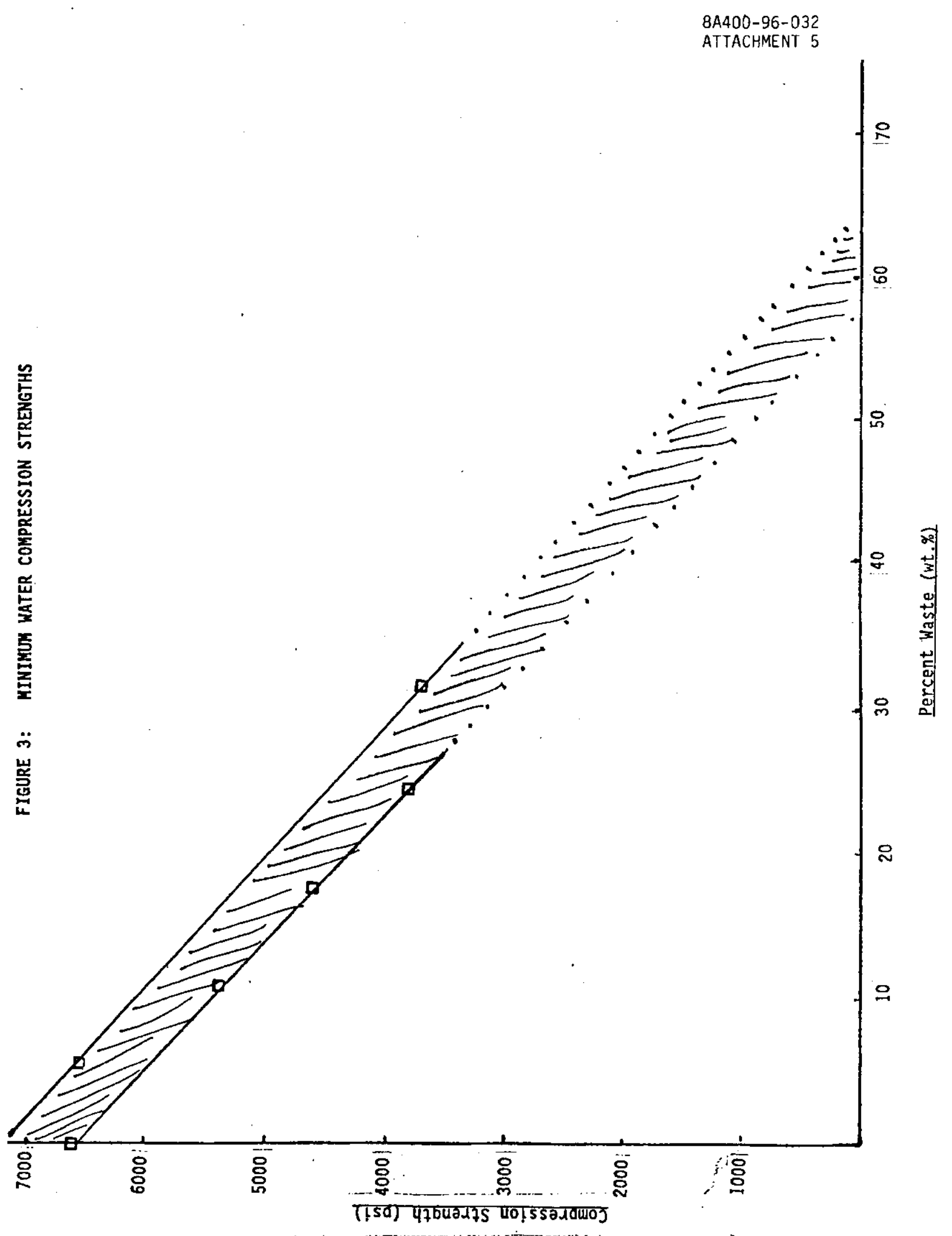


HNF-5988 Rev. 0

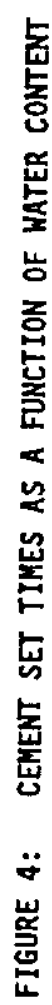

8A400-96-032

ATTACHMENT 5

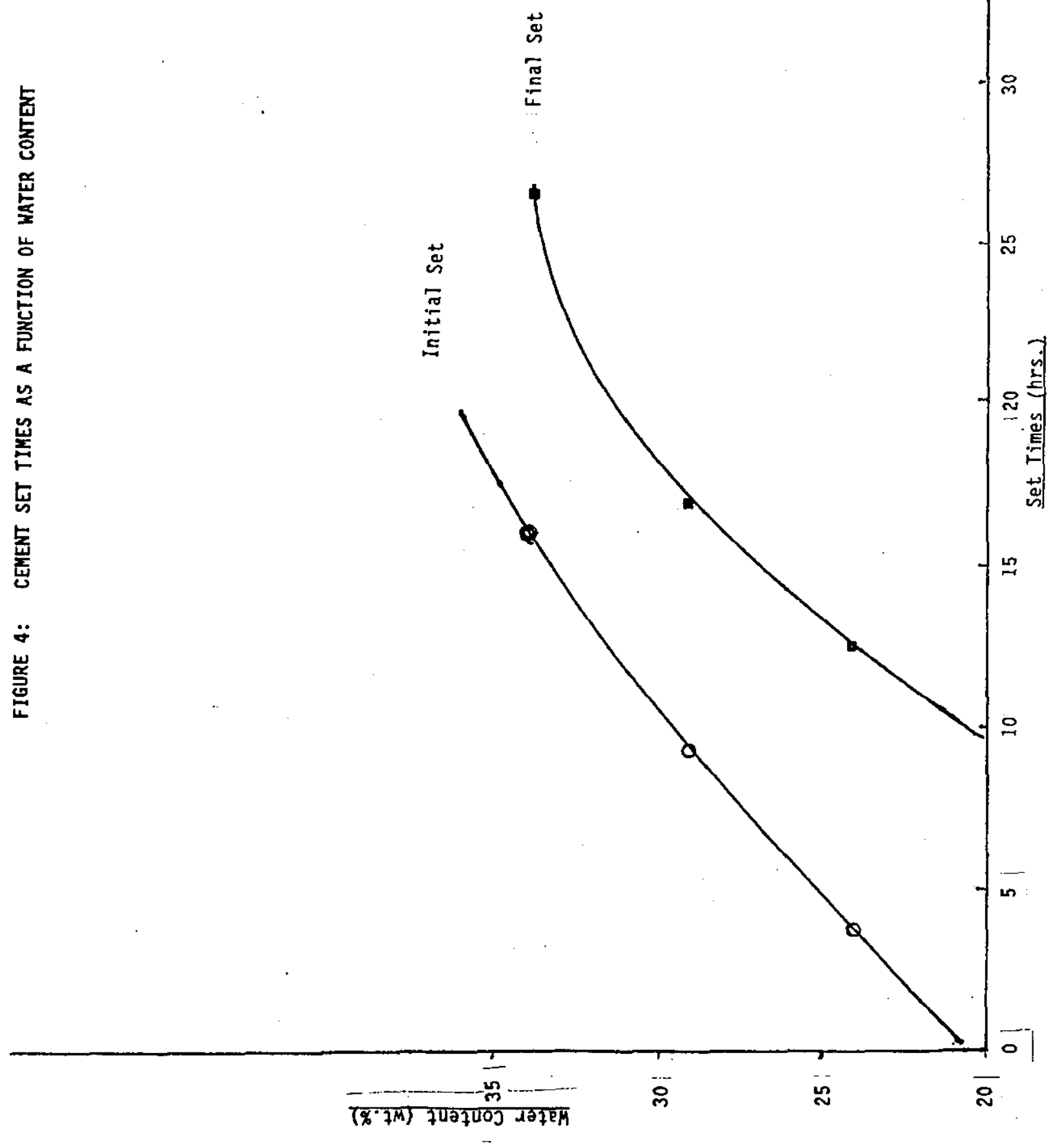


HNF-5988 Rev. 0

8A400-96-032

ATTACHMENT 5

\section{ONE GALLON SINGLE SHAKER}

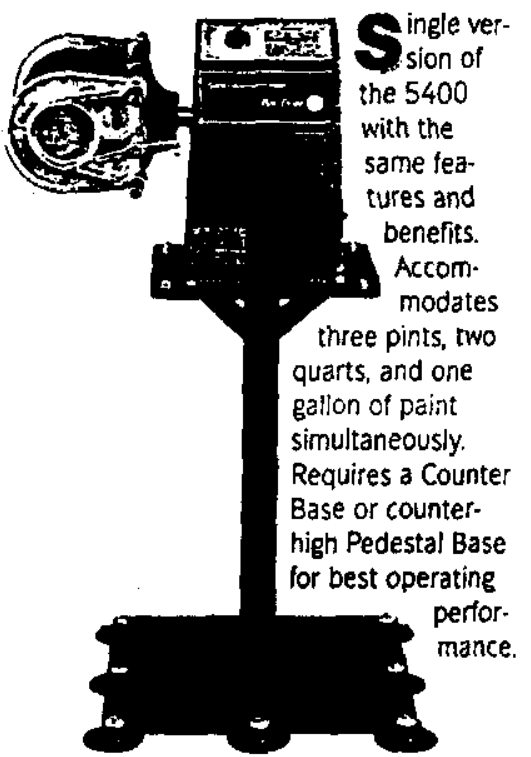

1 Operates on $120 \mathrm{~V}, 60 \mathrm{~Hz}$. or $220 \mathrm{~V}$. $50 \mathrm{~Hz}$.

$217^{\prime \prime} \mathrm{L} \times 24^{*} \mathrm{~W} \times 17^{*} \mathrm{H}$

$(43 \mathrm{~cm} \times 61 \mathrm{~cm} \times 43 \mathrm{~cm}$ )

5hipping weight: $138 \mathrm{lbs}$ ( $63 \mathrm{kgs}$.)

3 ULCSA Listed
Features a t/s.p. motor and heavy-duty ciamp assembly. Designed for industrial or high-volume uses. Choose between a six minute or one hour timer. HeavyDuty/Explosion-Proof Option available.

\section{EXPLOSION-PROOF OPTION}

Features an explosion-proof motor and wiring for safe use in flammable environments. Optional Explosion-Proof "On-Off" Switch. Heavy-Duty/ Explosion. Proof Option available.

\section{AIR-DRIVEN OPTION}

All the features and benefits of the 5400

Series in an air-driven shaker. Air

\section{1 pedestal base}

- uts your paint shaker at counter height without using valuable counter space. Rubber suction feet securely hold base to the floor reducing vibration and noise. for Red Devil 5400/5410 Series and 5710 paint shakers.

$18^{\prime \prime} \mathrm{L} \times 20^{\circ} \mathrm{W} \times 29^{\prime \prime} \mathrm{H}$ $(46 \mathrm{~cm} \times 51 \mathrm{~cm} \times 74 \mathrm{~cm})$ Shipping Weight: 75 lbs. (34 kgs.)

Model No. Description 0-5151-00 Pedestal Base

\section{HEAVY-DUTY OPTION}

requirement of 8 CFM at 100 psi. Explosion-Proof. Can be used in Class I. Croup D Hazardous Environments.

\section{MODEL NO. OESCRIPTION}

$0-5410-02$ Single Shaker, 6 Min. Timer

$0.5410 .0 \mathrm{M}$ Single Shaker, 15 Minute Timer

$0.5410 .0 \mathrm{H}$ Single Shaker, 1 Hour Timer

$0-5410 . \mathrm{E} 2$ Shaker, $220 \mathrm{~V}, 50 \mathrm{~Hz}$.

0.5410.H3 Heavy-Duty, 1 Hour Timer

0-5410-32 6 Minute Timer

$0-5410 \times 2 \quad$ Explosion-Proof

$0.5410 . \times 3$ Heavy-Duty/Explosion-Proof

5322000 Opt, explosion-Proof Swikch

\section{COUNTER BASE}

wo piece cast iron base featuring coil spring suspension for smooth. quiet. counter-top operation. For Red Devil $5400 / 5410$ Series and 5710 paint shakers.

$118 \mathrm{~h}^{\prime \prime L} \times 20 \% " \mathrm{~W} \times 2^{\prime \prime} \mathrm{H}$ $147 \mathrm{~cm} \times 53 \mathrm{~cm} \times 5 \mathrm{~cm}$ ) Shipping Weight: $20 \mathrm{lbs}$. (9 kgs.)

Model No. Description

0.5153-00 Counter Base

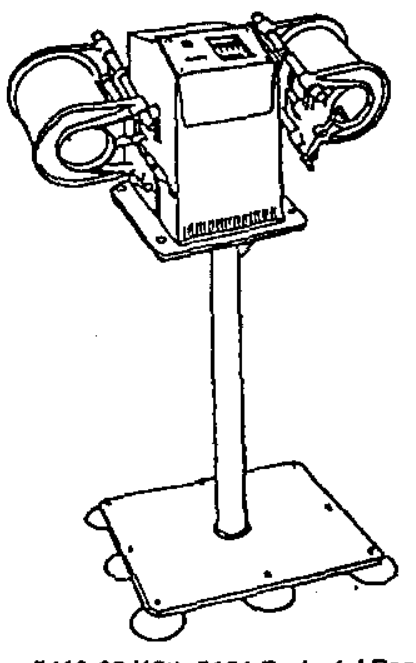

